
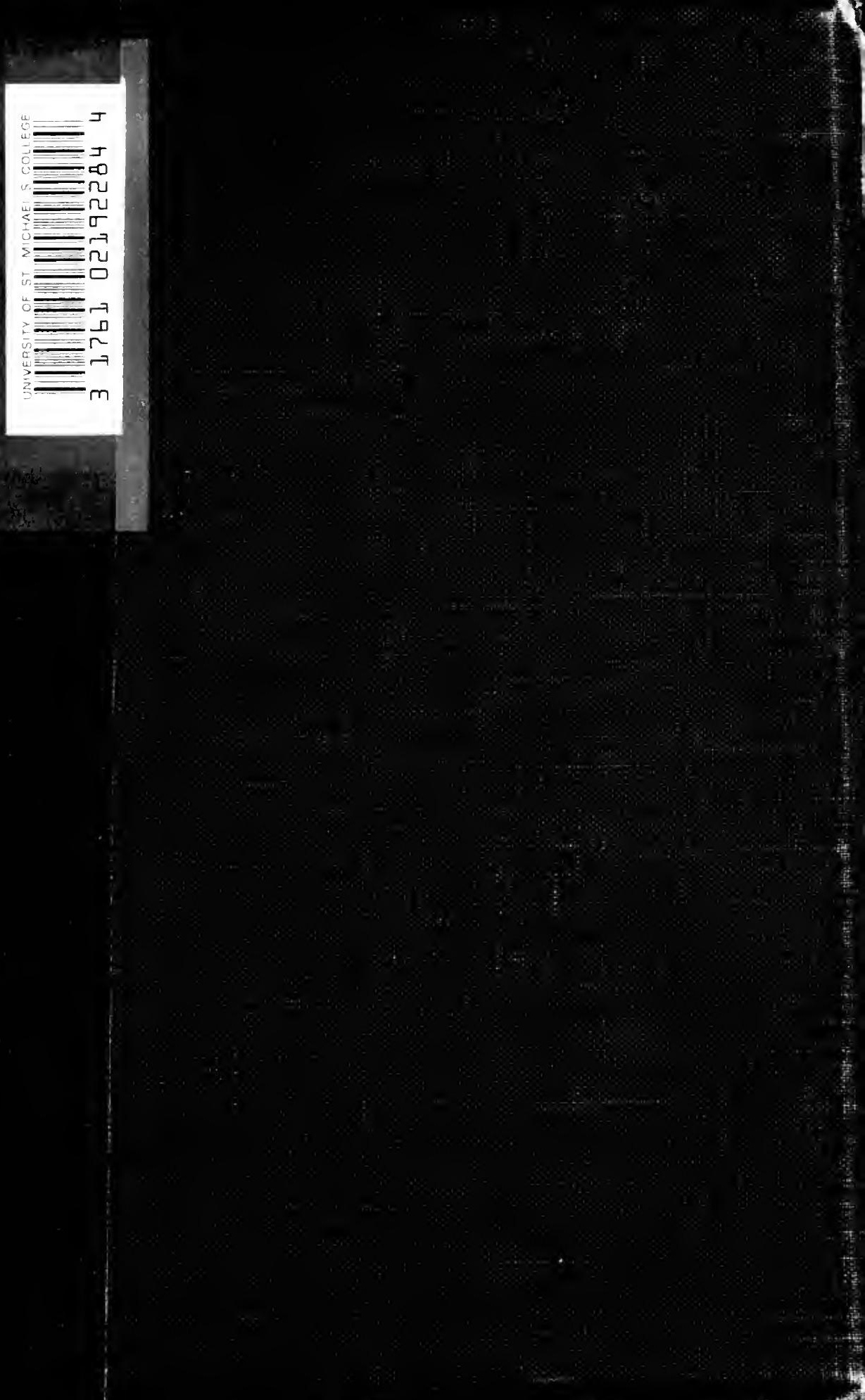

EARLY ENGLISH PROSE ROMANCES 
$+$ 


\section{EARLY ENGLISH PROSE ROMANCES}

EDITED BY

WILLIAM J. THOMS

NEW EDITION, REVISED AND ENLARGET

LONDON

GEORGE ROUTLEDGE AND SONS, I_IMITEN NEW YORK: E. P. DUTTON AND CO. 


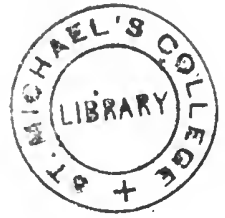

MADE AND PRINTED IN GREAT BRITAIN BY MORRISON AND GIBB LTD., EDINBCRGH 


\section{CONTENTS}

PAGES

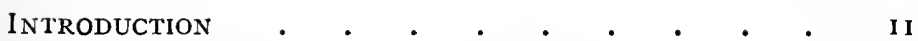

Eleven of the Hundred Merry Tales . • . $3 \mathbf{I}$

The History of Revnard the FoX . . . . 4 I

ROBERT THE DEUYLL . . . . . . . . . . 167

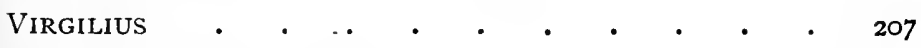

The History of Hamlet . . . . . . . . 237

The Famous Historie of Fryer BaCON . . • . 285

The History of GuY Earl of Warwick . • • 329

THE History of Friar RUSH • • • . . . 409

The Pleasant Historie of Thomas of Reading • • 441

The Noble Parentage and The Atchievements of ROBIN HOOD . . . . . . . . . $52 \mathrm{I}$

ThE History of GEORgE A GREeN • • . • . 557

The Pleasant Historie of Tom a Lincolne . . 6oi

The KNight of The SWanne . . . . . . . . 69I

The History of the Damnable Life and Deserved

Death OF DR. JOHN Faustus • • • • • 785 


\section{PUBLISHERS' NOTE}

This volume consists of a reprint of The Early Prose Romances, edited by the late Professor Henry Morley, which formed a volume of The Carisbrooke Library issued under his supervision, together with those tales from the late W. J. Thoms' Early English Prose Romances which Professor Morley omitted from his collection. It thus contains the whole of Thoms' series and such stories as Morley inserted in excess thereof. Professor Morley's Introduction has been retained, as, although it covers only the seven stories contained in his edition, it is yet of value and great interest.

$$
\text { G. R. \& S., L. }
$$




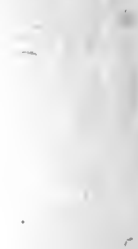

? 


\section{N T R O D U C T I O N}

THIS volume contains seven old stories. The first of them 1 is the old Beast Epic of "Reynard the Fox," in Caxton's translation from the Flemish. Jacob Grimm believed that these fables of beasts applied, with a strong national feeling, to corruption growing among strong men who wronged the poor and used religion only as a cloak for violence and fraud, were from their origin Teutonic. Like fables elsewhere could in great measure be accounted for by the like suggestion of natural resemblance between beasts and men. But it has been observed that the earliest known use of such fabling by a German writer is in Fredegar's Chronicle, quoted under the year 612 as a "rustica fabula" of the Lion, the Fox, and the Stag, which distinctly follows Asop, and undergoes change afterwards from the fancy of narrators. The story also of the remedy suggested by the Fox to the sick Lion (see in this volume a chapter of Caxton's "Reynart") comes from Æssop. It was developed in the eighth century in a Latin poem ascribed to the Lombard Paulus Diaconus, who may have had it at the court of Charlemagne as matter already familiar among the Franks. Either from Byzantium or through contact with Rome, such fables could readily have passed into the hearing or the reading of Teutonic monks, who cared about God and the people, steeped the fables in minds active for reform, and developed them, as the Teutonic races developed also the Arthurian myths, into forms inseparable from their nationality. 
The sick Lion reappears in the tenth century in the oldest poem elaborated as a Beast Epic, the "Ecbasis cujusdam Captivi." Its author belonged to the monastery of St. Evre, at Toul. Strict reforms among the brethren, in the year 936, caused his Ecbasishis going out. He was brought back, and as a sign of his regeneration wrote the poem, in which he figured himself "per tropologiam" as a calf, who, having gone out from safety, became captive to the wolf. The "Ecbasis" has already incidents that become further developed in the myth of "Reynart."

The next stage of growth is marked by the Latin poem "Ysengrimus," which was first named "Reinardus Vulpes." It was written about the year II 48 by a Flemish priest, Nivardus of Ghent. Here we have the names that afterwards entered so completely into the speech of Europe that the old French word for a fox, Goupil, was replaced by Renard, Reinaert. Reynard or Reginhard means absolutely hard, a hardened evil-doer whom there is no turning from his way. It is altogether out of this old story that the Fox has come by that name. Isegrim, the Wolf's name, is also Flemish-Isengrin meaning the iron helm. The bear they named Bruno, Bruin, for the colour of his coat.

The earliest French version of this national satire is lost. There are traces of it to be found in the later "Roman de Renard" which confirm the belief that it was known to and used by the Alsatian Heinrich der Glichezare (the name means simulator), who about the year II80 wrote the first "Reinart" in German. He first called it "Isengrine's Not:"-

Nû vernemet seltsarniu dinc

und vremdiu maere

der der Glichesaere

inkünde gît, si sint gewaerlich

Er ist geheizen Heinrich,

der hât diu buoch zesamene geleit

von Isengrînes arbeit.

The poem was afterwards entitled "Reinhart Fuhs." There remain two MSS. of it, one at Heidelberg, the other in the Bishop's Library at Kalocsa, in Hungary. Its vigorous author was one of 
the poets who lived of old by voice as well as pen, themselves reciting what they wrote.

From a French poem on the same subject, written in the beginning of the thirteenth century by a priest, Pierre de St. Cloud, came the Flemish poem of "Reinhart," by Willem, at the beginning of the thirteenth century. This was continued by another poet of less mark about the year 1380. A prose commentary on this appeared in 1480 , and a Low German translation of it was printed and published at Lubeck in 1498 . In the earliest form of the story, in the tenth century, the Fox triumphed. Willem's "Reinaert" ended with the exile of the Fox from court. It was the continuer of Willem in 1380 who brought the Fox back, and told of his judicial combat with Isegrim, and showed hypocrisy again triumphant.

Willem's Low German poem of "Reinaert" was followed by a prose "Hystorie van Regnaert die Vos," printed at Gouda, in Holland, by Gerard Leeu, in 1479. Caxton's translation was made from the Low German, and retains many Teutonic words in their Dutch form, which was also the form most nearly allied to English. Caxton's long residence at Bruges made the language as familiar to him as his own, and sometimes his English includes a word from the other side of the boundary between English and Dutch. The first edition of Caxton's translation was finished at Westminster in June $148 \mathrm{r}$. There was a second edition in 1489 , of which the only known copy is in the Pepys Library at Cambridge.

Caxton's translation is, as the reader will find, free, vigorous, and lively; but, as printed by himself, it is not only without breaks of paragraph, but there is a punctuation in which the end of one sentence is now and then detached from its own connection and joined to the beginning of another, and in yarious ways the pleasant features of the story are seen dimly sometimes as through a veil. I have, therefore, corrected absolute mistakes, and broken the story into paragraphs that mark the briskness of its dialogue and of its homely wit. Old words and grammatical forms have been left, but I have preferred to print familiar words that remain 
to us in modern English in the spelling that now brings their sense most quickly to the reader's mind. An exact transcript of Caxton's "History of Reynard the Fox" is easily to be had. It was published in I 880 by Professor Arber, of Mason's College, Birmingham, in his "English Scholar's Library," and can be received from him through the post for eighteenpence.

This old story, said Thomas Carlyle, "comes before us with a character such as can belong only to very few-that of being a true world's Book, which, through centuries, was everywhere at home, the spirit of which diffused itself into all languages and all minds. The quaint Esopic figures have painted themselves in innumerable heads; that rough, deep-lying humour has been the laughter of many generations."

"Reynard the Fox" was German in its origin; "Robert the Devil," French. In each tale there was the mediæval popular sense of cruel oppression by the strong. In "Reinaert," as first written, fraud and cruelty were banished with the Fox out of the Lion's court ; but the old continuer of the story brought them back, and left them, as they were in the world, or as they seemed to be, triumphant over earthly opposition. In " Robert the Devil" force of cruelty was exaggerated to the utmost, for the purpose of insisting on the higher spiritual force that was alone able to triumph over it, and for the purpose of teaching that no sinner, however great, can be beyond the reach of rescue by a true repentance.

The legend of "Robert the Devil" was developed first in France out of elements that are to be found in the early tales of widely separated peoples. From France the developed story spread into Spain. It scarcely passed into Italy. In Germany it never was acclimatised, though adopted into modern German romance literature. In the Netherlands the romance of "Robrecht den Duyvel" was forbidden by the Bishop of Antwerp on the $x$ rth of April 1621 .

The oldest known version of the story of "Robert the Devil" was one in Latin prose by Etienne de Bourbon, a Dominican Friar who died soon after the middle of the thirteenth century. 
It was part of a work that he left unfinished, a collection of historical anecdotes. legends, and apologues, and is there given as a story which he had heard from two of his brethren, and from one who said that he had read it. The story must, therefore, have been contained, earlier than the year 1250 , in some monastic writing which is now unknown. The tale is given by Etienne de Bourbon as a religious history to enforce the manifold use of penitence. "De multiplici utilitate penitencie. Penitentia vincit et superat hostes, et a casu et a miseria elevat."

To the thirteenth century belongs also the first version of the tale in French, as a romance in octosyllabic rhyming couplets. Of this there are two MSS. at Paris in the National Library, one of the thirteenth century, and one of the fourteenth. The earlier of these was edited in 1837 , in an edition limited to 130 copies, by G. S. Trébutien.

There is also a thirteenth-century prose version of the tale in French prefixed to the old "Croniques de Normandie." The writer of this, whom Littré believes to have lived at the close of the century, also refers to written authority for what he tells. "selon ce quil mest appareu pur aucunes escriptures." The two oldest printed copies of the "Croniques de Normandie," with the prefixed tale of "Robert the Devil," differing much in arrangement, both appeared at Rouen in the same year, 1487 .

In 1496 the story first appeared, printed at Lyon, as a distinct prose tale, "The Terrible and Marvellous Life of Robert the Devil who was named afterwards the Man of God." It was followed, as it has since often been followed, by "The Romance of Richard, son of Robert the Devil, who was Duke of Normandy." This prose life-differing in some main features from that prefixed to the "Chronicles of Normandy"-was reprinted at Paris in 1497, and has from that time to this been frequently reprinted. It is the accepted French prose version of the tale.

The accepted verse form was that of a "Dit de Robert le Deable," which exists in three MSS. at Paris, and was a recasting in the fourteenth century of preceding versions. The Dit is in strophes 
of four alexandrines, rhymed together, and it alters the old close of the story.

Between the romance and the Dit there was produced also a dramatic version, "Miracle de Nostre Dame de Robert-le-Diable." This was first edited and printed at Rouen in 1836 , with Introduction by $\mathrm{C}$. Deville, Paulin Paris, and others.

Reference has also been made to an unpublished metrical version of the legend made in the sixteenth century by Jacques de la Hogue.

From the French prose book the story was first translated into English for the edition twice printed, without date, by Wynkyn de Worde, Caxton's most energetic assistant and successor, who printed as many as four hundred. and ten books, and was the introducer of Roman type into England. Wynkyn de Worde's version-that which is here given-of the "Lyfe of Robert the Devyll" was printed by William J. Thoms in 1827 in "Ancient English Fictions, a Collection of Early Prose Romances," of which there was a second enlarged edition published in $185^{8}$, in three volumes, as "Early English Prose Romances." Except "Reynard the Fox," the "Historie of Hamlet," and "Guy of Warwick," the stories in this volume have been chosen from the collection made by that acute and genial student of the past.

In the earliest known form of the tale of "Robert the Devil" there is no place named as the scene of it, and we are not told that the wicked man who was to repent was, as a child, called Devil by his playfellows. Normandy first appears as his home in the metrical romance, with Rome for the scene of the penance. There are variations in the matter of the taie as it is found in Etienne de Bourbon, in the romance, in the Dit, in the Chronique, and in the first French prose version of the "Life of Rubert the Devil" as a distinct book for the use of the people.

The prose story in the Chronique gives five or six more incidents of Robert's evil-doing, and omits only the blinding of his father's messengers. It says nothing of his wonderful birth and the discovery of it from his mother. It ascribes Robert's conversion to the teaching of a holy man, a hermit who took 
charge of him when he was wounded. There is no war with the Saracens at the end of this version of the tale; no marriage with the Emperor's daughter.

The romance, like the separate prose life of $\mathrm{r} 496$, which is in general accord with the romance and the Dit, brought the fierce impulse to repentance out of the storm of Robert's own nature. This puts more force into the hero's character, more life into the passion of the tale. The romance and the prose life of 1496 tell of the war with the Saracens and the love of the Emperor's daughter; but in the romance Robert refuses marriage, and passes the rest of his life as a holy anchorite. In the popular prose life his refusal to marry is overcome by the express command of God. Robert marries the Emperor's daughter, succeeds his father in Normandy, and passes the rest of his life as a just and religious ruler of his people.

It is not to be supposed that there was any historical foundation for the legend. Robert the Devil has been identified with the Norman Robert I. the Magnificent, who died in 1035; also with Robert II., Courte-Heuse, son of William the Conqueror, who died in II34. Le Héricher has found him in the Norman Rollo. Trébutien says that there is nothing to hinder us from believing that he was, not Duke but Dux, son of an Aubert who in the eighth century ruled over the future Normandy. There is nothing to hinder us from so believing, because faith is free; and there is nothing that will help to such belief. It is a Church legend shaped from popular ideas to enforce the efficacy of repentance. It was told first of a nameless person in an unnamed place; it was then furnished with name and place to give it more solidity, and made emphatic by exaggerations of the pictures that set forth on one side the greatness of the sin, and on the other side showed the completeness of the penance and the pardon. The sinner's violence is that of a devil. In his repentance he abases himself below humanity. This is shown vividly by his putting away the use of speech and of intellect; he takes on himself the actions of a fool, and does not sit at the same table with his fellow-men, but eats and sleeps with the dogs. Full 
pardon comes of full repentance, tested by long resistance of temptation to reveal the secret of his self-abasement.

This volume contains also two tales of conjurors, Virgilius and Friar Bacon.

The story of Virgilius is chiefly of Italian origin. From early days among his countrymen, Vergil was half a god. Silius Italicus, Pliny tells. us, kept Vergil's birthday by a religious visit to his monument in Naples as to a temple. Martial counted the Ides of October as sacred to Vergil, "Octobres Maro consecravit Idus ;" and Statius also made a temple of the tomb-

\section{"Maroneique sedens in margine templi Sumo animum."}

A vague sense of divine greatness in Vergil led to the use of his works as an oracle. By opening his book at random and letting the eye fall on a passage, there was to be found in that passage an oracular solution for any difficulty. This use of the sortes Virgiliane was familiar to the Emperor Hadrian, and is not yet dead. No other books have been so used except Homer and the Bible; but there were few readers of Homer in the Middle Ages, among followers of the Western Church.

Then came centoni of Vergilian verse, in which lines and phrases were rearranged to make Vergilian poems upon subjects not treated by Vergil. The most famous of these, made by the Emperor Valentinian with aid of Ausonius, is a nuptial cento, in which the pure Vergil was made to speak immodestly.

The Christians found in Vergil's fourth eclogue-Pollio-a prophecy of Christ. Pope afterwards, following that idea, mixed up in his "Messiah" Vergil's Pollio with the prophecies of Isaiah. This prophecy of the birth of a child with whom there should come a new and happy age of justice, love. and peace, was fastened upon by the Christians as early as the fourth century. To Lactantius the prophecy was of Christ's second coming.

The description of magical charms in the eighth ecloguePharmaceutria-and the visit to the unknown world in the sixth 
book of the Aneid, contributed, no doubt, to the growth of the idea that Vergil was a great magician; but there is no definite speaking of him in that character before the twelfth century. At the close of the thirteenth century, when the genius of Dante first breathed the spirit of the artist into modern literature, Dante's great master was Vergil, greatest of the poets known to him, and gifted beyond all men with the poet's insight, which is clearest use of human wisdom.

In the popular literature of the thirteenth century there was in French verse by a monk of Hauteseille, in Lorraine, a variation on "The Seven Sages" called "Dolopathos." Dolopathos was an imagined king of Sicily who lived in the time of Augustus. and sent his son Lucinianus to be taught at Rome by Vergil. Before the son returned to Sicily his mother had died and his father married again. Vergil saw in the stars great danger threatening him, and Lucinianus was bidden to keep strict silence until Vergil himself told him to speak. The stepmother caused the son to be condemned to death by his father. The day of execution was delayed by story-telling until the seventh day, when Vergil came and bade his pupil speak. In consequence of what he told, the stepmother was burnt alive.

Among the people of Naples, apt at story-telling, in the twelfth century, tales of Vergil the magician began to multiply. Naples had been a favourite place of, residence with the poet, and after his death at Brundusium, B.C. r9, his remains were taken to Naples and entombed by the Via Puteolana, on the road from Naples to Puteoli. Conrad of Querfurt, in a letter from Italy, dated II94, describing his travels, tells of Naples provided by Vergil with a palladium in the form of a small model of the city enclosed in a bottle with a narrow neck; also of a magical bronze horse, and a bronze fly that kept flies out of the city, and other wonders that we find woven into the tale of Vergil the Enchanter. Gervase of Tilbury, about eighteen years later, in his "Otia Imperialia," tells more such tales, and there are more references to Vergil's magic in Alexander Neckham's book "De Naturis Rerum." The people of Naples adopted Vergil as the protecting genius of 
the city, and some of their tales were clearly based on legends and traditions from the East. Vergil's releasing of the Devil recalls the tale of the Fisherman and Genie in the "Arabian Nights." Apollonius Tyaneus also was said to have made a bronze fly that kept flies out of Byzantium. Professor Domenico Comparetti, in his two volumes published at Leghorn in 1872 - Virgilio nel Medio Evo"-gives many interesting details of the growth of the tradition, and finds in many of the tales of Vergil a popular association of ideas with objects familiar to the people of Naples. When the palladium had been transformed from a model of Naples to an egg, the old castle built in I 54 changed its name in the fourteenth century from Castello di mare to Castel dell' uovo. In the statutes of a religious house it is described as Castellum ori incantati. Meanwhile the tales spread over Italy and beyond Italy, from lip to lip through the story-tellers, and became more and more familiar in books. But there have been no manuscripts found of the French story-book, "Les Faits Merveilleux de Virgille," which come down to us in rare printed copies of the earlier part of the sixteenth century. It was translated into English, into Dutch, and into German; there is also at Copenhagen a MS. translation of it into Icelandic through the Dutch.

The English translation is that given in this volume, as printed, with woodcuts, in Gothic letter, at Antwerp, without date, by John Doesborcke. "This boke treatethe of the lyfe of Virgilius and of his death, and many maravyles, that he dyd in his lyfe tyme by witchcraft and nigromansy, thorough the help of the devylls of hell." From the one known copy Utterson reproduced in 1812 an edition of sixty copies, from one of which it was reprinted in 1828 by W. J. Thoms in the collection already named, of which a translation into German, with additional matter by R. O. Spazier, was published at Brunswick in 1830 .

" The Historie of Hamlet," that next follows, is from a book printed by Richard Bradocke for Thomas Pavier in 1608, of which there is only one known copy. Nash's " Epistle," prefixed to Greene's “ Menaphon," publịshed in 1589 , refers to a play of 
"Hamlet" then existing, which was earlier than Shakespeare's. This may have been founded upon the tale as told in the "Histoires Tragiques" of Belleforest, together with tales from the Italian of Bandello, whose novels Belleforest and his fellow-translator, Boiastuau, adopted. If it was taken from the English book, which is translated from Belleforest, then the first edition of the English translation was of earlier date than 1589 .

The tale of "Hamlet" first appears in the third book of the Danish history of Saxo Grammaticus. And who was he? $\mathrm{He}$ was a Danish historian, of noble family, who lived in the latter half of the twelfth century, and died soon after the year 1203. He began life as a monastic writer, who for his Latinity was called "Grammaticus." Upon the suggestion of his patron, Absalon, Archbishop of Iund, he wrote a history of Danish kings and heroes, which, till the tenth century, is legendary. The historian delighted in the legends of the people, and reported them with evident fidelity. This gives especial interest to ten books of his Danish history; in the remaining six he is more simply historian. A translation of Saxo Grammaticus into Danish is a popular book among the Danes. A translation of it into English will some day, I hope, become current in England. I know where there is a translation of it to be had, which should be made accessible to many readers.

In Saxo's third book we are told how, when Rörik Slyngebond, towards the close of the seventh century, was king of Denmark, Gervendill was chief in Jutland. After the death of Gervendill, his two sons, Horvendill and Fengo, succeeded him. Horvendill won to himself glory as a vikingr, that stirred envy in Koller, king of Norway. Koller hunted the seas for Horvendill, and at last met him, and was killed by him on an island in the spring-time, and fought with him the kind of island-duel known as "Holmgang." Horvendill's rich gifts from his booty won the favour of his king, Rörik; so he married Rörik's daughter, Gerutha, and became by her the father of Amleth-Hamlet. All this prosperity of Horvendill stirred envy in his brother Fengo. Fengo fell on Horvendill with open force, slew him, succeeded to his rule, and reigned tyrannically. 
He also beguiled the mind of his brother's wife, Gerutha, and married her. Amleth, her son, then simulated madness. It is to be noted also that Amloda signified a foolish person. He soiled himself by daily lying in the ashes. He cut little sticks to points and hardened them in fire, and made men laugh by saying that he got them ready to avenge his father. Shrewd minds and guilty minds suspected him. They sought to make him betray himself to a fair woman in a wood, and to certain youths, but a foster-brother took care that he should not be beguiled. Amleth understood the devices, and when offered a horse, mounted with his face looking hindward and took the tail for a bridle. His answers of feigned insanity were always witty. When he was told that the sand by the seashore was meal, he said, "Yes, ground by the storms and the white-crested waves." In the younger Edda there is a fragment of verse which gives Amlodi's Mill as one of the poetical names for the sea. In other ways Amleth contrived so to tell truth as to seem a fool. But Fengo saw the underlying wit, and as he could not make away with him in Denmark for fear of King Rörik, sent him to England with companions who carried lines which Amleth searched for, found, and altered so that they asked for the killing of their bearers, and that Amleth should be married to the king of England's daughter. So the tale goes on, very much as we have it in the English prose history. There was no place in Danish history for a real Hamlet. His adventures were those of a fable current among the people, which owed its permanence to the fact that Saxo thought it worth recording. It seems to have been a tradition of Jutland, for in Saxo's time Amleth's grave was said to be south of the town of Hald, in the district of Randers.

The story of "Hamlet" passed from Saxo into the Danish Chronicle rhymed by a monk, Niel of Sorö, about the year 1480 , and first printed at Copenhagen in 1495 . Fengo is there said to have been slain in his own house at Viborg in Jutland.

Belleforest took his story from the Latin of Saxo, with rhetorical and moral elaborations, and some variation. Thus in the tale as it was told by Saxo, the spy who was to overhear Hamlet's dis- 
course with his mother was hidden under the straw that in old times was strewn upon the floor. Amleth went about crowing like a cock, and stabbed when his feet came upon somebody concealed under the straw. Belleforest, unaccustomed to such carpeting of royal chambers, translated the word stramentum into tapestry; for Belleforest was a protégé of Margaret of Navarre, familiar with the houses of French nobles in a time of growing luxury. He died in $15^{8} 3$, aged fifty-three. Margaret of Navarre began her care for him when he was seven years old, and had just lost his father. He was educated by her and bred for the bar, but turned poet and man of letters. Outliving his better days, he wrote much prose of any kind that would earn bread, and among other works the collection of tales which included that showing, "Avec quelle ruse Amleth, qui depuis fut roy de Dannemarck, vengea la mort de son père Horvendille, occis par Fengon son frère, et autre occurrence de son histoire."

The English version of Hamlet is followed in this volume by the old story of Friar Bacon, the Franciscan friar whose clear study of Nature gave him fame as a magician in the stories of the people. The real Roger Bacon, born in 1214 , was in his cradle in Somersetshire when the Barons obtained from King John his signature to Magna Charta. He belonged to a rich family, sought knowledge from childhood, and avoided the strife of the day. He studied at Oxford and Paris, and the death of his father may have placed his share of the paternal estate in his hands. He spared no cost for instructors and transcribers, books and experiments; mastered not only Latin thoroughly, but also Hebrew and Greek, which not more than five men in England then understood grammatically, although there were more who could loosely read and speak those tongues. He was made Doctor in Paris, and had the degree confirmed in his own University of Oxford. 'Ihen he withdrew entirely from the civil strife that was arising, and joined the house of the Franciscans in Oxford, having spent all his time in the world and two thousand pounds of money in the search for knowledge. Roger 
Bacon's family committed itself to the king's side in the civil war which Henry's III.'s greed, his corruption of justice, and violation of the defined rights of his subjects, brought upon him. The success of the Barons ruined Bacon's family, and sent his mother, brothers, and whole kindred into exile. Meanwhile the philosopher, as one of the Oxford Franciscans, had come under Grosseteste's care, and joined an Order which prided itself on the checks put by it on the vanity of learning. But, in spite of their self-denials, the Franciscans, at Oxford and elsewhere, included many learned men, who, by the daily habit of their minds, were impelled to give to scholarship a wholesome practical direction. They were already beginning to supply the men who raised the character of teaching at the University of Oxford till it rivalled that of Paris. Friar Bacon was among the earliest of these teachers; so was Friar Bungay, who lives with him in popular tradition.

Roger Bacon saw how the clergy were entangled in subtleties of a logic far parted from all natural laws out of which it sprang. $\mathrm{He}$ believed that the use of all his knowledge, if he could but make free use of it, would be to show how strength and peace were to be given to the Church. And then the Pope, who had been told of his rare acquirements and his philosophic mind, bade Roger Bacon, disregarding any rule of his Order to the contrary, write for him what was in his mind. Within his mind were the first principles of a true and fruitful philosophy. But to commit to parchment all that he had been pining to say would cost him sixty pounds in materials, transcribers, necessary references, and experiments. He was a Franciscan, vowed to poverty, and the Pope had sent no money with the command to write. Bacon's exiled mother and brothers had spent all they were worth upon their ransoms. Poor friends furnished the necessary money, some of them by pawning goods, upon the understanding that their loans would be made known to his Holiness. There was a difficulty between the philosopher and his immediate superiors, because the Pope's command was private, and only a relief to Bacon's private conscience. His immediate rulers had received no orders to relax the discipline wlfich deprived Franciscans of the luxury of 
pen and ink. But obstacles were overcome, and then Roger Bacon produced within a year and a half, I 268-69, his "Opus Majus" (Greater Work), which now forms a large closely-printed folio; his "Opus Minus" (Lesser Work), which was sent after the "Opus Majus" to Pope Clement, to recapitulate its arguments and strengthen some of its parts; and his "Opus Tertiam" (Third Work), which followed as a summary and introduction to the whole, enriched with further novelty, and prefaced with a detail of the difficulties against which its author had contended-details necessary to be given, because, he said, that he might obey the Pope's command the friar had pawned to poor men the credit of the Holy See. These books, produced by Roger Bacon at the close of Henry III.'s reign, and when he was himself fiftythree years old, rejected nearly all that was profitless, and fastened upon all that there was with life and power of growth in the knowledge of his time. They set out with a principle in which Bacon the Friar first laid the foundations of the philosophy of Bacon the Chancellor of later time. He said that there were four grounds of human ignorance: trust in inadequate authority; the force of custom; the opinion of the inexperienced crowd; and the hiding of one's own ignorance with the parading of a superficial wisdom. Roger Bacon advocated the free honest questioning of Nature ; and where books were requisite authorities, warned men against the errors that arose from reading them in bad translations: He would have had all true students endeavour to read the original text of the Bible and of Aristotle. He dwelt on the importance of a study of mathematics, adding a particular consideration of optics, and ending with the study of Nature by experiment, which, he said, is at the root of all other sciences, and a basis of religion. Roger Bacon lived into the reign of Edward I., and died in the year 1292. Friar Bacon's optics appear in that chapter of the popular tale which tells how he took a town by use of a great burning-glass, focussing a chief building in the middle of it, and when he had so set it on fire, and drawn off to it the defenders on the walls, giving the sign for an attack upon the walls. The Brazen Head was an old friend with the 
popular story-teller. William of Malmesbury, who died about I 142, says that Pope Sylvester the Second had one. Gower, in the third book of his "Confessio Amantis," tells the story of Grosteste, who was Roger Bacon's teacher.

"For of the greté clerk Grostest

I rede how busy that he was

Upon the clergie and heved of bras

To forge, and make it for to telle

Of suché thingés as befelle.

And seven yerés besinesse

He laidé, but for the lachesse

Of half a minute of an houre

Fro firsté he began laboure

He lost all that he haddé do."

Albertus Magnus is said to have made a brazen man, who answered questions truly, but grew to be so loquacious that the master's pupil, Thomas Aquinas, whose studies were disturbed by the incessant talking, about the year 1240 , broke his head to silence him.

The Friar Bungay who was joined with Roger Bacon in popular fiction was another learned Franciscan, Thomas (called also John) of Bungay in Suffolk. He is said to have taught both at Oxford and Cambridge, and to have been buried at Northampton.

The prose "History of Friar Bacon" here given may probably have been first published before Robert Greene's play of the "Honorable History of Frier Bacon and Frier Bongay, as it was plaied by her Majesties servants," and printed in r 594. But there were frequent slightly differing editions of the popular prose Look upon which the play was founded.

William J. Thoms, in his preface to "The Tale of Friar Bacon," illustrates the popular taste for conjuring-matches, of which Friar Bungay's contest with Vandermast is an example, by a citation, through Flögel's "History of Court Fools," from a "History of Bohemia," by Dubravius. This tells us that when Charles IV. married the Bavarian Princess Sophia, the bride's father brought 
into Prague, as an agreeable addition to the wedding festival, a waggon-load of magicians. 'I'wo of the chief of them were selected to contend together. One was the great Bohemian sorcerer Zytho, who, after desperate trials of skill, at last opened his mouth from ear to ear, seized his opponent, the Bavarian master Gouin, and crammed him down his throat, head, shoulders, body, legs, but stopped at his boots, which he spat out as not eafable because they had not been cleaned. He then disgorged his rival safe and sound. The reader who is gifted with a proper mediæval spirit should have no difficulty in swallowing both these conjurors, with Friar Bacon, Friar Bungay, Vergil, and as many more.

The next story in our collection is a comic specimen of popular heroics, a tall copy of the widely popular tale of "Guy of Warwick." Its writer towered above common men with eloquence raised high upon the stilts of blank verse that was printed like to prose. Prose has its music, but is always bad when it so runs into successive lines of metre that the artifice is obvious. Such artifice of manner weakens faith in the sincerity of what is said.

As a metrical romance, "Guy of Warwick" is as old as the thirteenth century, and has been doubtfully ascribed to a Franciscan friar, Walter of Exeter. The story of Guy is laid in days before the Norman conquest, and associated with the days of King Athelstane and the battle of Brunanburh. Guy is said to have been the son of Siward, Baron of Wallingford, to have married Felice, only daughter of the Saxon warrior Rohand, to have lived as a hermit after overcoming Colbrond the Dane, and to have died in the year 929. The romance sprang from the life of the twelfth century. In the prose form here given its mediaval spirit is not wholly lost under the fine rhetoric of clothes with which its body is overlaid. The earliest edition of the romance in French prose was printed at Paris in 1525 . The earliest edition in English prose was printed by William Copland, who died before I 570 . 
The old Danish tale of "Friar Rush," a satire on the monks, is found in Low German verse of the end of the fifteenth or beginning of the sixteenth century. It was printed also in High German verse at Strasburg in $\mathbf{1 5}$ I5. It was printed again at Nürnberg soon after the middle of the sixteenth century, and again at Magdeburg in 1587 . Both in the Low German and the High German versions the Devil Russche or Rausch was received as cook in a Danish monastery to the north of the Lake of Esrom, where there is now, by its wooded shore, a village of that name, about eleven miles from Elsineur, in Seeland. Pontoppidan, in his "Theatrum Dania," says that before the Monastery of Esserum was made into a dwelling-house, Brother Rush's effigy was to be seen there, with an epitaph in lines each beginning with Latin words and ending with Danish. They showed also for a long time in the same monastery Brother Rush's cauldron and gridiron. There is a Danish poem on the subject, and also this popular tradition, translated by W. J. 'Ihom from. Thiele's "Danske Folksagn."

\section{"BROTHER RUSH.}

"It is related that when the Devil once upon a time saw how piously and virtuously the Monks lived in the Monastery of Esrom, he took upon himself the shape of a man, and went to the gate and knocked at it, for to be let in, saying that his name was Rush. Then he gave himself out that he was a Cook's-boy, and was received as such by the Abbot. But when he was once by himself with the Master Cook, he set himself up against him, and got himself therefore punishment. At this he was sore displeased; and as he had previously a cauldron with water over the fire, and he now perceived that it boiled, he took with all his might the Master Cook, and placing him head downwards in it, began thereupon to run about and to cry, lamenting the misfortune as if it had happened to his master in cooking. Thus he cheated in this manner with falsehood all the brothers in the cloister, that they thought him altogether free, and he was now appointed by them the Master Cook. But it was what he had 
strived after, in order that he might afterwards deprave them altogether; for now he cooked the meat so unctuously and lickerishly, that the monks neglected fasts and prayers, and gave themselves to feasting. Nay, it is said also that he brought women into the Monastery, and came thereby much in the Abbot's favour, so that he at last caused him to become a Brother, because he well desired constantly to have such a cook at hand. From that time strife and malice prevailed so severely in the Monastery that it had surely come in the power of the Evil One, if none of the Brethren had repented in time. For instance, once Brother Rush was in the wood, and having there seen a beautiful fat cow, he slew it, and took himself one quarter with him to the Monastery, but hung up the rest on a tree in the forest. Then presently came by the countryman who owned the cow ; and when he perceived how the three quarters hung in the tree, he hid himself in the other trees to watch until the thief fetched away the remainder. Then he saw, as he sat there, how the Devils had their sport in the forest, and heard much talking about Rush, how he would invite the Abbot and Monks to the banquet with him in Hell. This caused the countryman great alarm, and the next day he went to the Abbot and related to him all that he had seen and heard in the forest.

"When the Abbot heard this he caused all the monks to come to him in the church, and they began there to pray and to sing, so that Rush, as he could not abide the like, was desirous to sneak away. But the Abbot grasped him by the cloak and exorcised him into a red horse, and gave him into the power of Hell. For many years after these events they showed in the Monastery of Esrom Rush's Iron Cauldron and Gridiron."

Friar Rush comes, in fact, from the land of the Pucks. His legend abounds in touches common to the old Northern conceptions of a tricksy and malicious spirit, deepened afterwards in meaning by association with such satire on the earthly life of monks as we have in the old "Land of Cockayne." 
So ends the list of the good things in this hamper of romance, which is filled up, by way of packing-straw, with some of the "Hundred Merry Tales." He said "that I had my good wit out of the "Hundred Merry Tales," said Beatrice of Benedict. Only two copies of this once popular book are known, and they were both printed by John Rastell. One of them was partly recovered in $18{ }_{15}$ by the Rev. J. J. Conybeare, in leaves, from more than one copy of it that had been used in making the pasteboard found binding another book. It was reprinted at once after its discovery, by Mr. S. IV. Singer, in an edition of two hundred and fifty copies, and reprinted again in 1864 by $\mathrm{Mr}$. W. Carew Hazlitt, in the first of the three series of his pleasant collection of "Shakespeare Jest Books." In I866 Dr. Herman Oesterley published another edition of "A Hundred Merry Tales," from the other known copy, which is dated 1526 , and is in the Royal Library of the University of Göttingen, for which it was bought in 1768 at an auction in Lüneburg. The tales here used as packing-straw are taken from Dr. Herman Oesterley's edition of the complete book.

H. M.

CARISBROOKE, July 1889. 


\section{ELEVEN OF THE HUNDRED MERRY TALES.}

Of him that fayd that a womas tong was lightift met of degeftio.

A CERTAYN artificer in londõ there was which was fore fyk that coud not well dygeft hys mete/ to whõ a phyfycõ cam to gyue hym councell $\&$ feyd $y^{t}$ he mult vfe to ete metis $y^{t}$ be light of dygeftyon as fmall byrdys/ as fparous or fwallous \& efpecyall $y^{t}$ byrd $y^{t}$ ys callyd a wagtale whofe flefhe ys merueloufe lyght of dygeftyõ becaufe that byrd ys euer mouyng \& ftyryng. The fik man heryng the pheficion feyd fo anfweryd hym $\mathbb{S}$ feyd/Syr yf that be the caufe $y^{t}$ thofe birdys be lyght of dygeftyon/ Than I know a mete mych lyghter of dygeftion thã other fparow fwallow or wagtayle/ \& that ys my wyuys tõg for it is neuer in reft but euer mouying \& ftyrryng.

T By thys tale ye may lerne a good generall rule of phefyk.

Of the woman that folowyd her fourth hulbandys herce so zeept.

A woman ther was whych had had .iiii. hurbãdes. It fortunyd alfo that this fourth hufband died \& was brought to chirch vppon $y^{\mathrm{e}}$ bere/ whõ this womã folowyd $\&$ made gret mone \& wext very fory. In fo mych that her neybours thought the wold fowne \& dy for forow/ wherfor one of her gollyps cam to her \& fpake to her in her ere $\&$ bad her for goddes fake to comfort her felf $\&$ refrayne that lamentacõn or ellys it wold hurt her gretly \& pauenture put her in ieoperdy of her lyfe. To whõ this womã ãfweryd \& fayd/ 
I wys good gofyp I haue gret caufe to morne if ye knew all/ for I haue byryed .iii. huibandys befyde thys man/ but I was neuer i the cafe $y^{t} I$ am now/for there was not one of the but whe that I folowid the corfe to chyrch yet I was fure alway of an other hurbãd before that $y^{e}$ corfe cam out of my houfe/\& now I am fure of no nother hurband \& therfore ye may be fure I haue gret caufe to be fad and heuy.

I By thys tale ye may fe that the olde puerbe ys trew that yt is as gret pyte to fe a woman wepe as a gofe to go barefote.

\section{Of the woman that fayd her wooer came to late.}

A NOTHER woman there was that knclyd at $y^{\mathrm{e}}$ mas of requiẽ whyle the corfe of her hufbande lay on the bere in the chyrch. To whom a yonge man came to fpeke wyth her in her ere as thoughe hyt had bene for fom matre concernyng the funerallys/ howe be yt he fpake of no fuch matter but only wowyd her that he myghte be her hufbande/ to whome fhe anfweryde \& fayde thus/ Syr by my trouthe I am fory that ye come fo late/ for I am fped all redy/ For I was made fure yefter day to a nother man.

T By thys tale ye may perceyue that women ofte tymes be wyfe and lothe to lofe any tyme.

\section{- Of the horfman of yrelond that prayd Oconer to hang op} the frere.

ONe callyd Oconer an yrifh lorde toke an horfeman pryfoner that was one of hys gret enmys/ whiche for any requeft or yntrety $\mathrm{y}^{\mathrm{t}} \mathrm{y}^{\mathrm{e}}$ horfman made gaue iugement that he fhulde incõtynēt be hãgyd/ \& made a frere to Shryue hym and bad hym make hym redy to dye. Thys frere $y^{t}$ throue hym examyned hym of dyuers fynes \& afkyd hym amõg othere whyche were the grettyfte fynnys that euer he dyde/ thys horfeman anfweryd \& fayde one of the grettyft actys that euer I dyde whyche I now moft repent is that when I toke Oconer the lafte weke in a churche and ther I myght haue brennyd hym church and all \& becaufe I had confcyence 
\& pyte of brennyng of the church $I$ taryed $y^{e}$ tyme fo long $y^{e}$ oconer efcaped/\& that fame deferring of brennyng of the church $\&$ fo long taryeng of that tyme is one of the worlt actys $y^{t}$ euer I dyd wherof I molte repente/ Thys frere perceyuyng hym in that mynd fayd pece man in the name of god $\&$ change $y^{t}$ mynde $\&$ dye in charite or els thou fhalt neuer come in heuen/ nay quod the hors man I wyll neuer change $y^{t}$ mynde what fo euer fhall come to my foule/ thys frere pceyuyng hym thys ftyll to contynew hys mïde cã to oconer \& feyd fyr in $y^{\mathbf{e}}$ name of god haue fome pyte vppõ.thys mannys fowle \& let hyn not dye now tyll he be in a better mynde/ For yf he dye now he ys fo far out of charyte $\mathrm{y}^{\mathrm{t}}$ vtterly hys foule thalle be dampnyd/ and fhewyd hym what mynde he was in \& all the hole matter as ys before fhewyd. Thys horfman heryng $y^{e}$ frere thys intrete for hym fayd to oconer thys/ Oconer thou feeyit well by thys mannys reporte $y^{t}$ yf I dye now I am out of charyte \& not redy to go to heuen \& fo it ys $y^{t} I$ am now out of charyte in dede/ but thou feeft well $y^{t}$ this frere ys a good man he is now well dyfpofyd \& in charyte/ and he is redy to go to heuen \& fo am not I/ therfore I pray the hang vp thys frere whyle that he hys redy to go to heuyn and lette me tary tyl a nother tyme $y^{t}$ I may be $\tilde{i}$ charyte and redy \& mete to go to heuyn. This Oconer heryng this mad anfwere of hym fparyd the man \& forgaue hym hys lyfe at that feafon.

I By thys ye may fe that he that is in daunger of his enmye $\mathrm{y}^{t}$ hath no pyte/ he can do no better than fhew to hym the vttermorte of hys malycyous mynde whych that he beryth toward hym.

\section{Of the preft that fayd nother corpus meus nor corpum metum.}

THE archdekyn of Effex $y^{t}$ had bene long in auctoryte in a tyme of vyfytacion when all the preeftys apperyd before hym callyd afyde .iii. of $y^{e}$ yõg preftys whych were accufyd $y^{t}$ they coud not well fay theyr deuyne feruyce/ $\&$ afkyd of thẽ whẽ they fayd mas whether they fayd corpus meus or corpũ meũ. The furit preeft fayd $y^{t}$ he fayd corpus meus. The fecõd fayd $y^{t}$ he fayd corpũ meũ. And thẽ he ankyd of the thyrd how he fayd/ whych 
anfweryd \& fayd thus/ fyr becaufe it is fo gret a dout $\&$ dyuers men be in dyuers opynyons/ therfore becaufe I wold be fure I wold not offend whẽ I come to $y^{e}$ place I leue it clene out $\&$ fay nothyng therfore/ wherfore he then openly rebukyd them all thre. But dyuers that were prefent thought more defaut in hym becaufe he hym felfe before tyme had admyttyd them to be preetìs.

I By thys tale ye may fe that one ought to take hede how he rebukyth an other left it torne moft to hys owne rebuke.

\section{Of the .ii. frerys wherof the one louyd not the ele hed nor the other the tayle.}

Two frerys fat at a gentylmans tabyll whych had before hym õ a faftyng day an ele $\&$ cut the hed of the ele \& layd it vppõ one of $y^{e}$ Freres trẽchars/ but the Frere becaufe he wold haue had of $y^{e}$ myddyll part of the ele fayd to the gentylman he louyd no ele heddes/ this gentylman alio cut the tayle of $y^{\mathrm{e}}$ ele \& leyd it on the other Freres trẽchar/ he lykewyfe becaufe he wold haue had of the myddyll pte of $y^{\mathbf{e}}$ ele fayd he louyd no ele taylys. Thys gentylmã perceyuyng that: gaue the tayle to the Frere $y^{t}$ fayd he louyd not the hed/ \& gate the hed to hym that fayd he louyd not $y^{e}$ tayle. And as for the myddell part of the ele he ete part him felf \& part he gaue' to other folke at $y^{e}$ table/ wherfore thefe freres for anger wold ete neuer a moffell/ \& fo they for all theyr craft \& fubtylte were not onely deceyued of $\mathbf{y}^{\mathrm{e}}$ beft moffel of $\mathrm{y}^{\mathrm{e}}$ ele/ but therof had no part at al.

I $\mathrm{By}$ this ye fe that they that couet the beft part fomtyme therfore lofe the meane part and all.

Of the welchma that fhroue hym for brekyng his faft on the fryday.

A Wélchman dwellynge in a wylde place of walys came to hys curate in the tyme of lent $\&$ was corfeffed. \& when his confeffyon 'was in nuaner at the end the curate afked him whether he had any other thyng to say $y^{t}$ greuyd his cõfcyẽce/ whych fore 
abafshyd anfweryd no word a gret whyle/ at laft by exortacion of hys gooftly fader he fayd $y^{t}$ there was one thyng in his mynd that gretly greuyd his cõfciēce which he was afhamed to vtter/ for it was fo greuous $\mathrm{y}^{\mathrm{t}}$ he trowid god wold neuer forgyue hym/ to whom the curate ãfweryd \& fayd $\mathrm{y}^{\mathrm{t}}$ goddys mercy was aboue all/ $\&$ bad hym not dyfpayre in the mercy of god/ For what fo euer it was yf he were repentaũte $y^{t}$ god wold forgyue him/ And fo by long exortacion at the latt he thewyd it \& feyd thus/ Syr it happenyd onis that as my wyfe was making a chefe vppon a fryday I wold haue fayed whether it had ben falt or freth and toke a lytyll of the whey in my hand \& put it in my mouth \& or I was ware part of it went downe my throte agaynft my wyll \& fo I brake my faft/ to whom the curate fayd $\&$ if ther be no nother thyng I warant god thall forgiue the. So whã he had well comfortyd hym $w^{t} y^{e}$ mercy of god the curate prayd hym to anfwer a queltion \& to tell hym treuth/\& when the welchman had promyfyd to tell the treuth/the curate fayd that there were robberys and murders done nye the place where he dwelt \& dyuers men foũd flayne \& alkyd hym whether he were coofentyng to any of them/ to whõ he anfwerid \& rayd yes \& fayd he was ptee to many of them $\&$ dyd helpe to robbe and to fle dyuers of them. Then the curate afkyd hym why he dyd not cõfeffe him therof/ the welch man ãiweryd \& layd he toke $\mathrm{y}^{\mathrm{t}}$ for no fynne for it was a cuftome amonge them $\mathrm{y}^{\mathrm{t}}$ whan any boty came of any rych merchaunt rydyng $\mathrm{y}^{\mathrm{t}}$ it was but a good neybours dede one to help a nother when one callyd a nother/\& to they toke that but for good felyhisp \& neybourhod.

T Here ye may fe $y^{t}$, fome have remorfe of confcyence of fmall venyall finys $\&$ fere not to do gret offencys $w^{t}$ out thame of $y^{\mathrm{e}}$ world or drede of god : $\&$ as $y^{\mathrm{e}}$ cõen puerb is they ftũble at a ftraw \& lepe ouer a blok.

Of the merchañt of londõ that put nobles $\tilde{\imath}$ his mouth $\check{\imath}$ his deth bed.

A RYCH couetous marchãte ther was $y^{t}$ dwellyd in Lõdon whych euer gaderyd money \& coud neuer fynd in hys hert to ipend 
noght vppon hym felf nor vppon no mã els/ whych fell fore fyk/ $\&$ as he lay on hys deth bed had hys purs lyeng at hys beddys hed $/ \&$ had fuche a loue to hys money that he put his hand in his purs $\&$ toke out thereof .x. or .xii. li i nobles \& put them in his mouth/ And becaufe his wyfe and other pceyuyd him very fyk and lyke to dye they exortyd hym to be confeffyd and brought $y^{e}$ curate vnto him/ whych when they had caufyd hym to fey Benedicite $y^{\mathrm{e}}$ curat bad hym cry god mercy \& fhew his fynnys. Than this fyk man began to fey 1 cry god mercy I haue offendyd in $y^{\mathrm{e}} \cdot \mathrm{vij}$. dedly fynnys \& broken the .x. comaundementys/ \& becaufe of the gold in hys mouth he mufflede fo in hys fpeche that the curate cowde not well vnderftande hym/ wherefore the curate afked hym what he hadde in hys mouthe that letted hys ipeche/ I wys maftere perfone quod the fyk man muffelynge I haue nothyng in my mouth but a lyttyll money becaufe I wot not whether I thall go 1 thoughte I wolde take fome fpendyng money wyth me for I wot not what nede I thall haue therof/ And incontynent after that feyynge dyed before he was confeffed or repentant that ony man could perceue/ and fo by lykelyhode went to the deuyll.

I By thys tale ye may fe that they that all theyre lyuys wylle neuer do charyte to theyr neyghbours/ that god in tyme of theyr dethe wyll not fuffer them to haue grace of repentaunce.

\section{Of the mylner that ftale the nuttys \& of the tayler that ftale a fheep.}

THERE was a certayn ryche hufbandman in a vyllage whych loued nottes merueloufly well \& fet trees of filberdys \& other nut trees in his orchard/ \& norifhid them well all hys lyfe/ \& when he dyed he made hys executours to make promife to bery $w^{t}$ hym yn hys graue a bage of nottis or els they fholde not be hys executours/ which executours for fere of lofyng theyre romys fulfyllyd hys wyll \& dyd fo. It happenyd $y^{t}$ the fame nyght after that he was beryed there was a mylnere in a whyte cote came to this mãys garden to thẽtẽt to ftele a bag of nottis/\& in $y^{e}$ way he met $w^{t}$ a tayler in a blak cote an vnthrift of hys accoyntaũce \& Ihewyd hym hys intent/ This tayler lykewyie fhewyd 
hym $y^{t}$ he intẽdyd $y^{e}$ fame tyme to ftele a fhepe/ \& fo they both there agreyd to go forthward euery man feuerally $w^{t}$ hys purpofe $\&$ after $y^{t}$ they apoynted to make good chere ech $w^{t}$ other \& to mete agayne in $y^{e}$ chyrch porch/\& he that came furf to tary for the other.

This mylner when he had fpede of hys nottis came furft to the chyrch porche $\&$ there taryed for hys felowe and the mene whyle fatte ftyll there \& knakked nottys.

It fortuned than the fexten of the church becaufe yt was abowt .ix. of the clok cam to ryng curfu. \& when he lokyd in $y^{\mathrm{e}}$ porch \& faw one all in whyte knakkyng nottes/ he had went it had bene $\mathrm{y}^{\mathrm{e}}$ dede man ryfen owt of hys graue knakkynge $\mathrm{y}^{\mathrm{e}}$ nottes $\mathrm{y}^{\mathrm{t}}$ were byryed $\mathrm{w}^{\mathrm{t}}$ hym $\&$ ran home agayn in all haft and tolde to a krepyll $y^{t}$ was in hys howfe what he had fene. This crepyll thus heryng rebukyd $y^{e}$ fexten \& feyd $y^{t} y f$ he were able to go he wold go thyder \& cõiure $y^{\mathrm{e}}$ fprite/ by my trouth quod $\mathrm{y}^{\mathrm{e}}$ fexten $\&$ yf thou darft do $y^{t} I$ wyl bere the on my nek \& fo they both agreed. The fexten toke $y^{e}$ crepul on hys nek \& cam in to $y^{e}$ chyrchyard agayn/ \& $y^{e}$ mylner in $y^{e}$ porch faw one comyng bering a thing on his bak had went it had ben $y^{e}$ taylour cõmyng $w^{t}$ the Thepe \& rofe vp to mete thẽ/\& as he cam towarde the he ankeyd \& feyd/ Is he fat/ is he fat/ $y^{e}$ fexten heryng. hym fey fo/ for fere caft the crepull down \& feyd fat or lene take hym ther for me/ and ran away/ \& the creple by myracle was made hole $\&$ rã away as faft as he or fafter/ This mylner perceyuing $\mathrm{y}^{t}$ they were .ii. \& $y^{t}$ one ran after a nother fuppofyng $y^{t}$ one had fpyed $y^{e}$ tayler ftelyng $y^{e}$ thepe $\& y^{t}$ he had ron after hym to haue taken hym/ and fered $y^{t}$ fom body alfo had fpyed hym ftelyng nottes he for fere left hys nottes behynd hym and as fecretly as he cowde ran home to hys myll/ And anon after $\mathrm{y}^{\mathrm{t}}$ he was gon $\mathrm{y}^{\mathrm{e}}$ tayler cam $w^{t}$ the ftolyn thepe vppon hys nek to the chyrch porch to feke the mylner \& when he fownd ther the not thalys he fuppofyd $\mathrm{y}^{\mathrm{t}}$ hys felow had be ther and gone home as he was in dede/ wherefore he toke $\mathrm{vp} \mathrm{y}^{\mathrm{e}}$ thepe agayne on hys nek and went to ward the $\mathrm{myl} /$ But yet duryng this whyle the fexte which ran away wẹnt not to hys owne houfe but wêt to the pyrh pryftis chãber/ 
\& Thewd hym how the fpryte of $y^{\mathrm{e}}$ man was ryfẽ out of hys graue knakkig nottes as ye haue hard before/ wherfor $y^{e}$ preft fayd that he wold go cõiure hym yf the fexten wold go wt hym/ \& fo they both agreed/ $\mathbf{y}^{\mathrm{e}}$ preft dyd on hys furples \& a ftole about hys nek $\&$ toke holy water $\mathrm{w}^{t}$ hym and cam $\mathrm{w}^{t}$ the fextẽ toward $\mathrm{y}^{\mathrm{e}}$ church/ $\&$ as fone as he enteryd in to $y^{e}$ church yarde, The tayler $w^{t}$ the whyte thepe on hys nek intendyng as I before haue hewid yow to go down to $\mathrm{y}^{\mathrm{e}}$ myll met $\mathrm{w}^{\mathrm{t}}$ them $\mathcal{S}$ had went $\mathrm{y}^{\mathrm{t}} \mathrm{y}^{\mathrm{e}}$ preft in hys furples had ben $\mathrm{y}^{\mathrm{e}}$ mylner in hys whyte cote/ \& feyd to hym by god I haue hym I haue hym meanyng by the thepe $y^{t}$ he had ftolyn/ the preft-perceyuynge the tayler all in blak \& a whyte thyng on his nek had went it had ben $y^{\mathrm{e}}$ deuyll beryng away the fpryte of $y^{e}$ dede man $y^{t}$ was beryed $\&$ ran away as fatte as he coud takyng $y^{e}$ way downe toward the myll/ \& $y^{e}$ fexten ronnyng after hĩ. This tayler feyng one folowyng hĩ had went $y^{t}$ one had folowed the mylner to haue don hym fome hurt \& thought he wold folow if nede were to help $y^{e}$ mylner. \& went forth tyl he cam to the myll \& knokked at $y^{\mathrm{e}}$ myldore/ $\mathrm{y}^{\mathrm{e}}$ mylner beyng $w^{\mathrm{t}} \mathrm{yn}$ afked who was ther $y^{e}$ tayler ãfwerd $\&$ faid by god I haue caught one of them \& made hi fure $\&$ tyed hym faft by $y^{\mathbf{e}}$ leggys menynge by the thepe $y^{t}$ he had itolen \& had the on hys nek tyed fait by the leggys. But $y^{e}$ mylner heryng hym fey $y^{t}$ he had hym tyed faft by the leggys had wente it had bẽ the conttable $y^{t}$ had take the tayler for ftelyng of the fhepe $\&$ had tyed him by the leggys/ $\&$ ferid $y^{t}$ he had comen to haue taken hym alfo for Atelyng of the nottys/ wherfore the mylner openyd a bak dore \& ran away as faft as he coud. The taylour heryng the bak dore openyng wẽt on $y^{\mathrm{e}}$ other fyde of $\mathrm{y}^{\mathrm{e}}$ myll/ \& there faw the mylner ronnyng away/ \& ftode there a littyll whyle mufyng $w^{t} y^{e}$ fhepe on his nek. Then was the parym preeft \& the fexte ftandyng there vnder the mylhoufe hydyng them for fere \& faw the taylour agayn $w^{t} y^{e}$ thepe on his nek had wend ftyll it had bene the dyuyll $w^{t}$ the fpryt of the dede man on hys nek $\&$ for fere ran away/ but becaufe they knew not the ground well/ the preeft lepte into a dyche almoft ouer the hed lyke to be drounyd that he cryed wyth a loud voyce help help. Then the taylour lokyd about \& faw 
the mylner roñe away $\&$ the fexten a nother way $\&$ hard the preeft cry help: had wend it had bene the corftable $w^{t}$ a gret cõpany cryeng for help to take hym $\&$ to bryng hym to pryfon for ftelyng of $y^{e}$ thepe wherfore he threw downe the thepe \& ran away a nother way as falte as he coud/ $\&$ fo euery man was afferd of other wythout caufe.

व By thys ye may fe well it is foly for any man to fere a thyng to mych tyll that he fe fome proue or caufe.

\section{Of the woman that poworyd the potage in the Tugoys male.}

There was a iuftyce but late in $y^{e}$ realme of englond called mafter Uauyfour a very homly man \& rude of condycions \& louyd neuer to fpẽd mych money/ This mafter Uauyfour rode on a tyme in hys cyrcute in a place of the north cõtrey where he had agreed $w^{t}$ the fhyryf for a certayn fome of money for hys chargys thorowe the fhyre/ fo that at euery Inne \& lodgyng thys mafter vauefour payd for hys own coftys. It fortunyd fo $y^{t}$ when he cam to a certayn lodgyng he cõmaunded one Torpyn hys feruãt to fe $y^{t}$ he vfed good hulbondry \& to faue fuche thynges as were laft $\&$ to cary it $\mathrm{w}^{\mathrm{t}}$ hym to ferue hym at the next baytyng. Thys Torpyn doyng hys mafters cõmaũdemẽt toke $\mathrm{y}^{\mathrm{e}}$ brokyn brede brokyn mete $\&$ all fych thig $y^{t}$ was laft $\&$ put it in hys male/ 'The wyfe of $y^{\mathrm{e}}$ houfe pceyuyng $\mathrm{y}^{\mathrm{t}}$ he toke all fuche fragmentys \& vytayle $w^{t}$ hym $y^{t}$ was laft $\&$ put it in hys male/ the brought vp $y^{t}$ podege $y^{t}$ was laft $i$ the pot \& when torpyn had torned hys bak a lytyll fyde the pouryd $y^{\mathrm{e}}$ podege in to $y^{\mathrm{e}}$ male whych ran vpon hys robe of fkarlet $\&$ other hys garmẽtys \& rayed then very euyll that they were mych hurt therwt. Thys Torpyn fodeynly tornyd him \& faw it/ reuylyd the wyfe therfor $\&$ ran to hys mafter $\&$ told hym what the had don/ wherfor mafter Uauefour incõtinẽt callyd $y^{\mathrm{e}}$ wyfe \& feyd to her thus. Thou drab quod he what haft thou dõ why haft thou pouryd $y^{\mathrm{e}}$ podege in my male $\&$ marryd my raymẽt $\&$ gere/ O fyr quod $y^{\mathrm{e}}$ wyfe I know well ye ar a iudge of $\mathrm{y}^{\mathrm{e}}$ realme/ \& I perceyue by you : your mid is to do ryght $\&$ to haue that that is your owne/ $\&$ your mynd is to haue all thyng $w^{t}$ you $y^{t}$ ye haue payd for/both brokyn brede mete 
\& other thynges $y^{t}$ is left : \& fo it is reafon that ye haue/ \& therfore becaufe your feruant hath taken the brede \& the mete \& put it i your male I have therfore put in your male the podege $y^{t}$ be laft becaufe ye haue well \& truly payd for them for yf I muld kepe ony thyng from you $y^{t}$ ye haue payd for : peraduenture ye wold troble me in the law an other tyme.

T Here ye may fe $y^{t}$ he $y^{t}$ playth the nygarde to mych fometyme yt torneth hym to hys owne lorle.

\section{Of the man that wold haue the pot ftand there as he wold.}

A YoNGE man late maryed to a wyfe thowght it was good polycy to get the mayftry of her in the begynnynge. Cam to her the pot fethynge ouer $y^{e}$ fyre all though the mete therin were not inough fodenly cormaundyd her to take the pot from the fyre. whyche anfweryd \& fayde that $y^{e}$ mete was not redy to ete. And he fayd agayne I wyll haue it taken of for my pleafure. This good woman loth yet to offend hym fet $y^{e}$ pot befyde the fyre as he bad. And anone after he cõmaũded her to fet the pot behynde the dore/ \& the fayd therto agayne ye be not wyfe therin. But he precifely fayd it fholde be fo as he bad. And the gentylly agayne did his cõmaũdment. This man yet not fatysfyed cõmaunded her to fet the pot a hygh vpon the hen roft/ what quod $\mathrm{y}^{\mathrm{e}}$ wyf agayne I trow ye be mad. And he fyerfly than cõmaunded her to fet it there or els he fayd the fholde repẽt She fomewhat aferde to moue his pacience toke a ladder and fet it to the rooft/ and wẽt herfelf vp the ladder and toke the pot in her hande prayeng her hurbande than to holde the ladder faft for flydynge/ whiche fo dyd.

And whenne the hurbande lokyd vp and fawe the Potte ftande there on hyght he fayde thus. Io now ftandyth the pot there as I wolde haue it This wyfe herynge that fodenly pouryd the hote potage on his hed \& fayd thus. And now bene the potage there as I wolde haue them.

I By this tale men may fe it is no wyfedome for a man to attempte a meke womãs pacyẽce to far left it torne to his owne hurte $\&$ damage. 
THE HISTORY

OF

REYNARD THE FOX. 


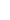

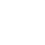




\section{EARLY PROSE ROMANCES. \\ I.}

THE HISTORY OF REYNARD :

THE FOX.

Here beginneth the History of Reynard the Fox.

In this hisforp ben written the parables, good lerynge, ${ }^{1}$ and diverse points to be marked, by which points men may learn to come to the subtle knowledge of such things as daily ben used and had in the counsels of lords and prelates, ghostly and worldly, and also among merchants and other common people. And this book is made for need and profit of all good folk, as far as they in reading or hearing of it shall mowe ${ }^{2}$ understand and feel the foresaid subtle deceits that daily ben used in the world; not to the intent that men should use them, but that every man should eschew and keep him from the subtle false shrews, that they be not deceived. Then who that will have the very understanding of this matter, he must oft and many times read in this book, and earnestly and diligently mark well that he readeth; for it is set subtlely, like as ye shall see in reading of it ; and not once to read it, for a man shall not with once over reading find the right understanding ne comprise it well ; but ofttimes to read it shall cause it well to be understood. And for them: that understandeth it, it shall be right joyous, pleasant, and profitable. 


\section{CHAPTER $\mathbf{I}$.}

How the Lion, King of all Beasts, sent out his commandments that all Beasts should come to his feast and Court.

Ir was about the time of Pentecost or Whitsuntide, that the woods commonly be lusty and gladsome, and the trees clad with leaves and blossoms, and the ground with herbs and flowers sweet smelling, and also the fowls and birds singing melodiously in their harmony, that the Lion, the noble King of all Beasts, would in the holy days of this feast hold an open Court at state; which he did to know ${ }^{1}$ over all in his land, and commanded by straight commissions and commandments that every Beast should come thither, in such wise that all the Beasts great and small came to the Court save Reynart the Fox: for he knew himself faulty and guilty in many things against many Beasts that thither should comen, that he durst not adventure to go thither. When the King of all Beasts had assembled all his Court, there was none of them all but that he had complained sore on Reynart the Fox.

\section{CHAPTER II.}

\section{The first complaint made Isegrim the Wolf on Reynart.}

ISEGRIM the Wolf, with his lineage and friends, came and stood before the King, and said, "High and Mighty Prince, my Lord the King, I beseech you that through your great might, right, and mercy, that ye will have pity on the great trespass and the unreasonable misdeeds that Reynart the Fox hath done to me and to my wife: that is to wit, he is comen in to my house against the will of my wife, and there he hath bepissed my children whereas they lay, in such wise as they thereof ben waxen blind. Whereupon was a day set, and was judged that Reynart should come and have excused him hereof, and have sworn on the holy saints that he was not guilty thereof. And

1 Dial to know, caused to be made known, 
when the book with the saints was brought forth, tho ${ }^{1}$ had Reynart bethought him otherwise, and went his way again into his hole, as he had naught set thereby. And, dear King, this knowen well many of the Beasts that now be comen hither to your Court. And yet hath he trespassed to me in many other things. He is not living that could tell all that I now leave untold. But the shame and villainy that he hath done my wife, that shall I never hide ne suffer it unavenged, but that he shall make to me large amends.

\section{CHAPTER III. \\ The complaint of Courtoys the Hound.}

WHEN these words were spoken, so stood there a little Hound and was named Courtoys, and complained to the King, how that in the cold winter in the hard frost he had ben sore forwintered, in such wise as he had kept no more meat than a pudding, which pudding Reynart the Fox had taken away from him.

\section{Tho spake Tybert the Cat.}

With this so came Tybert the Cat, with an irous ${ }^{2}$ mood, and sprang in among them, and said: "My Lord the King, I here hear that Reynart is sore complained on, and here is none but that he hath enough to do to clear himself. That Courtoys here complaineth of, that is passed many years gone, howbeit, that I complain not ; that pudding was mine, for I had won it by night in a mill. The miller lay and slept. If Courtoys had any part hereon, that came by me too."

Tho spake Panther, "Think ye, Tybert, that it were good that Reynart should not be complained on? He is a very murderer, a rover, and a thief, he loveth no man so well, not our Lord the King here, but that he well would that he should lose good and worship, so that he might win as much as a leg of a fat hen. I shall tell you what I saw him do yesterday to Cuwart the Hare, that here standeth in the King's peace and safeguard. He promised 
to Cuwart and said he would teach him his Credo, and make him a good chaplain. He made him go sit between his legs, and sang and cried loud, 'Credo, Credo!' My way lay ther by there that I heard this song. Tho went I near and found Master Reynart that had left that he first read and sang, and began to play his old play. For he had caught Cuwart by the throat, and had I not that time comen he should have taken his life from him, like as ye here may see on Cuwart the Hare the fresh wound yet. Forsooth, my Lord the King, if ye suffer this unpunished, and let him go quit that hath thus broken your peace, and will do no right after the sentence and judgment of your men, your children many years hereafter shall be misprised and blamed therefor."

"Sikerly, Panther," said Isegrim, "ye say truth. It were good that right and justice were done, for them that would fain live in peace."

\section{CHAPTER IV.}

How Grymbart the Dasse ${ }^{1}$ the Fox's sister's son spake for Reynart and answered tofore. the King.

Then spake Grymbart the Dasse, and was Reynart's sister's son, with an angry mood.

"Sir Isegrim that is evil said. It is a common proverb an enemy's mouth saith seld well. What lie ye and wite ${ }^{2}$ ye mine Eme $^{3}$ Reynart? I would that ye would adventure that who of you twain had most trespassed to other should hang by the neck as a thief on a tree. But and if he were as well in this court and as well with the King as ye be, it should not be thought in him that it were enow that ye should come and ask him forgiveness; ye have bitten and nipped mine uncle with your fell and sharp teeth many more times than I can tell . Yet will I tell some points that I well know. Know not ye how ye misdealed on the plaice which he threw down from the car, when ye followed after from afar, and ye ate the good plaice alone, and gave him no more than the grate or bones which ye might not eat yourself. In like-

1 Dasse, Badger (Dutch, dasje).

2 Wite, blame.

3 Eme, uncle. 
wise did ye to him also of the fat fitch of bacon which savoured so well that ye alone ate it in your belly, and when mine Eme asked his part tho answered ye him again in scorn, 'Reynart, fair youngling, I shall gladly give you your part'-but mine Eme gat ne had nought, ne was not the better. Notwithstanding he had won the flitch of bacon with great dresad, for the man came and threw him in a sack that he scarcely came out with his life. Such manner things hath Reynart many times suffered through Isegrim. O ye lordes, think ye that this is good? Yet is there more. He complaineth how that Reynart mine Eme hath much trespassed to him by cause of his wife. Mine Eme hath lain by her, but that is well seven years tofore, ere he wedded her; and if Reynart for love and courtesy did with her his will, what was that? She was soon healed thereof. Hereof by right should be no complaint, were Isegrim wise. He should have believed that he doth to himself no worship thus to slander his wife. She plaineth not. Now maketh Cuwart the Hare a complaint also. That thinketh me a vyseuase. ${ }^{1}$ If he read ne learned aright his lesson, should not Reynart his master beat him therefor? If the scholars were not beaten ne smitten and reprised ${ }^{2}$ of their truantry, they should never learn. Now complaineth Courtoys that he with pain had gotten a pudding in the winter, at such time as the $\operatorname{cost}^{3}$ is evil to find. Thereof him had be better to have held his peace, for he had stolen it. Male quasisti et male perdidisti. It is right that it be evil lost that is evil won. Who shall blame Reynart if he have taken from a thief stolen good. It is reason. Who that understandeth the law, and can discern the right, and that he be of high birth as mine Eme Reynart is, knoweth well how he shall resseyue stolen good. Yet all had he Courtoys hanged when he found him with the menour ${ }^{4}$ he had not much misdone nor trespassed, save against the Crown, that he had done justice without leave. Wherefore for the honour of the King he did it not, all hath he but little thanks. What scathed it him that he is thus complained

1 Visevase, wish-wash.

2 Reprised, reprehended.

3 Cost, food (kost).

4 With the menour, in the very act, i.e., with the thing stolen in his hands. 
on? Mine Eme is a gentle and true man. He may suffer no falsehood. He doth nothing but by his priest's counsel. And I say you, sith that my lord the King hath do proclaim ${ }^{I}$ his peace, he never thought to hurt any man; for he eateth no more than once a day; he liveth as a recluse; he chastiseth his body, and weareth a shirt of hair; it is more than a year that he hath eaten no flesh. As I yesterday heard say of them that came from him he hath left and given over his Castle Maleperduys and hath builded a cluse; therein dwelleth he and hunteth no more ne desireth no winning, but he liveth by alms and taketh nothing but such as men give him for charity, and doth great penance for his sins, and he is waxen much pale and lean of praying and waking, for he would be fain with God."

Thus as Grymbart his Eme stood and preached these words, so saw they coming down the hill to them Chanticleer the Cock and brought on a bier a dead hen of whom Reynart had bitten the head off, and that must be showed to the King for to have knowledge thereof.

\section{CHAPTER V. \\ How the Cock complained on Reynart.}

Chanticleer came forth and smote piteously his hands and his feathers; and on each side of the bier wenten tweyne sorrowful hens, that one was called Cantart and that other good hen Crayant, they were two the fairest hens that were between Holland and Arderne. These hens bare each of them a burning taper which was long and straight. These two hens were Coppen's sisters, and they cried so piteously "Alas and weleaway" for the death of their dear sister Coppen. Two young hens bare the bier, which cackled so heavily and wept so loud for the death of Coppen their mother, that it was very hard. Thus came they together tofore the King.

And Chanticleer tho said, "Merciful lord, my lord the King, please it you to hear our complaint and abhor the great scathe

1 Hath do proclaim, hath caused to be proclaimed. 
that Reynart hath done to me and my children that here stand. It was so that in the beginning of April, when the weather is fair, as that $I$, as hardy and proud because of the great lineage that I am come of and also had, for I had eight fair sons and seven fair daughters which my wife had hatched, and they were all strong and fat, and went in a yard which was walled round about, in which was a shed wherein were six great dogs which had totore and plucked many a beast's skin in such wise as my children were not afraid. On whom Reynart the thief had great envy because they were so sure that he could none get of them; how well. ofttimes hath this fell thief gone round about this wall and hath laid for us in such wise that the dogs have be set on him and have hunted him away; and once they leapt on him upon the bank, and that cost him somewhat for his theft: I saw that his skin smoked. Nevertheless he went his way. God amend it!

"Thus were we quit of Reynart a long while. At last came he in likeness of an hermit, and brought to me a letter for to read, sealed with the King's seal, in which stood written that the King had made peace over all in his realm, and that all manner beasts and fowls should do none harm nor scathe to any other. Yet said he to me more that he was a cloisterer or a closed recluse becomen, and that he would receive great penance for his sins. He showed me his slavyne and pylche ${ }^{1}$ and an hairen shirt thereunder, and then said he, "Sir Chanticleer after this time be no more afraid of me, ne take no heed, for I now will eat no more flesh. I am forthon so old that I would fain remember my soul. I will now go forth, for I have yet to say my sexte, none, and mine evensong. To God I betake 2 you." Tho went Reynart thence, saying his Credo, and laid him under an hawthorn. Then I was glad and merry, and also took none heed, and went to my children and clucked them together, and went without the wall for to walk; whereof is much harm comen to us, for Reynart lay under a bush and came creeping between us and the gate, so that he caught one of my children and laid him in his male. ${ }^{3}$ Whereof

1 Slavyne and pilch, old shoes (Dutch, sloffen) and skincoat.

2 Betake, commend, entrust, 3 Male, bag, wallet. 
we have great harm, for sith he hath tasted of him there might never hunter ne hound save ne keep him from us. He hath waited by night and day in such wise that he hath stolen so many of my children that of fifteen I have but four, in such wise hath this thief forslongen ${ }^{1}$ them. And yet yesterday was Coppen my daughter, that here lieth upon the bier, with the hounds rescued. This complain I to you, gracious King, have pity on mine great and unreasonable damage and loss of my fair children!"

\section{CHAPTER VI.}

How the King spake touching this complaint.

Then spake the King:

"Sir Dasse, hear ye this well of the recluse of your Eme? He hath fasted and prayed, that if I live a year he shall abye ${ }^{2}$ it. Now hark, Chanticleer, your plaint is enough. Your daughter that lieth here dead, we will give to her the death's rite. We may keep her no longer, we will betake her to God. We will sing her vigil and bring her worshipfully on earth, and then we will speak with these lords and take counsel how we may do right and justice of this great murder, and bring this false thief to the law.

Tho began they Placebo domino, with the verses that to longen, ${ }^{3}$ which if I should say were me too long. When this vigil was done and the commendation, she was laid in the pit, and there upon her was laid a marble stone polished as clear as any glass, and thereon was hewen in great letters in this wise: COPPE CHANTEKLERS DOUGHTER, WHOM REYNART THE FOX HATH BYTEN, LYETH HIER VNDER BURYED, COMPLAYNE YE HER FFOR, SHE IS SHAMEFULLY COMEN TO HER DETH.

After this, the King sent for his lords and the wisest of his council for to take advice how this great murder and trespass should be punished on Reynart the Fox. There was concluded

1 Forslongen (verschlungen), swallowed.

2 Abye, pay for. 3 To longen, belong thereto, 
and appointed for the best that Reynart should be sent for, and that he left not for any cause, but he came into the King's court for to hear what should be said to him; and that Bruin the Bear should do the message.

The King thought that all this was good and said to Bruin the Bear, "Sir Bruin, I will that ye do this message; but see well to for yourself, for Reynart is a shrew, and fell, ${ }^{1}$ and knoweth so many wiles that he shall lie and flatter, and shall think how he may beguile, deceive, and bring you to some mockery."

Then said Bruin, "What, good lord, let it alone! Deceiveth me the Fox, so have I ill learned my casus. I trow he shall come too late to mock me." Thus departed Bruin merrily from thence, but it is to dread that he came not so merrily again.

\section{CHAPTER VII.}

\section{How Bruin the Bear was sped of Reynart the Fox.}

Now is Bruin gone on his way toward the Fox with a stout mood, which supposed well that the Fox should not have beguiled him. As he came in a dark wood in a forest whereas Reynart had a bypath when he was hunted, there beside was an high mountain and land, and there must Bruin in the middle goon over for to go to Maleperduys. For Reynart had many a dwelling-place, but the Castle of Maleperduys was the best and the fastest burgh that he had. There lay he in when he had need, and was in any dread or fear. Now when Bruin was comen to Maleperduys, he found the gate fast shut. Tho went he tofore the gate, and sat upon his tail, and called, "Reynart, be ye at home? I am Browning. The King hath sent me for you that you should come to Court, for to plead your cause. He hath sworn there by his God, come ye not, or bring I you not with me, for to abide such right and sentence as shall be there given, it shall cost you your life. He will hang you or set you on the rack. Reynart, do by my counsel, and come to the Court." 
Reynart lay within the gate, as he oft was wont to do, for the warmth of the sun. When Reynart heard Bruin, tho went he inward into his hole. For Maleperduys was full of holes, here one hole and there another, and yonder another, narrow, crooked and long, with many ways to go out, which he opened and shut after that he had need. When he had any prey brought home, or that he wist that any sought him for his misdeeds and trespasses, then he ran and hid him from his enemies into his secret chambers, that they could not find him; by which he deceived many a beast that sought him. And tho thought Reynard in himself how he might best bring the Bear in charge and need, and that he abode in worship.

In this thought Reynart came out, and said, "Bruin, Eme, ye be welcome! I heard you well tofore, but I was in mine evensong, therefore have I the longer tarried a little. Dear Eme, he hath done to you no good service, and I con him no thank, ${ }^{1}$ that hath sent you over this long hill; for I see that ye be also weary, that the sweat runneth down by your cheeks. It was no need : I had nevertheless comen to Court to-morrow: but I sorrow now the less, for your wise counsel shall well help me in the Court. And could the King find none less messenger but you for to send hither? That is great wonder. For next the King ye be the most gentle, and richest of levies and of land. I would well that we were now at the Court, but I fear me that I shall not con well go thither, for I have eaten so much new meat that me thinketh my belly will break or cleave asunder, and because the meat was new I ate the more."

Tho spake the Bear, "Lief Neve, ${ }^{2}$ what meat have ye eaten that maked you so full?"

"Dear Eme, that I ate, what might it help you that if I told you? I ate but simple meat. A poor man is no lord, that may ye know, Eme, by me. We poor folk must eat ofttimes such as we gladly would not eat if we had better. They were great honey-

1 Con him no thank. To can or con thank was an old phrase for acknowledgment of thanks due.

2 Lief neve, dear nephew, 
combs; which I must needs eat for hunger. They have made my belly so'great that I can nowhere endure."

Bruin then spake anon, "Alas, Reynart, what say ye! Set ye so little by honey? Me ougint to prize and love it above all meat. Lief Reynart, help me that I might get a deal of this honey, and as long as I live I shall be to you a true friend, and abide by you, as far as ye help me that I may have a part of this honey."

\section{CHAPTER .VIII.}

\section{How Bruin ate the honey.}

BRUIN, Eme, I had supposed that ye had japed ${ }^{1}$ therewith."

"So help me God, Reynart, nay. I should not gladly jape with you."

Then spake the red Reynart, "Is it then earnest, that ye love so well the honey? I shall do let you have so much that ten of you should not eat it at one meal, might I get therewith your friendship."

"Not we ten, Reynart Neve!" said the Bear. "How should that be? Had I all the honey that is between this and Portugal I should well eat it alone."

Reynart said, "What say ye, Eme? Hereby dwelleth an husbandman named Lantfert, which hath so much honey that ye should not eat in seven years; which ye shall have in your hold if ye will be to me friendly and helping against mine enemies in the King's Court."

Then promised Bruin the Bear to him, that if he might have his beliy full he would truly be to him tofore all other a faithful friend.

Hereof laughed Reynart the shrew, ${ }^{2}$ and said, "If ye would have seven hamper barrels full I shall well get them and help you to have them." These words pleased the Bear so well, and made him so much to laugh that he could not well stand.

Tho thought Reynart, "This is good luck; I shall lead him thither that he shall laugh by measure."
1 Japed, jested.
2 Shrew, malicious deceiver. 
Reynart said then, " This matter may not be long tarried. I must pain myself for you. Ye shall well understand the very yonste $^{1}$ and good will that I bear to you ward. I know none in all my lineage that I now would labour for thus sore."

That thanked him the Bear and thought he tarried long.

"Now, Eme, let us go a good pace, and follow ye me. I shall make you to have as much honey as ye may bear." The Fox meant, of good strokes; but the caitiff marked not what the Fox meant; and they went so long together, that they came unto Lantfert's yard. Tho was sir Bruin merry.

Now hark of Lantfert. Is it true that men say, so was Lantfert a strong carpenter of great timber, and had brought that other day tofore into his yard a great oak, which he had begun to cleave. And as men be woned ${ }^{2}$ he had smitten two betels ${ }^{3}$ therein one after that other, in such wise the oak was wide open. Whereof Reynart was glad, for he had found it right as he wished, and said to the Bear all laughing, "See now well sharply to! In this tree is so much honey that it is without measure. Assay if ye can come therein, and eat but little, for though the honeycombs be sweet and good, yet beware that ye eat not too many, but take of them by measure, that ye catch no harm in your body; for, sweet Eme, I should be blamed if they did you any harm."

"What, Reynart, cousin, sorrow ye not for me! Ween ye that I were a fool?"

"Measure is good in all meat," Reynart said. "Ye say truth. Wherefore should I sorrow? Go to the end and creep therein."

Bruin the Bear hasted sore toward the honey, and trode in with his two foremost feet, and put his head over his ears into the clift of the tree. And Reynart sprang lightly and brake out the betle of the tree. Tho helped the Bear neither flattering ne chiding; he was fast shut in the tree. Thus hath the Neve, with deceit, brought his Eme in prison in the tree, in such wise as he could not get out with might ne with craft, head ne foot.

1 Yonste (gunst), favour.

3 Betels, heavy mallets used for beating in wedges, \&c. 
What profiteth Bruin the Bear that he strong and hardy is? That may not help him. He saw well that he was beguiled. $\mathrm{He}$ began to howl, and to bray, and crutched with the hinder feet, and made such a noise and rumour, that Lantfert came out hastily, and knew nothing what this might be, and brought in his hand a sharp hook. Bruin the Bear lay in the clift of the tree, in great fear and dread, and held fast his head, and nipped both his fore feet. He wrang, he wrestled, and cried, and all was for naught. He wist not how he might get out.

Reynart the Fox saw from far how that Lantfert the carpenter came, and tho spake Reynart to the Bear, "Is that honey good? How is it now? Eat not too much, it should do you harm; ye should not then well con go to the Court. When Lantfert cometh, if ye have well eaten he shall give you better to drink, and then it shall not stick in your throat."

After these words tho turned him Reynart toward his castle, and Lantfert came and found the Bear fast taken in the tree. Then ran he fast to his neighbours and said "Come all in to my yard, there is a bear taken!" The word anon sprang over all in the thorp. 'There ne bleef ${ }^{1}$ neither man ne wife, but all ran thither as fast as they could, every one with his weapon, some with a staff, some with a rake, some with a broom, some with a stake of the hedge, and some with a flail; and the priest of the church had the staff of the cross, and the clerk brought a vane. The priest's wife Julocke came with her distaff,--she sat tho and span, - there came old women that for age had not one tooth in their head.

Now was Bruin the Bear nigh much sorrow that he alone must stand against them all. When he heard all this great noise and cry he wrestled and plucked so hard and so sore that he gat out his head. But he left behind all the skin and both his ears, in such wise that never man saw fouler ne loather beast, for the blood ran over his eyes. And or he could get out his feet he must lete ${ }^{2}$ there his claws or nails and this rough hand. This market came to him evil, for he supposed never to have gone, his

$$
\text { i Bleef (blieb), remained. } \quad 2 \text { Lete, leave. }
$$


feet were so sore, and he might not see for the blood which ran so over his eyes.

Lantfert came to him with the priest, and forthwith all the parish, and began to smite and strike sore upon his head and visage. He received there many a sore stroke. Every man beware hereby: who hath harm and scathe, every man will be thereat and put more to. That was well seen on the Bear, for they were all fierce and wroth on the Bear, great and small, yea Hughelyn with the crooked leg, and Ludolf with the broad long nose, they were both wroth. That one had a leaden malle, and that other a great leaden wapper, therewith they wappred and all forslingred $^{1}$ hin, Sir Bertolt with the long fingers, Lantfert, and Ottram the long. This did to the Bear more harm than all the other, that one had a sharp hook and the other a crooked staff well leaded on the end for to play at the ball. Baetkyn and Aue, Abelquak, my dame Baue, and the priest with his staff, and dame Julocke his wife, these wroughten to the Bear so much harm that they would fain have brought him from his life to death, they smote and stack him all that they could.

Bruin the Bear sat and sighed and groaned, and must take such as was given to him. But Lantfert was the worthiest of birth of them all, and made most noise; for dame Pogge of Chafporte was his mother, and his father was Macob-the stoppelmaker, a much stout man. There as he was alone Bruin received of them many a cast of stones. Tofore them all sprang first Lantfert's brother with a staff, and smote the Bear on the head that he ne heard ne saw; and therewith the Bear sprang up between the bush and the river among a heap of wives, that he threw a deal of them in the river, which was wide and deep.

- There was the parson's wife one of them, wherefore he was full of sorrow when he saw his wife lie in the water. He lusted no longer to smite the Bear, but called, "Dame Julocke in the water! Now every man see to, All they that may help her!

1 Wappered and forslingered, beat at and overwhelmed with blows. The Low German slingen, to swallow, is to be distinguished from Low German, slingern, the word here. 
Be they men or women, I give to them all pardon of their penance, and release all their sins!" All they then left Bruin the Bear lie, and ciid that the priest bade.

When Bruin the Bear saw that they ran all from him, and ran to save the women, tho sprang he into the water and swam all that he could. Then made the priest a great shout and noise, and ran after the Bear with great anger, and said, "Come and turn again, thou false thief!" The Bear swam after the best of the stream and let them call and cry, for he was glad that he was so escaped from them. He cursed and banned the honey tree, and the Fox also that had so betrayed him that he had crept therein so deep that he lost both his hood and his ears. And so forth he drove in the stream well a two or three mile. Tho wax he so weary that he went to land for to sit and test him, for he was heavy; he groaned and sighed, and the blood leapt over his eyes, he drew his breath like as one should have died.

Now hark how the Fox did. Ere he came from Lantfert's house he had stolen a fat hen and had laid her in his male, and ran hastily away by a bye path where he weened that no man should have comen. He ran toward the river, that he sweat, he was so glad that he wist not what to do for joy, for he hoped that the Bear had been dead. He said, "I have now well sped, for he that should most have hindered me in the Court is now dead, and none shall wite ${ }^{1}$ me thereof, may I not, then, by right be well glad ?" With these words the Fox looked to the riverward, and espied where Bruin the Bear lay and rested him. Tho was the Fox sorrier and heavier than tofore was merry, and was as angry, and said in chiding to Lantfert, "Alas, Lantfert, lewd fool! God give him a shames death that hath lost such good venison, which is good and fat, and hath let him go which was taken to his hand! Many a man would gladly have eaten of him. He hath lost a rich and fat Bear." Thus all chiding he came to the river, where he found the Bear sore wounded, bebled, and right sick, which he might thank none better thereof than Reynart, which he spake to the Bear in scorn: 
"Chiere priestre, Dieu vous garde! Will ye see the red thief?"

Said the Bear to himself, "The ribaud and the fell deer, ${ }^{1}$ here I see him coming."

Then said the Fox, "Have ye aught forgotten at Lantfert's? Have ye also paid him for the honeycombs that ye stole from him? If ye have not, it were a great shame, and not honest; I will rather be the messenger myself for to go and pay him. Was the honey not good? I know yet more of the same prize. Dear Eme, tell me ere I go hence into what order will ye go that wear this new hood? Were ye a monk or an abbot? He that shaved your crown hath nipped off your ears, ye have lost your top and don off your gloves, I trow verily that ye will go sing compline."

All this heard Bruin the Bear, and waxed all angry, and sorry for he might not avenge him. He let the Fox say his will, and with great pain suffered it, and start again in the river, and swam down with the stream to that other side.

Now must he sorrow how that he should come to the Court, for he had lost his ears and the skin with the claws of his forefeet; for though a man should have slain him he could not go; and yet he must needs forth, but he wist not how.

Now hear how he did. He sat upon his hams and began to rustle over his tail ; and when he was so weary, he wentled ${ }^{2}$ and tumbled nigh half a mile; this did he with great pain so long till at last he came to the Court. And when he was seen so coning from far, some doubted what it might be that came so wenteling.

The King at last knew him, and was not well paid, ${ }^{3}$ and said, "This is Bruin the Bear, my friend! Lord God, who hath wounded him thus? $\mathrm{He}$ is passing red on his head: me thinketh he is hurt unto the death. Where may he have been?" Therewith is the Bear came tofore the king, and said:

1 Deer, wild beast.

2 Wentled, twisted, wriggled round and round. There is a mollusc called for its spiral "wentle-trap" from G. wendel-treppe, a winding staircase.

3 Paid, satisfied. 


\section{CHAPTER IX.}

The complaint of the Bear upon the Fox.

"I Complain to you, merciful lord, sir King, so as ye may see how that I am handied, praying you to avenge it upon Reynart the fell beast; for I have gotten this in your service. I have lost both my foremost feet, my cheeks, and mine ears, by his false deceit and treason."

The King said, "How durst this false thief Reynart do this? I say to you, Bruin, and swear by my crown, I shall so avenge you on him that ye shall con me thank!"

He sent for all the wise beasts and desired counsel how that he might avenge this over-great wrong that the Fox had done. Then the council concluded, old and young, that he should be sent for, and dayed ${ }^{1}$ earnestly again, for to abide such judgment as should there be given on him of all his trespasses. And they thought that the cat Tybert might best do this message if he would, for he is right wise. The King thought this counsel good.

\section{CHAPTER X.}

How the King sent another time Tybert the Cat for the Fox, and how Tybert sped with Reynart the Fox.

Then the King said, "Sir Tybert, ye shall now go to Reynart and say to him this second time, that he come to Court unto the plea for to answer; for though he be fell to other beasts, he trusteth you well and shall do by your counsel: And tell him if he come not he shall have the third warning and be dayed, and if he then come not, we shall proceed by right against him and all his lineage without mercy.

Tybert spake, "My lord the King, they that this counselled you were not my friends. What shall I do there? He will not, for me neither, come ne abide. I beseech you, dear King, send

1 Dayed, cited for an appointed day. 
some other to him. I am little and feeble. Bruin the Bear, which was so great and strong, could not bring him. How should I then take it on hand?"

"Nay," said the King, "Sir Tybert, ye ben wise and well learned. Though ye be not great, there lieth not on. Many do more with craft and cunning than with might and strength."

Then said the Cat, "Sith it must needs be done; I must then take it upon me. God give grace that I may well achieve it, for my heart is heavy, and evil willed thereto."

Tybert made him soon ready toward Maleperduys. And he saw from far come flying one of Saint Martin's birds, tho cried he loud and said, "All hail, gentle bird, turn thy wings hitherward, and fly on my right side." The bird flew forth upon a tree which stood on the left side of the Cat. Tho was Tybert woe; for he thought it was a shrewd token and a sign of harm. For if the bird had flown on his right side he had been merry and glad, but now he sorrowed that his journey should turn to unhappe. Nevertheless he did as many do, and gave to himself better hope than his heart said. He went and ran to Maleperduys ward, and there he found the Fox alone standing tofore his house.

Tybert said, "The rich God give you good even, Reynart. The King hath menaced you for to take your life from you if ye come not now with me to the court."

The Fox tho spake and said, "Tybert, my dear cousin, ye be right welcome. I would well truly that ye had much good luck." What hurted the Fox to speak fair. Though he said well, his heart thought it not, and that shall be seen ere they depart.

Reynart said, "Will we this night be together. I will make you good cheer, and to-morrow early in the dawning we will together go to the Court. Good Nephew, let us so do, I have none of my kin that I trust so much to as to you. Here was: Bruin the Bear,-the traitor! He looked so shrewdly on me, and methought he was so strong. that I would not for a thousand mark have gone with him; but, cousin, I will..tomorrow early go with you." 
Tybert said, "It is best that we now go, for the moon shineth all so light as it were day; I never saw fairer weather."

"Nay, dear cousin, such might meet us by day-time that would make us good cheer and by night peradventure might do us harm. It is suspicious to walk by night. Therefore abide this night here by me."

Tybert said, "What should we eat if we abode here?"

Reynart said, "Here is but little to eat. Ye may well have an honeycomb, good and sweet. What say ye, Tybert, will ye any thereof?"

Tybert answered, "I set nought thereby. Have ye nothing else? If ye gave me a good fat mouse I should be better pleased."

"A fat mouse!" said Reynart. "Dear cousin, what say ye? Hereby dwelleth a priest and hath a barn by his house; therein ben so many mice that a man should not lead them away upon a wain. I have heard the priest many times complain that they did him much harm."

"Oh, dear Reynart, lead me thither for all that I may do for you!"

"Yea, Tybert, say ye me truth? Love ye well mice?"

"If I love them well?" said the Cat. "I love mice better than anything that men give me. Know ye not that mice savour better than venison, yea, than flawnes ${ }^{1}$ or pasties? Will ye well do, so lead me thither where the mice ben, and then shall ye win my love, yea all had ye slain my father, mother, and all my kin."

Reynart said, "Ye mock and jape therewith."

The Cat said, "So help me God, I do not!"

"Tybert," said the Fox, "wist I that verily, I would yet this night make that ye should be full of mice."

"Reynart!" quoth he, "Full? That were many."

"Tybert, ye jape !"

"Reynart," quoth he, "in truth I do not. If I had a fat mouse I would not give it for a golden noble."

1 Flawns, custard tarts. 
"Let us go, then, Tybert," quoth the Fox, "I will bring you to the place ere I go from you."

"Reynart," quoth the Cat, "upon your safe-conduct, I would well go with you to Monpelier."

"Let us then go," said the Fox, "we tarry all too long."

Thus went they forth, without letting ${ }^{1}$ to the place whereas they would be, to the Priest's barn, which was fast walled about with a mud wall. And the night tofore the Fox had broken in, and had stolen from the Priest a good fat hen; and the Priest, all angry, had set a gryn ${ }^{2}$ tofore the hole to avenge him; for he would fain have taken the Fox. This knew well the fell thief, the Fox, and said, "Sir Tybert, cousin, creep into this hole, and ye shall not long tarry but that ye shall catch mice by great heaps. Hark how they pipe! When ye be full, come again; I will tarry here after you before this hole. We will to-morrow go togetiner to the Court. Tybert, why tarry ye thus long? Come off, and so may we return soon to my wife which waiteth after us, and shall make us good cheer."

Tybert said, "Reynart, cousin, is it then your counsel that $\mathbf{I}$ go into this hole? These Priests ben so wily and shrewish I dread to take harm."

"Oh ho, Tybert!" said the Fox, "I saw you never so sore afraid. What aileth you?"

The Cat was ashamed, and sprang into the hole. And anon he was caught in the gryn by the neck, ere he wist. Thus deceived Reynart his guest and cousin.

As Tybert was ware of the gryn, he was afraid and sprang forth; the gryn went to. Then he began to wrawen, for he was almost $y$-strangled. He called, he cried, and made a shrewd noise.

Reynart stood before the hole and heard all, and was well paid, and said, "Tybert, love ye well mice? Be they fat and good? Knew the Priest hereof, or Mertynet, they be so gentle that they would bring you sauce. Tybert, ye sing and eat, is

1 Letting, hindrance.

2 Gryn, snare or trap. A word used by Chaucer. 
that the guise of the Court? Lord God, if Isegrim were there by you, in such rest as ye now be, then should I be glad; for oft he hath done me scathe and harm."

Tybert could not go away, but he mawed and galped so loud, that Mertynet sprang up, and cried loud, "God be thanked, my gryn hath taken the thief that hath stolen our hens. Arise up, we will reward him!"

With these words arose the Priest in an evil time, and waked all them that were in the house, and cried with a loud voice, "The Fox is taken!"

There leapt and ran all that there was. The Priest himself ran, all mother naked. Mertynet was the first that came to Tybert. The Priest took to Locken his wife an offering candle, and bade her light it at the fire, and he smote Tybert with a great staff. There received Tybert many a great stroke over all his body. Mertynet was so angry that he smote the Cat an eye out. The naked Priest lift up and should have given a great stroke to Tybert, but Tybert that saw that he must die sprang between the Priest's legs with his claws and with his teeth. That leap became ill to the Priest and to his great shame.

When Dame Julocke knew that, she sware by her father's soul, that she would it had cost her all the offering of a whole year, that the Priest had not had that harm, hurt, and shame, and that it had not happened; and said, "In the Devil's name was the gryn there set! See Mertynet, lief son, this is a great shame and to me a great hurt!" The Fox stood without, tofore the hole, and heard all these words, and laughed so sore that he vnnethe ${ }^{1}$ could stand. Thus scorned and mocked the Fox the Priest's wife, Dame Julocke, that was full of sorrow. The Priest fell down aswoon. They took him up, and brought him again to bed. Tho went the Fox again in to his burgh ward and left Tibert the Cat in great dread and jeopardy, for the Fox wist none other but that the Cat was nigh dead. But when Tibert the Cat saw them all busy about the Priest, tho began he to bite and gnaw the gryn in the middle asunder, and sprang out of 
the hole, and went rolling and wentling towards the King's Court. Ere he came thither it was fair day, and the sun began to rise: And he came to the Court as a poor wight. He had caught harm at the Priest's house by the help and counsel of the Fox. His body was all tobeaten, and blind on the one eye. When the King wist this, that Tibert was thus arrayed, he was sore angry, and menaced Reynart the thief sore, and anon gathered his council to wit what they would advise him, how he might bring the Fox to the law, and how he should be fetched.

Tho spake Sir Grymbart, which was the Fox's sister son, and said, "Ye lords, though my. Eme were twice so bad and shrewish, yet is there remedy enough. Let him be done to as to a free man. When he shall be judged he must be warned the third time for all ; and if he come not then, he is then guilty in all the trespasses that ben laid against him and his, or complained on."

"Grymbart, who would ye that should go and daye him to come? Who will adventure for him his ears, his eye, or his life; which is so fell a beast? I trow there is none here so much a fool."

Grymbart spake, "So help me God, I am so much a fool that I will do this message myself to Reynart, if ye will command me."

\section{CHAPTER XI.}

How Grymbart the Dasse brought the Fox to the law tofore the King.

"Now go forth, Grymbart, and see well tofore you. Reynart is so fell and false, and so subtle, that ye need well to look about you and to beware of him."

Grymbart said he should see well to.

Thus went Grymbart to Maleperduys ward, and when he came thither he found Reynart the Fox at home, and Dame Ermelyn his wife lay with her whelps in a dark corner.

Tho spake Grymbart and saluted his Eme and his Aunt, and said to Reynart, "Eme, beware that your absence hurt you not in such matters as be laid and complained on you; but if ye 
think it good, it is high time that ye come with me to the Court. The withholding you from it can do you no good. There is much thing complained over you, and this is the third warning; and I tell you for truth, if ye abide to-morrow all day, there may no mercy help you. Ye shall see that within three days that your house shall be. besieged all about, and there shall be made tofore it gallows and rack. I say you truly ye shall not then escape, neither with wife ne with child, the King shall take all your lives from you. Therefore it is best that ye go with me to the Court. Your subtle wise counsel shall peradventure avail you. There ben greater adventures falle, ere this; for it may hap ye shall go quit of all the complaints that ben complained on you, and all your enemies shall abide in the shame. Ye have oftimes done more and greater things than this."

Reynart the Fox answered, "Ye say sooth. I trow it is best that I go with you, for there lacketh my counsel. Peradventure the King shall be merciful to me if I may come to speak with him, and see him under his eyen." Though I had done much more harm, the Court may not stand without me; that shall the King. well understand. Though some be so fell to me ward, yet it goeth not to the heart. All the council shall conclude much by me. Where great Courts ben gathered, of kings or of great lords, whereas needeth subtle counsel, there must Reynart find the subtle means. They may well speak and say their advice, but tho mine is best, and that goeth tofore all other. In the Court ben many that have sworn to do me the worst they can, and that causeth me a part to be heavy in my heart, for many may do more than one alone that shall hurt me. Nevertheless, nephew, it is better I go with you to the Court and answer for myself, than to set me my wife and my children in adventure for to be lost. "Arise up, let us go hence. $\mathrm{He}$ is over mighty for me. I must do as he will. I cannot better it ; I shall take it patiently and suffer it."

Reynart said to his wife Dame Ermelyn, "I betake you my children, that ye see weil to them and specially to Reynkin, my youngest son. He-beliketh me so well I hope he shall follow my steps. And there is Rossel a passing fair thief, I love them as well 
as any may love his children. If God give me grace that I may escape, I shall, when I come again, thank you with fair words." Thus took Reynart leave of his wife.

Ah, gods! how sorrowíl abode Ermelyn with her small whelps, for the victualler and he that sorrowed ${ }^{1}$ for Maleperduys was gone his way, and the house not purveyed nor victualled.

\section{CHAPTER XII.}

\section{How Reynart shrove him.}

WheN Reynart and Grymbart had gone a while together, tho said Reynart, "Dear Cousin, now am I in great fear, for I go in dread and jeopardy of my life. I have so much repentance for my sins that I will shrive me, dear Cousin, to you; here is none other priest to get. If I were shriven of my sins my soul should be the clearer."

Grymbart answered, "Eme, will ye shrive you, then must ye promise first to leave your stealing and roving."

Reynart said, that wist he well. "Now hark, dear Cousin, what I shall say. Confiteor tibi, pater, of all the misdeeds that I have done, and gladly will receive penance for them."

Grymbart said, "What say ye, will ye shrive you? Then say it in English, that I may understand you."

Reynart said, "I have trespassed against all the beasts that live; in especial against Bruin the Bear, mine Eme, whom I made his crown all bloody; and taught Tybert the Cat to catch mice, for I made her leap in a grynne where she was all to-beaten; also I have trespassed greatly against Chanticleer with his children, for I have made him quit of a great deal of them. The King is not gone all quit, I have slandered him and tie Queen many times, that they shail never be clear thereof. Yet have I beguiled. Isegrim the Wolf, oftener than I can tell well. I called him Eme, but that was to deceive him; he is nothing of my kin. I, made him a monk at Eelmare, where I myself also became one;

1 Sorrowed, took care (sorge). 
and that was to his hurt and no profit. I made bind his feet to the bell rope, the ringing of the bell thought him so good that he would learn to ring; whereof he had shame, for he rang so sore that all the folk in the street were afraid thereof and marvelled what might be on the bell, and ran thither tofore he had comen to axe the religion, wherefore he was beaten almost to the death. After this I taught him to catch fish, where he received many a stroke ; also I led him to the richest priest's house that was in Vermedos, this priest had a spynde wherein hung many a good flitch of bacon wherein many a time I was wont to fill my belly; in this spynde I had made an hole in which I made Isegrim to creep. There found he tubs with beef and many good flitches of bacon, whereof he ate so much without measure that he might not come out at the hole where he went in ; his belly was so great and full of the meat, and when he entered his belly was small; I went in to the village and made there a great shout and noise; yet hark what I did then, I ran to the priest where he sat at the table and ate, and had tofore him as fat capon as a man might find: that capon caught $I$, and ran my way therewith all that I might. The priest cried out, and said, 'Take and slay the Fox! I trow that man never'saw more wonder. The Fox cometh in my house and taketh my capon from my table: where saw ever man an hardier thief!' and as me thought he took his table knife and cast it at me, but he touched me not. I ran away, he shoved the table from him and followed me crying 'Kill and slay him!' I too go, and they after, and many moo came after, which all thought to hurt me.

"I ran so long that I came whereas Isegrim was, and there I let fall the capon, for it was too heavy for me, and against my will I left it there, and then I sprang through a hole whereas I would be. And as the priest took up the capon, he espied Isegrim and cried, 'Smite down here, friends, here is the thief, the Wolf! See well to, that he escape us not !' 'They ran all together with stocks and staves, and made a great noise, that all the neighbours camen out, and gave him many a shrewd stroke, and threw at him great stones, in such wise that he fell down as he had been 
dead. They slipped him and drew him over stones and over blocks without the village and threw him into a ditch, and there he lay all the night. I wot never how he came thence, sith I have goten of him, for as much as I made him to fill his belly, that he sware he would be mine help a whole year.

"Tho led I him to a place where I told him there were seven hens and a cock which sat on a perch and were much fat. And there stood a fall-door by, and we climbed thereup. I said to him if he would believe me, and that he would creep into the door, he should find many fat hens. Isegrim went all laughing to the doorward, and crept a little in, and tasted here and there, and at last he said to me, 'Reynart, ye bord and jape with me, for what I seek I find not.' Then said I, 'Eme, if ye will find, creep further in. He that will win, he must labour and adventure. They that were wont to sit there, I have them away.' Thus I made him to seek further in, and shoved him forth so far, that he fell down upon the floor, for the perch was narrow. And he fell so great a fall, that they sprang up all that slept, and they that next the fire cryden that the fall-door was open and something was falle, and they wist not what it might be. They rose up and light a candle, and when they saw him, they'smiten, beaten; and wounded him to the death. I have brought him thus in many a jeopardy, more than I can now reckon. I should find many more, if I me well bethought, which I shall tell you hereafter. Also I have bedriten ${ }^{1}$ with dame Ersewynde his wife. I would I had not done it. I am sorry for it. It is to her great shame, and that me repenteth."

Grymbart said, "Eme, I understand you not."

He said, "I have trespassed with his wife."

"Ye shrive you, as though ye held somewhat behind. I wot not what ye mean, ne where ye have learned this language."

: "Ach, Dear Neve, it were great shame if I should say it openly as it happened. I have lain by mine aunt, I am your Eme, I should anger you if I spake villainy of women. Nephew, now

1 Bedriven, had experience (Dutch, bedreven; German, betrieben). 
have I told you all that I can think on. Set me penance, and assoil me, for I have great repentance."

Grymbart was subtle and wise. He broke a rod off a tree and said, "Eme, now shall ye smite yourself thrice with this rod on your body, and then lay it down upon the ground, and spring three times thereover, without bowing of your legs and without stumbling, and then shall ye take it up and kiss it friendly in token of meekness and obedience of your penance that I gave you. Herewith be ye quit of all sins that ye have done to this day, for I forgive it you all."

The Fox was glad.

Tho said Grymbart to his Eme, "Eme, see now forthon that ye do good works : read your psalms, go to church, fast, and keep your holydays, and give your alms; and leave your sinful and ill life, your theft, and your treason, and so may ye come to mercy."

The Fox promised that he would so do, and then went they both together to the Court ward.

A little beside the way as they went stood a cloister of black nuns, where many geese, hens and capons went without the walls; and as they went talking the Fox broúght'Grymbart out of the right way thither, and without the walls by the barn went the polaylle. The Fox espied them, and saw a fat young capon which went alone from his fellows, and leapt, and caught him that the feathers flew about his ears, but the capon escaped.

Grymbart said, "What, Eme, cursed man, what will ye do! Will ye for one of these pullets fall again in all your sins of which ye have shriven you? Ye ought sore repent you."

Reynart answered, "Truly, cousin, I had all forgotten. Pray God that he forgive it me, for I will never do so more."

Then turned they again over a little bridge, yet the Fox alway looked after the polaylle; he could not refrain himself; that which clevid by the bone might not out of the flesh: though he should be hanged he could not let the looking after the polaylle as far as he might see them. 
Grymbart saw his manner, and said, "Foul false deceiver, how go your eyen so after the polaylle!"

The Fox said, "Cousin, ye misdo to say to me any such words. Ye bring me out of my devotion and prayers. Let me say a pater noster for all the souls of polaylle and geese that I have betrayed, and oft with falsehood stolen from these holy nuns."

Grymbart was not well apaid, but the Fox had ever his eyen toward the polaylle ${ }^{1}$ till at last they came in the way again, and then turned they to the Courtward. How sore quaked tho Reynart when they approached the Court! For he wist well that he had for to answer to many a foul feat and theft that he had done.

\section{CHAPTER XIII.}

How the Fox came to the Court, and how he excused him tofore the King.

AT the first when it was known in the Court that Reynart the Fox and Grymbart his cousin were comen to the Court, there was none so poor nor so feeble of kin and friends but that he made him ready for to complain on Reynart the Fox.

Reynart looked as he had not been afraid, and held him better than he was, for he went forth proudly with his nephew through the highest street of the Court, right as he had been the King's son, and as he had not trespassed to any man the value of an hair : and went in the middle of the place standing tofore Noble the King and said-

"God give you great honour and worship. There was never King that ever had a truer servant than I have been to your good grace, and yet am. Nevertheless, dear lord, I know well that there ben many in this Court that would destroy me if ye would believe them; but nay, God thank you, it is not fitting to your crown to believe these false deceivers and liars lightly. To God mote it be complained how that these false liars and flatterers nowadays in the lord's Courts ben most heard and believed, the 
shrews and false deceivers ben borne up for to do to good men all the harm and scathe they may. Our Lord God shall once reward them their hire."

The King said, "Peace, Reynart, false thief and traitor! How well can ye bring forth fair tales! And all shall not help you a straw. Ween ye with such flattering words to be my friend, ye have so oft served me so as ye now shall well know. The peace that I have commanded and sworn, that have ye well holden, have ye?"

Chanticleer could no longer be still, but cried, "Alas, what have I by this peace lost !"

"Be still, Chanticleer, hold your mouth. Let me answer this foul thief. Thou shrewd fell thief," said the King, "thou sayest that thou lovest me well : that hast thou showed well on my messengers, these poor fellows, Tibert the Cat and Bruin the Bear, which yet ben all bloody; which chide not ne say not much, but that shall this day cost thee thy life. In nomine Patris et Christi filii."

Said the Fox, "Dear lord and mighty King, if Bruin's crown be bloody what is that to me? When he ate honey at Lantfert's house in the village and did him hurt and scathe, there was he beaten therefor; if he had willed, he is so strong of limbs, he might well have be avenged ere he sprang into the water. Tho came Tybert the Cat, whom I received friendly. If he went out without my counsel for to steal mice to a priest's house, and the priest did him harm, should I abye that, then might I. say I were not happy. Not so, my liege lord. Ye may do what ye will, though my matter be clear and good ; ye may siede ${ }^{1}$ me, or roast, hang, or make me blind. I may not escape you. We stand all under your correction. Ye be mighty and strong. I am feeble, and my help is but small. If ye put me to the death it were a small vengeance."

Whiles they thus spake, up sprang Bellyn the Ram and his ewe Dame Olewey, and said, "My lord the King, hear our complaint." Bruin the Bear stood up with all his lineage and his

1 Siede, seethe, boil. 
fellows. Tybert the Cat, Isegrim the Wolf, Cuwart the Hare, and Panther; the Boar, the Camel, and Brunel the Goose; the Kid and Goat; Boudewyn the Ass, Borre the Bull, Hamel the $\mathrm{Ox}$, and the Weasel; Chanticleer the Cock, Pertelot with all their children, all these made great rumour and noise, and came forth openly tofore their lord the King, and made that the Fox was taken and arrested.

\section{CHAPTER XIV.}

How the Fox wias arrested and judged to death.

Hereupon was a Parliament; and they desired that Reynart should ben dead. And whatsomever they said against the Fox he answered to each to them. Never heard man of such beasts such plaints of wise counsel and subtle inventions. And on that other side, the Fox made his excuse so well and formably thereon, that they that heard it wondered thereof. They that heard and saw it may tell it, forth for truth; I shall short the matter and tell you forth of the Fox. "The King and the Council heard the witnesses of the complaints of Reynart's misdeeds. It went with them as it oft does, the feeblest hath the worst. They gave sentence, and judged that the Fox should be dead and hanged by the neck. Tho list not he to play. All his flattering words and deceits could not help him. The judgment was given, and that must be done. Grymbart, his nephew, and many of his tineage might not find in their hearts to see him die, but took leave sorrow; fully, and roomed the court. ${ }^{1}$.

The King bethought him, and marked how many a youngling departed from thence all weeping, which were nigh of his kin; and said to himself, "Here behoveth other counsel hereto; though Reynart be a shrew, there be many good of his lineage."

Tybert the Cat said, "Sir Bruin and Sir Isegrim, how be ye thus slow? It is almost even. Here ben many bushes and hedges. If he escaped from us and were delivered out of this peril, he is so subtle, and so wily, and can so many deceits, that 
he should never be taken again. Shall we hang him? How stand ye all thus? Ere the gallows can be made ready it shall be night."

Isegrim bethought him tho, and said, "Hereby is a gibbet or gallows." And with that word he sighed.

And the Cat espied that, and said, "Isegrim, ye be afraid. Is it against your will? Think ye not that he himself went and laboured that both your brethren were hanged? Were ye good and wise, ye should thank him, and ye should not therewith so long tarry."

\section{CHAPTER XV.}

How the Fox was led to the gallows.

ISEGRIM balked ${ }^{1}$ and said, "Ye make much ado, Sir Tybert; had we an halter which were meet for his neck and strong enough, we should soon make an end."

Reynart the Fox, which long had not spoken, said to Isegrim, "Short my pain. Tybert hath' a strong cord which caught him in the Priest's house. He can climb well, and is swift; let him bear up the line. Isegrim and Bruin, this becometh you well, that ye thus do to your Nephew! I am sorry that I live thus long; haste you, ye be set thereto ; it is evil doo that ye tarry thus long. Go tofore, Bruin, and lead me; Isegrim, follow fast, and see well to, and be ware that Reynart go not away."

Tho said Bruin, "It is the best counsel that I ever yet heard, that Reynart here saith."

Isegrim commanded anon and bad his kin and friends that they should see to Reynart that he escaped not, for he is so wily and faise. They helden him by the feet, by the beard; and so kept him that he escaped not from them.

The Fox heard all these words, which touched him nigh, yet spake he and said, "Oh, dear Eme, methinketh ye pain yourself sore for to do me hurt and scathe. If I durst, I would pay you of mercy, though my hurt and sorrow is pleasant to you. I wot

1 Balked, brayed (Dutch, balken; vulg., bölken). 
well, if mine Aunt, your wife, bethought her well of old ferners, ${ }^{1}$ she would not suffer that I should have any harm; but now I am he that now ye will do on me what it shall please you. Ye Bruin and Tybert, God give you shames death but ye do to me your worst. I wot whereto I shall. I may die but once, I would that I were dead already. I saw my father die, he had soon done."

Isegrim said, "Let us go, for ye curse us because we lengthen the time. Evil might we fare if we abide any longer."

$\mathrm{He}$ went forth with great envy on that one side, and Bruin stood on the other side, and so led they him forth to the gallows ward. Tybert ran with a good will tofore, and bare the cord; and his throat was yet sore of the grynne, and his croppe did him woe of the stroke that he was take in; that happened by the counsel of the Fox, and that thought he now to quit.

Tybert Isegrim and Bruin went hastily with Reynart to the place there as the felons ben wont to be put to death. Noble the King and the Queen and all that were in the Court followed after, for to see the end of Reynart. The Fox was in great dread if him myshapped, and bethought him oft how he might save him from the death; and tho three that so sore desired his death, how he might deceive them and bring them to shame; and how he might bring the King with leasings for to hold with him against them. This was all that he studied, how he might put away his sorrow with wiies, and thought thus: "Though the King and many one be upon me angry, it is no wonder, for I have well deserved it; nevertheless, I hope for to be yet their best friend. And yet shall I never do them good. How strong that the King be, and how wise that his council be, if I may brook $^{2}$ my words I know so many an invention, I shall come to mine above ${ }^{3}$ as far as they would comen to the gallows."

Tho said Isegrim, "Sir Bruin, think now on your red crown which by Reynart's mean ye caught; we have now the time that we may well reward him. Tybert, clime up hastily and bind the 
cord fast to the lynde, and make a riding knot or a strope, ye be the lightest; ye shall this day see your will of him. Bruin, see well to, that he escape not, and hold fast. I will help that the ladder be set up, that he may go upward thereon."

Bruin said, "Do. I shall help him well."

The Fox said, "Now may my heart be well heavy for great dread; for I see the death tofore mine eyen, and I may not escape. My lord the King, and dear Queen, and forth all ye that here stand, ere I depart from this world I pray you of a boone: that I may tofore you all make my confession openly, and tell my defaults all so clearly that my soul may not be acumbred, and also that no man hereafter bear no blame for my theft ne for my treason. My death shall be to me the easier, and pray ye all to God that he have mercy on my soul."

\section{CHAPTER XVI.}

How the Fox made openly his confession tofore the "King and tofore all them that would hear it.

ALL they that stood there had pity when Reynart said tho words, and said it was but a little request if the King would grant it him, and they prayed the King to grant it him.

The King gave him leave.

Reynart was well glad, and hoped that it might fall better, and said thus :

"Now help, Spiritus Domini, for I see here no man but I have trespassed unto. Nevertheless yet was I, unto the time that I was weaned from the teat, one of the best children that could anywhere be found. I went tho and played with the lambs, because I heard them gladly bleat. I was so long with them that at the last I bit one; there learned .I first to lappen of the blood. It savoured well; me thought it right good. And after I began to taste of the flesh thereof, I was licorous; so that after that I went to the gate into the wood, there heard I the kids bleat and I slew of them twain. I began to wax hardy 
after. I slew hens, polaylle and geese wherever I found them. Thus worden ${ }^{1}$ my teeth all bloody. After this, I wex so fell and so wroth that whatsomever I found that I might over, I slew all. Thereafter came I by Isegrim, now in the winter, where he hid him under a tree, and reckoned to me that he was mine eme. When I heard him then reckon alliance, we became fellows, which I may well repent. We promised each to other to be true, and to use good fellowship, and began to wander together. He stole the great things and I the small, and all was common between us. Yet he made it so that he had the best deal ${ }^{2}$; I got not half my part. When that Isegrim gat a calf a ram or a wether, then grimmed he, and was angry on me, and drove me from him, and held my part and his too, so good is he. Yet this was of the least. But when it so lucked that we took an ox or a cow, then came thereto his wife with seven children; so that unto me might vnnethe come one of the smallest ribs, and yet, had they eaten all the flesh thereof, therewithall must I be content; not for that I had so great need, for I have so great scatte ${ }^{3}$ and good of silver and of gold, that seven wains should not can carry it away."

When the King heard him speak of this great good and riches, he burned in the desire and covetyse thereof, and said, "Reynart, where is the riches becomen? tell me that."

The Fox said, "My lord, I shall tell you. The riches was stolen. And had it not be stolen, it should have cost you your life and you should have been murdered, - which God forbid!-and should have been the greatest hurt in the world."

When the Queen heard that, she was sore afraid and cried aloud, "Alas and weleaway! Reynart, what say ye? I conjure you by the long yay that your soul shall go, that ye tell us openly the truth hereof, \&s much as ye know of this great murder that should have be done on my lord, that we all may hear it !"-

Now hearken how the Fox shall flatter the King and Queen, and shall win both their good will and loves, and shall hinder

"Scatte, treasure, money; "shot" in the locker. 
them that labour for his death. He shall unbind his pack and lie, and by flattery and fair words shall bring forth so his matters that it shall be supposed for truth.

In a sorrowful countenance spake the Fox to the Queen, "I am in such case now that I must needs die, and had ye me not so scre conjured I will not jeopardise my soul, and if I so died I should go therefor in to the pain of hell. I will say nothing but that I will make it good, for piteously he should have been murdered of his own folk. Nevertheless they that were most principal in this feat were of my next kin, whom gladly I would not betray, if the sorrow were not of the hell."

The King was heavy of heart, and said, "Reynart, sayest thou to me the truth?"

"Yes," said the Fox. "See ye not how it standeth with me? Ween ye that I shall damn my soul? What should it avail me if I now said otherwise than truth? My death is so nigh. There may neither prayer ne good help me." Tho trembled the Fox, by dissembling, as he had been afraid.

The Queen had pity on him, and prayed the King to have mercy on him, in eschewing of more harm, and that he should doo the people hold their peace, and give the Fox audience, and hear what he should say.

Tho commanded the King openly that each of them should be still, and suffer the Fox to say unberisped ${ }^{1}$ what that he would.

Then said the Fox, "Be ye now all still, sith it is the King's will, and I shall tell you openly this treason. And therein will I spare no man that I know guilty."

\section{CHAPTER XVII.}

How the Fox brought them in danger that would have brought him to death, and how he got the grace of the King.

Now hearken how the Fox began. In the beginning he appealed Grymbart his dear Cousin, which ever had helped him in his need.

1 Unberisped, untroubled, unexcited (Dutch, rispen). 
He did so because his words should be the better believed; and that he forthon might the better lie on his enemies. Thus began he first and said:

"My lord, my father had found King Ermeryk's treasure dolven in a pit; and when he had this great good, he was so proud and orguilious that he had all other beasts in despite which tofore had been his fellows. He made Tybert the Cat to go into that wild land of Ardenne to Bruin the Bear for to do him homage, and bad him say, if he would be King that he should come in to Flanders. Bruin the Bear was glad hereof, for he had long desired it, and went forth in to Flanders; where my father received him right friendly. Anon he sent for the wise Grymbart, mine nephew, and for Isegrim the Wolf, and for Tybert the Cat. Tho these five came between Gaunt and the thorp called Yfte, there they held their council an whole dark night. long. What with the devil's help and craft, and for my father's riches, they concluded and swore there the King's death. Now hearken, and hear this wonder. The four swore upon Isegrim's crown that they should make Bruin a king and a lord, and bring him in the stool at Akon, ${ }^{1}$ and set the crown on his head; and if there were any of the King's friends or lineage that would be contrary or against this, him should my father with his good and treasure fordrive, and take from him his might and power.

"It happed so that on a morrowtide early when Grymbart, my nephew, was of wine almost drunk, that he told it to Dame Sloepcade, his wife, in counsel, and bade her keep it secret. But she anon forgat it, and said it forth in confession to my wife upon an heath where they both wenten a pilgrimage, but she must first swear, by her truth and by the holy Three Kings of Cologne, that for love ne for hate she should never tell it forth, but keep it secret. But she held it not, and kept it no longer secret but till she came to me ; and she then told to me all that she heard, but I must keep it in secret. And she told me so many tokens that I felt well it was truth; and for dread and fear mine hair stood right up, and my heart became as heavy as lead and as cold as

I Akon, Aachen, Aix-la-Chapelle. 
ice. I thought by this a likeness which here aforetime befell to the frosshis ${ }^{1}$ which were free and complained that they had none lord ne were not bydivongen, ${ }^{2}$ for a comynte $^{3}$ without a governor was noi good, and they cried to God with a loud voice that he would ordain one that might rule them, this was all that they desired. God heard their request, for it was reasonable, and sent to them a Stork which ate and swallowed them in, as many as he could find; he was alway to them unmerciful. Tho complained they their hurt, but then it was too late; they that were tofore free and were afraid of nobody ben now bound and must obey to strength their king : herefor, ye rich and poor, I sorrowed, that it might happen us in likewise.

"Thus, my lord the King, I have had sorrow for you whereof ye can me but little thank. I know Bruin the Bear for such a shrew and ravener, wherefore I thought if he were king we should be all destroyed and lost. I know our sovereign lord the King of so high birth, so mighty, so benign and merciful, that I thought truly it had been an evil change for to have a foul stinking thief and to refuse a noble mighty stately Lion; for the Bear hath more mad folly in his.unthrifty head, and all his ancestors, than any other hath. Thus had I in mine heart many a sorrow, and thought alway how I might break and foredo my father's false counsel, which of a churl and a traitor and worse than a thief would make a lord and a king. Alway I prayed God that he would keep our King in worship and good health, and grant him long life, but I thought well if my father held his treasure he should with his false fellows well find the way that the King should be deposed and set aside. I was sore bethought how I might best wit ${ }^{4}$ where my father's good lay. I awaited at all times as nigh as I could, in woods, in bushes, in fields; where my father laid his eyen; were it by night or by day, cold or wet, I was alway by him to espy and know where his treasure was laid.

"On a time I lay down all plat on the ground and saw my

\footnotetext{
1 Frosshis, frogs.

2 Bydwongen, held in restraint (Dutch, bedwingen; German, bezwingen).

3 Comynte, community.

Wit, know.
} 
father come running out of an hole. Now hark what I saw him do. When he came out of the hole, he looked fast about if anybody had seen him. And when he could nowhere none see, he stopped the hole with sand and made it even and plain like to. the other ground by. He knew not that I saw it. And where his footspore stood, there stryked he with his tail, and made it smooth with his mouth, that no man should espy it. That learned I there of my false father, and many subtleties that I tofore knew nothing of. Then departed he thence and ran to the village ward for to do his things; and I forgot not, but sprang and leapt to the hole ward, and how well that he had supposed that he had made all fast $I$ was not so much a fool but that $I$ found the hole well, and scratched and scraped with my feet the sand out of the hole, and crept therein. There found I the most plenty of silver and of gold that ever I saw. Here is none so old that ever so much saw on one heap in all his life. Tho took I Ermelyne my wife to help, and we ne rested night ne day to bear. and carry away, with great labour and pain, this rich treasure in to another place that lay for us better, under an hawe in a deep hole. In the mean while that mine housewife and I thus laboured, my father was with them that would betray the King. Now may ye hear what they did. Bruin the Bear and Isegrim the Wolf sent all the land about if any man would take wages that they should come to Bruin and he would pay them their souldye or wages tofore. My father ran all over the land and bare the letters. $\mathrm{He}$ wist little that he was robbed of his treasure; yea though he might have wonnen all the world, he had not conne find a penny thereof.

"When my father had been over all in the land between the Elbe and the Somme, and had gotten many a soldier that should the next summer have comen to help Bruin, tho came he again to the Bear and his fellows, and told them in how great a venture he had be tofore the boroughs in the land of Saxon, and how the hunters daily ridden and hunted with hounds after him in such wise that he unnethes escaped with his life. When he had told this to these four false traitors, then showed he them letters 
that pleased much. To Bruin therein were written twelve hundred of Isegrim's lineage by name, without the bears, the foxes, the cats, and the dassen, all these had sworn that with the first messenger that should come for them they should be ready, and come for to help the Bear if they had their wages a month tofore. This aspied I, I thank God. After these words my father went to the hole where his treasure had lain; and would look upon it. Tho began he a great sorrow; that he sought he found nothing. He found his hole broken, and his treasure borne away. There did he that I may well sorrow and bewail, for great anger and sorrow he went and hung himself. Thus abode the treason of Bruin by my subtilty after. Now see mine infortune. These traitors Isegrim and Bruin ben now most privy of counsel about the King, and sit by him on the high bench. And I, poor Reynart, have ne thanks ne reward. I have buried mine own father, because the King should have his life. My lord," said the Fox, "where ben they that would so do, that is, to destroy them self for to keep you."

The King and the Queen hoped to win the treasure and without council took to them Reynart and prayed him that he would do so well as to tell them where this treasure was.

Reynart said, "How should I' tell the King, or them that would hang me for love of the traitors and murderers which by their flattery would fain bring me to death? Should I tell to them where my good is, then were I out of my wit."

The Queen then spake, "Nay, Reynart, the King shall let you have your life, and shall altogether forgive you,' and ye shall be from henceforth wise and true to my lord."

The Fox answered to the Queen, "Dear lady, if the King will believe me, and that he will pardon and forgive me all my old trespasses, there was never King so rich as I shall make him. For the treasure that I shall do him have is right costly and may not be numbered."

The King said, "Ach Dame, will ye believe the Fox? Save your reverence, he is born to rob, steal, and to lie." This cleaves to his bones, and can not be had out of the flesh." 
The Queen said, "Nay, my lord, ye may now well believe him. Though he were tofore fell, he is now changed otherwise than he was. Ye have well heard that he hath impeached his father and the Dasse his nephew, which he might well have laid on other beasts if he would have been false, fell, and a liar."

The King said, "Dame, will ye then have it so, and think ye it best to be don, though I supposed it should hurt me I will take all these trespasses of Reynart upon me and believe his words. But I swear by my crown, if he ever hereafter misdo and trespass, that shall he dear abye and all his lineage unto the ninth degree."

The Fox looked on the King stoundmele, ${ }^{1}$ and was glad in his heart, and said, " My lord, I were not wise if I should say things that were not true."

The King took up a straw from the ground, and pardoned and forgave the Fox all the misdeeds and trespasses of his father and of him also.

If the Fox was tho merry and glad, it was no wonder; for he was quit of his death and was all free and frank of all his enemies.

The Fox said, " My Lord the King and noble Lady the Queen, God reward you this great worship that ye do to me. I shall think and also thank you for it in such wise that ye shall be the richest king of the world; for there is none living under the sun that I vouchsafe better my treasure on, than on you both."

Then took the Fox up a straw and proffered it to the King, and said, "My most dear Lord, please it you to receive here the rich treasure which King Ermeryk had. For I give it unto you with a free will, and knowledge it openly."

The King received the straw, and threw it merely from him with a joyous visage, and thanked much the Fox.

The Fox laughed in himself.

The King then hearkened after the counsel of the Fox. And all that there were were at his will.

" My Lord," said he, "hearken and mark well my words. In

I Stoundmele, for a space of time. 
the west side of Flanders there standeth a wood and is named Hulsterlo, and a water that is called Krekenpyt lieth thereby. This is so great a wilderness, that oft in a whole year man nor wife cometh therein, save they that will, and they that will not eschew it. There lieth this treasure hidden. Understand well that the place is called Krekenpyt, for I advise you, for the least hurt, that ye and my Lady go both thither; for I know none so true that I durst on your behalf trust; wherefore go yourself. And when ye come to Krekenpyt ye shall find there two birch trees standing althernext ${ }^{1}$ the pit. My Lord, to tho birch trees shall ye go: there lieth the treasure untherdolven. ${ }^{2}$ There must ye scrape and dig away a little the moss on the one side. - There shall ye find many a jewel of gold and silver, and there shall ye find the crown which King Ermeryk wore in his days. That should Bruin the Bear have worn, if his will had gone forth. Ye shall see many a costly jewel, with rich stones set in gold work, which cost many a thousand mark. My Lord the King, when ye now have all this good, how oft shall ye say in your heart and think, 'Oh how true art thou, Reynart the Fox, that with thy subtle wit delvest and hidest this great treasure! God give thee good hap and welfare wherever thou be!'"

The King said, "Sir Reynart, ye must come and help us to dig up this treasure. I know not the way. I should never conne find it. I have heard often named Paris, London, Aachen, and Cologne; as me thinketh this treasure lieth right as ye mocked and japed, for ye name Krekenpyt. That is a feigned name."

These words were not good to the Fox, and he said with an angry mood, and dissembled and said, "Yea, my Lord the King, ye be also nigh that as from Rome to Maye. Ween ye that I will lead you to flume ${ }^{3}$ Jordan. Nay, I shall bring you out of weening and show it you by good witness."

He called loud, "Cuwart the Hare, come here tofore the King." The beasts saw all thitherward and wondered. what the King would. 
The Fox said to the Hare, "Cuwart, are ye acold; how tremble ye and quake so? Be not afraid; and tell my Lord the King here the truth, and that I charge you, by the faith and truth that ye owe him and to my Lady the Queen, of such thing as I shall demand of you."

Cuwart said, "I shall say the truth, though I should lose my neck therefor. I shall not lie, ye have charged me so sore, if I know it."

"Then say, know ye not where Krekenpyt standeth? Is that in your mind?"

The Hare said, "I knew that well twelve year agone, where that standeth. Why ask ye that ? It standeth in a wood named Hulsterlo, upon a warande ${ }^{1}$ in the wilderness. I have suffered there much sorrow for hunger and for cold, yea, more than I can tell. Pater Symonet the Friese was woned ${ }^{2}$ to make there false money, wherewith he bare himself out and all his fellowship; but that was tofore ere I had fellowship with Ryn the Hound, which made me escape many a danger; as he could well tell if he were here, and that I never in my days trespassed against the King otherwise than I ought to do with right."

Reynart said to him, "Go again to yonder fellowship. Hear ye, Cuwart? My Lord the King desireth no more to know of you."

The Hare returned and went again to the place he came from. The Fox said, "My Lord the King, is it true that I said?" "Yea, Reynart," said the King, "forgive it me; I did evil that I believed you not. Now, Reynart, friend, find the way that ye go with us to the place and pit where the treasure lieth."

The Fox said, "It is a wonder thing. Ween ye that I would not fain go with you; if it were so with me that I might go with you in such wise that it no shame were unto your lordship, I would go. But nay, it may not be. Hearken what I shall say, and must needs, though it be to me villainy and shame. When

1 Warande, warren, a place privileged by a franchise from the King for keeping or hunting certain animals, to the exclusion of all persons entering without permission. 
Isegrim the Wolf, in the devil's name, went into religion and became a monk shorn in the order, tho the provender of six monks was not sufficient to him, and had not enough to eat, he then plained and wailed so sore that I had pity on him, for he became slow and sick. And because he was of my kin, I gave him counsel to run away, and so he did. Wherefore I stand accursed, and am in the Pope's ban and sentence. I will to-morrow betimes, as the sun riseth, take my way to Rome for to be assoiled ${ }^{1}$ and take pardon. And from Rome $I$ will over the sea into the Holy Land, and will never return again till $I$ have done so much good that I may with worship go with you. It were great reproof to you, my Lord the King, in what land that I accompanied you that men should say ye reysed ${ }^{2}$ and accompanied yourself with a cursed and person agravate."

The King said, "Sith that ye stand accursed in the censures of the Church, if I went with you men should arette villainy unto my crown I shall then take Cuwart or some other to go with me to Krekenpyt ; and I counsel you, Reynart, that ye put you yourself out of this curse."

"My Lord," quoth the Fox, "therefore will I go to Rome as hastily as I may. I shall not rest by night nor day till I be assoiled."

"Reynart," said the King, "me thinketh ye ben turned into a good way. God give you grace to accomplish well your desire."

As soon as this speaking was done, Noble the King went and stood upon an high stage of stone and commanded silence to all the beasts, and that they should sit down in a ring round upon the grass, everiche in his place after his estate and birth. Reynart the Fox stood by the Queen, whom he ought well to love.

Then said the King, "Hear ye all that be poor and rich, young and old, that standeth here. Reynart, one of the head officers of my house, had done so evil, which this day should have been hanged, hath now in this Court done so much, that I and my wife the Queen have promised to him our grace and 1 Assoiled, absolved.

2 Reysed, travelled (reisen). 
friendship. The Queen hath prayed much for him, insomuch that I have made peace with him. And I give to him his life and member freely again, and I command you upon your life that ye do worship to Reynart and his wife, and to his children, wheresomever ye meet them by day or night. And I will also hear no more complaints of Reynart. If he hath heretofore misdone and trespassed, he will no more misdo ne trespass, but now better him. He will to-morrow early go to the Pope for pardon and forgiveness of all his sins, and forth over the sea to the Holy Land, and he will not come again till he bring pardon of all his sins."

This .tale heard Tyselyn the Raven and leapt to Isegrim to Bruin and to Tybert, there as they were, and said, "Ye caitifs, how goeth it now? Ye unhappy folk, what do ye here? Reynart the Fox is now a squire and a courtier, and right great and mighty in the Court. The King hath skylled him quite of all his brokes, ${ }^{1}$ and forgiven him all his trespasses and misdeeds. And ye be all betrayed and appeached."

Isegrim said, "How may this be? I trow Tyselyn that ye lie."

"I do not, certainly," said the Raven.

Tho went the Wolf and the Bear to the King. Tybert the Cat was in great sorrow, and he was so sore afraid that for to have the Fox's friendship he would well forgive Reynart the loss of his one eye that he lost in the priest's house, he was so woe he wist not what to do, he would well that he never had seen the Fox.

\section{CHAPTER XVIII.}

How the Wolf and the Bear were arrested by the labour of Reynart the Fox.

ISEGRIM came proudly over the field tofore the King, and he thanked the Queen, and spake with a fell mood ill words on the Fox, in suchwise that the King heard it and was wroth, and

1 Skylled him quite of all his brokes, judged him acquitted of all his dealings. 
made the Wolf and the Bear anon to be arrested. Ye saw never wood $^{1}$ dogs do more harm than was done to them. They were both fast bounden, so sore that all that night they might not stir hand ne foot. They might scarcely roar ne move any joint. Now hear how the Fox forth did. He hated them. He laboured so to the Queen that he got leave for to have as much of the Bear's skin upon his rigge ${ }^{2}$ as a foot long and a foot broad, for to make him thereof a scrip; then was the Fox ready if he had four strong shoon. Now hear how he did for to get these shoon.

He said to the Queen, "Madam, I am your pilgrim. Here is mine Eme, Sir Isegrim, that hath four strong shoon which were good for me. If he would let me have two of them I would on the way busily think on your soul, for it is right that a pilgrim should always think and pray for them that do him good. Thus may ye do your soul good if ye will. And also if ye might get of mine aunt Dame Frsewynde also two of her shoon to give me, she may well do it, for she goeth but little out, but abideth alway at home."

Then said the Queen, "Reynart, you behoveth well such shoes; ye may not be without them. They shall be good for you to keep your feet whole for to pass with them many a sharp mountain and stony rocks. Ye can find no better shoes for you than such as Isegrim and his wife have and wear. They be good and strong. Though it should touch their life, each of them shall give you two shoes for-to accomplish with your high pilgrimage."

\section{CHAPTER XIX.}

How Isegrim and his wife Ersez'ynde must suffer their shoes to be plucked off, and how Reynart did on the shoes for to go to Rome with.

Thus hath this false pilgrim gotten from Isegrim two shoes from his feet, which were hauled off the claws to the sinews. Ye saw never fowl that men roasted lay so still as Isegrim did when his 
shoes were hauled off. $\mathrm{He}$ stirred not, and yet his feet bled. Then when Isegrim was unshod tho must Dame Ersewynde his wife lie down in the grass with an heavy cheer. And she lost there her hinder shoes.

Tho was the. Fox glad, and said to his Aunt in scorn, " My dear Aunt, how much sorrow have ye suffered for my sake, which me sore repenteth, save this, hereof I am glad for ye be the liefest ${ }^{l}$ of all my kin. Therefore I will gladly wear your shoes. Ye shall be partner of my pilgrimage and deal of the pardon that I shall with your shoes fetch over the sea."

Dame Ersewynde was so woe that she unnethe might speak. Nevertheless this she said, "Ah. Reynart, that ye now all thus have your will, I pray God to wreak ${ }^{2}$ it!"

Isegrim and his fellow the Bear held their peace and were all still. They were evil at ease for they were bound and sore wounded. Had Tybert the Cat have been tizere, he should also somewhat have suffered, in such wise as he should not have escaped thence without hurt or shame.

The next day, when the sun arose, Reynart then did grease his shoes which he had of Isegrim and Ersewynde his wife, and did them on, and bound them to his feet, and went to the King and to the Queen and said to them with a glad cheer, "Noble Lord and Lady, God give you good morrow, and I desire of your grace that I may have male ${ }^{3}$ and staff blessed as belongeth to a pilgrim."

Then the King anon sent for Bellyn the Ram, and when he came he said, "Sir Bellyn, ye shall do mass tofore Reynart, for he shall go on pilgrimage ; and give to him male and staff."

The Ram answered again and said, "My Lord, I dare not do that, for he hath said that he is in the Pope's curse."

The King said what thereof master Gelys hath said to us, if a man had don as many sins as all the world and he would tho sins forsake, shrive him and receive penance, and do by the priest's counsel, God will forgive them and be merciful unto him.

1 Liefest, best lored.

3 Male, bag, scrip.

-Wreak, avenge. 
Now will Reynart go over the sea into the Holy Land, and make him clear of all his sins.

Then answered Bellyn to the King, "I will not do little ne much herein but if ye save me harmless in the spiritual court, before the bishop Prendelor and tofore his archdeacon Looswinde and tofore Sir Rapiamus his official."

The King began to wax wroth, and said, "I shall not bid you so much in half a year! I had liever hang you than I should só much pray you for it!"

When the Ram saw that the King was angry, he was so sore afraid that he quoke for fear, and went to the altar and sang in his books and read such as him thought good over Reynart, which little set thereby save that he would have the worship thereof.

When Bellyn the Ram had all said his service devoutly, then he hung on the fox's neck a male covered with the skin of Bruin the Bear and a little psalter thereby. Tho was Reynart ready toward his journey. 'Tho looked he toward the King, as he had been sorrowful to depart; and feigned as he had wept, right as he had yamerde ${ }^{1}$ in his heart; but if he had any sorrow it was because all the other that were there were not in the same plight as the. Wolf and Bear were brought in by him. Nevertheless he stood and prayed them all to pray for him, like as he would pray for them. The Fox thought that he tarried long and would fain. have departed, for he knew himself guilty.

The King said, “ Reynart, I am sorry ye be so hasty, and will no longer tarry."

"Nay, my lord, it is time, for we ought not spare to do well, I pray you to give me leave to depart: I must do my pilgrimage."

The King said, "God be with you," and commanded all them of the court to go and convey Reynart on his way, save the Wolf and the Bear which fast lay bounden. There was none that durst be sorry therefor, and if ye had seen Reynart how personably he went with his male and psalter on his shoulder, and the shoes on his feet, ye should have laughed. He went and showed him 
outward wisely, but he laughed in his heart that all they brought him forth which had a little tofore been with him so wroth. And also the King which so much hated him, he had made him such a fool that he brought him to his owne intent. He was a pilgrim of deuce ace."

"My Lord the King," said the Fox, "I pray you to return again. I will not that ye go any further with me. Ye might have harm thereby. Ye have there two murderers arrested. If they escape you, ye might be hurt by them. I pray God keep you from misadventure!" With these words he stood up on his afterfeet, and prayed all the beasts; great and small, that would be partners of his pardon, that they should pray for him.

They said that they all would remember him.

Then departed he from the King so heavily that many of them ermed. ${ }^{1}$

Then said he to Cuwart the Hare and to Bellyn the Ram merrily, "Here, friends, shall we now depart? Yea, with a good will accompany me further. Ye two made me never angry. Ye be good for to walk with, courteous, friendly, and not complained on of any beast. Ye be of good conditions and ghostly of your living; ye live both as I did when I was a recluse. If ye have leaves and grass ye be pleased, ye reck not of bread of flesh ne such manner meat."

With such flattering words hath Reynart these two flattered that they went with him till they came tofore his house Maleperduys.

\section{CHAPTER XX.}

How Cuneart the Hare was slain by the Fox.

WhEN the Fox was come tofore the gate of his house, he said to Bellyn the Ram, "Cousin, ye shall abide here without, I and Cuwart will go in, for I will pray Cuwart to help me to take my leave of Ermelyne my wife, and to comfort her and my children." Bellyn said, "I pray him to comfort them well." 
With such flattering words brought he the Hare into his hole in an evil hour. There found they Dame Ermelyne lying on the ground with her younglings, which had sorrowed much for dread of Reynart's death. But when she saw him come, she was glad. But when she saw his male and psalter, and espied his shoes, she marvelled and said, "Dear Reynart, how have ye sped?"

He said I was arrested in the court, but the King let me gon. I must go a pilgrimage. Bruin the Bear and Isegrim the Wolf they be pledge for me. I thank the King he hath given to us Cuwart here, for to do with him what we will. The King said himself that Cuwart was the first that on us complained, and by the faith that I owe you I am right wroth on Cuwart."

When Cuwart heard these words he was sore afraid. He would have fled but he might not, for the Fox stood between him and the gate, and he caught him by the neck. Tho cried the Hare, "Help, Bellyn, help! Where be ye? This pilgrim slayeth me?" But that cry was soon done, for the Fox had anon bitten his throat a two.

Tho said he, "Let us go eat this good fat hare." The young whelps came also. Thus held they a great feast, for Cuwart had a good fat body. Ermelyne ate the flesh and drank the blood; she thanked oft the King that he had made them so merry. The Fox said, "Eat as much as ye may, he will pay for it if we will fetch it."

She said, "Reynart, I trow ye mock. Tell me the truth how ye be departed thence."

"Dame, I have so flattered the king and the queen that I suppose the friendship between us shall be right thin. When he shall know of this he shall be angry, and hastily seek me for to hang me by mine neck. Therefore let us depart, and steal secretly away in some other forest where we may live without fear and dread, and there that we may live seven year and more an they find us not. There is plenty of good meat of partridges, woodcocks, and much other wild fowl, Dame, and if ye will come with me thither there ben sweet wells and fair and clear running brooks; Lord God, how sweet air is there. There may we be in peace 
and ease, and live in great wealth. For the King hath let me gon because I told him that there was great treasure in Krekenpyt, but there shall he find nothing though he sought ever. This shall sore anger him when he knoweth that he is thus deceived. What ! trow ye how many a great leasing must I lie ere I could escape from him. It was hard that I escaped out of prison; I was never in greater peril ne nearer my death. But how it ever go I shall by my will never more come in the King's danger. I have now gotten my thumb out of his mouth, that thank I my subtilty."

Dame Ermelyne said, "Reynart, I counsel that we go not into another forest where we should be strange and elenge. We have here all that we desire. And ye be here lord of our neighbours; wherefore shall we leave this place and adventure us in a worse? We may abide here sure enough. If the King would do us any harm or besiege us, here ben so many by or side holes, in such wise as we shall escape from him ; in abiding here we may not do amiss. We know all bypaths over all, and ere he take us with might he must have much help thereto. But that ye have sworn that ye shall go oversea and abide there, that is the thing, that toucheth me most."

"Nay, Dame, care not therefor. How more forsworn, how more forlorn. I went once with a good man that said to me that a bedwongen ${ }^{1}$ oath, or oath sworn by force, was none oath. Though I went on this pilgrimage it should not avail me a cat's tail. I will abide here and follow your counsel. If the King hunt after me, I shall keep me as well as I may. If he be me too mighty, yet I hope with subtlety to beguile him. I shall unbind my sack. If he will seek harm he shall find harm."

Now was Bellyn the Ram angry that Cuwart his fellow was so long in the hole, and called loud, "Come out, Cuwart, in the devil's name; how long shall Reynart keep you there? Haste you, and come! Let us go."

When Reynart heard this, he went out and said softly to Bellyn the Ram, "Lief Bellyn, wherefore be ye angry? Cuwart speaketh with his dear Aunt. Methinketh ye ought not to be displeased 
therefor. He bade me say to you ye might well go tofore, and he shall come after; he is lighter of foot than ye. He must tarry awhile with his Aunt and her children, they weep and cry because I shall go from them."

Bellyn said, "What did Cuwart? Methought he cried after help."

The Fox answered, "What say ye, Bellyn? Ween ye that he should have any harm? Now hark what he then did. When we were comen into mine house, and Ermelyne my wife understood that I should go over sea, she fell down in a swoon; and when Cuwart saw that, he cried loud, 'Bellyn, come help mine Aunt to bring her out of her swoon." "

'Then said the Ram, "In faith I understood that Cuwart had been in great danger."

'The Fox said, "Nay truly, or Cuwart should have any harm in my house I had liever that my wife and children should suffer much hurt."

\section{CHAPTER XXI.}

How the Fox sent the head of Cumart the Hare to the King by Bellyn the Ram.

The Fox said, "Bellyn, remember ye not that yesterday the King and his council commanded me that ere I should depart out of this land I should send to him two letters? Dear cousin, I pray you to bear them, they be ready written."

The Ram said, "I wot never. If I wist that your inditing and writing were good, ye might peradventure so much pray me that I would bear them, if I had anything to bear them in."

Reynart said, "Ye shall not fall to have somewhat to bear them in. Rather than they should be unborne I shall rather give you my male that I bear; and put the King's letters therein, and hang them about your neck. Ye shall have of the King great thanks therefor, and be right welcomen to him."

Hereupon Bellyn promised him to bear these letters.

Tho returned Reynart into his house and took the male and 
put therein Cuwart's head, and brought it to Bellyn for to bring him in danger, and hang it on his neck, and charged him not to look in the male if he would have the King's friendship. "And if ye will that the King take you into his grace and love you, say that ye yourself have made the letter and indited it, and have given the counsel that it is so well made and written. Ye shall have great thanks therefor."

Bellyn the Ram was glad hereof, and thought he should have great thanks, and said, "Reynart, I wot well that ye now do for me. I shall be in the Court greatly praised when it is known that I can indite and make a letter, though I cannot make it. Ofttimes it happeneth that God suffereth some to have worship and thank of the labours and cunning of other men, and so it shall befall me now. Now, what counsel ye, Reynart? Shall Cuwart the Hare come with me to the Court?"

"Nay," said the Fox, "he shall anon follow you. He may not yet come, for he must speak with his Aunt. Now go ye forth tofore. I shall show to Cuwart secret things which ben not yet known."

Bellyn said, "Farewell, Reynart," and went him forth to the Court. And he ran and hasted so fast, that he came tofore midday to the Court, and found the King in his palace with his Barons. The King marvelled when he saw him bring the male again which was made of the Bear's skin. The King said, "Say on, Bellyn, from whence come ye? Where is the Fox? How is it that he hath not the male with him ?"

Bellyn said, "My Lord, I shall say you all that I know. I accompanied Reynart unto his house. And when he was ready, he asked me if $I$ that would for your sake bear two letters to you. I said, for to do. you pleasure and worship, I would gladly bear to you seven. Tho brought he to me this male wherein the letters be, which ben indited by my cunning, and I gave counsel of the making of them. I trow ye saw never letters better ne craftlier made ne indited."

The King commanded anon Bokart, his secretary, to read the letters, for he understood all manner languages. Tybert the Cat 
and he took the male off Bellyn's neck, and Bellyn hath so far said and confessed that he therefore was dampned. ${ }^{1}$

The clerk Bokwart undid the male, and drew out Cuwart's head, and said, "Alas, what letters ben these! Certainly, my Lord, this is Cuwart's head."

"Alas," said the King, "that ever I believed so the Fox!" There might men see great heaviness of the King and of the Queen. The King was so angry that he held long down his head, and at last, after many thoughts, he made a great cry, that all the beasts were afraid of the noise.

Tho spake Sir Firapeel the Leopard, which was sybbe ${ }^{2}$ somewhat to the King, and said, "Sire King, how make ye such a noise! Ye make sorrow enough though the Queen were dead. Let this sorrow go, and make good cheer. It is great shame. Be ye not a Lord and King of this land? Is it not all under you, that here is?"

The King said, "Sir Firapeel, how should I suffer this? One false shrew and deceiver has betrayed me and brought me so far, that $I$ have forwrought ${ }^{3}$ and angered my friends the stout Bruin the Bear and Isegrim the Wolf, which sore me repenteth. And this goeth against my worship, that I have done amiss against my best Barons, and that I trusted and believed so much the false Fox. And my wife is cause thereof. She prayed me so much that I heard her prayer, and that me repenteth, though it be too late."

"What though, Sir King," said the Leopard. "If there be any thing misdone it shall be amended. We shall give to Bruin the Bear to Isegrim the Wolf and to Ersewynde his wife for the piece of his skin and for their shoes, for to have good peace, Bellyn the Ram. For he hath confessed himself that he gave counsel and consented to Cuward's death. It is reason that he abye it. And we all shall go fetch Reynart, and we shall arrest him and hang him by the neck, without law or judgment. And there with all shall be content."

1 Dampned, conclemned.

$2 S y b b$, related by blood.

3 Forworought, overwrought. 


\section{CHAPTER XXII.}

How Bellyn the Ram and all his lineage were given in the hands of Isegrim and Bruin, and how he was slain.

THE King said, "I will do it gladly."

Firapeel the Leopard went tho to the prison and unbound them first, and then he said, "Ye, sirs, I bring to you a fast pardon and my lord's love and friendship. It repenteth him, and is sorry, that he ever hath done spoken or trespassed against you, and therefore ye shall have a good appointment. And also amends he shall give to you, Bellyn the Ram and all his lineage fro now forthon to doomsday, in such wise that wheresomever ye find them, in field or in wood, that ye may freely bite and eat them without any forfeit. And also the King granteth to you that ye may hunt and do the worst ye can to Reynart and all his lineage without misdoing. This fair great privilege will the King grant to you ever to hold of him. And the King will that ye swear to him never to misdo, but do him homage and fealty. I counsel you to do this, for ye may do it honourably."

Thus was the peace made by Firapeel the Leopard, friendly and well. And that cost Bellyn the Ram his tabart ${ }^{1}$ and also his life, and the Wolf's lineage hold these privileges of the King. And in to this day they devour and eat Bellyn's lineage where that they may find them. This debate was begun in an evil time, for the peace could never sith $^{2}$ be made between them.

The King did forth with his Court and feast length twelve days longer for love of the Bear and the Wolf, so glad was he of the making of this peace.

\section{CHAPTER XXIII.}

How the King held his feast, and how Lapreel the Cony complained unto the King upon Reynart the Fox.

To this great feast came all manner of beasts, for the King did do cry this teast over all in that land. There was the most joy and

1 Tabart, coat. The sleeveless coat of a labourer.

2 Sith, after, 
mirth that ever was seen among beasts. There was danced mannerly the hovedance, ${ }^{1}$ with shalms, trumpets, and all manner of minstrelsy. The King did do ordain so much meat that everych found enough. And there was no beast in all his land so great ne so little but he was there, and there were many fowls and birds also, and all they that desired the King's friendship were there, saving Reynart the Fox, the red false pilgrim which lay in await to do harm and thought it was not good for him to be there. Meat and drink flowed there. There were plays and esbatemens. The feast was full of melody. One might have lust to see such a feast.

And right as the feast had dured eight days, about mid-day came in the Cony Lapreel tofore the King, where he sat on the table with the Queen, and said all heavily that all they heard him that were there, "My lord, have pity on my complaint, which is of great force and murder that Reynart the Fox would have done to me yester morrow as I came running by his borugh at Maleperduys. He stood before his door without, like a pilgrim. I supposed to have passed by him peaceably toward this feast, and when he saw me come he came against me saying his beads. I saluted him, but he spake not one word, but he raught out his right foot and dubbed me in the neck between mine ears that I had weened I should have lost my head, but God be thanked I was so light that I sprang from him. With much pain came I off his claws. He grimmed as he had been angry by cause he held me no faster. Tho I escaped from him I lost mine one ear, and I had four great holes in my head of his sharp nails that the blood sprang out and that. I was nigh all aswoon, but for the great fear of my life I sprang and ran so fast from him that he could not overtake me. See, my Lord these great wounds that he hath made to me with his sharp long nails. I pray you to have pity of me, and that ye will punish this false traitor and murderer, or else shall there no man go and come over the heath in safety whiles he haunteth his false and shrewd rule."

1 Hovedance, court (hof) dance. 


\section{CHAPTER XXIV.}

\section{How Corbant the Rook complained on the Fox for the death of his zoife.}

Right as the Cony had made an end of his complaint, came in Corbant the Rook flowen in the place tofore the King and said, "Dear lord, hear me. I bring you here a piteous complaint. I went to-day by the morrow ${ }^{1}$ with Sharpebek my wife for to play upon the heath. And there lay Reynart the Fox down on the ground, like a dead caitiff. His eyes stared and his tongue hung long out of his mouth, like an hound had been dead. We tasted ${ }^{2}$ and felt his belly but we found thereon no life. Tho went my wife and hearkened, and laid her ear tofore his mouth for to wit if he drew his breath, which misfell her evil: For the false fell Fox awaited well his time, and when he saw her so nigh him he caught her by the head and bit it off. Tho was $I$ in great sorrow and cried loud, 'Alas! alas! what is there happened?' Then stood he hastily up and raught so covetously after me that for fear of death I trembled, and flew upon a tree thereby, and saw from far how the false caitiff ate and slonked ${ }^{3}$ her in, so hungrily that he left neither flesh ne bone, no more but a few feathers. The small feathers he slang them in with the flesh; he was so hungry, he would well have eaten twain. 'Tho went he his strete. Tho flew I down with great sorrow, and gathered up tise feathers for to show them to you here. I would not be again in such peril and fear as I was there for a thousand mark of the finest gold that ever came of Araby. My Lord the King, see here this piteous work. This ben the feathers of Sharpebek my wife! My Lord, if ye will have worship ye must do herefor justice, and avenge you in such wise as men may fear and hold of you, for if ye suffer thus your safe conduct to be broken, ye yourself shall not go peaceably in the highway. For the lords that do not justice, and suffer that the law be not executed upon the 
thieves, murderers, and them that misdo, they be partners tofore God of all their misdeeds and trespasses, and eueryche then will be a lord himself. Dear Lord see well to, for to keep yourself."

\section{CHAPTER XXV.}

How the King was sore angry of these complaints.

NoBLE the King was sore moved and angry when he had heard these complaints of the Cony and of the Rook. He was so frightful to look on that his eyen glimmered as fire; he brayed as loud as a bull, in such wise that all the Court quoke for fear; at the last he said, crying, "By my crown, and by the truth that I owe to my wife, I shall so awreak and avenge these trespasses that it shall be long spoken of after. That my safe conduct and my commandment is thus broken, I was over nice that I believed so lightly the false shrew. His false flattering speech deceived me. He told me he would go to Rome, and from thence over the sea to the Holy Land. I gave him male and psalter, and made of him a pilgrim, and meant all truth. Oh, what false touches can he! How can he stuff the sleeve with flocks! But this caused my wife. It was all by her counsel. I am not the first that have been deceived by women's counsel, by which many a great hurt hath befallen. I pray and command all them that hold of me, and desire my friendship, be they here or wheresomever they be, that they with their counsel and deeds help me to avenge this over great trespass, that we and ours may abide in honour and worship and this false thief in shame. That he no more trespass against our safeguard, I will myself in my person help thereto all that I may."

Isegrim the Wolf and Bruin the Bear heard well the King's words, and hoped well to be avenged on Reynart the Fox, but they durst not speak one word. The King was so sore moved that none durst well speak.

At last the Queen spake, "Sire, pour dieu ne croyes mye toutes choses que on vous dye, et ne Iures pas legierment. A man of 
worship should not lightly believe, ne swear greatly, unto the time he knew the matter clearly; and also he ought by right hear that other party speak. There ben many that complain on other and ben in the default themself. Audi alteram partem: hear that other party. I have truly holden the Fox for good, and upon that that he meant no falsehood I helped him that I might. But howsomever it cometh or goeth, is he evil or good, me thinketh for your worship that ye should not proceed against him over hastily. That were not good ne honest, for he may not escape from you. Ye may prison him or flay him, he must obey your judgment."

Then said Firapeel the Leopard, "My Lord, me thinketh my Lady here hath said to you truth and given you good counsel; do ye well and follow her, and take advice of your wise council. And if he be founden guilty in the trespasses that now to you be showed, let him be sore punished according to his trespasses. And if he come not hither ere this feast be ended, and excuse him as he ought of right to do, then do as the council shall advise you. But and if he were twice as much false and ill as he is, I would not counsel that he should be done to more than right."

Isegrim the Wolf said, "Sir Firapeel, all we agree to the same; as far as it pleaseth my lord the King, it cannot be better. But though Reynart were now here, and he cleared him of double so many plaints, yet should I bring forth against him that he had forfeited his life. But I will now be still and say not, because he is not present. And yet, above all this, he hath told the King of certain treasure lying in Krekenpyt in Hulsterlo. There was never lied a greater leasing; therewith he hath us all beguiled, and hath sore hindered me and the Bear. I dare lay my life thereon that he said not thereof a true word. Now robbeth he and stealeth upon the heath all that goeth forth by his house. Nevertheless, Sir Firapeel, what that pleaseth the King and you that must well be done. But and if he would have comen hither he might have been here, for he had knowledge by the King's messenger." 
The King said, "We will none otherwise send for him, but I command all them that owe me service and will my honour and worship that they make them ready to the war at the end of six days, all them that ben archers and have bows, guns, bombards, horsemen and footmen, that all these be ready to besiege Maleperduys. I shall destroy Reynart the Fox if I be a king. Ye lords and sirs, what say ye hereto? Will ye do this with a good will?"

And they said and cried all, "Yea we, Lord, when that ye will, we shall all go with you!"

\section{CHAPTER XXVI.}

How Grymbart the Dasse warned the Fox that the King was wroth with him and zeould slay him.

All these words heard Grymbart the Dasse, which was his brother son. He was sorry and angry. If it might have profited he ran then the highway to Maleperduys ward. He spared neither bush ne hawe, but he hasted so sore that he sweat. He sorrowed in himself for Reynart his rede Eme, and as he went he said to himseif," "Alas, in what danger be ye comen in! Where shall ye become! Shall I see you brought from life to death, or else exiled out of the land! Truly I may be well sorrowful, for ye be head of all our lineage; ye be wise of council, ye be ready to help your friends when they have need, ye can so well show your reasons that where ye speak ye win all."

With such manner wailing and piteous words came Grymbart to Maleperduys, and found Reynart his Eme there standing, which had gotten two pigeons as they came first out of their nest to assay if they could fly, and because the feathers on their wings were too short they fell down to the ground; and as Reynart was gone out to seek his meat he espied them and caught them, and was comen home with them.

And when he saw Grymbart coming, he tarried and said, "Wẹlcome, my best beloved Nephew that I know in all my 
kindred. Ye have run fast, ye ben all besweat ; have ye any new tidings ?"

"Alas," said he, "lief Eme, it standeth evil with you. Ye have lost both life and good. The King hath sworn that he shall give you a shameful death. He hath commanded all his folk within six days for to be here. Archers, footmen, horsemen, and people in wains! And he hath guns, bombards, tents, and pavilions. And also he hath do laden torches. See tofore you, for ye have need. Isegrim and Bruin ben better now with the King than I am with you. All that they will is done. Isegrim hath don him to understand that ye be a thief and a murderer; he hath great envy to you. Lapreel the Cony, and Corbant the Rook have made a great complaint also. I sorrow much for your life, that for dread I am all sick."

"Puf!" said the Fox. "Dear Nephew, is there nothing else? Be ye so sore afraid hereof? Make good cheer hardily. Though the King himself and all that ben in the Court hath sworn my death, yet shall I be exalted above them all. They may all fast jangle, clatter, and give counsel, but the Court may not prosper without me and my wiles and subtlety.

\section{CHAPTER XXVII.}

How Reynart the Fox came another time to the Court.

"DEar Nephew, let all these things pass, and come here in and see what I shall give you; a good pair of fat pigeons. I love no meat better. They ben good to digest. They may almost be swolowen in all whole; the bones ben half blood; I eat them with that other. I feel myself other while encumbered in my stomach, therefore eat I gladly light meat. My wife Ermelyne shall receive us friendly, but tell her nothing of this thing for she should take it over heavily. She is tender of heart ; she might for fear fall in some sickness; a little thing goeth sore to her heart. And tomorrow early I will go with you to the Court, and if I may come to speech and may be heard, I shall so answer that I shall touch 
some nigh ynowh. Nephew, will not ye stand by me as a friend ought to do to another?" -

"Yes truly, dear Eme," said Grymbart, "and all my good is at your commandment."

"God thank you, Nephew," said the Fox. "That is well said. If I may live, I shall quite it you."

"Eme," said Grymbart, "ye may well come tofore all the lords and excuse you. 'There shall none arrest you ne hold as long as ye be in your words. The Queen and the Leopard have gotten that."

Then said the Fox, "Therefor I am glad; then I care not for the best of them an hair ; I shall well save myself."

They spoke no more hereof, but went forth into the burrow, and found Ermelyne there sitting by her younglings, which arose up anon and received them friendly. Grymbart saluted his aunt and the children with friendly words. The two pigeons were made ready for their supper, which Reynart had taken. Each of them took his part, as far as it would stretch ; if each of them had had one more there should but little have left over. The Fox said, "Lief Nephew, how like ye my children Rossel and Reynerdine? They shall do worship to all our lineage. They begin already to do well. That one catcheth well a chicken, and that other a pullet. They conne well also duck in the water after lapwings and ducks. I would oft send them for provender, but I will first teach them how they shall keep them from the grynnes, from the hunters, and from the hounds. If they were so far comen that they were wise, I durst well trust to them that they should well victual us in many good divers meats that we now lack. And they like and follow me well, for they play all grimming, and where they hate they look friendly and merrily; for thereby they bring them under their feet, and bite the throat asunder. This is the nature of the Fox. They be swift in their taking, which pleaseth me well."

"Eme," said Grymbart, "ye may be glad that ye have such wise children. And I am glad of them also because they be of my kin." 
"Grymbart," said the Fox, "ye have sweat and be weary. It were high tide that ye were at your rest."

"Eme, if it pleaseth you, it thinketh me good." Tho lay they down on a litter made of straw. 'The Fox his wife and his children went all to sleep, but the Fox was all heavy and lay, sighed, and sorrowed ${ }^{1}$ how he might best excuse himself.

On the morrow early he roomed ${ }^{2}$ his castle and went with Grymbart. But he took leave first of Dame Ermelyne his wife and of his children, and said, "Think not long. I must go to the Court with Grymbart, my cousin. If I tarry somewhat, be not afraid; and if ye hear any ill tidings, take it alway for the best. And see well to yourself and keep our castle well. I shall do yonder the best I can, after that I see how it goeth."

"Alas, Reynart," said she, "how have ye now thus taken upon you for to go to the Court again? The last time that ye were there, ye were in great jeopardy of your life. And ye said ye would never come there more."

"Dame," said the Fox, "the adventure of the world is wonderly; it goeth otherwhile by weening. Many one weeneth to have a thing which he must forego. I must needs now go thither. Be content. It is all without dread. I hope to come at altherlengest within five days again."

Herewith he departed, and went with Grymbart to the Court ward. And when they were upon the heath then said Reynart, "Nephew, sith I was last shriven I have done many shrewd turns. I would ye would hear me now of all that I have trespassed in: I made the Bear to have a great wound for the male which was cut out of his skin; and also I made the Wolf and his wife to lose their shoon; I peased ${ }^{3}$ the King with great leasings, and bare him on hand that the Wolf and the Bear would have betrayed him and would have slain him, so I made the King right wroth with them where they deserved it not; also I told to the King that there was great treasure in Hulsterlo of which he was never the better ne richer, for I lied all that I said; I led Bellyn 
the Ram and Cuwart the Hare with me, and slew Cuwart and sent to the King by Bellyn Cuwart's head in scorn ; and I dowed ${ }^{1}$ the Cony between the ears that almost I benamme ${ }^{2}$ his life from him, for he escaped against my will, he was to me overswift; the Rook may well complain for I swallowed in Dame Sharpebek his wife. And also I have forgotten one thing, the last time that I was shriven to you, which I have sith bethought me; and it was of great deceit that I did; which I now will tell you.

"I came with the Wolf walking between Houthulst and Elverdynge. There saw we go a red mare, and she had a black colt or a foal of four months old which was good and fat. Isegrim was almost storven for hunger, and prayed me go to the Mare and wit of her if she would sell her foal.

"I ran fast to the Mare and asked that of her. She said she would sell it for money.

"I demanded of her, how she would sell it.

"She said, "It is written on my hinder foot. If ye can read and be a clerk ye may come see and read it.'

"Tho wist I well where she would be, and I said, 'Nay, for sooth, I cannot read. And also I desire not to buy your child. Isegrim hath sent me hither, and would fain know the price thereof.'

"The Mare said, 'Let him come then himself, and I shall let him have knowledge.'

"I said, 'I shall ;' and hastily went to Isegrim, and said, 'Eme will you eat your bellyful of this colt, so go fast to the Mare for she tarrieth after you. She hath do write the price of her colt under her foot. She would that I should have read it, but I can not one letter, which me sore repenteth for I went never to school. Eme will ye buy that colt? Can ye read, so may ye buy it.'

" 'Oh, Nephew, that can I well. What should me let? I can well French, Latin, English, and Dutch. I have gone to school at Oxenford, I have also with old and ancient doctors been in the audience and heard pleas, and also have given sentence, I am licensed in both laws; what manner writing that any man

\footnotetext{
1 Dowed, struck.
}

2 Benamme, took away, 
can devise I can read it as perfectly as my name: I will go to her, and shall anon understand the price,' and he bade me to tarry for him, and he ran to the Mare, and asked her how she would sell her foal or keep it. She said, 'The sum of the money standeth written after on my foot.' He said, 'Let me read it.' She said, 'Do,' and lifte up her foot, which was new shod with iron and six strong nails; and she smote him, without missing, on his head, that he fell down as he had been dead. A man should well have ridden a mile ere he arose. The Mare trotted away with her colt, and she left Isegrim lying shrewdly hurt and wounded. He lay and bled, and howled as an hound. I went tho to him and said, 'Sir Isegrim, dear Eme, how is it now with you? Have you eaten yenowh of the colt? Is your belly full? Why give ye me no part? I did your errand. Have slept ye your dinner? I pray you tell me, what was written under the mare's foot? What was it, prose or rhyme, metre or verse? I would fain know it. I trow it was cantum, for I heard you sing, me thought, from fear; for ye were so wise that no man could read it better than ye.'

"'Alas, Reynart, alas !' said the Wolf, 'I pray you to leave your mocking. I am so foul arrayed and sore hurt than an heart of stone might have pity on me. The Mare with her long leg had an iron foot, I weened the nails thereof had been letters, and she hit me at the first stroke six great wounds in my head that almost it is cloven. Such manner letters shall I never more desire to read.' 'Dear Eme, is that truth that ye tell me? I have great mervaylle. I held you for one of the wisest clerks that now live. Now I hear well it is true that I long since have read and heard, that the best clerks ben not the wisest men. The lay people otherwhile wax wise. 'The cause that these clerks ben not the wisest is that they study so much in the cunning and science that they therein doole.' Thus brought I Isegrim in this great laste and harm, that he vnneth byhelde his life.

"Iief Nephew now have I told you all my sins that I remember. Whatsoever falle at the Court-I wote never how it shall stand with me there-I am not now so sore afraid, for I am clear from 
sin. I will gladly come to mercy and receive penance by your counsel."

Grymbart said, "The trespasses ben great. Nevertheless who that is dead must abide dead, and therefore I will forgive it you altogether, with the fear that ye shall suffer therefor ere ye shall conne excuse you of the death, and hereupon I will assoil you. But the most hinder that ye shall have shall be, that ye sent Cuwart's head to the Court, and that ye blinded the King with sutthe ${ }^{1}$ lies. Eme, that was right evil done."

The Fox said, "What, lief nephew! Who that will go through the world this to hear and that to see and that other to tell, truly it may not clearly be done. How should any man handle honey but if he licked his fingers? I am ofttimes rored and pricked in my conscience as to love God above all thing and mine even Crysten as myself, as is to God well acceptable and according to his law. But how ween ye that reason within forth fighteth against the outward will, then stand I all still in myself, that me thinketh I have lost all my wits, and wote not what me aileth, I am then in such a thought $I$ have now all left my sins, and hate all thing that is not good, and climb in high contemplation abone his commandments. But this special grace have I when I am alone; but in a short while after, when the world cometh in me; then find I in my way so many stones, and the foot spores ${ }^{2}$ that these loose prelates and rich priests go in, that I am anon taken again. Then cometh the world and will have this; and the flesh will live pleasantly; which lay tofore me so many things that $I$ then lose all my good thoughts and purpose. I hear there sing, pipe, laugh, play, and all mirth, and I hear that these prelates and rich curates preach and say all otherwise than they think and do. There learn I to lie, the leasings ben most used in the lord's courts; certainly lords, ladies, priests, and clerks, maken most leasings. Men dare not tell to the lords now the truth. There is default. I must flatter and lie also or else I should be shut without the door. I have often heard men say truth and rightfully, and have their reason made with a leasing like to their

$$
\text { I Sutthe, flattering. } \quad \text { Spores, tracks. }
$$


purpose, who brought it in and went through because their matter should seem the fairer. The leasing ofttimes cometh unavised, and falleth in the matter unwittingly, and so, when she is well clad, it goeth forth through with that other.

"Dear Nephew thus must men now lie nere and there, say sooth, flatter and menace, pray and curse, and seek every man upon his feeblest and weakest. Who otherwise will now haunt and use the world than devise a leasing in the fairest wise, and that bewimple with kerchiefs about in such wise that men take it for a truth, he is not run away from his master. Can he that subtilty in such wise that he stammer not in his words, and may then be heard, Nephew, this man may do wonder. He may wear scarlet and grise. ${ }^{1}$ He winneth in the spiritual law and temporal also, and wheresomever he hath to do. Now ben there many false shrews that have great envy that they have so great fardel, ${ }^{2}$ and ween that they can also well lie; and take on them to lie and to tell it forth. He would fain eat of the fat morsels. But he is not believed ne heard. And many ben there that be so plump and foolish that when they ween best to pronounce and show their matter and conclude, they fall beside and out thereof, and cannot then help themself, and leave their matter without tail or head ; and he is acompted for a fool ; and many mock them therewith. But who can give to his leasing a conclusion, and pronounce it without tatelying, like as it were written tofore him, and that he can so blind the people that his leasing shall better be believed than the truth : that is the man. What cunning is it to say the truth that is good to do? How laugh these false subtle shrews that give counsel, to make these leasings and set them forth, and maken unright go above right, and maken bills and set in things that never were thought ne said, and teach men see through their fingers; and all for to win money and let their tongues to hire for to maintain and strengthen their leasings. Alàs, Nephew, this is an evil cunning, of which life-scathe and hurt may come thereof.

"I say not but that otherwhile men must jape, bourd, ${ }^{3}$ and lie
1 Grise, fur.
2 Fardel, burden.
3 Bourd, jest. 
in small things; for whoso saith alway truth, he may not now go nowhere through the world. There ben many that play Placebo. Whoso alway saith truth, shall find many lettings in his way. Men may well lie when it is need, and after amend it by counsel. For all trespasses there is mercy. There is no man so wise, but he dooleth ${ }^{1}$ other while."

Grymbart said, "Well, dear Eme, what thing shall. you let? Ye know all thing at the narrowest. Ye should bring me hastily in doting; your reasons passen my understanding. What need have ye to shrive you? Ye should yourself by right be the priest, and let me and other sheep come to you for to be shriven. Ye know the state of the world in such wise as no man may halt tofore you."

With such manner talking they came walking in to the Court. The Fox sorrowed somewhat in his heart, nevertheless he bare it out and striked forth through all the folk till he came into the place where the King himself was.

And Grymbart was alway by the Fox and said, "Eme, be not afraid, and make good cheer! Who that is hardy, the adventure helpeth him. ${ }^{2}$ Ofttimes one day is better than sometime a whole year."

The Fox said, "Nephew, ye say truth. God thank you, ye comfort me well."

And forth he went, and looked grimly, here and there, as who saith, "What will ye? here come I." He saw there many of his kin standing which yonned ${ }^{3}$ him but little good, as the Otter, Beaver, and other to the number of ten whom I shall name afterward. And some were there that loved him.

The Fox came in and fell down on his knees tofore the King, and began his words and said :-

1 Dooleth, errs (Dutch, doolen).

2 Fortune favours the bold.

3 Yonned, conceded. First English unnan, to grant. 


\section{CHAPTER XXVIII.}

How Reyuart the Fox excused him before the King.

"GoD from whom nothing may be hid, and above all thing is mighty, save my Lord the King and my Lady the Queen and give him grace to know who hath right and who hath wrong. For there live many in the world that seem otherwise outward than they be within. I would that God showed openly every man's misdeeds, and all their trespasses stooden written in their foreheads, and it cost me more than I now say; and that ye, my Lord the King, knew as much as I do how I dispose me both early and late in your service. And therefore am I complained on of the evil shrews, and with leasings am put out of your grace and conceit, and would charge me with great offences, without deserving, against all right. Wherefore $\mathrm{I}$ cry out harowe on them that so falsely have belied me, and brought me in such trouble. Howbeit, I hope and know you both my Lord and my Lady for so wise and discreet, that ye be not led nor believe such leasings ne false tales out of the right way, for ye have not be woned so to do. Therefore, dear Lord, I beseech. you to consider by your wisdom all things by right and law. Is it in deed or in speech, do every man right. I desire no better. He that is guilty and found faulty, let him be punished. Men shall well know ere I depart out of this Court who that I am. I cannot flatter, I will always show openly my head."

\section{How the King answered upon Reynart's excuse.}

ALL they that were in the palace weren all still and wondered that the Fox spake so stoutly.

The King said, "Ha, Reynart, how well can ye your fallacy and salutation doon! But your fair words may not help you. I think well that ye shall, this day, for your works be hanged by your neck. I will not much chide with you, but I shall short your pain. That ye love us well, that have ye well showed on 
the Cony and on Corbant the Rook. Your falseness and your false inwentions shall without long tarrying make you to die. A pot may go so long to water, that at the last it cometh tobroken home. I think your pot, that so oft hath deceived us, shall now hastily be broken."

Reynart was in great fear of these words. He would well he had ben at Cologne when he came thither. Then thought lie I must here through, how that I do.

"My Lord the King," said he, "it were well reason that ye heard my words all out. Though I were dampned to the death, yet ought ye to hear my words out. I have yet heretofore time given to you many a good counsel and profitable, and in need alway have biden by you where other beasts have wyked ${ }^{1}$ and gone their way. If now the evil beasts with false matters have tofore you with wrong belied me, and I might not come to mine excuse, ought I not then to plain? I have tofore this seen that I should be heard before another; yet might these things well change and come in their old state. Old good deeds ought to be remembered. I see here many of my lineage and friends standing, that seem they set now little by me, which nevertheless should sore dere $^{2}$ in their hearts, that ye, my Lord the King, should destroy me wrongfully. If ye so did, ye should destroy the truest servant that ye have in all your lands. What ween ye, Sir King, had I knowen myself guilty in any feat or broke, ${ }^{3}$ that I would have comen hither to the law among all mine enemies? Nay, sire, nay. Not for all the world of red gold. For I was free and at large. What need had I to do that? But, God be thanked, I know myself clear of all misdeeds, that I dare welcome openly in the light and to answer to all the complaints that any man can say on me. But when Grymbart brought me first these tidings, tho was I not well pleased but half from myself, that I leapt here and there as an unwise man, and had I not been in the censures of the Church I had without tarrying have comen, but I went dolynge ${ }^{4}$ on the heath, and wist not what to do for sorrow.

1 Wyked, flinched (Dutch, ayken; German, zueichen).

2 Dere, take hurt. $\quad 3$ Broke, usage. : Dolynge, grieving. 
And then it happened that Mertyne, mine Eme, the Ape, met with me, which is wiser in clergy than some priest. He hath ben advocate for the Bishop of Cameryk nine year during. He saw me in this great sorrow and heaviness, and said to me, 'Dear Cousin, me thinketh ye are not well with yourself, what aileth you? Who hath displeased you? Thing that toucheth charge ought to be given in knowledge to friends. A true friend is a great help; he findeth oft better counsel than he that the charge resteth on, for whosomever is charged with matters is so heavy and acombred with them that oft he can not begin to find the remedy, for such be so woe like as they had lost their inwytte.' 1 I said 'Dear Eme, ye say truth, for in likewise is fallen to me. I am brought into a great heaviness, undeserved and not guilty, by one to whom I have alway been an hearty and great friend; that is the Cony which came to me yesterday in the morning whereas I sat tofore my house and said matins.'

"He told me he would go to the Court, and saluted me friendly, and I him again.

"Tho said he to me, 'Good Reynart, I am an hungred and weary. Have ye any meat?'

"I said, 'Yea, ynowh ; come near.'

"Tho gave I him a couple of manchets ${ }^{2}$ with sweet butter. It was upon a Wednesday, on which day I am not wont to eat any flesh, and also I fasted because of this feast of Whitsuntide which approached. For who that will taste of the overest wisehede, and live ghostly in keeping the commandments of our Lord, he must fast and make him ready against the high feasts. Et ros estote parati. Dear Eme, I gave him fair white bread with sweet butter, wherewith a man might well be eased that were much hungry.

"And when he had eaten his bellyful, tho came Rossel, my youngest son, and would have taken away that was left. For young children would alway fain eten. And with that he tasted for to have taken somewhat, the Cony smote Rossel tofore his mouth that his teeth bled, and he fell down half aswoon. When

1 Inroytte, inner consciousness.

- Manchets, small loaves of white bread. 
Reynardyn, mine eldest son, saw that, he sprang to the Cony and caught him by the head, and should have slain him had I not rescued him. I helped him, that he went from him, and beat my child sore therefor.

"Lapreel the Cony ran to my Lord the King and said I would have murdered him. See, Eme, thus come I in the words and I am laid in the blame. And yet he complaineth, and I plain not.

"After this came Corban the Rook fleeing with a sorrowful noise. I asked what him ailed.

"And he said, "Alas my wife is dead. Yonder lieth a deacl hare full of moths and worms, and there she ate so much thereof that the worms have bitten atwo her throat.'

"I asked him how cometh that by. He would not speak a word more, but flew his way, and let me stand.

"Now saith he that I have bitten and slain her. How should I come so nigh her? For she fleeth and I go afoot. Behold, dear Eme, thus I am born on hand. I may say well that I am unhappy. But peradventure it is for mine old sins. It were good for me if I could patiently suffer it.

"The Ape said to me, 'Nephew, ye shall go to the Court tofore the lords, and excuse you.'

" 'Alas, Eme, that may not be, for the Archdeacon hath put me in the Pope's curse because I counselled Isegrim the Wolf for to leave his religion at Elmare and forsake his habit. He complained to me that he lived so straitly, as in long fasting, and many things reading and singing, that he could not endure it ; if he should long abide there, he should die. I had pity of his com. plaining, and I holpe him as a true friend, that he came out. Which now me sore repenteth, for he laboureth all that he can against me to the King for to do me be hanged. Thus doth he evil for good. See, Eme, thus am I at the end of all my wits and of counsel. For I must go to Ronie for an absolution, and then shall my wife and children suffer much harm and blame. For these evil beasts that hate me shall do to them all the hurt they may, and fordrive them where they can. And I would well defend them if I were free of the curse, for then I would go to 
the Court and excuse me, where now I dare not. I should do great sin if I came among the good people, I am afraid God should plague me.'

" Nay, cousin, be not afraid. Ere I should suffer you in this sorrow, I know the way to Rome well. I understand me on this work. I am called there Mertyne the bishop's clerk, and am well beknowen there. I shall do cite the Archdeacon and take a plea against him, and shall bring with me for you an absolution against his will, for I know there all that is for to be done or left. There dwelleth Simon, mine Eme, which is great and mighty there. Who that may give aught, he helpeth him anon. There is Prentout, Wayte, Scathe, and other of my friends and allies. Also I shall take some money with me if I need any. The prayer is with gifts hardy ${ }^{1}$; with money alway the right goeth forth. A true friend shall for his friend adventure both life and good, and so shall I for you in your right. Cousin, make good cheer! I shall not rest after to-morrow till I come to Rome, and I shall solicit your matters. And go ye to the Court as soon as ye may. All your misdeeds and the sins that have brought you in the great sentence and curse, I make you quit of them and take them in myself. When ye come to the Court ye shall find there Rukenawe my wife, her two sisters, and my three children, and many more of our lineage. Dear cousin, speak to them hardily. My wife is sondrely ${ }^{2}$ wise, and will gladly do somewhat for her friends. Who that hath need of help shall find in her great friendship. One shall alway seek on his friends, though he hath angered them, for blood must creep where it cannot go. And if so be that ye be so overcharged that ye may have no right, then send to me by night and day to the Court of Rome, and let me have knowledge thereof, and all tho that ben in the land, is it King or Queen, wife or man, I shall bring them all in the Pope's Curse and send there an interdict that no man shall read ne singen ne christen children, ne bury the dead, ne receive sacrament, till that ye shall have good right. Cousin, this shall I well get, for the Pope is so sore old that he is but little set by, and the cardinal 
of Pure Gold hath all the might of the Court. He is young and great of friends, he hath a concubine whom he much loveth, and what she desireth that getteth she anon. See, Cousin, she is mine niece, and I am great and may do much with her, in such wise what I desire I fail not of it but am alway furthered therein. Wherefore, Cousin, bid my Iord the King that he do you right I wote well he will not warn ${ }^{1}$ you, for the right is heavy enough to every man.'

"My Lord the King, when I heard this I laughed, and with great gladness came hither, and have told you all truth. If there be any in this Court that can lay on me any other matter with good witness, and prove it, as ought to be to a noble man, let me then make amends according to the law; and if ye will not leave off hereby, then set me day and field, and I shall make good on him all so ferre as he be of as good birth as I am and to me like, and who that can with fighting get the worship of the field, let him have it. This right hath standen yet hitherto, and I will not it should be broken by me. The law and right doth no man wrong."

All the beasts both poor and rich were all still when the Fox spake so stoutly. The Cony Lapreel and the Rook were so sore afraid that they durst not speak, but piked and striked them out of the Court both two, and when they were a room far in the plain they said, "God grant that this fell murderer may fare evil. He can bewrap and cover his falsehood, that his words seem as true as the gospel. Hereof knoweth no man than we: how should we bring witness. It is better that we wyke ${ }^{2}$ and depart, thain we should hold a field and fight with him; he is so shrewd, yea though there of us were five we could not defend us, but that he should slay us all."

Isegrim the Wolf and Bruin the Bear were woe in themself when they saw these twain room the court.

The King said, "If any man will complain, let him come forth, and we shall hear him: yesterday camen here so many, where ben they now Reynart is here?"

The Fox said, "My Lord, there ben many that complain that 1 Warn, refuse. 2 Wyke, flinch, yield. 
and if they saw their adversary they would be still and make no plaint; witness now of Lapreel the Cony and Corbant the Rook, which have complained on me to you in my absence, but now that I am comen in your presence they flee away, and dare not abide by their words.' If men should believe false shrews it should do much harm and hurt to the good men, as for me it skilleth not. Nevertheless, my lord, if they had by your commandment asked of me forgiveness, how be it they have greatly trespassed, yet I had for your sake pardoned and forgive them; for I will not be out of charity, ne hate ne complain on mine enemies. But I set all thing in God's hand, he shall work and avenge it as it pleaseth him."

The King said, "Reynart, me thinketh ye be grieved as ye say. Are ye withinforth as ye seem outward? Nay, it is not so clear ne so open, nowhere nigh, as ye here have showed. I must say what my grief is, which toucheth your worship and life, that is to wit that you have done a foul and shameful trespass when I had pardoned you all your offences and trespasses, and ye promised to go over the sea on pilgrimage, and gave to you male and staff. And after this ye sent me by Bellyn the Ram the male again and therein Cuwart's Head. How might ye do a more reprovable trespass? How were ye so hardy to dare to me do such a shame? Is it not evil done to send to a lord his servant's head? Ye cannot say nay hereagainst, for Bellyn the Ram, which was our chaplain, told us all the matter how it happed? Such reward as he had when he brought us the message, the same shall ye have, or right shall fail."

Tho was Reynart so sore afraid that he wist not what to say. He was at his wit's end, and looked about him piteously, and saw many of his kin and allies that heard all this, but nought they said. He was all pale in his visage, but no man proffered him hand ne foot to help him.

The King said, "Thou subtle fellow and false shrew, why speakest thou not? Now dumb?"

The Fox stood in great dread, and sighed sore that all heard him. But the Wolf and the Bear were glad thereof. 


\section{CHAPTER XXIX.}

How Dame Rukcnaze answered for the Fox to the King.

DAme Rukenawe the She Ape, Reynart's Aunt, was not well pleased. She was great with the Queen and well beloved. It happened well for the Fox that she was there, for she understood all wisdom, and she durst well speak, where as it to do was. Wherever she came everich was glad of her.

She said, "My Lord the King, ye ought not to be angry when ye sit in judgment, for that becometh not your nobleness. A man that sitteth in judgment ought to put from him all wrath and anger. A lord ought to have discretion that should sit in justice. I know better the points of the law than some that wear furred gowns, for I have learned many of them and was made cunning in the law. I had in the Pope's palace of Woerden a good bed of hay, where other beasts lay on the hard ground, and also when I had there to do I was suffered to speak, and was heard tofore another because I knew so well the law. Seneca writeth that a lord shall overall do right and law, he shall charge none to whom he hath given his safeguard to above the right and law; the law ought not to halt for no man. And every man that standeth here would well bethink him what he hath done and bedriven ${ }^{1}$ in his days, he should the better have patience and pity on Reynart. Let every man know him self, that is my counsel. There is none that standeth so surely but otherwhile he falleth or slideth. Who that never misdid ne sinned is holy and good, and hath no need to amend him. When a man doth amiss and then by counsel amendeth it. that is humanly and so ought he to do ; but alway to misdo and trespass and not to amend him, that is evil and a devily life. Mark then what is written in the gospel, Estote misericordes, be ye merciful; yet standeth there more, Nolite judicare et non judicabimini, deem ye no man and ye shall not be deemed. There standeth also how the pharisees brought a woman taken in adultery and would have stoned her to death. They

1 Bedriven, experienced (Dutch, bedreven). 
asked Our Lord what he said thereto; he said, "Who of you all is without sin let him cast the first stone.' Tho abode no man but left her there standing. Me thinketh it is so here. There be many that see a straw in another's eye that can not see a balke in his own. There be many that deem other, and himself is worst of all. Though one fall oft, and at last ariseth up and cometh to mercy, he is not thereof damned. God receiveth all them that desire his mercy. Let no man condemn another though they wist that he had done amiss; yet let them see their own defaults, and then may they themself correct first, and then Reynart my Cousin should not fare the worse. For his father and his grandfather have alway been in more love and reputation in this Court than Isegrim the Wolf or Bruin the Bear with all their friends and lineage. It hath been heretofore an unlike comparison, the wisdom of Reynart my Cousin, and the honour and worship of him, that he hath done, and the counsel of them; for they know not how the world goeth. Me thinketh this Court is all turned upside down. These false shrews, flatterers, and deceivers, arise and wax great by the lordes, and ben enhanced up; and the good, true, and wise ben put down, for they have been wont to counsel truly and for the honour of the King. I cannot see how this may stand long."

Then said the King, "Dame, if he had done to you such trespass as he hath done to other it should repent you. Is it wonder that I hate him? He breaketh away my safeguard. Have ye not heard the complaints that here have been showed of him, of murder, of theft, and of treason? Have ye such trust in him? Think ye that he is thus good and clear? then set him up on the altar, and worship and pray to him as to a saint. But there is none in all the world that can say any good of him; ye may say much for him, but in the end ye shall find him all nought. $\mathrm{He}$ hath neither kin ne one friend that will enterprise to help him. He hath so deserved. I have great marvel of you. I heard never of none that hath fellowshipped with him that ever thanked him or said any good of him, save you now, but alway he hath striked them with his tail." 
Then the he Ape answered and said, "My lord, I love him and have him in great charity. And also I know a good deed that he once in your presence did, whereof ye could him great thank. Though now it be thus turned, yet shall the heaviest weigh most. A man shall love his friend by measure, and not his enemy hate overmuch. Steadfastness and constancy is fitting and behoveth to the lords, how soever the world turneth. Me ought not to praise too much the day, till even be come. Good counsel is good for him that will do thereafter.

\section{CHAPTER XXX.}

\section{A parable of a Man that delivered a Serpent from peril of death.}

"Now two year past came a Man and a Serpent here into this Court for to have judgment, which was to you and yours right doubtful. The Serpent stood in an hedge whereas he supposed to have gone through, but he was caught in a snare by the neck that he might not escape without help, but should have lost his life there. The Man came forth by, and the Serpent called to him and cried, and prayed the Man that he would help him out of the snare, or else he must there die.

"The Man had pity of him, and said, 'If thou promise to me that thou wilt not envenom me, ne do me none harm ne hurt, I shall help thee out of this peril.'

"The Serpent was ready, and swore a great oath that he now ne never should do him harm ne hurt.

- "Then he unloosed him and delivered him out of the snare. And they went forth together a good while that the Serpent had great hunger, for he had not eaten a great while tofore, and sterte to the Man and would have slain him. The Man sterte away and was afraid, and said, 'Wilt thou now slay me? hast thou forgotten the oath that thou madest to me that thou shouldest not misdo ne hurt me?'

"The Serpent answered, "I may do it good tofore all the world that $I$ do. The need of hunger may cause a man to break his oath.' 
"The Man said, 'If it may be not better, give me so long respite till we meet and find that may judge the matter by right.'

"l'he Serpent granted thereto. Thus they went together so long that they found Tyseln the Raven and Slyndpere his son; there rehearsed they their reasons.

"Tyseln the Raven judged anon that he should eat the Man. He would fain have eaten his part, and his son also.

"The Serpent said to the Man, "How is it now ? What think ye? Have I not won?'

"The Man said, 'How should a robber judge this? He should have avail thereby. And also he is alone : there must be two or three at least together, and that they understand the right and law, and that done let the sentence gon; I am nevertheless ill on enough.'

"They agreed and went forth both together so long that they found the Bear and the Wolf, to whom they told their matter.

"And they anon judged that the Serpent should slay the Man. For the need of hunger breaketh oath alway. The Man then was in great doubt and fear, and the Serpent came and cast his venom at him; but the Man leapt away from him with great pain, and said, "Ye do great wrong that ye thus lie in await to slay me. Ye have no right thereto.'

"The Serpent said, 'Is it not enough yet? It hath been twice judged.'

" 'Yea,' said the Man, 'that is of them that ben wont to murder and rob. All that ever they swear and promise they hold not. But I appeal this matter into the Court tofore our Lord the King, and that thou mayst not forsake. ${ }^{1}$ And what judgment that shall be given there, shall I obey and suffer, and never do the contrary.'

"The Bear and the Wolf said that it should be so, and that the Serpent desired no better. They supposed if it should come tofore you it should go there as they would. I trow ye be well remembered hereof. Tho came they all to the Court tofore you; and the Wolf's two children came with their father, which were called Empty Belly and Never Full, because they would eat of 
the Man; for they howled for great hunger. Wherefore ye commanded them to avoid your Court.

"The Man stood in great dread, and called upon your good grace, and told how the Serpent would have taken his life from him, to whom he had saved his life, and that, above his oath and promise, he would have devoured him.

"The Serpent answered, 'I have not trespassed, and that I report me wholly unto the King. For I did it to save my life, for need of life one may break his oath and promise.'

"My Lord that time were ye and all your Council herewith accombred. For your noble grace saw the great sorrow of the Man, and ye would not that a man should for his gentleness and kindness be judged to death. And on that other, sith hunger, and need to save the life, seeketh narrowly to be holpen, here was none in all the Court that could ne knew the right hereof. There were some that would fain the Man had be holpen. I see them here standing. I wot well they said that they could not end this matter.

"Then commanded ye that Reynart, my nephew, should come and say his advice in this matter. That time was he above all other believed and heard in this Court, and ye bade him give sentence according to the best right and we all shall follow him, for he knew the ground of the law.

"Reynart said, "My Lord, it is not possible to give a true sentence after their words, for in hearsaying ben oft leasings. But and if I might see the Serpent in the same peril and need that he was in when the Man loosed him and unbound, then wist I well what I should say. And who that would do otherwise he should misdo against right.'

"Then said ye, my Lord, 'Reynart, that is well said. We all accord hereto ; for no man can say better.'

"Then went the Man and the Serpent into the place whereas he found the Serpent. Reynart bade that the Serpent should be set in the snare in likewise as he was. And it was done.

"Then said ye, my Lord, 'Reynart, how thinketh you now? What judgment shall we give?' 
"'Then said Reynart the Fox, 'My Lord, now ben they both like as they were tofore. They have neither won ne lost. See, my Lord, how I judge for a right, also ferre as it shall please your noble grace. If the Man will now loose and unbind the Serpent, upon the promise and oath that he tofore made to him, he may well do it. But if he think that he for anything should be encumbered or hindered by the Serpent, or for need of hunger would break his oath and promise, then judge I that the Man may go freely where he will, and let the Serpent abide still bounden, like as he might have done at the beginning: for he would have broken his oath and promise, whereas he holp him out of such fearful peril. Thus thinketh 'me a rightful judgment that the Man shall have his free choice like as he tofore had.'

"Lo my Lord this judgment thought you good, and all your council which at that time were by you ; and followed the same, and praised Reynart's wisdom, that he had made the Man quit and free. Thus the Fox wisely kept your noble honour and worship, as a true servant is bound to do to his Lord. Where hath the Bear or the Wolf done ever to you so much worship? They conne well huylen and blasen, steal and rob, and eat fat morsels and fill their bellies, and then judge they for right and law that small thieves that steal hens and chickens should be hanged, but they themself that steal kine, oxen, and horses, they shall go quit and be lords. And same as though they were wiser than Solomon, Avicene, or Aristoteles; and each will be holden high proud, and praised of great deeds and hardy; but and they come where as it is to do, they ben the first that flee. Then must the simple go forth tofore, and they keep the reward behind. Och, my Lord, these and other like to them be not wise, but they destroy town, castle, land, and people. They reck not whose house burneth, so that they may warm them by the coals. They seek all their own avail and singular profit. But Reynart the Fox and all his friends and lineage sorowen ${ }^{1}$ and think to prefer the honour, worship, fordeel, ${ }^{2}$ and profit of their lord, and for wise counsel

1 Sorowen, take care.

2 Fordeel, advantage (Dutch, Voordeel; German, Vortheil). 
which oft more profiteth here than pride and boast. This doth Reynart, though he have no thank. At long it shall be well known who is best and doth most profit. My Lord, ye say that his kin and lineage draw all afterward from him, and stand not by him for his falsehood and deceivable and subtle touches. I would another had said that; there should then such wrake be taken thereof that him might growl that ever he saw him. But, my Lord, we will forbear you ; ye may save your pleasure; and also I say it not by you. Were there any that would bedrive anything against you, with words or with werkes, him that would we so do to, that men should say we had been there. There as fighting is, we ben not wont to be afraid. My Lord, by your leave, I may well give you knowledge of Reynart's friends and kin. There ben many of them that for his sake and love will adventure life and good. I know myself for one. I am a wife. I should, if he had need, set my life and good for him. Also I have three full waxen children which ben hardy and strong, whom I would all together adventure for his love, rather than I should see him destroyed; yet had I liever die than I saw them miscarry tofore mine eyes, so well love I them.

\section{CHAPTER XXXI.}

\section{Which ben friends and kin unto Reynart the Fox.}

"THE first child is named Bytelouse, which is much cherished and can make much sport and game, wherefore is given to him the fat trenchours and much other good meat, which cometh well to profit of Fulrompe his brother. And also my third child is a daughter, and is named Hatenit, she can well pick out lice and nits out of men's heads. 'These three ben to each other true, wherefore I love them well."

Dame Rukenawe called them forth and said, "Welcome, my dear children: to me forth, and stand by Reynart, your dear nephew." 
Then said she, "Come forth all ye that be of my kin and Reynart's, and let us pray the King that he will do to Reynart right of the land."

Tho came forth many a beast anon, as the Squirrel, the Muskrat, the Fitchews, the Marten, the Beaver with his wife Ordegale, the Genete, ${ }^{1}$ the Otter, the Boussyng, and the Ferret, these twain eat as fain polaylle as doth Reynart. The Otter and Pantecroet his wife, whom I had almost forgotten, yet were they tofore, with the Beaver, enemies to the Fox, but they durst not gainsay Dame Rukenawe. for they were afraid of her. She was also the wisest of all his kin of counsel and was most doubted. ${ }^{2}$ There came also more than twenty other, because of her, for to stand by Reynart. There came also Dame Atrote with her two sisters, Weasel and Hermelin, the Ass, the Badger, the Water-rat, and many more to the number of forty, which all camen and stoden by Reynart the Fox.

"My Lord the King," said Rukenawe, " come and see here if Reynart have any friends. Here may ye see we ben your true subjects, which for you would adventure both life and good if ye had need. Though ye be hardy, mighty, and strong, our wellwilled friendship cannot hurt you. Let Reynart the. Fox well bethink him upon these matters that ye have laid against him, and if he cannot excuse them, then do him right. We desire no better. And this by right ought to no man be warned." 3

The Queen then spake, "This said I to him yesterday. But he was so fierce and angry that he would not hear it."

The Leopard said also, "Sire, ye may judge no further than your men give their verdict ; for if ye would go forth by will and might, that were not worshipful for your estate. Hear always both parties, and then by the best and wisest counsel give judgment discreetly according to the best right."

The King said, "This is all true, but I was so sore moved when I was informed of Cuwart's death and saw his head, that I was hot and hasty. I shall hear the Fox. Can he answer and

1 The genete is related to the civet cat.

2 Doubted, feared. 3 Warned, refused. 
excuse him of that is laid against him, I shall gladly let him go quit ; and also at request of his good friends and kin."

Reynart was glad of these words, and thought, God thank mine Aunt, she hath the rys do blosme again. ${ }^{1}$ She hath well holpen me forth now. I have now a good foot to dance on. I shall now look out of mine eyen, and bring forth the fairest leasing that ever man heard, and bring myself out of this danger.

\section{CHAPTER XXXII.}

How the Fox with subtlety excused him for the death of Cuwart the Hare and of all other matters that zere laid against him, and how with flattering he gat again his peace of the King.

Then spake Reynart the Fox and said, "Alas, what say ye! is Cuwart dead? And where is Bellyn the Ram? What brought he to you when he came again? For I delivered to him three jewels; I would fain know where they ben becomen. That one of them should he have given to you, my Lord the King, and the other two to my Lady the Queen."

'The King said, "Bellyn brought us nought else but Cuwart's head, like as I said you tofore; whereof I took on him wrake. I made him to lose his life, for the foul caitiff said to me that he himself was of the counsel of the letters making that were in the male."

"Alas, my lord, is this very truth? Woe to me caitiff that ever I was born! Sith that these good jewels be thus lost, mine heart will break for sorrow. I am sorry that I now live! What shall my wife say when she heareth hereof? She shall go out of her wit for sorrow . I shall never, all so long as I live, have her friendship. She shall make much sorrow when she heareth thereof."

The She Ape said, "Reynart, dear Nephew, what profiteth that ye make all this sorrow? Let it pass, and tell us what these jewels were. Peradventure we shall find counsel to have them again. If they be above earth Master Akeryn shall labour for them in

1 She has made the twig blossom again. 
his books, and also we shall curse for them in all the churches, unto the time that we have knowledge where they been. They may not be lost."

"Nay, Aunt, think not that, for they that have them will not lightly depart from them. There was never King that ever gave so rich jewels as these be. Nevertheless ye have somewhat with your words eased mine heart and made it lighter than it was. Alas, lo, here ye may see how he or they to whom a man trusteth most is often by him or them deceived. Though I should go all the world through, and my life in adventure set therefor, I shall wit where these jewels ben becomen."

With a dismalled and sorrowful speech, said the Fox: "Hearken ye all my kin and friends, I shall name to you these jewels what they were, and then may ye say that I have a great loss. That one of them was a ring of fine gold, and within the ring next the finger were written letters enamelled with sable and azure, and there were three Hebrew names therein. I could not myself read ne spell them, for I understand not that language; but Master Abrion of Trier he is a wise man, he understandeth well all manner of languages and the virtue of all manner herbs, and there is no beast so fierce ne strong but he can dompte him, for if he see him once he shall do as he will, and yet he believeth not on God. He is a Jew, the wisest in conning, and specially he knoweth the virtue of stones. I showed him once this ring. $\mathrm{He}$ said that they were tho three names that Seth brought out of Paradise when he brought to his father Adam the Oyle of Mercy, and whosomever beareth on him these three names he shall never be hurt by thunder ne lightning, ne no witchcraft shall have power over him, ne be tempted to do sin. And also he shall never take harm by cold though he lay three winters long nights in the field, though it snowed, stormed, or frore, never so sore, so great might have these words, witness of Master Abrion. Without forth on the ring stood a stone of three manner colours; the one part was like red crystal, and shone like as fire had been therein, in such wise that if one would go by night him behoved none other light, for the shining of the stone made and gave as great a light as it 
had been midday; that other part of the stone was white and clear as it had been burnished, who so had in his eyen any smart or soreness, or in his body any swelling, or headache, or any sickness, withoutforth if he striked this stone on the place where the grief is he shall anon be whole; or if any man be sick in his body of venom, or ill meat in his stomach, of colic, strangulation, stone, fistel, or cancer, or any other sickness, save only the very death, let him lay this stone in a little water and let him drink it, and he shall forthwith be whole and all quit of his sickness. Alas," said the Fox, "we have good cause to be sorry to lose such a jewel! Furthermore the third colour was green like glass, but there were some sprinkles therein like purple; the master told for truth, that who that bare this stone upon him should never be hurt of his enemy, and was no man, were he never so strong and hardy, that might misdo him; and wherever that he fought he should have victory, were it by night or by day, also ferre as he beheld it fasting; and also thereto, wheresomever he went and in what fellowship, he should be beloved, though he had hated him tofore, if he had the ring upon him they should forget their anger as soon as they saw him. Also though he were all naked in a field again an hundred armed men, he should be well hearted and escape from them with worship ; but he must be a noble gentleman and have no churl's conditions, for then the stone had no might. And because this stone was so precious and good, I thought in myself that I was not able ne worthy to bear it, and therefore I sent it to my dear Lord the King, for I know him for the most noble that now liveth, and also all our welfare and worship lieth on him, and for he should be kept from all dread, need, and ungheluck. ${ }^{1}$

"I found this ring in my father's treasure, and in the same place I took a glass or a mirror and a comb which my wife would algates have. A man might wonder that saw these jewels. I sent these to my I.ady the Queen, for I have founden her good and gracious to me. This Comb might not be too much praised. It was made of the bone of a clean noble beast named Panthera,

1 Ungheluck, misfortune (unglück). 
which feedeth him between the great Inde and Earthly Paradise. $\mathrm{He}$ is so lusty fair and of colour, that there is no colour under the heaven but some likeness is in him; thereto he smelleth so sweet, that the savour of him boteth ${ }^{1}$ all sickness ; and for his beauty and sweet smelling all other beasts follow him, for by his sweet savour they ben healed of all sickness. This Panthera hath a fair bone, broad and thin; when so is that this beast is slain all the sweet odour rested in the bone, which cannot be broken, ne shall never rot, ne be destroyed by fire, by water, ne by smiting, it is so hardy, tight and fast, and yet it is light of weight. The sweet odour of it hath great might ; that who that smelleth it sette nought by none other lust in the world, and is eased and quit of all manner diseases and infirmities, and also he is jocund and glad in his heart. This Comb is polished as it were fine silver, and the teeth of it be small and strait, and between the greater teeth and the smaller is a large field and space where is carven many an image subtilly made and enamelled about with fine gold; the field is checked with sable and silver, enamelled with cybore ${ }^{2}$ and azure, and therein is the history how Venus, Juno, and Pallas strove for the apple of gold which each of them would have had, which controversy was set upon Paris that he should give it to the fairest of them three.

"Paris was that time an herdman, and kept his father's beasts and sheep without Troy. When he had received the apple, Juno promised to him if he would judge that she might have the apple, he should have the most riches of the world. Pallas said if she might have the apple she would give him wisdom and strength, and make him so great a lord that he should overcome all his enemies and whom he would. Venus said, "What needest thou riches or strength, art not thou Priamus' son, and Hector is thy brother, which have all Asia under their power? Art not thou one of the possessors of great 'Troy? If thou wilt give to me the apple, I shall give thee the richest treasure of the world, and that

1 Boteth, is boot for, remedies.

3 Cybore, "cyboire" was the decorated case that contained the consecrated elements of the host. From Greek ' $\kappa \iota \beta \omega \rho \iota \nu$. 
shall be the fairest woman that ever had life on earth, ne never shall none be born fairer than she. Then shalt thou be richer than rich, and shalt climb above all other, for that is the treasure that no man can prize enough ; for honest fair and good women can put away many a sorrow from the heart, they be shamefast and wise, and bring a man in very joy and bliss.' Paris heard this Venus, which presented him this great joy and fair lady, and prayed her to name this fair lady that was so fair, and where she was. Venus said, 'It is Helen, King Menelaus' wife of Greece, there liveth not a nobler, richer, gentler, ne wiser wife in all the world. Then Paris gave to her the apple, and said that she was fairest. How that he gat afterward Helen by the help of Venus, and how he brought her in to 'Troy and wedded' her, the great love and jolly life that they had together, was all carven in the field, everything by himself, and the story written.

"Now ye shall hear of the Mirror. The glass that stood thereon was of such virtue that men might see therein all that was done within a mile, of men of beasts and of all thing that me would ${ }^{1}$ desire to wit and know. And what man looked in the glass, had he only disease of pricking or motes; smart, or pearls in his eyen, he should be anon healed of it, such great virtue had the glass. Is it then wonder if 1 be moved and angry for to lose such manner jewels? The tree in which this glass stood was light and fast and was named Cetyne. ${ }^{2}$. It should endure ever ere it would rot, or worms should hurt it, and therefore King Solomon ceiled his temple with the same wood withinforth. Men praised it dearer than fine gold ; it is like to tree of hebenus, of which wood King Crompart made his horse of tree for love of King Morcadigas' daughter that was so fair; whom he had weened for to have won. That horse was so made within, that whosoever rode on it, if he would, he should be within less than one hour an hundred miles thence; and that was well proved, for Cleomedes the king's son would not believe that that horse of tree had such might and virtue. He was young, lusty, and hardy, and desired to do great

1 Me would, one would. "Man" and "ne" were our Teutonic forms for the French "on."

? Shittim wood. 
deeds of praise for to be renowned in this world, and leapt on this horse of tree. Crompart turned a pin that stood on his breast, and anon the horse lift him up and went out of the hall by the window, and ere one might say his pater noster he was gone more than ten mile away. Cleomedes was sore afraid, and supposed never to have turned again, as the history ${ }^{1}$ thereof telleth more plainly. But how great dread he had, and how far that he rode upon that horse made of the tree of hebenus ere he could know the art and craft how he should turn him; and how joyful he was when he knew it; and how men sorrowed for him ; and how he knew all this, and the joy thereof when he came again, all this I pass over for losing of time; but the most part of all came to by the virtue of the wond, of which wood the tree that the glass stood in was made. And that was, without forth of the glass, half a foot broad, wherein stood some strange histories, which were of gold, of sable, of silver, of yellow, azure, and cynope, these six colours were therein wrought in such wise as it behoved; and under every history the words were graven and enamelled, that every man might understand what each history was. After my judgment there was never mirror so costly, so lustly, ne so pleasant. In the beginning stood there an Horse, made fat, strong, and sore envious upon an Hart which ran in the field so far and swiftly that the Horse was angry that he ran so far tofore him and could not overtake him. He thought he should catch him and subdue him, though he should suffer much pain therefor. The Horse spake tho to a Herdman in this wise, 'If thou couldst taken an Hart that I well can show thee, thou shouldst have great profit thereof; thou shouldst sell dear his horns, his skin, and his flesh.' 'The Herdman said, ' How may I come by him ?' 'The Horse said, 'Sit upon me, and I shall bear thee, and we shall hunt him till he be take.' The Herdman sprang and sat upon the Horse, and saw the Hart ; and he rode after; but the Hart was light of foot and swift, and outran the Horse far. They hunted so far after him that the Horse was weary, and said to the Herdman that sat on him, 'Now sit off,

1 The romance of Clyomon and Clanydes. 
I will rest me, I am all weary, and give me leave to go from thee.' The Herdman said, 'I have arrested thee; thou mayst not escape from me; I have a bridle on thy head and spurs on my heels; thou shalt never have thank hereof; I shall bedwynge and subdue thee, hadst thou sworn the contrary.'

"See how the Horse brought himself in thraldom and was taken in his own net. How may one better be taken than by his own proper envy suffer himself to be taken and ridden. There ben many that labour to hurt other, and they themselven ben hurt and rewarded with the same.

"There was also made an Ass and an Hound which dwelled both with a rich man. The man loved his Hound well, for he played oft with him as folk do with Hounds. The Hound leapt up and played with his tail, and licked his master about the mouth. This saw Howdwin the Ass, and had great spite thereof in his heart, and said to himself, 'How may this be? and what may my lord see on his foul Hound, whom I never see doth good ne profit save springeth on him and kisseth him? But me, whom men putten to labour, to bear and draw and do more in a week than he with his fifteen should do in a whole year,-and yet sitteth he nevertheless by him at the table and there eateth bones, flesh, and fat trenchours, - and I have nothing but thistles and nettles, and lie on nights on the hard earth, and suffer many a scorn. I will no longer suffer this. I will think how I may get my lord's love and friendship, like as the Hound doth. Therewith came the lord, and the Ass lift up his tail and sprang with his fore feet on the lord's shoulders and blared, grinned, and sang, and with his feet made two great boles about his ears, and put forth his mouth and would have kissed the lord's mouth as he had seen the Hound done. Tho cried the lord, sore afraid, 'Help! help! this Ass will slay me!' Then came his servants with staves and smiten and beat the Ass so sore that he had weened he should have lost his life. Tho returned he to his stable and ate thistle and nettles and was an Ass as he tofore was. In likewise whoso have enough and spite of another's welfare, and were served in likewise, it should be well behoveful. Therefore it is 
concluded that the Ass shall eat thistles and nettles and bear the sack. Though men would do him worship he cannot understand it, but must use old lewd manners. Whereas asses getten lordships, there men see seldom good rule. For they take heed of nothing but on their singular profit; yet ben they take up and risen great, the more pity is.

" Hearken further how my father and lybert the Cat went together, and had sworn by their truth that for love ne hate they should not depart. And what they gat they should depart to each the half. Then on a time they saw hunters coming over the field with many hounds. They leapt and ran fast from themward all that they might, as they that were afraid of their life.

" 'Tybert,' said the Fox, 'whither shall we now best flee? the hunters have espied us. Know ye any help?' , My father trusted on the promise that each made to other, and that he would for no need depart from him. 'Tybert,' said he, 'I have a sackful of wiles if we have need; as far as we abide together we need not to doubt hunters ne hounds.'

"Tybert began to sigh and was sore afraid, and said, ' Reynart, what availlen many words? I know but one wile, and thither must I too.'

"And tho clamb he up on a high tree into the top under the leaves, whereas hunter ne hound might do him none harm, and left my father alone in jeopardy of his life, for the hunters set on him the hounds all that they could. Men blew the horns, and cried, and hallooed, 'The Fox! Slee and take!' When Tybert the Cat saw that, he mocked and scorned my father and said; 'What, Reynart, cousin, unbind now your sack where all the wiles ben in! It is now time. Ye be so wise called; help yourself, for ye have need.'

"This much must my father hear of him to whom he had most his trust on, and was almost taken, and nigh his death. And he ran and fled with great fear of his life, and let his male slide off because he would be the lighter. Yet all that could not help him, for the hounds were too swift and should have bitten him; but he had one adventure that thereby he found an 
old hole, wherein he crept, and escaped thus the hunters and hounds.

"Thus held this false deceiver Tybert his sykernes that he had promised. Alas, how many ben there now a days that keep not their promise, and set not thereby though they break it! And though I hate Tybert herefor, is it wonder? But I do not. Sikerly, I love my soul too well thereto. Nevertheless, if I saw him in adventure and misfall in his body or in his goods, I trow it should not much go to my heart, so that another did it. Nevertheless, I shall neither hate him ne have envy at him. I shall, for God's love, forgive him. Yet is it not so clear out of mine heart but a little ill-will to himward abideth therein as this cometh to my remembrance; and the cause is that the sensuality of my flesh fighteth against reason.

"Ther stood also in that Mirror, of the Wolf, how he found once upon a heath a dead horse flayen, but ail the flesh was eaten. Then went he and bote great morsels of the bones, that for hunger he took three or four at once and swallowed them in, for he was so greedy that one of the bones stack thwart in his mouth. Whereof he had great pain, and was of great fear of his life. He sought all about for wise masters and surgeons, and promised great gifts for to be healed of his disease. At last, when he could nowhere find remedy, he came to the Crane with his long neck and bill, and prayed him to help him, and he would love and reward him so well that he should ever be the better. The Crane hearked after this great reward, and put his head into his throat, and brought out the bone with his bill.

"The Wolf start aside with the plucking, and cried oit, 'Alas, thou doest me harm! but. I forgive it thee. Do no more so, I would not suffer it of another.'

The Crane said, 'Sir Isegrim, go and be merry, for ye be all whole. Now give to me that ye promised.'

"The Wolf said, "Will ye hear what he saith? I am he that hath suffered and have cause to plain, and he will have good of me ! He thanketh not me of the kindness that I did to him. He put his head in my mouth, and I suffered him to draw it out 
whole without hurting; and be did to me also harm. And if any here should have a reward, it should be I, by right.'

"Thus the unkind men nowadays reward them that do them good. When the false and subtle arise and become great, then goeth worship and profit all to nought. There ben many, of right that ought reward and do good to such as have helpen them in their need, that now find causes and say they be hurt, and would have amends where they ought to reward and make amends themself. Therefore it is said, and truth it is, who that will chide or chastise see that he be clear himself.

"All this and much more than I now can well remember was made and wrought in this glass. The master that ordained it was a cunning man and a profound clerk in many sciences. And because these jewels were over good and precious for me to keep and have, therefore I sent them to my dear Lord the King and to the Queen in present. Where ben they now that give to their lords ${ }^{\circ}$ such presents. The sorrow that my two children made when I sent away the glass was great ; for they were wont to look therein and see themself how their clothing and array became them on their bodies. Oh, alas! I knew not that Cuwart the Hare was so nigh his death when I delivered him the male with these jewels. I wist not to whom I might better have taken them, though it should have cost me my life, than him and Bellyn the Ram. They were two of my best friends. Out, alas! I cry upon the murderer. I shall know who it was, though I should run through all the world to seek him, for murder abideth not hid, it shall come out. Peradventure he is in this company that knoweth where Cuwart is becomen, though he telleth it not; for many false shrews walk with good men, from whom no man can keep him, they knowen their craft so well and can well cover their falseness. But the most wonder that I have is that my Lord the King here sayeth so felly, that my father nor I did him never good. That thinketh me marvel, of a king. But there come so many things tofore him that he forgetteth that one with that other, and so fareth by me: Dear Lord, remember not ye when my Lord your father lived, and ye an youngling of two year were, that 
my father came from school from Monpellier whereas he had five year studied in recipes of medicines. He knew all the tokens of the urine as well as his hand, and also all the herbs, and nature of them which were viscous or laxative. He was a singular master in that science. He might well wear cloth of silk and a gilt girdle. When he came to Court he found the King in a great sickness, whereof he was sorry in his heart, for he loved him above all other lords. The King would not forego him, for when he came all other had leave to walk where they would; he trusted none so much as him. He said, 'Reynart, I am sick, and feel me the longer the worse.' My father said, 'My dear Lord, here is an urinal: make your water therein, and as soon as I may see it I shall tell what sickness it is and also how ye shall be holpen.' The King did as he counselled him, for he trusted no man better that lived. Though so were that my father did not as he should have done to you, but that was by counsel of evil and foul beasts -I had wonder thereof - but it was a raising against his death. He said, 'My Lord, if ye will be whole ye must eat the liver of a wolf of seven year old, that may ye not leave or else ye shall die ; for your urine showeth it plainly.'

"The Wolf stood thereby and said nought.

"But the King said to him, 'Sir Isegrim, now, ye hear well that I must have your liver if I will be whole.'

"Tho answered the Wolf and said, "Nay my lord not so, I wot well I am not yet five year old. I have heard my mother say so.'

"My father said, "What skilleth these words? Let him be opened, and I shall know by the liver if it be good for you or not.'

"And therewith the Wolf was taken to kitchen, and his liver taken out, which the King ate and was anon all whole of all his sickness. Then thanketh he my father much, and commanded all his household upon their lives that after that time they should call him Master Reynart.

" He abode still by the King, and was believed of all things, and must always go by his side ; and the King gave to him a gar- 
land of roses which he must always wear on his head. But now this is all turned. All the old good things that he did be forgotten, and these covetous and ravenous shrews ben taken up and set on the high bench, and ben heard and made great, and the wise folk ben put aback, by which these lords oft lack, and cause them to be in much trouble and sorrow. For when a covetous man of low birth is made a lord, and is much great, and above his neighbours hath power and might, then he knoweth not himself, ne whence he is consen, and hath no pity on no man's hurt, ne heareth no man's request, but if he may have great gifts. All his intent and desire is to gather good, and to be greater. Oh, how many covetous men ben now in lords' courts! They flatter and smeke, ${ }^{1}$ and please the prince, for their singular avail, but and the prince had need of them or their good, they should rather suffer him to die, or fare right hard, ere they would give or lend him. They be like the Wolf that had liefer the King had died than he would give him his liver. Yet had I liefer ere that the King or the Queen should fare amiss, that twenty such wolves should lose their lives; it were also the least loss. My lord, all this befell in your youth, that my father did thus. I trow ye have forgotten it.

"And also I have my self done you reverence, worship, and courtesy. Unroused be it, though ye now thank me but little, but peradventure ye remembered not that I shall now say, - not to any forwitting of you, for ye be worthy all worship and reverence that any man can do ; that have ye of Almighty God by inheritance of your noble progenitors, wherefore I your humble subject and servant am bounden to do to you all the service that I can or may. I came on a time walking with the Wolf Isegrim, and we had gotten under us both a Swine. And for his loud crying we bit him to death; and, sire, ye came from far out of a grove against us. Ye saluted us friendly, and said we were welcome, and that ye and my Lady the Queen, which came after you, had great hunger and had nothing for to eat, and prayed us for to give you part of our winning. Isegrim spake so soft that a man unnethe might 
hear him, but I spake out and said, 'yea, my lord, with a good will. 'Though it were more, we will well that ye have part.' And then the Wolf departed as he was wont to do; departed, and took that one half for himself, and he gave you a quarter for you and for the Queen. That other quarter he ate and bit as hastily as he might, because he would eat it alone. And he gave to me but half the lungs, that I pray God that evil might he fare.

"Thus showed he his conditions and nature. Ere men should have sungen a Credo, ye, my lord, had eaten your part, and yet would ye fain have had more, for ye were not full. And because he gave you no more, ne proffered you, ye lift up your right foot and smote him between the ears that ye tore his skin over his eyen, and tho he might no longer abide, but he bled, howled, and ran away, and left his part there lying. Tho said ye to him, 'Haste ye again hither, and bring to us more. And here after see better to how ye deal and part.' Then said I, 'My lord, if it please you I will go with him, I wot well what ye said.' I went with him. He bled and groaned, as sore as he was, all softly; he durst not cry loud. We went so far that we brought a calf. And when ye saw us come therewith ye laughed, for ye were well pleased, ye said to me that I was swift in hunting: 'I see well that ye can find well when ye take it upon you. Ye be good to send forth in a need. The calf is good and fat, hereof shall ye be the dealer.' I said, 'My lord, with a good will. The one half, my lord, shall be for you. And that other half for my lady the Queen. The moghettis, liver, lungs, and the inward, shall be for your children. The head shall Isegrim the Wolf have, and I will have the feet.' Tho said ye, 'Reynart, who hath taught you to depart so courteously?' 'My lord,' said I, 'that hath done this priest that sitteth here with the bloody crown. He lost his skin with the uncourteous departing of the swine, and for his courtesy and ravin he hath hurt and shame.'

"Alas there be many wolves now a days that, without right and reason, destroy and eat them that they may have the overhand of. They spare neither flesh ne blood, friend ne enemy. What they 
can get that take they. $\mathrm{O}$, woe be to that land and to towns where as the wolves have the overhand!

"My lord, this and many other good thing have I done for you, that I could well tell if it were not too long, of which now ye remember little by the words I hear of you. If ye would all thing oversee well, ye would not say as ye do. I have seen the day that there should no great matter be concluded in this Court without mine advice. Albeit that this adventure is now fallen, it might happen yet that my words shall be heard and also believed as well as another's, as far as right will, for I desire none other. For if there be any can say and make good by sufficient witnesses that I have trespassed, I will abide all the right and law that may come thereof; and if any say on me anything of which he can bring no witnesses, let me then be ruled after the law and custom of this court."

The King said, "Reynart, ye say reasonably. I know not of Cuwart's death more than that Bellyn the Ram brought his head hither in the male. Thereof I let you go quit, for I have no witness thereof."

"My dear lord," said Reynart, "God thank you. Sykerly ye do well. For his death maketh me so sorrowful that methinketh my heart will break in two. Oh, when they departed from me, mine heart was so heavy that I should have swooned. I wot well it was a token of the loss that tho was so nigh coming to me."

All the most part of them that were there and heard the Fox's words of the jewels, and how he made his countenance and stretched him, had verily supposed that it had not be feigned but that it had be true. They were sorry of his loss and misadventure, and also of his sorrow. The King and the Queen had both pity of him, and bade him to make not too much sorrow, but that he should endeavour him to seek them. For he had so much praised them that they had great will and desire to have them. And because he had made them to understand that he had sent these jewels to them, though they never had them yet they thanked him, and prayed him to help that they might have them.

The Fox understood their meaning well, he thought toward 
them but little good for all that. He said, "God thank you, my lord and my lady, that ye so friendly comfort me in my sorrow. I shall not rest night ne day, ne all they that will do anything for me, but run, and pray, threaten, and ask all the four corners of the world, though I should ever seek, till that I know where they ben bicomen. And I pray you, my Lord the King, that it they were in such place as I could not get them by prayer, by might, ne by request, that ye would assist me and abide by me; for it toucheth yourself, and the good is yours; and also it is your part to do justice on theft and murder, which both ben in this case."

"Reynart," said the King, "that shall I not leave, when ye know where they ben. Mine belp shall be alway ready for you."

"Oh, dear lord, this is too much presented to me. If I had power and might I should deserve against you."

Now hath the Fox his matter fast and fair, for he hath the King in his hand as he would. Him thought that he was in better case than it was like to have be; he hath made so many leasings that he may go freely where he will, without complaining of any of them all, save of Isegrim, which was to himward angry and displeased, and said, "O noble King, are ye so much childish that ye believe this false and subtle shrew, and suffer yourself with false lies thus to be deceived? Of faith it should be long or I should believe him, he is in murder and treason all bewrapped, and he mocketh you tofore your visage. I shall tell him another tale. I am glad that I see now him here. All his leasings shall not avail him ere he depart from me."

\section{CHAPTER XXXIII.}

Hon Isegrim the Wolf complained again on the Fox.

"My lord, I pray you to take heed. This false thief betrayed my wife once foul and dishorestly. It was so that in a winter's day they went together through a great water, and he bare my wife an honde that he would teach her take fish with her tail, and that 
she should let it hang in the water a good while and there should so much fish cleave on it that four of them should not conne eat it. The fool, my wife, supposed he had said truth. And she went in the mire ere she came into the water, and when she was in the deepest of the water he bad her hold her tail till that the fish were comen. She held her tail so long that it was frozen hard in the ice and could not pluck it out. And when he saw that, he sprang up after on her body. She could not defend herself, the silly beast, she stood so deep in the mire. Hereof he cannot say nay, for I found him with the deed. Alas, what pain suffered I tho at my heart! I had almost for sorrow lost my five wits, and cried as loud as I might, and when he saw me so nigh he went his way. I went to her in a great heaviness, and went deep in that mire and that water ere I could break the ice, and much pain suffered she ere she could have out her tail, and yet left a gobbet of her tail behind her. And we were like both thereby to have lost our lives, for she yelped and cried so loud for the smart that she had ere she came out, that the men of the village came out, with staves and bills, with flail and pickforks, and the wives with their distaffs, and cried despitously, "Slay! slay! and smite down right!" I was never in my life so afraid, for unnethe we escape. We ran so fast that we sweat. There was a villain that stake on us with a pike which hurted us sore; he was strong and swift a foot. Had it not be night, certainly we had been slain. The foul old queans would fain have beaten us. They said that we had bitten their sheep. They cursed us with many a curse. Tho came we in a field full of broom and brambles, there hid we us from the villains, and they durst not follow us further by night, but returned home again. See my lord this foul matter. Ye ought to do justice thereon sharply."

Reynart answered and said, "If this were true, it should go too nigh mine honour and worship. 'God forbid that it should be found true! It is well true that I taught her how she should in a place catch fish, and showed her a good way for to go over into the water without going into the mire. But she ran so desirously when she heard me name the fish, that she neither way ne path 
held, but went into the ice wherein she was forfrorn. And that was because she abode too long. She had fish enough, if she could have be pleased with measure. It falleth oft, who that would have all loseth all. Over covetous was never good. For the beast cannot be satisfied, and when I saw her in the ice so fast I went to have holpen her, and to have brought her out, but it was all pain lost, for she was too heavy for me. Tho came Isegrim, and saw how I did all my best, and he, as a foul churl, foul and rybadously slandereth me with her, as these foul unthrifts ben wont to do. But, my dear Lord, it was none otherwise. He belieth me falsely. Peradventure his eyen dazzled as he looked from above down. He cried and cursed me, and swore many an oath I should dear abye it. When I heard him so curse and threaten I went my way, and let him curse and threaten till he was weary. And tho went he and help his wife out, and then he leapt and ran, and she also, for to get them an heat and to warm them, or else they should have died for cold. And whatsomever I have said, afore or after, that is clearly all truth. I would not for a thousand mark of fine gold lie to you one leasing. It were not fitting for me. Whatsomever fall of me, I shall say the truth, like as mine elders have always done sith the time that we first understood reason. And if ye be in doubt of anything that I have.said otherwise than truth, give me respite of eight days, that I may have counsel, and I shall bring such information with good true and sufficient record that ye shall all your life during trust and believe me, and so shall all your council also. What have I to do with the Wolf? It is tofore clearly enough showed that he is a foul villainous caitiff, and an unclean beast, when he dealed and departed the swine. So it is now knowen to you all by his own words, that he is a defamer of women as much as in him is, ye may well mark euerychone. Now ask ye his wife if it be so as he saith. If she will say the truth I wot well she shall say as I do."

Tho spake Ersewynde the Wolf's wife, "Ach, fell Reynart, no man can keep himself from thee,-thou canst so well utter thy words and thy falseness and reason set forth. But it shall be 
evil rewarded in the end. How broughtest thou me once into the well, where the two buckets hung by one cord running through one pulley, which went one up and another down, thou sattest in that one bucket beneath in the pit in great dread. I came thither and heard thee sigh and make sorrow, and asked thee how thou camest there. Thou saidst that thou hadst there so many good fishes eaten out of the water that thy belly would burst. I said, 'Tell me how I shall come to thee.' Then saidst thou, 'Aunt, spring into that bucket that hangeth there, and ye shall come anon to me. I did so; and I went downward, and ye came upward. 'Tho was I all angry.' 'Thou saidst, 'Thus fareth the world, that one goeth up and another goeth down.' Tho sprang ye forth and went your way, and I abode there alone, sitting an whole day sore and hungered and a cold; and thereto had I many a stroke ere I could get thence."

"Auntie," said the Fox, "though the strokes did you harm, I had liever ye had them than I, for ye may better bear them ; for one of us must needs have had them. I taught you good, will ye understand it and think on it, that ye another time take better heed and believe no man over hastily, is he friend or cousin, for every man seeketh his own profit. They be now fools that do not so, and specially when they be in jeopardy of their lives."

\section{CHAPTER XXXIV.}

\section{A fair parable of the Fox and the Wolf.}

"My Lord," said Dame Ersewynde, "I pray you hear how he can blow with all winds, and how fair bringeth he his matters forth."

"Thus hath he brought me many time in scathe and hurt," said the Wolf. "He hath once betrayed me to the She Ape, mine aunt, where I was in great dread and fear, for I left there almost mine one ear. If the Fox will tell it, how it befel, I will give him the fordele thereof, for I cannot tell it so well but he shall beryspe me."

"Well," said the Fox, "I shall tell it without stammering. I shall say the truth. I pray you hearken me. He came into the 
wood and complained to me that he had great hunger; for I saw nim never so full but he would alway have had fain more. I have wonder where the meat becometh that he destroyeth. I see now on his countenance that he beginneth to grymme for hunger. When I heard him so complain, I had pity of him. And I said, I was also hungry. Then went we half a day together and found nothing. Tho whined he and cried, and said he might go no further. 'Then espied I a great hole, standing in the middis ${ }^{1}$ under an hawe which was thick of brambles, and I heard a rushing therein, I wist not what it was. Then said I, 'Go therein and look if there be anything there for us; I wot well there is somewhat.' Tho said he, 'Cousin, I would not creep into that hole for twenty pound, but ${ }^{2}$ I wist ${ }^{3}$ first what is therein. Methinketh that there is some perilous thing. But I shall abide here under this tree, if ye will go therein tofore. But come anon again, and let me wete ${ }^{4}$ what thing is therein. Ye can many a subtlety, and can well help yourself, and much better than I.' See my Lord the King, thus he made me, poor wight, to go tofore into the danger, and he, which is great, long, and strong, abode without and rested him in peace. Await if I did not for him there. I would not suffer the dread and fear that I there suffered, for all the good in earth, but if I wist how to escape. I went hardily in. I found the way dark, long, and broad. Ere I right in the hole came, so espied I a great light which came in from that one side. There lay in a great Ape with twain great wide eyen, and they glimmed as a fire; and she had a great mouth with long teeth, and sharp. nails on her feet and on her hands; I weened it had be a mermouse, a baubyn, or a mercatte, for I saw never fouler beast. And by her lay three of her children, which were right foul, for they were right like the mother. When they saw me come, they gapeden wide on me and were all still. I was afraid and would well I had been thence; but I thought, I am therein, I must there through, and come out as well as I may. As I saw her, me thought she seemed more ${ }^{5}$

1 Middis, midst.

4 Wete, know.

2 But, except.

3 Wist, knew.

5 More, bigger. 
than Isegrim the Wolf, and her children were more than I. I saw never a fouler meyne. ${ }^{1}$ They lay on foul hay which was all bepissed. They were beslabbed and beclagged to their ears too in her own dung. It stank that I was almost smothered thereof. I durst not say but good, and then I said, 'Aunt, God give you good day, and all my cousins, your fair children, they be of their age the fairest that ever I saw. O, Lord God, how well please they me! how lovely ! how fair be they! Each of them for their beauty might be a great king's son! Of right we ought to thank you, that ye thus increase our lineage. Dear Aunt, when I heard say that ye were delivered and laid down I could no longer abide, but must come and friendly visit you. I am sorry that I had not erst knowen it.'

" 'Reynart, cousin,' said she, "ye be welcome. For that ye have found me, and thus come see me, I thank you. Dear cousin, ye be right true, and named right wise in all lands, and also that ye gladly further and bring your lineage in great worship. Ye must teach my children with yours some wisdom, that they may know what they shall do and leave. I have thought on you, for gladly ye go and fellowship with the good.'

"Oh how well was I pleased when I heard these words. This deserved $I$ at the beginning when I called her aunt; howbeit that she was nothing sybbe to me; for my right Aunt is Dame Rukenawe that yonder standeth, which is wont to bring forth wise children.

"I said, 'Aunt, my life and my good is at your commandment, and what I may do for you by night and by day. I will gladly teach them all that I can.'

"I would fain have be thence for the stench of them; and also I had pity of the great hunger that Isegrim had.

"I said, 'Aunt, I shall commit you and your fair children to God and take my leave. My wife shall think long after me.'

": 'Dear cousin,' said she, 'ye shall not depart till ye have eaten ; for if ye did l would say ye were not kind.'

'Tho stood she up and brought me in another hole, whereas

I Meyne, household. 
was much meat of harts and hinds, roes, pheasants, partridges, and much other venison, that I wondered from whence all this meat might come. And when I had eaten my bellyful, she gave me a great piece of an hind for to eat with my wife and with my household when I come home. I was ashamed to take it, but I might none otherwise do. I thanked her and took my leave. She bade me I should come soon again. I said I would, and so departed thence merrily that I so well had sped. I hasted me out, and when I came, saw Isegrim which lay groaning. And I asked him how he fared. He said, 'Nephew, all evil, for it is wonder that I live: Bring ye any meat to eat? I die for hunger.'. Tho had I compassion of him and gave him that I had, and saved him there his life; whereof then he thanked me greatly, howbeit that he now oweth me evil will.

"He had eaten this up anon, tho said he, "Reynart, dear cousin, what found ye in that hole? I am more hungry now than I was tofore. My teeth ben now sharped to eat."

"I said then, "Eme, haste you then lightly into that hole. Ye shall find there enough. There lieth mine Aunt with her children; if ye will spare the truth, and lie great leasings, ye shall have there all your desire. But and ye say truth, ye shall take harm.'

"My Lord, was not this enough said and warned, who so would understand it, that all that he found, he should say the contrary. But rude and plump beasts cannot understand wisdom ; therefore hate they all subtle inventions, for they cannot conceive them. Yet nevertheless, he said he would go in, and lie so many leasings, ere he should mishap, that all men should have wonder of it; and so went forth into that foul stinking hole, and found the marmosette. She was like the devil's daughter, and on her hung much filth clottered in gobbets.

"Tho cried he, 'Alas, me growleth of these foul nickers! Come they out of hell? Men may make devils afraid of them. Go and drown them, that evil might they fear! I saw never fouler worms, they make all mine hair to stand right up.'

" 'Sir Isegrim,' said she, 'what may I do thereto? They ben my children, and I must be their mother. What lieth that in 
your way, whether they be foul or fair? They have you nothing cost. Here hath been one to-day before you which was to them nigh of kin, and was your better and wiser; and he said that they were fair. Who hath sent you hither with these tidings?'

" "Dame, will ye wit, I will eat of your meat. It is better bestowed on me than on these foul wights.'

"She said, 'Here is no meat.'

" He said, 'Here is enough.'

"And therewith he stert with his head toward the meat, and would have gone into the hole where the meat was. But mine aunt stert up with her children, and run to him with their sharp long nails so sore that the blood ran over his eyen. I heard him cry sore and howl, but I know of no defence that he made but that he ran fast out of the hole. And he was there scratched and beaten, and many an hole had they made in his coat and skin. His visage was all on a blood and almost he had lost his one ear. $\mathrm{He}$ groaned and complained to me sore : then asked I him if he had well lied. He said, 'I said like as I saw and found, and that was a foul beast with many foul wights.'

" 'Nay, Eme,' said I, 'ye should have said Fair niece how fare ye and your fair children which ben my wellbeloved cousins?' The Wolf said, 'I had liefer that they were hanged ere I that said.'

" 'Yea, Eme, therefore must ye receive such manner payment. It is better otherwhile to lie than to say truth. They that ben better wiser and stronger than we be have done so tofore us.'

"See, my Lord the King, thus got he his red coif. Now standeth he all so simply as he knew no harm. I pray you ask ye him if it was not thus. He was not far off, if I wot it well."

\section{CHAPTER XXXV.}

How Isegrim proffered his glove for the Fox to fight with him.

THE Wolf said, "I may well forbear your mocks and your scorns and also your fell venomous words, strong thief that ye are. Ye said that I was almost dead for hunger, when ye help me in my need. 
That is falsely lied, for it was but a bone that ye gave to me, ye had eaten away all the flesh that was thereon. And ye mock me and say that I am hungry, here where I stand. That toucheth my worship too nigh, - what many a spity word have ye brought forth with false leasings !-and that I have conspired the King's death, from the treasure that ye have said to him is in Hulsterlo,and ye have also my wife shamed and slandered that she shall never recover it, and I should ever be disworshipped thereby if I avenged it not. I have forborne you long, but now ye shall not escape me. I can not make hereof great proof, but I say here tofore my lord and tofore all them that ben here that thou art a false traitor and a murderer, and that I shall prove and make good on thy body within lists in the field, and that body against body, and then shall our strife have an end. And thereto I cast to thee my glove, and take thou it up I shall have right of thee or die therefor."

Reynart the Fox thought, How come I on this campaign? we ben not both like. I shall not well conne stand against this strong thief. All my proof is now come to an end.

\section{CHAPTER XXXVI.}

How the Fox took up the glove. And how the King set to them day and ficld for to come and do their battle.

YET thought the Fox I have good advantage: the claws of his forefeet ben off, and his feet ben yet sore thereof, when for my sake he was unshoed. He shall be somewhat the weaker.

Then said the Fox, "Who that saith that I am a traitor or a murderer, I say he lieth falsely; and that art thou specially Isegrim. Thou bringest me there as I would be. This have I oft desired. Lo here is my pledge that all thy words ben false, and that I shall defend me and make good that thou liest."

The King received the pledges, and admitted the battle, and asked borowes ${ }^{1}$ of them both that on the morn they should come 
and perform their battle, and do as they ought to do. Then the Bear and the Cat were borowes for the Wolf; and for the Fox were borowes Grymbart the Dasse and Byteluys.

\section{CHAPTER XXXVII.}

How Rukenawe the She Ape counselled the Fox hore he should behave him in the field against the Wolf.

The She Ape said to the Fox, "Reynart Nephew, see that ye take heed in your battle. Be cold and wise. Your Eme taught me once a prayer that is of much virtue to him that shall fight; and a great master and a wise clerk, and was abbot of Boudelo, that taught him, he said, who that said devoutly this prayer fasting shall not that day be overcomen in battle ne in fighting. Therefore, dear Nephew, be not afraid, I shall read it over you tomorrow, then may ye be sure enough of the Wolf. It is better to fight than to have the neck asunder."

"I thank you, dear aunt," said the Fox. "The quarrel that I have is rightful, therefore I hope I shall speed well, and that shall greatly be inine help."

All his lineage abode by him all the night and holp him to drive away the time.

Dame Rukenawe the She Ape, his aunt, thought alway on his profit and fordele. And she did all his hair from the head to the tail be shorn off smooth; and she anointed all his body with oil of olive ; and then was his body also glat ${ }^{1}$ and slipper that the Wolf should have none hold on him. And he was round and fat also on his body.

And she said to him, "Dear cousin, ye must now drink much that to-morrow ye may the better make your urine; but ye shall hold it in till ye come to the field And when need is and time, so shall ye piss full your rough tail and smite the Wolf therewith in his beard. And if ye might hit him therewith in his eyen, then shall ye byneme him ${ }^{2}$ his sight. That should much hinder him. 
But else, hold alway your tail fast between your legs that he catch you not thereby; aid hold down your ears lying plat after your head that he hold you not thereby; and see wisely to yourself. And at beginning flee from his strokes, and let him spring and run after you, and run tofore where as most dust is, and stir it with your feet that it may flee in his eyen, and that shall much hinder his sight. And while he rubbeth his eyen, take your advantage and smite and bite him there as ye may most hurt him, and alway to hit him with your tail full of piss in his visage, and that shall make him so woe that he shall not wit where he is. And let him run after you for to make him weary. Yet his feet ben sore of that ye made him to lose his shoes, and though he be great he hath no heart. Nephew, certainly this is my counsel. The connyng goeth tofore strength; therefore see for yourself, and set yourself wisely at defence, that ye and we all may have worship thereof. I would be sorry if ye mishapped. I shall teach you the words that your Eme Martin taught me, that ye may overcome your enemy, as I hope ye shall do without doubt."

Therewith she laid her hand upon his head, and said these words: "Blaerde Shay Alphenio Kasbue Gorfons Alsbuifrio. Nephew, now be ye sure from all mischief and dread. And I counsel you that ye rest you a little, for it is by the day ye shall be the better disposed ; we shall awake you in all in time."

"Aunt," said the Fox, "I am now glad. God thank you, ye have done to me such good I can never deserve it fully again. Methinketh there may nothing hurt me sith that ye have said these holy words over me."

Tho went he and laid him down under a tree in the grass, and slept till the sun was risen. Tho came the Otter and waked him, and bad him arise, and gave him a good young duck and said, "Dear cousin, I have this night made many a leap in the water ere I could get this young fat duck. I have taken it from a fowler. Take and eat it."

Reynart said, "This is good handsel. If I refused I were a fool. I thank you, cousin, that ye remember me. If I live I shall reward you." 
The Fox ate the duck without sauce or bread. It savoured him well, and went well in. And he drank thereto four great draughts of water. Then went he to the battle ward, and all they that loved him went with him.

\section{CHAPTER XXXVIII.}

Hore the Fox came into the field and how they fought.

When the King saw Reynart thus shorn and oiled he said to him, "Ey, Fox, how well can ye see for yourself!"

He wondered thereof; he was foul to look on.

But the Fox said not one word, but kneeled down low to the earth unto the King and to the Queen, and striked him forth into the field.

The Wolf was there ready and spake many a proud word. The rulers and keepers of the field were the Leopard and the Losse. 1 They brought forth the book on which sware the Wolf that the Fox was a traitor and a murderer, and none might be falser than he was, and that he would prove on his body and make it good. Reynart the Fox sware that he lied as a false knave and a cursed thief, and that he would do good on his body.

When this was done, the governors of the field bade them do their devoir. Then roomed they all the field, save Dame Rukenawe the She Ape, she abode by the Fox and bade him remember well the words that she had said to him. She said, "See well to. When ye were seven years old ye were wise enough to go by night without lantern or moonshine where ye wist to win any good. Ye ben named among the people wise and subtle. Pain yourself to work so that ye win the prize, then may ye have ever honour and worship, and all we that ben your friends."

He answered, "My dearest aunt, I know it well. I shall do my best, and think on your counsel. I hope so to do that all my lineage shall have worship thereby, and mine enemies shame and confusion."

She said, "God grant it you."

1 Losse, lynx (Dutch, los). 


\section{CHAPTER XXXIX. \\ How the Fox and the Wolf fought together.}

THEREwITH she went out of the field and let them twain go together. The Wolf trode forth to the Fox in great wrath, and opened his forefeet, and supposed to have taken the Fox in them. But the Fox sprang from him lightly, for he was lighter to foot than he. The Wolf sprang after, and hunted the Fox sore. Their friends stood without the lists and looked upon them. The Wolf strode wider than Reynart did, and oft overtook him, and lift up his foot and weened to have smitten him. But the Fox saw to, and smote him with his rough tail, which he had all bepissed, in his visage. Tho weened the Wolf to have ben plat blind; the piss started in his eyen. Then must he rest, for to make clean his eyen. Reynart thought on his fordele, and stood above the wind scraping and casting with his feet the dust, that it flew the Wolf's eyenful. The Wolf was sore blinded therewith, in such wise that he must leave the running after him, for the sand and piss cleaved under his eyen, that it smarted so sore that he must rub and wash it away.

Tho came Reynart in a great anger and bote ${ }^{1}$ him three great wounds on his head with his teeth, and said, "What is that, Sir Wolf! Hath one there bitten you? How is it with you? I will all otherwise on you yet. Abide. I shall bring you some new thing. Ye have stolen many a lamb, and destroyed many a simple beast, and now falsely have appealed me and brought me in this trouble. All this shall I now avenge on thee. I am chosen to reward thee for thine old sins, for God will no longer suffer thee in thy great raven and shrewdness. I shall now assoil thee, and that shall be good for thy soul. Take patiently this penance, for thou shalt live no longer. The hell shall be thy purgatory. 'Thy life is now in my mercy, but and if thou wilt kneel down and ask me forgiveness, and knowledge thee to be overcomen, yet though thou be evil, yet I will spare thee. For

1 Bote, bit. 
my conscience counselleth me I should not gladly slay no man."

Isegrim weened with these mocking and spiteous words to have gone out of his wits; and that dered ${ }^{1}$ him so much that he wist not what to say, buff ne haff, he was so angry in his heart. The wounds that Reynart had given him bled and smarted sore, and he thought how he might best avenge it.

With great anger he lift up his foot and smote the Fox on the head so great a stroke that he fell to the ground. Tho stert the Wolf to, and weened to have taken him. But the Fox was light and wily, and rose lightly up, and met with him fiercely. And there began a fell battle which dured long. The Wolf had great spite on the Fox, as well it seemed. He sprang after him ten times each after other, and would fain have had him fast. But his skin was so slipper and fat of the oil, that alway he escaped from him. O, so subtle and snelle ${ }^{2}$ was the Fox, that many times when the Wolf weened well to make sure of him, he stert then between his legs and under his belly, and then turned he again and gave the Wolf a stroke with his tail in his eyen, that Isegrim weened he should have lost his sight, and this did he often times. And alway when he had so smitten him, then would he go above the wind and raise the dust, that it made his eyen full of stuffs. Isegrim was woebegone, and thought he was at an afterdele $;^{3}$ yet was his strength and might much more than the Fox's. Reynart had many a sore stroke of him when he raught ${ }^{4}$ him. They gave each other many a stroke and many a bite when they saw their advantage, and each of them did his best to destroy that other. I would I might see such a battle. That one was wily, and that other was strong. That one fought with strength, and that other with subtlety.

The Wolf was angry that the Fox endured so long against him. If his foremost feet had been whole, the Fox had not endured so long; but the sores were so open that he might not well run.

3 At an afterdele, about to pass away. Dutch, dalen, is to sink, as the sun when it is setting, begint te dalen.

\$ Raught, reached him. 
And the Fox might better off and on than he, and also he swang his tail oft under his eyen, and made him that him thought that his eyen should go out.

At last he said to himself, I will make an end of this battle. How long shall this caitiff dure thus against me? I am so great, I should, if I lay upon him, press him to death. It is to me a great shame that I spare him so long. Men shall mock and point me with fingers to my shame and rebuke, for I am yet on the worst side. I an sore wounded; I bleed sore; and he drowneth me with his piss and casts so much dust and sand in mine eyen that hastily I shall not conne see, if I suffer him any longer. I will set it in adventure and seen what shall come thereof.

With that he smote with his foot Reynart on the head that he fell down to the ground, and ere he could arise he caught him in his feet and lay upon him as he would have pressed him to death. Tho began the Fox to be afraid, and so were all his friends when they saw him lie under. And on that other side all Isegrim's friends were joyful and glad. The Fox defended him fast with his claws as he lay upward with his feet, and gave many a clope. ${ }^{1}$ The Wolf durst not with his feet do him much harm, but with his teeth snatched at him as he would have bitten him. When the Fox saw that he should be bitten and was in great dread, he smote the Wolf in the head with his foremost claws and tare the skin off between his brows and his ears, and that one of his eyen hung out ; which did hım much pain. He howled, he wept, he cried loud, and made a piteous noise, for the blood ran down as it had been a stream.

\section{CHAPTER XL.}

How the Fox, bcing under the Wolf, with flattering wordes glosed him, that the Fox came to his above again.

The Wolf wiped his eyen, the Fox was glad when he saw that. He wrestled so sore, that he sprang on his feet while he rubbed his eyen. The Wolf was not well pleased therewithal, and smote

1 Clope, blow (Dutch, klop). 
after him ere he escaped, and caught him in his arms, and held him fast, notwithstanding that he bled. Reynard was woe then. There wrestled they long and sore. The Wolf waxed so angry that he forgat all his smarts and pain, and threw the Fox all plat under him, which came him evil to pass, for his one hand, by which he defended him stert in the falling into Isegrim's throat, and then was he afraid to lose his hand.

The Wolf said tho to the Fox, "Now choose, whether ye will yield you as overcome or else I shall certainly slay you. Thy scattering of the dust, thy piss, thy mocking, ne thy defence, ne all thy false wiles, may not now help thee. Thou mayest not escape me. Thou hast heretofore done me so much harm and shame, and now I have lost mine one eye and thereto sore wounded."

When Reynart heard that it stood so rowme ${ }^{1}$ that he should choose to knowledge him overcomen and yield him or else to take the death, he thought the choice was worth ten mark, and that he must say that one or that other. He had anon concluded what he would say, and began to say to him with fair words in this wise :

"Dear Eme, I will gladly become your man with all my good. And I will go for you to the holy grave, and shall get pardon and winning for your cloister of all the churches that ben in the holy land, which shall much profit to your soul and your elders' souls also. I trow there was never such a proffer proffered to any king. And I shall serve you like as I should serve our holy father the Pope. I shall hold of you all that I have, and ever ben your servant, and forth I shall make that all my lineage shall do in like wise. Then shall ye be a lord above all lords. Who should then dare do anything against you? And furthermore whatsomever I take of polaille, geese, partridge, or plover, fish or flesh, or whatsomever it be, thereof shall ye first have the choice, and your wife and your children, ere any come in my body. Thereto I will alway abide by you, that where ye be there shall no hurt ne scathe come to you. Ye be strong, and I am wily: let us abide together that, one with the counsel and that other

1 Rowme, ruefully (Dutch, rouw, sorrow). 
with the deed, then may there nothing misfall to usward. And we ben so nigh of kin each to other that of right should be no anger between us. I would not have foughten against you if I might have escaped. But ye appealed me first unto fight, tho must I do that I not do would gladly. And in this battle I have ben curtoys to you, I have not showed the utterest of my might on you like as I would have done if ye had been a stranger to me; for the Nephew ought to spare the Eme, it is good reason and it ought so to be. Dear Eme, so have I now do, and that may ye mark well when I ran tofore you, mine heart would not consent thereto. For I might have hurt you much more than I did, but I thought it never; for I have not hurt you, ne done you so much harm that may hinder you, save only that mishap that is fallen on your eye. Ach ! therefore I am sorry, and suffer much sorrow in my heart. I would well, dear Eme, that it had not happed you, but that it had fallen on me, so that ye therewith had been pleased; howbeit that ye shall have thereby a great advantage. For when ye hereafter sleep ye need not to shut but one window where another must shut two. My wife and my children and my lineage shall fall down to your feet, tofore the King and tofore all them that ye will, desire and pray you humbly that ye will suffer Reynart, your nephew, live; and also I shall knowledge oft to have trespassed against you, and what leasings I have lied upon you. How might any lord have more honour than I proffer you. I would for no good do this to another. Therefore I pray you to be pleased herewithall. I wote well, if ye would, ye might have slew me; but and ye so done had, what had ye won? So must ye ever after this time keep you from my friends and lineage. Therefore he is wise that can in his anger measure himself, and not be over hasty, and to see well what may fall or happe afterward to him. What man that in his anger can well advise him, certainly he is wise. Men find many fools that in heat hasten them so much that after they repent them and then it is too late. But, dear Eme, I trow ye be too wise so to do. It is better to have praise, honour, rest, and peace, and many friends that be ready to help him, than to have shame, 
hurt, unrest, and also many enemies lying in a wait to do him harm. Also it is little worship to him that hath overcomen a man then to slay him. It is great shame, not for my life, though I were dead that were a little hurt."

Isegrim the Wolf said, "Ay, thief, how fain wouldest thou be loosed and discharged from me, that hear I well by thy words. Were thou now from me on thy free feet thou wouldst not set by me an egg shell. Though thou promisedst to me all the world of fine red gold, I would not let thee escape. I set little by thee and all thy friends and lineage. All that thou hast here said is but leasings and feigned falseness. Weenest thou thus to deceive $m e$ ? it is long since that I knew thee. I am no bird to be locked, ne take by chaff. I know well enough good corn. $\mathrm{O}$, how wouldest thou mock me if I let thee thus escape. Thou mightest well have said this to one that knew thee not, but to me thou losest thy flattering and sweet fluting, for I understand too well thy subtle lying tales. Thou hast so oft deceived me that me behoveth now to take good heed of thee. Thou false stinking knave, thou sayest that thou hast spared me in this battle. Look hitherward to me. Is not mine one eye out? And thereto hast thou wounded me in twenty places in my head. Thou wouldest not suffer me so long to rest as to take once my breath. I were over much a fool if I should now spare thee or be merciful to thee. So many a confusion and shame as thou hast done to me; and that also that toucheth me most of all, that thou hast disworshipped me and sklaundred Ersewynde my wife, whom I love as well as myself, and falsely deceivedst her, which shall never out of my heart : for as oft as it cometh to mine mind all mine anger and hate that I have to thee reneweth."

In the meanwhile that Isegrim was thus speaking, the Fox bethought him how he might help himself, and stuck his other hand after between his legs, and grepe the Wolf fast. And he wrong him so sore that for woe and pain he must cry loud and howl. Then the Fox drew his other hand out of his mouth. The Wolf had so much pain and anguish of the sore wringing, that he spit blood. 


\section{CHAP'TER XLI.}

How Isegrim the Wolf was overcomen and how the battle was taken up and finished. And hoze the Fox had the worship.

THIs pain did him more sorrow and woe than his eye did that so sore bled, and also it made him to overthrow all in a swoon. Then Reynart the Fox leapt upon him with all his might, and caught him by the legs, and drew him forth through the field that they all might see it, and he stack and smote him sore. Then were Isegrim's friends all full of sorrow, and went all weeping unto their Lord the King, and prayed him that he would do cease the battle, and take it up into his hand.

The King granted it. And then went the keepers of the field the Leopard and the Lossem and said to the Fox and to the Wolf, "Our Lord the King will speak with you, and will that this battle be ended. He will take it into his hand. He desireth that ye will give your strife unto him, for if any of you here were slain it should be great shame on both sides. For ye have as much worship of this field as ye may have."

And they said to the Fox, "All the beasts give to you the prize that have seen this battle."

The Fox said, "Thereof I thank them, and what that shall please my lord to command that shall not I gainsay. I desire no better but to have won the field. Let my friends come hither to me. I will take advice of them what I shall do."

They said, "That they thought it good ; and also it was reason in weighty matters a man should take advice of his friends."

Then came Dame Slopecade and Grymbart the Dasse her husband, Dame Rukenawe with her two sisters, Byteluys and Fulrompe her two sons and Hatenit her daughter, the Flyndermows ${ }^{1}$ and the Weasel. And there came more than twenty which would not have come if the Fox had lost the field. So who that winneth and cometh to hys aboue, he getteth great loos and worship: and who that is overthrown and hath the worse, to 
him will no man gladly come. There came also to the Fox the Beaver, the Otter and both their wives Panthecrote and Ordegale. And the Ostrole, the Marten, the Fitchews, the Ferret, the Mouse, and the Squirrel, and many more than I can name. And all because he had won the field. Yea some came that tofore had complained on him, and were now of his next kin, and they showed him right friendly cheer and countenance. Thus fareth the world now. Who that is rich and high on the wheel, he hath many kinsmen and friends that shall help to bear out his wealth : but who that is needy and in pain or in poverty findeth but few friends and kinsmen; for every man almost escheweth his company and way.

There was then great feast. They blew up trumpets and piped with shalmoyses.

They said all, "Dear Nephew, blessed be God that ye have sped well. We were in great dread and fear when we saw you lie under."

Reynart the Fox thanked all them friendly, and received them with great joy and giadness. Then he asked of them what they counselled him. If he should give the field unto the King or no?

Dame Slopecade said, "Yea hardily cousin. Ye may with worship well set it in to his hands, and trust him well enough."

Tho went they all with the keepers of the field unto the King. And Reynart the Fox went tofore them all, with trumpets and pipes and much other minstrelsy. The Fox kneeled down tofore the King.

The King bad him stand up, and said to him, "Reynart ye be now joyful. Ye have kept your day worshipfully. I discharge you, and let you go freely quit where it pleaseth you. And the debate between you, I hold it on me, and shall discuss it by reason and by counsel of noble men, and will ordain thereof that ought be done by reason, at such time as Isegrim shall be whole. And then I shall send for you to come to me, and then by God's grace I shall give out the sentence and judgment." 


\section{CHAPTER XLII.}

\section{An ensample that the Fox told to the King when he had won the field.}

"MY worthy and dear Lord the King," said the Fox, "I am weil agreed and paid therewith. But when I came first into your Court there were many that were fell and envious to me, which never had hurt ne cause of scathe by me. But they thought that they might best over me, and all they crieden with mine enemies against me and would fain have destroyed me, because they thought that the Wolf was better withholden and greater with you than I was, which am your humble subject. They knew none other thing, why ne wherefore. They thought not as the wise be wont to do, that is what the end may happen.

"My lord these ben like a great heap of hounds which I once saw stand at a lord's place upon a dunghill, whereas they awaited that men should bring them meat. Then saw they an hound come out of the kitchen and had taken there a fair rib of beef ere it was given him. And he ran fast away withal ; but the cook had espied or ${ }^{1}$ he went away, and took a great bowl full of scalding water and cast it on his hips behind; whereof he thanked nothing the cook, for the hair behind was scalded off and his skin seemed as it had be through sodden. Nevertheless he escaped away and kept that he had won.

"And when his fellows the other hounds saw him come with this fair rib, they called him all and said to him, 'Oh how good a friend is the cook to thee, which hath given to thee so good a bone, whereon is so much flesh.'

"The hound said, "Ye know nothing thereof. Ye' praise me like as ye see me tofore with the bone. But ye have not seen me behind. Take heed, and behold me afterward on mine buttocks, and then ye shall know how I deserved it.'

"And when they had seen him behind on his hips how that his skin and his flesh was all raw and through sodden, tho 
growled they all and were afraid of that syedyng water; and would not of his fellowship, but fled and ran away from him, and let him there alone.

"See, my Lord, this right have these false beasts. When they be made lords, and may get their desire, and when they be mighty and doubted, 1 then ben they extortioners and scatte and pylle the people and eaten them like as they were forhungred hounds. These ben they that bear the bone in their mouth. No man dare have to do with them, but preyse all that they bedrive. ${ }^{2}$ No man dare say otherwise but such as shall please them, because they would not be shorn. And some help them forth in their unrighteous deeds because they would not have part, and lick their fingers, and strengthe them in their evil life and works. $\mathrm{O}$, dear Lord, how little seen they that do thus after behind them, what the end shall be at last. They fall from high to low in great shame and sorrow, and then their works come to knowledge and be open in such wise that no man hath pity ne compassion on them in their mischief and trouble, and every man curse them and say evil by them to their shame and villainy. Many of such have been blamed and shorn full nigh, that they had no worship ne profit but lose their hair as the hound did, that is their friends which have help them to cover their misdeeds and extortions like as the hair covereth the skin. And when they have sorrow and shame for their old trespasses, then each body plucketh his hand from him, and flee, like as the hounds did from him that was scalded with the syedyng water, and let him these extortions in their sorrow and need.

My dear Lord King, I beseech you to remember this example of me; it shall not be against your worship ne wisdom. What ween ye how many ben there such false extortioners now in these days,-yea much worse than an hound that beareth such a bone in his mouth - in towns, in great lords' courts, which with great facing and bracing oppress the poor people with great wrong, and sell their freedom and privileges, and bear them on hand of things that they never knew ne thought, and all for to get good 
for their singular profit. God give them all shame, and soon destroy them, whosomever they be that so do!

"But God be thanked," said the Fox, "there may no man indite me, ne lineage, ne kin, of such works, but that we shall acquit us, and comen in the light. I am not afraid of any that can say on me any thing that $I$ have done otherwise than a true man ought to do. Alway the Fox shall abide the Fox, though all his enemies had sworn the contrary. My dear Lord the King, I love you with my heart above all lords, and never for no man would I turn from you, but abide by you to the utterest. How well it hath been otherwise informed your highness, I have nevertheless alway do the best, and forth so will do, all my life that I can or may."

\section{CHAPTER XLIII.}

How the King forgave the Fox all things, and made him Sovereign and greatest over all his lands.

THE King said, "Reynart, ye be one of them that oweth me homage ; which I will that ye alway so do. And also I will that, early and late, ye be of my council and one of my justices. See well to that ye not misdo ne trespass no more. I set you again in all your might and power, like as ye were tofore, and see that ye further all matters to the best right. For when ye set your wit and counsel to virtue and goodness, then may not our Court be without your advice and counsel, for here is none that is like to you in sharp and high counsel, ne subtler in finding a remedy for a mischief. And think ye on the example that ye yourself have told, and that ye haunt righteousness and be to me true. I will from henceforth work and do by your advice and counsel. He liveth not that if he misdid you, but I should sharply avenge and wreke it on him. Ye shall overall speak and say my words, and in all my land shall ye be, above all other, sovereign and my bayle. ${ }^{1}$ That office I give you. Ye may well occupy it with worship." Ail Reynart's friends and lineage thanketh the King highly.

1 Bayle, bailiff, deputy, one who keeps in custody. 
The King said, "I would do more for your sake than ye ween. I pray you all that ye remember him that he be true."

Dame Rukenawe then said, "Yes sykerly, my Lord, that shall he ever be, and think ye not the contrary. For if he were otherwise, he were not of our kin ne lineage, and I would ever missake him, and would ever hinder him to my power."

Reynart the Fox thanked the King with fair courteous words, and said, "Dear Lord, I am not worthy to have the worship that ye do to me. I shall think thereon and be true to you all so long as I live, and shall give you as wholesome counsel as shall be expedient to your good grace."

Herewith he departed with his friends from the King.

Now hark how Isegrim the Wolf did. Bruin the Bear, Tybert the Cat, and Ersewynde and her children with their lineage drewen the Wolf out of the field, and laid him upon a litter of hay, and covered him warm, and looked to his wounds which were well twenty-five. And there came wise masters and surgeons which bound them and wash them. He was so sick and feeble that he had lost his feeling, but they rubbed and wryued ${ }^{1}:$ him under his temples and eyen, that he sprang out of his swound, and cried so loud that all they were afraid. They had weened that he had been wood. ${ }^{2}$

But the masters gave him a drink that comforted his heart and made him to sleep. They comforted his wife, and told to her that there was no death-wound ne peril of his life. Then the Court brake up; and the Beasts departed and went to their places and homes that they came from.

\section{CHAPTER XLIV.}

How the Fox with his friends and lineage departed nobly from the King and went to his castle Malperduys.

ReynarT the Fox took his leave honestly of the King and of the Queen. And they bade him he should not tarry long, but shortly return to them again.

I Wryued, rubbed (Dutch, wryzen, to rub),

2 IVood, mad. 
He answered and said, "Dear King and Queen, alway at your commandment I shall be ready, if ye need anything, which God forbid. I would alway be ready with my body and my good to help you, and also all my friends and lineage in likewise shall obey your commandment and desire. Ye have highly deserved it, God quite it you, and give you grace long to live. And I desire your license and leave to go home to my wife and children. And if your good grace will anything, let me have knowledge of it, and ye shall find me alway ready."

Thus departed the Fox with fair words from the King.

Now who that could set him in Reynart's craft, and could behave him in flattering and lying as he did, he should I trow be heard, both with the Lords Spiritual and Temporal. They ben many, and also the most part, that creep after his way and his hole. The name that was given to him abideth alway still with him. He hath left many of his craft in this world which alway wax and become mighty: for who that will not use Reynart's craft now is nought worth in the world, nor in any estate that is of might. But if he can creep in Reynart's net and hath been his scholar, then may he dwell with us, for then knoweth he well the way how he may arise, and is set up above of every man. There is in the world much seed left of the Fox which now overall groweth and cometh sore up. Though they have no red beards, yet there ben founden more foxes now than ever were heretofore. The righteous people ben all lost; Truth and Righteousness ben exiled and fordriven; and for them ben abiden with us Covetyse, Falsehood, Hate, and Envy; these reign now much in every country. For is it in the Pope's court, the Emperor's, the King's, Duke's, or any other lord's, wheresomever it be, each man laboureth to put other out from his worship, office and power, for to make himself to climb high, with lies, with flattering, with simony, with money, or with strength and force. There is nothing beloved ne known in the court nowadays but Money. The Money is better beloved than God. For men do much more therefor: for whosomever bringeth Money shal: be well received, and shall have 
all his desire, is it of lords or of ladies or any other. That Money doth much harm. Money bringeth many in shame and dread of life, and bringeth false witness against true people for to get Money. It causeth uncleanness of living, lying, and lechery. Now clerks gon to Rome, to Paris, and to many another place, for to learn Reynart's craft : is he clerk, is he layman, everiche of them treadeth in the Fox's path, and seeketh his hole. The world is of such condition now, that every man seeketh himself in all matters. I wot not what end shall come to us hereof. All wise men may sorrow well herefor. I fear that for the great falseness, theft, robbery, and murder, that is now used so much and commonly, and also the unshamefast lechery and avoultry, ${ }^{1}$ bosted, blowen abroad with the avaunting of the same, that without great repentance and penance therefor that God will take vengeance and punish us sore therefor. Whom I humbly beseech, and to whom nothing is hid, that he will give us grace to make amends to him therefor and that we may rule us to his pleasure.

And herewith will I leave; for what have I, to write of these misdeeds? I have enough to do with mine own self. And so it were better that I held my peace and suffer, and the best that I can, do, for to amend myself now in this time. And so I counsel every man to do, here in this present life, and that shall be most our profit. For after this life cometh no time that we may occupy to our advantage for to amend us. For then shall every man answer for himself and bear his own burthen.

Reynart's friends and lineage to the number of forty have taken also their leave of the King, and went all together with the Fox, which was right glad that he had so well sped and that he stood so well in the King's grace. He thought that he had no shame, but that he was so great with the King that he might help and further his friends, and hinder his enemies, and also to do what he would without he should be blamed; if he would be wise.

The Fox and his friends went so long together that they camen to his burgh to Malperduys, there they all took leave of each 
other with fair and courteous words. Reynart did to them great reverence, and thanked them all friendly of their good faith and also worship that they had done and showed to him. And proffered to each of them his service, if they had need, with body and goods. And herewith they departed, and each of them went to their own houses.

'The Fox went to Dame Ermelyne his wife, which welcomed him friendly. He told to her and to his children all the wonder that to him was befallen in the Court, and forgot not a word, but told to them every deal how he had escaped. Then were they glad that their father was so enhanced and great with the King. And the Fox lived forthon with his wife and his children in great joy and gladness.

Now who that said to you of the Fox more or less than ye have heard or read, I hold it for leasing. But this that ye have heard or read, that may ye believe well. And who that believeth it not, is not therefore out of the right belief; howbeit there be many if that they had seen it they should have none less doubt of it. For there ben many things in the world which ben believed though they were never seen : also there ben many figures, plays, founden that never were done ne shaped, but for an example to the people that they may there learn better to use and follow virtue and to eschew sin. and vices. In like wise may it be by this book that who that will read this matter, though it be of japes and bourds, yet he may find therein many a good wisdom, and learnings by which he may come to virtue and worship. There is no one man blamed herein; it is spoken generally. Let every man take his own part as it belongeth and behoveth, and he that findeth him guilty in any deal or part thereof, let him repent and amend him. And he that is verily good, I pray God keep him therein. And if any thing be said or written herein that may grieve or displease any man, blame not me but the Fox, for they be his words and not mine.

Prayeng alle them that shal see this lytyl treatis/ to correcte and 
amende/ Where they shal fynde faute/ For I haue not added ne mysnusshed but haue folowed as nyghe as I can my copye whiche was in dutche/ and by me william Caxton translated in to this rude and symple englyssh in thabbey of westmestre. fynysshed the vj daye of Juyn the yere of our lord M.CCCC.Lxxxj. and the xxj yere of the regne of kynge Edward the iiijth/ 
ROBERT THE DEUYLL. 



\section{II.}

\section{ROBERT. THE DEU YLL.}

\section{Here begynneth the lyfe of the most myscheuoust Robert the Deuyll, which zelas afterwarde called the seruant of God.}

gat befel in fyme past, there was a duke in Normandye which was called Ouberte, the which duke was passynge ryche of goodes, and also vertuous of lyuynge, and loued and dred God above all thynge, and dyde grete almesse dedes, and exceeded all other in ryghtwysnesse and justyce, and most cheualrouse in dedes of armes and notable actes doynge. This duke helde open house upon a Crystmasse daye, in a towne which was called Naverne, upon the Seyne, to the which courte came all the lordes and noble blode of Normandy. And because this noble duke was not maryed, his lordes nobles with one assente besought hym to marye and take a wyfe, to thentente that his lygnage might be multyplyed thereby, and that they myght have a ryght heyre to enherite his landes after his dysceyse. To the whyche request this good duke answered and sayd: "My lordes, what thynge that ye thynke best for me to do shall be done, upon a condycyon, in that ye wyll that I be maryed, that ye puruey me a wyfe accordynge to my myn estate, for and yf I shall coueyte ony heyre or noblyer of blode than I am myselfe, that myghte not stand with ryght, and yf I take one that is not of so noble an house as I am, that sholde be to me grete shame, and all my lygnage; wherefore me thynke it were better that I kepe me as I am, than to do that thynge that sholde not be myne honeste, and afterwarde repente me." Whan these wordes were spoken, and well consydered by the lordes that 
stode there present, then there rose up a wyse baron, and sayd to the duke: " My lorde ye speke very wysely, and lyke a noble prynce, but $y f$ it please your hyeness to gyue audyence and here me speke, I shall shewe you of a certayne persone of whome ye shall enjoye yourselfe to here of her, and the whyche ye shall obteyne I know well." Than answered the duke, and sayd: "Shewe me then who that persone is." "Gracyous lorde," sayd the baron unto the duke, "the duke of Bourgone hath a doughter whyche excedethe al other in beaute, curteyse and deboynayre wysdome and good maneres, the whiche ye may have yf ye wyll desyre her, for I knowe well there wyll no man say naye thereto." To the whiche the good duke answered and said, that lady playsed hym ryght well, and that the baron had gyven hym good and wyse counsell. And in short tyme after that, this lady was demaunded of her fader, the duke of Bourgone, which gave hym her wyllyngly: And then theyr bridale was kepte honourably, which were to longe to write.

How the duke of Normandye with grete royalte broughte his wyfe, the doughter of the duke of Bourgone, in to Roan in Normandye, after he had maryed her.

AFTER that the forsayd duke had maryed the sayd ladye, he brought her with a grete company of barons, knyghtes, and ladyes, with grete tryumphe and glorye, into the land of Normandye; and in the cyte of Roan, ${ }^{1}$ in the which cyte she was honourably receyued, and with grete melodye; and there was grete amyte betwene the Bourgonyons and the Normans, which I lete passe for to come the soner to my mater. The forsayd duke and duchesse lyued togyder the space of xviii yere without any childe. Whether it were Godde's wyl it sholde be so, or it were thrughe theyr own defaulte, I can not juge, for it were better other whyle that some people had no chylderne, and also it were better for the fader and the moder to gete no chyldren, thenne to lacke of chastysynge, the chyldren and fader and moder sholde al go to 
the deuyll : yet was this duke and duchesse deuout people, which loved and drede God, and gave grete almesse; and what tyme this duke wolde meddle with his lady, he euer prayed to God to sende hym a chylde, to honoure and serue God, and to multyply and fortyfy his lynage; but nother with prayer nor with almesse dedes this good duke and duchesse could gete no chyldren.

How upon a tyme this duke and duchesse walked alone, sore complanynge the one to the other that they coude have no chylde togyder.

UPON a tyme this duke and duchesse walked, and the duke began to shewe his mynde to his ladye, saynge, "Madame, we be not fortunate in so much that we can gete noo chyldren; and they that made the maryage betwene us bothe they dyde grete synne, for I beleue and ye had been geuen to an other man, ye sholde haue had chyldren, and I also yf I had another ladye." This lady understood his sayenge: she answered softly, saynge thus: "Good lorde, we must thanke God of that which he sendeth us, and take it pacyently of what so euer it be."

How Robert the Deuyll was conceyued, and how his moder gave him to the deuyll in his concepcyon.

THis duke upon a tyme rode oute an hountyng in a grete angre and pensyfness, for thought that he coulde haue no chylde, sore complanynge, saynge to hymselfe, I see many women haue many fayre chyldren in whiche they enjoy gretely, by which I se wel that I am hated of God, and meruayle it is that I fall not in dyspare, for it greueth me so sore at my herte that I can gete no chyldren. The deuyll, which is alwaye redy to deceyue mankynde, tempted the good duke, and troubled his mynde so that he wyst not what to do or say. Thus moued, he left his huntynge and wente home to his palayes, where he found his ladye also vexed and moued. As he came home he toke her in his armes, and kyssed her, and dyde his will with her, sayenge his prayers to 
our Lorde in this wyse: "O ! Lord Jhesu, I beseche the that I may get a chylde, at this houre, by the whiche thou mayst be honoured and served." But the ladye being so sore moued, spake thus folyshly, and said : "In the deuyle's name be it, in so muche as God hath not the power that I conceyue; and yf I be conceyued with chylde in this houre, I gyve it to the devyll, body and soule." And this same houre that this duke and duches were thus moued, the sayd lady was conceyued with a man chylde, whiche in his lyf wrought moche myschefe, as ye shall here after this, but afterwards he was converted, and dyde grete penance, and dyed a holy man, as is shewed here after.

\section{How Robert the Deuyll was borne, and what great pain his moder suffered in hys byrthe.}

THis duchesse, as we haue herd before, was conceyued with the forsayd chylde, which she bare ix monethes as comonly women goo with chylde; and ye may well perceyue that this lady coude not be delyuered without grete payn, for she traueylled more than a moneth, and yf good prayers had not been, and almesse dedes, good werkes, and great penance done for her, she had deyed of chylde, for all the ladyes and gentylwomen that there were with her wened, she wold have perysshed and deyed in traualynge. Wherefore they were gretly abasshed and aferde with the merueylouse noise and tokens that they herde and se in the byrth of the said Robert the Deuyll, in that whan this chylde was borne, the sky waxed as darke as though it had been nyghte, as it is shewed in olde cronycles, that it thondred and lyghtened so sore, that men thought the firmament had been open, and all the worlde sholde haue perysshed. And there blewe soo moche wynde out of the iiii.quarters of the worlde, and was such storme and tempest, that al the hous trembled so sore, that it shoke a grete pece of it to the earth, in so moche that all they that were in the house wened that the worlde had been at an ende, and that they, with the house and all, sholde haue sonken. But in shorte tyme it pleased God that all this trouble ceased, and the 
weder clered up, and the chylde was brought to chyrch to be crystened, whiche was named Robert. This childe was large of stature at his byrthe as he had been a yere old, whereof the people had grete wonder; and as this chylde was a berynge to the chirche to be crystned and home ayenst, it neuer ceased cryenge and houlynge. And in shorte space he had longe teeth wherwith he bote the norshes pappes in such wyse, that there was no woman durst gyue hym souke, for he bote off the hedes of theyr brestes; wherefore they were fayne to gyue hym souke and to brynge hym up with an horne. And whan he was twelve moneth olde, he coude speke and go alone better than other chyldrne that were thre yere old. And the elder that this chylde Robert waxed, more cursted; and there was no man that coude rule hym : and whan he founde or coude come by ony chyldrne he smote and bote and cast stones at them, and brake theyr armes and legges and neckes, and scratte out theyr eyen owt of theyr hedes, and therein was all his delyte and pleasure.

\section{How all the chyldren with one assent named this chylde Roberte the Deuyll.}

THis chylde within fewe yeares grewe maruaylously, and more and more encresed of all, and boldness, and shrewdness, and set by no correccyon, but was euer smyttynge and tastynge, and cursed dedes doynge. And some tyme there gadred togyder all the boyes of the strete to fyghte with him, but whan they se hym they durst not abyde hym, but cryed one to another, "Here cometh the wode ${ }^{1}$ Robert!" an other many cryed, "Here cometh the cursed madde Robert!" and some cryed, "Here cometh Robert the Deuyll!" and thus cryenge they voyded all the stretes, for they durst not abyde and loke hym in the face, and forthwith the chyldrne that knewe hym with one assente called hym Roberte the Deuyll, whiche name he kepte durynge his lyfe, and shall do as longe as the world standeth. Whan this chyld was seuen yere old or there aboute, the duke his fader seynge and 
consyderynge his wycked condycyons, called hym and sayd unto hym thus, "My sone me thyncke it necessary and tyme, for me to gete you a wyse scole mayster, to lerne vertues and doctrine, for ye be of age ynoughe," and whan the duke had thus sayd, he betoke ${ }^{1}$ his sone to a good dyscreet and wyse scole mayster to rule and teche hym all good condycyons and maners.

\section{How Robert kylled his scole mayster.}

IT fell upon a daye that his scole mayster sholde chastyse Robert and would have made hym to have lefte his cursed condycyons, but Robert gate a murderer or bodkin, and thrust his mayster in the bely that his guttes fell at his fete, and so fell downe deed to the erth, and Robert threw his boke ayenst the walles in despyte of his mayster saynge thus now haue I taughte the that never preste, nor clerke shal correct me, nor be my mayster. And from thens forth there coude no mayster be founde that was so bolde to take in hande to teche and correcte this Roberte, but were glad to let hym alone and have his owne wayes, and he put hymselfe to uyce and myschefe, and to no maner of vertue nor grace, nor wolde he lerne for no man lyuynge, but mocked both God and holy chyrche. And when he came to the churche and founde the prestes, and clarkes syngynge Goddes seruyce, he came preuely behind them, and caste ashes or duste in theyr mouthes in dyspyte of God. And when he sawe any body in the chyrche besy in their prayers he would come'behynde thern and gyue them a'sowse in the necke that theyr hedes kyssed the ground, in so moche that euery body cursed hym for his wycked dedes doynge. And the duke his fader seynge his myscheuous dyspocysyon and cursed lyfe of his sone, he was so angry with hymselfe, that he wyshed hymself many tymes dede and out of the worlde. And the duchese in lykewyse was gretly moued and muche sorrowefull by cawse of the myscheuous lyfe of her sone, saynge in this wyse, "My lord our sone is nowe of sufficient age and able to bere armes, wherefore me thynke it were best that ye 
made hym knyght if than he wolde remembre thordre of knyghthode whereby he myght leve his wyckedness." The duke was here withall content. And Robert had at that tyme but eyghtene yere of age.

\section{How Robert the Deuyll wais made knyght by the duke his fader.}

This duke assembled upon a hye feast of Whitsontyde, all his barons and nobles of his lande, and the next of his kyn and frendes, in the presence of whome he called his sone to hym saynge thus, "Herke my sone Robert, and take hede what I shall tell you, it is so that by thaduyce of my counsell and good frendes, I am now aduysed to make you a knyght, to thentent that ye be with other knyghtes to haunte chevalrye and knyghtes condycions, to thentente that ye shall leve and forsake your uyces and moost hatfull lyf." Robert herynge this, answered his fader, "I shall do your comandment, but as for the odre of knyghthode I set nothynge thereby, for there is no degre shall cause me leve my condycyons nor chaunge my lyfe, for $I$ am not in that mynde to do no better than I have done hetherto, nor to amende for no man lyuynge." : It was the costome of that lande, that on Whitsonyght the chyrche shold be watched, and tended with moche people, and theder cam Robert like a madman, and overthrowynge al them that came in his waye ferynge nother God nor the Deuyll, and he was never styll of all the nyght, and in the mornynge whan it was day Robert was made knyght. Then this duke comaunded a tournament to be made in the which the said Robert wrought maystryes, and dyde meruaylous dedes of armes, in kyllynge and berynge downe hors and man, no man refusynge nor feryinge. Of some he brake armes and some legges, and bare them thorowe and kylled them out of hande ; from hym went none unmarked ; in whiche iustynge Robert kylled $\mathrm{x}$ horses. The duke herynge how his sone myscheued and murdred all that came in his handes he went hymself into the tournament and comaunded upon a grete payne to sease and ren no more. Then Robert rored for anger as he had ben wode and wolde, not obeye his faders comaundement 
but abode styl in the fylde smytynge some that he kylled of the moste valiauntes that thether were comen to tournaye. Than euery man cryed upon Robert to cease, but it auayled not, for he wolde not cease for no man, nor was there no man so bolde to encountre hym, for bycause that he was so stronge this Robert dyde so moche myschefe that all the people were in a rore, and assembled all with one assent in a great angre and ranne to the duke complaynynge, saynge thus: "Lorde, ye be gretely to blame that ye suffre your sone to do as he dothe; we beseche yow for goddes sake to fynde some remedye for hym, to cause hym to cease or leue his mysrule."

How Robert the Deuyll rode about the countree of Normandy, robbynge, stelynge, morderynge, and brennynge chyrches, abbayes and other holy places of relygyon, and forsynge of women.

Than whan Robert se there was no man more lefte in the felde, and that he coude do no more myschef there, than he toke his horse with the spores to seke his aventures, and began to do every day more harm than other one, for he forsed and rauysshed maydens and wyues without nombre, he kylled murdred so moche people, that it was pyte, also he robbed chyrches, abbayes, hermytages, and fermes, there was not an abbaye in all the countrey but he robbed and pylled them. These wycked dedes of Robert came to the eres of the good duke, and all they that were thus robbed and rebuked came to complayne of the grete outrage and suppressyon done by Robert, and styll was doynge thorowe out all the countree. One sayd, "My lorde, youre sone hathe forsed my wyfe," another sayd, "he hath rauyshed my doughter," the other sayd, "he hath stolen my goodes, and robbed my hous ;" and other sayd, "he hath wounded me to deth," with many semblable offences. Thus lay they greuously complanynge before the good duke, that grete pyte it was there for to se the good duke herynge the greuous and lamentable complayntes of the great murdre done by Robert his sone, thoroughout all the lande of Normande. Than his herte was suppressed with so grete 
sorrowe and thought, that the salt teres breste out of his eyen, and he wepte tenderly and sayd; "O ryght wyse God creatoure of heaven and erth, I haue so many tymes prayed ye to send me a chylde and all my delyte was to haue a son, to the entente that I myght of hym have grete joye, and solace. And now haue I one, the whiche doth my herte soo moche payne, sorowe and thought that I wote in no wyse what to begyn, nor doo, nor saye thereto, but good Lorde onely I crye upon the for helpe, and remedye to be a lytel released of my payne and sorowe."

How the duke sent out men of armes for to take Robert his sone, which Roberte toke them all, and put out theyr eyen in dyspyte of his fader, and sente them so home agayne.

There was a knyght of the Dukes hous, whiche perceyued that this good duke was uery sorrowfull and pensyfe, and knewe no remedy; then this knyght spake and sayd to hym: "My lorde, I wold aduyse you to sende for your sone Robert and let hym be brought to your presence, and there before your nobles, and nexte frendes to rebuke hym, and than commaund hym to leaue hys cursed lyf, and yf he wyll not, ye to do justice upon hym as on a straunge man." Hereto the duke consented, and thought the knyght gaue hym good counsell, and incontynent he sente out men to seke Robert, and in ony wyse they were to brynge hym to hys presence. This Robert, herynge of the complayntes made of all the people upon hym unto hys fader, and that his fader had sent out men to take hym, wherefore all them that he coude gete, he put out theyr eyen, and so he toke the men that his fader sende for hym, and put out theyr eyen in despyte of his fader. And whan he had thus blynded his fader's seruauntes, he sayd to them in mockynge, "Syrs, nowe shall ye slepe the better; go now home to my fader, and tell hym that I set lytel by hym, and bycause he sendeth you to brynge me to hym, therefore to hys dyspyte I have put out your eyen." These poore seruauntes whiche the duke had sent for Robert his sone, came home with great payne and in grete heuynesse saynge thus: "O good lorde se howe 
youre sone Robert that ye dyde send us for hath arayed us, and blynded us." 'The good duke seynge his men in this case, he waxed very angry, and full of yre and began to compasse in his mynde how and by what meanes he myght come by to take Robert his sone.

How the duke of Normandy made a proclamation throughout his lande, hou' men sholde take Robert his sone, with al his company, and brynge them everychone to pryson.

THAN spake a wyse lorde, sayinge thus, "My lorde take noo more thought, for ye shall never se the day that Robert your sone wyll come in your presence, in so moche as he hath done so great and greuouse offences to your comons, and your owne messengers that ye sende for hym. But it were of necessite for you to correct and punysshe hym for hys great offences, that he dayly doth, and hath done, for we fynde it wryten, that the lawe byndeth you therto." The duke, wyllynge to accomplyshe the councel of his lordes, sende out messangers in all the hast, unto all the portes, good townes and barons, throughout all his dukedome, commandynge on his behalfe all shryues, baylufes, or other offycers to do theyr uttermoost dylygence to take Robert his sone prysoner and to holde and kepe hym surely in pryson with all his company and affinyte. Whan Roberte herde of this proclamation, he with all his company were sore aferde of the dukes malyce and whan Robert se this he was almost out of his wyt for wode angre, and wheted hys teeth lyke a bore, and sware a grete othe saynge thus, "that he wolde have open war with his fader, and subdewe and spyll all his lordshyppe."

How Robert made hym a strong hous in a darke thycke wyldernes where he wrought myscheff without comparyson and aboue al mesure or natural reason.

THEN whan Robarte herde and knewe of the forsayd thynges, he lete make in a thycke wylde foreste a stronge house, wherein he made his dwellynge place, and this place was wylde and strong, 
and more meter for wylde beestes, than for any people to abyde in, and there Robert assembled and gadered for his company, all the moost myscheuouste and falsest theues that he coude fynde or heere of in his faders lande, to wete morderers, theues, streterobers, rebelles, brenners of chyrches and houses, forsers of women, robbers of chyrches, and the moost wyckeste and curseste theues that were under the sone, Robert had gadered to doo hym seruyce; wherof he was Capytayne. And in the forsayd wyldernesse, Robert wyth his company dyde so moche myschefe, that no tonge can tell. He mordred marchauntes, and all that came by the waye, no man durst loke out nor come abrode for fere of Robert and his company, of whome every man was aferde ; for they robbed all the countree, in so moche, that no man durst loke out, but they were kylled of Robert or his men. Also poore pelgremes that went on pelgremage were murdered by Robert and his company, in so moche, that euery man fledde from them, lyke as the shepe fledde from the wolfe: for they were as wolues warynge, sleyinge all that they coude come. by, and thus, Robert and his company ledde an ungracious lyfe. Also he was a grete glotten of etynge and drynkynge, and neuer fastynge, though it were neuer so great a fastynge daye. In Lente, or on Ymber dayes, he ete flesshe, as well on Frydayes as on Sondayes; but after he had done all this myschefe, he. suffred grete. payne, as. hereafter ye shal here.

\section{How Robert the Deuyll killed wii heremytes.}

IT befell upon a tyme that Robert, whiche euer inagyned and studyed in his mynde howe and by what meane he might doo móost myschefe and murdre, as he had ben ever accustomed before he rode out of his hous or theuyshe neste to seke his pray, and in the myddel of the wode he sawe vii hooly hermytes, to whome he rode as faste as he coulde with his swerde redy drawen, lyke a man oute of his mynde, and there he slewe this vii heremytes, the whiche were bolde and good men, but they were so vertuous and holy, that they suffred the marterdome for 
the loue of God. And whan he had slayne these vii devout men, he spake in mockage, and said: "I haue founde here a neste of a many pope holy sons whome I haue shauen them crounes: I trowe they be dronke; they were wonte to knele upon theyr knees, and now they lye upon theyr backes." There dyde Robert a cursed dede and blode shedynge, in despyte of God and holy chyrche; and after that he hadde done this myscheuous dede he rode out of the wode lyke a deuyll out of helle, semynge worse thenne wode, and his clothes were all dyed rede with the blode of the people that he had murdred and slayne, and thus arayed he rode ouer the feldes, and clothes, handes, face, all were rede of the blode of the holy heremytes, whiche he had so pyteously murdred in the wyldernesse.

How Robert the Deuyll rode to his moder the duchesse of Normandye, beynge in the castell of Darques: she was come to a feste.

RoBert rode so ferre and so longe, that he came to the castell of Darques; but he mette before with a shypherde which had tolde him that his moder the duchesse should come of the said castell to dyner, and so he rode theder. But whan Robert came there, and the people see hym come, they ranne awaye frome hym, lyke the hare frome the houndes; one ranne and shette hym in hys house, an other ranne into the chyrche for fere. Robert seynge this, that all the people fled from hym for fere, he began to sygh in his herte, and sayd to hymself,- - "O ! Almyghty God, how may this be, that every man thus fleeth from me! Nowe I perceyue that I am the moost myscheuouste and the moost cursedest wretche of this worlde, for I sente better to be a Jewe or a Sarasyne, than any Crysten man, and I se wel that I am worste of all yll. Alas! sayd Robert the Deuyll, I may well hate and curse mine ungracyous and cursed lyfe, wherfore I am worthy to be hated of God and the worlde." In this minde and heuynesse came Robert to the castell gate, and lyghte downe from his horse, but there was no man that durste abyde about hym, nor come nyghe hym to holde his horse ; and he hadde no seruante to serue hym, 
but let his horse stande there at the gate, and drewe out his swerde, whiche was all blody, and incontynente toke the waye unto the halle, where the duchesse his moder was. Whan the duchesse sawe Robert her sonne come in this wyse, with a blody swerde in his hande, she was sore aferde, and wolde haue flede a way frome hym, for she knewe wel his condycyons. Robert, seynge that euery body dyde flee from hym, and that his owne moder wolde haue fledde in lykewyse, he called unto her pyteously afarre, and said: "Swete lady moder, be not aferde of me, but stande styl tyl I haue spoken with you, and flee not from me, in the worshyp of Crystes passyon!" Than Roberte's herte beynge full of thought and repentaunce, wente nygher her, saynge thus : "Dere lady moder, I praye and requyre you tell me how and by what manner or wherby cometh it that $I$ am soo vycyous and curste, for I knowe wel I haue it other by you or of my fader; wherefore incontynent I hertly desyre and praye you that ye shewe me the trouth hereof."

\section{How the Duchesse desyred Robert her sone to smyte of her hede, and than she tolde him hozer she had gyuen hym to the deuyll in his concepcyon.}

THE duchesse had gretly meruaylynge whan she herde her sone speke these wordes; and piteously wepynge, with a sorrowful herte saynge thus to hym: "My dere sone, I requyre you hertly that ye wyll smyte of my heed." This sayd the lady, for very grete pyte that she had upon hym, for bycause she had gyuen hym to the deuyll in his concepcyon. Robert answerde his moder with an hevy and a pityeous chere, saynge thus: " $O$ ! dere moder, why sholde I do so, that so moche myschefe have done, and this sholde be the worste dede that euyer I dyde; but I praye you to shewe me that I desyre to wete ${ }^{1}$ of you." Then the duchesse, herynge his hertely desyre, tolde unto hym the cause why he was so vicious and full of myschefe, and how she gaue hym to the deuyll in his concepcyon, herselfe myspraysynge, said thus unto 
Roberte: "O! sonne, I am the moost unfortunate woman lyuynge. and I knowledge that it is all my faute that ye be soo cursed and wycked a leuer."

\section{Hoze Robert the Deuyll toke leue of his moder.}

ROBERT herynge his moders saynge he fell downe to the erthe into a swone, for very grete sorowe, and laye styll a longe whyle, than he remeued agayne and came to hymself and began bytterly to wepe, and complayne, saynge thus: "The fendes of hell be with grete dylygence to applye theym to gete and haue my body and soule, but nowe from this tyme forthe, I forsake theym and all theyr werke, and wyll neuer do more harme but good, and amende my lyfe and leue my synes and do penaunce therefore." Than after this Robert spake to his moder, the whiche was in grete sorowe, and heuynesse saynge thus: " $\mathrm{O}$ moost reuerente lady moder, I hertely beseche and requyre you that it wilde please you to haue me recommaunded unto my fader; for I wyll take the waye to Rome to be assoyled of my synnes, which are innumerable, and to abhomynable to recounte. Therefore I wyll neuer slepe one nyght there I slepe an other, tyll I come at Rome and god wyll."

How Robert departed from his moder, and rode into the wyldernesse where he founde his companye.

ROBERT in grete haste lyght upon his horse and rode to the wode where he had lefte his companye the whiche he founde. The duchesse made grete lamentacyon for her sone Robert, whiche had taken his leue of her, and sayd many tymes to herselfe, "Alas what shall I do, for it is all my faute that Roberte my sone hath done so moche myschefe:" and in the meane whyle that the duchesse made this sorowe and bewayllynge for her sone Robert, in came the duke into the chambre, and as soone as she sawe hym she began to tell hym of his sone Robert, pyteously wepynge; shewynge hym what he had sayd and done. Than the 
good duke axed whether Robert were disposed to leue his vycyous lyfe, and yf he were sory for his grete offences. "Ye my lorde," sayd she, "he is sore repentaunce:" then began the Duke sore to sygh, and sayd, "Alas it is all in vayne, that Robert thynketh to do, for I fere he shall neuer have power to make restytycyon of the hurtes and harmes the whiche he hathe doone in his lyfe. But I beseche Almyghty God to prolonge his lyfe, and sende hym a respyte that he may amende hys lyfe, and do penaunce for his synnes."

\section{Hone Robert the Deuyll tolde his company he wolde goo to Rome for to be assoyled of his synnes.}

Now is Robert come agayne to his companye which he founde syttynge at dyner, and whan they sawe hym they rose up and dyde hym reuerence; than Robert began to rebuke theym for theyr vycyous lyuynge sayynge thus, "My welbeloued felowes, I requyre you in the reuerence of God, that ye wyll herken, and take hede to this that I shall shewe you. Ye knowe well how that we haue ledde hetherto an ungracyous and moost uycyous lyfe, robbed and pylled chyrches, forced women, rauysshed maydens, robbed and kylled marchauntes. We have robbed and kylled nonnes, holy aunkers, ${ }^{1}$ preestes, clerkes, and many other people without nombre haue we murdred and robbed, wherefore we be in the way of endles dampnacyon, except that God haue mercy upon us. Wherefore I requyre you everychone for goddes sake that ye wyll chaunge your opynyon, and leue your abhomynable synnes, and do penaunces therefor, for I wyll goo to Rome to be shryuen and to haue penaunce for my synnes." When Robert thus had sayd, one of the theues rose and sayd to his companye in mockage, "Nowe Syrs, take hede the Foxe wyll be an Aunker for he begynneth to preche. Robert mocketh fast with us, for he is our captayne, and doth more harme alone than all we do: how thynke ye wyll he be longe thus holy." Yet sayd Robert, "Gentyll felawes I praye you for goddes sake leue- your con-

\footnotetext{
1 Aunkers, anchorites.
} 
dycyons, and thynke on our soule, and do penaunce for your moost fellest stynkynge synnes, and crye upon oure lorde for mercy and forgeueness, and he wyl forgeue you." Whan Robert had sayd thus, than spake to hym one of the theues and sayd, "I praye you mayster be in pease, for it auayleth not what ye saye, ye do but spende your tyme in wast, for I nor my companye wyll not amende our lyfe for no man lyuynge." And all his companye commended his saynge, and sayden all with one voyce, "He sayth trewe, for and we sholde dye, we wyll not leue our olde condycyons and cursed lyfe, but and yf we haue done moche hurte hetherto, we wyll do moche more hereafter."

\section{How Robert the Deuyll killed all his companye.}

ROBERT herynge the faste and wycked opynyon and myscheuous purpose of his company waxed angry, and thought, yf they remayne and abyde styll here, they wyl doo grete myschefe and murdre. But he wente preuely unto the dore and shyte it fast, and gate a grete staffe and layde one of the theues on the hede that he fell downe and deed to the erth. And so he serued one after an other, tyll he hadde kylled them everychone, thenne sayd he thus to them, "Syrs, I haue rewarded you after your deserte, and by cause ye have done me good seruyse, I haue gyuen you good wages, for whosoeuer serueth a good mayster he is lyke to haue good wages." Whan Robert thus had done he wolde have brente the hous, but he consydered the great good that was therin, wherfore he let it stande, shytte faste the dores about and locked them, and brought awaye the keye with hym to his faders.

How Robert the Deuyll sente the keye of his chefe hous or theuysshe lodgynge to his faders the duke of Normandye, and howe he zerente to Rome.

THAN whan Robert had done all that said is, he tooke up his hande and blessed hym, and rode through the forest the neere waye to Rome. Robert rode that daye so long tyll that the nyght 
came on, and was passynge sore and hongred, for he had eten no mete of all that daye, and fortuned to come rydynge by an Abbaye, whyche he had many tymes robbed, and the abbote was his kynnessman. And Robert rode in to this abbaye and sayd neuer a worde, but whan the monkes se Robert come they were aferde, and ranne awaye, saynge one to another, "Here cometh the ungracyous Robert, the Deuyll hath brought him hether." Whan Robert herde this, and se them all renne awaye frome him, than his sorrowe begun to renewe, and sayd in himself, in sore syghynge and sorowfull herte: "I may well hate my cursed lyfe, for euery man fleeth from me, and I haue spent my tyme ungracyously, and in euyll and cursed werkes." And there withall he rode streyght in the chyrche dore and alyghte doun from his horse, deuoutely sayinge his prayers to God in this wyse: "O Lord Jhesu I moost synfull wretche and vessell of all stynkynge synnes, I praye the that thou wylte haue mercy on me and preserue and kepe me from all daungers and peryll." And then he wente and spoke to the abbotte and monkes so swetely and so peteously and amyably that they began to go towarde hym, to whom Roberte sayd peteously, wepynge knelynge on his knees: "My lorde I knowledge myself that I haue greuously offended you, and haue done grete harme and injurye unto your abbay. Wherfore I requyre and praye you, in all the honoure of Crystes passyon, of forgyuenesse." And than he spake to the Abbote in thys wyse, "My Lorde abbott I praye you hertely haue me recomaunded to my lorde my fader the duke of Normandye, and delyuer hym this keye of the chefe hous where I haue dwelled with my companye, the whiche I haue all slayne to thentent that they sholde do no more harme. And in the hous lyeth all the goodes and tresoure that I haue stolen from you and other men, wherfore I an ryght sory, and I beseeche you of forgyuenesse, and I pray you that this good nay be rendred agene unto such people as they haue belongynge to before." Robert abode that nyght in the abbay, but in the mornynge erly he wente thens and left behinde hym his horse and his swerde where withall he had doone grete myschefe, And so he went alone towards Rome. 
And on the same daye rorie the Abbote to the Duke of Normandye, and gaue hym the keve that Robert had delyuered hym, and told the duke how he was gone to Rome. 'Than the duke gaue all the poor people theyr goodes agen that they lost befor, as ferre as it coude be founde in the hous. We wyll sease of the Duke and the Abbott, and speke of Robert whiche goth to Rome warde alone, with grete devocyon.

\section{How Robert came to Rome for remyssyon of his synnes.}

ROBERT went so longe ouer hylles and dales alone, tyll at last with grete payne and pouerte he came to Rome in to the cyte, upon a shere Thursdaye at nyght, and on the Frydaye after, the pope hymselfe sayd the deuyne seruyce, as the custom was in saint Peter's chyrche. And Robert presed fast to have comen to the pope, but the pope's seruantes se that Robert presed so sore to come to the pope, they smote hym, and bad hym goo back. But the more they smote hym, the more he presed and thronge to gette nygh the pope, and so at last he gate to hym, and fell doune on his knees at the feet of the pope, cryenge with a loud voyce, saynge thus: "O ! holy fader, haue mercy on me!" and thus laye Robert cryenge longe, whyle the people that were by the pope were angry that Robert made suche a noyse, and wolde haue dryuen hym thens, but the pope seynge Robert's grete desyre, had pyte upon hym, and sayd to the people, "Iate hym alone, for in all that I can se he hath grete deuocyon." Wherefore the pope commaunded them all to holde their pease, that he myght the better here and understande Robert. Then sayd Robert to the pope in this manner: " $\mathrm{O}$ ! holy fader, I am the moost and the greteste syner of all the worlde!" The pope toke Robert up by the hande, and sayde to hym : "Good frende, what is your desyre, and what eleth you to make all this noyse?" Then sayd Robert: "O ! holy fader, I beseche you to here my confessyon, for I be not by you assoyled, I am dampned worlde withouten ende. for it is meruayle that the deuyll bere me not awaye body and soule, seynge the foule innumerable synne that I am laden and bounden 
withall more than any man lyuynge. And in soo moche that ye are he that gyueth helpe and comforte to them that have nede, therefore I humbly beseche you for the passyon of our Lorde Jhesu Cryst to here and purge me of my abhomynable synnes, wherby I am deceued and departed from al the joyes of heuen, and I am wors than a Jewe." The pope herynge this, demed and thought in hymselfe whether this were Robert the Deuyll, and axed hym, "Sone, be ye -Robert the whiche I haue herde so moche spekynge of, the whiche is worst of all men." Then Robert answered and sayd, "Ye." Than the pope sayd : "I will assoyle you, but I conjure you in the name of God that ye do no man harme." The pope and all that were aboute hym were aferde to loke upon Robert. Robert fell on his knees with great deuocyon and repentaunce of hys synnes, saynge, "Holy fader, nay as longe as I lyue I promyse God and his blessed moder I will neuer hurte Crysten creature." Than incontynent the pope toke Robert aparte, and herde his confessyon, to whome Robert shrowe him deuoutly, shewynge how his moder had gyuen hym to the deuyll in his concepcyon, whereof the pope was sore aferde.

\section{How the pope sente Robert thre myle without Rome to an holy heremyte.}

THE pope this herynge was gretly abasshed, and blessyd him, and sayd to Robert: "My dere sone, ye muste goo thre myle without the towne, and there ye shall fynde an heremyte whiche is my goostly fader, and to hym ye shall confesse you, and say that I sende you to hym, and he shall asoyle you." Robert answered the pope: "I wyll go with a good wyll;" and toke his leue of the pope saynge, "God gyue me grace to do that may be to the helth of my soule." Soo that nyght Robert abode in Rome, for it was late, and in the mornynge erly Robert went out of Rome towarde the place where he sholde fynde the heremyte; and so he wente so longe over hylles and dales with grete desyre to be shryuen of his synnes, and at last he came where the heremyte 
dwelled, whereof he was glad, and came to the heremyte and told hym how the pope had sent hym theder to be confessed of hym. Than the heremyte sayd he was hertly welcome; and within a whyle Robert began to confesse and shewe his synne, and first he shewed the heremyte how his moder had gyuen hym to the deuyll in his concepcyon; and how he smote the chyldren in his youth or he coude goo alone; and how he kylled his scole master; and how many knyshtes he kylled at the iustynge whan his fader made hym knyght; and he rode thorowe his fader's land, robbynge and steiynge, forsynge of women, rauysynge of maydens; and how he thrast out the eyen of his fader's men in despyte of hym; and how he had kylled vii heremytes; and shortly showed hym all the offences that euer he dyde, sethen the houre of hys byrth tyll that tyme, whereof the heremyte had maruayle, but he was glad that Robert was repentaunt for hys synnes. Whan Robert had thus confessed hym, the heremyte sayd to hym: "Sone, thys nyght ye shall abyde here, and to morrowe I shall gyue good councell of that ye haue to do." Robert that was so curst and myscheuous, ferful cruel, and proude as a lyon, is now as gentyll and curteys, and swete of wordes, and wyse in his dedes, as euer was ony duke or prynce lyuynge. Then Robert was so wery and ouercome with goynge, that he coude nother ete nor drynke, but went aparte and sayd his prayers to Almighty God, prayenge hym thrughe his endeles mercy, that he wolde kepe hym from the fendes temptacyon and deceyte. The heremyte made Robert to lye that nyght in a lytell chapell that stode nye his celle, and the heremyte prayed all the nyght. to our lorde for Robert, which sawe that he had grete repentaunce for his synnes, and thus prayenge the heremyte fell a sleep.

How God sent an aungell to the heremyte to shewe him the penaunce that he sholde gyue to Robert for his synnes.

THE heremyte being thus a slepe, ther cam to hym an aungell, saynge to hym in this wyse: "Holy fader, here and take hede of the message that God commaundeth the ; yf that Robert wyll 
be shryven of his synnes, he must kepe and counterfete the wayes of a fole, and be as he were dombe; and he may ete no maner of mete, but that he can take it from the dogges; and in this wyse, without spekynge, and counterfetynge the fole, and no thynge etynge but what he can take from the dogges, must he be tyll tyme that it please God to shewe hym that his synne be forgyuen." And with this vycyon the heremyte awoke out of his slepe, and began to remembre hymselfe of this that sayd is, and thanked our Lorde of his message done to hym. And whan the day began to apere, the heremyte called Robert unto hym, with fare and comfortable wordes saynge to him, "My frende, come hether to me;" and incontynent Robert came to hym with grete deuocyon, hym confessynge. And whan Robert had shryuen him, the heremyte sayd thus unto hym: "Sone, I thought and aduysed me of the penance that ye shall haue, to get remyssyon of your synnes, in whiche ye gretly offended ayenst God, that is to wete ye must counterfayte and playe the fole; and ye may ete no mete but that ye can take it from the dogges whan men gyue them ought ; also you must kepe you dombe without speche, and lye among dogges, for thus hath God thys nyght commaunded me by a aungell to gyue you this for your penaunce, and ye may offende no man the whyle your penaunce be a doynge; and this penaunce ye must doo for your synnes in maner and forme as I haue tolde you, tyll suche tyme as it shall please your Lorde to sende you worde that your synnes be forgyuen." Robert beynge mery and glad, thankynge our Lorde that he was assoyled of his synnes, and had therfor so lyght penaunce as hym thought that it was. Nowe taketh Robert leve of the heremyte, and goth to do his sharpe penaunce, whiche he helde but lyghte, remembrynge his grete abhomynable stynkynge synnes that he hath done all the dayes of his lyfe. This was a fayre myracle, for he that was so vycyous and so furyous a rebell, and proude a synner, is now so full of uertues and fayre condycyons and tame as a lambe. 
How Robert the Deuyll toke lez'e of the heremyte, and zient agayne to Rome to do his penaunce that the heremyte had gyuen him:

Rовект had taken leue of the heremyte, and is gone towarde Rome, there for to do his penaunce. And whan he came into the cyte he began to lepe and renne about the stretes, makynge hymselfe as he had ben a fole. And the chyldren in the stretes se Robert renne in this wyse, and they after hym shoutynge and cryenge and castynge with myre and derte, and all suche fylth as they founde in the stretes, and the burgeyses of the cyte laye in theyr wyndowes and laughed and mocketh with Robert. Than whan Robert had thus played the fole in Rome.a certayne season, he came on a tyme to themperour's courte and se the gate dyde stande open and came streyght into the hall, and there jetted up and downe from the one syde to the other; sometyme he went faste and sometyme softely, and than he hopped and ran, and other whyle stode styll, but he stode not longe in one place, The emperour seynge Robert thus playenge the fole, he sayd to one of his seruantes, se yonder is a fayre fauoured yonge. man, me thynke he is out of his mynde, the whiche is grete domage, for he is fayre and a well made man, go and gyue hym mete. This emperour's seruaunte dyde as he was commaunded, and called Robert to hym and wolde have gyuen hym some mete, but Robert nolde ete nor drynke. And whyle Robert sate thus at the table, the emperour sawe one of his houndes whiche was bytten with an other dogge, wherefore, themperour cast hym a bone, and the dogge caught the bone and began to gnawe there on, and Robert seynge that lept from the table and toke it from hym, but the dogge fought with Roberte for the bone, and helde faste the one ende, and Robert the other ende, but Robert se it would be no better, but set him downe on the grounde, and gnewe on the one ende of the bone and the dogge on the other. Themperour and they that loked there on laughed at Robert and the dogge, but Robert dyde so moche that he gate the bone alone, and laye and gnewe it for he was sore enhongred. Themperour seynge that 
Robert was so sore enhongred, he caste to an other dogge an hole lofe, but Robert toke it from hym and brake an two peces and gaue the dogge half, for bycause he gate it for the dogges sake. Themperour seynge this lough there at and sayd to his seruauntes; "We haue here nowe the moste foolysshe fole, and the verayst nedy that euer I sawe, for he taketh the dogges mete from them, and eteth it himself; ther by a man may perfytely knowe that he is a natural fole." All that were in the hall gaue the dogges as moche mete as they might ete, to thentent that Robert myght fyll his belye with them, and whan he had fylled his belly, whyle he rose up, and walked up and downe in the hall with a staffe in his hande, smytynge upon stoles and benches lyke as and yf he had ben a very innocent fole. And thus walkynge he loked on euery syde, and sawe a dore where men wente in to a fayre gardyne, in the whiche gardyne there stode a fayre fontayne or well, and theder went Robert to drynke, for he was euyll a thurst. And whan nyght came on, Robert folowed the forsayd dogge where soo euer he wente, the whiche was accustomed to lye euery nyght under a steyre, and there he went and layde him downe; and Robert followed hym under the steyre and layde hym downe by the dogge. Themperour seynge this, had compassyon on Robert and commaunded that men sholde bere hym a bedde, that he myginte lye there upon to slepe; anone two seruantes brought Robert a bedde to slepe there on, but he poynted to bere it awaye ayene, for he had leuer to lye upon the floure and colde erth, than upon a softe bedde. Whereof themperour had grete meruayle, and commaunded that men sholde bere hym clene strawe, whiche they dyde. Than Robert whiche was feynte and wery of goynge, layde him downe to slepe on the strawe. Now haue this in your myndes, ye proude hertes and synners, thynke on Roberts grete penaunce and wylfull pouerte, and how he so grete a gentylman borne, forsoke his fader and his moder, and all his frendes, and his countree and lande, and all his dylycate metes and drynkes, and gaye raymentes and wordely pleasure, with all that of suche a state aperteyneth; how wyllyngly he hathe all forsaken for the saluacyon of his soule; and is gone out of 
a duke's bedde to a dogges canell, and with dogges he ete and dranke and slepte, and rose whan they rose. And in this penaunce lyued Robert vii yeres or there aboute, and the dogge that he communly slept withall perceyued that he foure the better, and had more mete for Robert's sake, than he was wonte to haue before, and that no man dyde bete hym, for his sake; wherfore he began to loue Robert passynge well, in so moche men myghte as soone haue kylled hym as dryuen hym from Robert.

How Robert threwe dowene a bryde on a foule dongehyll, and how he put a lyuynge catte in an hole sathynge potte with podred befe.

IT befel upon a tyme there was a bryde sholde goo to chyrche to be wedded, whiche was gayly apparelled, as unto a bryde apperteyned. Robert seynge this bryde thus gayly arayed, toke her by the hande, and ledde her thorough a passynge foule donge hyll, and there made her fall and fouled her gaye araye, and than he ranne lyghtly awaye, shoutynge and laughynge, and ranne unto the brydes kytchen where her dyner was appereyled and caughte a lyuynge catte and caste her in the potte of pouldred befe. The whiche incontynente was tolde to themperoure, whereat he and all his lordes laughed, and had grete game thereat; and they loued Robert passynge well, for he made moche myrth without harme.

How the Seneschall had gadred a grete armye of men of zerre of Saresyns, and layde syege to Rome, by cause the cmperoure wolde not gyue hym his doughter in maryage.

In the meane season whyle Robert was thus in Rome doynge his penaunce as a forsayd, which dured seuen yeres or there about in the emperoure's courte, the whiche emperour had afayre doughter, but she was borne domband neuer spoke. And the emperours senesshal dyuerse tymes had desyred his doughter in maryage of the emperoure, but he wolde neuer graunte hym her. Wherfore the senesshall was gretly moued and angry ther with themperoure, for he thoughte 
he myght haue wonne of hym his empyre by force and myght; in soo moche the seneschall came upon a tyme with a grete hoost of Sarasyns, and layde syege to the cyte of Rome, wherof the emperour had grete maruayle and wondred. Than the emperour gadred and assembled all the lordes barons askinge of them counsell, saynge thus, "My lordes, gyue me good counseyl that we may withstande this Hethen dogges whiche haue layde syege here to our cyte; wherefore I take grete thought, for they kepe all my lande under theyr subieccyon and they wyll brynge us to confusyon yf that God out of his endles mercy helpe us not. Wherfore I praye you euerychone to go fyght with them with all our power and myght, and dryue them awaye." Than answered the lordes and knyghts all with one assent, saynge, "Souerayne lorde your counseyl is good and wyse, wherefore we be all ready to goo with you and gyue them batayle and defende our ryght bothe lande and cyte." The emperour thanked them of this answere and was glad therof, and made proclamacyon throughout all his landes and cytees that eury man old and younge that were able to bere armes sholde make them redy to fyght ayenst theyr moost cruell enmyes the Sarasyns which were come into his lande. And contynent whan this proclamation was done amonge the comyns euery man was wyllynge and redy to go with themperour to fyght and defende theyr ryght, and so they went forth in a fayre ordynaunce with themperour to fyght upon theyr mortall enmyes the Hethen dogges. And for all that themperour had moche mo people than the seneschall, yet the seneshall had wonne the felde, hadde not God of his grace sente theder Robert to resyste and helpe the Romaynes in theyr grete necessyte.

How our Sauyour Jhesu hauynge compassyon on the cry'sten blode, sent Robert by an aungell a whyte horse and harneys, commaundynge hym to go rescue and helpe the Romayns ayenst the Ethen dogges the Sarasyns.

THE emperour and the Romayns went to the batayle as sayd is ayenst the Sarasyns, and Robert was at home, where he 
was accostomed to walke in the gardyne to a fountayne or well to drynke, and this was on the same daye that themperour with his hoste sholde gyue batayle ayenst the Sarasyns: than came there a uoyce out of Heuen sente from our Lorde, saynge in this maner: "Robert, God commaundeth you, by me, that ye incontynent arme you with this harneys, and lyght upon this horse that God hath sente you, and ryde in all the hast possyble and rescue the emperour and his people." Robert herynge the commaundement of God, was abasshed in his mynde, and durst not do ayenst goddes commaundement, but in contynent he armed hym and lepte on the hors without tarynge and rode his waye. The emperour's doughter whiche I tolde you of before, stode at a wyndowe and sawe Robert thus armed on horsbacke, than if she coude haue spoken she wolde haue tolde it, but she coude not speke for she was dombe, but she remembred and bare it surely in her mynde. Robert thus horst and harnayst, rode into themperours hoost whiche he sawe sore ouer pressed with theyr enmyes the Turkes, in so moche, that had not God and Robert rescued them, the crysten had ben all slayne. But whan Robert was come into the hoost he put him in the moost prese of the Turkes and faughte and layde on eche syde on these cursed houndes; there a man myght haue sene armes, legges, hedes tomble on the grounde, both horse and man that neuer rose after: it was a worlde to se the murdre that Robert dyde amonge the dampned dogges the Sarasyns. So to make shorte tale, Robert dyde so moche, that the Sarasyns were constrayned to flye awaye and themperour helde the felde and had the vyctorye of them.

How Robert turned agayne to the forsayd fountayne, and there unarmed hym, whan he had thus subdued and vaynquysshed the Sarasyns and put them to flyght.

Now hath the emperour gotten the felde and the honoure, thanked be God, and Robert is torned agayne to the sayd fountayne, and there unarmed hym and layde the harneys on the 
hors, whiche incontynent was vanyshed awaye that no man coude knowe nor perceyue where he become; and Robert bode styll standynge by the fountayne. Themperour's doughter seynge this had grete meruayll of this, and wolde haue told it forth but she was dombe and coude no speke. Robert had a race ${ }^{1}$ in his face, whiche he gote in the batayll, but he was none otherwyse hurte; the emperour was glad, and thanked God of his victory ayenst the false dogges the Sarasyns; and thus beynge mery, he came home to his palays. And whan they were all set to dyner, Robert presented hymselfe before themperour as he was wonte to do, playnge the fole, and makynge him dombe as afore rehersed is. The emperour reioysed in hymselfe whan he se Robert, for he loued hym well; and whan he perceyued Robert's hurte in his face, and thought that some of his seruauntes had hurte hym whyle he was out, wherfore he was angry, and said: "Here in this court be some enuyous men, for whyle we haue ben out at batayle, they haue beten and hurte this poore innocent creature in his face, which is grete synne, for though he be a fole he dooth no man harme." So themperour commaunded them all upon a grete payne that no man sholde do hym harme, yf they dyde they sholde be punysshed, that all other sholde be ware by them. Than the emperoure began to axe his knyghtes yf there were any of them that coude telle of the knyght with the whyte hors that came preuely in to the felde, and so valyauntely rescued them. Themperour's doughter this herynge poynted themperour her fader that it was Robert; but the emperour understode not what his doughter mente when she poynted, for she could not speke. Wherfore he called her maystres to hym, and axed her what his doughter mente by her poyntynge, and her maystres answered and sayd: "Your doughter menes by her poyntynge that this day ye haue goten the batayll and vyctorye thrughe the helpe of your fole Robert, and the race that is in his face he hath gotten it in the batayll." The emperour understandynge the mynde and intent of his doughter, he was angry and sayd to her maystres: "Ye sholde teche and lerne my doughter wysdome, and no folye ne

1 Race, raze, graze. 
peuysnesse wherewithall I am myscontent." The doughter seynge that her fader was angry, pointed no more, notwithstandynge she wyst well that it was trewe that she poynted and mente, for in as moche as she had sene the aungell bring hym the hors and harneys. This remayned in this wyse a certayne season, and after that the Sarasyns were put to flyght by the Romaynes, as sayd is, yet came the senesshall agayne with moche more company, and layde syege to Rome. And the Romaynes sholde haue lost the felde ayen, had not the knyghte on the whyte horse bene, to whome God sent hors and harnays as he had done before. To make shorte tale, this knyght dyde so moche that the Sarasyns were put to flyght, and the Romaynes won the felde and vyctorye as they dyde before. There were some of the emperour's meyny layde wayte where this knyghte became, but as soon as the batayle was done he was gone no man coude tell were he was become, saue only the emperour's doughter which see hym at the fountayne agayne unarmynge hym.

\section{How Robert gatte the thyrde batalye as he dyde before which she} kepte secrete.

IN a short tyme after this the senesshall tourned agayne with a moche greter power than he had before, and layde syege to Rome. And when the emperour rode to the batayle, he commaunded his knyghtes and barones to take good hede fro whens that knyght came with the whyte horse, and what he was and where he became, for he had grete desyre to knowe what he was. The knyghtes answered that it sholde be done. The day came that they must ryde forth to the batayle, and sertayne of the best knyghtes rode pryuely into a wood that stode a lytell there besyde, and there they wayted whiche waye the knyghte on the whyte horse should come to the batayle; but they loste theyr laboure, for they coude not tell whens he come. But when they sawe. hym in the batayle, they rode towarde hym to helpe hym and receyue hym. This same batayle was sore foughten on both partyes, but the Sarasyns lost there courage, for Robert layde on 
soo grete and myghty strokes, that no man myght stande under his hande; so that in conclusyon Robert dyde so moche and so valyantly, that the Sarasyns were put to the discomfyture wherot themperour was gretly enioyed; the senesshall with the Sarasyns were passynge angry and sore moued therewith all.

\section{How one of the Emperour's knyghtes hurte Robert in his thyghe with a spere.}

THAN when this batayle was done, euery man rode home, and Robert wolde haue tourned agayne to the fountayne to unarme hym as he was was wonte to do before, but the forsayd knyghtes were torned agayne to the wood, to awayte for the knyght with the whyte hors; and whan they sawe hym come, they rode all at ones out of the wood, and cryed with a loud voyce saynge unto hym : "O noble knyght, tary and speke with us, who that ye be, and whens and out of what lande ye come, to the entent that we may shewe it to the emperour, whiche specyally he desyreth for to knowe." Robert this herynge was sore ashamed, and smote his white hors with his sporres, flyngynge ouer hylles and ouer valleyes, for bycause he wolde not be knowen But there followed hym a bolde knyght, well horsed, with a spere, wenynge to haue kylled his whyte horse, but he myste, and smote Robert in the thyghe with his spere, and the spere heed brake of and stack styll in his thyghe, but yet for all this he coude gete no knowlege of the knyght with the whyte horse, for he rode from them all euerychone, whereof they were passynge sory. Robert rode so sore, tyll at the laste he came unto the fountayne and unarmed hym, and layde the harnays on the horse as he had done before, whiche in contynente was vanysshed awaye and gone; and he drew out the spere hed out of his thyghe, and hyd it bytwene two grete stones by the fountayne; than he layde grece and mosse upon his wounde, for he durst let no man loke therto, for fere he sholde haue ben knowen. And all this sawe and marked the emperour's doughter; for bycause she se that Robert was a fayre and well fauoured yonge knyght, she began to cast her loue unto hym. 
And whan Robert hadde dressed his wounde, he came in to the halle. to gete hym some mete, and he halted as lytell as he coude, and kept it secretly, that almoost no man coude perceyue it, and suffred moore payne a thousande tymes than it semeth by hym. Shortly after this, came home the knyght that had hurte Robert, and began to recounte to themperour how the knyght with the whyte horse had outryden hym, and how he had hurte hym sore ayenst his wyll, and sayd to the emperour: "I beseche you, my lorde emperour, here what I shall tell you, and in what maner ye shall knowe who is he that hath holpen you ; it is best ye make a proclamacyon and publyshe thrugheout your empyre, and yf there be ony knyght in whyte harnays and a whyte horse that he be brought to your presence, and that he brynge with hym the spere-heed where withall he was hurte in his thyghe, shewynge the wounde, and that ye gyve hym youre doughter to wyfe, and halfe youre empyre with her." 'Themperour this herynge, was of his counseyll very gladde, and incontynent all haste proclamed and publysshed thrugheout all the empyre, and thought that the knyght had gyuen hym good counseyll.

How the Senesschall thruste a spere-heed in to his thyghe, wenynge to have begyled the Emperour, and to haue wonne his doughter thereby.

IT befell in shorte tyme after, that the senesshall had knowlege and understandynge of the emperour's proclamation, and how he myght wynne themperour's doughter, whiche he had many tymes bene about. He dyde grete dylygence, and caused to be sought and gotten a whyte horse and white harnays, and thryste a spere heed in his thyghe, wenynge therby to deceyue themperour, and to gete his doughter to wyfe. And whan this was done he commanded all his men to arme them, and ryde wyth hym to the emperour. And he rode so sore tyll he came to Rome with great royalte and solace, and without any taryenge he rode streyght to the emperour, saynge to hym in this wyse: "My lorde I am he that you so valyauntly receyued: thre tymes I haue caused you to haue 
honoure and victorye ayenst the cursed Sarasyns." Themperour thynkynge upon no treason nor deceyte, sayd: "Ye be a valyaunt and a wyse knyght; but I had went the contrarye, for we haue taken you for a vylayne and a forsworne knyght." The senesshall was very angry and sore moued here withall, and answered the emperoure shortly and angerly! "My lorde emperour, meruayll you nothynge here of, for I am not such a cowarde as ye wene that I be:" and thus saynge he toke out the spere-heed and shewed it the emperour, and uncouered the wounde the whiche he had made hymselfe in hys thyghe. The knyghte stode by whiche that hurt Robert before, and began to compasse in his mynde, for he se well that it was not the heed of the spere, but he durst saye nothynge for fere, lest the senesshall wolde haue kylled hym. We wyll leue nowe of the senesshall, and speke of Robert, which is among dogges, sore wounded, as ye have herde before.

\section{How God sent an aungell to the heremyte that he sholde goo to Rome} and seke Robert, for he hal full doone his penaunce.

THE heremyte whiche ye haue herde of before, that shroue and sette Robert his penaunce, laye on a nyght in his selle and slepte, and thus slepynge there cam to hym a voyce, and bad hym lyghtly aryse and goo to Rome, to the place where Robert was doynge his penaunce; and the aungell tolde the heremyte all the doynges of Robert, shewynge how that his penaunce was fully done, and that God hadde forgyuen hym his synnes, whereof the heremyte was uery gladde, and in the mornyng erly he arose and wente to Rome warde, and in lyke wyse in the same mornynge the senesshall rose be tyme and went to Rome to the emperoure to desyre and haue his doughter accordynge to the publycacyon and crye, to the whiche the emperoure consented her to hym without any long aduysement. But whan the doughter understode that she was gyuen to the senesshall she raylled and raged as though she hadde ben wood and madde; she tare her hare from her heed, and all to tare her clothes, but it myght nothynge 
auayle her, for she was constrayned, and must be arayed lyke a bryde, and an emperour's doughter which shold be maryed, and the emperour ladde her by the hande hymselfe to the chyrche royally accompanyed with lordes and ladyes and gentylwomen, but the doughter made the gretest sorowe of the worlde in so moche that no man coude content her mynde.

How the Emperour's doughter thrughe the grace of God began for to speke the fyrste worde that ever she spake in her lyfe.

THAN as the emperour with all his estate was come in to the chyrche, the emperour's doughter whiche was dumbe, sholde marye the senesshall; there dyde our lorde a fayre myracle, for the loue of the holy man Robert, to the entente he sholde be exalted, whome euery body helde fer a fole and with hym mocked. Whan the preest sholde begyn the seruyce, and to marye the senesshall and this yonge mayde togyder, the doughter thrughe the grace of God began to speke to the emperoure her fader in this wyse: "Fader I holde you not wyse, but fer ouer sene in that ye byleue that this proude folysshe traytoure telleth you, for all that he telleth you is lyes; but here in this towne is a holy and deuoute persone, for whose sake God hath gyuen me my speche, wherfore I loue hym in my herte, for I haue alwaye, sene and marked his valyance and holynes, but noo man wolde byleue me what poyntynge or sygnes that I made." Thenne the emperoure this herynge, was almoost oute of his mynde for joye, whan he herde his doughter thus speke, the whiche neuer spake before, wherby he knewe well ynough that the senesshall hadde betrayed and deceyued hym. The senesshall this herynge, was wode angry and foule ashamed, and lyghten upon his horse and rode awaye and all his companye. The pope beyng presente axed the mayden who the man was that she spoke of. Than the mayde ladde the pope and the emperour her fader to the fountayne where Robert was wonte to arme and unarme hym, and there she toke out the spere heed from bytwene the two stones where that Robert had hydde it, 
and than she caused the spere to be brought forth; whereof the heed was broken, whiche was lyghtely brought to her, and that heed and the spere joyned togyder in one as cloes as thoughe they hadde not be broken. Than sayd the mayd to the pope, "We have hadde thre tymes vyctorye by his noble valyaunce ayenst the myscredaunte Sarasyns, for I haue thre tymes sene his horse and harnays wherwith he hath thre tymes armed and unarmed hym, but I can not tell who broughte hym horse and harnays, nor unto whom he delyuered it, but I knowe well that whan he hadde this done he layde hymselfe downe by the dogges." And the mayden sayd unto the emperoure her fader in this wyse, "This is he that hathe saued youre landes and youre honoure, and gate you vyctorye of the Hethen houndes the Sarasyns, wherfore ye ought of deute to rewarde hym, and yf it please you we wyll go all to hym and speke with hym." 'Than wente they for the fole, the emperour and the doughter with all the lordes and ladyes unto Robert, whome they founde lyenge among dogges, they folowed hym and dyde hym reuerence, but Robert answered them not.

How the heremyte found Robert, and commaunded hym to speke, saynge to hym, that his penaunce was full done and his synnes forgyuen.

ThE emperour spake to Robert and said, "I praye you, swete frende, come to me and shewe me your thyghe I wyll nedes se." Whan Robert herde themperour say these wordes he wyst well ynoughe wherfore he was comen to hym, but he lete hym as thoughe he had not understonden hym. And Robert dyde many madde conceytes to make the pope and themperour to laughe and forgete that they spoke of. But the pope spake to Robert, and coniured hym in the name of God that on the crosse dyed for our redempcyon, that yf it be Goddes wyll that thou haste spoken that thou speke now unto us. And than Robert rose up lyke a fole and gaue the pope his blessynge. And here withall Robert loked behynde hym and saw the heremyte that set him his penaunce, and 
as soon as the heremyte se Robert whiche he had long sought, he cryed to hym with a loude voyce that every man myght here hym that were there: " My frende herken unto me, I knowe well that ye be Robert that men calle the Deuyll, but now ye be in grace and conceyte with Almyghty God, and for that foule and hydeous name ye shall haue a fayre name, and be called the Seruante of God. Ye be he that hath saued this lande from the Sarasyns, wherfore I praye you that ye serue and worshyp God as ye haue done hyderto, for oure Lorde sendeth me now to you commaundynge you to speke, and no more to counterfeyte the fole ; for it is Goddes wyll and commaundement, for he hath forgyuen you all your synnes, for by caus ye haue made satysfacyon and full done your penaunce." Whan Robert herde this he fell lyghtely on his knees and lyfte up his handes towarde Heuen saygne thus, "I gyue laude and thankes to God, creator of Heuen and erthe, that it hath pleased the to forgyue me myne abhomynable and grate synnes thrughe so lytell and lyght penaunce that I haue done:" therefore, whan the pope, the emperour and the doughter, and all that were there present herde Robert speke thus swetely, they were all heerof gretely enioyed and had grete meruayll of. Themperoure seynge his noble valyaunce vertue and curtesye that in hym was and wolde haue gyuen hym his doughter to wyfe, but the heremyte wolde not it sholde be so; wherfore euery man departed and wente home.

\section{How Robert tourned agayne to Rome for to marye the Emperour's doughter by the commaundement and wyll of God.}

Now the storye telleth as after that Robert had remyssyon of his synnes and was gone towarde his countre, than out of Rome God commaunded hym that he sholde tourne agayne to Rome and marye the emperour's doughter, which loued hym passyngly well, and he sholde haue by her a sone wherby the Crysten beleue sholde be encreased and fortefyed and defended. Robert at the commaundement of God turned agayne a Rome and maryed themperour's doughter with grete tryumphe and solace, for them- 
perour and all the Romayns were therof very glad. This brydale was royally kepte and euery man that se Robert loued hym aboue all other; and the people sasd one to another, that they were gretely beholdynge to Robert, that he had redemed them from theyr mortall enmyes the Sarasyns. This feest was grete and notable and dured xiiij dayes, and whan the feest and brydale was done Robert wolde departe with his lady into Normandye to vysyte his fader and mother, and toke leue of themperour whiche gaue hym many royall and grete gyftes, as golde and siluer and precyous stones of diuerse colours. Also themperour gaue hym knyghtes and squyers to ryde and conduyte him in to his countree.

\section{How Robert and his lady came to Rowane in Normandye with grete honour and worship.}

ROBERT and his lady rode soo ferre they came into Normandye into the noble cyte of Rowane with grete myrth and solace, where they were receyued with grete tryumphe; for the comyntees of the countree were sorye and in grete heuyness that theyr duke Robert's fader was dyseased, for bycause that he was a wyse and a renomed prynce. A lytell besyde dwelled a cursed knyght, whiche hadde done the duchesse grete wronge and suppressed many knyghtes after her husbondes dysease. But whan Robert was come, euery man dradde hym and dyde hym grete reuerence and worshypp. Than some sayd we wende he had ben deed, and all the lordes and burgeys of Rowane, gadred them togyder and with grete honoure and reuerence they receyued Robert and helde hym as theyr lorde and souerayne. But whan they hadde receyued hym honourably, they shewed hym of this before sayd knyght; he hadde many tymes suppressed, and done wronge to his moder, sythen the deth of his fader. Than whan Robert herde and understode this, he sente lyghtely men of armes to take the sayd knyght, the whiche dyde so moche that they toke hym and brought hym to Robert whiche made hym to be hanged, wherfore the duches was ryght glad. But she was moche more 
gladder that Robert her sone was come home, for she wende he hadde ben deed. And whan Robert and his moder were thus togyder, he recounted unto her how the emperour had gyuen hym his doughter in maryage, and how he had done his penaunce. The duchesse herynge her sones wordes, she began to wepe very sore, for bycause he had suffred so grete pouerte and penaunce thrughe his defaute.

How' the Emperour sent a messanger unto the Duke Robert, that he sholde come and rescue hym ayenst the Senesshall.

IN the meane season, whyles Robert was, thus at Rowane with his moder and his lady in grete joye and solace, there came a messanger fro the emperour -unto Robert whiche dyde hym reuerence, and saynge thus unto hym: "My lorde duke, the emperour hathe sente me hyther to you, and he prayeth you for to come and rescue hym ayenst the false traytoure the senesshall with the Sarasyns, which haue layde syege to Rome." Whan Robert herde these wordes, he was sorye in his mynde for themperour, and shortly assembled as many men of armes as he coulde get in his lande of Normandye, and forth withall rode with them towarde Rome, to helpe and socoure the emperour. But before he coude come thyder the false traytour the senesshall had slayne the emperour, which was grete pyte. But Robert wente streyght into Rome, and lyghtly with all his power and myght went ayenst the senesshall. And whan Robert aspyed the false traytoure, he descryed hym, saynge thus: "Abyde, thou false traytour, now thou shalte neuer escape my handes yf thou abyde me in the felde, for thou art now nygh thy lyve's ende. Thou dydest putte ones a spere-heed in thy thygh for to haue" deceyued the Romayns, defende now thy lyue ayenst me, for thou shalte neuer escape myn handes, and thou hast also slayne my lorde themperoure, wherefore thou shalt be well rewarded after that thou hast deserued." And with these wordes Robert, with grete desyre and myghty courage, rode unto the senesshall and gaue hym suche stroke on the helmette, that he clove helmet and heed 
unto the teeth, and in contynente the traytour fell downe deed unto the erth. And Robert made hym to be brought in to Rome, to the entente that he sholde there be slayne to reuenge the Romayns, the whiche was done in the presence of all the people that were in Rome; and in this wyse fenysshed that traytour the senesshall his lyfe, and had a shameful death, wherby men may make and take hede that it is grete folye to coveyte or desyre thynges passynge theyr degre; for and the senesshall had not desyred the emperoure's doughter, the whiche passed and exceeded ferre aboue his degree, he had not dyed this shameful deth, but myght haue lyued and the emperour also, and haue dyed good frendes.

\section{How that the Duke Robert tourned agayne to Rowayne after he had made the Senesshall to be slayne.}

RoBERT the duke defended the cyte from theyr enemyes, and than he retourned agayne with all his companye unto Rowane to his wyfe, whiche was passynge sorrowfull and pensyfe. But whan she herde that the traytour the senesshall had slayne her fader, she was almoost out of her mynde; but Robert's moder comforted her in the best maner that she coude or myght. And for to make shortely an ende of our mater, and so to fenysshe this boke we wyll lette passe to wryte of the grete dole and sorowe of the yonge duchesse, and speke of the young duke Robert, whiche in his youth was about to all myschefe and vyce, and all ungracyousnes, without ony measure or reason, for he was a greter devourer, and a more vengeable, than any lyon, nothynge. sparynge, nor on no man hauying mercy nor pyte. And after this he lyued xii yere in grete penaunce, like a wylde man, without ony speche, and lyke a dumbe beest etynge and drynkynge with dogges, and there after was he exalted and honoured of them whiche before dyde holde hym for a fole or an innocente, and mocked with hym. This Robert lyued longe in vertue and honoure with that noble ladye his wyfe, and he was beloued and dradde of hyghe and lowe degre, for he dyde ryght and justyce, 
as well ouer the ryche as ouer the poore, kepynge his land in reste and in pease, and begote a chylde with her, and whiche he called Rycharde, whiche dyde afterwarde many noble actes and dedes of armes with grete Charlemayne kynge of Fraunce, for he dyde helpe hym for to gere and fortefye the Crysten fayth, and he made alwayes grete warre upon the Sarasyns. And he lyued in his land in rest and pease, and was beloued of poore and ryche, and all his comente loued hym in lykewyse as Robert his fader was loued, for they lyued bothe deuoutly and in vertue. Wherfore I praye God that we may so lyue in this lyfe we may optayne and come to euerlastynge lyfe. To the whiche brynge us he that bought us and al mankynde with his preecyous blode and bytter passyon. Amen.

Thus endeth the lyfe of Robert the Deuyll,

That was the seruaunt of the Lorde,

And of his condycyons that was full euyll,

Emprynted in London by Wynken de Worde.

Here endeth the lyfe of the most feerfullest and unmercyfullest and myscheuous Robert the Deuyll, whiche was afterwarde called the Seruaunt of our Lorde Jhesu Cryste. Emprynted in Flete-strete in the sygne of the sonne, by WYNKYN DE WORDE. 
V I R G I L I U S. 
(1) 


\section{III. \\ VIRGILIUS.}

Hoze Romulus cam reithin the fayer towne of Reynes that he destroyed, and how he slewe his broder Remus that was lorde of Raynes.

Rfs Z7omuluts harbe say of his broder Remus, and of the towne of Raynes, than he was uery heauy; for the walles of Raynes was so hygh that a man that stode in the deche myght nat schote ouer well with a hande bowe; and the walles of Rome was so lowe that a man myght wel lepe ouer, and with no deches.

It fortuned that Remus went to see his broder Romulus at Rome, and toke with hym manye folke after his estate and byrthe, and left his wyfe in abydynge, in the towne of Raynes in Champanion, with a lytyll chylde or yonge son named Remus after his owne name. And whan he was com before Rome, and sawe the walles, he sayd three tymes that the walles were to lowe; moreouer he sayde, with a ronne he wolde lepe ouer them; and bye and bye he take a ronne and lept klene ouer.

And whan his broder Romulus had harde this, howe his broder had lepte ouer, he sayd that he had done yll, and therefore he shuld lese his hed. And as Romulus dyd enter into his broders palayce, then he toke Remus, and he with his owne handes smote of his broders hed, and slew hym.

And it was nat longe tyme after that he raysed a great armey of people thorowghe all his contreye, and prepared hym towarde the towne of Raynes in Champanien, and began to set his ordinaunce towarde the walles of the towne, and dyd destroye the 
palayce, towers, and other places to the erthe, in so muche that he lefte but a few standynge or none: but he coulde nat fynd the wyfe of Remus, his suster, for she was fled away out of the towne, under the erthe at a false porte to hyr frendes and kynffolke, for she was one of the greatest borne women that was than there aboute. And as Romulus had destroyed the lande and towne of Raynes, he departed and went home toward the cytie of Rome with all his hooste, where he was receyued rychelye.

Howe the son of Remus, that also was named Remus after his fader, dyd slewe his unkell Romulus and afterwarde was made emperoure, and so reyned emperoure.

THAN was the wyfe of Remus very sadde and morned very sore when she knewe of the dethe of hyr husbond, and also of the destructyon of the towne of Raynes destroyed by the handes of hys brother. And she caused workemen shulde make the walles ageyne after hyr broders departyng fro it, insomoche that she made the towne of Raynes more stronger and fayrer than it was euer afore, and renewed it rychely after hyr myght and power: for she was not of so great myght as she was when her husbonde was alyue.

And also this noble ladye norysshed her chylde well, and within a lyttyl space he began to wexe bygge and stronge, and myghty anoughe to bere armure. Than sayd his moder to hym :

"My dere son, when wyll you wreke your faders dethe that your unkell slewe?"

$\because$ And he answered to his moder: "Within this iij moneythes."

And forthewith he caused his kynsffolke to reyse theyr people; and when they were gathered they departed.

He cam with a great power towarde Rome, and when he cam to Rome he entered in thereat, no maner of bodye ayenste sayinge. And when he was within, he made a crye that no man should do no comons harme. Than went he to the Emperours palayce. And when the Emperour knewe that he was come, he asked counsayl; and the senyatours answered, that thẹre was no 
remedy but deth : bycause ye slewe his fader, so shall he ageyne slee you. And with that cam in Remus into the palayce of his unkle Romulus, no body ayenst sayinge; and there he saw his unkell afore him stand in his emperly stole. Than was he inflamed with yre and drewe out his swerde, and toke his uncle by the here, and smote of his hed. And whan it was done, he asked the lordes and senyatours of Rome, or they wolde thereforre warre? and they answered all, "nay :" and gaue to hym the hole empyre and crowned hym as ryght heyer; and whan he was Emperour he sent for his moder and she came to hym.

And than was Rome made with stronge walles and deches, and than gatte Rome name ; and there haunted many dyuerse nacyons; and they dyd buylde and edefye many fayre dwellynge places in Rome. This Remus was a stronge man of bodye, ryche of good, wyse in counsayll, and had under hym many landes and lordshyppes.

This Remus had a knyght of his moders behalfe, that was ryght hardy and bolde in batayle, and he toke or maryed a wife in the cytie of Rome, that was one of the greatest senyatours dawghters of Rome and hyghest of lynage. And Remus reyned not long after, but dyed, and his sone was made Emperoure and reygned after hym. And this knyght of Champanien, that had maryed the senyatours dawghter, he made great warre with hym, and dyd hym very muche harme.

This knyght had one son by his wyfe, that with great travalynge of laboure was bourne, and there was he named Virgilius of Vigilo, for by cause that he was a great space of tyme watched so with men.

\section{Howe Virgilius was sette to schole.}

As Virgilius was borne, than the towne of Rome quaked and trembled. And in his youthe he was wyse and subtell, and was put to schole.

And shortly after dyed his fader, and than Virgilius moder wolde no more marye ayen, for she loued her lord so well. And after the decese of hyr husbond, hyr kynsfolke wold haue put her fro 
hyr enherytaunce that she had lyinge within and without Rome, and one of the fayreste castels and strongest in all the towne or there abowt that could be emagined or made by any man. And she complayned often to the Emperoure, that was nere of kynne unto hyr husbonde; but the Emperoure was a angery man and wolde nat here hyr complayntes, also he was nat beloued of the lordes nor of the comon people.

Within short tyme after, he decesyd and his sone and heyer Persydes was emperoure after his faders dethe, and ruled after his own mynde all the lande. And he had all the Romans under hym, insomuche that he ruled them so strayghtly that they were sore adrad of hym.

And Virgilius was at scole at Tolenten, where he stodyed dyligently, for he was of great understandynge. Upon a tyme the scholers hadde lycence to goo to play and sporte them in the fyldes after the vsaunce of the holde tyme: and there was also Virgilius therby also, walkynge amonge the hylles all about. It fortuned he spyed a great hole in the syde of a great hyll, wherin he went so depe that he culde not see no more lyght. And then he went a lytell ferther therin, and then he saw som lyght agayne, and then wente he fourth streyghte. And with in a lytyll wyle after, he harde a voice that called, "Virgilius, Virgilius;" and he looked aboute and he colde nat see no bodye: Than Virgilius spake and asked, "Who calleth me!" than harde he the voyce agayne, but he sawe no body; than sayd he, "Virgilius, see ye not that lytyll bourde lyinge besyde you there marked with that worde?" Than answered Virgilius, "I see that borde well enough."

The voyce sayd, "Doo a waye that bourd, and lette me oute ther atte."

Than answered Virgilius to the voyce that was under the lytell borde, and sayd, "Who art thow that talkest me so!"

Than answered the deuyll: "I am a deuyll coniured out of the body of a certeyne man, and banysshed here tyll the day of iugement, without that $I$ be delyuered by the handes of men. Thus, Virgilius, I pray the delyuer me out of this payn, and I shall shewe 
unto the many bokes of nygromancy, and howe thow shalt cum by it lyghtly and knowe the practyse therein, that no man in the scyence of negromancy shall pass the. And moreouer I shall showe and informe you so that thou shalt haue all thy desyre, wherby my thynke it is a great gyfte for so lytyll a doynge, for ye may also thus all your power ${ }^{1}$ frendys helpen, and make rythe your ennemyes unmyghty."

Thorowgh that great promyse was Virgilius tempted; he badde the fynd showe the bokes to hym that he myght haue and occupy them at his wyll. And so the fynde shewed hym, and than Virgilius pulled open a bourde, and there was a lytell hole, and therat wrange the deuyll out lyke a yeel, and cam and stode by fore Virgilius lyke a bygge man. Therof Virgilius was astoned and meruelyed greatly therof that so great a man myght come out at so lytell a hole.

Than sayd Virgilius, "Shulde ye well passe into the hole that ye cam out of?"

"Ye, I shall well," sayd the deuyll.

"I holde the beste plegge that I have, ye shall not do it." "Well," said the deuyll, " thereto I consent."

And than the deuyll wrange hym selfe into the lytell hole ayen, and as he was therein Virgilius kyuered the hole ageyn with the bourd close, and so was the deuyll begyled and myght not there come out ayen, but there abydeth shytte styll therin.

Then called the deuyll dredefully to Virgilius, and sayd, "What haue ye done?"

Virgilius answered, "Abyde there styll to your day apoynted." And fro thensforth abydeth he there.

And so Virgilius becam very connynge in the practyse of the blacke scyence.

It was so that the moder of Virgilius wexed olde, in so muche that she lost her herynge. Than called she one of hyr seruauntes, and sayd to hym, "Ye must to Tolleten, and tell Virgilius my sone that he come and redresse his enherytaunce within and 
without Rome, and gyue up the schole, for he shulde be by ryght one of the greateste of all Rome."

The messenger departed and wente toward Tolleten where Virgilius was, and whan he cam there, he founde Virgilius teychyng and lernynge the greattest lordes of the lande, and other landes also: for I ensure ye, he was a fayr and a wyse yonge man, and conynge in the scyence of negromancy aboue all men than lyuynge.

He salued Virgilius, and shewed unto hym all the mater that he cam for; and whan Virgilius harde all the matter howe it was, he was very heuy, not for the good, but for his moder; for Virgilius had good anough. He rewarded the messenger, and also sende his moder iiij somers ${ }^{1}$ laden with money, and with other costely iewels, and sende hyr also one whyte horse; and so the messengre took his leue of Virgilius, and so departed.

And Virgilius abydyng styll in Tolenten emagened in his mynde howe he myght best conuey the rest of his good to Rome and that he myght followe. And whan he ordeyned and set in order all the rest, he toke his leue and departed fro Tolenten toward Rome, with many of his scholers with him.

Whan he cam to Rom to his moder, he salewed his moder, and she hym; for she was glad of his commynge, for she saw hym not afore by the space of xij years a fore.

\section{How Virgilius did make his complaynt to the Emperour as he was com to Rome.}

As Virgilius was com to Rome he was receyued ryght worshypfullye of his power kynsfolke, and not of the ryche, for they withhelde his landes oute of his hande; for that cause was he nat welcome to them, but were angery of his comyng, for they wolde nat ete with hym nor drynk with hym.

Than was Virgilius angery, and than gaue he to all his power kyndsfolke that with helde nothynge fro his moder, landes, harneyse, horses, siluer and golde and other thynges. And 
he gaue to his naybours great thankes for the kyndnes that they showed to his moder in his absence. After this dyd Virgilius abyde longe tyme with -hys moder, tyll the tyme that the Emperour reysed a newe custom or taxe. 'Than went all the lordes to the Emperour that helde any lande of hym, and also Virgilius with all his company and many kynsfolke and frendes. And whan he cam before hym, he salewed hym, and shewed unto hym howe he was enheryted of his landes and tenementes, and of those that with helde it, and desyred that he myght haue it ageyne. Than answered the Emperour, that he shulde take thereof counsayll. And forthwith he went to counsayll with them that loued not Virgilius : and they answered to the Emperour; "Me thynketh that the land is well deuyded to them that hath it, for they may helpe you in your nede. What nedeth you for to care for the dysherytynge of one schole mayster? and byd hym take hede and loke of his schole, for he hath no ryght to any lande here aboute the citie of Rome." And thus the Emperour sayd that he must take pacyence by the space of iij. or v. yere that we myght examyne with in our selfe whether ye be ryght eyer or no. And with that answere was Virgilius very angry, and sayd that he shulde be auenged.

And whan he cam home he sende for all his poor kynsfolke and fryndes, and put them in his houses and dwellynge places that he hadde within Rome, and purueyed them of mete and drynke, and byd them make mery tyll Julio, that the corne and frute is rype. And whan it was rype, Virgilius by his negromancy dyde caste the ayer ouer all the frute and corne of his landes that his enemyes hylde fro hym, and caused it to be gathered and brought in to his howses, that none of his enemyes had none thereof. In this maner of wyse dyd Virgilius deseyue his enemyes of all the frute and corne, insomuch that they had not on pennys worth of that goods that they witheld fro hym.

And whan Virgilius enemyes sawe the frute so gathered, they assembled a great power, and cam towarde. Virgilius to take hym and smyte of his hed. And when they were assembled, they: were so stronge, that the Emperour for fere fled out of Rome, for 
they were xij. seniatours that had all the worlde under them; and Virgilius had had ryght he had ben one of the xij. but they had dysheryted hym and his moder. And whan Virgilius knewe of theyr commynge, he closed all his landes with the ayer rounde about all his lande, that none lyuynge creature myght there come in to dwelle ayenst his wyll or pleasure.

\section{Howe the Emperoure of Rome beseged Virgilius beynge in his castell.}

As Virgilius enemyes cam to destroye and take hym, and when they cam before his castell, he closed theym with the aeyer that they had no myght to gowe nor for warde nor back ward, but abyde styll, where of they merueyled. And than Virgilius answered, "Ye cum to dysheryt me, but ye shall nat; and knowe ye well that you shall haue no profyte of the frutes as longe as I lyue; and ye maye tell to the Emperour that I shall tarry iij. or v. yeres tyll he take counsayll. I desyne not to plete in the lawe, but I shall take my good where I fynde it; and also tell the Emperour I care nat for all his warre nor all that he can do to me." Than returned Virgilius and made ryche all his poure kynsfolke. And, whan Virgilius was returned, than wente they home and knewe nat what they shoulde do.

Than cam they to the Emperour and complayned of Virgilius, and sayde, that Virgilius sayde, that he set nat by the Emperoure and all that he coude make. And when the Emperoure harde this, he was greatly amoued and sore anangered, and sayd, that I shall brynne and set on fyer all his howses, and also I shall smyte of his hedde. And there with all not longe taryinge, he caused his lordes and knyghtes that helde lande of hym, that they shulde reyse all theyr men of armes that they had under them, to be redy at a day at his commaundement; and at the day apoynted the Emperour and all his hooste were assembled. They tooke theyr way towarde the place of Virgilius, that was rounde aboute well walled and closed with aeyr ; that whan the Emperour cam before the walles with all his hoste, they myght not gowe nor 
forwarde nor backwarde. And than went fro his castell fourthe Virgilius, and with his negromancy he made also a lyght in suche maner that they coulde nat goo forwarde nor returne, but stande styll. And he made also by his cunnyn, that the Emperour thought that he was closed rounde aboute with a great water, in so muche that they myght nat come to the castell, nor for to come fro the castell, but stode styll; and thus dyd Virgilius serue the Emperoure and all hys hooste.

And moreouer cam Virgilius to the emperoure, and sayde, "Lorde Emperoure, ye have no power with all your strength to do me harme nor my landes also; for be ryght ye shulde make of me as one of your greatest lordes and nearest of your kynred, for I at your nede maye helpe you more than al your other folke."

Than answered the Emperour to Virgilius, "You begyler, may I ons get you under my handes, I wyll geue the that thow hast deserued."

Than answered Virgilius, and sayd, "Lorde Emperour, I fere you nat. But thynke you well, that I shall tame you well a nowghe, that ye shall be glad to know me for one of your kynsfolke and of your blode; but ye wolde dysheryte me, but ye shall not."

Than caused Virgilius muche mete to be dressed bytwene his howse and the hoste, that the Emperour and his folke myght se it, and howe they dressed it; but they myght haue none thereof but the smoke or reke, for they of the hoste was shyt in with the aeyr as thowghe it hadde ben a great water. And so dyd Virgilius serue the Emperour and his folke, nor was there no body in his hoste that coulde fynde any remedy to helpe them there agayn.

Upon a tyme as they were in that thraldome afore the castell, there cam a man that colde skyll in the scyence of negromancy, and cam afore the Emperoure, and sayd, that he wolde by hys practyce make slepe all Virgilius folke; and so he dyd, in so muche that Virgilius his selfe myght scant withdrawe hym fro slepynge. Than was he sorye and wyste nat what to do, for the Emperours folke was delyuered, and began to come upon Virgilius walles. 
And whan Virgilius saw that, he loked in his boke of negromancye where in he was very parfeyte, and there he founde in what maner he myght delyuer his folke fro slepe. And than he cungered that he made the Emperoure stand styll agene, that he myght nat remeue out of his place, nor all his folke, nor the mayster of negromancy myght nat remeue nor styrre, as thowgh they were deed : and they that were upon the ladders, one fote uppe, another downe, and so stode styll, and also some stode with one foot on the lader, and a nother upon the wall, and so for to stand styll till it pleased Virgilius.

Whereof the Emperour was sore auexed and angery, and asked his mayster if they shulde stand styll in that maner? and he gaue hym no answere, but he spake to Virgilius and sayd that he wulde showe upon hym his cunnynge.

And than Virgilius answered, and bad hym do his beste, "for I set nat a strawe by you nor all that you can do to me."

And thus helde Virgilius the Emperour and all his folke closed in this maner with the ayer, by space of a day. And in the nyght came Virgilius to the Emperour and sayd; "It is a shame for so noble a prynce thus to stop the way, and take upon hym that he can nat do."

Than sayd the Emperour to Virgilius : "Helpe me oute of this daunger, and I shall restore ageyne to you all your landes and tenementes, and haue all thynges at your owne wyll."

Than answered Virgilius to the Emperour, "I wyll delyuer you out of this daunger, so that ye wyll gyue me grace."

"Ye, by my crowne; and I knowe you for on of my kynred and I dessyre to haue you with me in my felawshyp."

And than Virgilius put a waye the closynge, and reseyued the Emperour and all his folke into his castell, where golde and ryches were plenty, and serued them with mete and drynke ryght plentyously, after theyr degre, of the deyntyest and strangest that myght be gotte, that they saw neuer afore. And the Emperour was there more rychely serued than euer he was before or after. And Virgilius rewarded euery persone after his degree, and with manye costely and meruelouse gyftes. 
Hozve the Emperour restored ageyne unto Virgilius all his enherytaunce and gooddes, and gaue to hym many other thynges.

'Thun toke they leue of Virgilius and retourned home ageyne. And whan they were returned home, the Emperour gaue to Virgilius his land ageyn and all that he asked, and was the greattest lorde of the Emperours counsayll.

After that it hapenyd that Virgilius was enamoured of a fayre ladye, the fayrest in all Rome. Virgilius made a crafti negromancy that tolde hir all his mynde: when the lady knewe his mynde, she thowght in hyr selfe to deseyue hym, and sayde, if he wyll come at mydnyght to the castell walle, she shulde lette downe a basket with stronge cordes, and there to drawe hym vppe at hyr wyndowe. And with this answere was Virgilius very glad, and sayd, he shudde doo it with a good wyll.

Howe the gentyl woman pulled vppe Virgilius, and howe she let hym hange in the basket when he was haife way wp to hyr wyndowe, and howe the people wondered and mocked hym.

A DAY was set that Virgilius sholde come to a tower that stode in the market place of Rome, and in all the towne was none so hygh. And at the day apoynted Virgilius cam to the tower, and the gentyl woman was thereat waytynge, and as she sawe hym there stande, she let downe the basket at the wyndowe. And when it was downe Virgilius went in; and whan he was therein, she pulled hym up tyll that he came half waye; and there she let him hange, and made the corde faste.

Than the gentylwoman spake: "Ye be deceyued, and I shall let you hange tyll to morowe, for it is market day, that all the fulke may wonder of you and your dyshoneste that you wolde haue do." And therewithall she shyt her wyndowe, and let hym hang tyll the mornynge that it was daye, tyll all the mien in Rome wyst it; and also the Emperour, that was ashamed, and sent for the gentylwoman, and bad hyr let hym downe, and so she dyd. And whan he was downe, he was ashamed, and sayd, that shortly 
after he wolde be auenged on hyr; and so went home to his gardayne that was the fayrest that stode within Rome. Than toke he his bokes, and by his connynge put out all the fyer that was in Rome, and none of them without myght bryng in fyer into the cytie; and this dured for the space of a daye and a nyght. But Virgilius had anowghe, and no body els had, nor myght not make no fyer within Rome.

\section{Howe Virgilius put out all the fyer of Rome.}

THE Emperoure and all his barons and the comons of Rome merveyled that there was no fyer in al the cytie; and than they thowght in theyr myndes that Virgilius had put it out. Than the Emperour sent for Virgilius, and prayd hym of his counsayll that men myght have fyer ageyne. Than he must cause a scaffolde to be made in the mydle of the market-place, and there ye muste set the gentylwoman in hyr smocke that hynge me in the basket yesterday; and than lett make a crye thorowgh all the cytie of Rome, who so wyll haue ony fyer must come to the scaffolde in the market-place, and of the gentylwoman there they shuld have fyer, or otherwyse none: and knowe that one the other can gyve none, nor sell none; and thus ye must do if ye wyll haue ony fyer. When they harde this, they cam with great multytude to the scaffolde.

\section{Howe the gentylwoman was put upon the scaffolde, and howe the} folke of the towne went and fetched /yer.

Tне Emperoure and all his lordes sawe that there was no other remedye but they muste nedes do after Virgilius counsayll. He did cause a scaffolde to be made in the market-place, and caused the gentyll woman to be set there on in hyr smocke; and there men fetche fyer; the pore men with candels and strawe, and the ryche men lyghted they theyr torches. Thre dayes must the gentylwoman stande in that manere or els they shulde haue no fyer. And after the thyrde day went the gentylwoman home 
sore ashamed, for she knewe well that Virgilius had done that violence to hyr.

Within a whyle after maryed Virgilius a wyfe: and when that was done, Virgilius made a merueylous paleyce with iiij corners : and as it was made, he layed the Emperoure therin in one of the corners, and herde that all the men did say in that quarter. And in lykewise dyd he bryng him in the other iij quarters, and so he harde what they sayde in the other quarters of Rome, and thus gowyng by the iiij quarters harde he what they sayde thorowe all Rome; they myght nat speke so secretly but he harde it.

\section{Howe Virgilius made saluatio Romæ.}

THE Emperour asked of Virgilius howe that he myght make Rome prospere and haue many landes under them, and knowe when any lande wolde ryse agen theym.

And Virgilius sayd to the Emperoure, "I woll within short space that do." And he made vpon the Capitolium, that was the towne house, made with caruede ymages, and of stone, and that he let call Saluacio Rome ; that is to say, this is the Saluacyon of the cytie of Rome. And he made in the compace all the goddes that we call mamettes and ydolles, that were under the subiection of Rome; and euery of the goddes that there were had in his hande a bell; and in the mydle of the godes made he one god of Rome. And when so euer that there was any lande wolde make ony warre ageynst Rome, than wolde the godes tourne theyr backes towarde the god of Rome; and than the god of the lande that wolde stande up ageyne Rome clynked his bell so longe that he hathe in his hand, tyll the senatours of Rome hereth it, and forthwith they go there and see what lande it is that wyll warre a gaynst them; and so they prepare them, and goeth a geyne them and subdueth theym.

This forsayde token knewe the men of Carthago, that was sore a greued for the great harme that the Romans had done them. And they toke a pryuay counseyll in what manner they myght destroy that worke, Than thought they in there mynde to sende 
iij men out and gaue them great multytude of golde and syluer. And these iij men toke theyr leue of the lordes and went towarde the cytie of Rome. And when they were come to Rome they reported themselfe sothesayers and trewe dremers.

Vpon a tyme wente these iij men to a hyll that was within the cytie, and there they buryed a great potte of money very depe in the erthe, and when that was done and kyuered ageyne, they went to the brygge of Tyber and let fall in a certayne place a great barell with golden pens.

And when this was done these thre men went to the seniatours of Rome and said:

"Worshypfull lordes, we haue this nyght dremed, that with in the fote of a hyll here with in Rome is a great pot with money. Wyll ye lordes graunt to us, and we shall do the coste to seke there after?"

And the lordes consented and than they toke laberours and delued the money out of the erthe.

And when it was done, they went a nother tyme to the lordes, and sayde :

"Worshypful lordes, we haue also dremed that in a certeyne place of Tyber lyeth a barell full of golden pens $;{ }^{1}$ if that you wyll graunte to us that we shall go seke it:"

And the lordes of Rome thynkyng no dyscepte, graunted to those sothesayers, and badde them do that that they shulde do there best. And than the sothe sayers was glad. And than they hyred shyppes and men, and went toward the place where it was; and when they were come they sowght in everye place there about, and at the laste founde the barelfull of golden pens, whereof they were glade; and than they gaue to the lordes costely gyftes.

And than to come to theyr purpose, they cam to the lordes a geyne, and sayde to them :

"Worshypfull lordes, we haue dremed a geyne that under the foundacyon of Capitolium, there where Saluatio Romæ standeth, be xij barelles full of golde; and pleasyeth you lordes that you wolde graunt us lycence, it shall be to your great auantage." 
And the lordes, styrred with couytayse, graunted them, bycause ij tymes a fore they told trewe. Whereof they were glad, and gatte laberours, and began to dygge under the fundacyon of Saluatio Romæ. And when they thought that they had dygged a noughe they departed fro Rome, and the next daye folowynge fell that house downe, and all the worke that Virgilius had made. And so the lordes knew that they were deseyued, and were sorowfull, and after that hade nat no fortune as they had a fore tymes.

How the Emperour asked counsayll. of Virgilius hone the nyght ronners and yll doers myght be ryd out of the stretes.

THE Emperour had manye complayntes of the nyght ronners and theues, and also of great murderynge of people in the nyght, in so muche that the Emperour asked counsayll of Virgilius, and sayd that he hath great complayntes of the theues that ronnyth by nyght, for they kyll many men; "what counsayll Virgilius is best to be done?"

Than answered Virgilius to the Emperour, "Ye shall make a horse of coper, and a coper man apon his backe, hauynge in his handes a flayll of yron, and that horse ye shall do brynge a fore the towne howse, and then ye shall lett crye that a man fro henseforth at $\mathbf{x}$. of the clocke shulde ryng a bell, and he that after the bell ronge was in the strete should be slayne, no worke thereof be done."

And whan this crye was made the roffyans set nat a poynt, but kept the streetes as they dyd a fore, and wolde nat let therfore; and as sone as the bell was ronge at $\mathrm{x}$. of the clocke, then lept the horse of coper with the coper man thorowgh the stretes of Rome, insomuche that he lefte nat one strete in Rome unsowght. And as sone as he found any man or woman in the strete he slewe them starke deed, insomuche that he slewe a boue CC. persons or more.

And this seying, the theues and nyght ronners howe they might fynde a remedy therefore thought in theyr myndes to make a 
dragge with a ladder theron; and as they wolde gowe out be nyght they toke theyr ladders with them, and when they harde the horse come, than caste they the dragge upon the howses, and so went up a pon theyr ladders to the top of the howses, so that the coper man myght nat toche them; and so abyd they styll in theyr wycked doyng.

Than came they a gene to the Emperoure and complayned, and than the Emperoure asked counsayll of Virgilius; and Virgilius answered and sayd, "that he muste get to coper houndes and set them of eyther syde of the coper horse, and let crye a geyne that no body after the bell is ronge shulde departe oute of theyr howse that wolde lyue."

But the nyght walkers carede not a poynt for that crye; but when they harde the horse comynge, with theyr ladders clymed upon the howse, but the dogges lept after, and tered them all to peces; and thus the noyse went thorowgh Rome, in so muche that no body durst in the nyght go in the strete, and thus all the nyght walkers were destroyed.

\section{How Virgilius made a lampe that at all tymes brenned.}

For profeyte of the comon people, Virgilius on a great myghty marbell pyller, dyd make a brygge that cam vp to the paleyce, and so went Virgilius well vp the pyller oute of the paleyce. That paleyce and the pyller stode in the mydde of Rome; and vpon this pyller made he a lampe of glasse that allwaye byrned without gowyng out, and no body myght put it out. And this lampe lyghtened ouer all the cytie of Rome fro the one corner to the other, and there was nat so lytell a strete but it gaue suche lyght that semed ij torches there had stande. And vpon the walles of the palayce made he a metall man that helde in his hande a metall bowe that poynted euer upon the lampe for to shote it out; but alway burned the lampe and gaue lyght ouer all Rome. And vpon a tyme went the burgeyses daughters to play in the paleyse and beheld the metall man; and one of them asked in sporte, Why he shat nat? And than she cam to the man and 
with hyr hande toched the bowe, and than the bolte flew oute, and brake the lampe that Virgilius made. And it was wonder that the mayden went nat out of her mynde for the great fere she had, and also the other burgeyses daughters that were in hyr companye, of the great stroke that it gaue when it hyt the lampe, and when they sawe the metall man so swyftly ronne his waye. And neuer after was he no more sene. And this forsayd lampe was abydynge byrnyng after the deth of Virgilius by the space of C.C.C. yeres or more.

How Virgilius made a orcharde by the fountayne, the fayrest and goodlyest that euer culde be founde in all the worlde.

GREAT wonder dyd Virgilius in his tyme; for after that palayce he made an horcharde wherin he set all maner of trees berynge frute, and also many herbes growynge in that yarde. And as the tyme was, sawe men dayly, rype frute, fayre blossoms, full plentyous. In the myddell of the orcharde was a fayer clere fountayne, the fayrest that euer was sene; and in this orchard was many dyuers of byrdes syngyng, for they myght well cum in, but they culde no more flye out ageyne, for it was closed in such with the ayer ; and men harde also theyr byrdes syng that was within, and culde not goo forth. Also he had in his orcharde all maner of tame bestes that were profitable for men. Also he made of the water that ran out of the fountayn a standynge water about the trees, the clerest that myght be, and there in was of all maner of fysshe that culde be thought. Also in this orcharde all maner of joyfulnes, both of trees, herbes, fowles, and bestes thereof that men myght thynke, or be immagened by mannes reasons. Alsc he dyd make greater thynges than all this; for he made a vaute or seller in the orcharde, the fayreste that myght be made or thought by mannes reason, which seller he made for to put in his money and ryches that he had; for he was so ryche, and so great multitude that he knewe no ende. And. he set ij metall men before the dore to kepe it, and in eche hande a great hamer, and therwith they smyte vpon a anuilde, one after the other, inso- 
muche that the byrdes that flye ouer hereth it, and by and bye falleth there 'down deed; and otherwyse had Virgilius not his good kepte.

\section{Howe Virgilius made his z'yle a y'mage.}

A IMAGE made Virgilius a hye in the ayer that myght nat fall; and the people of Rome myght nat open noder wyndowe nor doer but they must nedes see it. And this image had this properte, that no woman after she had seen the image had no luste to do bodely lust; and therefore the women had great enuy, and they compleyned them to Virgilius' wyfe that they theyr sporte and dalyinge had loste and prayed hyr that she wolde destroy that image and make it fall. And than wayted Virgilius' wyfe hir tyme, and went $v p$ the brigge of the ayer and cast down the image. And when Virgilius cam and founde his image downe, he was very angery, and sayd to his selfe, that it shulde nat auayll them, for he wolde set it up ageyne: and swore that he shulde know who had cast it downe. And he set it ageyne, and asked his ladye, and she had caste downe it? and she sayd, "Naye."

And than cam the women ageyne to Virgilius' wyfe, and sayd, "That it was worse than it was before, and prayed hyr, that she shulde caste it downe ageyne."

And than Virgilius went pryuyley into a corner, and wayted his wyfe, for he had sene before howe the women had complayned: them to hyr. And than went Virgilius' wyfe and caste downe the image; and Virgilius, that had hyd hym, sawe howe his wyfe had. caste it downe, and with a anger wold haue cast her after with. the ymage; and hesayd, "The deuyll satisfye you, for I dyd it for the beste. But I shall neuer more medyll, but I shall let the women do theyr wyll." And fro thenseforthe began Virgilius to hate his wyfe.

\section{Howe Virgilius went to the Sodans daughter.}

Often tymes herde Virgilius tell of the fayrnes of the Sodans dawghter, insomuche that he was enamoured of hyr, thoughe he. neuer sawe hyr ; than by his connynge made he a brygge in the: 
ayer, and went ouer to hyr, and when he had spoke with hyr, and showed hyr his mynde, than she consented to hym, notwithstandyng she neuer sawe hym afore.

And she sayde on a time that she wolde departe with hym into his countre, and knowe what maner a man he were, and what dwellyng he had. Than answered Virgilius, and sayde to hyr : "What wyll $\mathrm{I}^{\circ}$ doo: but, ye shall passe ouer many landes, and you shall not trede in them.", Than caryed he hyr ouer into his owne lande, ouer the brygge that he had made in the ayer, and so browght hyr to Rome; and when he was at home, he asked hyr "If she sawe no body?" and she said, "No, but hym alone."

And thanne showed Virgilius to hyr hys palayce and orchard, and the metall men, that stode styll a pece smytynge : and he shewed to hyr also all his treasur, and he presented it to hyr; and she wolde nat reseyue it, sayinge, "That she had to muche of hyr faders to kepe." And Virgilius helde her in his orcherde as longe as it please hym. And as the Soudan founde nat is dawghter he was sorofull, for because he woste nat where she was become. And they sowght all about, but in no place culde theye fynde hyr.

\section{Howe Virgilius brought agene the Sodans daughter into hyr faders} lande, and howe he founde hyr slepynge vpon hyr bedde.

When the Sodans dawghter had byd longe with Virgilius in his orcharde, than desyred she to goo home to hyr faders lande. And than toke Virgilius the Sodans dawghter in his hannes, and caste hyr vpon the brygge in the ayer, and he his selfe brought hyr to hyr faders palayce, and put hyr in hyr chamber vpon hyr bed; and than he betoke hyr to the goddes, and so returned he home to his place towarde Rome.

And in the begynnynge of the day arose the Sodan that was sore vexed for the lesynge of his dawghter; and than cam one of hyr chamberlaynes to the Emperoure, and tolde hym howe his dawghter was come ageyne, and lay" vpon hyr bed and slepte. 
Than cam he to hyr hastely and asked hyr where she had bene, and howe she was come there ageyne?

"Fader," sayd she, "there was a fayre man of a straunge land, and he brought me thorowgh the ayer to his paleyce and orcharde; but I haue nat spoke to man nor woman but to hym alone, and I knowe nat what lande it is."

The Sodan answered and sayde to hyr, "That she shulde brynge some of the frute of that cuntrey with hyr:" and she sayde she wolde.

And within a wyle came Virgilius to Babylone, and toke the Sodans daughter with hym ageyne, and so departed ageyne to his cuntrey with hyr, and kepte hir longe as pleased hym; and when she departed ageyne she toke with hir walnottes and other frute.

And when she was come home she shewed her father the walnuttes and other frutes of the lande. " $\mathrm{Ha}$, ha," sayde he, "it is on the syde of France that so often (he) hath borne you away."

\section{Howe Virgilius was taken there.}

THE Sodan cam upon a tyme to his dawter and sayde; " $\mathrm{My}$ daughter, when he commethe agene to you that was wonte to careye you awaye, gyue to hym this drynke that I shall gyue to you, but drynke ye none thereof, I warne you : for when he hath drunkyn thereof he shall slepe, and when he is a slepe let me know therof: than shall we take hym, and know fro whens he is."

And the lady dyd as she was commaunded. And whan Virgilius was com, she gaue hym to drynke of the drynke that hir fader gaue hyr: and when he had drunke, he slepte, and so was taken.

Than was Virgilius brought to the Sodan, and the lordes, and also the dawter of the Sodan. And than the Sodan showed his knyghtes that that was the man that had stolen his dawghter away: and than he sayd to Virgilius: "Ye be welcome; for your pleasure that ye haue had, ye shall suffer dethe."

Than answered Virgilius to the Sodan: "I wolde that I had 
neuer sene hir, and if that ye wyll let me gowe I shall neuer come ageyne :"

Than answered the Sodan and the lordes: "That shall we nat do ; but for youre myssedede ye shall suffer a shamefull dethe."

Than answered the Sodans dawghter, "Yf ye put hym to deth I shall suffer deth with hym."

Than answered the Sodan: "Therto I consente, for ye shall be burned with hym."

Than answered Virgilius, "That shall you nat do, with all the strength and myght that ye can do, thoughe' ye be of so great power."

Hone Virgilius cami out and led zeith hym the fayer lady the Sodans . daughter, and how he founded the towne of Naples.

WhaN Virgilius harde of this, he made with his cunnynge than the Sodan and all his lordes (thynk) that the great ryuer of Babylon was in the myddell among them ranne, and that they swemed, and laye, and spronge lyke duckes. And thus toke Virgilius with hym the fayre lady upon the brygge in the ayer. And when they were bothe upon the brygge, he delyuered the Sodan fro the ryuere, and all the lordes. And than they sawe Virgilius caray awaye his dawghter ouer the see upon a brygge in the ayer, wher of he merueyled and was very sorye, and wyste nat what to do, for he culde nat remedy it. And in this maner dyd he conuey the Sodans dawghter ouer the see to Rome.

And Virgilius was sore enamored of that lady. Than he thought in hys mynde, howe he myght mareye hyr, and thoughte in his mynde to founde in the myddes of the see a fayer towne with great landes belongyng to it ; and so he dyd by his cunnynge, and called it Napells. And the fundacyon of it was of egges. And in that towne of Napells he made a tower with iiij corners, and in the toppe he set a napyll upon a yron yarde, and no man culde pull away that apell without he brake it : and thorowghe that yron set he a botel, and on that botel set he a egge; and he henge the apell by the stauke upon a cheyne, and so hangyth it styll. 
And whenne the egge styrreth so shulde the towne of Napels quake, and whan the egge brake than shulde the towne synke. When he had made an ende he lette call it Napels.

And in this towne he layde a part of his treasur that he had, therin: and also set therin his louer, the fayer lady the Sodans dawghter: and he gaue to her the towne of Napels and all the landes therto belongynge, to hir use and hyr chyldren. And within short whyle after, he maryed her to a sertayne lorde or knyght of Spayn.

Within shorte wyle after, it fortuned that the Emperour had a great fantasy to the towne of Napells, for it bare the name in the tyme for one of the fayrest in the world: and it lay also in the fayrest market place aboute Rome. Than secretly sende the Emperour letters to all his lordes that were under hym, that they shoulde, as shortely as they myght, rayse theyr folke, and to come to Rome for to besege the towne of Napels. And so they dyd, insomuche that they assembled a great companye, and wente towarde the towne of Napels and destroyed all afore hym. And when he was come to Napels he beseiged it. And the knyght that maryed the lady that was within Napels defended the towne nobely ageynste the Emperoure and all his hoste. And in the meane wyle sente this knyght a messengere to Virgilius, whiche tolde hym all howe the Emperour beseged the towne of Napels: wherwith Virgilius was angery, and sent worde that the knyght shulde nat set be hym nat all his hoste, for I shall prouyde well a nough for you: and so departed the messenger to Napels.

\section{Howe the Emperour beseged the towne of Napels.}

AND when Virgilius knewe that the Emperour beseged Napels, than made he all the fresshe water to be lyke rayne, in suche maner that the Emperours folke had neuer a drop of water and they of Napels had a noughe; and in the meane season reysed Virgilius his hoste, and cam towarde the Emperoure to Napels. But the Emperour myght no lenger taray, for the horse and men dyed for faute of water, and so he loste a great parte of theym. 
Than the Emperoure seynge this, departed home ageyn to the cytie of Rome, all eschamed and dyscumfyt ; and as he returned homewarde, in the waye, he met with Virgilius comynge with all his companye towarde Napels.

And when Virgilius sawe the Emperoure, he cam to hym, and salued hym in this manere: "O noble Emperoure, howe fortuned this to you, that be so nooble a prynce as you be, to gyue up the seage of Napels, and to returne home agene to the cytie of Rome, all dyscumfit, without doynge any harme at all so schortly?"

Than wyste the Emperoure well that Virgilius mocked hym, and he was therwith very angery.

And than went Virgilius to Napeis, and he caused the lordes of the towne to make a othe that they shulde beyre no Romans within the forsayde towne.

\section{Hone Virgilius dyd strengthe the towne of Napels with scholers and merchauntes.}

As Virgilius reseyued the othes of the lordes of Napels than returned he ageyne to Rome, and feched his bokes and other mouable goodes, and browght it to Napels, and let his good a lone that he had shet in the seller. And his dwellynge he gaue to his frendes to kepe, and his dwellynge places, and so departed to Napels. There he made a schole and gaue therto much landes, that euery scholer a bydynge and gowyng to schole had lande to lyue on of the towne; and they that gaue up the schole they loste the lande: and there cam many fro Tuleten to schole. And when he had ordeyned the towne well with scholers, than made he a warme bath that euery man myght bathe hym in that wolde; and that bathe is there to this tyme, and it was the fyrste bathe that euer was. And after this made he a brygge the fayrest that euer man sawe, and there myght men se all maner of fayer shyppes that belonged to merchaunsedyse, and all other thynges of the see. And the towne in those days was the fayrest and noblest in all the worlde. And in this schole aforesayde dyde Virgilius rede the great conynge 
and scyaunce of egromancy, for he was the conyngest that euer was a fore, or after, in that scyence. And within schorte space his wyfe dyed, and she had neuer no chyldren by hym. And moreouver aboue all men he loued scholers, and gave much moneye to bye bokes with all. And thus he ruled them ryght nobely, for he myght do it ryght well, for he was one of the greatest borne men of all the world, and had beene the greateste lorde of all Rome.

\section{Howe Virgilius made in Rome a metall serpente.}

THAN made Virgilius at Rome a metall serpente with his cunnynge, that who so euer put his hande in the throte of the serpente, was to swere his cause ryght and trewe; and if hys cause were false he shulde nat plucke his hande out a geyne: and if it were trewe they shulde plucke it out a geyne without any harme doynge. So it fortuned that there was a knyght of Lumbardye that mystrusted lis wyfe with one of his men that was moost set by in the conseyte of his wyfe: but she excused hyr selfe ryght noblye and wysely. And she consented to goo with hym to Rome to that serpent, and there to take hyr othe that she was not gylty of that, that he put apon hyr. And therto consented the knyght.

And as they were bothe in the carte, and also hyr man with hyr, she sayd to the man; that when he cam to Rome, that he shulde clothe hym with a foles-cote, and dysgyse hym in suche maner that they shulde nat knowe hym, and so dyd he. And when the day was come that he shulde come to the serpent, he was there present.

And Virgilius knewe the falsenes of the woman by his cunnynge of egromancy. Than sayd Virgilius to the woman: "With drawe your othe and swere nat."

But she wolde nat do after hym, but put hyr hande into the serpentes mouthe. And when hyr hande was in, she sware before hyr husbande that she had no more to do with hym than with that fole, that stode hyr by ; and by cause that she sayd trowthe 
she pulled out hyr hande a geyne out of the throte of the serpent nat hurt. And than departed the knyght home and trusted hyr well euer after.

And Virgilius hauyng therat great spyte and anger that the woman had so escaped, destroyed the serpent: for thus scaped the lady a waye fro that great daunger. And then spake Virgilius, and sayde: that the women be ryght wyse to enmagen ungracyousenes, but in goodness they be but innocentes.

\section{Howe Virgilius dyed.}

Thus as Virgilius in his life had done many maruylous and sotyll thynges, and also had promysed to the Emperour many other dyuerse thynges and meruylouse: for he promysed to make the trees and spyces to bere frute thre tymes in a yere: and euery tree shulde haue rype frute and also blossomes at one tyme thereon growynge: also he shulde maken the shyppes for to sayle a geynste the streme as with the streme at all tymes; and he wolde haue made the peny to be as lyghtely gat as spente. And these thynges afore sayde promysed Virgilius to the Emperour for to do, and many other dyuerse thynges that were to longe for to reherse here, if that it fortuned hym nat to dye in the mene wyle.

And after this made Virgilius a goodly castell that hadde but one goying in thereto, and no man myght nat enter in therto, but at the one gate, or els nat. And also aboute the same castell flowed there a water and it was unpossyble for any man there to haue anye enterynge. And this castell stode without the cytie of Rome and this enteringe of this gate was made with xxiiij yron flayles, and on euery syde was there xij men on eche syde, styll a pece smytynge with the flayles neuer seasynge, the oon after the other; and no man myght cum in, without the flayles stood styll, but he was slayne. And these flayles was made with such a gyn that Virgilius stopped them when he lyst to enter in therat, but no man els culde fynde the way. And in this castell put Virgilius parte of his treasure ther in pryuyly; and when this was done he imagyned in his mynde by what meane he myght make his selfe 
yonge ageyn, bycause he thought to lyve longer many yeres, to do manye wonders and marueylouse thynges.

And vpon a tyme went Virgilius to the Emperoure, and asked hym, of lycence by the space of iij wekes. But the Emperoure in no wyse wold graunte unto hym, for he wold haue Virgilius at all tymes by hym.

Than harde he that Virgilius went to his house and toke with hym one of his men that he aboue all men trusted, and knewe well that he wolde best kepe his counsayll; and they departed to his castell that was without the towne, and when they, were afore the castell there sawe the man men stande with yron flayles in theyr handes sore smytyng.

Than sayd Virgilius to his man: "Enter you fyrste into the castell."

Than answered the man and sayd, "If I shulde enter the flayles wolde slee me."

Than shewed Virgilius to the man of eche syde the enterynge in and all the vyces that therto belonged; and when he had shewed hym all the wayes, he made sease the flayles and went into the castell. And when they were bothe in, Virgilius turned the vyces ageyne, and so went the yron flayles as they dyd a fore.

Then sayde Virgilius, "My dere beloued frende, and he that I above all men truste, and knowe moost of my secret;" and than led he the man into the seller where he had made a fayer lampe at all seasons burnynge. And than sayd Virgilius to the man: "Se you the barell that standeth here?" and he sayde, "ye there muste put me. Fyrst ye muste slee me, and hewe smalle to peces, and cut my head in iiij peces, and salte the heed under in the bottum, and then the peces there after, and my herte in the myddel, and then set the barell under the lampe, that nyght and daye therin may droppe and leke: and ye shall ix dayes longe, ones in the daye fyll the lampe, and fayle nat. And when this is all done, than shall I be renued and made yonge ageyn, and lyue longe tyme and maney wynters mo, if that it fortune me nat to be taken of a boue and dye."

And when the man harde his master Virgilius speke thus, he 
was sore abasshed, and sayd : "That will I neuer whyle I lyue, for in no maner wyll I slee you."

And then sayd Virgilius: "Ye at this tyme must do it, for it shall be no grefe unto you."

And at the last Virgilius treated his:man so muche, that he consented to hym: and then toke the seruant Virgilius, and slewe hym, and when he was thus slayn, he hewe hym in peces and salted hym in the barell, and cut his heed in iiij. peces as his master bad hym, and than put the herte in the myddell and salted them wele: and when all this was done, he hynge the lampe ryght ouer the barell, that it myght at all tymes droppe in therto. And when he had done all this, he went out of the castell and turned the vyces, and then went the coper men smyghtynge with their flayles so strongly upon the yron anueldes as they dyd afore, that there durst no man enter: and he came euery day to the castell and fylled the lampe, as Virgilius had bad hym.

And as the Emperoure myssed Virgilius by the space of seuen dayes, he merueyled greatly where he shulde be by come; but Virgilius was kylled and layed in the seller by his seruaunte that he loued so well.

And than the Emperour thought in his mynde to ask Virgilius seruaunte, where Virgilius his master was : and so he dyd, for he knewe well that Virgilius loued hym above all men in the worlde. Than answered the seruaunte to the Emperoure, and sayde, "Worschypfull lorde, and it please your grace I wot nat where he is, for it is seuen dayes past that I sawe hym laste; and than wente he forthe I cannot tell whyther, for he wulde nat let me goo with hym."

Than was the Emperoure angery with that answere, and sayd: "Thou lyest falce thefe that thou art; but without thou showe me shortly where he is, I shall put the to dethe."

With those wordes was the man abashed, and sayde: "Worshypfull lorde, seuen dayes a goo I went with hym without the towne to the castell, and there he went in, and there I left hym, for he wold nat let me in with hym."

Then sayd the Emperour, "Goo with me to the same castell?" 
and so he dyd; and whan they cam a fore the castell and wolde haue entered, they myght nat, bycause flayles smyt so faste.

Than sayde the Emperoure: "Make pease this flayles, that we may cum in."

Than answered the man : "I knowe nat the way."

Than sayd the Emperour, "Than shalt thou dye;" and than thorowgh the fere of dethe he turned the vyce and made the flayles stande styl, and then the Emperoure entered into the castell with all his folke, and soughte al a bout in euery corner after Virgilius; and at the laste they sowghte so longe that they cam into the seller where they sawe the lampe hang ouer the barell, where Virgilius lay in deed. Than asked the Emperoure the man : "Who had made hym so herdey to put his mayster Virgilius to dethe?" And the man answered no worde to the Emperoure. And than the Emperour, with great anger, drewe out his swerde, and slewe he there Virgilius man.

And when all this was done, than sawe the Emperoure and all folke a naked chylde, iij. tymes rennynge a boute the barell, saynge the wordes: "cursed be the tyme that ye cam euer here;" and with those wordes vanyshed the chylde away, and was neuer sene a geyne: and thus abyd Virgilius in the barell, deed.

Then was the Emperour very heuy for the dethe of Virgilius, and also all Virgilius kynred, and also all the scholers that dwelled aboute the towne of Napels, and in especyall all the towne of Napels, for by cause that Virgilius was the founder therof, and made it of great worshypp. Than thought the Emperoure to haue the good and ryches of Virgilius, but there were none so harday that durste cum in to fetche it, for fere of the coper men, that smote so faste with theyr yron flayles: and so abyd Virgilius treasure in the seller. And Virgilius dyd many other merueylouse thynges that in this boke is not wryten. And thus (God) gyue us grace that we may be in the boke of euer lastynge blysse. Amen.

Thus endethe the lyfe of Virgilius with many dyuers consaytes that he dyd. Emprynted in the cytie of Anwarpe By me Johnn Doesborcke dwellynge at the camer porte. 


\section{THE HISTORY OF HAMLET}

PRINCE OF DENMARK. 

IV.

\section{THE HISTORY OF HAMLET}

PRINCE OF DENMARK.

\section{CHAPTER I.}

How Horvendile and Fengon were made Governors of the Province of Ditmarsh, and how Horvendile married Geruth, the daughter to Roderick, chief $K$. of Denmark: by whom he had Hamlet: and how after his marriage his brother Fengon slew him traitorously, and married his brother's wife, and what followed.

2ुou $\mathfrak{m u s t} \mathfrak{u n d e x s f a n d , ~ t h a t ~ l o n g ~ t i m e ~ b e f o r e ~ t h e ~ K i n g d o m ~ o f ~}$ Denmark received the faith of Jesus Christ, and embraced the doctrine of the Christians, that the common people in those days were barbarous and uncivil, and their Princes cruel, without faith or loyalty. They sought nothing but murder, and deposing or (at the least) offending each other; either in honours, goods, or lives; not caring to ransom such 'as they took prisoners, but rather sacrificing them to the cruel vengeance, naturally imprinted in their hearts. They lived in such sort, that if they were sometimes a good prince, or king among them, who being adorned with the most perfect gifts of nature, would addict himself to virtue, and use courtesy, although the people held him in admiration (as virtue is admirable to the most wicked), yet the envy of his neighbours was so great, that they never ceased until that virtuous man were dispatched out of the world;

$\checkmark$ King. Roderick, as then reigning in Denmark, after he had 
appeased the troubles in the country, and driven the Sweathlanders and Slaveans from thence, he divided the kingdom into divers Provinces, placing Governors therein. Such Governors after (as the like happened in France) bare the names of Dukes, Marquises, and Earls, giving the government of Jutie (at this present called Ditmarsh) lying upon the country of Cimbrians, in the straight or narrow part of land, that sheweth like a point or cape of ground upon the sea, which neithward bordereth upon the country of Norway.

The governors appointed by King Roderick were two valiant and warlike Lords, Horvendile and Fegon, sons to Gervendile, who likewise had been governor of that Province.

Now the greatest honour that men of noble birth could at that time win and obtain, was in exercising the art of piracy upon the seas; assailing their neighbours, and the countries bordering upon them : and how much the more they used to rob, pill, and spoil other Provinces, and Islands far adjacent, so much the more their honours and reputation increased and augmented. Herein Horvendile obtained the highest place in his time, being the most renowned pirate that in those days scoured the seas, and havens of the North parts. His great fame, so moved the heart of Collere, King of Norway, that he was much grieved to hear that Horvendile surmounted him in feats of arms, thereby obscuring the glory by him already obtained upon the seas. Honour more than covetousness of riches, was (in those days) the reason that provoked those barbarian princes, to overthrow and vanquish one the other; not caring to be slain by the hands of a victorious person. This valiant and hardy king, having challenged Horvendile to fight with him body to body, the combat was by him accepted, with conditions, that he which should be vanquished, should lose all the riches he had in his ship, and that the vanquisher should cause the body of the vanquished, that should be slain in the combat, to be honourably buried, death being the prize and reward of him that should lose the battle.

Collere, King of Norway, although a valiant, hardy, and courageous prince, was in the end vanquished and slain by 
Horvendile: who presently caused a tomb to be erected, and therein, with all honourable obsequies fit for a prince, buried the body of King Collere, according to their ancient manner, and superstitions in those days. The conditions of the combat were fulfilled, bereaving the King's ships of all their riches; and having slain the King's sister, a very brave and valiant warrior, and overrun all the coast of Norway, and the Northern Islands, Horvendile returned home again laden with much treasure. $\mathrm{He}$ sent the most part thereof to his sovereign, King Roderick, thereby to procure his good liking, and so to be accounted one of the greatest favourites about his majesty.

The King, allured by those presents, and esteeming himself. happy to have so valiant a subject, sought by a great favour and courtesy, to make him become bounden unto him perpetually, giving him Geruth his daughter to his wife, of whom he knew Horvendile to be already much enamoured. The more to honour him, King Roderick determined himself in person to conduct his daughter Geruth into Jutie, where the marriage was celebrated according to the ancient manner. Of this marriage proceeded Hamlet, of whom I intend to speak.

Fengon, brother to this Prince Horvendile, fretting and despiteing in his heart at the great honour and reputation won by his brother in warlike affairs, was solicited and provoked by a foolish jealousy to see him honoured with royal alliance. He feared thereby to be deposed from his part of the government : or rather desiring to be only governor, thereby to obscure the memory of the victories and conquests of his brother Horvendile, determined whatsoever happened to kill him. This he did in such sort, that no man once so much as suspected him, every man esteeming that from such and so firm a knot of alliance and consanguinity, there could proceed no other issue than the full effects of virtue and courtesy. But as I said before, the desire of bearing sovereign rule and authority, respecteth neither blood nor amity, nor careth for virtue as being wholly without respect of laws, or majesty divine: for it is not possible that he which invadeth the country and taketh away the riches of another man 
without cause or reason, should know, or fear God. Was not this a crafty and subtle counsellor? but he might have thought that the mother, knowing her husband's case, would not cast her son into the danger of death.

Fengon, having secretly assembled certain men, and perceiving himself strong enough to execute his enterprise, Horvendile his. brother being at a banquet. with his friends, suddenly set upon him, where he slew him as traitorously, as cunningly he purged himself of so detestable a murder to his subjects. Before he had any bloody or violent hands, or once committed parricide upon his brother, he had incestuously abused his wife, whose honour he ought as well to have sought and procured, as traitorously he pursued and effected his destruction. And it is most certain, that the man that abandoneth himself to any notorious and wicked action, whereby he becometh a great sinner, he careth not to commit much more heinous and abominable offences.

Fengon covered his boldness and wicked practice with so great subtilty and policy, and under a veil of mere simplicity, that he was favoured for the honest love that he bare to his sister-in-law, for whose sake he affirmed he had in that sort murdered his brother, so that his sin found excuse among the common people, and of the nobility was esteemed for justice.

For Geruth being as courteous a Princess as any then living in the North parts, and one that had never once so much as offended any of her subjects, either commons or courtiers, this adulterer and infamous murderer slandered his dead brother, that he would have slain his wife, and that he by chance finding him upon the point ready to do it, in defence of the lady had slain him, bearing off the blows which as then he struck at the innocent Princess, without any other cause of malice whatsoever. Herein he wanted no false witnesses to approve his act, which deposed in like sort as the wicked calumniator himself protested, being the same persons that had borne him company and were participants of his treason. Instead of pursuing him as a parricide and an incestuous person, all the courtiers admired and flattered him in his good fortune : making 
more account of false witnesses and detestable wicked reporters, and more honouring the calumniators, than they esteemed of those that sought to call the matter in question, and admiring the virtues of the murdered Prince, would have punished the massacrers and bereavers of his life. This was the cause that Fengon, emboldened and encouraged by such impunity, durst venture to couple himself in marriage with her whom he used as his concubine during good Horvendile's life, in that sort spotting his name with a double vice, and charging his conscience with abominable guilt and twofold impiety. The unfortunate and wicked woman, that had received the honour to be the wife of one of the valiantest and wisest Princes in the North, abased herself in such vile sort, as to falsify her faith unto him, and which is worse, to marry him that had been the tyrannous murderer of her lawful husband: winich made divers men think that she had been the causer of the murder, thereby to live in her adultery without control. But where shall a man find a more wicked and bold woman than a great personage once having loosed the bands of honour and honesty? This Princess, who at the first, for her rare virtues and courtesies, was honoured of all men, and beloved of her husband, as soon as she once gave ear to the tyrant Fengon, forgot both the rank she held among the greatest dames, and the duty of an honest wife on her behalf.

But I will not stand to gaze and marvel at women : for that there are many which seek to blaze and set them forth : in which their writings, they spare not to blame them all for the faults of some one or few women. But I say that either nature ought to have bereaved men of that opinion to accompany with women, or else to endow them with spirits as that they may easily support the crosses they endure, without complaining so often and so strangely, seeing it is their own beastliness that overthrows them. For if it be so, that a woman is so imperfect a creature as they make her to be : and that they know this beast to be so hard to be tamed as they affirm : why then are they so foolish to preserve them, and so dull and brutish as to trust their deceitful and wanton embracings. But let us leave her in this extremity of 
lasciviousness, and proceed to show you, in what sort the young Prince Hamlet behaved himself, to escape the tyranny of his uncle.

\section{CHAPTER II.}

How Hamlet counterfeited the madman, to escape the tyranny of his uncle, and how he was tempted by a woman (through his uncle's procurement), who thereby thought to undermine the Prince, and by that means to find out whether he counterfeited madness or not: and how Hamlet would by no means be brought to consent unto her; and what followed.

GERUTH having, as I said before, so much forgotten herself, the Prince Hamlet perceived himself to be in danger of his life, as being abandoned of his own mother, and forsaken of all men. Assuring himself that Fengon would not detract the time to send him the same way his father Horvendile was gone, to beguile the tyrant in his subtleties (that esteemed him to be of such a mind, that if he once attained to man's estate, he would not long delay the time to revenge the death of his father) he counterfeited the madman with such craft and subtle practices that he made shew as if he had utterly lost his wits. Under that veil he covered his pretence, and defended his life from the treasons and practices of the tyrant his uncle. And although he had been at the school of the Roman Prince, who because he counterfeited himself to be a fool, was called Brutus, yet he imitated his fashions and his wisdom. For every day being in the Queen's Palace (who as then was more careful to please Fengon, than ready to revenge the cruel death of her husband, or to restore her son to his inheritance) he rent and tore his clothes, wallowing and lying in the dirt and mire, his face all filthy and black; he ran through the streets like a man distraught, not speaking one word, but such as seemed to proceed from madness and mere frenzy. All his actions and gestures were no other than the right countenances of a man wholly deprived of all reason and understanding: in such sort that as then he seemed fit for nothing but to make 
sport to the pages and ruffling courtiers that attended in the court of his uncle and father-in-law. But the young Prince noteri them well enough, minding one day to be revenged in such manner that the memory thereof should remain perpetually to the world.

Behold, I pray you, a great point of a wise and brave spirit in a young Prince, by so great a show of imperfection in his person for advancement, and his own embasing and despising, to work the means and prepare the way for himself to be one of the happiest kings in his age. In like sort, never any man was reputed by any of his actions more wise and prudent than Brutus, dissembling a great alteration in his mind, for that the occasion of such his device of foolishness proceeded only of a good and mature counsel and deliberation; not only to preserve his goods and shun the rage of the proud tyrant, but also to open a large way to procure the banishment and utter ruin of wicked Tarquinius, and to enfranchise the people (which were before oppressed) from the yoke of a great and miserable servitude. And so did not only Brutus, but this man and worthy Prince, to. whom we may also add King David, that counterfeited the madman among the petty kings of Palestina, to preserve his life from the subtle practices of those kings. I show this example unto such as, being offended with any great personage, have not sufficient means to prevail in their intents, or revenge the injury by them received. But when I speak of revenging any injury received upon a great personage or superior, it must be understood by such an one as is not our sovereign, against whom we may by no means resist, nor once practise any treason nor conspiracy against his life. He that will follow this course, must speak and do all things whatsoever that are pleasing and acceptable to him whom he meaneth to deceive, practise his actions, and esteem him above all men, clean contrary to his own intent and meaning. For that is rightly to play and counterfeit the fool, when a man is constrained to dissemble, and kiss his hand, whom in his heart he could wish an hundred foot deep under the earth, so he might never see him more, if it were not a thing 
wholly to be disliked in a Christian, who by no means ought to have a bitter gall, or desires infected by revenge.

Ham et in this sort counterieiting the madman, many times did divers actions of great and deep consideration, and often made such and so fit answers, that a wise man would have judged from what spirit so fine an invention might proceed. Standing by the fire and sharpening sticks like poinards and pricks, one in smiling manner asked him wherefore he made those little staves so sharp at the points. "I prepare," saith he, "piercing darts, and sharp arrows to revenge my father's death." Fools, as I said before, esteemed those his words as nothing; but men of quick spirits, and such as had a deeper reach, began to suspect somewhat, esteeming that under that kind of folly there lay hidden a great and rare subtlety such as one day might be prejudicial to their prince. They said that under colour of such rudeness he shadowed a crafty policy, and by his devised simplicity, he concealed a sharp and pregnant spirit; for which cause they counselled the King to try and know, if it were possible, how to discover the intent and meaning of the young Prince.

But they could find no better, nor more fit invention to entrap him, than to set some fair and beautiful woman in a secret place, that with flattering speeches and all the craftiest means she could use, should purposely seek to allure his mind. To this end certain courtiers were appointed to lead Hamlet into a solitary place within the woods, whither they brought the woman. And surely the poor Prince at this assault had been in great danger, if a gentleman that in Horvendile's time had been nourished with him had not shown himself more affectioned to the bringing up he had received with Hamlet, than desirous to please the Tyrant, who by all means sought to entangle the son in the same nets wherein the father had ended his days. This gentleman bare the courtiers, appointed as aforesaid of this treason, company; more desiring to give the Prince instructions what he should do than to entrap him. He made full account that the least show of perfect sense and wisdom that Hanlet should make would be sufficient to cause him to lose his life: and therefore by certain signs, he 
gave Hamlet intelligence in what danger he was like to fall if by any means he seemed to obey. This much abashed the Prince, as then wholly being in affection to the Lady. But by her he was likewise informed of the treason, as being one that from her infancy loved and favoured him, and would have been exceeding sorrowful for his misfortune, whom she loved more than herself. The Prince in this sort having both deceived the courtiers and the lady's expectation, every mar thereupon assured themselves that without all doubt he was distraught of his senses; that his brains were as then wholly void of force, and incapable of reasonable apprehension, so that as then Fengon's practice took no effect. But for all that he left not off: still seeking by all means to find out Hamlet's subtilty, as in-the next chapter you shall perceive.

\section{CHAPTER III.}

How Fengon, uncle to Hamlet, a second time to entrap him in his politic madness, caused one of his counsellors to be secretly hidden in the Queen's chamber, behind the arras, to hear what speeches passed between Hamlet and the Queen, and how Hamlet killed him and escaped that danger, and what followed.

Among the friends of Fengon, there was one that above all the rest, doubted of Hamlet's practises, in counterfeiting the madman. He for that cause said, that it was impossible that so crafty a gallant as Hamlet that counterfeited the fool, should be discovered with so common and unskilful practices, which might easily be perceived, and that to find out his politic pretence it were necessary to invent some subtle and crafty means, more attractive, whereby the gallant might not have the leisure to use his accustomed dissimulation. To effect this he said he knew a fit way and a most convenient mean to effect the King's desire, and thereby to entrap Hamlet in his subtilties, and cause him of his own accord to fall into the net prepared for him, and thereby evidently show his secret meaning.

His device was thus, that King Fengon should make as though 
he were to go some long voyage, concerning affairs of great importance, and that in the meantime Hamlet should be shut up alone in a chamber with his mother. Wherein some other should secretly be hidden behind the hangings, unknown either to him or his mother, there to stand and hear their speeches, and the complots by them to be taken, concerning the accomplishments of the dissembling fool's pretence. He assured the King that if there were any point of wisdom and perfect sense in the gallant's spirit, that without all doubt he would easily discover it to his mother, as being devoid of all fear that she would utter or make known his secret intent, being the woman that had borne him in her body, and nourished him so carefully. He withal offered himself to be the man that should stand to hearken, and bear witness of Hamlet's speeches with his mother; that he might not be esteemed a counsellor in such a case wherein he refused to be the executioner, for the behoof and service of his Prince.

This invention pleased the King exceeding well. He esteemed it as the only and sovereign remedy to heal the Prince of his lunacy, and to that end making a long voyage, issued out of his palace, and rode to hunt in the forest. Meantime the counsellor entered secretly into the Queen's chamber, and there hid himself behind the arras, not long before the Queen and Hamlet came thither. Hamlet being crafty and politic, as soon as he was within the chamber, doubting some treason, and fearing if he should speak severely and wisely to his mother touching his secret practices he should be understood, and by that means intercepted, used his ordinary manner of dissimulation. He began to come like a cock beating with his arms in such manner as cocks use to strike with their wings, upon the hangings of the chamber, whereby, feeling something stirring under them, he cried, "A rat, a rat," and presently drawing his sword thrust it into the hangings. This done, he pulled the counsellor, half dead, out by the heels, made an end of killing him, and being slain, cut his body in pieces, which he caused to be boiled and then cast it into an open vault, that so it might serve for food to the hogs.

By this means, having discovered the ambush, and given the 
inventor thereof his just reward, he came again to his mother, who in the meantime wept and tormented herself, to see all her hopes frustrate, for that, what fault soever she had committed, yet was she sore grieved to see her only child made a mere mockery, every man reproaching her with his folly. One point thereof she had as then seen before her eyes, which was no small prick to her conscience, esteeming that the Gods sent her that punishment for joining incestuously in marriage with the tyrannous murderer of her husband. He likewise ceased not to invent all the means he could, to bring his nephew to his end, accusing his own natural indiscretion, as being the ordinary guide of those that so much desire the pleasures of the body, who shutting up the way to all reason respect not what may ensue of their lightness and great inconstancy. For a pleasure of small moment is sufficient to give them cause of repentance, during their lives, and make them curse the day and time that ever any such apprehensions entered into their minds, or that they closed their eyes to reject the honesty requisite in Ladies of her quality, and to despise the holy institution of those dames that had gone before her both in nobility and virtue. Geruth called to mind the great praises and commendations given by the Danes to Rinde, daughter to King Rothere, the chastest Lady in her time, and withal so shamefast that she would never consent to marriage with any prince or knight whatsoever; surpassing in virtue all the ladies of her time, as she herself surmounted them in beauty, good behaviour, and comeliness.

While in this sort the Queen sat tormenting herself, Hamlet entered into the chamber, who having once again searched ever: corner of the same, distrusting his mother as well as the rest, and perceiving himself to be alone, began in sober and discreet manner to speak unto her saying,-

"What treason is this, O most infamous woman, of all that ever prostrated themselves to the will of an abominable man, who under the veil of a dissembling creature covereth the most wicked and detestable crime that man could ever imagine, or was committed. How may I be assured to trust you, that like a vile wanton 
adulteress, altogether impudent and given over to her pleasure, runs spreading forth her arms joyfully to embrace the traitorous viilainous tyrant, that murdered my father, and most incestuously receivest the villain into the lawful bed of your loyal spouse, impudently entertaining him instead of the dear father of your miserable and discomforted son, if the gods grant him not the grace speedily to escape from a captivity so unworthy the degree he holdeth, and the race and noble family of his ancestors. Is this the part of a queen, and daughter to a king? to live like a brute beast, to follow the pleasure of an abominable king, that hath murdered a far more honester and better man than himseif in massacring Horvenciile, the honour and glory of the Danes, who are now esteemed of no force nor valour at all, since the shining splendour of knighthood, was brought to an end by the most wickedest, and cruelest villain living upon earth. I for my part will never account him for my kinsman, nor once know him for mine uncle, nor you my dear mother for not having respect to the blood that ought to have united us so straitly together, and who neither with your honour nor without suspicion of consent to the death of your husband could ever have agreed to have married with his cruel enemy. O Queen Geruth, it is licentiousness only that hath made you deface out of your mind the memory of the valour and virtues of the good King your husband and $\mathrm{my}$ father! It was an unbridled desire that guided the daughter of Roderick to embrace the Tyrant Fengon, and not to remember Horvendile, unworthy of so strange entertainment; neither that he killed his brother traitorously, and that she being his father's wife betrayed him, although he so well favoured and loved her, that for her sake he utterly bereaved Norway of her riches and valiant soldiers, to àgment the treasures of Roderick, and make Geruth wife to the hardiest prince in Europe. It is not the part of a woman, much less of a Princess, in whom all modesty, courtesy, compassion and love ought to abound, thus to leave her dear child to fortune in the bloody and murderous hands of a villain and traitor. Brute beasts do not so: for lions, tigers, ounces, and leopards fight for the safety and defence of their 
whelps; and birds that have beaks, claws, and wings, resist such as would ravish them of their young ones; but you to the contrary expose and deliver me to death, whereas ye should defend "me. Is not this as much as if you should betray me, when you, knowing the perverseness of the tyrant and his intents, full of deadly counsel as touching the race and image of his brother, have not once sought nor desired to find the means to save your child and only son by sending him into Swethland, Norway, or England, rather than to leave him as a prey to your infamous adulterer? Be not offended, I pray you, Madame, if transported with dolour and grief I speak so boldly unto you, and that I respect you less than duty requireth, for you having forgotten me, and wholly rejected the memory of the deceased King my father, must not be abashed if I also surpass the bounds and limits of due consideration. Behold into what distress I am now fallen, and to what mischief my fortune and your over great lightness, and want of wisdom have induced me, that I am constrained to play the madman to save my life, instead of using and practising arms, following adventures, and seeking all means to make myself known to be the true and undoubted heir of the valiant and virtuous King Horvendile. It was not without cause, and just occasion, that my gestures, countenances, and words seem all to proceed from a madman, and that $I$ desire to have all men esteem me wholly deprived of sense and reasonable understanding, because I am well assured, that he who hath made no conscience to kill his own brother (accustomed to murders, and allured with desire of government without control in his treasons) will not spare to save himself with the like cruelty, in the blood and flesh of the loins of his brother, by him massacred: and therefore, it is better for me to fain madness than to use my right senses as nature hath bestowed them upon me. The bright shining clearness thereof I am forced to hide under this shadow of dissimulation, as the sun doth her beams under some great cloud, when the weather in summer time overcasteth. The face of a madman serveth to cover my gallant countenance, and the gestures of a fool are fit for me, to the end that guiding myself 
wisely therein I may preserve my life for the Danes, and the memory of my late deceased father. For the desire of revenging his death is so engraven in my heart that if I die not shortly, I hope to take such and so great vengeance, that these countries shall for ever speak thereof. Nevertheless I must stay the time, means, and occasion; lest by making over great haste I be now the cause of mine own sudden ruin and overthrow, and by that means, end, before I begin to effect my heart's desire. He that hath to do with a wicked, disloyal, cruel, and discourteous man, must use craft, and politic inventions, such as a fine wit can best imagine, not to discover his enterprise: for seeing that by force I cannot effect my desire, reason alloweth me by dissinulation, subtilty, and secret practices to proceed therein. 'To conclude, weep not, Madame, to see my folly, but rather sigh and lament your own offence, tormenting your conscience in regard of the infamy that hath so defiled the ancient renown and glory that (in times past) honoured Queen Geruth : for we are not to sorrow and grieve at other men's vices, but for our own misdeeds, and great follys. I desire you, for the surplus of my proceedings, above all things, as you love your own life and weifare, that neither the King, nor any other, may by any means know mine intent, and let me alone with the rest, for I hope in the end to bring my purpose to effect."

Although the Queen perceived herself nearly touched, and that Hamlet moved her to the quick, where she felt herself interested, nevertheless she forgot all disdain and wrath, which thereby she might as then have had, hearing herself so sharply chidden and reproved, for the joy she then conceived, to behold the gallant spirit of her son, and to think what she might hope, and the easier expect, of his great policy and wisdom. But on the one side she durst not lift up her eyes to behold him, remembering her offence, and on the other side she would gladly have embraced her son, in regard of the wise admonitions by him given unto her. They quenched the flames of unbridled desire that before had moved her to affect King Fengon, and engrafted in her heart the virtuous actions of her lawful spouse, whom inwardly she much lamented, 
when she beheld the lively image and portraiture of his virtue and great wisdom in her child, representing his father's haughty and valiant heart. So overcome and vanquished with this honest passion, and weeping most bitterly, having long time fixed her eyes upon Hamlet, as being ravished into some great and deep contemplation, and as it were wholly amazed, at the last embracing him in her arms, with the like love that a virtuous mother may or can use, to kiss and entertain her own child, she spake unto him in this manner.

"I know well, my son, that I have done thee great wrong in marrying with Fengon, the cruel tyrant and murderer of thy father and my loyal spouse. But when thou shalt consider the small means of resistance, and the treason of the palace, with the little cause of confidence we are to expect or hope for of the courtiers, all wrought to his will, as also the power he made ready, if I should have refused to like of him, thou wouldst rather excuse, than accuse me of lasciviousness or inconstancy, much less offer me that wrong, to suspect that ever thy mother Geruth once consented to the death and murder of her husband. I swear unto thee by the majesty of the Gods that if it had lain in my power to resist the tyrant, although it had been with the loss of my blood, yea and my life, I would surely have saved the life of my Lord and husband with as good a will and desire, as since that time, I have often been a means to hinder and impeach ${ }^{1}$ the shortening of thy life, which being taken away, I will no longer live here upon earth : for seeing that thy senses are whole and sound, I am in hope to see an easy means invented for the revenging of thy father's death. Nevertheless, mine own sweet son, if thou hast pity of thyself, or care of the memory of thy father, although thou wilt do nothing for her that deserveth not the name of a mother in this respect, I pray thee carry thine affairs wisely; be not hasty, nor over furious in thy enterprises; neither yet advance thyself more than reason shall move thee to effect thy purpose. Thou seest there is almost no man wherein thou mayest put thy

1 Impeach, hinder; a sense in which the word was once frequently used, and the original sense. 
trust, nor any woman to whom I dare utter the least part of my secrets, that would not presently report it to thine adversary. $\mathrm{He}$, although in outward show he dissembleth to love thee, the better to enjoy his pleasures of me, yet he distrusteth and feareth me for thy sake, and is not so simple to be easily persuaded that thou art a fool or mad. If thou chance to do anything that seemeth to proceed of wisdom or policy, how secretly soever it be done, he will presently be informed thereof, and I am greatly afraid that the devils have showed him what hath past at this present between us-Fortune so much pursueth and contrarieth our ease and welfare-or that this murder that now thou hast committed, be not the cause of both our destructions, which I by no means will seem to know, but will keep secret both thy wisdom and hardy enterprise. I beseech the Gods, my good son, that they guide thy heart, direct thy counsels, and prosper thy enterprise, so that I may see thee possess and enjoy that which is thy right, and wear the crown of Denmark, by the Tyrant taken from thee. May I rejoice in thy prosperity, and therewith content myself, seeing with what courage and boldness thou shalt take vengeance upon the murderer of thy father, as also upon all those that have assisted. and favoured him in his murderous and bloody enterprise."

"Madame," said Hamlet, "I will put my trust in you, and from henceforth mean not to meddle further with your affairs, but beseech you, as you love your own flesh and blood, that you will from henceforth no more esteem of the adulterer mine enemy, whom I will surely kill, or cause to be put to death in despite of all the devils in hell. Have he never so many flattering courtiers to defend him, yet will I bring him to his death; and they themselves also shall bear him company therein, as they have been his perverse counsellors in the action of killing my father, and his companions in his treason, massacre, and cruel enterprise. Reason requireth, that even as traitorously they then caused their Prince to be put to death, that with the like, nay well much more justice they should pay the interest of their felonious actions.

"You know, Madame, how Hother your grandfather, and father to the good King Roderick, having vanquished Guimon, caused 
him to be burnt, for that the cruel villain had done the like to his lord Gevare, whom he betrayed in the night time. And who knoweth not that traitors and perjured persons deserve no faith nor loyalty to be observed towards them. Conditions made with murderers, ought to be esteemed as cobwebs, and accounted as if they were things never promised nor agreed upon. If I lay hands upon Fengon, it will neither be felony nor treason, he being neither my King nor my Lord; but I shall justly punish him as my subject, that hath disloyally behaved himself against his Lord and sovereign Prince. And seeing that glory is the reward of the virtuous, and the honour and praise of those that do service to their natural Prince, why should not blame and dishonour accompany Traitors, and ignominious death all those that dare be so bold as to lay violent hands upon sacred Kings, that are friends and companions of the gods, as representing their majesty and persons. To conclude, glory is the crown of virtue, and the price of constancy, and seeing that it never accompanieth with infelicity, but shunneth cowardice and spirits of base and traitorous conditions, it must necessarily follow, that either a glorious death will be mine end, or with my sword in hand, laden with triumph and victory, I shall bereave them of their lives that made mine unfortunate, and darkened the beams of that virtue which I possessed from the blood and famous memory of my Predecessors. For why should men desire to live, when shame and infamy are the executioners that torment their consciences. Villainy is the cause that withholieth the heart from valiant enterprises, and diverteth the mind from honest desire of glory and commendation, which endureth for ever? I know it is foolishly done to gather fruit before it is ripe, and to seek to enjoy a benent not knowing whether it belong to us of right: but I hope to effect it so well, and have so great confidence in my fortune that hitherto hath guided the action of my life, that I shall not die without revenging myself upon mine enemy, and that himself shall be the instrument of his own decay, and execute that which of myselt I durst not have enterprised."

After this Fengon, as if he had been out some long journey, 
came to the Court again and asked for him that had received the charge to play the intelligencer, to entrap Hamlet, in his dissembled wisdom. He was abashed to hear neither news nor tidings of him, and for that cause asked Hamlet what was become of him, naming the man. The Prince, that never used lying, and who in all the answers that ever he made during his counterfeit madness never strayed from the truth, as a generous mind is a mortal enemy to untruth, answered and said, that the counsellor he sought for was gone down through the privy; where, being choked by the filthiness of the place, the hogs meeting him had filled their bellies.

\section{CHAPTER IV.}

How Fengon the third time devised to send Hamlet to the King of England, with secret letters to have him put to death; and how' Hamlet, when his companions slept, read the Letters, and instead of them, counterfeited others, willing the King of England to put the two Messengers to death, and to marry his daughter to Hamlet, which was effected, and how Hamlet escaped out of England.

A MAN would have judged anything, rather than that Hamlet had committed that murder. Nevertheless Fengon could not content himself, but still his mind gave him, that the fool would play him some trick of legerdemain, and willing would have killed him. But he feared King Roderick, his father-in-law, and further durst not offend the Queen, mother to the fool, whom she loved and much cherished, showing great grief and heaviness to see him so transported out of his wits. And in that conceit, seeking to be rid of him, Fengon determined to find the means to do it by the aid of a stranger, making the King of England minister of his massacring resolution. He chose rather that his friend should defile his renown, with so great a wickedness, than himself to fall into perpetual infamy, by an exploit of so great crueity. 'To the King of England Fengon purposed to send 
Hamlet, and by letters desire the King of England to put Hamlet to death.

Hamlet understanding that he should be sent into England, presently doubted the occasion of his voyage. For that cause, speaking to the Queen, he desired her not to make any show of sorrow or grief for his departure, but rather counterfeit a gladness, as being rid of his presence, whom, although she loved, yet she daily grieved to see him in so pitiful estate, deprived of all sense and reason. He desired her further, that she should hang the hall with tapestry, and make it fast with nails upon the walls, and keep the brands for him which he had sharpened at the points then when as he said he made arrows to revenge the death of his father. Lastly, he counselled her, that the year after his departure being accomplished, she should celebrate his funerals: assuring her, that at the same instant, she should see him return with great contentment and pleasure unto her for that his voyage. Now to bear him company, were assigned two of Fengon's faithful ministers, bearing letters engraved in wood, that contained Hamlet's death, in such sort as he had advertised the King of England. But the subtle Danish prince, being at sea, whilst his companions slept, read the letters, and knew his uncle's great treason, with the wicked and villainous minds of the two courtiers that led him to the slaughter. $\mathrm{He}$ razed out the letters that concerned his death, and instead there. of graved others, with commission to the King of England to hang his two companions. Not content to turn the death they had devised against him upon their own necks, he wrote further, that King Fengon willed him, to give his daughter to Hamlet in marriage. So arriving in England, the messengers presented themselves to the King, giving him Fengon's letters; who having read the contents, said nothing as then, but staid convenient time to effect Fengon's desire. Meantime he used the Danes familiarly, doing them that honour to sit at his table, for that kings as then were not so curiously nor solemnly served as in these our days. For in these days mean kings and lords of small revenue are as difficult and hard to be seen, as in times 
past the monarchies of Persia used to be : or as it is reported of the great King of Ethiopia, who will not permit any man to see his face, which ordinarily he covereth with a veil. And as the messengers sat at the table with the King, subtle Hamlet was so far from being merry with them, that he would not taste one bit of meat, bread, nor cup of beer whatsoever, as then set upon the table. It was not without great wondering of the company, abasheil to see a young man and a stranger not to esteem of the delicate meats and pleasant drinks served at the banquet, rejecting them as things filthy, evil of taste, and worse prepared. The King who for that time dissembled what he thought, caused his guests to be conveyed into their chamber, willing one of his secret servants to hide himself therein, and so certify him what speeches passed among the Danes at their going to bed.

Now they were no sooner entered into the chamber, and those that were appointed to attend upon them gone out, but Hamlet's companions asked him why he refused to eat and drink of that which he found upon the table, not honouring the banquet of so great a king, that entertained them in friendily sort, with such honour and courtesy as it deserved. They said further, that he did not well, but dishonoured him that sent him, as if he sent men into England that feared to be poisoned by so great a king. The Prince, that had done nothing without reason and prudent: consideration, answered them and said: "What! think you, that I will eat bread dipt in human blood, and defile my throat with the rust of iron, and use that meat that stinketh and savoureth of man's flesh, already putrified and corrupted, and that scenteth like the savour of a dead carrion long since cast into a vault!. And how would you have me to respect the King, that hath the countenance of a slave, and the Queen who, instead of great majesty, hath done three things more like a woman of base parentage, and fitter for a waiting Gentlewoman than beseeming a Lady of her quality and estate." Having said so, he used many injurious and sharp speeches as well against the King and Queen, as others that had assisted at the banquet for the entertainment of the Danish Ambassadors. But therein Hamlet 
said truth, as hereafter you shall hear; for that in those days, the North parts of the world living as then under Satan's laws, were full of enchanters, so that there was not any young gentleman whatsoever that knew not something therein sufficient to serve his turn, if need required. As yet in those days in Gothland and Biarmy, there are many that knew not what the Christian religion permitteth, as by reading the histories of Norway and Gothland you may easily perceive. And so Hamlet, while his father lived, had been instructed in that devilish art, whereby the wicked spirit abuseth mankind, and advertiseth him (as he can) of things past.

It toucheth not the matter herein to discover the parts of divination in man, and whether this Prince by reason of his over great melancholy, had received those impressions, divining that which never any but himself had before declared. The Philosophers discoursing of divers deep points of philosophy attribute the force of those divinations to such as are Saturnists by complexion, who oftentimes speak of things which, their fury ceasing, they then already can hardly understand who are the pronouncers. For that cause Plato saith, many diviners and many poets, after the force and vigour of their fire beginneth to lessen, do hardly understand what they have written, although entreating of such things while the spirit of divination continueth upon them, they do in such sort discourse thereof that the authors and inventors of the arts themselves by them alleged cornmend their discourses and subtle disputations. Likewise I mean not to relate that which divers men believe, that a reasonable soul becometh the habitation of a meaner sort of devils, by whom men learn the secrets of things natural. Much less do I account of the supposed governors of the world feigned by magicians, by whose means they brag to effect marvellous things. It would seem miraculous that Hamlet should divine in that sort which after proved so true, if, as I said before, the devil had not knowledge of things past. But to grant that he knoweth things to come I hope you shall never find me in so gross an error, nor will compare and make equal derivation and conjecture with those that are made by the 
spirit of God and pronounced by the holy prophets that tasted of that marvellous science, to whom only were declared the secrets and wondrous works of the almighty. Yet there are some imposturous companions that impute so much divinity to the Devil the father of lies, that they attribute unto him the truth of the knowledge of things that shall happen unto men. They allege the conference of Saul with the witch, although one example out of the Holy Scriptures specially set down for the condemnation of wicked man, is not of force to give a sufficient law to all the world. For they themselves confess that they can divine, not according to the universal cause of things, but by signs borrowed from such.like causes, which are always alike; and by those conjectures they can give judgment of things to come. But all this being grounded upon a weak support, which is a simple conjecture, and having so slender a foundation, as some foolish or late experience, the fictions being voluntary, it should be a great folly in a man of good judgment, specially one that embraceth the preaching of the gospel and seeketh after no other but the truth hereof, to repose upon any of these likelihoods or writings full of deceit.

As touching magical operations, I will grant them somewhat therein; finding divers histories that write thereof, and that the Bible maketh mention and forbiddeth the use thereof. Yea the laws of the Gentiles and ordinances of Emperors, have been made against it, in such sort, that Mahomet the great Heretic and friend of the Devil, by whose subtleties he abused most part of the East countries, hath ordained great punishmenis for such as use and practise those unlawful and damnable arts. Which for this time leaving off, let us return to Hamlet, brought up in these abuses, according to the manner of his country, whose companions hearing his answer reproached him of folly, saying that he could by no means show a greater point of indiscretion than in despising that which is lawful, and rejecting that which all men received as a necessary thing. They said that he had grossly forgotten himself, as in that sort to accuse such and so excellent a man as the King of England, and to slander the Queen, being then as famous and wise a princess, as any at that day reigning in the Islands thereabouts, who 
would cause him to be punished, according to his deserts. But he continuing in his dissimulation, mocked, saying that he had not done anything that was not good and most true. On the other side the King being advertised thereof by him that stood to hear the discourse, judged presently that Hamlet speaking so ambiguously was either a perfect fool, or else one of the wisest princes in his time, answering so suddenly, and so much to the purpose, upon the demand by his companions made touching his behaviour. The better to find the truth he caused the babbler to be sent for, of whom he inquired in what place the corn grew whereof he made bread for his table, and whether in that ground there were not some signs or news of a battle fought whereby human blood had therein been shed? The babbler answered that not far from thence there lay a field full of dead men's bones, in times past slain in a battle, as by the great heaps of wounded skulls, might well appear, and for that the ground in that part was become fertiler than other grounds, by reason of the fat and humours of the dead bodies, that every year the farmers used there to have in the best wheat they could find to serve his majesty's house. The King perceiving it to be true, according to the young Prince's words, asked where the hogs had been fed that were killed to be served at his table? Answer was made him, that those hogs getting out of the said field wherein they were kept, had found the body of a thief that had been hanged for his demerits, and had eaten thereof. Whereat the King of England being abashed, would needs know with what water the beer he used to drink of, had been brewed? which having known, he caused the river to be digged somewhat deeper, and therein found great store of swords and rusty armours, that gave an ill savour to the drink.

It were good that I should here dilate somewhat of Merlin's prophesies which are said to be spoken of him before he was fully one year old. If you consider well what hath already been spoken, it is no hard matter to divine of things past, although the minister of Satan therein played his part, giving sudden and prompt answers to this young Prince, for that herein are nothing but natural things, such as were well known to be true, and there- 
fore not needful to dream of things to come. This known, the King was greatly moved with a certain curiosity to know why the Danish Prince said that he had the countenance of a slave, suspecting thereby that he reproached the baseness of his blood and that he would affirm that never any Prince had been his sire. Wherein to satisfy himself, he went to his mother, and leading her into a secret chamber, which he shut as soon as they were entered, desired her of her honour to show him of whom he was engendered in this world. The good Lady, well assured that never any man had been acquainted with her love touching any other man than her husband, sware that the King her husband only was the man, but the King her son, already convinced with the truth of the Danish Prince's answers, threatened his mother to make her tell by force, if otherwise she would not confess it. She for fear of death, acknowledged that she had given herself to a slave, and made him father to the King of England. Whereat the King was abashed and wholly ashamed. I give them leave to judge who esteem themselves honester than their neighbours, and suppose that there can be nothing amiss in their houses, whether they would make more inquiry than is requisite to know that which they would rather not have known. Nevertheless, dissembling what he thought, and biting upon the bridle, rather than he would deprive himself, by publishing the lasciviousness of his mother, this King of England thought better to leave a great sin unpunished than thereby to make himself contemptible to his subjects, who peradventure would have rejccted him, as not desiring to have a bastard to reign over so great a kingdom.

But as he was sorry to hear his mother's confession, on the other side he took great pleasure in the subtilty and quick spirit of the young Prince, and for that cause went unto him to ask him why he had reproved three things in his Queen convenient for a slave, and savouring more of baseness than of royalty, and far unfit for the majesty of a great Prince. The King, not content to have received a great displeasure by knowing himself to be a bastard, and to have heard with what injuries he charged her whom he loved best in all the world, would not content himself until he 
also understood that which displeased him as much as his own proper disgrace. This was that his Queen was the daughter of a chambermaid, and withal Hamlet noted certain foolish countenances she made, which not only showed of what parentage she came, but also that her humours savoured of the baseness and low degree of her parents, whose mother, he assured the King, was as then yet holden in servitude. The King admiring the young Prince, and beholding in him some matter of greater respect than in the common sort of men, gave him his daughter in marriage, according to the counterfeit letters by him devised, and the next day caused the two servants of Fengon to be executed, to satisfy, as he thought, King Fengon's desire. But Hamlet, although the sport pleased him well, and that the King of England could not have done him a greater favour, made as though he had been much offended, threatening the King to be revenged. The King, to appease him, gave him a great sum of gold, which Hamlet caused to be molten, and put it into two staves, made hollow for the same purpose, to serve his turn therewith as need should require. Of all other the King's treasures he took nothing with him into Denmark but only those two staves. As soon as the year began to be at an end, having somewhat before obtained licence of the King, his father-in-law, to depart, Hamlet went for Denmark. Then with all speed that he could he should return again into England to marry the King of England's daughter, and so set sail for Denmark.

\section{CHAPTER V.}

How Hamlet, having escaped out of England, arrived in Denmark the same day that the Danes zvere celebrating his funerals, supposing him to be dead in England; and how he revenged his father's death upon his uncle and the rest of the courtiers; and rehat followed.

HaMlet in that sort sailing into Denmark, being arrived in the country, entered into the palace of his uncle the same day that 
they were celebrating his funerals. Going into the hall, he procured no small astonishment and wonder to them all, no man thinking other but that he had been dead. Among the which many of them had rejoiced not a little, for the pleasure which they knew Fengon would conceive for so pleasant a loss; and some were sad, as remembering the honourable King Horvendile, whose victories they could by no means forget, much less deface out of their memories that which pertained unto him. These greatly rejoiced to see a false report spread of Hamlet's death, and that the tyrant had not as yet obtained his will of the heir of Jutie. They rather hoped God would restore him to his senses again for the good and welfare of that province. Their amazement at the last being turned into laughter, all that as then were assistant at the funeral banquet of him whom they esteemed dead, mocked at each other for having been so simply deceived. Wondering at the Prince, that in his so long a voyage he had not recovered any of his senses, they asked what was become of them that had borne him company into Great Britain, to whom he made answer (showing them the two hollow staves, wherein he had put his molten gold, that the King of England had given him to appease his fury, concerning the murder of his two companions) and said, here they are both. Whereat many that already knew his humours, presently conjectured that he had played some trick of legerdemain, and to deliver himself out of danger, had thrown them into the pit prepared for him. So fearing to follow after them and light upon some evil adventure, they went presently out of the court, and it was well for them that they did so, considering the tragedy acted by him the same day. It had been accounted his funeral, but in truth their last day that as then rejoiced. For when every man busied himself to make good cheer, and Hamlet's arrival provoked them more to drink and carouse, the Prince himself at that time played the butler and a gentleman attending on the tables. He did not suffer the pots nor. goblets to be empty, whereby he gave the noblemen such store of liquor, that all of them being full laden with wine and gorged with meat, were constrained to lay themselves down in the same. 
place where they had supped, so much their senses were dulled, and overcome with the fire of over great drinking, a vice common and familiar among the Almaines, and other nations inhabiting the north parts of the world. When Hamlet perceived this, and found so good opportunity to effect his purpose and be revenged of his enemies, and by that means to abandon the actions, gestures, and apparel of a madman, occasion so fitly finding his turn, and as it were effecting itself, he failed not to take hold thereof. Seeing those drunken bodies, filled with wine, lying like hogs, upon the ground, some sleeping, others vomiting the over great abundance of wine which without measure they had swallowed up, Hamlet made the hangings about the hall to fall down and cover them all over, which he nailed to the ground, being boarded, and at the ends thereof he stuck the brands whereof I spake before by him sharpened, which served for pricks, binding and tying the hangings, in such sort, that what force soever they used to loose themselves, it was impossible to get from under them. And presently he set fire in the four corners of the hall, in such sort that of all that were as then therein not one escaped away. They were forced to purge their sins by fire, and dry up the great abundance of liquor by them received into their bodies, all of them dying in the inevitable and merciless flames of the hot and burning fire.

The Prince perceiving this, became wise, and knowing that his uncle before the end of the banquet had withdrawn himself into his chamber, which stood apart from the place where the fire burnt, he went thither, and entering into the chamber laid hand upon the sword of his father's murderer, leaving his own which, while he was at the banquet, some of the courtiers had nailed fast into the scabbard. Then going to Fengon, Hamlet said, "I wonder, disloyal king, how tiou canst sleep here at thine ease when all thy palace is burnt. The fire thereof has burnt the greatest part of thy courtiers and ministers of thy cruelty and detestable tyrannies. What is more, I cannot imagine how thou shouldst well assure thyself and thy estate, as now to take thy ease, seeing Hamlet so near thee armed with the shaits by him 
prepared long since and at this present ready to revenge the traitorous injury by thee done to his Lord and Father."

Fengon then knew the truth of his nephew's subtle practice, and heard him speak with stayed mind. What is more, he perceived a sword naked in his hand, which he already lifted up to deprive hin of his life. He leaped then quickly out of the bed, taking hold of Hamlet's sword, that was nailed into the scabbard, which as he sought to pull out, Hamlet gave him such a blow upon the chin of the neck, that he cut his head clean from his shoulders, and as he fell to the ground said: "This just and violent death is a first reward for such as thou art. Now go thy ways, and when thou comest in hell, see thou forget not to tell thy brother, whom thou traitorously slewest, that it was his son that sent thee thither with the message, to the end that being comforted thereby, his soul may rest among the blessed spirits, and quit me of the obligation which bound me to pursue his vengeance upon mine owne-blood, that seeing it was by thee that I lost the chief thing that tied me to this alliance and consanguinity."

This was a man, to say the truth, hardy, courageous, and worthy of eternal commendation, who arming himself with a crafty, dissembling and strange show of being distract out of his wits, under that pretence deceived the wise, politic, and crafty : thereby not only preserving his life from the treasons and wicked practices of the tyrant, but, which is more, by a new and unexpected kind of punishment revenged his father's death many years after the act committed. He directed his courses with such patience, and effected his purposes with so great boldness and constancy, that he left a judgment to be decided among men of wisdom which was more commendable in him, his constancy, or magnanimity, or his wisdom in ordering his affairs, according to the premeditable determination he had conceived.

If vengeance ever seem to have any show of justice, it is then, when piety and affection constrain us to remember our fathers unjustly murdered, as the things whereby we are dis- 
pensed withal, and which seek the means not to leave treason and murder unpunished : seeing David a holy and just king, and of nature simple, courteous, and debonaire, yet when he died he charged his son Solomon, that succeeded him in his throne, not to suffer certain men that had done him injury to escape unpunished. . Not that this holy king, as then ready to die, and to give account before God of all his actions, was careful or desirous of revenge, but to leave this example unto us, that where the Prince or country is interested, the desire of revenge cannot by any means (how small soever) bear the title of condemnation, but is rather commendable and worthy of praise : for otherwise the good kings of Judah, nor others, had not pursued them to death that had offended their predecessors, if God himself had not inspired and engraven that desire within their hearts. Hereof the Athenian laws bear witness, whose custom was to erect images in remembrance of those men that, revenging the injuries of the commonwealth, boldly massacred tyrants and such as troubled the peace and welfare of the citizens.

Hamlet having in this manner revenged himself, durst not presently declare his action to the people, but to the contrary determined to work by policy, so to give them intelligence what he had done, and the reason that drew him thereunto. Being accompanied with such of his father's friends that then were rising, he stayed to see what the people would do, when they should hear of that sudden and fearful action. The next morning the towns bordering thereabouts desiring to know from 'whence the flames of fire proceeded which they had seen the night before, came thither, and perceiving the King's palace burnt to ashes and many bodies, most part consumed, lying among the ruins of the house, all of them were much abashed, nothing being left of the palace but the foundation. But they were much more amazed to behold the body of the King all bloody, and his head cut off lying hard by him. Thereat some began to threaten revenge, yet not knowing .against whom. Others, beholding so lamentable a spectacle, armed themselves. The rest rejoiced, yet dare not to make any show thereof. Some detested the 
cruelty, others lamented the death of their Prince; but the greatest rart, calling Horvencile's murder to remembrance, acknowledging a jusi judgment from above, inat had thrown down the price of the tyrant. In this sort the diversities of opinions among the multitude of the people being many, yet every man ignorant winat would be the issue of that tragedy, none stirred from thence, neither yet attempted to move any tumult, every man fearing his own skin and distrusting his neighbour, esteeming each other to be consenting to the massacre.

\section{CHAPTER VI.}

How Hamist, horing slain his Uncle and burnt his palace, made ar cristion to the Danes, to show them what he had done; and hore they made him King of Denmark; and what followed.

Haylet then seeing the people to be so quiet, and most part of them not using any mords, all searching only and simply the cause of this ruin and destruction, not minding to lose any time, but aiding himself with the commodity thereof, entered among the multitude of people, and, standing in the middle, spake unto them as followe:n :-

"If there be any among you, good people of Denmark, that as yet have fresi within your memories the wrong done to the valiant King Horrendile, let him not be moved, nor think it strange to benold the confused, hicleous, and fearful spectacle of this present caiamity. If there be any man that affecteth fidelity, and alloweth of the jore and duty that man is bound to show his parents, and find it a just cause to call to remembrance the injuries and wrongs that have been done to our progenitors, let him not be ashamed behoicing this massacre, much less offended to see so ieariul a ruin both of men and of the bravest nouse in all this cour:y. Fo: tise hand that hath done this justice could not effect it by any o:he: means, neitier yet was it lawful for him to do it othermise than by ruirating both sensible and insensible things, thereby to preserve tine memory of a just vengeance 
"I see well, nyy good friends, and am very glad to know so good attention and devotion in you, that you are sorry before your eyes to see Fengon so murciered, and without a head, which heretofore you acknowledged for your commander. But I pray you remember, this body is not the body of a king, but of an execrable tyrant, and a parricide most detestable. O Danes, the spectacle was much more hideous when Horvendile your King was murdered by his brother. What, should I say a brother? Nay, rather by the most abominable executioner that ever beheld the same. It was you that saw Horvendile's members massacred, and that with tears and lamentations accompanied him to the grave. His body disfigured, hurt in a thousand places, and misused in ten times as many fashions. And who doubteth, seeing experience hath taught you, that the tyrant, in massacring your lawful King, sought only to infringe the ancient liberties of the common people? It was one hand only that murdering Horvendile, cruelly despoiled him of life, and by the same means unjustly bereaved you of your ancient liberties, and delighted more in oppression than to embrace the pleasant countenance of prosperous liberty, without adventuring for the same? And what mad man is he, that delighteth more in the tyranny of Fengon, than in the clemency and renewed courtesy of Horvendile? If it be so, that by clemency and affability, the hardest and stoutest hearts are mollified and made tractable, and that evil and hard usage causeth subjects to be outrageous and unruly: why behold you not the debonair carriage of the first, to compare it with the cruelties and insolences of the second, in every respect as cruel and barbarous as his brother was gentle, meek, and courteous. Remember, $\mathrm{O}$ you Danes, remember, what love and amity Horvendile showed unto you, with what equity and justice he swayed the great affairs of this kingdom, and with what humanity and courtesy he defended and cherished you, and then I am assured that the simplest man among you will both remember and acknowledge, that he had a most peaceable, just, and righteous King taken from him, to place in his throne a tyrant and murderer of his brother. Fengon hath perverted all right, abolished the 
ancient Laws of our fathers, contaminated the memories of our ancestors, and by his wickedness polluted the integrity of this kingdom, upon the neck thereof having placed the troublesome yoke of heavy servitude. He has abolished that liberty wherein Horvendile used to maintain you, and suffer you to live at your ease. And should you now be sorry to see the end of your mischiefs, and that this miserable wretch, pressed down with the burden of his offences, at this present payeth the usury of the parricide committed upon the body of his brother. Who would not himself be the revenger of the outrage done to me, whom he sought to deprive of mine inheritance, taking from Denmark a lawful successor, to plant a wicked stranger, and bring into captivity those that my father had enfranchised, and delivered out of misery and bondage? And what man is he that having any spark of wisdom, would esteem a good deed to be an injury, and account pleasures equal with wrongs and evident outrages? It were then great folly and temerity in Princes and valiant commanders in the wars, to expose themselves to perils and hazards of their lives for the welfare of the common people, if that for a recompense they should reap hatred and indignation of the multitude. To what end should Hother have punished Balder, if instead of recompense, the Danes and Swethlanders had banished him to receive and accept the successors of him that desired nought but his ruin and overthrow? What is he that hath so small feeling of reason and equity, that would be grieved to see treason rewarded with the like, and that an evil act is punished with just demerit, in the party himself that was the occasion? Who was ever sorrowful to behold the murderer of innocents brought to his end? or what man weepeth to see a just massacre done upon a Tyrant, usurper, villain, and bloody personage?

"I perceive you are attentive, and abashed for not knowing the author of your deliverance, and sorry that you cannot tell to whom you should be thankful for such and so great a benefit as the destruction of a tyrant, and the overthrow of a place that was the storehouse of his villainies and the true receptacle of all the thieves and traitors in this kingdom. But behold here in your 
presence him that brought so good an enterprise to effect. It is I, my good friends, it is I, that confess I have taken vengeance for the violence done unto my lord and father, and for the subjection and servitude that I perceived in this Country, whereof I am the just and lawful successor. It is I alone, that have done this piece of work whereunto you ought to have lent me your hands and therein have aided and assisted me, I have only accomplished that, which all of you might justly have effected, by good reason, without falling into any point of treason or felony. It is true that I hope so much of your good wills towards the deceased King Horvendile, and that the remembrances of his virtues is yet so fresh within your memories, that if I had required your aid herein you would not have denied it, specially to your natural Prince. But it liked me best to do it myself alone, thinking it a good thing to punish the wicked without hazarding the lives of my friends and loyal subjects, not desiring to burthen other men's shoulders with this weight, for that I made account to effect it well enough without exposing any man into danger, and by publishing the same should clean have overthrown the device which at this present I have so happily brought to pass. I have burnt the bodies of the courtiers to ashes, being companions in the mischiefs and treasons of the tyrant, but I have left Fengon whole, that you might punish his dead carcass, seeing that when he lived you durst not lay hands upon him, to accomplish the full punishment and vengeance due unto him, and so satisfy your choler upon the bones of him that filled his greedy hands and coffers with your riches, and shed the blood of your brethren and friends. Be joyful then, nly good friends, make ready the nosegay for this usurping King, burn his abominable body and cast the ashes of him that hath been hurtful to all the world, into the air; drive from you the slarks of pity, to the end that neither silver, nor crystal cup, nor sacred tomb may be the restful habitation of the relics and bones of so detestable a man. Let not one trace of a parricide be seen, nor your country defiled with the presence of the least member of this tyrant without pity, that your neighbours may not smell the con- 
tagion, nor our land the polluted infection of a body condemned for his wickedness. I have done my part, to present him to you in this sort, now it belongs to you to make an end of the work and put to the last hand of duty, whereunto your several functions call you. For in this sort you must honour abominable princes : and such ought to be the funeral of a tyrant, parricide, and usurper both of the bed and patrimony that no way belonged unto him, who having bereaved his country of liberty, it is fit that the land refuse to give him a place for the eternal rest of his bones.

"O my good friends, seeing you know the wrong that hath been done unto me, what my griefs are and in what misery I have lived since the death of the King, my lord and father, and seeing that you have both known and tasted these things then whenas I could not conceive the outrage that I felt: what need I recite it unto you? What benefit would it be to discover it before them that knowing it would burst as it were with despite to hear of my hard chance, and curse Fortune for so much abasing a royal Prince as to deprive him of his majesty, although not any of you durst so much as show one sight of sorrow or sadness? You know how my stepfather conspired my death, and sought by divers means to take away my life, how I was forsaken of the Queen my mother, mocked of my friends, and despised of mine own subjects. Hitherto I have lived laden with grief, and wholly confounded in tears, my life still accompanied with fear and suspicion, expecting the hour when the sharp sword would make an end of my life and miserable anguishes. How many times counterfeiting the madman, have I heard you pity my distress, and secretly lament to see me disinherited, and yet no man sought to revenge the death of my father, nor to punish the treason of my incestuous uncle, fuil of murders and massacres? This charity ministered comfort, and your affectionate complaints made me evidently see your goodwills, that you had in memory the calamity of your Prince, and within your hearts engraven the desire of vengeance for the death of him that deserved a long life. What heart can be so hard and untractable, or spirit so 
severe, cruel and rigorous, that would not relent at the remembrance of my extremities, and take pity of an orphan child, so abandoned of the world? What eyes were so void of moisture, but would distil a field of tears, to see a poor prince assaulted by his own subjects, betrayed by his mother, pursued by his uncle, and so much oppressed that his friends durst not show the effects of their charity and good affection? 0 ; my good friends, show pity to him whom you have nourished, and let your hearts take some compassion upon the memory of my misfortunes?" I speak to you that are innocent of all treason, and never defiled your hands, spirits, nor desires with the blood of the great and virtuous Horvendile. Take pity upon the Queen some time your sovereign lady; and my right. honourable mother, forced by the tyrant, and rejoice to see the end and extinguishing of the object of her dishonour: which, constrained her to be less pitiful to her own blood so far as to embrace the murderer of her own dear spouse, charging herself with a double burden of infamy and incest, together with injuring and disannulling of her house, and the ruin of her race. This hath been the occasion that made me counterfeit folly, and cover my intents under a veil of mere madness, which hath wisdom and policy thereby to enclose the fruit of this vengeance which that it hath attained to the full point of efficacy and perfect accomplishment you yourselves shall be judges, for touching this and other things concerning my profit, and the managing of great affairs, I refer myself to your counsels, and thereunto am fully determined to yield, as being those that trample under your feet the murderers of my father, and despise the ashes of him that hath polluted and violated the spouse of his brother, by him massacred, that hath committed felony against his Lord, traitorously assailed the majesty of his King, and odiously thralied his country under servitude and bondage, and you his loyal subjects from whom he bereaved your liberty, and feared not to add incest to parricide, detestable to all the world, to you also it belongeth by duty and reason commonly to defend and protect Hamlet, the minister and executor of just vengeance, who being jealous of your honour and reputa- 
tion, hath hazarded himself, hoping you will serve him for fathers, defenders, and tutors, and regarding him in pity, restore him to his goods and inheritances. It is I that have taken away the infamy of my country, and extinguished the fire that embraced your fortunes, I have washed the spots that defiled the reputation of the Queen, overthrowing both the tyrant and the tyranny and beguiling the subtleties of the craftiest deceiver in the world, and by that means brought his wickedness and impostures to an end. I was grieved at the injury committed both to my father, and my native country, and have slain him that used more rigorous commandments over you, than was either just or convenient to be used unto men that have commanded the valiantest nations in the world. Seeing then he was such a one to you, it is reason, that you acknowledge and think well of the benefit for the good I had done your posterity, and admiring my spirit and wisdom, choose me your King, if you think me worthy of the place. You see I am the author of your preservation, heir of my father's kingdom, not straying in any point from his virtuous action, no murderer, violent parricide, nor man that ever offended any of you but only the vicious. I am lawful successor in the kingdom, and just revenger of a crime above all others most grievous and punishable. It is.to me, that you owe the benefit of your liberty received, and of the subversion of that tyranny that so much afflicted you. I have trodden under feet the yoke of the iyrant, and overwhelmed his throne, and taken the sceptre out of the hands of him that abused a holy and just authority : but it is you that are to recompense those that have well deserved, you know what is the reward of so great desert, and being in your hands to distribute the same, it is of you, that I demand the price of my virtue and the recompense of my victories."

This oration of the young Prince so moved the hearts of the Danes, and won the affections of the nobility, that some wept for pity other for joy, to see the wisdom and gallant spirit of Hamlet. Having made an end of their sorrow, all with one consent proclaimed him King of Jutie and Chersonese, at this present the 
proper country of Denmark. Having celebrated his coronation, and received the homages and fidelities of his subjects, he went into England to fetch his wife, and rejoiced with his father-in-law touching his good fortune. But it wanted little that the King of England had not accomplished that which Fengon with all his subtilties could never attain.

\section{CHAPTER VII.}

How Hamlet after his coronation went into England, and how the King of England secretly would have put him to death, and how he slew the King of England: and returned again to Denmark with two wives, and what followed.

HAMLET being in England showed the King what means he had wrought to recover his kingdom. But when the King of England understood of Fengon's death, he was both abashed and confused in his mind, at that instant feeling himself assailed with two great passions, for that in times past, he and Fengon having been companions together in arms, had given each other their faith and promises, by oath, that if either of them chanced to be slain by any man whatsoever, he that survived, taking the quarrel upon him as his own, should never cease till he were revenged, or at the least do his endeavour. This promise incited the barbarous king to massacre Hamlet. But the alliance, presenting itself before his eyes, and beholding the one dead, although his friend; and the other alive, and husband to his daughter, made him deface his desire of revenge. But in the end the conscience of his oath and promise obtained the upper hand, and secretly made him conclude the death of his son-in-law, which enterprise, after that, was cause of his own death and overrunning of the whole country of England by the cruelty and despight conceived by the King of Denmark. I have purposely omitted the dis: course of that battle, as not much pertinent to our matter, as also, not to trouble you with too tedious a discourse, being content to show you the end of this wise and valiant King Hamlet, who 
revenging himself upon so many enemies, and discovering all the treasons practised against his life, in the end served for a sport to fortune, and an example to all great personages, that trust overmuch to the felicities of this world, that are of small moment and less continuance.

The King of England, perceiving that he could not easily effect his desire upon the King his son-in-law, as also not being willing to break the laws and rites of hospitality, determined to make a stranger the revenger of his injury, and so accomplish his oath made to Fengon without defiling his hands with the blood of the husband of his daughter, and polluting his house by the traitorous massacring of his friend. In reading of this history it seemeth Hamlet should resemble another Hercules, sent into divers places of the world, by Euristheus, solicited by Juno, where he knew any dangerous adventure, thereby to overthrow and destroy him; or else Bellerophon sent to Ariobatus to put him to death; or, leaving profane histories, another Urias by King David appointed to be placed in the forefront of the battle, and the man that should be first slain by the barbarians. For the King of England's wife being dead not long before (although he cared not for marrying another woman) desired his son-in-law to make a voyage for him into Scotland, flattering him in such sort, that he made him believe that his singular wisdom caused him to prefer him to that embassage, assuring himself that it were impossible that Hamlet, the subtlest and wisest prince in the world, should take anything in the world in hand without effecting the same.

Now the Queen of Scots being a maid and of a haughty courage, despised marriage with all men, as not esteeming any worthy to be her companion, in such manner that by reason of this arrogant opinion there never came any man to desire her love but she caused him to lose his life. But the Danish King's fortune was so good that Hermetrude, for so was the Queen's name, hearing that Hamlet was come thither to entreat a marriage between her and the King of England, forgot all her pride, and despoiling herself of her stern nature, being as then determined to make him, being the greatest Prince as then living, her husband, and deprive 
the English Princess of her spouse, whom she thought fit for no one but herself. And so this Amazon without love, disdaining Cupid, by her free-will submitted her haughty mind. 'The Dane arriving in her Court, she desired to see the old King of England's letters, and mocking at his fond appetites, whose blood as then was half congealed, cast her eyes upon the young and pleasant Adonis of the North, $\epsilon$ steeming herself happy to have such a prey fall into her hands, whereof she made her full account to have the possession. She that never had been overcome by the grace, courtesy, valour, or riches of any prince nor lord whatsoever, was as then vanquished with the only report of the subtleties of the Dane. She, knowing that he was already affianced to the daughter of the King of England, spake unto him and said, "I never looked for so great a bliss, neither from the Gods, nor yet from fortune, as to behold in my countries the most complete Prince in the North, and he that hath made himself famous and renowned through all the nations of the world, as well neighbours as strangers, for the only respect of his virtue, wisdom, and good fortune, serving him much in the pursuit and effect of divers things by him undertaken. I think myself much beholden to the King of England, although his malice seeketh neither my advancement nor the good of you, my Lord, to do me so much honour as to send me so excellent a man to entreat of a marriage (he being old and a mortal enemy to me and mine) witi me that am such a one as every man seeth is not desirous to couple with a man of so base quality as he, whom you have said to be the son of a slave. But, on the other side, I marvel that the son of Horvendile, and grandchild to King Roderick, he that by his foolish wisdom and feigned madness surmounted the forces and subtleties of Fengon, and obtained the kingdom of his adversary, should so much abase himself, having otherwise been very wise and well advised in all his actions, touching his bedfellow, and he that for his excellency and valour surpasseth human capacity, should stoop so low as to take to wife her that, issuing from a servile race, hath only the name of a king for her father, for that the baseness of her blood will always cause her to show what are the virtues and noble qualities of her 
ancestors. And you, my Lord," said she, "are you so ignorant as not to know that marriage should not be measured by any foolish opinion of an outward beauty, but rather by virtues and antiquity of race, which maketh the wife to be honoured for her prudence, and never degenerating from the integrity of his ancestors? Exterior, beauty also is nothing, where perfection of the mind doth not accomplish and adorn that which is outwardly seen to be in the body, and is lost by an accident and occurrence of small moment. As also such toys have deceived many men, and drawing them like enticing baits, have cast them headlong into the gulf of their ruin, dishonour, and utter overthrow. It was I to whom this advantage belonged, being a Queen, and such a one as for nobility may compare myself with the greatest princes in Europe, being nothing inferior unto any of them neither for antiquity of blood, nobility of parents, nor abundance of riches. I am not only a Queen, but such a one as that, receiving whom I will for my companion, can make him bear the title of a King, and with my body give him possession of a great kingdom and goodly province. Think then, my Lord, how much I account of your alliance, who being accustomed with the sword to pursue such as durst embolden themselves to win my love, it is to you only to whom I make a present both of my kisses, embracings, sceptre, and crown. What man is he, if he be not made of stone, would refuse so precious a pawn as Hermetrude with the kingdom of Scotland? Accept, sweet King, accept this Queen, who with so great love and amity desireth your so great profit, and can give you more contentment in one day than the Princess of England would yield you pleasure during her life. Although she surpass me in beauty, her blood being base, it is fitter for such a King as you are to choose Hermetrude, less beautiful, but noble and famous, rather than the Engiish lady with great beauty, but issuing from an unknown race, without any title of honour."

Now, think if the Dane hearing such forcible reasons, and understanding that by her which he half-doubted, as also moved without choler for the treason of his father-in-law, that purposely 
sent him thither to lose his life, and being welcomed, kissed, and played withal by this Queen, young and reasonable fair, if he were not easy enough to be converted, and like to forget the affection of his first wife, with this to enjoy the realm of Scotland, and so open the way to become King of all Great Britain?

To conclude, he married her and led her with him to the King of England's Court, which moved the King from that time forward much more to seek the means to bereave him of his life. He had surely done it, if his daughter, Hamlet's other wife, more careful of him that had rejected her thạn of her father's welfare, had not discovered the enterprise to Hamlet, saying, "I know well, my Lord, that the allurements and persuasions of a bold and altogether shameless woman, being more lascivious than the chaste embracements of a lawful and modest wife, are of more force to entice and charm the senses of young men : but for my part I cannot take this abuse for satisfaction to leave me in this sort, without all cause, reason, or precedent fault once known in me your loyal spouse, and take more pleasure in the alliance of her who one day will be the cause of your ruin and overthrow. And although a just cause of jealousy and reasonable motion of anger dispense with me at this time to make no more account of you than you do of me, that am not worthy to be so scornfully rejected, yet matrimonial charity shall have more force and vigour in my heart than the disdain which I have justly conceived to see a concubine hold my place and a strange woman before my face enjoy the pleasures of my husband. This injury, my Lord, although great and offensive, which to revenge, divers ladies of great renown have in times past sought and procured the death of their husbands, cannot so much restrain my good-will, but that I may not choose but advertise you what treason is devised against you, beseeching you to stand upon your guard for that my father's only seeking is to bereave you of your life, which if it happen, I shall not long live after you. Many reasons induce me to love and cherish you, and those of great consequence, but specially and above ail the rest, I am and must be careful of you, when I feel your 
unboris child; for which respect, without so much forgetting yourself, you ought to make more account of me than of your concubine.' Her I will love because you love her, contenting myself that your son hateth her, in regard to the wrong she doth to his mother. For it is impossible that any passion or trouble of the mind whatsoever can quench those fierce passions of love that made me yours, neither that I should forget your favours past, when loyally you sought the love of the daughter of the King of England. Neither is it in the power of that thief that hath stolen your heart, nor my father's choler, to hinder me from seeking to preserve you from the cruelty of your dissembling friend (as heretofore, by counterieiting the madman, you prevented the practices and treasons of your uncle Fengon), the complot being determined to be executed upon you and yours."

Without this advertisement the Dane had surely been slain, and the Scots that came with him. For the King of England, inviting his son-in-law to a banquet with the greatest courtesies that a friend can use to him whom he loved as himself, had the means to entrap him, and cause him dance a pitiful galliard, to celebrate the marriage between him and his new, lady. . But Hamlet went thither with armour under his clothes, and his men in like sort, by winich means he and his escaped with little hurt; and so after that liappened the battle before spoken of, wherein the King of England losing his life, his country was the third time sacked by the barbarians of the islands and country of Denmark.

\section{CHAPTER VIII.}

How Hamlet, being in Denmark, was assailed by Wiglerus, his uncle, and after betrayed by his last wife, called Hermetrude, and was slain: after whose death she married his enemy, Wiglerus.

HAMLET having obtained the victory against the King of England, and slain him, laden with great treasures and accompanied with his two wives, set forward to sail into Denmark. But by the 
way he had intelligence, that Wiglerus, his uncle, and son to Roderick, having taking the royal treasure from his sister Geruth, mother to Hamlet, had also seized upon the kingdom, saying that neither Horvendile nor any of his held it but by permission, and that it was in him, to whom the property belonged, to give the charge thereof to whom he would. But Hamlet, not desirous to have any quarrel with the son of him from whom his predecessors had received their greatness and advancement, gave such and so rich presents to Wiglerus, that he, being contented, withdrew himself out of the country and territories of Geruth's son. But within certain time after, Wiglerus, desirous to keep all the country in subjection, enticed by the conquest of Scanie and Sialandie, and also that Hermetrude, the wife of Hamlet, whom he loved more than himself, had secret intelligence with him, and had promised him marriage so he would take her out of the hands of him that held her, sent to defy Hamlet, and proclaimed open war against him. Hamlet, like a good and wise Prince, loving especially the welfare of his subjects, sought by all means to avoid that war. But again, refusing it, he perceived a great spot and blemish in his honour; and accepting the same, he knew it would be the end of his days. The desire of preserving his life was on the one side, and his honour on the other side, pricking him forward; but at the last, remembering that never any danger whatsoever had once shaken his virtues and constancy, he chose rather the necessity of his ruin than to lose the immortal fame that valiant and honourable men obtained in the wars. There is as much difference between a life without honour and an honourable death, as glory and renown is more excellent than dishonour and evil report.

But the thing that spoiled this virtuous Prince was the overgreat trust and confidence he had in his wife Hermetrude, and the vehement love he bare unto her. $\mathrm{He}$ did not once renent the wrong in that case done to his lawful spouse, and but for the which peradventure that misfortune had never happened unto him. He never thought that she whom he loved above all things would have so villainously betrayed him, he not once remem- 
bering his first wife's speeches, who prophesied unto him that the pleasures he seemed to take in his other wife would in the end be the cause of his overthrow. They had ravished him of the best part of his senses, and quenched in him the great prudence that made him admirable in all the countries in the ocean seas and through all Germany. Now, the greatest grief that this King (besotted on his wife) had, was the separation of her whom he adored, and assuring himself of his overthrow, he was desirous either that she might bear him company at his death, or else to find her a husband that should love her, he being dead, as well as ever he did. But the disloyal Queen had already provided herself of a marriage, to put her husband out of trouble and care for that. He perceiving him to be sad for her sake, when she should have absented herself from him, she to blind him the more, and to encourage him to set forward to his own destruction, promised to follow him whithersoever he went, and to take the like fortune that befell to him, were it good or evil, and that so she would give him cause to know how much she surpassed the English woman in her affection towards him, saying, that woman is accursed that feareth to follow and accompany her husband to the death. To hear her speak, men would have said that she had been the wife of Mithridates, or Zenobia Queen of Palmyra, she made so great a show of love and constancy. But by the effect, it.was after easily perceived how vain the promise of this inconstant and wavering Princess was, and how incomparable the life of this Scottish Queen was to the vigour of her chastity, being a maid before she was married. For that Hamlet had no sooner entered into the field but she found means to see Wiglerus, and the battle began, wherein the miserable Danish Prince was slain. But Hermetrude presently yielded herself, with all her dead husband's treasures, into the hand of the tyrant, who, more than content with that metamorphosis so much desired, gave order that presently the marriage, bought with the blood and treasure of the son of Horvendile, should be celebrated.

Thus you see that there is no promise or determination of a woman but that a very small discommodity of fortune mollifieth 
and altereth the same, and which time doth not pervert; so that the misfortunes subject to a constant man shake and overthrow the natural slippery loyalty of the variable steps of women, wholly without any faithful assurance of love or true unfeigned constancy; for, as a woman is ready to promise, so is she heavy and slow to perform and effect that which she hath promised, as she that is without end or limit in her desires, flattering herself in the diversity of her wanton delights, and taking pleasure in diversity and change of new things, which as soon she doth forget and grow weary of. And, to conclude, such she is in all her actions; she is rash, covetous, and unthankful, whatsoever good or service be done unto her. But now I perceive I err in my discourse, vomiting such things unworthy of this sex; but the vices of Hermetrude have made me say more than I meant to speak, as also the Author from whence I take this history hath almost made me hold his course, I find so great a sweetness and liveliness in this kind of argument : and the rather because it seemeth so much the truer, considering the miserable success of poor King Hamlet.

Such was the end of Hamlet, son of Horvendile, Prince of Jutie, to whom, if his fortune had been equal with his inward and natural gifts, I know not which of the ancient Grecians and Romans had been able to have compared with him for virtue and excellency. But hard fortune followed him in all his actions, and yet he vanquishing the malice of his time, with the vigour of constancy, hath left us a notable example of haughty courage, worthy of a great Prince, arming himself with hope in things that were wholly without any colour or show thereof, and in all his honourable actions made himself worthy of perpetual memory, if one only spot had not blemished and darkened a good part of his praises. For that the greatest victory that a man can obtain is to make himself victorious. and lord over his own affections, and that restraineth the unbridled desires of his concupiscence. For if a man be never so princely, valiant, and wise, if the desires and eriticements of his flesh prevail and have the upper hand, he will abase his credit, and, gazing after strange beauties, become a fool, and, as it were, incensed, dote on the presence of women. This 
fault was in the great Hercules, Samson, and the wisest man that ever lived upon the earth, following this train, therein impaired his wit; and the most noble, wise, valiant, and discreet personages of our time, following the same course, have left us many notable examples of their worthy and notable virtues.

But I beseech you that shall read this history not to resemble the spider that feecleth of the corruption that she findeth in the flowers and fruits that are in the gardens, whereas the bee gathereth her honey out of the best and fairest flowers she can find. For a man that is well brought up should read the lives of whoremongers, drunkards, incestuous, violent, and bloody persons, not to follow their steps, and so to defile himself with such uncleanness, but to shun paliardise, ${ }^{1}$ abstain the superfluities and drunkenness in banquets, and follow the modesty, courtesy, and continency that recommendeth Hamlet in this discourse, who, while other made good cheer, continued sober; and where all men sought as much as they could to gather together riches and treasure, he, simply accounting riches nothing comparable to honour, sought to gather a multitude of virtues, that might make him equal to those that by them were esteemed as gois, having not as then received the light of the Gospel, that men might see among the barbarians and them that were far from the knowledge of one only God, that nature was provoked to follow that which is good and those forward to embrace virtue, for that there was never any nation, how rude or barbarous soever, that took not some pleasure to do that which seemed good, thereby to win praise and commendations, which we have said to be the reward of virtue and good life. I delight to speak of these strange histories, and of people that were unchristened, that the virtue of the rude people may give more splendour to our nation, who, seeing them so complete, wise, prudent, and well advised in their actions, might strive not only to follow-imitation being a small matter-but to surmount them, as our religion surpasseth their superstition, and our age more purged, subtle, and gallant than the season wherein they lived and made their virtues known.

1 Paliardise, paillardise, immodesty. 


\section{THE FAMOUS HISTORIE OF FRYER BACON.}





\section{V.}

\section{THE FAMOUS HISTORIE OF FRYER BACON.}

\section{Of the Parents and Birth of Fryer Bacon, and how he addicted himselfe to Learning.}

In most men's opinfons he was borne in the west part of England and was sonne to a wealthy farmer, who put him to schoole to the parson of the towne where hee was borne: not with intent that he should turne fryer (as he did), but to get so much understanding, that he might manage the better that wealth hee was to leave him. But young Bacon tooke his learning so fast, that the priest could not teach him any more, which made him desire his master that he would speake to his father to put him to Oxford, that he might not lose that little learning that hee' had gained : his master was very willing so to doe : and one day meeting his father, told him, that he had received a great blessing of God, in that he had given him so wise and hopefull a child, as his sonne Roger Bacon was (for so was he named), and wished him withall to doe his duty, and to bring up so his child, that hee might shew his thankfulnesse to God, which could not better be done then in making of him a scholler; for he found by his sodaine taking of his learning, that hee was a child likely to prove a very great clerke : hereat old Bacon was not well pleased (for he desired to bring him up to plough and to the cart, as hee himselfe was brought), yet he for reverence sake to the priest, shewed not his anger, but kindly thanked him for his paines and counsell, yet ciesired him not to speake any more concerning that matter; 
for hee knew best what best pleased himselfe, and that he would doe : so broke they off their talke, and parted.

So soone as the old man came nome, he called to his sonne for his bookes, which when he had, he lock'd them up, and gave the boy a cart whip in the place of them, saying to him : Boy, I will have you no priest, you shall not be better learned than $\mathrm{I}$, you can tell now by the almanack when it is best sowing wheat, winen barly, pease, and beane: and when the best libbing ${ }^{1}$ is, when to sell graine and cattell $I$ will teach thee; for $I$ have all faires and markets as perfit in my memory, as Sir John our priest has masse without booke: take mee this whip, I will teach thee the use of it, it will be more profitable to thee then this harsh Latin : make no reply, but follow my counsell, or else by the masse thou shalt feele the smart hand of my anger. Young Bacon thought this but hard dealing, yet would he not reply, but within sixe or eight dayes he gave his father the slip, and went to a cloyster some twenty miles off, where he was entertained, and so continued his learning, and in small time came to be so famous, that he was sent for to the University of Oxford, where he long time studied, and grew so excellent in the studies of art and nature, that not England onely, but all Christendome admired him.

\section{How the king sent for Fryer Bacon, and of the wonderfuil} things he shewed the king and queene.

THE'king being in Oxfordshire, at a Noblemans house, was very desirous to see this famous fryer, for he had heard many times of his wondrous things that he had done by his art: therefore hee sent one for him to desire him to come to the court. Fryer Bacon kindly thanked the king by the messenger, and said, that he was at the kings service, and would suddenly attend him : but sir, saith he (to the gentleman), I pray make you haste, or else I shall be two houres before you at the court. For all your learning (answered the gentleman) I can hardly beleeve this, for schollers, old-men and travellers, may lye by authority. To

1 Libbing, gelding (Dutch, lubben). 
strengthen your beliefe (said Fryer Bacon) I could presently shew you the last wench that you kissed, but I will not at this time. One is as true as the other (said the gentleman) and I would laugh to see either. You shall see them both within these foure houres, quoth the fryer, and therefore make what haste you can. I will prevent that by my speed (said the gentleman), and with that rid his way : but he rode out of his way, as it should seem; for he had but five miles to ride, and yet was he better than three houres a riding them; so that Fryer Bacon by his art was with the king before he came.

The king kindly welcommed him, and said that hee long time had desired to see him; for he had as yet not heard of his life. Fryer Bacon answered him that fame had belide him, and given him that report that his poore studies had never deserved, for hee beleeved that art had many sonnes more excellent then himselfe was. The king commended him for his modesty, and told him; that nothing could become a wise man lesse than boasting : but yet withall he requested him now to be no niggard of his knowledge, but to shew his queene and him some of his skill. I were worthy of neither art or knowledge (quod Fryer Bacon), should I deny your maiestie this small request: I pray seat yourselves, and you shall see presently what my poore skill can performe : the king, queene, and nobles sate them all down. They having so done, the fryer waved his wand, and presently was heard such excellent musicke that they were all amazed, for they all said they had never heard the like. This is, said the fryer, to delight the sense of hearing, I will delight all your other sences ere you depart hence: so waving his wand againe; there was lowder musicke heard, and presently five dancers entred, the first like a court-laundresse, the second like a footman, the third like an usurer, the fourth like a prodigall, the fift. like a foole: these did 'divers excellent changes, so that they gave content to all the beholders, and having done their dance, they all 'vanished away' in their order as they came in. Thus feasted he two of their sences; then waved he his wand againe, and there was another kind of musicke heard, and whilest 
it was playing, tinere was sodainly before them a table richly covered with all sorts of delicates: then desired he the king and queene to taste of some certaine rare fruits that were on the table, which they and the nobles there present did, andswere very highly pleased with the taste; they being satisfied, all vanished away on the sodaine. Then waved he his wand againe, and sodainly there was such a smell; as if all the rich perfumes in the whole world had bin there prepared in the best manner that art could set them out: wililst hee feasted thus their smelling, he waved his wand againe, and there came divers nations in sundry haibits (as Russians, Polanders, Indians, Armenians), all bringing sundry kinds of furres, such as their countries yeelded : all which they presented to the king and queene: these furres were so soft in the touch, that they highly pleased all those that handled them, then after some odde fantasticke dances (after their countrey manner) they vanished away: then asked Fryer Bacon the king's majesty, if that hee desired any more of his skill? the king answered that hee was fully satisfied for that time, and. that hee onely now thought of something that hee might bestow on him, that might partly satisfie the kindnesse that hee had received. Fryer Bacon said, that hee desired nothing so much as his maiesties love, and if that he might be assured of that, hee would thinke himselfe happy in it : for that (said the king) be thou ever sure of it, in token of which receive this jewell, and withall gave him a costly jewell from his necke. The fryer did with great reverence thanke his maiestie, and said : as your maiesties vassall you shall ever finde me ready to do you service, your time of neede shall finde it both beneficiall and delightfull. But amongst all these gentlemen, I see not the man that your grace did send for me by, sure he hath lost his way, or else met with some sport that detaines him so long. I promised to be here before him, and all this noble assembly can witnesse I am as good as my word : I heare him comming : with that entered the gentlleman all bedurted (for he had rid through ditches, quagmires, plashes; and waters, that hee was in a most pittifull case) he seeing the fryer there looked full angerly, and bid a plague on. 
all his devils, for they had led him out of his way, and almost drowned him. Be not angry sir (said Fryer Bacon) here is an old friend of yours that hath more cause: for she hath tarried these three houres for you (with that hee pulled up the hangings, and behinde them stood a kitchen-mayde with a basting-ladle in her hand) now am I as good as my word with you : for I promised to helpe you to your sweetheart, how do you like this? So ill, answered the gentleman, that $I$ will be revenged of you. Threaten not (said Fryer Bacon) least I do you more shame, and doe you take heed how you give schollers the lye againe: but because I know not how well you are stored with money at this time, I will bear her charges home: with that she vanished away: the king; queene, and all the company laughed to see with what shame this gentleman indured the sight of his greasie sweetheart: but the gentleman went away discontented. This done Fryer Bacon tooke his leave of the King and Queene, and received from them divers gifts (as well as thankes) for his art he shewed them.

\section{How Fryer Bacon deceived his Man, that would fast for his} conscience sake.

Fryer Bacon had one onely man to attend on him and he too was none of the wisest, for he kept him in charity, more then for any service he had of him. This man of his (named Miles) never could indure to fast as other religious persons did, for alwayes hee had in one corner, or another, flesh which hee would eate when his maister eat bread only, or else did fast and abstaine from all things. Fryer Bacon seeing this, thought at one time or other to be even with him, which he did one Fryday in this manner. Miles on the Thursday night had provided a great blacke-pudding for his Frydayes fast : this pudding put he in his pocket (thinking belike to heate it so, for his maister had no fire on those dayes) on the next day, who was so demure as Miles, hee looked as though hee would not have eat any thing: when his maister offerd him some bread, hee refused it, saying his sinnes deserved 
a greater penance then one dayes fast in a whole weeke: his maister commended him for it, and bid him take heed that he did not dissemble : for if he did, it would at last be knowne; then were I worse then a Turke said Miles: so went he forth as if he would have gone to pray privately, but it was for nothing but to prey upon his blacke pudding; that pulled he out, (for it was halfe roasted with the heate) and fell to it lustily; but he was deceived, for having put one end in his mouth, he could neither get it out againe nor bite it off, so that hee stamped out for helpe: his maister hearing him, came; and finding him in that manner, tooke hold of the other end of the pudding, and led him to the hall, and shewed him to all the schollers; saying: see here my good friends and fellow students what a devout man my servant Miles is, he loveth not to break a fast day, witnesse this pudding that his conscience will not let him swallow : I will have him to be an example for you all, then tyed hee him to a window by the end of the pudding, where poore Miles stood like a beare tyed by the nose to a stake, and indured many floutes and mockes : at night his maister. released him from his penance; Miles was glad of it, and did vow never to breake more fast dayes whilst that he lived.

\section{How Fryer Bacon saved a Gentleman that had given himselfe to the Devill.}

In Oxfordshire there lived a gentleman, that had through his riotous expences wasted a faire inheritance that was left him by his father: after which hee grew so poore, that he had not wherwith to buy himselfe so much bread as would mainteine his miserable life: the memory of his former state that hee had lived in, and the present want that he now sustained, made him to grow desperate and regardlesse both of his soule and bodies estate: which gave the devill occasion to worke upon his weaknesse in this maner following.

On a time, hee being alone full of griefe and care, (griefe for his folies past, and care how to get a poore living for the 
remainder of his dayes) the Devill came to him and asked him what hee wanted (hee came not in a shape terrible, but like an old penny-father). This gentleman was amazed at his sodaine presence, but hearing him demand of his wants, hee tooke to him courage and said: I want all things, I want money to buy my apparrell, money to buy mee meat, money to redeeme my land and money to pay my debts : can or will you helpe mee in this misery? I will, answered the Devill, on some conditions helpe you to money for to supply all these wants and that sodainly. On any condition, said the Gentleman, helpe mee, and I sweare for to performe them: I take no oathes (answered the Devill) I must have bonds, if you will doe so, meet mee by the woods side to morrow morning, and there I will have the moneys ready: I will, said the gențleman (for hee poore man was glad of it on any conditions, as he said before). The next day hee went to the wood where the Devill had promised to meet him : long had he not been there, but he beheld the Devil comming, and after him two other like servingmen with bagges of money: this reioyced the poore gentlemans heart to thinke that hee should once again live like a man. The Devill comming to him said : sonne I will performe my promise unto you if that you will seale to the conditions that I have here already drawne: willingly, said the gentleman, I will, I pray read them. The Devill read them to this effect : that he lent him so much money as he should have need of, to be imployed to these uses following: First, to redeeme his mortgaged land: next to pay his debts: lastly, to buy him such necessaries as hee wanted: this to be lent on this condition, that so soone as he had paid all debts, that he should be at the lenders disposing, and his without any delay, freely to yeeld himselfe to him upon the first demand of the aforesaid lender. To this the gentleman sealed, and had the money carried to his chamber, with..which money hee in short time redeemed his land, and bought such things as he needed, and likewise payed all his debts, so that there was not any man that could aske him one penny.

Thus lived this gentleman once againe in great credit, and grew 
so great a husband that he increased his estate, and was richer then ever his father before him was : but long did this joy of his not continue, for one day hee being in his studie the Devil appeared unto him, and did tell him that now his land was redeemed, and his debts paid, and therefore the time was come that hee must yeeld himselfe to his mercy, as hee was bound by bond. This troubled the gentleman to heare, but more to thinke how that he must become a slave to a stranger that hee did not know (for hee knew not as yet that he was the Devill) but being urged to answer for himselfe (by the devill) hee said that hee had not as yet paid all his debts, and therefore as yet hee was not liable to the bonds strait conditions. At this the Devill seemed angry and with a fearefull novse transfformed himselfe to an ugly shape, saying, alas poore wretch, these are poore excuses that thou framest, I know them all to be false, and so will prove them to thy face to morrow morning, till when I leave thee to despaire: So with great noyse he went his way, leaving the gentleman halfe dead with feare.

When he was gone, the gentleman reviving bethought himselfe in what a miserable state he was now in, then wished he that he had lived and died poorely, then cursed he all his ambitious thoughts, that led him first to desire againe that wealth which he had so vainly by his riot lost : then would hee curse his prodigall expences that were the originall of all his misery: thus was he tormented a long time in his minde, at last he fully resolved to end his wretched life by some violent death, and to that end he went forth thinking to kill himselfe, which he had done, had it not beene for the Fryer : for as he was falling upon his sword, Fryer Bacon came by and called to him to hold, which he did. Fryer Bacon demanded of him the cause why he was so desperate that he would run headlong to hell? $\mathrm{O}$ sir, said he, the cause is great, and the relation is so terrible to me, that I would intreat you not to trouble me any more, but to leave me to my owne will : his answer filled the Fryer with amazement and pitty both at once, which made him to urge him in this manner. Sir, should I leave you to this wilfull damnation, I were unfit ever 
hereafter to weare or touch any robe that belongeth unto the holy order, whereof I am a brother: you know (I doubt not) that there is given power to the church to absolve penitent sinners, let not your wilfulnesse take away from you that benefit which you may receive by it : freely confesse your selfe (I pray you) unto me, and doubt not but I shall give your troubled conscience ease : Father (said this Gentleman) I know all that you have spoken is truth, and I have many times received comfort from the mother church, (I dare not say our, for I feare that shee will never receive ne for a childe) I have no part in her benediction, yet since you request so earnestly the cause, I will tell you, heare it and tremble. Know then that I have given my selfe to the Devill for a little wealth, and he to morrow in this wood must have me: now have you my griefe, but I know not how to get comfort. This is strange (quoth Fryer Bacon;) yet be of good comfort, penitentiall teares may doe much, which see you doe not spare; soone I will visit you at your house, and give you that comfort (I hope) that will beget you againe to goodnesse: the Gentleman with these words was somewhat comforted and returned home: At night Fryer Bacon came to him, and found him full of teares for his haynous offences, for these teares he gave him hope of pardon, demanded further what conditions hee had made with the Devill; the gentleman told him, how that he had promised himselfe to him so soone as hee had paid all his debts: which he now had done, for he owed not one peny to any man living. Well said Fryer Bacon, continue thy sorrow for thy sinnes, and to morrow meete him without feare, and be thou content to stand to the next mans iudgement that shall come that way, whether thou doest belong to the Devill or no : feare not, but do so, and be thou assured that I will be he that shall come by, and will give such iudgement on thy side, that thou shalt be free from him: with that Fryer Bacon went home, and the gentleman went to his prayers.

In the morning the gentleman (after that hee had blessed himselfe) went to the wood where he found the Devill ready for him. So seone as he came neere, the Devill said, Now, deceiver, are you 
come : now shall thou see that I can and will prove that thou hast paid all thy debts, and therefore thy soule belongeth to me. Thou art a deceiver (said the gentleman) and gavest me money to cheat me of my soule, for else why. wilt thou be thy own judge? let me have some other to iudge between us. Content, said the Devill, take whom thou wilt. 'Then I will have (said the gentleman) the next man that commeth this way. Hereto the Devill agreed. "No sooner were these words ended, but Fryer Bacon came by, to whom this gentleman speake, and requested, that he would be iudge in a waighty matter betweene them two: the Fryer said, he was content, so both parties were agreed: the Devill said they were, and told Fryer Bacon how the case stood between them in this manner.

Know Fryer, that I seeing this prodigall like to starve for want of food, lent him money, not onely to buy him victuals, but also to redeeme his lands and pay his debts, conditionarily that so soone as his debts were paid, that hee should give himselfe freely to mee, to this, here is his hand (shewing him the bond) now my time is expired, for all his debts are paid, which he cannot denie. This case is plaine, if it be so that his debts are paid : his silence confirmes it, said the Divell, therefore give him a iust sentence. I will, said Fryer Bacon: but first tell me (speaking to the gentleman) didst thou never yet give the Devill any of his mony backe, nor requite him any wayes. Never had hee any thing of me as yet (answered the gentleman). Then never let him have any thing of thee and thou art free. Deceiver of mankind, said he (speaking to the Devill) it was thy bargaine, never to meddle with him so long as hee was indebted to any, now how canst thou demand of him any thing, when he is indebted for all that hee hath to thee, when hee payeth thee thy money, then take him as thy due ; till then thou hast nothing to doe with him : and so I charge thee to be gone. At this, the Devill vanished with great horror; but Fryer Bacon comforted the gentleman, and sent him home with a quiet conscience, bidding him never to pay the Devils money backe as he tendred his :owne safety: which he promised for to observe. 
How Liryer Bacon made a Brasen head to speake, by the which hee would have walled England about with Brasse.

FRYER BACON reading one day of the many conquests of England, bethought himselfe how he might keepe it hereafter from the like conquests, and so make himselfe famous hereafter to all posterities. This (after great study) hee found could be no way so well done as one; which was to make a head of brasse, and if he could make this head to speake (and heare it when it speakes) then might hee be able to wall all England about with brasse. To this purpose hee got one Fryer Bungey to assist him, who was a great scholler and a magician, (but not to bee compared to Fryer Bacon) these two with great study and paines so framed a head of brasse, that in the in ward parts thereof there was all things like as in a naturall mans head : this being done, they were as farre from perfectione of the worke as they were before, for they knew not how to give those parts that they had made motion, without which it was impossible that it should speake : many bookes they read, but yet could not finde out any hope of what they sought, that at the last they concluded to raise a spirit, and to know of him that which they could not attaine to by their owne studies. To do this they prepared all things ready and went one evening to a wood thereby, and after many ceremonies used, they spake the words of coniuration, which the Devill straight obeyed and appeared unto them, asking what they would? Know, said Fryer Bacon, that wee have made an artificiall head of brasse, which we would have to speake, to the furtherance of which wee have raised thee, and being raised, we will here keepe thee, unlesse thou tell to us the way and manner how to make this head to speake. The Devill told him that he had not that power of himselfe. Beginner of lyes (said Fryer Bacon) I know that thou dost dissemble, and therefore tell it us quickly, or else wee will here bind the to remaine during our pleasures. At these thretnings the Devill consented to doe it, and told them, that with a continuel fume of the six hotest simples it should have motion, and in one month space speak, the 'Time of the moneth or day hee knew not: also 
hee told them, that if they heard it not before it had done speaking, all their labour should be lost: they being satisfied, licensed the spirit for to depart.

Then went these two learned fryers home againe, and prepared the simples ready, and made the fume, and with continuall watching attended when this Brasen head would speake. Thus watched they for three weekes without any rest, so that they were so weary and sleepy, that they could not any longer refraine from rest. Then called Fryer Bacon his man Miles, and told him, that it was not unknown to him what paines Fryer Bungy and himselfe had taken for three weekes space, onely to make, and to heare the Brasen-head speake, which if they did not, then had they lost all their labour, and all England had a great losse thereby : therefore hee intreated Miles that he would watch whilst that they slept, and call them if the head speake. Feare not, good master (said Miles) I will not sleepe, but harken and attend upon the head, and if it doe chance to speake, I will call you : therefore I pray take you both your rests and let mee alone for watching this head. After Fryer Bacon had given him a great charge the second time : Fryer Bungy and he went to sleepe, and Miles, alone to watch the brasen head: Miles, to keepe him from sleeping, got a tabor and pipe, and being merry disposed, sung this song to a Northren

\section{TUNE OF CAM'ST THOU NOT FROM NEW-CASTLE.}

To couple is a custome, all things thereto agree :

Why should not I then love? since love to all is free.

But Ile have one that's pretty, her cheekes of scarlet die,

For to breed my delight, when that I am her by.

Though vertue be a dowry, yet Ile chuse money store :

If my love prove untrue, with that I can get more. 
The faire is oft unconstant, the blacke is often proud.

Ile chuse a lovely browne, come fidler scrape thy crowd.

Come fidler scrape thy crowd, for Peggie the brown is she Must be my Bride, God guide that Peggie and I agree.

With his owne musicke and such songs as these spent he his time, and kept from sleeping at last. After some noyse the head spake these two words, TIME IS. Miles hearing it to speake no more, thought his master would be angry if hee waked him for that, and therefore he let them both sleepe, and began to mocke the head in this manner : Thou brazen-faced head, hath my master tooke all this paines about thee, and now dost thou requite him with two words, TIME Is: had hee watched with a lawyer as long as he hath watched with thee, he would have given him more, and better words then thou hast yet, if thou canst speake no wiser, they shal sleepe till doomes day for me: TIME IS: I know TIME IS, and that you shall heare goodman Brazenface.

TO THE TUNE OF DAINTIE COME THOU TO ME.

Time is for some to plant,

Time is for some to sowe;

Time is for some to graft

The horne as some doe know.

Time is for some to eate, Time is for some to sleepe, Time is for some to laugh, Time is for some to weepe.

Time is for some to sing, Time is for some to pray, Time is for some to creepe, That have drunke all the day.

Do you tell us copper-nose, when Time is, I hope we Schollers know our times, when to drinke drunke, when to kiss our hostes, 
when to goe on her score, and when to pay it, that time comes seldome. After halfe an houre had passed, the head did speake againe, two wordes, which were these: TIME wAS. Miles respected these words as little as he did the former, and would not wake them, but still scoffed at the brazen head; that it had learned no better words, and have such a tutor as his master, and in scorne of it sung this song.

\section{TO THE TUNE OF A RICH MERCHANT MAN.}

Time was when thou a kettle wert fill'd with better matter :

But Fryer Bacon did thee spoyle, when he thy sides did batter.

Time was when conscience dwelled with men of occupation :

Time was when Lawyers did not thrive, so well by mens vexation.

Time was when kings and beggers of one poor stuffe had being:

Time was when office kept no knaves : that time it was worth seeing.

Time was a bowle of water, did give the face reflection;

Time was when women knew no paint, which now they call complexion.

Time was: I know that brazen-face, without your telling, I know Time was, and I know what things there was when Time was, and if you speake no wiser, no master shall be waked for mee. Thus Miles talked and sung till another halfe houre was gone, then the brazen head spake again these words; TIME Is PAST : and therewith fell downe, and presently followed a terrible noyse, with strange flashes of fire, so that Miles was halfe dead with feare: at this noyse the two Fryers awaked, and wondred to see the whole roome so full of smoake, but that being vanished they night perceive the brazen head broken and lying on the ground : at this sight they grieved, and called Miles to know how 
this came. Miles halfe dead with feare, said that it feil downe of itselfe, and that with the noyse and fire that followed he was almost frighted out of his wits: Fryer Bacon asked him if hee did not speake? yes (quoth Miles) it spake, but to no purpose, Ile have a parret speake better in that time that you have been teaching this brazen head. Out on thee villaine (said Fryer Bacon) thou hast undone us both, hadst thou but called us when it did speake, all England had been walled round about with brass, to its glory, and our eternal fames : what were the wordes it spake? very few (said Miles) and those were none of the wisest that I have heard neither : first he said, TIME Is. Hadst thou call'd us then (said Fryer Bacon) we had been made for ever. Then (said Miles) half an hour after it spake againe and said, TIME waS. And wouldst thou not call us then? (said Bungey) Alas (said Miles) I thought he would have told me some long tale, and then I purposed to have called you : then half an houre after he cried, TIME IS PAST, and made such a noyse, that hee hath waked you himselfe mee thinkes. At this Fryer Bacon was in such a rage that hee would have beaten his man, but he was restrained by Bungey: but neverthelesse for his punishment, he with his art strucke him dumbe for one whole months space. Thus the greate worke of these learned Fryers was overthrown (to their great griefes) by this simple fellow.

How Fryer Bacon by his art took a towne, when the King had lyen before it three months, without doing to it any hurt.

IN those times when Fryer Bacon did all his strange trickes, the Kings of England had a great part of France, which they held a long time, till civill warres at home in this land made them to lose it : it did chance that the King of England (ior some cause best knowne to himselfe) went into France with a great armie, where after many victories, he did beseige a strong towne and lay before it full three moneths, without doing to the towne any great damage, but rather received the hurt himselfe:' This did so vexe the King, that he sought to take it in, any way, either by 
policy or strength: to this intent hee made proclamation, that whosoever could deliver this towne into his hand, hee should have for his paines ten thousand crownes truely paid. This was proclaimed, but there was none found that would undertake it. At length the newes did come into England of this great reward that was promised. Fryer Bacon hearing of it, went into France, and being admitted to the kings presence, hee thus spake unto him : Your malestie I am sure hath not quite forgot your poore subject Bacon, the love that you shewed to mee being last in your presence, hath drawn mee for to leave my countrey, and my studies, to doe your maiestis service: I beseech your grace, to command mee so farre as my poore art or life may doe you pleasure. The king thanked him for his love, but told him, that hee had now more need of armes than art, and wanted brave souldiers more than learned schollers. Fryer Bacon answered, Your grace saith well; but let mee (under correction) tell you, that art oftentimes doth those things that are impossible to armes, which I will make good in some few examples. I will speak onely of things performed by art and nature, wherein shall be nothing magical : and first by the figuration of art, there may be made instruments of navigation without men to rowe in them, as great ships to brooke the sea, only with one man to steere them, and they shall sayle far more swiftly than if they were full of men : also chariots that shall move with an unspeakable force, without any living creature to stirre them. Likewise, an instrument may be made to fly withall, if one sit in the midst of the instrument, and doe turne an engine, by which the wings being artificially composed, may beat ayre after the manner of a flying bird. By an instrument of three fingers high, and three fingers broad, a man may rid himself and others from all imprisonment: yea, such an instrument may easily be made, whereby a man may violently draw unto him a thousand men, will they, nill they, or any other thing. By art also an instrument may be made, wherewith men may walke in the bottome of the sea or rivers without bodily danger : this Alexander the Great used (as the ethnick philosopher reporteth) to the end he might behold the secrets of the seas. 
But physicall figurations are farre more strange : for by that may be framed perspects and looking glasses, that one thing shall appeare to be many, as one man shall appeare to be a whole army, and one sunne or moone shall seem clivers. Also perspects may be so framed, that things farre off sinall seem most nigh unto us : with one of these did Iulius Cresar from the sea coasts in France marke and observe the situation of the castles in England. Bodies may also be so framed that the greatest things shall appeare to be the least, the highest lowest, the most secret to bee the most manifest, and in such like sort the contrary. Thus did Socrates perceive, that the dragon which did destroy the citie and countrey adioyning, with his noisome breath, and contagious influence, did lurke in the dennes between the mountaines: and thus may all things that are done in cities or armies be discovered by the enemies. Againe, in such wise may bodies be framed, that venemous and infectious influences may be brought whither a man will: in this did Aristotle instruct Alexander; through which instruction the poyson of a basiliske, being lift up upon the wall of a citie, the poison was convayd into the citie, to the destruction thereof: also perspects may be made to deceive the sight, as to make a man beleeve that hee seeth great store of riches, when that there is not any. But it appertaineth to a higher power of figuration, that beams should be brought and assembled by divers flexions and reflexions in any distance that we will, to burne any thing that is opposite unto it, as it is witnessed by those perspects or glasses that burne before and behinde; but the greatest and chiefest of all figurations and things figured, is to describe the heavenly bodies, according to their length and breadth in a corporall figure, wherein they may corporally move with a daily motion. These things are worth a kingdom to a wise man. These may suffise, my royall lord, to shew what art can doe: and these, with many things more, as strange, I am able by art to performe. Then take no thought for winning this towne, for by my art you shall (ere many dayes be past) have your desire.

The king all this while heard him with admiration : but hearing 
him now, that hee would undertake to win the towne, hee burst out in these speeches: most learned Bacon, doe but what thou hast said, and I will give thee what thou most desirest, either wealth, or honour, choose which thou wilt, and I will be as ready to performe, as I have been to promise.

Your maiesties love is all that I seeke (said the fryer) let mee have that, and I have honour enough, for wealth, I have content, the wise should seek no more: but to the purpose. Let your pioniers raise up a mount so high, (or rather higher) than the wall, and then shall you see some probability of that which I have promised.

This mount in two days was raised: then Fryer Bacon went with the king to the top of it, and did with a perspect shew to him the towne, as plainly as if hee had beene in it: at this the king did wonder, but Fryer Bacon told him, that he should wonder more, ere next day noone: against which time, he desired him to have his whole army in readinesse, for to scale the wall upon a signal given by him, from the mount. This the king promised. to doe, and so returned to his tent full of joy, that he should gain this strong towne. In the morning Fryer Bacon went up to the mount and set his glasses, and other instruments up: in the meane time the king ordered his army, and stood in a readinesse for to give the assaults: when the signal was given, which was the waving of a flagge: ere nine of the clocke Fryer Bacon had burnt the state-house of the towne, with other houses only by his mathematicall glasses, which made the whole towne in an uprore, for none did know how it came : whilest that they were quenching of the same Fryer Bacon did wave his flagge: upon which signall given, the king set upon the towne, and tooke it with little or no resistance. Thus through the art of this learned man the king got this strong towne, which hee could not doe with all his men without Fryer Bacons helpe.

How Fryer Bacon over-came the German coniurer Vandermast, : and made a spirit of his onue carry him into Germany.

THE king of England after hee had taken the town shewed great mercy to the inhabitants, giving some of thein their lives freely, 
and others he set at liberty for their gold: the towne hee kept at his owne, and swore the chiefe citizens to be his true subiects. Presently after the king of France sent an ambassadour to the king of England for to intreat a peace betweene them. This ambassadour being come to the king, he feasted him (as it is the manner of princes to doe) and with the best sports as he had then, welcomed him. The ambassadour seeing the king of England so free in his love, desired likewise to give him some taste of his good liking, and to that intent sent for one of his fellowes (being a Germane, and named Vandermast) a famous coniuror, who being come, hee told the king, that since his grace had been so bountiful in his love to hin, he would shew him (by a servant of his) such wonderfull things that his grace had never seene the like before. The king demanded of him of what nature those things were that hee would doe: the ambassadour answered that they were things done by the art of magicke. The king hearing of this, sent straight for Fryer Bacon, who presently came, and brought Fryer Bungey with him.

When the banquet was done, Vandermast did aske the king, if he desired to see the spirit of any man deceased : and if that hee did, hee would raise him in such manner and fashion as he was in when that he lived. The king told him, that above all men he desired to see Pompey the Great, who could abide no equall. Vandermast by his art raised him, armed in such manner as hee was when he was slaine at the battell of Pharsalia; at this they were all highly contented. Fryer Bacon presently raised the ghost of Iulius Cæsar, who could abide no superiour, and had slaine this Pompey at the battell of Pharsalia: at the sight of him they were all amazed, but the king who sent for Bacon : and Vandermast said that there was some man of art in that presence, whom he desired to see. Fryer Bacon then shewed himselfe, saying; it was I Vandermast, that raised Cæsar, partly to give content to this royall presence, but chiefely for to conquer thy Pompey, as he did once before, at that great battell of Pharsalia, which he now againe shall doe. Then presently began a fight between Cæsar and Pompey, which continued a good 
space, to the content of all, except Vandermast. At last Pompey was overcome and slaine by Cæsar: then vanished they both away.

My lord ambassadour (said the king) me thinks that my Englishman has put down your German : hath he no better cunning than this? Yes, answered Vandermast, your grace shall see me put downe your Englishman ere that you goe from hence; and therefore Fryer prepare thy selfe with thy best of art to withstand me. Alas, said Fryer Bacon, it is a little thing will serve to resist thee in this kind. I have here one that is my inferior (shewing him Fryer Bungey) try thy art with him; and if thou doe put him to the worst, then will I deale with thee, and not till then.

Fryer Bungey then began to shew his art: and after some turning and looking in his booke, he brought up among them the Hesperian Tree, which did beare golden apples : these apples were kept by a waking dragon, that lay under the tree : He having done this, bid Vandermast finde one that durst gather the fruit. Then Vandermast did raise the ghost of Hercules in his habit that he wore when that he was living, and with his club on his shoulder: Here is one, said Vandermast, that shall gather fruit from this tree: this is Hercules, that in his life time gathered of this fruit, and made the dragon crouch: and now againe shall hee gather it in spight of all opposition. As Hercules was going to plucke the fruit, Fryer Bacon held up his wand, at which Hercules stayed and seemed fearful. Vandermast bid him for to gather of the fruit, or else he would torment him. Hercules was more fearfull, and said, I cannot, nor I dare not: for great Bacon stands, whose charms are farre more powerfull than thine, I must obey him Vandermast. Hereat Vandermast curst Hercules, and threatned him: But Fryer Bacon laughed, and bid not to chafe himself ere that his journey was ended: for seeing (said he) that Hercules will doe nothing at your command, I will have him doe you some service at mine : with that he bid Hercules carry him home into Germany. The Devill obeyed him, and tooke Vandermast on his backe, and went away with him in all their sights. Hold Fryer, cried the ambassadour, I will not loose Van- 
dermast for half my land. Content yourself my lord, answered Fryer Bacon, I have but sent him home to see his wife, and ere long he may returne. The king of England thanked Fryer Bacon, and forced some gifts on him for his service that he had done for him : for Fryer Bacon did so little respect money, that he never would take any of the king.

\section{How Fryer Bacon through his wisdom saved the endangered lives of three Brethren.}

THE peace being concluded betweene the King of England and the King of France, the King of England came againe into his country of England, where he was received very ioyfully of all his subjects: But in his absence had happened a discord betweene three brethren, the like hath not beene often heard. This it was: A rich gentleman of England dyed, and left behind him three sonnes. Now for some reason (which was best known to himselfe) he appointed none of them by name to be his heyre, but spake to them all after this manner: You are all my sonnes, and I love you all as a father should doe, all alike, not one better than the other; and cause I would alwayes doe rightly so neere as I can, I leave all my lands and goods to him that loves me best: These were his last words that he spake concerning any worldly affaires.

After he was dead and buried, there arose a great controversie betwixt them, who should inherit their fathers goods and lands, every one pleading for himselfe, how that he loved his father best. All the cunning lawyers of the kingdome could say nothing to the purpose, concerning this case, so that they were inforced to begge of the king a grant for a combat: for they would not share the lands and goods among them, but every one desired all or else nothing. The king seeing no other way to end this controversie, granted a combat: the two eldest being to fight first, and the conqueror to fight with the youngest, and the survivor of them was to have the land.

The day being come that was set for these combatants, they 
all came in armed for the fight. Fryer Bacon being there present, and seeing such three lustie young men like to perish, and that by their owne flesh and bloode, grieved very much, and went to the king desiring his maiestie that he would stay the fight, and he would finde a meanes without any bloodshed to end the matter : the king was very glad hereof, and caused the combatants to be brought before him, to whom he said: gentlemen, to save the blood of you all, I have found a way, and yet the controversie shall be ended that is now amongst you: Are you contented to stand to his iudgment that I shall appoint? They all answered, that they were. Then were they bid to returne three days aiter. In that time Fryer Bacon had caused the body of their deceased father to be taken out of the ground, and brought to the court: the body hee did cause to be bound to a stake, naked to the middle upwards and likewise prepared three bowes and shafts for the three brethren: all these kept hee secretly.

The third day being come, came these three brethren, to whom Fryer Bacon in the presence of the king gave the three bowes and shafts, saying, be not offended at what I have done, there is no other way but this to judge your cause : See here is the body of your dead father, shoot at him, for he that cometh nearest to his heart, shall have all the lands and goods.

The two eldest prepared themselves, and shot at him, and stucke their arrowes in his breast. Then bid they the youngest to shoot: but he refused it, saying, I will rather lose all, then wound that body that I so loved living: Had you ever had but halfe that love (in you) to him that I have, you would rather have had your own bodies mangled, than to suffer his lifelesse corps thus to be used; nay, you doe not onely suffer it, but you are the actors of this act of shame : and speaking this, he wept.

Fryer Bacon seeing this, did give the iudgement on his side, for he loved his father best, and therefore had all his lands and goods: the other two brothers went away with shame for what they had done. This deed of Fryer Bacons was highly commended of all men : for he did not onely give true judgement, 
but also saved much blood that would have beene shed, had they beene suffered to have fought.

\section{How Fryer Bacon served the Theeves that robbed him, and of the sport that his man Miles had with them.}

Ir was reported about the countrey how that the king had given Fryer Bacon great store of treasure. The report of this wealth made three theeves plot to rob Fryer Bacons house, which they put in practise one evening in this fashion. They knockt at the doore and were let in by Miles: No sooner were they in, but they. took hold of him, and led him into the house, and finding Fryer Bacon there, they told him that they came for some money, which they must and would have ere they departed from thence. He told them, that he was but ill stored with money at that time, and therefore desired them to forbeare him till some other time. They answered him againe, that they knew that hee had enough, and therefore it was but folly to delay them, but straight let them have it by faire means, or else they would use that extremitie to him that hee would bee loth to suffer. Hee seeing them so resolute, told them that they should have all that hee had, and gave to them one hundred pounds a man. Herewith they seemed content, and would have gone their wayes. Nay, said Fryer Bacon, I pray gentlemen at my request tarry a little, and heare some of my mans musicke: you are hyred reasonable well already, I hope in courtesie you will not deny mee so small a request. That will wee not, (said they all).

Miles thought now to have some sport with them, which hee had, and therefore played lustily on his tabor and pipe. So soone as they heard him play (against their wills) they fell a dauncing, and that after such a laborious manner, that they quickly wearied themselves (for they had all that while the bagges of money in their handes.) Yet had Fryer Bacon not revenge enough of them, but bid his man Miles lead them some larger measure as hee thought fitting, which Miles did. Miles straight ledde them out of the house into the fields, they followed him, dauncing after a 
wilde anticke manner : then led hee them over a broad dike full of water, and they followed him still, but not so good a way as he went (for he went over the bridge, but they by reason of their dauncing, could not keepe the bridge, but fell off, and dauncing through the water) then led hee them through a way where a horse might very well have been up to the belly: they followed him, and were so durtie, as though they had wallowed in the myre like swine: sometimes gave hee them rest onely to laugh at them : then were they so sleepie when hee did not play, that they fell to the ground. Then on a sudden would hee play againe, and make them start up and follow him. Thus kept hee them the better part of the night. At last hee in pittie left playing, and let them rest. They being asleep on the bare ground he tooke their money from them, and gave them this song for their farewell, to the tune of, "Oh doe me no harme good man."

You roaring boyes, and sturdy theeves, you pimpes, and aples squires:

Lament the case of these poor knaves, and warme them by your fires.

They snorting lye like hogs in stie. but hardly are so warme :

If all that cheat, such hap should meet, to true men 'twere no harme.

They money had, which made them glad, their ioy did not indure :

Were all theeves serv'd as these have beene, I thinke there would bee fewer.

When that they wake, their hearts will ake, to thinke upon their losse :

And though the gallows they escape, they goe by weeping crosse.

They were scarce any thing the better for this song, for they slept all the while: so Miles left them at their rest : but they had small cause to sleepe so soundly as they did, for they were more wett than ere was scold with cucking. Miles gave his master his money againe, and told the story of their merry pilgrimage: he 
laughed at it, and wisht all men had the like power to serve all such knaves in the like kind. The theeves waking in the morning and missing their money, and seeing themselves in that plight, thought that they had been served so by some divine power, for robbing a church-man, and therefore they swore one to the other, never to meddle with any churchman againe.

How Vandermast, for the disgrace that he had received by Fryer Bacon sent a souldier to kill him; and how Fryer Bacon escaped killing, and turned the souldier from an Atheist to be a good Christian.

FRYER BACON sitting one day in his study, looked over all the dangers that were to happen to him that moneth, there found he, that in the second week of the moneth between sunne rising and setting, there was a great danger to fall on him, which without great care of prevention take away his life. This danger which he did foresee, was caused by the Germane coniurer Vandermast, for he vowed a revenge for the disgrace that he had received. To execute the same, hee hyred a Walloon souldier, and gave him one hundred crownes to do the same, fifty beforehand, and fifty when hee had killed him.

Fryer Bacon, to save himselfe from this danger that was like to happen to him, would alwayes when that he read, hold a ball of brasse in his hand, and under that ball would he set a bason of brasse, that if hee did chance to sleepe in his reading, the fall of the ball out of his hand into the bason, might wake him. Being one day in his study in this manner, and asleepe, the Walloon souldier was got in to him, and had drawne his sword to kill him: but as hee was ready for to strike, downe fell the ball out of Fryer Bacon's hand, and waked him. Hee seeing the souldier stand there with a sword drawne, asked him what hee was? and wherefore hee came there in that manner? The souldier boldly answered him thus : I am a Walloon, and a souldier, and more then this, a villaine: I am come hither, because I was sent; I was sent, because I was hyred; I was hyred, because I durst do it : 
the thing I should doe, is not done : the thing to be done, is to kill thee: thus have you heard what I am and why I came. Fryer Bacon wondered at this man's resolution; then asked hee of him, who set him on worke to bee a murderer? Hee boldly told him, Vandermast the Germane coniurer : Fryer Bacon then asked him what religion he was of? He answered, of that which many doe professe, the chief principles of which were these : to goe to an ale-house, and to a church with one devotion, to absteine from evil for want of action, and to doe good against their wills. It is a good profession for a devil (said Fryer Bacon.) Doest thou believe hell? I believe no such thing, answered the souldier. Then I will shew thee the contrary, said the Fryer: and presently raised the ghost of Iulian the Apostate, who came up with his body burning, and so full of wounds, that it almost did affright the souldier out of his wits. Then Bacon did command this spirit to speake, and to shew what hee was, and wherefore hee was thus tormented? Then spake hee to it in this manner : I sometimes was a Roman Emperor : some count greatnesse a happinesse: I had happinesse beyond my empire, had I kept that, I had beene a happy man : would I had lost my empire when I lost that. I was a Christian, that was my happiness; but my selfe love and pride made me to fall from it; for which I now am punished with never ceasing torments, which I must still endure : the like which I enioy is now prepared for unbeleeving wretches like myself, so vanished he away.

All this while the souldier stood quaking, and sweat as he had felt the torments himselfe; and falling downe on his knees desired Fryer Bacon to instruct him in a better course of life, then he had yet gone in. Fryer Bacon told him, that he should not want his helpe in any thing, which he performed, instructing him better: then gave he him money, and sent him to the warres of the holy land, where he was slain.

\section{How Fryer Bacon deceived an old Usurer.}

Not farre from Fryer Bacon, dwelt an olde man that had great store of money which hee let out to use, and would never doe 
any good with it to the poore, though Fryer Bacon had often put him in minde of it, and wished him to do some good whilest he lived. Fryer Bacon seeing this, by his art made an iron pot, which seemed full of gold. This being done, he went to this rich usurer, and told him, that he had some gold which he had gathered in his time that he had lived; but it being much in quantity, hee feared that if it were knowne, it would be taken from him, because it was unfitting a man of his coat should have so much : now he desired him that hee would let him have some hundred pounds, which was not the sixth part of his gold, and he should kepe it for him. The usurer was glad to heare of this, and told him that he should have it, and that he would keep his gold as safe as himself would: Fryer Bacon was glad to heare of this, and presently fetcht the pot : at the sight of which the usurer laughed, and thought to himself, how all that gold was his owne, for hee had a determination to gull the fryer, but he gulled himselfe. So here is the gold (said Fryer Bacon) now let me have of you one hundred pounds, and keep you this gold till I pay it backe again. Very willingly (said the usurer) and told him one hundred pounds out, which Fryer Bacon tooke and delivered him the note, and so went his way. This mony did Fryer Bacon give to divers poore schollers, and other people and bid them pray for old Good-gatherers soules health (so was this usurer call'd) which these poor people did, and would give him thankes and prayers when they met him, which he did wonder at, for he never deserved the praires of any man. At last this old Good-gatherer went to looke on this pot of gold, but instead of gold he found nothing but earth, at which sight he would have died, had not his other. gold hindred him, which hee was to leave behind him : so gathering up his spirits, hee went to Fryer Bacon, and told him he was abused and cheated; for which he would have the law of him, unlesse he made him restitution. Fryer Bacon told him, that he had not cheated him, but bin his faithful steward to the poore, which he could not chuse but know, either by their prayers, or their thanks; and as for the law he feared it not, but bid him doe his worst. 'The old man seeing Fryer Bacon's 
resolution, went his way, and said, that hereafter hee would be his owne steward.

\section{How Miles, Fryer Bacons man did coniure for meat, and got meate for himselfe and his hoast.}

Miles chanced one day upon some businesse, to goe some six miles from home, and being loth to part with some company that he had, he was be-lated, and could but get halfe way home that night; to save his purse hee went to ones house that was his masters acquaintance : but when he came, the good man of the house was not at home, and the woman would not let him have lodging. Miles seeing such cold entertainment wished he had not troubled her, but being now there, he was loth to goe any further and therefore with good words he perswaded her for to give him lodging that night. She told him that she would willingly doe it, if her husband were at home, but he being now out of towne, it would be to her discredit to lodge any man. You neede not mistrust me, (said Miles) : locke me in any place where there is a bed, and I will not trouble you till to morrow that I rise. She thinking her husband would be angry if she should deny any of his friends so small a request, consented that he should lye there, if that he would be locked up: Miles was contented and presently went to bed, and she locked him into the chamber where he lay.

Long had not he beene a bed, but he heard the doore open; with that he rose and peeped through a chinke of the partition, and saw an old man come in : this man set down his basket that he had on his arme, and gave the woman of the house three or four sweet kisses : then did hee undo his basket, and pulled out of it a fat capon ready roasted, and bread, with a bottle of good olde sacke; this gave hee unto her, saying, Sweetheart, hearing thy husband was out of towne, I thought good to visite thee, I am not come emptie handed, but have brought some thing to be merrie withal : lay the cloihe sweete hony, and let us to banquet. She kindly thanked him, and presently did as he bad her: they 
were not scarce set at the table, but her husband returning backe, knockt at the doore. The woman hearing this was amazed, and knew not what to doe with her old lover: but looking on her apron strings, she straight found, (as women used to doe) a trick to put herself free from this feare; for shee put her lover under the bed, the capon and bread she put under a tub, the bottle of wine shee put behinde the chest, and then she did open the doore, and with a dissembling kisse welcomed her husband home, asking him the reason why that he returned so quickly. He told her, that hee had forgot the money that he should have carried with him, but on the morrow betimes hee would be gone. Miles saw and heard all this : and having a desire to taste of the capon and the wine, called the goodman. He asked his wife who that was? She told him, an acquaintance of his, that intreated lodging there that night. He bid her open the door, which she did, and let Miles out. Hee seeing Miles there, bid him welcome, and bade his wife to set them some meate on the table: she told him that there was not any ready, but prayed him to kepe his stomacke till morrow, and then she would provide them a good breakefast. Since it is so Miles (said the goodman) wee must rest contented, and sleepe out our hunger. Nay stay said Miles, if that you can eate, I can find you good meat; I am a scholler, and have some art. I would faine see it (said the goodman). You shall quoth Miles, and that presently. With that Miles pulled forth a booke out of his bosome, and began his coniuration in this fashion:

From the fearefull lake below, From whence spirits come and goe;

Straightway come one and attend

Fryer Bacons man, and friend.

Comes there none yet? quoth Miles: then I must use some other charme.

Now the owle is flowne abroad, For I heare the croaking toade; And the bat that shuns the day,

Through the darke doth make her way, 
Now the ghosts of men doe rise,

And with fearful hideous cryes,

Seeke revengement (from the good)

On their heads that spilt their blood,

Come some spirit, quicke I say

Night's the Devils holy-day :

Where ere you be, in dennes, or lake,

In the ivy, ewe, or brake:

Quickly come and me attend,

That am Bacons man and friend.

But I will have you take no shape

Of a bear a horse, or ape:

Nor will I have you terrible,

And therefore come invisible.

Now is he come, (quoth Miles) and therefore tell me wnat meat you will have mine hoast? Any thing Miles, (said the goodeman) what thou wilt. Why then (said Miles) what say you to a capon? I love it above all meat (said the goodman). Why then a capon you shall have, and that a good one too. Bemo my spirit that I have raised to doe mee service, I charge thee, seeke and search about the earth, and bring me hither straight the best of capons ready roasted. Then stood hee still a little, as though he had attended the comming of his spirit, and on the sudden said : It is well done, my Bemo, hee hath brought me (mine hoast), a fat capon from the King of Tripolis owne table, and bread with it. Aye but where is it Miles (said the hoast) I see neither spirit nor capon. Looke under the tub (quoth Miles) and there you shall finde it. He presently did, and brought (to his wives griefe) the capon and bread out. Stay (quoth Miles) we do yet want some drinke that is comfortable and good; I think mine hoast a bottle of Maliga sacke were not amisse, I will have it: Bemo, haste thee to Maliga, and fetch me from the governours a bottle of his best sacke. The poore woman thought that hee would have betrayed her and her lover, and therefore wished that he had beene hanged, when that hee came first into her house. Hee having stood a little while, as before, saide, Well done, Bemo, looke behinde the great chest (mine hoast). Hee did so, and brought out the bottle of sacke. Now (quoth hee) Miles sit downe, and wel- 
come to thine owne cheere: You may see wife (quoth he) what a man of art can doe, get a fatte capon, and a bottle of good sacke in a quarter of an houre, and for nothing, which is best of all : Come (good wife) sit downe, and bee inerry; for all this is paid for, I thanke Miles.

Shee sate, but could not eat a bit for anger, but wished that every bit they did eate might choake them: Her old lover too that lay under the bed all this while still looked when that Miles would discover him. When they had eaten and drunke well, the good man desired Miles that hee would let him see the spirit that fetched them this good cheere: Miles seemed unwilling, telling him that it was against the laws of art, to let an illiterate man see a spirit, but yet, for once hee would let him see it: and told him withali, that hee must open the door, and soundly beat the spirit, or else hee should bee troubled hereafter with it, and because he should not feare it, hee would put it in the shape of some one of his neighbours. The good man told him, that hee neede not to doubt his valour, he would beat him soundly, and to that purpose hee took a good cudgell in his hand, and did stande ready for him. Miles then went to the bed side, under which the old man lay, and began to coniure him with these words,
Bemo quickly come, appeare,
Like an old man that dwells neere ;
Quickly rise, and in his shape,
From this house make thy escape;
Quickly rise, or else I sweare,
Ile put thee in a worser feare.

The old man seeing no remedy, but that hee must needes come forth, put a good face on it, and rose from under the bed: Behold my spirit (quoth Miles) that brought me all that you have had; now bee as good as your word and swaddle him soundly. I protest (said the goodman) your Devill is as like Goodman Stumpe the tooth-drawer, as a pomewater is like an apple : is it possible that your spirits can take other mens shapes: Ile teach this to keepe his owne shape; with that hee beat the old man soundly, so that Miles was faine to take him off, and put the old 
man out of doore, so after some laughing, to bed they all went : but the woman could not sleepe for griefe, that her old lover had had such bade usage for her sake.

How Fryer Bacon did helpe a young man to his Sweetheart, which Fryer Bungye would have married to another; and of the mirth that was at the wedding.

AN Oxfordshire gentleman had long time loved a faire mayde, called Millisant; this love of his was as kindly received of her, as it was freely given of him, so that there wanted nothing to the finishing of their ioyes, but the consent of her father, who would not grant that she should bee his wife (though formerly he had been a meanes to further the match) by reason there was a knight that was a suitor to her, and did desire that hee might have her to his wife : but this knight could never get from her the least token of good wil : so surely was her love fixed upon the gentleman. This knight seeing himselfe thus despised, went to Fryer Bungye, and told him his mind, and did promise him a good piece of money if he could get her for him, either by his art, or counsell.

Bungye (being covetous) told him, that there was no better way in his mind, than to get her with her father to go take the air in a coach : and if hee could doe so, he would by his art so direct the horses, that they should come to an old chappell, where hee would attend, and there they might secretly be married. The knight rewarded him for his counsell, and told him that if it tooke effect, he would be more bountifull unto him, and presently went to her father, and told him of this. Hee liked well of it, and forced the poore maid to ride with them. So soone as they were in the coach, the horses ran presently to the chappell, where they found Fryer Bungye attending for them: at the sight of the church and the priest, the poore maid knew that she was betraid, so that for griefe shee fell in a swound: to see which her father and the knight, were very much grieved, and used their best skill for her recovery.

In this time, her best beloved, the gentleman, did come to her 
fathers to visit her, but finding her not there, and hearing that shee was gone with her father and the knight, he mistrusted some foul play: and in all hast went to Fryer Bacon, and desired of him some help to recover his love againe, whom he feared was utterly lost.

Fryer Bacon (knowing him for a vertuous gentleman) pittyed him; and to give his griefes some release, shewed him a glasse, wherein any one might see any thing done (within fifty miles space) that they desired: so soone as he looked in the glasse, hee saw his love Millisant with her father, and the knight, ready to be married by Fryer Bungye : at the sight of this hee cryed out that he was undone, for now should he lose his life in losing of his love. Fryer Bacon bids him take comfort, for he would prevent the marriage; so taking this gentleman in his armes, he set himselfe downe in an enchanted chaire, and suddenly they were carried through the ayre to the chappell. Just as they came in, Fryer Bungye was ioyning their hands to marry them: but Fryer Bacon spoyled his speech, for he strucke him dumbe, so that he could not speake a worde. Then raised he a myst in the chappell, so that neither the father could see his daughter, nor the daughter her father, nor the knight either of them. Then tooke he Millisant by the hand, and led her to the man she most desired : they both wept for ioy, that they so happily once more had met, and kindly thanked Fryer Bacon.

It greatly pleased Fryer Bacon to see the passion of these two lovers, and seeing them both contented, he marryed them at the chappell doore, whilest her father, the knight, and Fryer Bungye went groping within, and could not find the way out. Now when he had married them, he bid them get lodging at the next village, and he would send his man with money: (for the gentleman was not stored, and he had a great way to his house) they did as he bad them. That night hee sent his man Miles with money to them; but he kept her father, the knight, and Fryer Bungey till the next day at noon in the chappell, ere he released them.

The gentleman and his new married wife made that night a 
great supper for ioy of their marriage, and bid to it most of the village : they wanted nothing but musicke, for which they made great moane. This want, Fryer Bacon (though he was absent) supplied : for after supper there came such a maske, that the like was never seene in that village: for first, there was heard most sweet still musicke, then wind musicke: then came three apes, and three monkeys, each of them carrying a torch : after them followed sixe apes and monkeys more, all dressed in anticke coats: these last sixe fell a dancing in such an odde manner, that they moved all the beholders to much laughter: so after divers antick changes, they did reverence to the bridegroome and bride, and so departed in order as they came in. They all did marvell from whence these should come: but the bridegroome knew that it was Fryer Bacons art that gave them this grace to their wedding. The next daye he went home to his owne house with his bride : and for the cost he had bestowed on them, most part of the townes-folke brought them on their way.

Miles made one amongst them too; he for his masters sake was so plyed with cups, that he in three dayes was scarce sober: for his welcome, at his departure he gave them this song: to the tune of, "I have been a fiddler," \&c.

And did you heare of a mirth that befell, the morrow after a wedding day:

At carrying a bride at home to dwell, and away to Twiver, away, away!

The Quintin was set, and the garlands were made, 'tis a pity old custome should ever decay :

And woe be to him that was horst on a iade, for he carried no credit away, away.

We met a consort of fiddle-de-dees, we set them a cock-horse, and made them to play

The winning of Bullen, and Upsie-frees, and away to Twiver, away, away.

There was ne'er a lad in all the parish, that would goe to the plow that day:

But on his fore-horse his wench he carries, and away to Twiver, away, away. 
The butler was quicke, and the ale he did tap, the maidens did make the chamber full gay:

The serving-men gave me a fuddling cap, and I did carye it away, away.

The smithe of the towne his liquor so tooke, that he was perswaded the ground look'd blue, And I dare boldly to sweare on a booke, such smiths as he there are but a few.

A posset was made, and the women did sip, and simpering said they could eate no more:

Full many a maid was laid on the lip;

Ile say no more, but so give o're.

They kindly thanked Miles for his song, and so sent him home with a foxe at his tayle. His master asked him, where he had beene so long? He told him at the wedding. I know it, (said Fryer Bacon) that thou hast beene there, and I know also (thou beast) that thou hast beene every day drunke. That is the worst that you can say by me, master, for still poore men must be drunke, if that they take a cup more than ordinary; but it is not so with the rich. Why how is it with the rich then? I will tell you (said Miles) in a few words,

Lawyers they are sicke;

And Fryers are ill at ease ;

But poore men they are drunke;

And all is one disease.

Well sirrah (said Fryer Bacon) let me not heare that you are infected any more with this disease, lest I give you sowre sawce to your sweet meat. Thus did Fryer Bacon helpe these poore lovers, who in short time got the love of the old man, and lived in great ioy : Fryer Bungey's tongue was againe let loose, and all were friends.

How Vandermast and Fryer Bungye met, and how they strived z'ho should excel one another in their coniurations: and of their deaths.

VANDERMAST thinking that Fryer Bacon had beene dead, came into England, and in Kent met with Fryer Bungey: he owing 
him no good will for Fryer Bacons sake, took his horse out of the stable, and instead of it, leit a spirit like unto it. Fryer Bungye in the morning rose, and mounting this spirit, (which he thought had beene his horse) rode on his iourney : but he riding through a water, was left in the midst of it by this spirit; and being thus wet, hee returned to his inne. At the inne doore, Vandermast met him, and asked him, if that were swimming time of the year? Bungye told him, if that he had been so well horsed as he was, when Fryer Bacon sent him into Germany, he might have escaped that washing. At this Vandermast bit his lip, and said no more, but went in. Bungye thought that he would be even with him, which was in this manner. Vandermast loved a girl well, which was in the house, and sought many times to winne her for gold, love, or promises. Bungye knowing this, did shape a spirit like her, which he sent to Vandermast. Vandermast appointed the spirit to come to his chamber that night, and was very ioyful : but his ioy turned into sorrow, and his wanton hopes into a bad nights lodging: for Fryer Bungye had by his art spread such a sheet on his bed, that no sooner was he laid with the spirit on it, but it was carryed through the ayre, and let fall into a deepe pond; where Vandermast had been drowned, if he had not had the art of swimming : He got quickly out of the pond, and shaked himselfe like a rough water-spaniel : but being out, he was as much vexed as before, for he could not tell the way home, but was glad to keepe himselfe in heat that night with walking. Next day he coming to his inne, Fryer Bungye asked him how he did like his wash? He said, so well, that he wished him such another. Thus did they continually vexe each other, both in words, and ill actions. Vandermast desiring to do Fryer Bungey a mischiefe, did challenge him to the field (not to fight at sword and dagger, single rapier, or case of poinyards, but at worser weapons farre, it was at that diabolical art of magicke) there to shew which of them was most cunning, or had most power over the Devill: Bungye accepted of his challenge, and both provided themselves of things belonging to the art, and to the field they went. 
There they both spred their circles some hundred foot from one another: and after some other ceremonies did Vandermast begin: hee by his charmes did raise up a fiery dragon, which iid runne about Fryer Bungyes circle, and did scorch him with his heat so that he was almost ready to melt. Fryer Bungye tormented Vandermast in another element : for he raised up the sea-monster that Perseus killed, when he did redeem the faire Andromeda. This sea-monster did run about Vandermast, and such flouds of water did he send out of his wide mouth, that Vandermast was almost drowned. Then did Fryer Bungye raise a spirit up like saint George, who fought with the dragon, and killed it: Vandermast (following his example) raysed up Perseus, who fought also with his sea-monster, and killed it, so were they both released from their danger.

They being not contented with this tryall of their skill, went further in their coniurations, and raised up two spirits, each of them one. Bungye charged his spirit for to assist him with the greatest power hee had, that by it he might be able to overcome Vandermast. The Devill told him he would, if that he from.his left arme would give him but three drops of blood; but if that he did deny him that, then should Vandermast have power over him to doe what he would: the like told Vandermasts Devill to him : to this demand of the spirits, they both agreed, thinking for to overcome each other; but the Devill overthrew them both.

They having given the Devill this bloud, as is before spoken of, they both fell againe to their coniurations : first, Bungye did rayse Achilles with his Greekes, who marched about Vandermast and threatned him. Then Vandermast raised Hector with his Troians, who defended him from Achilles and the Greekes. Then began there a great battell between the Greekes and Troians, which continued a good space : at last Hector was slaine, and the Troians fled. Then did follow a great tempest, with thundring and lightning, so that the two coniurers wished that they had been away. But wishes were in vaine: for now the time was come, that the Devill would be paid for the knowledge that he had lent them, 
he would not tarry any longer, but then tooke them in the height of their wickednesse, and bereft them of their lives.

When the tempest was encled, (which did greatly affright the townes there by) the townesmen found the bodies of these two men, (Vandermast and Bungey) breathlesse, and strangely burnt with fire. The one had Christian buriall, because of his order sake : the other, because he was a stranger. Thus was the end of these two famous coniurers.

How Miles would coniure for money, and how he broke his legge for feare.

Miles one day finding his Masters study open, stole out of it one of his coniuring-bookes : with this booke would Miles needes coniure for some money: (for he saw that his master had money enough, and he desired the like, which did make him bold to trouble one of his masters devils :) in a private place he thought it best to doe it : therefore he went up to the top of the house, and there began to reade: long had he not read, but a devill came to him in an ugly shape, and asked him what he would have? Miles being affrighted, could not speake, but stood quaking there like an aspin leafe : the devill seeing him so, (to increase his feare) raised a tempest, and hurled fire about, which made Miles leape from off the leades, and with his fall broke his legge.

Fryer Bacon hearing this noyse, ranne forth, and found his man Miles on the ground, and the Devill hurling fire on the house top. First laid he the Devill againe : then went he to his man and asked how hee got that broken legg? Hee told him his Devill did it : for he had frighted him, and made him leape off from the house top. What didst thou there? (said his Master.) I went to coniure, Sir (said Miles) for money; but I have got nothing but a broken legge; and I now must beg for money to cure that, if you be not the more pittifull to me. I have oftentimes given you warning not to meddle with my bookes (said his Master) and yet you will still be doing: take heed, you had best, 
how you deale with the Devill againe : for he that had power to breake your legge will breake your necke, if you againe doe meddle with him : for this I doe forgive you : for your legge breaking hath paid for your sawcinesse : and though I gave you not a broken head, I will give you a plaister : and so sent him to the chirurgions.

How two young Gentlemen that came to Fryer Bacon, to knoze how their fathers did, killed one another; and how Fryer Bacon for griefe, did breake his rare Glasse, wherein he could see any thing that was done within fifty miles about him.

IT is spoken of before now, that Fryer Bacon had a glasse, which was of that excellent nature, that any man might behold any thing that he desired to see within the compasse of fifty miles round about him: with this glasse he had pleasured divers kinds of people : for fathers did oftentimes desire to see (thereby) how their children did, and children how their parents did ; one friend how another did; and one enemy (sometimes) how his enemy did : so that from far they would come to see this wonderfull glasse. It happened one day, that there came to him two young gentlemen, (that were countrey men, and neighbors children) for to know of him by his glasse, how their fathers did: Hee being no niggard of his cunning, let them see his glasse, wherein they straight beheld their wishes, which they (through their owne follies) bought at their lives losse, as you shall heare.

The fathers of these two gentlemen, (in their sonnes absence) were become great foes: this hatred betweene them was growne to that height, that wheresoever they met, they had not onely wordes but blowes. Just at that time, as it should seeme, that their sonnes were looking to see how they were in health, they were met, and had drawne, and were together by the eares. Their sonnes seeing this, and having been alwayes great friends, knew not what to say to one another, but beheld each other with angry lookes. At last, one of their fathers, as they might perceive in the glasse, had a fall, and the other taking advantage, 
stood over him ready to strike him. The sonne of him that was downe, could then containe himselfe no longer, but told the other young man, this his father had received wrong. $\mathrm{He}$ answered againe, that it was faire. At last there grew such foule words betweene them, and their bloods were so heated, that they presently stabbed one the other with their daggers, and so fell downe dead.

Fryer Bacon seeing them fall, ranne to them, but it was too late, for they were breathlesse ere he came. This made him to grieve exceedingly: he iudging that they had received the cause of their deaths by this glasse, tooke the glasse in his hand, and uttered words to this effect :

Wretched Bacon, wretched in thy knowledge, in thy understanding wretched; for thy art hath beene the ruine of these two gentlemen. Had I been busied in those holy things, the which mine order tyes me to, I had not had that time that made this wicked glasse : wicked I well may call it, that is the causer of so vile an act : would it were sensible, then should it feele my wrath; but being as it is, lle ruin it for ruining of them : and with that he broke his rare and wonderfull glasse, whose like the whole world had not. In this grief of his, came there newes to him of the deaths of Vandermast and Fryer Bungey: This did increase his griefe, and made him sorrowfull, that in three days he would not eate any thing but kept his chamber.

Howe Fryer Bacon burnt his books of Magick, and gave himselfe to the study of Divinity only; and hoze he turned Anchorite.

In the time that Fryer Bacon kept his chamber, hee fell into divers meditations: sometimes into the vanity of arts and sciences: then would hee condemne himselfe for studying of those things that were so contrary to his order and soules health; and would say, that magicke made a man a Devill: sometimes would hee meditate on divinity; then would he cry out upon himselfe, for neglecting the study of it, and for studying magick : sometime. would he meditate on the shortnesse of mans life 
then would he condemne himselfe for spending a time so short, so ill as he had done his: so would he goe from one thing to another and in all condemne his former studies.

And that the world should know how truly he did repent his wicked life, he caused to be made a great fire; and sending for many of his friends, schollers, and others, he spake to them after this manner: "My good friends and fellow students, it is not unknowne unto you, how that through my art $I$ have attained to that credit, that few men living ever had: of the wonders that I have done, all England can speak, both king and commons: I have unlocked the secret of art and nature, and let the world see those things, that have layen lid since the death of Hermes, that rare and profound philosopher: my studies have found the secrets of the starres; the bookes that I have made of them, doe serve for presidents to our greatest doctors, so excellent hath my judgment beene therein. I likewise have found out the secrets of trees, plants and stones, with their several uses; yet all this knowledge of mine I esteeme so lightly, that I wish that I were ignorant, and knew nothing : for the knowledge of these things, (as I have truly found) serveth not to better a man in goodnesse, but onely to make him proud and thinke too well of himselfe. What hath all my knowledge of natures secrets gained me? Onely this, the losse of a better knowledge, the losse of divine studies, which makes the immortall part of man (his soule) blessed. I have found, that my knowledge has beene a heavy burden, and has kept downe my good thoughts : but I will remove the cause, which are these bookes: which I doe purpose here before you all to burne." They all intreated him to spare the bookes, because in them there were those things that afterages might receive great benefit by. $\mathrm{He}$ would not hearken unto them, but threw them all into the fire, and in that flame burnt the greatest learning in the world. Then did he dispose of all his goods; some part he gave to poor schollers, and some he gave to other poore folkes: nothing left he for himselfe: then caused he to be made in the church-wall a cell, where he locked himselfe in, and there remained till his death. His time hee 
spent in prayer, meditation, and such divine exercises, and did seeke by all means to perswade men from the study of magicke. Thus lived he some two yeeres space in that cell, never comming forth: his meat and drink he received in at a window, and at that window he did discourse with those that came to him; his grave he digged with his owne nayles, and was laid there when he dyed. Thus was the Life and Death of this famous Fryer, who lived most part of his life a Magician, and dyed a true Penitent Sinner, and an Anchorite. 


\section{THE HISTORY OF GUY EARL OF WARWICK.}



VI.

\section{THE HISTORY OF GUY EARL OF WARWICK.}

\section{CHAPTER I.}

An account of his parents, birth, and youthful exploits; and how he fell in love with Earl Roband's beautiful daughter, who despised his suit.

I SHALL not trouble the reader with a long genealogy of the descent of our famous Guy of Warwick (the subject of our ensuing history); it shall therefore suffice to tell the reader, that in the sixth year of the reign of King Edgar the Great, this, our famous Guy, was born in the city of Warwick. His father was a gentleman of Northumberland, in which country he had been (in the time of the Mercian kings) the possessor of a fair estate: but the arms of King Edgar prevailing over the King of Mercia, as well as the rest of the Saxon kings that constituted the heptarchy, Guyraldus Cassibilanus (for that was the name of Guy's father), being engaged on the behalf of the King of Mercia, whose subject he was, lost his estate in the quarrel: and afterwards seeking to mend his fortune in our most southern climates, he came to Warwick, and was so well received of the gentry there, but especially of Earl Roband, who was then the King's governor, both of the town and castle, that he made him his steward; in which place he so well acquitted himself, that he married the daughter of an eminent knight in that town; and by her he had a son, who at his very birth looked like a hero, and whom his 
father named Guy, and who, in process of time, became Earl of Warwick, whose life and noble actions are the subject of our present history. There were not wanting some presages of his future greatness, even before he was born ; particularly, his mother, during her pregnancy, dreamed that she saw Mars descend in a bloody chariot, drawn by two fiery dragons; and telling her, "That the infant contained in her womb, should so excel in arms, that he should be the glory of this nation, and the terror of the Pagan world:" which dream she discovered to the Countess of Warwick, above a month before she was delivered of him. And indeed, being born, he gave early proofs of his being an extraordinary man ; for he was scarce come to be eight years old, before he gave the world some early prognostics of his great strength and martial genius, by beginning to practise running, wrestling, throwing stones, and other exercises, even above what his young years were capable of ; exceeding those that were both older and bigger than himself; and for which he was observed by all spectators. And as he grew more towards maturity, he delighted in. hardships, and such exercises as required both strength and labour; so that at sixteen there were but few that durst encounter with him; for then he would use to enter the lists, and always came off victorious. Which coming to Earl Roband's ears, he sent for him, and entertained him at dinner with himself, and several of the gentry of the country, who were very well pleased with his conversation; after which he played several prizes before the Earl, carrying the day, whatever he played with.

But by being at the Earl's house, he came to have a sight of fair Phælice, his beautiful daughter, with whom he was so extremely taken, that nothing but she could satisfy him. She was indeed so fair, that she could not be seen without being loved. She was so fair, Venus herself could never boast more beauty; and had she but been present at the famous contest between Juno, Pallas, and Venus, about the golden apple, on which was writ, "Let it be given to the fairest," she had certainly borne away the prize from them all. And some have affirmed, that all the odds between Venus and her was, that Venus had a mole, 
and she had none: for she had most directly Venus's hair, the same high forehead and attractive eyes: the roses and the lilies in her cheeks were mixed with that equality, that none could say which of them had the ascendant; her lips were of a perfect coral dye, nor.could the ivory match her teeth for whiteness. She was indeed from head to foot the mirror of all comeliness, an English phœnix, the only supreme fair ; of whom it was the general opinion, beauty could nowhere but in Phælice's face be found in its perfection; but these perfections were so many daggers, sticking poor Guy to the heart; for he imagined these charming looks of hers did unto him dart nothing but disdain; and that which his eyes looked on with delight, did nothing else but fill his heart with pain. One while her smiles gave him encouragement; another time the sternness of her looks tossed him upon the billows of despair. He would often sigh at the capriciousness of Fortune, that she should deal so very strangely by him, to give a wound that beauty would not heal. Then, recollecting himself, he would say, "Fond man, why will not beauty heal thy wound? Thou wrongest thyself and thy fair goddess too, for who can know a woman's heart by her looks? And looking on her is all that thou hast done. Well, now I will take a course shall be more resolute: I will speak, or let her know my mind by writing. But if I should, can I have any hopes that she should hear my words, or read my lines? She is Earl Roband's heir, and born too high to listen to such poor designs as mine. For, though I am a gentleman by birth, yet I have no earldoms, nor lordships neither; and women are exceedingly ambitious, and mounting up upon the wings of pride, do oftener match themselves for worldly treasure, than for that sacred love that is far more precious; which makes some rather wish there were no gold, than love should be so basely sold for it. And if my Phælice shoukl be such a one, what will my words, or tears, or sighs prevail? I only strive against the wind and tide, and heap continual torments on my soul. Why should I then attempt with waxen wings to fly where Phœbus's chariot burns so brightly? But hold," said he again, "thou timorous lover, and banish fear, or let thy passion go; be resolute, and 
thou shalt have success; for Phælice, douitiess, has a tender heart; and he that shoots Love's darts may well befriend thee, because thy love is so like his mother's picture. I am resolved to go to Phælice's bower, and from as true a heart as flesh can yield, entreat her in a happy hour to hear me, and with kind pity to remove my sorrows; to look upon me with a tender breast, since as her love is inclined, I hold my life."

This said, he unto Warwick Castle goes, where the rich jewel of his heart remained. Earl Roband bids him welcome, and prepares to entertain him with a match of hunting, but he to that lends an unwilling ear, and to prevent it pretends sudden sickness. The Earl was grieved at this alteration, and sent his own physician to him, who told him, that the only remedy consisted in his being presently let blood, and that his body, under that distemper, was very difficult and hard to cure.

To which Guy thus replied, "Doctor, I do applaud your juagment, and know full well that what you say is true. I find myself exceeding ill. But there is a flower, which, if I might but touch, would heal me better far than all the skill of Galen and Hippocrates to boot : it is called by a pretty pleasing name, and I think Phælix soundeth something like it."

"I know it not," replied the doctor to him, "nor is there in the herbal any flower that beareth such a name as I remember."

"Yes, yes," said Guy, "I am sure there is such a flower, and that it is to be got within this castle; nor doth it grow far from yonder tower. But, doctor, I can find it out myself, and therefore will not give you so much trouble." On which the doctor left him. Whilst Guy, bemoaning his unhappy state, sat sighing by a window all alone, which window had a very curious prospect into a pleasant and delightful garden; in which, as suddenly he cast his eye, he saw the adored empress of his thoughts, which did so much exhilarate his soul, that he despised physicians and their potions. Fear now was banished, and Hope reigned as king. "This is a lucky time," said Guy to himself, "which I so long have waited for. Now the bright sun of fortune shines upon me. Now may I end the grief that Love began, and court my 
Destiny while thus she smiles. Now I will enter into yonder shade to court the only paragon of beauty. Phælice, I come: now Cupid, now assist me : prepare an arrow ready for thy bow, and send it to the heart of her I love. And since I never went a wooing yet, be now propitious to me. Give such prevailing rhetoric to my tongue, that Phælice's heart may hang upon my lips. But above all, grant this, O gentle Cupid, that when I make most solemn protestations of my sincere and ever constant love, that she may believe my words."

Then down with speed he goes unto the garden, where softly knocking, he was soon let in by a young maid that waited upon Phælice; who seeing him, and thinking he had been sent thither by her father, as he was coming towards her, rose up to meet him; whom Guy, with Love's enchanting eye beholding, with a becoming mien, accosts her thus :

"Fairest of all the curious works of nature, whose equal never breathed in common air, more wonderful than any earth can yield, the bright idea of celestial beauty. Eternal honour wait upon thy name. The suit I have to thee is much like that which once Leander came to Hero with, hoping thereby to reap more lovely fruit than ever Mars gained from the queen of Love, when he outwitted Vulcan. The present which I bring, is a heart filled with love, and love can only satisfy my soul. Incline then, madam, to my humble motion : compassionate the griefs that I endure, and let that life that rests at your devotion be regarded. With pity take my dying heart in cure, and let it not expire in groaning torments, nor burst with griefs, because too well it loves thee. I know, dear Phælice, that great princes love thee, and deeds of honour for thy sake have done. But neither king nor prince can love thee more, no, nor so much as I, though but the son of thy great father's steward; for so inestimable is my love, that whatsoever all others shall pretend, can never countervail it."

Whilst thus poor Guy was making protestations, Phælice thus interrupted him :

"O'gentle youth, speak not of love, I pray thee, for that is a thing I have no mind to hear of : virginity with me shall live and 
die. Love is composed of play and idleness, and leadeth only unto vain delight. Besides, it is in thee too great a boldness, for thou art far inferior to my degree: and should thy love be to my father told, I know it would procure thee a reproof. And therefore learn instruction from the proverb, 'That princely eagles scorn to catch flies.' Then, if thou in thy suit wouldst have success, let thy desires be equal to thy fortune, and aim not at those things that are above it. Thou ownest, thyself, princes have courted me; then why should $I$, that have refused their courtship, stoop down so low as to my father's steward; nay, lower yet, unto his steward's son? My youth and beauty is but in its bloom, and I have no mind to throw it away on one that is so much inferior to me." And with this answer she departed from him, leaving poor Guy more troubled now than ever: for now, almost hopeless in love, he never does expect its comforts more :-

But all his time he does to sorrow give,

Wishing each day the last that he may live.

\section{CHAPTER II.}

How Guy, after his being despised by Phalice, grew almost distracted, till she, being admonished by a vision, shews herself more favourable to him.

LOADED with grief, poor Guy could take no rest, distracted in his melancholy mind, refusing all things that delightful-seemed, as harsh, distasteful, and abhorred by him. Phælice denies him love, and slights his suit; and then what comfort can the world afford him? He looks like one, whom faith had doomed to death. And like Orestes, in his frantic fits, he tears the golden tresses from his head; or mad Orlando, when of sense deprived; from whom the use of reason is departed: so fares it with this love-tormented man, whose ranging thoughts run all into disorder: Society he shuns, and keeps alone, accusing Destiny, and cursing Beauty. He is a friend to none, but hates himself beyond the bounds of nature and of love. "Venus," cries he, "how are thy" 
laws forgot, to punish him who never did offend thee? what is the cause that I am thus rejected? who interrupts my love to Beauty's mirror? I will drag him hence to roaring Frebus, there to be plagued with never ceasing tortures. I will to the court of Jove, where my loud shouts shall, with their clamour, rend the very skies. Shall I be cozened, as Orpheus was? Assist me, Thersus, to revenge this wrong. Where is Rhadamant, that Justice cannot pass? Eurydice even for a song is sold; fiends, furies, goblins, hydras, for a fall I am prepared to manage every one of you. I will mount upon the back of Pegasus, and in bright Phœbus's flames I will wrap myself. Then will I tumble windy Aolus to sleep in Thetis's watery crystal lap. From thence I will post unto the torrid zone, to find which way fair Phælice's love is fled. Jason had luck to win the golden fleece: I like the skin, but care not for the horns. Fair Helen was a wanton Grecian wench. Bold Mars will venture; Venus cannot help it. Trust a fair face! not I ; let him that list. What is Hercules without a club in his hand?"

Thus of his senses was poor Guy deprived; thus did he rave and say he knew not what, being left by Love as blind as Cupid's . eyes, till reason reassumed her rule again, and wild disordered passions ceased to tyrannise: for in nocturnal visions Phælice saw the power of Love, and gave to Guy her heart.

When Morpheus, drowsy serjeant of the night, had with his leaden key locked up the sense, and laid on Phælice's eyes his sable mace, the heart-tormentor Cupid, he that wounds, and makes poor lovers buy their bargains dear, sends from his bow a golden-headed shaft, and wounded Phælice in her maiden bed; and to her sight presents a martial man, in armour clad, and fit for all encounters. "Give him thy heart," said he, "for he deserves it. For comely shape and limbs, courage, and valour, the world hath not a champion that is like him. Great honour, lady, thou shalt thereby gain, to adorn thy birth, that is noble and renowned. He shall aspire to such a height of fame, that kings and princes shall his friendship covet.: He shall the glory of his country be, and by the sword perform such wondrous things, that kings shall 
court him to become their champion. Be not ambitious then that thou art high born, nor be disdainful of a mean estate. Be not defiled then with a scornful soul, nor lifted up, because Heaven has made thee fair ! for it is in vain against my bow to strive. If I say love, it must and shall be so. Fix not thy thoughts then upon worldly wealth, for coin has no affinity to love, although by stealth it draws away the heart. Nor can these money matches ever be happy ; for as the goods of fortune do decay, so does that Love which they beget consume. I know the sway that golder treasures bear, by false illusions, and by base deceits, and see how women's humours now-a-days run after riches to their own confusion. I see that every abject country peasant, with gold enough; can buy a dainty wife. But, Phælice, if thou knewest as well as I, how much displeased Heaven is at such abuses, thou wouldst scorn that ever virgins should be sold for gold and silver, as your cattle are. Love must be simple, harmless, plain, and pure; and grounded upon sincere affection; and it must likewise be reciprocal, or else it is not as it ought to be. Love's inward thoughts too, must in outward deeds (such as from sacred truth proceed) concur. Thy lover comes not for advancement to thee, because thy father is a worthy Earl; nor for Arabian spice, nor Indian gems; but as great Jupiter to Leda came, it is only to enjoy thy. love and beauty. Therefore, sweet virgin, use him well and kindly; make much of him, embrace him for thy own, and let him in thy heart have a chief place : let him no longer for thee moan and grieve, but when thou seest him next, give him encouragement; and in the arms of thy affection let him be embraced." And with that word EMBRACED, he shot and hit the very centre of her tender heart. Feeling the wound, shè starts, and then awaked, being thereby taught to pity smarting lovers; for Cupid to the head his arrow drew, because he would be sure it should hit home. With that she fetched a very grievous sigh, and from her eyes a shower of tears did fall. "Where is," quoth she, "the gentle love-god. gone, whose power I find so powerful over all? Oh! call him back, my fault I do confess ; I have in love been too, too void of pity. Sweet boy, solicit for me to thy mother; for at her altars 
now will I sacrifice; and from henceforth no other I will adore. No goddess in my ears shall gracious be, but she who hath the all-subduing power of conquering with delight obdurate hearts. Compassion now hath worthy conquest made of that strong fort that did resistance make. To make a league, one shaft had been sufficient ; a league for life, a truce that lasts till death.".

Guy, more than life, prefers his Phælice's love: Phælice loves him as dear as he doth her; but it is, alas! to him as yet unknown, though he made his apparent long before; that now she is his, he does not yet understand; his wound still bleeds, and there is no salve applied : till forced by his passion, and the pain he feels, he boldly thus his second suit begins :-

"Phælice, I have been long ago arraigned, and now I from your hand expect my judgment. I have been a prisoner in a gaol of woe, so long that now I do demand my sentence. Oh! speak unto me either of life: or death, for I am quite grown weary of my life. In that fair form of thine, if kindness dwell, express it with, 'I love;' if none there be, then say, 'I cannot unto love incline.' Thus thou with me mayst make a quick despatch. Let then tily. frowns or smiles declare my fate. For, for this kingdom's crown, I would not long endure these racking pains that now I undergo."

Phælice replied, "It is not at my dispose for to yield to love without my friends' consent, for then I should be guilty of the crime of being disobedient to my; parents. You know my father's greatness, in the land, and if he should (as probably he will) refuse the love of one he thinks too mean, how could we bear the stroke disgrace would strike? No remedy but: death could ease my sorrow, and shame would soon become my winding-sheet:"

"O doubt not of your father in this case," replied Guy, "for Warwick's noble Earl shall see such deeds of valour done by me, he neither will, nor can deny the match. Enjoin me what adventures thou thinkest fit, that wounds and scars may let my body blood."

"Why then," quoth Phælice, " make thy valour shine, throughout the world as glorious as the sun; and I will give to thee my heart, soul, and life, and which shall crown the rcst, my truest 
love : let deeds of honour by thy hands be done; and by a martial life enhance thy fame; and for a recompense of all thy toil, take Phælice for thy true and lawful wife."

"To gain thy love," said Guy, "I ask no more, and shall esteem it bought at an easy rate. $\mathrm{O}$ that $\mathrm{I}$ were at work, my task to prove with some such churlish man as Hercules."

"Phælice, this kiss is all that now I crave, And till I have purchased fame no more I'll nave."

\section{CHAPTER III.}

How Guy, taking leave of Phalice, took shipping for France, and landed in Normandy, where he fought with three champions, delivering a fair lady who was condemned to die.

GuY, now by Phælice freed from Sorrow's thrall, arms his great thoughts with Honour's enterprise, and so embarking, sails away from France, leaving behind him England, and his joy. $\mathrm{He}$ seeks for enemies, he longs for foes, and desires nothing more than a fair opportunity to signalise the glory of his arms. And being safe arrived in Normandy, and having escaped the fury of a storm, Guy and the Captain of the vessel both went ashore, and there refreshed themselves; but they had not long been there, before their ears were deafened with the loud shouts of a multitude of people, and with the louder noise of drums and trumpets; this warlike noise extremely pleased our Guy, for now he thought there would be work for him, who wanted nothing more than some encounter. Therefore inquiring of his host the cause of those loud noises that he heard without, he told him, "That a beautiful young lady, whose name was called Dorinda, having been ravished by the Duke of Blois's son, and charged him with the crime, she was committed by the Duke his father unto prison, as one that had accused him falsely of the crime; and that three ruffians were suborned to swear she laid that crime to him on purpose to prevent his marriage with the Princess of Parma, that she might be revenged for his breach of promise 
made to her; which so incensed the old Duke, that he condemned her to be burned, unless she had a champion to vindicate her innocence, by fighting with her three accusers. This news much pleased Guy, who was resolved to vindicate the innocent, and lay here a foundation for his future fame. So that inquiring farther into it, and finding that the cause he was about to undertake was just, he presently gave order for his horse and arms to be got ready; and so accoutring himself in his warlike habiliments, he then took his leave of his host, and also of the Captain, who had in vain endeavoured to dissuade him from it: and having desired the Captain (who would willingly have gone along with him) to wait for his return, he rode unto the place of combat, where he saw the lady fastened to the stake, with several friends about her, lamenting for her hard fate. Guy scarce had time for to take a view of her, before those villains who had falsely accused her, entered the lists well armed and mounted, and proudly wheeling to the right and left, they made a stand; one of them demanded in a very haughty manner, whether any there present durst enter the lists to vindicate the innocence of that condemned criminal: "Let him come forth, and I shall soon," said he, "make him repent his rash and unadvised undertaking." This set Guy all on fire, who thereupon entering the lists, rode up, and said, "Yes, here is a man, thou perjured villain, that dares to vindicate a wronged lady's honour; and know, that I so little fear you, that I will revenge her quarrel, not singly, with onc only, but with you all together; that so the matter may be the sooner ended." This speech of Guy's so much enraged his adversary, that giving order for the trumpets sounding, both couched their spears, and so encountered each other, and with so much fury, that the earth trembled under them; but Guy had so much the advantage, that coming with his spear directly on his adversary's breast, he found a passage through it to his heart, so that he straight fell down, and with one groan expired.

The remaining combatants, vowing revenge for their companion's death, charged both with desperate fury upon Guy, who thereupon drew out his massy and well-tempered blade, and 
brandishing it in his hand, soon made them feel it was like the sword of fate, which there was no withstanding; so that one falling dead by his companion, and the other being wounded, begged on his knees that life he had so justly forfeited; which, that he might more easily obtain, he made a free confession of his crime, and showed how they had all been hired to accuse the lady, by Philbertus, the Duke's son, who really was guilty; and for a thousand crowns had hired them all to bear false witness for him, against that lady whom he had abused.

This full discovery caused through all the field an universal shout; each magnifying the valour and generosity of Guy; and we may be assured the lady was not behindhand in sounding out the praise of her deliverer; but who this generous stranger was, was what all wished to know, but none could tell. When he alighted and unbound her, she joyfully embraced his knees, imploring a thousand blessings on his head, offering what rewards he pleased to have: but he refused them all, telling her, "What he did was out of love to virtue and to honour. But wished her to take care of her own safety, by timely getting out of the Duke's power, lest he should use some other means to take away her life." So bidding her farewell, he rode back to the ship, and there related to the Captain what befell him, who with no little joy heard the relation. Yet after some consideration, it was judged best to stay no longer in that harbour; and so they weighed their anchors, and sailed out to sea.

Then did brave Guy a treble victory win,

Or else the lady in bad plight had been.

\section{CHAPTER IV.}

How Philbertus, the Duke of Blois's son, hearing what Guy had done, followed him to the sea, where a dreadful fight happened between them, in which Philbertus and his men were taken prisoners.

As much haste as Guy and the Captain made to get out of the harbour, yet they were not got altogether out of danger; for 
Philbertus being informed that one Guy, a native of England, had not only overcome his knights of the post, but that his villainy was also thereby discovered, and the injured lady freed and got out of his reach; it made his anger boil up to the utmost pitch of rage, threatening to wreak his malice on the head of Guy, for doing him so great an injury; and therefore he secretly armed sixty of his servants and his attendants, and with them made all the haste imaginable to the port where he had information Guy's ship lay, thinking to surprise him and the lady there together. But finding himself disappointed, and that Guy had set sail three hours before his coming, his disappointment made his rage boil higher, especially believing Guy fled for fear of him, and that he was also conveying the lady away with him. Whereupon going on board a stout vessel that lay in the harbour, he commanded them to weigh anchor, and make all the sail they could after the English ship, which by a small boat just come into port, he was informed was sailed to the eastward. The mariners immediately got ready, and having a fair wind, and the ship being a very good sailer, in the running of a glass and a half they came within sight of the ship wherein Guy was. No sooner was the French ship come in sight, but the mariners gave notice of it to their Captain, who viewing of the ship with his prospect glass, told Guy, that he was sure they were pursued, and that the enemy being treble their number, their best way was to hoist up all their sails, and to make the best of their way; and that then, by the help of the evening, he did not doubt but to get clear of them. "Why, how many ships," said Guy, "are they that chase us?" "Why," said the Captain, "I discern no more than one at present, but it is a good stout ship, and carries thrice the men on board that we do."- "Well, well," said Guy, "if that be all be of good courage; and the first thing we do, let us tack about, and meet them like courageous Englishmen; I will bear the brunt of war myself alone. I would not for the crown of France, I will swear it, have it reported that Guy ever fled." This speech had the effect upon the seamen, that one and all cried, "Let us engage them straight." Nor did the Captain now 
appear less willing. And so they cried, "All hands aloft," to put them in a posture of defence; which they had no sooner done, but up the French ship comes, and grapples them; this Guy was glad to see, hoping he should be with them presently, and therefore he gave orders to let the French board them without much difficulty; who, by that means supposing they had been victorious, gave such a shout as victors do at land. This insolence made Guy so lay about him, each blow he struck had more than human force, and in a few moments all the deck was nothing but a scene of blood and slaughter; no armour was of proof against his sword, for at each blow fresh streams of blood ran down. Philbertus was amazed at the dismal sigint, and wished himself in his own ship again; and ordered those few that were left alive, if possible, to get to his own ship, and then immediately ungrapple; which Guy perceiving, having cleared his deck, he soon leaped on board of the Frencil ship, and singly there maintained a bloody fight, hewing them down with so much fury, that many of them, to escape his sword, leaped into the sea. Philbertus seeing this, gave all the encouragement to his men that was possible; and as one now grown desperate, charged on Guy's helmet with such force, as made it sparkle fire; at which undaunted Guy returned him such a blow, as at his feet made him fall down for dead; which made the soldiers all throw down their arms, and cry aloud for quarter. And thereupon Guy, who was always merciful to conquered foes, ended the battle, commanding all his men to fight no more: in which time Philbertus came to himself again, and with a low submission, begged his life, which Guy as freely gave him. And having removed him and the rest into his own ship, set fire to that of Philbertus, and sailed on his intended voyage, coasting along the shore, until they touched upon that part of Normandy that borders upon Germany; where Guy, with an undaunted courage, landed; and there was welcomed with the pleasing news, that a great tilt and tournament was to be held for Blanch the Emperor's daughter, a beautiful and an accomplished lady, who was to be the victor's prize, who thereby had a right to marry her, and to have with her a brace of grey. 
hounds, a falcon, and a milk white steed. Upon this welcome news, Guy discharges the Captain of the vessel, leaving the prisoners with him, to dispose of at his pleasure; who putting them to their ransom, they obtained their liberty, while Guy, with eager haste, rode to his royal tilting.

And flushed with victory already won,

Thought greater things might by him now be done.

\section{CHAPTER V.}

How Guy triumphed over all the German princes, and won the beauteous Blanch, the Emperor's daughter, and after leaving her, returned for England.

GuY of the Captain having took his leave, goeth where there was more business to be done: for hearing that there was to be a meeting of valiant knights from divers Christian lands, that did intend to run a race of valour, for which a great advantage was propounded, it was charming music to his greedy ear. The prize that drew them all unto this place, was the daughter to the Almain Emperor, fair Blanch, whose wondrous face had that attractive power, that it united all the graces in her. It was thither all the worthies posting came: who won the damsel (for so was the law) by manly courage, and victorious might, should have her mounted on a milk white steed, attended with two greyhounds and a falcon, all of the same colour (if white may be so called); this was his lot that could obtain the day, to bear away the honour, and the maid. Our English knight prepares him for the field, where kings and princes also present were, and dukes and earls a very great assembly held, about that wondrous fair, and beauteous prize. Though only one must speed, and hundreds miss, yet there each man imagines Blanch his own. The spacious field wherein they were assembled, hardly afforded room for the armed knights. The golden glittering armour that was there darted the sunbeams back into the clouds. The pampered horses proudly pranced about, to hear the clangour of the trumpets sound. 
A German Prince of an undaunted spirit did the first onset and encounter give unto an Earl, whose valour did requite him with blow for blow, as resolutely brave, till by a stroke on his head the Earl received, he was unhorsed, falling on the ground for dead.

Next, Guy with courage to the Prince comes forth, and fights just like another Hercules; like force he never felt before nor since; nor never was put into such hard extremes. Just where himself had laid the Earl before, there down comes he, both horse and man to the ground.

Duke Otton seeing this, was in a rage, and with such wrathful humours was incensed, he vowed by heaven that nothing should appease his fury, but the death of that proud foe. "Prepare thee now," quoth he, "to breathe thy last, monster or devil, whatsoever thou be." They join together in a dreadful fight, the clattering armour sounds, the splinters fly, and the ascending dust will not let them see : their blood allays it, streaming from their wounds. Both their swords break; they alight, and with main force Guy threw the Duke to the ground, that his bones, did crack.

Duke Rainer would revenge his cousin then, and for the encounter next of all prepares: "I see," quoth Guy, "that you are less than men, that with a blow or fall are vexed so soon. But come and welcome, I am ready for you. We say in England, THE WEAKEST MUST Go To THE WALL." Then they together rushed, and shook the ground, whilst animating trumpets sound the alarm. In Rainer's shoulder Guy made such a wound, that he soon lost the use of his right arm; who thereupon yielded himself as vanquished.

Then, for a while, all stood amazed at Guy, none being forward to encounter him, till Lovain's Duke resolved to try his fortune, having good hope that he might better speed. Then sitting fair on a proud steed that ill endured the bit, well mounted and well armed, "I think," quoth he, "thou some enchanter art, that in thine arm the force of magic hast." "I will teach thee to believe ere I have done," quoth Guy, "for thou shalt feel that I can charm. I will conjure with no other spell but iron, by which 
I will send thee unto heaven or to hell." With that he gave him such a cruel stroke, that he could but a weak reply return : then with a second and a third he broke his helmet. With that, "Hold, hold," cried he, "I have enough, I will rather yield than die. Let them fight for a woman that desire it; I think the devil scarce can deal with thee."

Then not a man more would encounter him, they all were terrified and stood in fear, and against Guy were all filled with rage: "What," said they, "shall a stranger bear the honour of this great day? what cursed fortune is this, that he should have the glory of the field?" Amongst themselves they cursed his happiness, and could have killed him, but that no man dared put his own life in hazard by so doing. If wishes might have done it, he had died; but there was, no man durst attempt to fight him.

The Emperor then sent a knight for Guy, and asked his name, and of his birth and country, which he told him. "Then," said his Majesty, "I must commend thy haughty courage, resolutely bold : brave Englishman, thou art thy country's pride : in Europe lives not such another man. I do admire thy worth, great is thy valour; my tongue cannot suffice to speak thy praise. Ascend to honour's just deserved seat, thou art a second Hector in mine eyes. This day thy worthy hand has showed me more than in my life before I ever saw. Come and receive thy due desert of me ; my daughter's love is free at thy dispose; the greyhounds, steed, and falcon, take unto thee; thy worthiness does merit more than these: hold, here is a jewel, wear it for my sake, which shall be as a witness of my love."

Guy thanked his highness for his gracious favours, and vowed him service whilst his life did last. Then to the Princess, with a mild behaviour, he cast a reverent, humble, modest look, saying, "Fair lady, fortune is my friend, that such a beauty to my lot is given. Madam, accept your loyal English knight, to do you service when you shall command it; who, while he hath a drop of blood to spend, will sacrifice it all on your behalf, against whosoever shall dare to contradict you. Too high it is for me 
to be your husband; it is enough to be your servant Guy. In England doth my marriage-love remain, to whom I must and will be true for ever; about whose face, such pains hath nature took, I durst have sworn, flesh never could have matched it. But now I find, and ever shall acknowledge it, there is a phœnix in the world besides her, and that is yourself : and I dare all mankind to say one tittle that shall contradict it; but which is fairest there is no eye can tell; no human judgment in the world can try it, or positively say which hath most beauty, Blanch or my fair bride. I dare be bold to call your beauties twins; and that compared unto either of you, Venus herself was but a black Moor. Oh Phælice! here is thy picture in this Princess. Methinks thou art present in her lovely looks. Thou that of my soul's faculties art mistress, recorded in Time's brazen-leafed book, if $I$ to thee prove false, even in thought, and much more in my actions, Jove's fearful vengeance light upon my head."

Quoth Blanch, "Thy constancy," and then she sighed, "is highly to be praised, and thou applauded. He that Love's promise will not faithfully keep, in horrors and in torments let him dwell. But I suppose thy vows are vet unmade, and so what thy sword won thy heart may take."

"Madam," said Guy, "what I avouch is true, and I dare call even Heaven to witness it : my protestations are above the skies; and he who made them, knows I speak the truth. Madam, the sun declines, and the day grows ancient, I will therefore humbly take my leave of you, for now my body is to repose inclined, although my troubled mind can take no rest; my restless mind is now in Warwick Castle, although my body be in Normandy. Here I make others bend, but there I bow, and lie as low as the humble ground; even at Love's feet to the ground I cast myself. Though victory my temples here have crowned, I cannot stay, I must to England back. My mind misgives me that Phælice is not well. Like my sad thoughts, my armour shall be black, and in a mournful iron shell it will suit me. For where the mind suspicious cares does nieet with, distrust is ever dealing doubtful snares. Yet I have much good fortune on my side, that know 
the means how to attain my bliss ; for Phælice ties her love to my conditions, and she for this, I trust, will be my own. By this, she may, but if she more request, there is nothing in the world that I will deny her."

With hasty journey therefore home he goes, leaving the vulgar unto nine days' wonder. And being safe arrived on English ground, he unto Phælice posted; for too long he thought each minute that he stayed away. And coming to her presence, he beholds her with greater joy, and with more cheerful looks than pen can write, or can by tongue be told.

What tongue can tell, what pen can write, how sweet

Are absent lovers' joys when once they meet.

\section{CHAPTER VI.}

How Guy returning to Warwick was received by Phalice; by whom he was sent forth again to seek new adventures; but before he went destroyed a monstrous dun cow upon Dunsmore Heath.

PHÆLICE having received the news of Guy's arrival upon the English shore, and of the mighty fame he had acquired, by all the warlike deeds his hands had done, expected soon to see him at her father's castle, preparing to receive him according to his worth, and to the great affection she had for him. Nor did her expectations fail her, for Guy made all the haste a man could make, to lay the prize of all his glorious conquests at her feet. Where being come, after salutes, and mutual embraces, Guy thus bespoke her:

"Fair foe," said he, "I come to challenge thee; for there is no man that I can meet will fight me. I have been where a crew of cowards are, but none that dare maintain the right of ladies; good, proper, and well spoken men, indeed, but let me win a Princess from them all. Phælice, this sword hath won an Emperor's daughter, as sweet a wench as any lives in all Europe. I bought her at the price of blood and wounds; well worth my bargain : but thy better face hath made me leave her to some other's lot; for I protest, 


\section{3j० THE HISTORY OF GUY EARL OF WARWICK.}

by Heaven, I could not love her. This stately steed, this falcon, and these hounds $I$ took, as in full payment of the rest; for $I$ have always kept my love to thee enclosed within the centre of my heart. My constancy to thee I have still preserved, leaving all other women as they are. But say, my Phælice, shall I now obtain thee? wilt thou consent that Hymen tie our hands? art thou resolved to keep still to thy vow, that none but I shall ever have thy heart? canst thou forsake the world, change thy condition, and now become thy true and faithful lover's wife?"

To whom fair Phælice thus replied again: "Know, worthy knight, my joys have been enlarged at the report of thy great deeds abroad: some were, I hear, in such a bloody sweat, their valour, fame, and reputation bleeds. Therefore, my Guy, I give thee humble thanks, that thou for me so much didst undergo, and for my sake such hard adventures made. To win a Princess, was a precious prize : but sure, methinks, if I Sir Guy had been, she greater favour from me should have found than take a horse, and turn a lady by. What! is a horse, a falcon, and a hound more worthy than so beautiful a lady? Perhaps you will say, it was done for love of me; I do imagine, nay, believe it is : and though I jest, I will do more for thee, than thou, or any but myself doth know; I will never marry while life's glass doth run, but only to thyself. But, give me leave, my love, to speak my mind; let me lock up my secrets in thy breast. $I$ had a vision did affection move : Cupid came to me, whilst I slumbering lay, and in my mother's name commanded me to love thee. And whilst he was to this persuading me, an armed man just as I see thee now, he set before my eyes, and thus he spake: 'Phælice, be gentle hearted, bow and yield, and do not the sovereign power of love oppose; but all thy loyalty, thy truth, and thy love, bestow them freely on this matchless youth: throughout the world his fame admired shall be; and mighty men shall tremble at his wrath; to end the quarrels of great kings shall he be often courted. His worthiness no common path shall tread; but actions to be feared he shall effect, and to pass bring things of the greatest moment.' This, in effect, he did to me relate, and 
to his will I have obedient been. Now how to hate thee if I would, I know not: for I have of perfect kindness learned the skill. Believe me, Guy, for if it were not thus, this secret of my heart thou shouldst not know. But now, my love, before thou dost possess thy constant Phælice in her marriage bed, thou must far greater and more worthy deeds perform than what thou hast already done: the winning of a lady and her steed are but small things to what thou yet must do. I will ever love thee, though thou never dost more, but cannot grant the use of love till then."

Quoth Guy, "Not grant the use of love, fair Phælice! then I perceive, I must again go travel and see what fate has for me still to do. I will content thee, love, one way or other, and either slay, or else be slain myself, ere $I$ into this realm again return; and thou confess I have thy dream fulfilled. Assist me, Heaven, as I sincerely mean, for I protest by all the powers above, no unjust quarrel ever shall make me fight, nor yet to wrong the wronged will I ever incline: for those that by oppression fall, I will stand; in honour's cause my life I will freely venture. Come, my Bellona, my sword do thou girt on, and in thy ivory arms embrace my armour, and such kind kisses as thou canst afford bestow upon me in the stead of charms. Upon Ulysses's loving wife I think, and how thou now her life doth imitate. Farewell, my Phælice, health and happiness attend thee to thy heart's desire for ever; and like success I beseech God to grant me, as I my love to thee shall keep entire. IVhen war's stern looks abroad I have performed, at my return Hymen will make amends."

Unto Earl Roband next does Guy repair, and tells him he is come to take his leave; for he must go where honour finds him work, and there receive the just rewards of virtue. "At home, my honourable lord," said he, "I find that valour has no stage for action, I will therefore search what is to be done abroad; from kingdom to kingdom I will go, and find out work, for no good comes of idleness; it only bringeth men up to sloth and cowardice, and I hate cowards as I hate the devil."

To which the Earl returned, "Dear Guy, thou makest me 
grieve at this sad news; and more because thou hast disappointed me. The news is more than I can well endure. I hoped I should enjoy thy wished for company, and thou wouldest go no more abroad; and now thou speakest of new adventures. $O$ ! change thy mind, brave Guy, and stay with me; no longer trust to fortune's treacherous smiles; though now she hath so kindly dealt with thee, yet she may leave thee to an unlucky hour, and turn her many favours into frowns. $\mathrm{O}$ ! do not over rashly hazard thy glory : lost honour is not easily got again.".

To this Guy answered thus, "My noble Lord, that man of dangers must not be afraid, that to adventures doth himself dispose, but must supported be with resolution, and for his foes still think himself too good. I will never fear I shall be overcome, whilst I have hands to fight, or legs to stand. Therefore I will leave your honour, wishing all health unto your happy state. If fortune means to frown, yet she shall see that I will disdain her hate. What star soever swayed when I was born, I have a mind will laugh at all misfortunes."

The Earl perceiving him resolved to go, told him, "That he would be no hindrance to his proceedings, and only would ask one request of him before he went :" Guy told him, "Whatsoever he asked that was within his power to perform, he should not be denied." Then said the Earl, "It is this, that when you are once again come safe to England, you will go abroad no more, but live at home with me." Which Guy having promised him, prepared for his departure, and soon after took his leave, going to the seaside, there to embark for France.

Being come there, and ready to embark, the wind proved contrary, and so continued for six days together; during which time fame through each corner of the land had made a mighty noise of an exceeding great and monstrous cow, lurking within the woods not many miles from Warwick, making most dreadful devastations, destroying man and beast, and putting all their keepers unto flight, being so mighty strong, that it was thought not possible to destroy it ; and some affirm, that she was at least four yards in height and six in length, and had a head propor- 
tionable, with two sharp horns growing direct, with eyes resembling lightning for their fierceness; and was of a dun colour, and from thence named the dun cow; and the place where she lay, being on the borders of a great heath, was from thence called Dunsmore Heath, which name it retains to this day.

Upon notice which was given to the King (who was then at York) of the havoc and slanghter which was made by this monstrous creature, he offered knighthood, and several other privileges, to any one that would undertake to destroy it. But such was the terror she had spread throughout the country, that none was found so hardy as to adventure himself on such a dangerous enterprise ; and the absence of Guy (who by this time was supposed to be in France) was generally lamented; all believing he would undertake it.

Guy (who was all this while waiting for a fair wind) hearing the discourse of the country, and hating to be idle, resolved privately to go and engage with this destroyer of his country; and so taking his sword, a strong battle-axe, and his bow and quiver with him, he rid incognito to the place where this monster used to lodge, which was in a great thicket of trees, which grew on the side of a heath, near a pool of standing water; finding, as he rid along, the cottages and houses everywhere thereabouts deserted, and the carcases of men and beasts lie scattered round about; which filled him with great pity and compassion for his country, and extreme resentment against that monstrous destroyer.

Being come at last within bow-shot of the place, the monster espied him, and thrusting her head through the thicket, her dreadful eyes were enough to fill any heart with terror but that of the courageous Guy, who notwithstanding her horrid roaring soon bent his bow of steel, and as he was one of the expertest archers England then could boast of, drawing his arrow to the head, let fly; which striking on the monster's hide, rebounded back as from an adamantine wall, without the least impression being made: at which, whilst Guy was in some admiration, the dreadful beast, swift as the eastern winds, came running towards him, with her sharp pointed horns, aiming directly at him, which he observing, 
lifted his battle-axe on high, and on the forehead struck her sucn a blow as made her to recoil, and roar most hideously, and yet enraged more, she came on again; and clapping her horns upon his breast, dinted his armour, though of highest proof, before he could avoid her, but wheeling his warlike steed about, he met her again, and with redoubled strokes, gave her a desperate wound under the ear, the only place she could be wounded in so sensibly; whereat she again roared, snorted, and stamped on the ground : and by this, Guy perceiving she was mortal, iollowed that stroke, with others no less forcible, by which at last she fell upon the ground; and Guy, alighting from his horse, hewed her so long, till with a horrid groan she breathed her last. 'Then leaving her almost deluged in her own blood, he rid to the next town that was inhabited, and there made known the monster's death, to the great joy of the inhabitants: the people loaded him with presents, and honoured him with thanks; and all the country came in to see that monster dead, which when alive they stood so much afraid of. 1

And, though Guy thought to get away before the King had notice of it, yet fame was swifter far than Guy, and he was sent for by the King before he could get on shipboard, and so was forced to go to York; where he was no sooner arrived, but the King embraced him, and after a splendid entertainment he gave him the order of knighthood, and many rich gifts, causing one of the ribs of the said monster to be hanged up in Warwick Castle. And Guy having departed from the King very well satisfied with his entertainment, and the wind now serving, he goes on board to seek fresh adventures in foreign lands.

Where he so many wondrous things did do, As stagger'd faith, and nonpluss'd reason too.

1 To this adventure Butler alludes in his Hudibras, when he describes Talgol the butcher, "mortal foe to cows:"

" He many a boar and huge dun cow

Did, like another Guy, o'erthrow ;

But Guy with him in fight compared,

Had like the boar or dun cow fared;

With greater troops of sheep he'd fought

Than Ajax, or bold Don Quixote." 


\section{CHAPTER VII.}

How Guy, with Heraud and two other knights, zeere assaulted by sixteen villains that lay in ambuscade for him in a wood, whom he destroyed; having killed two, and wounded the other of the knights: and afterwards assisted the Duke of Lovain, who was besieged by the Emperor, Erc.

Now Guy expects a favourable gale, and has it even to his heart's desire, and with a speedy passage doth he sail to seek new adventures once again in 'France, where finding none, from thence away he goes to Lovain, where the Emperor besieged the Duke thereof, because he had the misfortune to kill the Emperor's cousin, whom he greatly loved, and therefore took his death exceeding ill; and thereupon a quarrel did arise, and wars ensued between two mighty foes. Thither goes Guy to lend the Duke his aid. But in the way a plot to take away his life was, by the false Duke Otton, basely laid, although it was not effected ; for Guy so well about : him laid, that it succeeded not: the matter was, Otton before in France by Guy disgraced, had vowed, wherever he met him, he should die. And to that end, sixteen appointed were to lie in ambush, that they might surprise him, who in a forest slily hid themselves, and on a sudden all surrounded Guy, who only was attended with three knights, and never before was Guy in like distress. But seeing how it was, "Now, friends," said he, "show yourselves right bred English gentlemen. Here is indeed some odds, sixteen to three, but I, the fourth, will stand you in some stead; you three shall combat six, that is two to one, and leave the other ten alone to me." With that he drew his sword and laid so about him, that in the air their rattling armour echoed, and down they quickly dropped on every side. Guy quickly made dispatch of his half score. But there remained half a dozen more, who had slain two of his beloved knights, which he no sconer knew, but straight he stamped upon the ground, and with a fearful tone, he uttered forth these words: "Ah, villains! how my soul abhors this sight; for these how my revengeful 
passions strive! this bloody deed with blood I will repay; you die, though you had each a thousand lives. Two you have slain outright and wounded Heraud, which is the last cursed act you shall do." And then, with force almost exceeding all that human arm could ever boast, he lays upon them blows which made them reel, and quickly brought them breathless to the ground. At length, cut all in piecemeals for the fowls : "Lie there," quoth Guy, "and feast the hungry crows, or feed the savage beast that hither come. But for these worthy gentlemen that have lost their lives in the defence of me, and for my sake left England's pleasant soil, them will I inter in honourable wise, with what solemnity the place affords, and be myself a mourner at their funeral."

From thence unto a hermit not far off he rid, and did with care that charge to him commit, who did that office carefully perform, and bare home wounded Heraud to his cell, who was not dead (though Guy supposed him slain), but quickly by the hermit was recovered.

Now forth goes Guy, sad, pensive, and perplexed, grieving that destiny had dealt so hardly, to take away his dearly beloved company, and leave him as he travelled all alone, that none could ease the torments of his mind. But in his lonely solitary travel, at last his fortune brought him to a place that was for honour very much renowned, and there he met with tilts and tournaments, which entertained him with delight and glory. And there kind fortune gave him her consent to win the prize from every valiant knight; of all the worthy men that hither came, not one could match him in Duke Reyner's court.

Then to the Duke of Milan he repairs, where he is admired of all for his great worth; and understanding some affairs of weight fell out betwixt Duke Segwin of Lovain, and the Emperor, he from the Duke of Milan went his way, and forthwith took his journey to Lovain. But as he passed through the way, he met a pilgrim that with travel seemed faint, whom he greets, and with some news entreats him to refresh his longing ear. He with a sigh or two, said: "Sir, with news I have but little business; 
there is but one thing in the world I care for, and only that and nothing else I mind : I in despair do seek a man, because I have long sought, but cannot find him ; a man more to me than all the men in the world beside."

"Thou speakest," said Guy, "like one that hast some gratitude. But tell me, pray, what man art thou? And what is he for whom thou hast expressed so great a kindness?".

"I am an Englishman, of knight's degree," quoth Heraud, "and the subject of my grief is the loss of one Sir Guy, my countryman."

Guy then, with tears of joy, embraces him: "And art thou living, Heraud, my dear friend ?" said Guy, and kindly took him in his arms. "Then here I bid my sorrows all adieu; pray, who thy wounds did cure?.".

Heraud, no less surprised with joy and wonder to find Sir Guy his countryman again, cried out, "And have I found thee thus, my friend! my pains and travel have been well rewarded. It was the good old hermit that saved me, by the medicine he applied." Then each embraced and both renewed their joys at this so good and happy meeting. No angry star with inauspicious rays befell them then, but both were well content.

Then, mounting on their steeds, they bend their course, with. easy pace, unto Duke Lovain's court, where they his. city find in great distress, straitly besieged by the Emperor's forces. But Segwin was extremely satisfied that worthy Guy was come unto his aid; "for now," quoth he, "I dare be bold to say we have an honourable valiant man: advise me, warlike knight, what is to be done to free me from the danger I am in?"

"My lord," quoth Guy, "great as the danger seems, myself will find a way to set you free : let us presently upon them issue forth ; our courage will make the cowards fly."

"The counsel," quoth the Duke, "I do approve, and to thy project give my free consent. Let life, limb, blood be lost, I will follow thee. So let all do that come to me in love."

Then suddenly they rush out of the city, and on the Almains suddenly set, where they did such a bloody slaughter make that 
many thousand lives were soon cut off : of thirty thousand that besieged the town, there scarce was three thousand that escaped.

The Emperor at this was much perplexed, but with new forces gave a fresh assault, as knowing well they could not be relieved, and so their strength must weaken by degrees. And therefore coming with a new supply, believed he in short time might famish them. Guy and the Duke appear upon the walls, and tell him, " he shall never win the town, for they can spare his soldiers what provision they can desire," and so flung down abundance of victuals from the walls, and withal told them, "That if they wanted he could spare them more." "And now," quoth Guy, " that we have fed your bodies, I hope your stomachs will be up to fight; but I am afraid you are not rightly bred, but like some dunghill cocks, will crow and run away. But still, when cowards do a fray begin, before the battle ends away they run, and so yourselves have lately done, we see. Your tongues we heard, but could not feel your hands; your words were hot, but actions cool enough; though I confess your heels are wondrous nimble. We did believe that when you first came hither we should have found you men of strength and courage, but, having tried you, find it is no such matter, unless you could surprise us while we sleep; for waking we will encounter one for ten, and never wished to have a better match. And if you can do better, let us see it; therefore prepare, for we will be with you presently." And then upon their foes forthwith they flew, fighting like men that laughed pale Death to scorn; for they resolved they would their city free or never live to see another morning. Much blood was shed, and many lives it cost; but in the end the Almains lost the day. The Duke, with Guy, swiftly pursued their foes, who, like so many hares, fled away.

The victors to the city back repaired, with trophies of the glory they had gained, and all that heard the action much admired the great exploit so resolutely done. But unto Guy the Duke returned his thanks; "For thou," quoth he, "art Cæsar of our field."

"My lord," quoth Guy, "I take not so much joy that I have by my sword your freedom wrought, as I should glory, if it were 
my hap to make the Emperor and you good friends. Give me but leave, and I will do my endeavour, and put good will to a blunt soldier's wit."

The Duke consented, and desires Sir Guy to take a guard of soldiers from the town.

Then Guy forthwith went to the Emperor, and being by his officers conducted into his presence, he bespeaks him thus :

"All health to your imperial majesty, and peace to thee, if thou to us say peace; and love to thee, if thou wilt love embrace. As we are Christians, let us war no more, but fight against those that are foes to Heaven. We do not sue thee in a servile manner, as fearing. any force or power thou hast; for victory on our side displays its banner, and to our view yields a delightful prospect; no cause doth move us but the cause of conscience, to bring the heathen to religion's law : and therefore now, most noble Emperor, declare thy mind. Shall we be Christian foes, or Christian friends ? shall we among ourselves divide the name, or challenge them that have that name denied?"

Guy having ended what he had to say, the Emperor to him made this reply:

"Brave Englishman, hadst thou spoke thus before, thousands had lived, that now the sword has slain; but those must in the bowels of the earth remain, until the general resurrection : but, for the future, wars betwixt us shall cease, and I will embrace thee as my friend. Thy motion, honoured knight, to honour tends, and thou shalt live in fame's immortal praise; and when thou art buried in eternal night, thy name unto the end of days shall last."

"Come, go, great Prince," quoth Guy, "into the town, and with Duke Segwin there a league renew. Our end shall be to pull down pagans, those foes to religion."

The Emperor being brought by Guy into the city, the Duke of Iovain from his castle came, and after mutual salutations past, the Emperor was conducted to the castle, where, by the mediation of Sir Guy, there was a league between them soon concluded, to the great joy of all the people; which was, with feasting and rejoicing, welcome on every side. 


\section{CHAPTER VIII.}

How after Guy had made peace between the Emperor and the Duke of Lovain, he weis furnished with two thousand men, and ten ships of war, for the relief of Bizantium; and being scattered from the rest of the fleet, is set upon by three pirates, two of which he destroys and forces the third to fly.

GuY having thus accomplished his end of making peace between two contenders, the Emperor and the Duke of Lovain, they both entreat Guy to stay amongst them, to enjoy that peace he had procured. But by no means could they prevail upon him. $\mathrm{He}$ was for seeking out new scenes of action, but would no more employ his arms against Christians; and therefore earnestly entreated them to furnish him with forces to go against the faithless Saracens, who had broke in upon the Grecian empire, and besieged Bizantium. They both agreed, and left it to himself to take what force he thought sufficient, and they would furnish him with all things necessary for the war. Guy, after having returned thanks to both for their kind and generous offer, assured them he would so employ their forces as should be for the honour of all Christendom. And thereupon immediately selected two thousand of the choicest soldiers present; one of the Emperor's forces, and the other of them belonging to the Duke of Lovain, who with equal willingness went with him, as proud of being those whom he had chosen. Next, he embarked them on ten ships of war, and then took leave of the Emperor and the Duke, promising, that at his return he would present them with such trophies and evidences of his soldiers' courage as the fortune of war should yield him: and so departed with a prosperous gale.

Guy being now ploughing the briny ocean, almost a month, and meeting no adventure, thought fortune dealt a little hardly by him. But by a wind, common enough to those that sail upon the Lovain seas, disjoined from his fleet, she gave him new occasion for his valour; for he was met by three Turkish men of war (and three to one you will say is odds at football), who being of 
the Sallee rovers, supposed they had got a prize, as judging him a merchantman, and thereupon came boldly up, thought straight to have boarded him; which Guy perceiving, could not choose but smile, and tell his men they had now an occasion to exercise their valour, and thereupon drew out his flaming sword, so often tried in war, and charged on the assailing infidels with such a martial fury, that Mars himself could hardly have done more, glutting the gaping jaws of hungry Death, not only cutting down the men, but also spoiling all their shrouds and tackle; whilst valiant Heraud, and the rest remained not idle on the other side; for they having prepared hemp, tar, resin, and other like combustible materials, set them on fire, and threw them into the Turk's ship that engaged them: this was a stratagem till then unknown; which catching hold of the decks, masts, and rigging, soon set the ship on fire, which they being utterly unable to extinguish, soon quit their flaming castle, and rather chose to perish in the ocean; which the other ships beholding, and being much surprised to meet with such resistance, now found too late they had caught a tartar, and so hoisted their sails, preparing to be gone; which one of them had the good hap to do, but Guy resolving to make sure of the other, so closely grappled with her, that he soon leapt on board her, and there made such a slaughter, that all the deck was covered with the carcases of those that fell as victims to his sword; which so amazed the Turks, that they cried in vain to Mahomet to come and save them from those inhuman devils that assaulted them. But although Mahomet knew nothing of the matter, yet Guy, out of compassion, spared their lives. Then putting forty of his men on board, he sent the ship, with the remaining prisoners, to his friend the Duke, as the first fruits of what his valour purchased. No sooner had this brisk engagement ended, but Guy's nine ships came up with him again, which had by reason of a fog been separated from him. And the night coming on, Guy ordered they should stand off to the southeast, for fear of running fowl upon the rocks, too often met with in those parts.

No sooner was the longed for morning come, but from the 
main topmast, a seaman calling unto Guy, told him, he made the land; which ere the sun had run out half his race, the whole ship's crew beheld as well as he. And as unto the land they nearer drew, they could discover famed Bizantium's shore, which then was by the Turks and Saracens infested almost round. Guy thereupon ordered his forces to be landed at the next convenient harbour, and from thence sent Heraud with two other captains, to learn, if possible, how things then stood, both with respect to the besieged, and the besiegers. In five hours' time Heraud returned again, and from a Turk whom they had met without, and taken prisoner, they understood the city was besieged by fifty thousand men, who were most Turks and Saracens, and that it had been so for three months' time, but that it was defended by the Christians, commanded by Albertus, a very worthy Saxon.

This news was very welcome unto Guy, who now thought he had a fair opportunity to show his valour, and serve the Christian interest, by the destruction of the infidels. And there he immediately despatched Heraud his trusty friend, and one knight more, unto the Lord Albertus, to let him know that he was come from Germany, and lay ready now in such a port, with two thousand Christians under his command; ready to serve him; and if he would in the evening make a sally out at the gate that looks towards the sea, he would be ready with his. men to force his way through the enemy's camp, and join him, and, so come into the city to assist him.

Heraud and his companion undertook to deliver this message to Albertus; and by the help of Turkish habits, passed all the guards, without the least suspicion; and coming to the gates, declared they had a message to Albertus, whereupon they were let in, and straight conducted to the castle, where Albertus and his chief officers were sitting in council of war, to whom after due reverence paid, they gave an account of their business; but having declared this only by word of mouth, Albertus and his officers seemed somewhat doubtful, as not knowing but it might be a stratagem, contrived by the enemy, to take the city; but when Heraud had delivered Albertus a letter under Guy's own hand, to 
whose great fame for martial deeds Albertus was no stranger, they quickly changed their sentiments, and treated them as they deserved, for such a welcome message, to which they gave a ready and cheerful compliance; entertaining them with all imaginable civility and kindness, promising not to fail sallying out at the time and gate appointed. Heraud and his friend returning back to Guy, acquainted him with all that passed, who being very joyful that things succeeded so well, landed his men with all imaginable silence and dexterity, drawing them up in battalia upon the shore, and giving orders to those that continued on board, to stand off at sea, till he should signify his pleasure to them to come into harbour. After which he marched towards the city with all the privacy and silence that could be. But for all his caution the enemy had perceived them and taken the alarm; so that, gathering together from all quarters, they were ready to receive him : Guy, no wit discouraged, made a short speech to his soldiers, telling them of the goodness of their cause, and the assistance they should have from their friends in the city, bid them fall on undauntedly, and the day was their own : upon which they gave a great shout, and Guy, drawing his flaming sword, fell on his foes with such undaunted fury, that they soon bore down all that were before them ; so that wherever they came, the mangled bodies of their foes overspread the crimson plain. Guy, with redoubled blows, slaughtering wherever it was he turned himself: thus the dispute continued for more than two hours' space ; in which Guy had so well improved his time, that he and his small forces, with the assistance of three thousand from the city, who sallied out according to their promise, had destroyed almost thirty thousand men. So that the Pagan army, finding themselves thus worsted on all sides, retreated to their camp in much confusion; which filled, the Soldan with revengeful thoughts, which he resolved forthwiti to execute; and presently after gave orders to his soldiers, early next morning, to assault the city, which he supposed, wearied with the last night's fatigue, would scarce be able to make much resistance. Guy suffered their retreat that night, not thinking it convenient to pursue them, and with his soldiers entered the 
town, where, by Albertus and his officers, and all the citizens beside, he and his men were joyfully received, and kindly welcomed. Albertus in his arms embracing Guy, conducted him to his own lodgings, and kindly thanked him for his brave assistance ; then gave him a most noble treat, where they drank healths to the Emperor, and all the German Princes, to whom Sir Guy professed himself a subject; whom they thought happy above other Princes, in having such a subject as Sir Guy. And after they had ate and drank sufficiently, they all retired to rest their weary limbs, after the great fatigue they had undergone.

Early next morning, as the Soldan ordered, the army was prepared for the assault, the drums all rattling, and the trumpets sounding; at which the army gave so great a shout, as made the hills resound the echo back, the noise whereof awaked our warlike Guy from the sweet sleep which he till then had taken; who, rising, straight ascended to the tower, and there beheld the army of the enemies, who, with their scaling ladders, were marching towards the walls. Then he instantly gave order unto Heraud to get his forces in readiness; which being done, he turned to Albertus, and bespoke him thus: "My lord, the honour of all Christendom lies now at stake, and therefore it concerns us now to make a brave defence. They intend to scale our walls; but in my opinion, we had much better meet them in their march, without the walls, than tarry for them here. Our forwardness will bring a damp upon them, and quite confound and break their measures too: fortune does always favour bold attempts: and victory, you see, has on our side declared herself already; which will both encourage our soldiers and dishearten those of our enemies."

Albertus readily approved of what Sir Guy had said, commending his high courage, and rendering thanks to Heaven, that had sent so stout a champion to defend the town. And then, because the enemy was near, each went to their respective posts in order to attack them : and opening the gates, all sallied out to meet them, according to the order Guy proposed; he with his Germans marching in the front. By this bold march of theirs to meet them, the enemy started, and believed they should have harder work 
of it than they thought of : and therefore, throwing down their scaling engines, they put themselves into battalia; which Guy perceiving, gave orders to his archers in the front to begin first, who, drawing their strongbows, poured in amongst them such a shower of arrows as almost darkened the sun itself, and, galling the Turkish horse, put them into disorder; whereupon Guy and Heraud broke into the main body, killing and wounding all that durst oppose them, still pressing them both to the right and left, with flights of arrows, which struck a mighty terror into the infidels. The Bizantines, led by Albertus, and encouraged by the warlike Guy, in a short time routed the left wing of the enemy; while Guy fought the main body, hewing the Pagans down on every side, and like the hand of fate dealt death at every blow; until at last, he came to the squadron by Colbron led, one of the Pagans' generals; who being newly to the battle come, began to wonder at the mighty havoc that Guy had made in the army ; and therefore, coming forwards towards Guy, he, in his haughty way, spoke to him thus: "Thou makest a show of valour, I perceive; but if thou any real valour hast, let us have a little sport between thee and I, only to see which of our swords cuts best : thou hast a weapon there that is much too small, and is, methinks, too blunt to make one bleed."- "Too blunt?" said Guy, "I tell thee, Pagan, thou shalt find it otherwise : I will whet it, ere we part, upon thy bones, and make thee quickly tell another tale. If it should fail me now, I should much wonder, for it has never failed me yet, I am sure; but often cut such lubbers down as thou art. Come, art thou ready? Bid thy friends adieu, for thou art never like to see them more." Then did they lend each other such hard blows, that sparks of fire did from their helmets fly : the numerous Pagans round about them flock, expecting all in the end the death of Guy; for Colbron was not only very strong, but had been long time champion to the Pagans. At length Guy gave him such a blow, that down comes Colbron and his strength to the ground. "Pagan," said Guy, "is my sword sharp, or no? For even now thou blamedst it as too blunt : rise up, for if thou canst not feel thy legs, off goes thy head, as sure 
as this is steel ;" and thereupon he gave him such a blow; as forthwith made him shorter by the head; which, when the amazed infidels beheld, they were with wonder all astonished; for they so confident of Colbron were, they durst have ventured goods, and life, and limb, on any combat that by him was fought.

Then Heraud (to give Guy some breathing time) challenged a Pagan, called Elendant, and dared and defied him to his face (for valiant Heraud did no courage want). The Pagan, somewhat hot, with fury filled, engaged Heraud, and soon was overcome, and to the lake below sent after Colbron : then Guy unto another champion goes, Morgade called, whom Guy so well belaboured, he quickly sent him after his two fellows : the Pagans seeing thus their champions slain, forsook the field, and fled unto their camp. Where when they came, they told all to the Soldan; who, filled with rage, and cursing all his gods, ordered his troops to rally once again; which, when they durst not do for fear of Guy, the Soldan rather than not be revenged, sent Guy a formal challenge, demanding him to fight a single combat with him; and by the event of that to end the war. Guy joyfully accepted of his terms; and all things being ready for the combat, they both met with such martial rage and fury as even made the earth itself to quake; the Soldan being prompted by despair, and Guy courageous :for the Christians' honour, redoubled on him such resistless blows, as made his gilded armour soon give way; and by that means Guy quickly found a passage to his heart, which so soon as with his trusty sword he had pierced, not able longer to support himself, cursing his gods, the Soldan fell down dead. This fatal sight being seen by Eskeldort, a bloody and tyrannic Turkish Prince, he straightway vowed revenge, and rides up armed to the place where Guy then stood; "Villain," quoth he, "whom like a $\operatorname{dog} I$ hate, I will make thee curse the time that thou wast born : know, therefore, I am come to fetch thy head; for to my mistress I have promised it. My dogs shall feed upon thy English flesh; they must devour thy body every bit. Come, I have vowed by Mahomet thou diest. Thy trusting in thy Saviour shall not save thee."

"And thou hast given away my head," said Guy, "unto a lady? 
It is a noble gift. An honest man will do what he has said, and never promise more than he designed. Come on thy ways, and take it quickly off, or else the lady will suppose you jeer her."

Then straight with disdain they rush together, laying on as hard as they could drive ; but Guy's keen sword did so hew Eskeldort, that for his head he durst no longer strive; but on a sudden, for to save his own, puts spurs to his horse, and in all haste is gone.

After this rout, the plunder of the field was by the victors taken; and then Guy returns in warlike triumph to the city, where they received him with the greatest pomp and truest joy, that they knew how to show; while as he rid triumphant through the streets, the people, from the houses' tops and windows, threw garlands down before him, and strewed his way with flowers, echoing along the streets, "Long live brave Guy, the noble and renowned English champion, our fortunate and great deliverer:" in memory whereof, they afterwards set up his statue in the marketplace, which has been since destroyed by the Turks.

Guy, after this deliverance of the city, having been treated as he well deserved, stayed with Albertus there about ten days, and then desired to return to England; and leaving half his men there, as Albertus had requested him, that to the city they might be a guard, he with the rest embarked on his ships, and, with great presents, sailed back for Germany.

Thus having wrought the Pagans' overthrow, .

He made the world his worth and valour know.

\section{CHAPTER IX.}

How Guy, being in a Forest, seeing a Lion and a Dragon fighting, took the Lion's part, and killed the Dragon: also how Guy and Heraud found Earl Terrey wounded, and his Lady taken from him by sixteen villains,'most of whom he killed, and restored the Lady to her Husband.

Guy and his ships, being becalmed at sea, put into harbour to refresh themselves, where Guy and his friend Heraud went 
ashore; and it so happening that a pleasant forest lay bordering near the place they landed at, they entered it, and walked a little way, to see if they could light of any venison; observing, as they went, how shady trees embraced each other in their green-leafed arms, and how famed echo keeps her dwelling there, and little birds there fearless sing their notes; they chanced to find a silver streaming spring, which there they looked on as a rarity; and with those crystal streams they cooled their heats, and quenched that thirst they had so long endured; and there to satisfy their craving stomachs, they made of herbs and roots a pleasant meal : when, on a sudden, an unusual noise (which seemed to be at no great distance off) invades their listening ears; but it resembled most a lion roaring. "Hark, hark," said Guy, "I am almost affrighted at this strange uncouth noise. Heraud, let us straight take horse, that we may be prepared for all events : I never heard a sound that scared me more in all my life. I will go seek it out. It comes from yonder way : some monster, some devil makes this noise, for it is no human voice, for certain." So forth he rides, and underneath a hill he finds a dragon fighting with a lion. "O ! this is princely sport, indeed," said Guy; "fight on, that I may see who gets the day, and then I will set upon the conqueror." The dragon winds his crooked knotted tail about the lion's legs, to throw him down; but then the lion fastened on his scales, and nimbly did avoid the fall intended him. Then both with the utmost fury bite and tear, and so maintain a long and bloody fight. At last the lion fainted, turns aside, and looks about, as if he would be gone. "Nay, then," quoth Guy, "lion, I will take thy part, and execute my vengeance on this dragon." With that courageously to work he goes, and with the dragon carries on the fight, giving him blows with all his might and strength, and yet cannot penetrate his scaly sides. The monstrous beast displays his flaggy wings, and with most dreadful yelling at him comes; whose very looks might make a man afraid, so terrible seemed his devouring jaws; wide, gaping, grisly, like the mouth of hell; more terrible than pen or tongue can utter; his blazing eyes burning like living fire; and from his gorge sulphureous 
smoke he belched; aloft his speckled crest he mounted, higher than Guy could reach at length of weapon's stroke. Thus in most ireful mood he bore himself, crying as loud as watery billows roar. And then his mortal sting he stretched out, exceeding far the sharpest point of steel; then turns and winds his scaly tail about the horse's legs : with that, Guy hews upon him with his blade, and laid on him three men's strength at every stroke; one fatal blow he gave him in his side, from whence did issue streams of swarthy blood; the sword had made the passage wide and broad, so that like a flood the gore overspread the ground, which made the dragon turn to have forsook him. "Nay, then," quoth Guy, "thou hast not long to live; I see thou faintest, and ready art to fall." Then did he give him such a parting blow, that down the dragon came unto the ground; roaring and bellowing at such a rate, that the hideous sound did more affright the conqueror than did his fighting with him; so he rides away, and lets the monster lie. But looking back, he espies, behind his horse, the rescued lion following at his heels, which made Guy alight to engage with him likewise. But when the beast beheld his weapon drawn, he fawned upon. him like a spaniel dog; and like that grateful lion which did save Andronicus, for pulling out a thorn, when by the laws he was condemned to be devoured by beasts upon the amphitheatre, the lion came, remembering his old kindness, and fawned upon him, and licked him, very kindly bearing, it seems, an old good turn in mind. Just so, this grateful lion dealt with him, for the same benefit which he had done, by saving him from the fierce and poisonous dragon. For though a lion is by nature cruel, as being a ravenous and devouring beast, yet, like a spaniel, he by his horse did run, and till he did again embark, stayed with him.

But the wind serving in a little time, Guy and his friend embarked again, and so pursued their voyage, and in Aimain arrived in a short time; and there, according to his worth and merit, was entertained by the Emperor, who bid him kindiy welcome into Christendom, and entertained him with a tournament, with kingly banquets, and with princely revelling; all striving to behold that 
mighty man, of whose great actions fame so loudly spoke; and of whose wondrous acts they had heard so much, and thought they could not do him too much honour.

But, taking leave of the Emperor and the rest, he travels to his old friend the Duke of Lovain, whom he had a particular respect for, and did above all others long to see. But, ere unto his journey's end he came, he met with an adventure by the way, and set a worthy wronged lady free, who forcibly was taken from her love, and he at the point of death, left sorely wounded. Of which take this following account.

The noble Terrey, a right valiant Earl, with his dear love, surnamed Osile the Fair (his precious and inestimable jewel), to take the air into the forest went, wherein a plot was laid to take away his life, that so another might enjoy his love. And on a sudden sixteen villains came upon the Earl and sadly wounded him: "Sirrah," said one, "thou hast a wench we claim; she must go with us; lie upon the ground, and if thou. livest till thou canst see a passenger, beg him to make a grave to bury thee." Guy, finding Terrey in this wretched case, and hearing how his wife was ravished from him, administered what comfort he was able. He with the loss of blood looked pale and wan, and almost ready was to die indeed. "Come, courage, noble Earl," said Guy to him; "I will do my best. to fetch thy love again, or else say, Guy is but a boasting coward." When Terrey heard the mention of that name, he straight revived, for of his worthy deeds fame had before sufficiently acquainted him. Then striving to arise from off the ground, he did his best endeavour to embrace him : "Thanks, gracious Heaven," quoth he, "with soul and heart, for sending such a man to right my wrongs."- "Which is the way," said Guy, "those villains went?" "The path by yonder oak," said woful Terrey. "I will follow them," said Guy, "and, by my knighthood, I will make each man come off by weeping cross." Scarce had he spoke, before he heard a shriek, which Terrey knew to be the fair Osile's. Away rid Guy, and, by that sound directed, he quickly found the barbarous villains out. Coming to them, "Wretched slaves," quoth he, "what is your design with this fair 
lady here? Enlarge her presently and set her free. You have done wrongs which you must dearly pay for: her husband wounded, and she used with violence, are crimes which all your lives can scarce atone for." With that they laughed, and said, "What fool is this, or rather madman, in his desperate mood, that fain by wilful death would get a name, and have the world report he hath been kind? Some frantic fit this fellow is surely in, that means to fight thus without fear or wit."- "If it be so," quoth Guy, "that fit is now on me, and you will find it will be a raging one." Witi that, Sir Guy, knitting his angry brow, bid the fair lady cease her pensive moans, "For you shall from these villains' hands be freed." Then, witi a courage admirably bold, at every blow some one or other dies: which when the lady saw, she straight cried out : "O pity, worthy knight, these mortal wounds. It is a sight I can no longer bear; be not so bloody in revenging me. Upon my knees, I humbly do entreat thee, for it is to me a terrifying sight. $\mathrm{O}$ ! with their lives thou takest mine away. If one more do die, my soul will faint and leave me. Thou worthily my honour hast defended, and hast enough revenged all my wrongs." "Lady," said Guy, "at your request I cease. Depart, base rascals, all but two begone."- "But, villains," said he to the two remaining, "it was you that did this virtuous lady bind," and thereupon he gave each such a blow, having his sword put up within its scabbard, that to the ground they fell immediately. Then, rising from the ground, they thus excused it: "My lord, we did it to preserve her for your honour's use."

'Then on his steed he let the lady ride, to seek her lord, whom she distressed left; and Guy became her guide unto the place; where, when they came, they found him dressed already; for in their absence there came by a hermit, which to his bleeding wounds did salve apply. Now Terrey and Osile abound in joy, and gratefully to Guy do all things give. "Be thou," said they, "renowned in life and death, whom while we live and breathe we will always honour."

"Nay, here's my hand," quoth Terrey, "worthy Guy,

..To fight for thee, I will be proud to die." 
CHAPTER $\mathrm{X}$.

How Guy and Heraud travelled with Earl Terrey, and hearing his father was besieged by Duke Otton, went to relieve him; and how Guy killed Duke Otton in single combat, and raised the siege.

THE light had now surrendered its dominion, and darkness ruled in all the lower world, when Earl Terrey, Guy, and fair Osile, wanting a guide through the unfrequented woods, heard the affrighting noise, on every side, of savage beasts that thirst for human blood. On every side a watchful eye they cast, lest on a sudden they should be surprised. At length they did espy two armed men, who listened to those cries as well as they, each having in his hand his naked sword. But, as they came nearer, Guy quickly knew the one of them was his dear friend Sir Heraud, and the other was as dear a friend of Terrey's, who by embracing did their gladness show. And when the Earl demanded of his cousin, what brought him to that lonely desert place? " $\mathrm{My}$ lord," said he, "I have unpleasing news, which yet in duty I am bound to tell : thy noble father is at this time besieged in his strong castle by Duke Otton's power, who hath protested by a solemn vow, that he about his ears will pull it down. And in revenge that thou hast got his love, he swears thy father's life shall not escape."

"His love!" quoth Terrey, "speak, my fair Osile, acquaint this worthy man with thy soul's thought. Did I persuade thee ever to break thy faith, or been an instigator unto aught that is unrighteous in the sight of Heaven?" "Never," said she ; "thou hast been truly just in all thy words, and all thy actions too: that wretch, indeed, pretended that he loved me, and would have forced my love away from thee. But to my dying day I will be thine : thou shalt enjoy me all the hours I live; and when I aiter this determination, may I be held accursed by God and man."

"Spoke like a virtuous lady," Guy replied ; " be ever constant, and thou needest not fear: nothing can lay a blemish on thy 
honour, whilst thou on love's foundation firmly standest. It is for love I range the world about, and every hour expose my life to dangers, and though an unknown stranger, am love's exile. But wherefore, Terrey, are thy looks so sad? 'Thou has thy love in person to embrace; but mine, alas ! is far off as England, and for some years I have not seen her face."

"My lord," said Terrey, "know you not my grief, and heard this messenger relate the cause? My father is in distress, and wants some succour; and I should be a rebel to the laws of nature, not to sympathise with him, making his trouble a just cause of sorrow."

"If that be all," said Guy, "thou art to blame to spend so much as one poor sigh thereon. My name is enough to terrify Duke Otton. Let him but hear I come, and he will be gone. Something that passed between us is the reason of it: in France he felt my sword, but did not like it. Since that he laid a plot against my life by viliains that surprised me in a wood; which treachery with vengeance I repaid : and who ever knew a traitor's end prove good? A curse is always the concomitant of base and wicked actions, in which the actors will be sure to suffer, as did Perillus first in his brazen bull. I will go with thee to relieve thy father; for the oppressed I have vowed to right. And reason now does much more strongly move it, since mine own wrongs urge me as well as thine. Therefore with speed let us hasten to the place, preventing mischief ere it run too far. Take time by the forelock, for he is bald behind, and good proves best when it is soonest done. Go then, with filial joy, like brave झneas, and fetch thine old Anchises out of Troy."

"Courageous knight," quoth Terrey, "thy bold heart, I do perceive, can with no fear be daunted: thou art composed of Mars's element, and made of powerful limbs, to manage arms ; my melancholy thou hast banished quite, and with strong hope armed me instead of it."

This said, in haste away they post themselves, and in a short time came unto the castle where proud Duke Otton and all his forces lay, relying much upon his well paid soldiers: but when 
his Captains of Guy's coming knew, they fled by night, and never bid farewell. This was discouragement unto the soldiers, to find their Captains had deserted them. But yet Duke Otton solemnly protested, thougin each man in the castle were a Guy, he would not basely quit his enterprise ; "For though life is dear," said he, "yet honour is dearer."

"Terrey," quoth Guy, "we must not now be tedious. For my experience oft hath been my tutor, and taught me, that when an advantage offers, and gives me an occasion to begin, the enemy's own fear subdues himself, to which our force being added soon completes our victory. We will not make our prison in this place, as long as there is field room to be got. And since the Duke has no respect for me, it is my desire alone to combat him. But if you will not leave this castle here, I will leave you all, and go myself alone." And with these words, Heraud and he were going to depart, which, when the castle soldiers did perceive, giving a shout said they, "Thou art our general, and wheresoever thou goest we will follow thee: thy honourable steps we will not leave, let fortune use us as she pleases."

Thus, full of courage, they all march along, giving the onset, fearless of their enemies, making those multitudes that seemed invincible to fly before their brave victorious foes, leaving the most part slaughtered in the field. But when the Duke beheld his flying soldiers, "Perish," said he, "base villains! here I will die! Where is this Englishman that haunts my coast, and thus pursueth me from place to place? I challenge him to leave the army, and meet me face to face, that we may have an end of all old grudges."

"Agreed," quoth Guy, "proud foe, I give consent. Repent thy wrongs, and make thy conscience clear; for thou hast lived to see thy honour lost, which worthy men do hold most dear of all things. The noble-minied brand that man with shame, that lets his name and honour die before him." Then they towards each other did approach, and with great violence they lances broke; which being done, they took their swords in hand, and fought until they had spent great store of blood; for envy did 
the Duke's keen weapon whet, and o: Guy's sword revenge did set an edge. At length, through loss of blood, the Duke fell down, and dying cried, "Farewell, vain world, farewell: by fortune's angry frown I am betrayed; by sad experience now, I tell the world there is nothing constant that the earth contains; death brings the proudest monarchs to their graves, and lays them level with the humblest swain. Bewitching vanities seduce and blind us; and greatness only tends to make us proud, making our sad catastrophe the greater. There is no peace like to a happy ending : my dying hour yields more repenting grace than in my life I ever could attain to." His immortal soul did with these words depart, and left the breathless body where it dwelt, while woful passions did Guy's heart afflict, now wishing Otton were again alive (for true humility still shows compassion, to see the afflicted overborne with woes). Guy sheathed his sword, and said, "Remain thou there, until on England's happy shore I land: for love of Phælice I will shed no more blood; I have from her been too long away: now I will return my wages to receive."

Then mourning over poor Duke Otton's fate, he gave his breathless body to his friends; and then he to the castle back returned, accompanied by Heraud his true friend; where with great joy they were received of all, especially by Terrey and Osile, and the old Earl their father, as those that had by much the greater interest in what Guy's martial prowess had achieved. But after he had staid two days to rest himself, being almost tired with their extreme kindness, Heraud and he took leave, and so departed, carrying their prayers and their good wishes with them.

Thus to be doing good was still Guy's lot;

Others the profit, he the honour got.

Where'er he came, he set th' oppressed free,

And to the prisoners he gave liberty:

But was the scourge of wicked tyrants still,

Not sparing those whom he found doing ill. 


\section{CHAPTER XI.}

How Guy and Heraud, after having parted from Earl Terrey, met with a monstrous boar, which Guy killed: how he was entertained by the Dukes of Lovain and Lorrain, and afterwards returned into England: hone he killed a dreadful dragon in Northumberland, and of the honour done him by the King, and his reception by fair Phalice.

GuY and his friend having thus taken their leave of Terrey and the fair Osile, as we have already said, bending their course towards their native land, resolved to see Duke Lovain in their way. But as they rode through a desert place, dark and obscured by the thick shady trees, which hardly would admit the sun to enter, they on a sudden met the hugest boar that ever mortal eye had yet beheld. "Although," said Guy to Heraud, "I intended to draw my sword no more till I saw England, and laid it down at my fair Phælice's feet, yet such a monster is sufficient warrant to draw it once again, lest it should live to be a plague to all the country near it. And, therefore, private keep thyself at a distance, and give me leave to encounter it alone." This said, away went Guy, and met the boar as he was hastening to him full of rage, which Guy perceiving, stood upon his guard, that so he might avoid his dreadful tusks; then on his swinish head so hard he laid, that dead he left him who had many slain, for from that wood scarce any man came back, which was the cause it was so unfrequented. The monster being dead, Guy cut his head off, huge as it was, and put it on his spear, and carried it unto Duke Lovain's court. The very monster's head appeared so terrible, it frighted people as they rode along, although they then were sure it could not hurt them.

Guy being come into Duke Lovain's court, did there present him with the monster's head, which had destroyed so many of his subjects.

"Guy," said the Duke, "I have had large experience of your great kindness, and your love to me : and this last valiant act that you have done, in killing this prodigious monstrous boar, 
which has of late made such exceeding havoc of my subjects, and of all passengers that came that way, surpasses all the rest, and makes me still much more indebted to you." But to declare the welcome that he gave him with all his warlike trumpets, drums, and clarions, and all his nobles coming to congratulate Guy's safe return, with all the entertainments that were made him; and how the Duke of Lorrain too came thither, on notice given of Guy's arrival there, that so he might embrace that matchless man, of whom fame had such wondrous things declared; I say, should I relate all this at large, it would swell this little book into a volume. Suffice it therefore here to let you know Guy so much longed to be with his fair Phrlice that he was weary of the honours done him, and begged they would let him now return to England, which, after having treated him ten days, they did consent to, and forthwith ordered one of their best ships to be new rigged and fitted up for Guy to sail to Engiand in ; and then, accompanying him to the seaside, "Go," said the Dukes, "and prosper, thou brave Englishman, the most renowned worthy of the world. Thrice happy is the land that gave thee birth, and much more happy is thy fairest Phælice, who must embrace the hero in her arms. May victory attend upon thy side, and may thy brows be with fresh laurels crowned."

Guy having given them his hearty thanks for all the undeserved honours paid him, straight hoisted sail, and having a fair wind, in four days' time arrived on English.ground ; the noise of which soon reached King Athelstan, who then at York his royal palace kepto Thither, being commanded by the King, he forthwith went to pay his duty and allegiance to him. The King received them (for Heraud was with Guy wherever he went) with so much joy and goodness that nothing could be more; welcoming them with such kind of words as these :

"Welcome to me, renowned martial man, my princely love upon you I bestow. I in your fortunate success rejoice, for fame has loudly told us all your story. Guy, thou hast laid a heavy hand, I hear, on Pagan infidels, and with thy sword has sent them home to the dark vauits where unbelievers dwell. Devour- 
ing beasts thou also hast destroyed, which have the terror been of human creatures; yet, worthy man, I think thou never didst slay, of all those monsters terrible and wild, a creature that is more cruel than there is one that at this day destroys whatever he meets, no farther off than is Northumberiand, which is a dreadful dragon that haunts there. I speak not this to animate thee on, and hazard thy life at setting foot on shore; for divers have endeavoured to destroy this wicked beast, and perished in the attempt. No, Guy, I speak only to show thy happiness, which has exceeded that of other men, by freeing of them from their fears and ciangers."

"Dread lord," said Guy, " as I am an English knight, faithful to God, and loyal to my king, I am resolved to go and see this dragon, and try whether my sword cannot work upon him; for I already have a dragon killed, with whom a lion first I found engaged, and whom he had also like to have overcome; but heaven my arm so strengthened that I soon overcame his power, and I will do this." 'Then, taking his humble leave, away he rides unto Northumberland to find the dragon, having a.dozen knights to be his guides, who brought him where the dragon kept his den, feasting himself with nought but human flesh. "Now it is enough," said Guy, "do you stand off, and give me leave to find this hydra's head. He that has fed so much on human flesh, shall never more devour a man again; but, gentlemen, if here you please to stay, you of our battle may spectator be."

Then going to the cave, the dragon espied him, and forth he starts with lofty speckled breast; of form most dreadful; which when Guy beheld, into its rest he forthwith puts his lance, then spurs his horse, and to the dragon makes, encountering each the other with such fury as shook the very ground under them. Then Guy recoils and turns about his horse, and comes upon him with redoubled might : the dragon meets him with resistless force, and, like a reed, bit his strong lance in two. "Nay, then," said Guy, " if you are good at biting, I have a tool to pick your teeth withal;" and drew his never-failing flaming sword, and on him fell with furious blows so fierce, that many wide and bloody 
wounds he made. At which the dragon yawned, like hell's wide mouth, roaring aloud with a hideous noise, and with his claws he rent and tore the ground. Impatient of the smart he underwent, he with his wings would raise his body up, but Guy, with a bold stroke, so cooled his courage, that to distend his wings he wanted strength; and, with a few strokes more, Guy brought him down upon the ground, all wallowing in his blood, and from his mouth a fiery flake proceeded, whilst Guy with all his might was severing his monstrous head from his more monstrous body, which when he had done, "Now, bloody fiend," said he, "thou hast thy deserved recompence for all the human blood which thou hast shed. And now upon this broken piece of spear unto the King I will bear thy monstrous head, which will by him, I am sure, be well accepted."

The joyful knights then went and took a view of that same fearful creature without fear, which was indeed of strange and ugly hue ; all wondering how it was possible to escape those teeth and claws so dreadful, sharp, and long. And when they had fixed the head upon a spear, and took measure of the body's length unto the King, who had removed his court from York to Lincoln, they repair with speed where he with some impatience waited their return; who in his arms embraced the warlike Guy, congratulating him on his victory: then, looking on the dragon's fearful head, "Heaven shield," said he, "and save me from all harm! Why, here is a face may well outface the devil. What staring eyes of burning glass be these, that might, alive, two flaming beacons seem! What scales of harness arm the crooked nose! and teeth more strong and sharp than those of steel! And also that gaping mouth and forked tongue may, even dead, make all the living fear, but more rejoice that thou hast overcome it. Victorious knight, thy actions we admire, and place thee highly in our royal favour: throughout the spacious orb thy fame shall spread more lofty than the primum mobile. To the succeeding age of the world thy victories shall be transmitted down; for I will have the monster's picture drawn on cloth of Arras, curiously wrought, which I in Warwick Castle will have placed, there to 
remain and tell to after ages that worthy Guy, a man of matchless strength and equal courage, destroyed a dragon thirty foot in length. And on this castle wall we will place his head, there to remain till length of time consume it. And, nobles all, make a triumphant festival, and give our knight the honour that he merits."

While thus at Lincoln Guy was entertained and feasted by the King in royal manner, he one day took an opportunity to tell the King the cause of his adventures, and that he did it for the love of Phælice, Earl Roband's only daughter; and then besought his royal majesty to intercede for him unto the Earl, who yet knew nothing of their loves; and that he would give consent unto their marriage.

The King assured him that he would not only use his interest with the Earl her father, to obtain his consent, but would himself honour their nuptials with his royal presence; with which Guy was well pleased, and humbly thanked his majesty.

Now all Guy's thoughts were taken up with Phælice, to whom he was preparing to be gone; but Phælice hearing that he was at I.incoln, and how he had been in Northumberland, and killed a dragon there, began to be impatient at his stay. And thereupon she came herself to Lincoln, and happily surprised her Guy as he was ready to depart for Warwick : with Juno's kind embrace, and Venus's kiss, Phælice embraced her long expected lover ; and Guy returned it with that eagerness, which in the wars of Mars he used to show, glad that he now has Phælice in his arms : but after the first transports were a little over, Phælice, to chide her lover, thus begins : "Forgetful love, and too, too slow," said she, "I fear thou didst not mind the honest friend. What! seek a dragon ere thou lookest for me! and hazard life, yet neither come nor send to know if I remained in happy state. Some jealous woman, would, perhaps, suppose she had been slighted, but I have no such thoughts; not but I wish, I must confess indeed, I had been the first that thou hadst seen on shore; but thou art welcome to thy Phælice now, and shalt no more unto the wars go forth, but lie within my peaceful arms at home. No, 
thou hast fought, my dear, too much already. For war's stern face has stole thy smiles away; but love will change thy countenance again, and make thy looks such as I saw them first, when I first chose and gave my heart to thee."

"Ah, Phælice!" Guy replied to her again, "what toils have I gone through for love of thee! and canst thou doubt that ever Guy should slight thee? No, first the sun shall cease to give us light, and all the stars shall leave their shining orbs, before one thought shall wander from my Phælice. I have learned the art of war enough already, now in Love's school I will take new lessons out, and doubt not but to be a good proficient in that more easy and delightful exercise. I have already made a friend, my Phælice, whose powerful intercession to thy father shall gain me his consent to marry thee; and when I tell thee it is the King himself, I doubt not but you will be of my opinion."

"His intercession," Phælice then replied, "will be, no doubt, effectual with my father; but I believe your merits are so great, you will have no need of any intercessor; for I am sure my father speaks of you as one for whom he has the utmost value."

"Why, then," said Guy, and smiled, "let us to Warwick, a place I love the best in all the world, because it is the place that brought up thee, and there I first was with thy beauty blessed. I love the castle and the castle ground, for there, my Phælice, thy face I first saw. Let us haste, my love, to that delightful seat; and seal those vows we have to each other made; I long, methinks at church to say these words, I Guy take Phalice to my zoedded zoife; and to hear immediate reply, And I take Guy to be my zedded husband."

To which Phælice, with an air that showed how well she was pleased, made reply:

"Though now our satisfaction's very great,

Yet until then our joys can't be complete ;

There's pleasure in the ways that to it tend,

But Hymen's joys must always crown the end." 


\section{CHAPTER XII.}

How Guy and Phalice zere married; with an account of their splendid wedding; how Guy soon after vowed a pilgrimage, and travelled into the Holy Land, \&.c.

GuY and fair Phælice having both agreed with speed to consummate their mutual joys, and tie that knot at Hymen's sacred temple, that only death can loose, first went to wait upon the King and Queen, and humbly to invite them to their wedding, which they agreed on such a day: then took their leaves, and thence repaired to Warwick. Earl Roband had received letters from the King, letting him know that Guy was then in England, and that for love of his fair beauteous daughter, he had undertook the dreadful toils of war; and was coming now to Warwick to ask his consent, and then to celebrate his nuptials there. Earl Roband, overjoyed at this good news, immediately went forth to meet his new elected son-in-law.

Guy, seeing that the Earl was coming towards him, alighted from his horse, and low on the ground he bowed himself, but the good Earl soon raised him with his hand, and tenderly embraced him in his arms, with all the expression of true love and friendship. Guy then informed him of his love to Phælice, begging his pardon for his great presumption, and humbly asking his consent to marry her: to whom Earl Roband made this kind reply: " $\mathrm{My}$ daughter, worthy Guy, I freely give thee, nor is there auything on this side heaven I have more desired than such a husband for her; that when in the annals of succeeding ages thy wondrous story shall at large be told, my daughter may be mentioned as thy wife, and that Earl Roband also was her father; and that from thee, and from my daughter Phælice, so numerous an issue may proceed as may in time fill all the world with heroes." Guy humbly thanked him for his consent, and told him, "The greatest honour he could boast of was to have such an Earl to be his father, and such a lady for his wife as Phælice."

Then Phælice being called, was asked if she was willing to have 
Guy to be her husband: who, with a virgin blush, declared her satisfaction. The next thing now was the happy day in which their nuptials were to be consummated.

And now the long-expected day is come, in which these lovers must complete their happiness; and all the honours Hymen can dispense, he freely gives to grace the wedding-feast, for royal Athelstan and his fair Queen, to grace this nuptial, in their pomp appeared : the nobles likewise, in their richest robes, with worthy knights and gentlemen, besides ladies of honour, strive to outvie each other in honouring valiant Guy and his fair bride. There wanted nothing that could be procured to please the eye, or to content the mind ; masks, midnight revels, tilts, and tournaments, with stately shows, and acting ancient stories, and banquets proper for such royal guests. The tables were with such great plenty stored that neither fish nor flesh was wanting; and bowls of nectar crowned their entertainment. Nor was the choicest music wanting there, while healths were drank to the fair bride.

Ten days this wedding-feast was celebrated, and the country round the better for it, for good Earl Roband never forgot the poor, and then the King and Queen, wishing all health and happiness to the new married couple, and the good Earl, that had so nobly treated them, returned again to Jincoln.

But as our lives are made of chequer work, and joy and mourning take their several turns, so this great joy was quickly after shadowed with a black cloud of sorrow; for hardly had the inconstant queen of night took her nocturnal ramble through the heavens (which journey usually she makes in eight and twenty days, or thereabouts), but good Earl Roband (Phælice's wrorthy father) resigns this life for immortality, and unto Guy bequeaths his whole estate; which filled them both with an unusual grief, in losing both a father and a friend. By his death, Guy became Earl of Warwick, confirmed therein by royal Athelstan; and all his land and lordships now are his, and he declared a nobleman of England.

But ah! how small a satisfaction it is that all the honours of the world can give us! For now Earl Guy, reflecting on past 
actions, can find no comfort in the sad reflection : he sees those things that gave him his renown were vain and wicked in the sight of Heaven. Oft would he sit and meditate alone, on those vain steps that his rash youth had trod; then to himself with groans and grievous sighs would he cry out, " $O$, pardon me, just Heaven! I have done nothing yet thy grace to purchase, but spent my time about a woman's face; for beauty I have shed a world of blood, hating all others for one mortal creature. How many days have I wasted for a wife, but for my sins never spent one weeping hour! It is now high time repentance to begin : henceforh the remnant of my days $I$ will spend in contrite sorrow for my former sins, that Heaven may pardon all the erring ways whereby fond flesh and blood deceived me. Unto the world I will now go learn to die, let me be censured for it as men list; I will please my Maker in whatever I can : ambitious pride hath been my youth's disease: I will teach age meekness ere my glass be run, and bid farewell to honour, wealth, and beauty; I will go through hell itself to purchase heaven."

Phælice, perceiving he was melancholy, unto him came, and with him thus discoursed:-_ "M! dearest lord, why are you so changed of late? Let me, as in your joys I share, so likewise in your sorrows bear a part. If I have in anything offended you, let me know it, and I will instantly confess my fault, and make you satisfaction."

"No, my dear love," said Guy, "it is not with thee, it is with myself that I an discontented. By the light of grace, I see the faults of nature: I am dead in sin, although I seem alive. Phælice, my sins, my countless sins appear, crying, 'Repent, and clear thy guilty conscience.' I must deal with thee as Bavarus (a Prince of Rome) dealt with Sygunda his wife, who, from a deep impression that he felt solemnly vowed perpetual chastity. Entreating thee, even as thou lovest my soul, not to dissuade me from what I have done : hast thou not heard what Ethelfride did (a Christian woman), some time England's queen, who, once with child, did from her husband's bed absent herself for ever? And canst not thou, the phœenix of the realm, by imitation win 
immortal praise, leaving thy pure and spotless chastity to be admired by succeeding ages? I know thou canst ; the greater part is divine, and will the soul's advantage much prefer. Thou didst procure, although I did excuse it, my pride, by conquests to obtain thy love. Heaven gave me valour, but I did abuse it ; my heart and thoughts were too much elevated: I thought the crowns of kings were things inferior, and hardly worth accepting: but now I all such follies lo contemn, resolving to become anotier man, and travel for the welfare of my soul ; not as before, upon my horse in armour, but in a gown of grey, a palmer's weed, obscure my journey; for no leave I will take, but only leave my endless love to thee: here is my ring, receive this small memorial, and wear the same, to make thee think on me : let me have thine, which for thy sake I will keep, till with his cold hand death shall close my eyes."

When Phælice heard this strange surprising tale, judge, you that can, how much she wrung her hands, how much she sighed, how many tears she shed, yet wondrous meekly, contradicting nothing: for the devotion of that age was such, those were thought blessed who retired themselves, and whined away. their days in solitude, leaving the world and its bewitching vanities.

And now he throws away his princely clothing, wherein he glittered with almost that splendour wherein the noonday sun to us appears: now his best habit was a homespun grey, such as employs the poor plain country people; a staff, a scrip, and in his hat a scollop shell, not to be known, nor in the least admired: and thus, with pensive heart and doleful tears, he leaves sweet England, and his fairest Phælice, who in her face a map of sorrow wears : all sad and mournful was her countenance, for she to all delight had bid farewell, since she from her beloved lord was parted thus.

Guy journeys on towards the Holy Land, where Jerusalem's fair city stood, in which our Saviour's head was crowned with thorns, without whose gate he shed for us his blood: to see his sepulchre was his design, the tomb that Joseph unto Jesus lent ; with tedious miles he tired his weary feet, and through vast deserts passed a 
thousand dangers. And whilst he thus pursuing was his way, he happened to meet with a most woful wight, a man that was no stranger to sorrow, for he had fifteen sons that were all captives, in slavish bondage and the extremest misery kept by a merciless and monstrous giant: which pressed their wretched father with that grief, that he was almost worn away to nothing; and being past all hopes to find relief, thus to himself bewailed his sad condition :

"Unhappy man, yea, thrice unhappy $I$, who court in vain the last of remedies : in vain I seek for death, which flies me still, though nothing else can ease the woes I feel ! Ah ! cruel tyrant, that of all my sons couldst not afford me one to comfort me, and with his hands to close my dying eyes! But out, alas! were they but happy there, I cared not, though I never saw them more! But oh, to think upon their miseries pierces my heart more than a thousand swords! And that which pierces deepest to my heart is this one thought, there they must still remain, and suffer without hope of remedy: this cutting thought is more than I can bear, and therefore thus I will end my wretched life." And as he spoke these words, he drew his sword, with an intent to sheath it in his bowels. But Guy, that listened to his sad complaint, stepped in in time, and happily prevented him. "Hold, father," said he, "yield not to despair; for you may live to see your sons at liberty: I have heard your sad complaint, and Heaven has sent me just in the nick of time to right your wrongs."

The melancholy man was much surprised to see a stranger in that lonely place ; then, looking steadfastly upon him, said, "Alas, poor pilgrim, I am beholden to thee, that to allay my cruel miseries wouldst flatter me to hope, when there is no room for it : my wrongs are grown so great they are past righting, and death alone is that which must relieve me."- "O, say not so," said Guy, "though I am a pilgrim, thou dost not know the strength that is in these arms, especially when Heaven invigorates them to fight in a just cause. I et me but know where thy sons are in captivity, and leave the rest to me."

"Know then, kind pilgrim," said the unhappy man, "since 
you have a mind to understand my misery, that in yon castle, made impregnable as well by art as nature, there dwells one Amarat, of monstrous size, that is from the race of ancient giants sprung, who does support his great and bulky carcass only by feeding upon human flesh; and therefore seizes all that pass these woods, and, dead or living, bears them hence, into that cursed shambles of destruction, making no difference of either sex, but this, that with the women he satisfies his lust, and with the men his hunger. My only daughter, unadvisedly, as her ill fortune sure enough would have it, passing this way, was taken by the monster: this stirred the anger of my fifteen sons, who were resolved to rescue their poor sister, but in the vain attempt were taken prisoners; yet, for their sister's sake, their lives are spared, though they endure a thousand deaths for one."

"Your case," said Guy, "is sad, and I must pity you ; but I am resolved to try what I can do, if you will but trust me with your sword and armour, to kill the tyrant, and redeem your children."

"Most willingly," replied the hopeless man, "would I contribute unto their release, but am afraid you will rather fall yourself into the tyrant's clutches, than redeem those that are there already ; but, however, my sword and armour at your service are ; and may you meet with the success that is answerable to your matchless courage." "Well," said Guy to him, "stay you, and pray, and doubt not my success against the tyrant."

Guy hereupon went up straight to the castle, his thoughts being employed to think what way he had best take to get the tyrant out; not doubting then but to overcome him easily. So going to the gate, he knocked thereat like one that would come in, and had some business of great consequence. The giant never was so roused before; for at his gate none used to knock so hard; he therefore takes his club and keys, and opening the gate goes out, staring about with watchful countenance: then seeing Guy, thus with disdain and anger he addresses him: "Sirrah," said he, "what business have you here? Have you a mind to feast the crows, and have your quarters hung upon these walls? For what else is it that you can expect? You might have heard that there 
is no ransom here for any one that falls into my clutches; but if you are ignorant, and know it not, this club that is in my hand shall teach you better."

Guy, nothing daunted with his bugbear words, replied again, "Why, how now! are you quarrelsome? You seem to be a very choleric person : but I have a weapon here shall match your club, and quickly bring you to a better temper." And so expecting no return again, he draws his sword, and with the same salutes him about the head, the shoulders, and sides, whilst his erected club did death proclaim ; striding like a Colossus over the Hellespont: but on the ground in vain he spent his strokes, for Guy was much too nimble for him still; for, before he could heave his club again, Guy would be sure to give him the other stroke, for Guy for that advantage always watched: at length, through thirst, the giant feeble grew, and said to Guy, "As thou art of human kind, give leave that nature's wants may be supplied, and let me go and drink in yonder place: thou canst not yield to a request more small than to grant life a draught of poor cold water." "I grant thee leave," quoth Guy; "go, drink thy fill; pledge both the savage boar and the dragon too; but never think again to drink cold water. Think, when thou drinkest, that now thou drinkest thy last." So to the spring he goes, and there his thirst he quenches with almost a tun of water. Guy was amazed to see him drink so much, and to the combat hastens him again : "Come, come," said he, "thou art long about thy liquor, thou wilt wrong the fish that in the river swim; but I will see they shall have satisfaction, for with thy blood their wants shall be supplied." "Villain," quoth Amarat (for that is the name by which this monstrous giant must be called), "I crush thee in an instant; thy life shall pay thy daring tongue's offence ; this club (which is about a hundredweight) shall my commission be to send thee packing: for ravens' diet thou shalt soon be dressed; I'll break thy bones, as though they were but reeds." Incensed much by this bold Pagan's brags, which worthy Guy no longer could endure, he spends his blows on those supporting posts, which like to columns did his body bear. The giant for those 
wounds in choler grew, and desperately at Guy he threw his club, which did directly light upon his body, and threw him by its weight upon the ground; and ere Guy could recover from his fall the giant got his club again in his fist, and struck at Guy another desperate blow; but missing Guy, stuck it fast into the ground. "Traitor," quoth Guy, "thy falsehood I will repay; this act, basely to spill my blood." Says Amarat, "Against an enemy there is nothing base: I will murder any way; could I but poison into thy nostrils blow, thou soon shouldst see I would dispatch thee by it."- "'Tis well," said Guy, "thou openest thy black thoughts: thy beastly bulk is sure the dwelling of the devils. They are thy tenants whilst thou livest here, but when thou comest to hell they will be thy landlords. Vile miscreant, prepare thee for that place, the just reward of such inhuman monsters. But breathe thyself a time, while I go drink; for flaming Phœbus with his fiery eye, torments me so with heat, that I believe my thirst could scarce be quenched with an ocean. Thou knowest to thee I granted the same kindness." Quoth Amarat, "Thou hast no fool of me; no, silly wretch, I have more wit than so: by all my gods I do rejoice to find that thirst constrains thee now ; for all the treasure that the world can boast of, one drop of water shall not cool thy veins. Relieve my foe! and unto my own wrong refresh my adversary! why this would be a madman's part indeed! if thou imaginest this, thou art a child. No, fellow, I have known the world too long to be so simple; now I know thy wants, I will not grant one minute's space of breathing." And with these words, heaving aloft his club into the air, he swings the same about, then rubs his temples, and his locks doth shake, and like the Cyclops in his pride he struts: "Sirrah," said he, "I heave a list to you, and the next blow I strike you will breathe your last; for with this stroke you shall for ever perish. Take thou no care for drink, for never more a draught of water shall come near thy lips, but with thy blood I will soon carouse full merry: here is at thee with a butcher's downright blow, for it is thy blood that must assuage my fury." 
"Infernal, false, obdurate fiend," said Guy, "thou seemest an imp of cruelty from hell : ungrateful monster, since thou hadst denied that thing to me wherein I used thee well, I will with my sword take the more deep revenge on thy accursed head, and quickly make thee shorter by so much. Now, thirst, farewell, I do disdain to drink, and therefore let the river keep its water, or let wild beasts be welcome thereunto, for with its pearly drops I will not meddle. Now, tyrant, know thy latest hour is come. For though perhaps you'll take the greeting ill, yet it is with a good will I give it you:" and thereupon he gave him such a blow as made the monster tumble on the ground. Then Guy set his foot upon the monster's breast, and from his shoulders did his head divide, which with a yawning mouth did widely gape; no dragon's jaws were ever larger seen, to open and to shut till life was gone: and then Guy took possession of the keys, and with them opened all the castle gates; where many woeful captives he set free, that had been long in misery confined, and had been tortured with great cruelties: and when he of their miseries inquired, each told a tale which from his eyes drew tears, and which they could not tell without sad sighs at the remembrance of their barbarous usage. There tender ladies in dark dungeons lay that in this desert wood had been surprised; and every day no other diet had than flesh of human creatures for their food: some with their lovers' bodies had been fed, burying their husbands' bodies in their wombs.

Now Guy bethinks him of the oppressed knight, with whom he left his pilgrim's gown and staff, and of his captive sons im. prisoned here; and blames himself that first of all he had not released the wronged brethren from their woes : then on he goes, and, as he searched about, he grievous cries and lamentations heard, which, as a clue, led him to the fatal place; where finding an obscure and darksome gate, all strongly covered over with plates of iron, he looked amongst his keys, and there found one that soon unlocked and gave him entrance there. He was no sooner entered but he beheld the strangest sight that ever his eyes had seen : men that had there by slow degrees been famished, 
and could but just be said to be alive, looking like pictures which the painters draw when to our eyes they death would represent: of these some by the thumbs were hanged up, some by the heels, and others by the middle. With diligence he takes them from the walls, telling them they were now at liberty; which happy sound revived their drooping spirits. Then Guy to the perplexed knight, their father, repairs, and tells him what success he had against the inhuman keeper of that castle; then bids him come, and there receive his sons: "Though poor and faint," said Guy, "yet they are alive; accept of that, and seek to nourish them." "The father's joy was scarce to be expressed; but when he saw what skeletons they were, how like the living images of death, he scarce had strength to outlive that wretched sight. And the glad sons, seeing themselves at liberty, and their poor aged father still alive, were at a loss how to express their thanks to him that had so generously delivered them.

Guy then unto their father gave the keys, saying, "This castle do I give to thee, where tyranny has dwelt so many years; let it be now a place where pious pilgrims and weary travellers may find refreshment. Those tender ladies that were prisoners here, let tinem be sent away with ease and safety where they desire, when they have strength to travel; and always see you use wronged women well. Men may revenge the wrongs that they receive, but women have no strength to right themselves."

The good old knight, surprised with joy and wonder, fell on the ground, and would have kissed Guy's feet. "Father," said Guy, "I pray forbear this homage; no honour is due to me for what I have done; it was a stronger arm than mine that did it, and unto Him let all the praise be given. And now, I pray, exchange with me again: take you your coat of mail, and your strong sword; give me my staff, and my poor palmer's weed, for to the Holy Land my course is bent.

Ambitious pride hath hurt me all it can, And now I'll mortify a sinful man." 


\section{CHAPTER XIII.}

How Guy's departure out of England is taken; how he employed his time in his pilgrimage; how Phalice spent her time in his absence; and how, in his return, he routed Amanthus's army, and restored his old friend Earl Terrey to his lordships; and afterwards riturned into England unknown.

How Guy turned pilgrim we before have told : but now it will be necessary to say something of what was said, both by the King and the nobility, of his so strange and sudden a departure : which was no sooner known at court, but both the King and the nobility were struck with admiration that Guy, who had so famous been for deeds of chivalry, and had performed so many mighty acts, all for love of $\mathrm{Ph}$ hlice, should so soon leave his fair and beauteous spouse for a toilsome solitary life : yet was his piety commended highly, who set a greater value on his soul, which by repentance he had refined from sin, than upon all the honour he had won, or glittering treasure that he was possessed of.

Now let us look on Guy, the man that sought to find out quarrels for his recreation; who for his Phælice ranged the world about, delighting most in combats and alarms : but he, from his former mind estranged, shuns all occasions that may cause debate. In his own wrongs he vowed no blow to strike; nor injury, nor abuse should force hin to it; for he his natural temper hath subdued, and taken patience by the hand for his guide, to lead his thoughts where meekness keeps her residence. No worldly joys can give his mind content: delights are gone, as though they never had been, and to repent is now his only care, for spending his youth in serving $\sin$; in contrite sorrow now he will pass his age, that litt:e time to come which life shall borrow. Sad were his looks, and pale was his complexion, his diet of the meanest, hard and spare: like a religious man he led his life, in a poor homely thin and threadbare habit; his dignities and honours were forgotten, nor did he the Warwick earldom now regard. Sometimes he would go and search into a grave, and there would 
find a rotten dead man's skull; and with the same would find a conference. examining at large each vanity, and then himself would answer for the head, as if the dead man answered for him self. "If thou hast been a monarch, where is thy crown? Or, who now stands in fear of thy stern looks?" "Death hath of my renown a conquest made, my golden sceptre he has taken from me, and now it is wielded by another hand; and I am now become so poor a thing, my poorest subjects envy not my place." "Perhaps thou hast been some counsellor of state, whose potent wit a mighty reason did rule; where is the policy of late thou hadst?" "Consumed and gone, like to an idle dream! I have not so much wit as will suffice to kill these worms that thus infest my coffin." "Perhaps thou wast some beauteous lady's face, for whose dear sake some have done strange exploits, even such as when the case was once my own, I for my dearest Phælice, have performed. Perhaps there was a skin about this skull fairer than that which Helen's was enclosed in; and on this scalp, bare and worm-eaten now, where nothing else is to be seen but bone, such yellow locks of hair were to be beheld, which for their beauty were esteemed like gold; and in those hollow caves two crystal eyes, and here such lips as love for kissing craves. But what is of all this beauty now become, so precious once in the esteem of men? By powerful death unto the dust it is turned, grown loathsome, filthy, and trodden under foot; and now there is only this poor picture left to tell the wise, All beauty is but vain." Such sad memorials he would oft prefer, of mortal frailty and the force of death, to teach the flesh how apt it is to mistake, and pass repentance off till it is too late: thus would he all things treat with such contempt that might seduce the soul from heavenly love.

Now for a while leave Guy to his own thoughts, and turn your eyes to another subject : to see new sorrows now look back to England ; and to long absent years commit the other. Leave doleful Guy to cares and aged grief, and look how Phælice his poor lady fares; like to a widow all in black attire, she doth express her inward grief of heart. She of her chamber does a 
prison make, and unto sorrow wholly is inclined. She that was late the pride of the English court, with majesty will now consort no longer; but lives like one that despises life and being, and every day did die unto the world; seeing her folly with the eyes of julgment, and noting well how fast false pleasures fly, leaving more pain than they can cause delight. Her thoughts run after her departed lord, and are in motion swifter far than he. "Where is the place," said she, "can give him rest, that for his pilgrimage hath thus forsaken me? Lament, my soul, under the heavy burden, to think poor Guy remembers thee in tears. Methinks he by some river side is sitting, and swells the waters with his weeping eyes: methinks he often cries out, 'Phælice, Phrlice,' and echo through the skies does carry it; then rising up, with might and main he runs, saying, 'Sweet echo, bring my love again.' Then comes he to a cypress tree, and says, 'Sylvanus, this was once the lovely boy whom thou didst praise for feature to the clouds, but here, alas! thy senseless joy is transformed; it is nothing now but tree, and boughs, and leaves, and made to wither as all beauties do.' And then, methinks, full sadly down he sits, and on his bended knees his elbow stays, with head on hand, saying, 'Farewell, vain honour, and all the pleasures of my youthful days; my true repentance has displaced you all ; a happy end brings sinful souls to heaven.' Ah. worthy man! that thus canst mortify thy rebel flesh to conquer Adam's nature, and, that thou blessed eternity mightst gain, dost live on earth but as a stranger in it ; dead, though alive; and newborn, though grown old; Irue, valiant Guy, that hast overcome the devil. As thy advice was when thou didst go hence, that I a vestal virgin's life should live; although, when I was a maiden, by love's art thou didst persuade me to become a wife, I vow by heaven, and Him that reigns above, to keep my thoughts as truly chaste as thine: my beauty all I can I will obscure by doleful lamentations, sighs, and tears; and will by abstinence attain the way to overcome the force of sin's temptations. This sentence very often I have read, 'A woman's chastity is virtue's Queen.' Ceres and Bacchus I will shun wịth care ; for they are 
virtue's foes and vice's friends, and oft to a licentious life da lead; but with sobriety I will still associate, and with spare diet take each day's repast : that soul thrives best that keeps the body bare. The courtly ornaments I wore of late in honour of King Athelstan's fair queen, even all those jewels and those robes of state, wherein to others I have appeared so glorious, shall with their pride and value now supply those naked poor that are about the streets; the gold and silver I am now possessed of shall all employed be about good works. The purchase of eternal happiness is of all wealth most precious unto me : all that in want repair to Warwick Castle, and crave relief, shall there be sure to find it. For the halt, lame, and blind, I will prepare an hospital, which shall be well endowed; and for the widow and the fatherless a special care I will be sure to take, that their necessities supplied may be ; and that young beginners may have wherewithal their calling to set up, I will take care: and for repairing of decayed highways, that travellers may better pass the roads, is also what I will take care about. These things I reckon to be the heavenly thrift, and laying treasure up where it cannot rust ; dispensing of the riches we receive, as each good steward is enjoined to do; that after this short life is done, we may enjoy a life that is eternal. Farewell, vain world, of thee I take my leave, and of those things winich thou dost most esteem ; thy shows are snares, deceitful are thy hopes, and only through false mirrors seemest fair. $O$, that in such disguise I could but travel (as once the kind Sulpitia did contrive in banishment to see her Lentulus) attending on $\mathrm{my}$ Guy, wherever he be; or Hypsicratea like, in man's apparel, following her exiled king through love's desire: it would something ease my wounded heart of sorrow so to divide the burden which I bear, for where affection takes affliction's part in hard extremes, some comfort is expressed. And misery is more easy to abide when friends do with friends divide their crosses. But all in vain it is that $I$ thus wish; it nought avails, my woe is still the same; though straying thoughts do wander here and there, my poor weak body must at home remain. Unto the Holy Land he is gone to travel, Heaven send me thither at my dying day. I 
will about my vows, and see them paid. The good that charity requires I will do; when grace persuades unto works of virtue, it is blessedness to further such desires; and while on earth I do remain a sinner, I will strive to please my God by living well."

In this resolve each day she spent her life, performing all those things she had proposed, and showed so great severity therein that she became the wonder of her sex, who were amazed, and even quite confounded, to see a lady so high born, so rich, and which is more, so rare a beauty too, pouring contempt upon all worldly pleasures; for she was deaf to all her friends' persuasions, nor unto any would she lend an ear that mentioned company or recreation, or what she had determined sought to alter; but such as of compassion would discourse her, she would for blessed Jesus's sake relieve.

Meanwhile her wandering lord from land to land with weary steps repairs, to seek out places which pious pilgrims used to frequent; whilst age and grief, and mournful languishing, with silver hairs had crowned his hoary head, so that good Guy was changed exceedingly : for sorrow and sore travel gives a man a countenance more aged far than they who, with less cares, much longer time had lived; his old acquaintance in those foreign parts, that had his worthy actions seen before, and witness been of all his bold adventures, had lost Sir Guy, as one that had never lived: those that in armour knew his martial face did never expect him in a friar's weed. Amongst the rest, to whom well known he had been, he met Earl 'Terrey, now a wandering exile, each unto other being grown strangers; through sorrow, which the senses oft deceive, they had forgot that ever they saw each other, though Guy and Terrey had sworn brothers been. But having to each other told their countries, and by what means they travellers became, and how one was a voluntary exile, but the other was constrained to be such: as they were parting with a kind adieu, "Oh, Englishman," said Terrey, with a sigh, "I once had a friend, thy countryman, who righted me in my extremest wrongs, and was a champion in the cause of virtue, and was to every tyrant a sworn foe, for on oppression's neck he would set his foot : tell me, dear friend, hast 
thou not heard of Guy, that had a hand to help, a sword to fight in the behalf of all that were oppressed ?" "I have," said Guy, "and knew him many years, he is Earl of Warwick now, and peer of England: what is thy name?" "My name," quoth he, "is Terrey, greater by birth than now my fortune makes me." "Terrey," quoth Guy, "I vow I will do thee right in what I can; my poor good-will esteem, for I too am a friend to the oppressed; and since thou lovest my friend, thy friend I will be. Direct me to the man that is thy foe, I will take thy part as far as strength will go; if Guy himself were here to join with us, he could but say, I will venture life for friends ; and be assured, though simple I appear, I have oft had as good success as he." Terrey with hearty thanks requites his love, then brings him to his foe, whom he defies, and with his adverse champion bravely fights, who by a mortal wound dies at his feet. Yet it was, it seems, a man of matchless worth, who for that combat they had singled out. When this was done, the Earl demands his name; "Pardon," quoth Guy, "that were against my vow; to no man living I will my name reveal, for I have now both name and nature changed. Nature's corruption now my strife is to leave, and to receive a new regeneration.

Farewell, my friend, if we on earth don't meet, In heaven hereafter we'll each other greet."

So he towards Júdea's ground departs, to see Samaria and Galilee, places which Christian pilgrims much frequent, because their Saviour's choice was to be there. He to redeem our loss did suffer, even from the manger to the bloody cross. Much time Guy spent, and many years bestowed in travelling about from place to place, surveying each place in the Holy Land, that all his friends in England now supposed that he among the living was no more, for from all pilgrims that had back returned, of noble Guy no tidings could be heard: this put the world to silence, men were mute, because of Guy they knew not what for to say: that dreadful champion that when in bright armour struck such a terror wheresoever he came, was neither known nor feared 
in simple grey; but did endeavour all that ever he could never to be known to any mortal wight : for unto none would he disclose his name, nor tell to what country he belonged : his noble thoughts in his own breast concealed, his chief design was to remain obscure:

Until by native love his mind was led, To lay his bones where he at first was bred.

\section{CHAPTER XIV.}

How Guy returned to England, which he found invaded by the Danes; and how he undertook to fight with Colbron, a Danish giant, whom he killed; upon which the Danish army was overthrown, and forced to fly' the land. And how' Guy afterwards took himself to a solitary cave, where he lized unknown.

As the most bright and glorious shining day will have a night of darkness to succeed, in which the earth will be wrapped up in clouds, and all the world be clothed in sable weeds, presenting us with drowsy heavy sleep, to keep the thoughts of death in memory, so youth the day of nature's strength and beauty, which had a splendour like the eye of heaven, must yield to fate, by the great law of nature, when length of years shall bring life's evening on. This cogitation dwelt in Guy's sage breast, and made him, when he was in Palestine, think of returning to his native country. He found himself to be well struck in years, and that his glass had but few sands to run, before the close of his declining days; and therefore he to England comes at last, there to be buried where he had been born; for this was all the cause that drew him back, to end his days there where they first began: that his poor body after all his toils, which through the world no resting-place had found, in English ground at last might safely rest.

Being arrived upon his native shore, his country in extreme distress he found; for in each place great store of armed troops against the foe was got in readiness. 'The King of Denmark to destroy the realm a mighty army had securely landed, which with incredible destruction marched, laying the country waste, and 
burning towns, and filling all the nation full of terror; which forced King Athelstan, for his security, with his small forces to retire to Winchester; which when the Danes once knew, they thither away, and with their warlike troops set down before it. But that was far too strong for them to take; their walls of stone were then invincible, nor had they cannon keys to let them in. The monk's invention was not then found out, of murdering men by wholesale with their gunpowder: a soldier then that would attain to honour, by manly strokes could only purchase it.

Beholding now how oft they were repulsed by those strong sallies that the English made, and that they were not like to take the city, they beat a parley, and therein proposed that they were willing to decide their quarrel by single combat, to save shedding blood, between a Dane and an Englishman; to which, when both sides had agreed, the Danes brought forth a mighty giant of a prodigious stature, demanding where the foxes all were hid; saying, "If there be one dare meet me here, that for his country will his valour show, let him come forth and try with me his manhood; or else the English are the worst of cowards. For craven cocks on their own dunghills will both crow and strike before they run and cry. Is English courage now become so low that none will fight? Are you so fearful grown? Then I pronounce you all faint-hearted fools, afraid to look upon a martial man. O what prodigious lies, in foreign lands, of these men's valour have I heard repeated! What great achievements have they oft performed, if lies be true! But they are sadly slandered; for in their feet their valour chiefly lies, for they with them can swiftly run away. They have an ancient proverb to instruct them, That it is best sleeping in a whole skin." Thus did he vaunt in terms of high disdain; and threw down his gauntlet, saying, "There is my glove."

All this and more Guy unperceived had heard, and for his country's sake could bear no longer the insulting boast of this proud Danish monster: and therefore straightway goes unto the King, and thus, in pilgrim's weeds, addresses him : "Dread Lord, though in this simple habit hid, this proud insulting foe I beg to 
combat; for though I seem unfit for what I ask, I never attempted aught but what I did: and therefore doubt not but to free your kingdom from the invasion of injurious Danes, by overcoming this their boasted champion."

To whom the royal Athelstan replied, "Palmer, thou seemest to be a man of courage; but I fear for Colbron thou art much too weak : ah! I remember once I had a champion, upon whose head my crown I would have ventured: but valiant Guy, alas ! is now no more. Had he been here, I had not been thus distressed."

To which Guy thus replied, "Great Athelstan, trust me for once, for though I am unknown, it is a just cause in which I do engage; and Heaven does still both favour and succeed the just side. I cannot see one brave an English king, but, aged as I am, my blood is fired, and nothing but his head shall be to me satisfaction for the affront."

At which bold speech of Guy's the King was amazed; and, wondering at the greatness of his spirit, said, "Palmer, I accept thee for my champion, and thou alone shalt be the man on whom I am resolved to venture England's crown." And thereupon ordered immediately that his own armour should be brought; which Guy, having received, soon put on ; then girting his massy sword about him, came to the King, and of him took his leave; the King assuring him he did not doubt but Heaven, in whose great cause he was engaged now, would be his strong defence, and give him victory. "Amen," quoth Guy; and with great courage goes from Winchester's north gate unto Hide Mead, where he soon found that monster of a man, treading two yards of ground at every step.

"Art thou," the giant cried, "that mighty man on whom the King will venture England's crown? What, can he find for me no fitter match than this poor rascal in a threadbare coat? Where are all his worthy knights and champions now? A wretch so base as thou art I disdain."

"Giant," said Guy, "I matter not thy words, for hadst thou manhood, thus thou wouldst not rail, nor spend with blasts of 
empty wind thy breath. A soldier's weapon best his tale can tell. Thy destiny thou on my sword shall find, which, whilst thou hast drops to bleed, will let thee blood: and thus I to chastise thee will begin." And thereupon such blows he on him laid, that Colbron never had felt the like before; who with his club waited to meet his sword, intending to have broke it with one blow. But Guy was well aware of his design, and by his own agility prevented him ; and therefore boldly he about him laid, until the lubbard's breath was almost gone. For with a weighty club did Colborn fight, which missing of his blow, fell on the ground, and the very earth itself gave way, so ponderous were the strokes that he designed. So long they held this wrathful furious fight that the spectators knew not what to judge; though Guy on Colbron still fresh wounds bestowed, as a presage of his ensuing victory; and by his activity escaped the danger with which each blow of Colbron's threatened him. At last, quoth Colbron, "Englishman, forbear, and sue for mercy, ere I strike thee down." "Villain," quoth Guy, "thy coward's fear I scorn, I will have thy life, or it my own shall cost. We will never part till one be conqueror; the King hath ventured England on my head, and therefore I will not yield an inch to thee, for all the wrath that Denmark ere could boast : thou shalt find metal in these aged limbs; although thy body bulkier be than mine, I have a heart bigger than thine by odds. Think on thy ancient grandsire, Gogmagog, who was at Dover fought by Corinæus, and by that worthy Briton overcome, though he with boldness like to thine had challenged him ; and as he then was served, so shalt thou now." And thereupon Guy gave him such a stroke it made wide ruptures in the giant's flesh, and very much provoked his furious choler, laying about him with the utmost rage ; meantime Guy managed both his parts so well, which was to lay on a load upon his foe, and save himself from his destructive blows, that he at length gave Colbron such a wound that on the earth he tumbled in his gore; whilst with his blood his soul departed hence, and in the sooty regions took fresh quarters.

Forthwith a shout from out of the town was heard, that made 
the welkin echo back the sound, which joyful was to every Fnglish heart, and brought as great a terror to the Danes, who with the utmost grief away departed.

King Athelstan then for his champion sent, to do him honour for this great exploit; who by the clergymen was first received with that solemnity his worth deserved; and next by all the nobles was embraced, and entertained with trumpets, drums, and other martial music. But Guy in these things took but little pleasure; refusing costly ornaments and jewels as things that he was out of love withal. To God he only gave the praise of all, blessing $\mathrm{His}$ name that thus had given him power to free his country from invading foes; and so entreats that he unknown might pass, to live where poverty regards not wealth, and be beholden to the help of none, and there, by stealth, sometime to view the world; for true content doth bring so great a treasure, it makes the beggar richer than the king. "With true content will I abide," said he, "in homely cottage free from all resort: for I have found within a monarch's court content can never long be made to dwell. No, there is ambition, pride, and envy there, and fawning flattery stepping still between." "Yet, gentle palmer," said the King, "I pray that thou at least wilt so far honour me, wherever thou resolvest to abide, as to acquaint me with thy name in private, which is the only boon I ask of thee. Tell me but who thou art, I will ask no more, and on my royal word I will conceal it."

"Why then," said he, "if it may please your majesty, I am your subject, Guy of Warwick named, that have for many years not seen your land, but been where youth by age and travel is tamed : yet there, dread prince, experience taught me wit, and of the follies of the world convinced me. And now I am returned to make my grave within that kingdom which first gave me life. Yet shall no creature else have the least notice of my arrival ; no, not my dear wife, till sickness comes, such as does threaten death ; then I will acquaint her of my last farewell."

The King thus having heard what Guy had said, went to him, and with joy in his arms embraced him, and with great admira- 
tion answers thus: "Most worthy Earl, preserver of thy country, it grieves my soul thou wilt not live with me. $O$ would thy resolutions were to make, that my persuasions might prevent thy vow! But it is too late, they are grown ripe, I see, and thou art fixed in thy determination. Well, worthy man, in this I joy, however, that to thy native soil thou bringest thy bones; where standing monuments of thy great deeds shall last unto the world's remotest ages. In Warwick Castle shall thy sword be lodged, to witness to the world what thou hast been. And lest the future age should grow neglectful in the preserving of thy memory, the castle keeper shall receive a salary, which I myself will straightways settle on him, to keep thy sword in memory of thee. Thy armour likewise, and thy martial spear, which did thee service in thy high designs, shall all be carefully preserved there; that all such men as have distrustful thoughts may think (if from a truth it did not spring) a king would scorn to cheat his people so. And in thy chapel (distant thence a mile) a bone shall hang of that devouring beast, which did so long near Coventry remain, whose rib, by measure, was at least six foot, destroying many that did that way pass, until thy valiant arm the savage slew. By tradition it may down be handed, and unto those that thither come reported, this was Guy's armour, this his massy blade; these bones of murdering beasts which he overcame; and this the tomb wherein his corpse was safe deposited: this the true picture of his shape at length; and this the spear that of his strength did witness, for sure I hold it as a thing ungrateful (when thy remains shall mouldered be to dust) if none shall cause some muse to sing thy fame, and tell the worth of Guy, that English hero. Thy countrymen cannot so forgetful be, when out of sight to leave thee out of mind, when thou for them hast done such mighty things."

This said, in humble duty, wondrous meek, Guy, with a lowly reverence, left the King, to seek some solitary cave or den, which he unto his mansion house converted; and buried whilst alive he poorly lives, making his meat of wholesome herbs and roots. Sometimes he would repair to Warwick Castle, and crave an alms 
at his dear lady's hands : who to pilgrims did more bounty show than any lady in the land besides : and she would ask all palmers that came there if they were ever in the Holy Land; or, if they in their travels had seen an Englishman, lord of that noble castle, who many years from hence had been away? "He was a knight that never was conquered yet by any human power: I only fear one cruel tyrant, who is called death; if he has met him, then, my dearest lord, I never shall behold thy face again, until that monster do as much for me, and so unite our hearts again together, which gracious Heaven grant : if Guy be dead, O let me on the earth no longer stay." Thus often did he hear his wife inquiring with deep complaints, from extreme passion flowing, yet by no means would grant her kind request, nor yet bestow one hopeful word of comfort; but yet would view her, as if his heart would break; then, to prevent his speaking, turn away; and so, even weeping, to his cell depart: there placing before his eyes a dead man's head; saying, "With thee I will shortly come to dwell, and therefore do despise this sinful flesh : my soul is weary of a guest so bad, and therefore doth at rest desire to be. My strength is from my feeble limbs departed, and sickness now begins to gripe my heart : my happiness is now apace approaching, and I am in hope my foe and I shall part. Long time, alas ! I have fed this adversary, by whom my soul hath been misled so oft. To my dear Phælice I will send my ring, which I to keep did promise for her sake. I now no longer will the time defer, for fear lest death surprise me unawares. Methinks I feel his messenger approach, and poor weak nature must be forced to yield."

Then called a herdsman as he passed by, and said, "Good friend, one kindness $I$ desire of thee, and hope thou wilt not deny it me, for it is a matter that concerns me highly: it is thou wilt repair to Warwick Castle, and for the Countess ask with trusty care, and then into her hand this ring deliver, and say the ancient pilgrim sent it her that lately at her gate with scrip did stand, to beg an alms in blessed Jesus's name. And if she ask thee where I may be found, direct her hither; she will well reward thee," 
"Sir," said the herdsman, "I shall be ashamed who never yet spake to a lady in my life: besides, I may perhaps come into trouble, to carry rings to the Earl of Warwick's countess. And then say I should lose it by the way, what would the Countess or yourself say to me?"

"Prithee," said Guy, "frame no such idle doubts, no prejudice can come to thee at all; the thing is honest about which thou goest, and none can call thee into question for it. A courteous ear the lady will give thee, and on my word you will receive no harm."

With that he goes and delivers the token to the Countess; which she receiving, was presently with admiration struck. "O friend," said she, "where is my husband's being?"

"Husband!" said he, "I nothing know of that. It was from an ancient beggar I received the ring, whose house I cannot well describe; for it is neither made of wood nor stone, but under ground he went into a hole. And in my conscience there alone he dwells, and never pays his landlord quarter's rent."

"Ah! it is my Guy," said she; "show me his cell, and for thy pains I will very well reward thee." And then ordering her steward to give the messenger a hundred marks for bringing her those welcome tidings, she straight went with him to the lonely cave, in which her lord led such a solitary life; but he, espying her, as weak and feeble as he was, went forth to meet her, and there her lord and she embraced each other, and wept a while ere they could speak a word: and after a good space that they had been silent, Guy first the doors of silence thus did break :

"Phælice," said he, "now take thy leave of Guy, who sent to thee, ere his sight decays : within thy arms I do entreat to die, and breathe my spirit hence from thy sweet soul. It is not long since to me thou gavest alms at Warwick's Castle gate; it is blessedness poor men's estate to pity. Look not so strange, my dear, lament not so. Ah! weep not, love, I do not want thy tears; for since my coming here I have plenty of tears of true remorse, conscience knows. Thou weepest not now, because I wept no more; but to behold me friendless, poor, and wretched. 
My love, I have sought the place that I desire, though few endeavour for eternal rest. The soul which unto heaven doth aspire, and only seeks after celestial things, must leave the world and all its fading joys, and all the vanities thereof detest: for could we see it with a spiritual eye, we should discern it full of nought but devils, that always lie in wait to ruin souls, and to that end are always laying baits to trap and ensnare them. O Phælice! I have spent (and then he wept) youth, nature's day, upon the love of thee; and for my God have kept old rotten age, the night of nature: Christ, my sin forgive; sorrow for this lies heavy on my soul. O blessed Saviour! pardon my misdeeds, in that I have destroyed so many men, even for one woman, to enjoy her love. And therefore in this solitary cave, with God above $I$ have sought my peace to make; against whom I have been more misled by sin than all the hairs upon my head can number. The other day, finding my body ill, and all the parts thereof with pain oppressed, I did compose this will and testament to be the last I ever ordain. Lo! here it is, and, if I can, I will read it, before I cease to be a living man.

\section{洎is last exaill and Testament.}

"Even in the name of Him whose mighty power did heaven and earth and all things else create, as one that is this instant hour to die, I do with an unfeigned heart and mind leave both the world and everything therein. My soul I give to Him that gave it me ; receive it, Jesus, as in Thee $I$ trust. I owe a debt of life that is due to death, and when I have paid Him He can ask no more. "It is but a little breath, a very vapour, and I could wish $\mathrm{He}$ had it long ago. But here is my comfort, whensoever He comes, it is ready for $\mathrm{Him}$, though $\mathrm{He}$ calls to-day. I owe the world that stock of wealth it lent me when I at first began to traffic with it. Less would have given nature more content: the world leaves me naked, as I came into it; I ask but one poor sheet to wrap me in. I do bequeath my numberless transgressions, my sins and evils, they that are so many, that they exceed the bounds of all arith- 
metic, those past, those present, all that are to come, to him that made them loads to burden me; Satan, receive them, for from thee they came. I give good thoughts, and every virtuous action, that every grace has guided me unto, to Him from whom proceedeth all that is good. For only evil I by nature do, being conceived, bred, and born in sin, and all my life has been most vile and vain. I give to sorrow all my sighs and tears, fetched from the bottom of a bleeding heart. I give to repentance, tears and watery eyes of a true convert, and unfeigned sighs. Let earth, or sea, a grave yield to my body: so Jesus to my soul grant room in heaven."

"Phælice, I faint, farewell, my loyal spouse : thy husband dies, assist me with thy prayers. I trust to meet thee in a better life, where tears from weeping eyes shall be wiped before the blessed Spirit ; come, in Jesus' name receive, and then convey my soul to heaven." With these last words death closed his eyes, and he to his Creator his blessed soul resigned, while mournful Phælice, well nigh dead with grief, to sorrow all her senses did abandon, and with her tears drowns her departed lord; beating her breast till breast and heart were sore, wringing her hands till she could no more strive. Then sighing said, "Ah ! cruel, cruel death, the dismal, doleful cause of all my sorrows, thou hast deprived me of my dearest lord. Since loathsome air my vital spirits draw, that thou, to recompense me for my loss, would strike that stroke which all my cares may kill: let me not see to-morrow's light, but make me cold as this dead carcass that before me lies; this true description of a mortal man :

Whose deeds of wonder, pass'd and gone before, Hath left him now at death's dark prison door."

Kissing his face with a farewell of tears, she leaves the body for the grave to claim; and from that place she bears as sad a soul as any of her sex on that occasion was ever known to do; 
her real grief soon sending her to her departed lord: living but fifteen dxys after his death, and then, through extreme sorrow, followed him.

\section{THEIR EPITAPH.}

UNDER this marble pile their lies a knight, Whose great achievements oft perform'd in fight, Has through earth's globe immortalised his name, And given him a never-dying fame;

For his great actions have perfumed the world, Like incense upon sacred altars hurl'd.

To save his country he did his life expose, 'Gainst savage beasts, and far more savage foes ; And in the height of all his valour's pride, He always fought upon the justest side. Nor in his youth more famed for war was he Than in old age he was for piety; In pilgrimage to Palestine he went, Upon himself imposing banishment :

All earthly pleasure he for heaven forsook, And to a pilgrim's life himself betook.

Now here he rests in peace, and by his side The fairest dame that ever made a bride; Who at so great a rate her lord did love As none could equal but the bless'd above :

So bright their virtues were, when here alive, Their names the world's great funeral shall survive. All sure must know, by that which I have said, That noble GUY and PHELICE here are laid. 
THE .

\section{HISTORY OF FRIAR RUSH.}





\title{
VII.
}

\section{THE HISTORY OF FRIAR RUSH.}

\author{
CHAPTER I. \\ How a Devil named Rush came to a Religious House to \\ seek a service.
}

Obere was some fime beyond the sea edified and founded a certain house and cloister of religious men, which house was founded at a great forest's side, for to maintain the service of Almighty God, and daily to pray for their benefactors and founders, and for the salvation of their own souls. This place, by reason of their founders and well-disposed people, which gave unto it largely of their goods and possessions, increased in riches, and every man had gold and silver at their will, and also of meat and drink they had great plenty; insomuch that they were so well at ease and had so much that they wist not what to do, they were so full of wantonness, whereby the service of Almighty God was not well maintained among them. For oftentimes they said neither matins nor evensong; and through their great negligence they forgot clean the charge that they were bound to when they entered into their religion, and they lived more like beasts without reason, than like men of good and holy conversation.

When the great Prince of Devils, which are the patrons of all vices, understood of the great misrule and vile living of these religious men, he consulted to keep them still in that state, and worse if it might be.

And these be the names of the devils:-Belphegor, who was Prince of Gluttony; Asmodeus, Prince of Lechery; and Beelze- 
bub, Prince of Envy, who with many other devils assembled together, rejoiced for the misorder of these religious men. And as they were all assembled together with one accord, they chose a Devil to go and dwell among these religious men, for to maintain them the longer in their ungracious living. This Devil was put in raiment like an earthly creature, and went to a religious house, and there he stood at the gate a certain space all alone with a heavy countenance.

Then, within a while after, the Prior came unto the gate and espied Rush, the young man, standing there all alone.

Anon he said unto him, "What dost thou here, and what wouldst thou have?"

The young man with great reverence answered and said, "Sir, I am a poor young man and out of service, and fain would have a master. And, sir, if it please you to have me, I shall do you diligent service, and shall do so well that you and all your brethren and convent shall be glad of me; for I shall keep so well your secrets, that I trust to obtain at all times your good love and favour, and all theirs also."

And when the Prior had heard his words, he was moved with pity, and said, "Go into the kitchen to the Cook, and show him that I have sent thee thither, and bid him show thee what thou shalt do: for thou shalt be with him a certain season, till that some other better thing fall."

Then the young man made his reverence to the Prior, and thanked him, and forth he went to the kitchen, where he found the master Cook.

Anon he made reverence unto him, and said, "Sir, my master the Prior hath sent me hither unto you, and he commandeth you to show me what I shall do, for I must be here and help you."

The master Cook answered and said, "You be welcome." And anon he set him to such business as he had to do.

And thus the Devil became under Cook in the place that he was assigned unto by the Prince of Devils. And then he said (laughing to himself) as followeth:

"I am right glad that my purpose is come so well to pass, for 
now all mine intent is fulfilled, and I doubt not but all shall be ours. For I shall make such debate and strife among the Friars, that they shall never be at concord and peace. And I shall make them good staves wherewith the one shall beat well the other: and oftentimes they shall lie together by the ears, insomuch that there was never seen nor heard tell of such a rumour and discord in no cloister in the world. And I shall use myself so, that I shall be in great love and favour among them."

Then within four or five days after, it fortuned that the Prior came into the kitchen, and there he found the young man, to whom he said, "Where wast thou born, and what is thy name?"

The young man answered and said, "Sir, I was born very far hence, and Rush is my name."

Then said the Prior unto him, "Rush, canst thou couple hounds together?"

"Yea, sir," said Rush, "that I can do right well; and more than that, I can convey a fair woman into your chamber, and convey her home again so secretly, that no man shall spy it. And also I shall keep your counsel so secretly that it shall never be known."

And when the Prior heard Rush speak so, he was right glad of him, and said, "Rush, if thou canst do as thou hast said, I shall reward thee well for thy labour, and thou shalt be my most wellbeloved servant; wherefore make an end of thy business, for soon thou shalt go a little way on a message for me." And so he departed and went to supper.

And when every man had supped, and Rush had done all his business in the kitchen, he came unto his master the Prior, and said, "Sir, what is your will with me?"

The Prior answered and said, "Here a little beside dwelleth a fair gentlewoman, the which I love very well, but I dare not discover my mind unto her myself. If thou canst find the means to bring her secretly unto me, I shall reward thee right well for thy labour and pain."

When Rush had heard the words of his master, and knew ạll 
his mind, he answered and said, "Sir, be of good cheer, and let me alone with that matter."

And so departed Rush from his master, and went straight unto this gentlewoman's house. And when he was thither come, he found the gentlewoman sitting all alone. And when Rush was espied of her, he made unto her great courtesy, and with many. reverences these words he said:

"Rest you merry, fair Mistress, the most fairest creature in the world. My Master greeteth you by me, desiring you to come and speak with him."

Then said the Gentlewoman to Rush, "Who is your Master, and what is his will with me?"

"Fair Mistress," said Rush, "I will show you. My Master is the Prior in a house of religion here beside, and he loveth you so well except that you come unto him I know he will be dead for sorrow."

And when the Gentlewoman had heard the words of Rush, she answered and said, "Fair Sir, it were great pity that the gentleman should die for my sake, and rather than he should so do for me, I will come to him, and show him all the courtesy that I can."

Rush was very glad of those comfortable words, and forth they went both together, till they came to the Prior's chamber. And when the Prior saw that she was come, he was the gladdest man in the world, and thanked Rush much for his labour and pain : and so the Prior received her into his chamber, and there he made her good cheer, and they had good meat and wine great plenty. And when the other friars perceived that Rush was such a privy fellow, and so well could keep counsel, they desired him to help them also, and so he did. They were so blinded with ignorance, that they never perceived that he was a very Devil, but every man had him in love and favour. 


\section{CHAPTER II.}

How Friar Rush threw the master. Cook into a kettle of water seething upon the fire, wherein he died.

Ir befell upon a day that Rush went forth to sport him, and it was very late ere he came home again, and the master Cook was very angry with him that he was so long absent.

As soon as Rush was entered into the kitchen, the Cook began to chide, and said unto him, "Thou knave, where hast thou been so long?" and with a great staff he laid upon Rush and beat him sore.

And when Rush saw that the Cook was angry, and so far out of reason, and that he had beaten him sore, anon he began to wax very angry with the master Cook, and said unto him, "Thou villain, why hast thou beaten me thus? I will be revenged on thee." Suddenly he caught him in his arms, and threw him into a great kettle which was full of water seething upon the fire, and said, "Lie thou there, in the Devil's name: for now thou shait neither fight nor chide no more with me:" and so Rush slew the master Cook.

Then when he had so done, he departed out of the kitchen, and went to the next town for his master. And in his absence certain of the friars came into the kitchen to speak with Rush, but they found nobody stirring therein, and some of them went to stand by the fireside, to tarry till Rush came in : for they thought he would not tarry long. And as they stood talking by the fireside, they spied a man in the kettle seething upon the fire. And anon they perceived that it was the master Cook, whereof they were greatly abashed. And with that, crying out, they went unto the Prior and showed him that the master Cook had drowned himself in a kettle seething upon the fire in the kitchen : for which tidings the Prior was right sorry.

In the mean season Rush came home, and anon the friars showed Rush of the great misfortune that was fallen on the master Cook in the kitchen, and he made as he had been sorry there- 
for, and had known nothing thereof, and he was in great love and favour with the Prior and all the friars, that they mistrusted him nothing for that deed, and so there was no more mention of the master Cook. Then the Prior commanded that Rush should be made Cook, and all the convent was right glad of that, and so he was himself also, for he thought his enterprises came well to pass after his mind, and as he would have it.

Thus Rush became master Cook in the kitchen, and dressed their meat marvellous well : for in the Lent, and in the Advent, both Fridays and also other days, he put bacon into their pottagepot, the which made the pottage to savour well. And he dressed their meat so deliciously, that the Prior and all the friars had great marvel that he did it so well : in so much that they said he did much better than their other master Cook did; and that he was a more cunninger man in his occupation, and could do much better in his office. Thus Rush continued in that office the space of seven years, and did right well, and every man had him in love and favour.

Then it fortuned upon a day the Prior and his brethren were assembled together in a general council, and as they stood talking together, the Prior remembered Rush, and anon he said unto his brethren, "Friends, we have here Rush, which is our master Cook in our kitchen, and he is an old servant, and much diligent and true service he hath done to us, and he hath continued among us longer than any servant that ever we had: wherefore methink it reason that he were promoted into some other office, and made a Brother among us." Then all the whole convent with one voice said they were content it should so be.

So the Prior sent for Rush, and when he was come before him and all his brethren, the Prior said, "Rush, it is so; thou hast been here a long season, and we have found thee hitherto a true and diligent servant, wherefore we: will that thou be promoted, and take upon thee an habit as we have; and to become a Brother among us."

-Rush answered and said, "My Masters, I thank you all," and then the Prior gave Rush his habit, and put it on his back. And 
so Rush became a Brother in the place; nevertheless he kept his office still.

\section{How Friar Rush made Truncheons for the Friars to fight withal.}

WHEN Rush had on the habit of a Friar, and was a Brother in the place, he had more vacation days than he had before. And as a king or a great prince prepareth ordinances against their wars, in likewise did Friar Rush : for when all his business was done in the kitchen, and that he had leisure, he went and sat in the port of the utter gate, and there he was making of good big truncheons of oak. And he made them with hilts over the hand for slipping, of the which the other Friars had great marvel, and demanded of lim wherefore he made those truncheons.

Rush answered and said, "Fair Sirs, I make them for this intent: that if there come any thieves hither for to rob us, and to spoil our place, yet sisall we have weapons to defend us withal. And therefore I make them. And, moreover, when any need shall be, come to me and every man shall have one, and they shall be ready at your commandment." And then the Friars thanked him and so departed.

Then it fortuned upon a day, that the Prior and sub-Prior fell at discord, and were grievously angry, the one with the other, and would have fought together but only for shame; nevertheless, the anger abode still in their hearts. IVithin a while after, the noise spread abroad among the Friars that the Prior and the sub-Prior were fallen at discord, for the which they were angry in their minds. And they that loved the Prior took his part; and they that loved the sub-Prior took his part: and so they murmured among themselves.

Then they appointed in their minds to revenge their quarrels at one time or other; and so, to make a more surer way in fulfilling their malicious minds and angry hearts, every man after other went privately to Friar Rush to lend them staves, insomuch that there was not a Friar in the place but he had one; and they never went without their staves under their halsit, and the one 
knew not that the other had any, they kept them so secretly. And when Friar Rush had delivered all his staves he was right glad in his heart, for he knew right well there should be a great fray among them either one time or other.

So it fortuned afterward, as it is a common custom among religious people at a high feast, to keep solemn service, and every man to be at matins at midnight, and so upon a good night, all the whole convent assembled together in the quier, and were ready to begin matins; they tarried for nothing but for the coming of the Prior. Then anon the Prior came into the quier, and sat him down in his place, and as he looked about him, he espied that the sub-Prior was there present. With that his heart began to grudge of the old anger that was fallen between them two, and he thought in his mind that he could never be revenged in a better time, and suddenly he rose out of his place and went to the sub-Prior, and with his fist he gave him a good buffet. The sub-Prior, who was moved with the stroke, started unto the Prior and gave him another buffet: and with that they went freshly together by the ears. And when the other Friars saw that, every man rose out of their places and drew out their truncheons, and together they went : who had been there should have seen good buffets given on both parties.

When Friar Rush saw that they were fighting together, anon he blew out all the candles and lamps that were burning in the church, and left no manner of light therein whereby the one might see the other : and when he had so done, he took his truncheon in his hand, and went into the quier among the thickest of the Friars, the which were fighting freshly without light, and there he laid so lustily about, that many of them he felled to the ground, and left them there for dead. And when he had so done, he stole his way from them, and as he went, he found standing in the portal of the quier a great old desk. And anon he took the desk between both his hands and threw it over the portal into the quier among all the Friars, and hurt many sore, in so much that some had an arm broken and some a leg, and other some had their noses clean pared from their faces, that the blood ran in 
their mouths, and as for broken heads to the hard scalp were no dainty, for every man had one, there escaped none free away. Who had been there should have had a goodly pastime to see the Friars creep about the quier, and instead of Domine labia they cried out, "Alas and well away!"

Then when the fray was done and all the noise ceased, Rush came in among them with a candle-light in his hand, and made as he had known nothing thereof, and said to them, "Fie for shame, Sirs! how fortuned this discord to fall among yourselves? I see well now you regard not your honour, nor the good name of your place. All the people shall say ye be not honest, nor good religious men, the which words I would be loth to hear, and I may not suffer our place so to fall in an evil name: wherefore, good Masters, I require you to set your hearts at rest, and put the matter into my hands, and I shall do so much that all shall be well, and you shall be good friends again, and no words shall be spoken thereof." Then every man complained to him of their great hurt. And he nade semblance as he had been sorry therefor; and then they that could go went up to their cells, and they that could not go did creep up as well as they could, and laid them down in their beds; and there they lay till they were whole again.

And in the space of three weeks and more God was evil served, for in all that space they sung neither matins nor evensong, nor never, entered into the church, for it was suspended, and for shame they durst never let it be known. And when they were all whole, and every man upon his feet again, and might go about the house, they brought again their staves to Friar Rush, and thanked him much, and then Friar Rush said unto them, "Sirs, when ye have need of them again, ye shall find them ready here at your commandment," for which they gave him thanks, and departed.

When Friar Rush saw that they were gone, and that he had all his staves again, he laughed unto himself and said, "I am right joyful that mine enterprises be come so well to pass, for I have done many mischievous deeds since I came first, and yet I will do more before I depart hence. For I shall cause them to 
be damned, and I shall bring their bodies and souls into the burning fire of hell, there to remain world without end and of me shall be spoken a thousand years hereafter."

\section{How' Friar liush grimed the waggon with tar, and what cheer he made in the country.}

Another time it fortuned that the Prior had a journey to ride into the country about a little business that he had there to do, and anon he called Rush his servant unto him and said, "Rush, go thy way into the court, and take with thee a dishful of grease; and grease well the wheels and axletrees of the waggon, and make all things ready against to-morrow in the morning, for I must ride forth to-morrow betimes."

Then Rush departed from his master, and went about his business, and instead of grease, he took a great vessel full of tar, and anointed the waggon all over with it, both within and without, and especially in the place where the Prior should sit : and when he had done, he returned to his master's chamber. Then the Prior demanded of Rush if he had done as he commanded him. "Yea, Sir," said Rush, "ye may ride when please you." And so they went to their beds. Then on the morrow after, the Prior and Rush his servant, with his other company, rose up very early in the morning for to accomplish their journey, and forth they went unto their waggon. And when the Prior was entered therein, he perceived himself all to be berayed ${ }^{1}$ and smeared, and all his clothes were filed therewith: and then he said to Rush, "Thou lewd fellow, what hast thou done to this waggon that I am thus arrayed therein?"

Rush answered and said, "Sir, I have done nothing but as you commanded me."

"That is not," said the Prior, "for I commanded thee to take grease and grease but the wheels and the axletrees, and thou hast taken tar and anointed it all over, both within and without. Why hast thou done so?"

1 Berayed, befouled. 
"Sir," said Rush, "I understood you bade me do so."

And when the Prior saw there was no other remedy, he commanded his servants to make ready another waggon, and in the mean season the Prior went into his chamber and put on another habit, and came again and mounted into the waggon and went their way, and so long they rode that they came to their journey's end.

And when they were alighted at their lodging the Prior called for his supper, and anon everything was made ready, and the good man of the house and the Prior sat down to supper together and made good cheer; and then the Prior called for wine of the best, and anon he had his commandment. And when the good man of the house and the Prior had supped, Rush and his fellows sat down to the reversions that their masters had left. But they had no wine: wherefore Rush was very sad, and ever he mused by what policy he might get some wine. And anon he called the wife of the house and said, "Mistress, I pray you fill a bottle of wine for me and my fellows," and so she did: and when that was gone they called for another: and then they called for the third, and so ended their supper. Then on the morrow, when the Prior had done all his business, and was ready to return home again, he called for a reckoning. And anon the good wife came in and gave him a reckoning of all things, both horse meat and man's meat; and at last she reckoned three bottles of wine that Rush and his fellows had. And when the Prior heard that his servants had drunk so much wine, anon he began to wax very angry, and asked her who commanded her to fill in so much wine?

The wife answered and said, "Sir, Rush your servant cornmanded me to fill it in, and he said that you should pay therefor."

Then anon the Prior called for Rush, and said unto him, "Thou lewd knave, why hast thou drunk so much wine? Might no less than bottles serve thee and thy fellows?"

"Sir," said Rush, "we have not drunk so much, for your horses hath had two of the bottles."

"My horses!" said the Prior; "what should they do with wine?" 
"Yes, Sir," said Rush, "your horses laboured sorer than we did, and were very weary, and they had nothing but hay and oats; wherefore, methought it needful to give them some good drink to their coarse meat to comfort their hearts withal, and to cause them to be the lustier, and to have the better courage to bring you homeward."

And when the Prior had heard that answer of Rush, and saw there was no remedy but patience, he paid for the wine, and all things that he had taken there, and so rode home in his waggon; and Friar Rush never went forth again with his master.

How the Prior made Friar Rush Sexton among the Friars, and how he charged him to give him knowledge hoze. many Friars were absent from matins at midnight, and what they were.

When the Prior was come home, he made Friar Rush sexton of the church, and his office was to ring the bell and to light the candles,-and to call the Friars to matins at midnight; and also the Prior commanded Rush and charged him that he should take good heed that there were none of the Friars absent from matins, and if there were, to give him knowledge thereof. Then said Rush to his master, "Sir, all your commandment shall be fulfilled," and so they departed.

And within three or four nights after, Rush espied certain of the Friars that were absent, and he marked them well, and on the morrow after he presented them to the Prior. And anon the Prior caused them to come before him, and gave them a check for their being absent. In a little time Rush had presented them all, which caused the Prior to be greatly offended with them.

When they perceived that Rush had made such complaints against them, they had him in much disdain, but they could not amend it; for he had them in such great fear, that never after they durst be absent, but well was he that might be first in the quier. When Rush perceived the Friars had him in so great fear, he devised to do some mischievous thing among them; and upon 
a night, a little before he should ring to matins, he went and brake down the stairs of the dorter, ${ }^{1}$ and when he had so done, he went and rung to matins, and lighted the lamps and candles in the church, and went into the dorter, and called up the Friars, and so came and sat at the stairs-foot as he was wont to do.

He had sitten there but a while, but anon there came one, who thought no hurt but to go soberly into the quier as he was wont to do, and when he came to the stairs down he fell, and had a marvellous great fall. Then said Rush, "Thou art one." Presently there came another, and likewise down he fell, and had a sore fall. "Thou art two," said Rush. Anon came the third Friar, which had a mighty great belly, and was a gross man, and he made great haste, for he feared that he should have been last, and when he came to the stairs down he fell on his fellows' necks, and he was so great and so heavy that almost he had mischieved his fellows that lay under him. "Thou makest three," said Rush. And with that there came seven or eight together, and down they fell all at once. "Softly, Masters, for shame," said Rush; "ye come too many at once. Ye were not wont to be so hasty, but now I perceive well ye would deceive me, and one would excuse the other, and therefore ye come so thick to blind me in my tale. How should I now give account to the Prior of them that be absent? Surely, I cannot tell, but now I see well ye be too subtle for me. I would some other man had my office," and made as though he had been very angry with them.

Then the Friars, such as could go, though it were to their pains, rose up again and limping went into the quier, and they that fell first and lay under were sore hurt and could not go, and specially the Friar with the great belly. Yet, nevertheless, they crept into the quier as well as they could. And when they were all assembled together in the quier, each of them complained to other of their great hurts, and so they began matins. Who had been there should have heard a heavy song and a sad, for they were not merry in their hearts, their pains were so great.

When matins was done they that could go went up again into 
their lodgings, and they that could not go lay still in the quier all night. On the morrow word was brought to the Prior of the great misfortune that was fallen among the Friars at midnight; for the which misfortune the Prior was greatly displeased and angry in his mind, and thought verily it was Rush's deed, for he had done divers evil turns before.

Then the Prior sent for Rush to come speak with him, and when he was come, the Prior said unto Rush, "How fell this misfortune to-night among the Friars, that they be so sore hurt?"

"Sir," said Rush, "I will show you. It is not unknown unto you that when you put me first into this office ye commanded me to give you knowledge when any of my brethren were absent from matins, and so have I done divers times, whereby many of them have been shent and chidden by you, and for that cause they owe me evil will, and fain would have me out of this office, if they wist how. And for to accomplish their desire, and to cause you to be displeased with me, I shall show you what they have done this night. Sir, it is so, that when the time was come I rung to matins, and lighted candles, and made all things ready, and when I had so done I went into the dorter to every man's cell and called them up, then I went and stood at the stairfoot for to tell them as they came down, as I was accustomed to do, and to know who came to matins and who did not. And for spite that I should not reckon them. they came all on a cluster, and for haste the one thrust the other down the stairs, and he that had the greatest belly had the hardest fall. Now, if they hurt themselves, what might I do withal?"

And when the Prior had heard the words of Rush he wist not what to say, but for to void all tribulations and misfortunes that might fall in time to come, he put Rush out of his office and set him in the kitchen again. And when he was there all alone, he laughed to himself and said, "This enterprise is well brought to pass, and I have made a good excuse thereof to the Prior; yea, will I do more ere I depart out of this place." 
How Rush went forth a-sporting, and was late forth, and how in his way coming home he found a cow, which cow he divided into two parts; the one half he took on his neck and carried it with him, and the other half he left still. And how soon he had made it ready for the Friars' suppers.

IT befell upon a time that Rush, when all his business was done in the kitchen, he would go forth into the country to sport him, and to pass the time with good company. As he walked on his way, his chance was to come into a village, which was two or three miles from the place where he did dwell, and when he was entered into the village he looked round about him in every corner to find out some company to make merry withal.

At the last he espied an alehouse, and in he entered, and there he found good fellows playing at cards, and drinking, and made cheer. Then Rush made obeisance to them, and sat down among them, and drank with the players, and afterwards he fell to play, and was as merry as any man in the company. So long he played and passed the time, that clean he had forgotten what he had to do at home, and the day went fast away, and the night approached.

Anon Rush looked up and perceived that it was almost night, remembered himself that there was nothing ready at home for the Prior's supper and convent, and it was almost supper time, wherefore he thought it was time to depart thence. So he paid for his drink and took his leave, and homeward he went. And in his way he found a fat cow grazing in the field, and suddenly he divided her into two parts; the one half he left lying there still, and the other half he took on his neck and carried it home, and quickly he made it ready. Some he put in the pot, and some upon the spit, and he made a great fire and set on the pot, and laid to the spit: and he made marvellous good pottage, and roasted the meat very well, and he made such speed, that everything was ready by the hour accustomed to go to supper, whereof the Prior and all the Friars had great marvel, that he had made everything ready so soon, and was so well done; for they knew 
that it was late ere he came home. For some of the Friars had been in the kitchen a little before, and saw neither cook nor fire, nor anything prepared toward supper, wherefore they gave great praise to Rush, and said he was very quick in his office.

How a Farmer of the Prior's sought his Cow, and how he was desolated by the way homeward, and was fain to lie in a hollow tree; and of the vision that he had.

THERE was a poor husbandman, dwelling there beside, which was a farmer of the Prior's: the which poor man had a cow abroad in the fields, that was accustomed every night to come home at a certain hour, and never failed. And at the last a mischance fell unto her, for Friar Rush had slain her as she stood in the field, and so she failed of her coming home at her hour as she was wont to do.

And when the poor man saw that his cow came not home, he thought in his mind it was not well with her, so forth he went in an evening for to seek his cow, and so long he travelled about in the fields, that at the last he found the one half of his cow lying there. But the other half was clean gone, and she was so cleanly divided in two parts, that he imagined in his mind that it was not possible to be done but by man's hands, for if any wild beasts had done it they would have spoiled the flesh. So he returned homeward again, and ere he came at the half way, the night was so dark that he could not see which way he went, and so he went out of his way, and house could he find none. At the last he came to an hollow tree wherein he sat him down, thinking there to take his rest all night, and he had not sat there but a while, but anon there assembled a company of Devils, and among them they had a great principal master whose name was Lucifer, and he was the first that spake.

And the first that was called was a Devil, named Belzabub, and with a loud voice he said unto him, "Belzabub, what hast thou done for us?"

Belzabub answered and said, "Sir, I have caused debate and 
strife to fall between brother and brother, insomuch the one hath slain the other."

"That is well done," said the master Devil, "thou shalt be well rewarded for thy labour."

Then forth he called another Devil, named Incubus, and demanded of him what he had done?

"Sir," said Incubus, "I have caused great debate and strife to fall between two lords, through the which they have had great wars, and many men have been slain."

Then said the master Devil, "Thou art a-true servant to:us, thou shalt be well rewarded for thy great labour and pain."

Then said the great master unto another Devil, named Norpell, "What hast thou done for us?"

"Sir," said Norpell, "I have been among players at the dice and cards, and I have caused them to swear many great oaths, and the one to slay the other: and also $I$ have caused debate and strife to fall between man and wife, and caused the wife to cut her husband's throat."

"That was well done," said the master, "thou shalt :be. well rewarded for thy labour."

Then forth came another Devil named Downesnest, and said, "Sir, I have caused two old women to fight so. sore together, and to beat each other about the head, that their eyes flew out."

"That was well done," said the master Devil, "with much thank thou shalt be rewarded for thy labour."

Then forth went Friar Rush freshly, and.with a good courage, and said, "sir, I am in a religious place, and I govern the prior and his convent as I will myself, and they have me in great love and favour; for I do them many great pleasures, and divers times I have caused debate and strife to fall among them, and I have made them staves, and caused them to fight stiffly together, and to break each other's heads, and their arms and legs, and yet will I do more among them' ere I depart 'out of the place, for I shall make so great debate and strife among them that the one shall slay the other, then they shall come and dwell with us in hell, and burn in perpetual fire without end." 
Then said the master Devil to Rush, "If thou have done as thou hast said, thou hast done well thy part, and I pray thee be diligent thyself about thy business, and stir them to sin, and specially to these three, that is to say, wrath, gluttony, and lechery, and briefly to make an end of thy enterprise, and slip it not : and when thou hast done, come home, and thou shalt be highly exalted and well rewarded for thy great labour and pain."

When Rush had told his tale, the great master Devil commanded every Devil to go his way and do the best he could; and thus they departed. Some went one way and some another, and thus they were scattered abroad in the world, to finish and make an end of their enterprises that they had taken in hand.

And when the poor husbandman which sat in the tree saw that all the Devils were departed and gone, he rejoiced in his heart and was right glad thereof, for as long as they were there, he was ever in great fear and dread. He was afraid that they should have seen him there, and ever he prayed unto Almighty God to be his guard, and save him from that foul and evil favoured company of devils, and to send him the light of the day that he were gone out of that place. For he was weary that he abode there so long, and oftentimes he looked up to see if he could perceive any light of the day whereby he might see to depart thence, for till then he durst not once stir out of that place, for he feared that they had been there still. Then within a while after, the day began to appear, and when he perceived that, anon he started up and looked round about him abroad in the fields, and when he perceived that there was nobody stirring, he thanked Almighty God that he was preserved out of that great jeopardy, and so departed.

Hon the Farmer which lay in the tree came unto the Prior on the morrow after, and tolde him the wordes that he had heard, and the words of Friar Rush, that he was a very devil.

As soon as the day began to appear the poor Farmer arose out of the tree, and took his way straight to the Prior, and he would never rest till he had spoken with him. And when he was come 
to his speech, anon he said: "Sir, this night hath fortuned to me a great adventure."

"How so?" said the Prior.

"Sir, yesternight late in the evening, I walked forth in the fields to seek a cow which I have missed this four or five days, and so long I wandered abroad till at the last I found the one half of my cow, but the other half was gone. And as I would have returned home again I was benighted so sore that I lost my way. Then I wist not whither to go, but spying a hollow tree, I sat me down, thinking there to take my rest till the day appeared again. And I had not sitten there but a while, but instantly there was assembled a great company of devils, which made a marvellous great noise, whereof I was sore afraid. They had among them a great master named Lucifer, who called all the rest to make a reckoning of all their service they had done since they departed out of hell: There I heard many marvellous tales. At the last forth came Friar Rush. Then said the great master Lucifer unto him, 'Rush, what hast thou done since thou departed out of hell?' and he answered that he had ruled you and all your convent, and caused you to chide and fight, and were never in unity and peace among yourselves. And he said he had caused you to live viciously, and yet he said he would do more ere he departed out of this place, for he will cause you to kill each other, and then you should be damned in hell, both body and soul. And so every devil departed and went about their business. Wherefore take heed, for he is a very devil."

- And when the Prior had heard the words of the Farmer, he thanked him for his labour, and so they departed. The Farmer went home to his house, but the Prior was marvellously abashed at the words of the Farmer, and went into his chamber and was much grieved in his heart that he had so lewdly misordered him. self against his Lord God. And with great contrition he kneeled down upon his knees, and asked Almighty God mercy and forgiveness for the great and grievous offences that he had com. mitted and done against $\mathrm{Him}$, and that he had so vilely misused the order of his religion. And when he had thus done he de- 
parted out of his chamber and went into the cloister, and caused all his brethren to come together. And when they were all assembled, the Prior told them every word as the husbandman had told him, and that Rush was a very devil and no earthly creature; at the which they were sore astonished, and were right sorry in their hearts that they had followed him so much in his mind, and done after his counsel, and were heavy in their hearts for their great and abominable sins that they had committed and done, and with great contrition they knelt down upon their knees and desired Almighty God for grace and pardon. Then the Prior caused every man to fall to contemplation and prayer.

Then forth they went and did the Prior's commandment, and briefly made them ready, and went to prayer all at once. And when they: were come to the midst of their service the Prior departed out of the church and went to the kitchen, wherein he found Rush, who was there very busy. Then the Prior commanded him to stand still, and by virtue of Almighty God and of all the company of heaven, he conjured Rush into the likeness of a horse, and commanded him to go and stand at the gate in the same place that he stood in when he came thither first, and to stand there till service-was done. So forth went Rush in the likeness of a horse, and stood at the gate as the Prior had commanded him.

And when service was done, the Prior and his brethren went to the gate to see what case Rush was in; and when they were come thither they found him ștanding in the likeness of a horse.

Then they demanded him to what intent he came into thei place, and why he tarried there so long.

"Sirs," said Rush, "I came hither to cause you to do all mis. chief, as .is aforesaid, and yet.I would have done more ere I had gone hence; for I would have caused you to slay one another, and to be damned both body and soul."

And when they had heard the words of Rush, every man held up his hands and thanked Almighty God that they had so well escaped that great misfortune.

Then Rush desired the Prior license to depart thence, and 
promised that he would never more come there, nor do any man more hurt; upon that condition the Prior gave him leave to depart. Thus Rush departed from the place, and the Friars went to their cloister, and lived there solitary and chaste ever after, and served Almighty God better than ever they did before.

\section{The Lamentation that Rush made when he was departed out of the house of Religion.}

WHEN Rush was banished out of the house of Religion, and was turned into the same likeness that he was, then he wandered abroad in the world with an heavy heart, and these words he said: "Alas, alas, what shall I do? I wot not now whither to go, for all my seven years' labour is lost."

And as he wandered about, by fortune he met with his master Lucifer, but he would not have seen him by his will. Nevertheless his master espied him quickly, and said to him, "Rush, what tidings with thee?"

"Sir," said Rush, "I have lost all my labour that I have gone about this seven years."

"How so?" said his master.

"Sir, I shall show you," said Rush. "The last time that we were assembled together, there was a poor man lay in an old tree hard beside us, and he heard all that we said : and when we were departed, he arose and went unto the Prior and showed him all that we said, and specially the words that I had spoken, and so all my labour is lost, and I am banished that place."

"Well," said the master Devil to Rush, "thou shalt go some other way abroad, and look if thou canst find anything to do."

Then Rush walked about in the country, and long it was ere he could get any service: At last he fortuned to come unto a husbandman's house which lacked a servant, where he was entertained, but sore against the wife's consent. For this husbandman's wife was a very fair woman, and she loved well the parish Priest, and he loved her again, insomuch that oftentimes they made good cheer and banqueted together, and so continued and 
kept company together a long time. Their meeting was so privy and so secret that it was never known, and they, sure enough of the good man, for he was accustomed every morning to rise early and to go far into the field. And because his wife would prevent his coming home to dinner, she would always give him his victuals in a bag with him, and a bottle full of drink, to the intent he should tarry in the fields from morning to night. She would not suffer him to keep a servant, or to have any manner of help : for she was afraid that if they should have a servant, her secrets should be known, and the goodman also feared that if he should take a servant, that he would have but little lust to tarry there; for the Devil himself could not endure the chiding and brawling of that woman.

How Rush came to a Husbandman labouring in the field and. desired to be entertained into his service.

RusH travelling up and down, came to a Husbandman who was labouring in the field, being all alone, and spake these words unto him : "Rest you merry, sir, methinks you take great pains to work so sore yourself ; will it please you to entertain a servant? I am a poor young man and am out of service, and I am very willing to serve you if you please : and I trust to do you such service, as shall be to your good content."

The husbandman answered him, and said: "Young man, I would gladly give you entertainment, but my wife will never be pleased with any servant that shall come into my house."

"Sir," said Rush, "let me alone, for I shall so work the matter, that my dame shall be well pleased with me."

"Well," said the husbandman, " tarry with me till I have done my business, and thou shalt go home with me."

When he had finished his day's work, Rush went home with him. They were no sooner come into the house, but the wife espying Rush, she began to gloom and to look marvellous angrily at him : which the good man perceiving, he said unto her, ": Dame, I pray thee to be contented, thou knowest well enough that I 
have more labour to do than I am able to make an end of alone, and therefore I have hired this young man to help me."

When his wife heard those words, she was more angry than before, and began to brawl and scold as if the Devil had been in her, and said unto him: "What a vengeance needest thou to take a servant? thou art able enough thyself to do all the business that we have to do, and why should we take more charge upon us than we are able to bear? but I now perceive thou art given to laziness, and hast little mind to work thyself."

When the good man heard her so highly displeased, he said, "Dame, I pray thee be contented, the young man is honest, and he hath promised me to be a good servant."

Yet for all these speeches she would not be pacified, but brawled still.

When Rush perceived her great impatience, he said unto her, "Dame, I pray you be contented, and be not angry with me, for you shall have no cause. My master hath hired me but for a while, upon a trial, and I trust, in that time, so to behave myself, as to give you both content. When my time cometh out, if you like my service you shall have it before any other whatsoever; if not, I will be very well content to depart."

When the wife heard Rush speak so reasonably, she pacified herself, and said no more; which caused the good man to be very glad, and so she set them to supper.

As they sat at meat, Rush demanded of his master what he should do the next day? His master answered, "Thou must rise early and go to the field, and make an end of that which I was about this day." Which was a great day's work. So when they had supped they went to bed.

Early in the morning Rush arose and went to the field, and wrought so lustily, that he had done his work betimes; for when his master came to bring him his breakfast, all his work was finished, whereat his master had great marvel. Then they sat down to breakfast, which being ended they went home, and did such things as were there to be done. When his dame saw that 
he had so soon ended his business, she thought that he was a profitable servant, and said little but let him alone.

In the evening Rush demanded of his master what he should do the next morrow? His master appointed him twice so much as he did the day before, which Rush refused not, but got up early in the morning, and went to the field, and about his work. So soon as his master was ready, he took his man's breakfast and came to the field, thinking to help Rush. He was no sooner come from his house but the Priest came to see his wife, and presently she made ready some good meat for them to be merry withal. And when the goodman came to the field, he found that Rush had done all that which he appointed, whereof he had great marvel. Then they sat down to breakfast, and as they sat together, Rush beheld his master's shoon, and perceived that for fault of greasing they were very hard. Then said Rush to his master, "Why are not your shoes better greased? I marvel that you can go in them, they be so hard; have you no more at. home?"

"Yes," said his master, "I have another pair lying under a great chest at home in my chamber."

Then said Rush, "I will go home and grease them, that you. may put them on to-morrow;" and so he walked homeward merrily and sung by the way. And when he approached near the house he sang out very loud. With that his dame looked out at the window, and perceived that it was her servant. She said unto the Priest, "Alas, what shall we do? our servant is come home, and my husband will not be long after." And with that she thrust the meat into the oven, and all that was upon the table.

"Where shall I hide me?" said the Priest.

"Go into the chamber, and creep under the great chest among the old shoon, and I shall cover you," and so he did.

And when Rush was come into the house his dame asked him why he came home so soon? Rush answered and said, "I have done all my business, and my master commanded me to comehome and grease his shoon." Then he went into the chamber 
and looked under the chest, and there he found the Priest, and he took him by the heels and drew him out, and said, "Thou Priest, what dost thou here?" With that, the Priest held up his hands and cried him mercy, and desired him to save his honesty, and he would never more come there; and so Rush let him go for that once.

How Rush came home to make clean the stable, and how he found the Priest under the manger covered with straze.

Within a while after this foresaid Priest thought once again to adventure himself and go to the husbandman's house. When he perceived that the goodman and Rush his servant was in the field a labouring, he went with all speed to the house, and when he was entered, the wife said he was welcome, and made ready a good dish of meat, and set it on the table before the Priest, then she drew drink and sat down beside him. They had not sitten there long, but anon Rush came singing homeward, and when she espied him she was abashed and wist not what to do, but thrust the meat into the oven as sne did before.

Then said the Priest, "Where shall I hide me?"

"Come with me," said the wife, "into the stable, and creep under the manger, and I shall cover you with straw, and tarry there till he be gone again."

Then she turned again into the house, where she found Rush her servant, and anon she demanded of him why he came home so soon? Rush answered that he had done all his business, and he was come to make clean the stable. When the wife heard that, she was sorry in her heart, for she doubted that he would find the Priest again. Then forth went Rush into the stable, and took a great fork in his hand and began to shake up the straw : and when he came to the heap that the Priest lay in, the which seemed to him very great, yet nevertheless with his fork he took all up at once and bare it out of the door, and laid it on a great heap of muck that lay there. And with his fork he shaked the straw abroad, and when he had shaken out a little, 
anon he was aware of the Priest's gown. Then he said, "What a devil art thou ?" and with his fork he turned the heap, and then he perceived that the Priest was come again. Then with his fork he gave him three or four good dry stripes and said, "Thou Priest, what dost thou here? Thou promised me the last day never more to come here, and now I see thou art a false Priest. But now I shall make an end of thee, and then shalt thou never deceive me more." And when the Priest heard him say so, he fell upon his knees and held up his hands, and prayed Rush to save his honour once again and he would never come there more, and if he did, then to do with him what he would.

Thus Rush let the Priest go the second time.

\section{How Rush came home and found the Priest in the cheese-basket,} and how he trailed him about the town.

Then within a fortnight or three weeks after, the Priest thought he was long absent from the husbandman's wife. And though it should cost him his life yet would he go thither once again. And on a day he perceiving the goodman was gone to the field, he took his way unto the house, and his wife quickly went and prepared good cheer for him, as she was wont to do; for they thought themselves sure enough for the time, but yet they were deceived. For when the goodman was come to the field, Rush had done all his business. Then they sat down and broke their fast with bread and cheese ; and as they sat eating, Rush spied a hair in the cheese, and then he said to his master, "I trow my dame would poison us, or else she washeth not the basket that the cheese lieth in. Behold it is all full of hairs. I will go home and wash the basket and make. it clean."

So leaving his master in the field and walking homewards, he sung merrily all the way. And when he approached near the house, the wife knew his voice and perceived that he was coming. Then wringing her hands she said unto the Priest, "Go hide you, or else you be but dead."

"Where shall I hide me?" said the Priest. 
"Go up into the chamber and leap into the basket that hangeth out at the window, and I shall call you when he is gone again."

Then anon in came Rush, and she asked him why he came home so soon. Then said Rush, "I have done all my business in the field, and my master hath sent me home to wash your cheese-basket, for it is full of hairs." So he went into the chamber, and with his knife he cut the rope that the basket hung by, and down fell Priest and all into a great pool of water that was under the window: Then went he into the stable for a horse and rode into the pool, and took the rope that hung at the basket, and tying it to the horse's tail, rode through the pool three or four times. Then he rode through the town to cause the people to wonder at him, and so came home again. And all this while he made as though he had known nothing, but looking behind him, espied the Priest.

Then he alighted down and said unto him: "Thou shalt never more escape me, thy life is lost." With that the Priest held up his hands and said, "Here is a hundred pieces of gold : take them, and let me go."

So Rush took the gold and let the Priest go. And when his -master came home he gave him the half of his money and bade him farewell, for he would go see the world.

\section{How Rush became a servant to a Gentleman, and how the Devil} was conjured out of the body of the Gentleman's daughter.

WhEN Rush was departed from the husbandman, he went abroad in the country to look if he could find any more adventures; and so long he travelled about that at last he espied a gentleman's place, unto the which he took his way. And when he was come thither, as chance was, he found the gentleman walking up and down before his gate. And when Rush was appeared near unto him, he put off his bonnet and saluted him saying: "Rest you merry, good Gentleman."

"Welcome," said he.

"Sir," said Rush, "I am a poor young man and am out of service, and fain would I have a good master." 
"What countryman art thou?" said the Gentleman; "and from whence comest thou?"

"Sir," said Rush, "I was born far hence, and many a mile have I gone to seek a good service, but none can I find."

"What canst thou do?" said the Gentleman: "and what is thy name?"

"Sir," said Rush, "I can do any manner of thing that shall please you to set me unto, and Rush is my name."

Then said the Gentleman unto him, "Rush, tarry here with me, and I will retain thee in my service."

When Rush heard the Gentleman speak so, he thanked him much and tarried there.

Then as the Gentleman and Rush went talking together, the Gentleman said unto him, "Rush, thou hast travelled far and gone through many strange countries: canst thou show me where to find any man can conjure a spirit out of a woman's body? "

"Sir," said Rush, "why ask you me that question ?"

"I shall show thee," said the Gentleman. "I have a daughter which is a fair young woman, but she is sore troubled in her mind, and as I suppose she hath some Devil within her body."

"Sir," said Rush, "I pray you let me see her, and I trust speedily to find remedy for her."

Then the Gentleman brought Rush into the place and showed him his daughter. And when he saw her he knew what she had within her body: Anon he said unto the Gentleman, "Sir, there is remedy enough for this."

"Well," said the Gentleman, "if thou canst find me any that can help her thereof, I will reward him well for his labour, and thee also."

"Sir, I will show you what is to be done. There is a place of religion a forty or fifty miles hence, wherein I was a servant a long time, and the Prior is a cunning man in that science: and I doubt not, but if he were here even now, she should be holpen within this hour."

When the Gentleman heard the words of Rush, he rejoiced in his heart and was full glad of that good tidings. 
And on the morrow after, the Gentleman sent his servant with his letters unto that house of religion, desiring the Prior to come and speak with him. When the Prior had read the Gentleman's letters, and knew for what cause he was sent for, he made him ready to ride with the messenger. Then forth they rode, and the next day they arrived at the Gentleman's place.

When the Gentleman understood that the Prior was come, he was glad and went to the gate, and with great reverence he received the Prior, and brought him into his place. Then the Gentleman commanded his servant to fill a cup of wine, that the Prior and he might drink together. And when they had drunk and refreshed themselves well, they walked forth into a fair garden, and they communed together of many things, and when they had finished all their communications, the Gentleman said unto the Prior: "Sir, the cause that you be come hither is this. It is so, that I have a young Gentlewoman to my daughter which is grievously vexed and troubled in her mind, and as I suppose she hath some wicked spirit in her body, and, sir, it was showed me by a servant of mine which was long servant in your place, that you could help her."

"Sir," said the Prior, "what is his name?"

The Gentleman said, "His name is Rush."

And when the Prior heard his name he knew him well enough, and said unto the Gentleman, "Sir, cause the gentlewoman to come before me, and I trust in Almighty God shortly to find a remedy for her."

When the Gentleman heard the Prior speak so, he was glad in his heart, and commanded in all haste to bring forth his daughter before the Prior: and when she was come into his presence, he commanded her to kneel down upon her knees, and also he commanded her father and her mother, and all the company that were there present, in likewise to kneel upon their knees, and pray unto Almighty God for the young Gentlewoman. And then he himself said certain prayers over her. Then he lifted up his hand and blessed her, and incontinent there flew a great Devil out of her mouth. 
And the Prior bound the Devil so, that never after he came there. Thus was the young Gentlewoman restored to her right mind and health again.

Then the Gentleman would have given to the Prior a great sum of money for his labour, but he would take none, but said unto the Gentleman: "Sir, I have a new church in building, and I lack lead to cover the roof: and as it is informed me, this is a plentiful country thereof. Wherefore, sir, if it will please you to give me as much as shall serve me: I and my brethren shall be your daily beadsmen, and you shall be prayed for as long as the world endureth."

"Ye shall have as much as shall serve you," said the Gentleman; "but how will ye do for the carriage?"

"Well enough," said the Prior.

Then the Gentleman brought him to a great heap of lead, and bade him take as much as would serve him. Presently the Prior called forth Rush and commanded him to take on his neck so much lead as would cover his church, and bear it home, and come again quickly. So Rush took the lead on his neck at once and carried it home, and he was there again within half an hour. Then the Prior took his leave of the Gentleman and departed, commanding Rush to bring him home also. Then Rush took him on his neck, and within one quarter of an hour he was at home. Then the Prior conjured Rush again into his own likeness, and commanded him to go into an old castle that stood far within the forest and never more to come out, but to remain there for ever. From which Devil, and all other Devils, defend us good Lord. Amen. 
THE PLEASANT HISTORIE OF THOMAS OF READING. 



\section{VIII.}

\section{THE PLEASANT HISTORIE OF THOMAS OF READING.}

In the dapes of King Henry the first, who was the first king that instituted the high Court of Parliament, there liued nine men, which for the trade of Clothing, were famous throughout all England. Which Art in those dayes was held in high reputation, both in respect of the great riches that thereby was gotten, as also of the benefit it brought to the whole Commonwealth: the yonger sons of knights and Gentlemen, to whom their Fathers would leaue no lands, were most commonly preferred to learne this trade, to the end, that thereby they might liue in good estate, and driue forth their days in prosperity.

Among all Crafts this was the onely chiefe, for that it was the greatest merchandize, by the which our Country became famous thorowout all Nations. And it was verily thought, that the one halfe of the people in the land liued in those dayes therby, and in such good sort, that in the Common-wealth there were few or no beggers at all : poore people, whom God lightly blessed with most children, did by meanes of this occupation so order them, that by the time that they were come to be sixe or seuen yeeres of age, they were able to get their owne bread: Idlenesse was then banished our coast, so that it was a rare thing to heare of a thiefe in those dayes. Therefore it was not without cause that Clothiers were then both honoured and loued, among whom these nine persons in this kings dayes were of great credit, viz. Tho. Cole of Reading, Gray of Glocester, Sutton of Salisburie, Fitzallen of Worcester, (commonly called William of Worcester) 


\section{PLEASANT HISTORIE OF THOMAS OF READING.}

Tom Doue of Excester, and Simon of South-hampton, alias Supbroth: who were by the King called, The sixe worthy Husbands of the West. Then were there three liuing in the North, that is to say, Cutbert of Kendall, Hodgekins of Hallifax, and Martin Byram of Manchester. Euery one of these kept a great number of seruants at worke, spinners, carders, weauers, fullers, dyers, sheerement, and rowers, to the great admiration of all those that came into their houses to behold them.

Now you shall vnderstand, these gallant Clothiers, by reason of their dwelling places, separated themselues in three seuerall companies : Gray of Glocester, William of Worcester, and Thomas of Reading, because their iourney to London was all one way, they conuersed commonly together: And Doue of Excester, Sutton of Salisburie, and Simon of South-hampton, they in like sort kept company the one with the other, meeting euer all together at Bazingstoke: and the three Northerne Clothiers did the like, who commonly did not meet till they came to Bosomes Inne in London.

Moreover, for the loue and delight that these Westerne men had each in others companie, they did so prouide, that their Waines and themselues would euer meet upon one day in London at Iarrats Hall, surnamed the Gyant, for that hee surpassed all other men of that age, both in stature and strength: whose merriments and memorable deeds I will set downe vnto you in this following discourse.

\section{CHAPTER I.}

How King Henry sought the fauour of all his subiects, especially of the Clothiers.

THIs King Henry, who for his great learning and wisdome was called Beauclerke, beeing the third Son to the renowned Conquerour: after the death of his brother William Ruffus, tooke vpon him the gouernment of this Land, in the absence of his second brother Robert Duke of Normandie, who at this time 
was at wars amongst the Infidels, and was chosen King of Jerusalem, the which he, for the loue he bare to his owne country, refused, and with great honour returned from the holy Land; of whose comming when King Henry vnderstood, knowing hee would make claime to the Crowne, sought by all meanes possible to winne the good will of his Nobility, and to get the fauor of the Commons by courtesie : for the obtaining whereof hee did them many fauours, thereby the better to strengthen himselfe against his brother.

It chanced on a time, as he, with one of his sonnes, and diuers of his Nobilitie, rode from London towards Wales, to appease the fury of the Welshmen, which then began to raise themselves in armes against his authority, that he met with a great number of Waines loaden with cloth, comming to London, and seeing them still driue one after another so many together, demanded whose they were: the Waine-men answered in this sort: Coles of Reading (quoth they.) Then by and by the King asked another saying: Whose cloth is all this? Old Coles, quoth hee: and againe anon after he asked the same questions to others, and still they answered, Old Coles. And it is to be remembred, that the king met them in such a place so narrow and streight, that hee with the rest of his traine, were faine to stand as close to the hedge, whilest the carts passed by, the which at that time being in number aboue two hundred, was neere hand an hour ere the King could get roome to be gone: so that by his long stay, he began to be displeased, although the admiration of that sight did much qualifie his furie; but breaking out in discontent, by reason of his stay, he said, I thought Old Cole had got a Commission for all the carts in the Country to cary his cloth. And how if he haue (quoth one of the Wainmen) doth that grieue you good sir? Yes, good sir, said our King, what say you to that? The fellow seeing the King (in asking the question) to bend his browes, though he knew not what he was, yet being abasht, he answered thus: Why sir, if you be angry, no body can hinder you; for possible sir, you haue anger at commandement. The king seeing him in vttering 
of his words to quiuer and quake, laughed heartily at him, as well in respect of his simple answere, as at his feare: and so soone after the last Wain went by, which gaue present passage vnto him and his Nobles: and thereupon entring into communication of the commoditie of cloathing, the king gaue order at his home returne, to have Old Cole brought before his Maiestie, to the intent he might haue conference with him, noting him to be a subiect of great abilitie: but by that time he came within a mile of Staines, he met another company of waines, in like sort laden with cloth, whereby the king was driven into a further admiration: and demanding whose they were, answere was made in this sort: They be good-man Suttons of Salisbury, good sir; and by that time a score of them were past, he asked againe, saying; whose are these; Suttons of Salisbury, qd. they, and so still, as often as the king asked that question, they answered, Suttons of Salisburie. God send me many such Suttons, said the king. And thus the farther he trauelled Westward, more Waines and more he met continually: vpon which occasion he said to his Nobles, That it would neuer grieue a king to die for the defence of a fertile Countrie and faithful subiects. I alwayes thought (quoth he) that Englands valor was more than her wealth, yet now I see her wealth sufficient to maintaine her valour, which I will seeke to cherish in all I may, and with my sword keepe my selfe in possession of that $I$ haue, Kings and Louers can brooke no partners: and therefore let my Brother Robert thinke, that although hee was Heir to England by birth, yet I am King by possession. All his fauourers I must account my foes, and will serue then as I did the vngratefull Earle of Shrewsbury, whose lands I haue seized, and banisht his body. . But now we will leaue the king to his iourney into Wales, and waiting his home returne, in the meane time tell you the meeting of these iolly Clothiers at London. 


\section{CHAPTER II.}

How William of Worcester, Gray of Gloucester, and old Cole of Reading, met altogether at Reading, and of their communication by the way as they rode to London.

WhEN Gray of Glocester, and William of Worcester were come to Reading, according to their custome, they alwayes called old Cole to haue his companie to London, who also duely attended their comming, hauing prouided a good breakefast for them: and when they had well refreshed themselues they tooke their horses and rode on towards the Citie: and in their iourney William of Worcester asked them if they had not heard of the Earle of Moraigne his escape out of the Land? What is he fled qd. Gray? I muse much at this matter, being in such great regard with the King as he was: but I pray you, doe you not know the cause of his going, qd. Cole? The common report, quoth Gray, is this, that the couetous Earle, who through a greedy desire, neuer left begging of the King for one thing or other, and his request being now denied him, of meere obstinacy and wilfull frowardnesse, hath banished himselfe out of the Land, and quite forsaken the Country of Cornwall, hauing made a vow neuer to set foote within England againe, and as report goeth, he with the late banisht Earl of Shrewsbury, haue ioyned themselues with Robert Duke of Normandy, against the King, the which actions of theirs hath inflamed the Kings wrath, that their Ladies with their children are quite turned out of doores succourlesse and friendlesse, so that it is told me, they wander vp and downe the Country like forlorne people, and although many doe pitie them, yet few doe releeue them.

A lamentable hearing, qd. William of Worcester, and with that casting their eyes aside, they espyed Tom Doue with the rest of his companions come riding to meete them, who as soone as they were come thither, fell into such pleasant discourses, as did shorten the long way they had to Colebroke, where alwayes at their comming towards London they dined: and being once 
entred into their Inne, according to olde custome, good cheere was prouided for them: for these Clothiers were the chiefest guests that trauailed along the way: and this was as sure as an act of Parliament, that Tom Doue could not digest his meat without musicke, nor drinke wine without women, so that his hostesse being a merry wench, would oftentimes call in two or three of her neighbours wiues to keepe him company, where, ere they parted, they were made as pleasant as Pies. And this being a continuall custome amongst them when they came thither, at length the womens husbands beganne to take exceptions at their wiues going thither: whereupon great controuersie grew betweene them, in such sort, that when they were most restrained, then they had most desire to worke their wills: now gip (quoth they) must we be so tyed to our taske, that wee may not drinke with our friends? fie, fie, vpon these yellow hose; will no other die serue your turne? haue wee thus long bin your wiues, and doe you now mistrust vs? verily you eate too much salt, and that makes you grow cholericke, badde liuers iudge all others the like, but in faith you shall not bridle vs so like asses, but wee will goe to our friends, when we are sent for, and doe you what you can. Well, quoth their husbands, if you be so head-strong, we will tame you: it is the duty of honest women to obey their husbands sayings. And of honest men (quoth they) to thinke well of their wiues; but who doe sooner empeach their credit, then their husbands, charging them, if they doe but smile, that they are subtill; and if they doe but winke, they account them wily : if sad of countenance, then sullen : if they be froward, then they are counted shrewes: and sheepish if they bee gentle: if a woman keepe her house, then you will say shee is melancholy; if shee walke abroade, then you call her a gadder; a Puritane, if she be precise; and a wanton, if shee be pleasant: so there is no woman in the world that knowes how to please you: that we thinke our selues accurst to be married wiues, liuing with so many woes. These men, of whose company you forewarne vs, are (for ought that euer we saw) both honest and courteous, and in wealth farre beyond your selues: then what 
reason is there, why we should restraine to visit them? is their good will so much to be requited with scorne, that their cost may not be counteruailed with our company? if a woman be disposed to play light of loue, alas, alas doe you thinke that you can preuent her? Nay, wee will abide by it, that the restraint of liberty inforceth women to be lewd: for where a woman cannot be trusted, she cannot thinke her selfe beloued, and if not beloued, what cause hath she to care for such a one? therefore husbands, reforme your opinions, and doe not worke your owne woes, with our discredit. The Clothiers, we tell you, are iolly fellowes, and but in respect to our courtesie, they would scorne our company.

The men hearing their wiues so well to plead for themselues, knew not how to answere, but said, they would put the burden on their consciences, if they deale vniustly with them, and so left them to their owne wills. The women hauing thus conquered their husbands conceits, would not leaue the fauour of their friends for frownes, and as aboue the rest Tom Doue was the most pleasantest, so was he had in most reputation with the women, who for his sake made this Song :

Welcome to Towne, Tom Doue, Tom Doue,

The merriest man aliue,

Thy company still we loue, we loue,

God grant thee well to thriue,

And neuer will (we) depart from thee,

For better or worse, my ioy,

For thou shalt still haue our good will,

Gods blessing on my sweet Boy.

This song went vp and downe through the whole Country, and at length became a dance among the common sort, so that Tom Doue, for his mirth and good fellowship, was famous in euery place. Now when they came to London, they were welcome to the Oast Iarrat the Gyant, and as soone as they were alighted, they were saluted by the Merchants, who waited their comming thither, and alwayes prepared for them a costly supper, where they commonly made their bargaine, and vpon euery bargaine made, they still vsed to send some tokens to the 
Clothiers wiues. The next morning they went to the hall, where they met the Northerne Clothiers, who greeted one another in this sort. What, my Masters of the West, well met: what cheere? what cheere? Euen the best cheere our Merchants could make vs: (quoth Gray.) Then you could not chuse but fare well, quoth.Hodgekins : and you be weary of our company, adieu, quoth Sutton: Not so, said Martin, but shall wee not haue a game ere wee goe? Yes faith for an hundred pounds. Well said, old Cole, said they: and with that Cole and Gray went to the Dice with Martin and Hodgekins, and the Dice running on Hodgekins side, Coles money began to waste. Now by the masse, quoth Cole, my money shrinkes as bad as Northerne cloth. When they had played long, Gray stept to it, and recouered againe the money that Cole had lost. But while they were thus playing, the rest being delighted in contrary matters, euery man satisfied his owne humour.

Tom Doue called for musicke, William of Worcester for wine, Sutton set his delight in hearing merry tales, Simon of Southhampton got him into the kitchin, and to the pottage pot he goes, for he esteemed more a messe of pottage, then of a venizon pasty. Now sir, Cutbert of Kendall was of another mind, for no meate pleased him so well as mutton, such as was laced in a red petticoate. And you shall vnderstand, that alwayes when they went to dice, they got into Bosomes Inne; which was so called of his name that kept it, who being a foule slouen, went alwayes with his nose in his bosome, and one hand in his pocket, the other on his staffe, figuring forth a description of cold Winter, for he alwayes wore two coates, two caps, two or three paire of stockings, and a high paire of shooes, ouer the which he drew on a great paire of lined slippers, and yet would oft complaine of cold wherefore of all men generally he was called Old' Bosome, and his house Bosomes Inne.

This lump of cold ice had lately married a young wife, who was as wily as she was wanton, and in her company did Cutbert onely delight, and the better to make passage to his loue, he would often thus commune with her: I muse, good wife, quoth 
he. Good wife, quoth she: Verily sir, in mine opinion, there is none good but God, and therefore call me Mistresse. Then said Cutbert, Faire Mistris, I haue often mused, that you being a proper woman, could find in your heart for to match with such a greazie Carle as this, an euill mannered mate, a foule lump of kitchin-stuffe, and such a one as is indeede, a scorne of men; how can you like him that all women mislikes? or loue such a loathsome creature? me thinks verily it should grieue you to lend him a kisse, much more to lie with him. Indeed sir, quoth she, I had but hard fortune in this respect, but my friends would haue it so, and truly my liking and my loue toward him are alike, he neuer had the one, nor neuer shall get the other : yet I may say to you before I married him, there were diuers proper young men that were sutors vnto me, who loued mee as their liues, and glad was he that could get my company, those were my golden dayes, wherein my pleasure abounded, but these yeeres of care and griefe, wherin my sorrowes exceede. Now no man regards mee, no man cares for mee, and albeit in secret they might beare mee good-will, yet who dares shew it? and this is a double griefe, he carries ouer me so iealous a minde, that I cannot looke at a man, but presently he accuseth me of inconstancy, although (I protest) without cause.

And in troth, qd. Cutbert, he should have cause to complaine for somewhat, were I as you. As sure as I liue, and so he shall, quoth she, if he doe not change his byas. Cutbert hearing her say so, began to grow further in requesting her fauour, wishing he might be her seruant and secret friend, and the better to obtaine his desire, he gaue her diuers gifts, insomuch that she began something to lissen vnto him : and albeit she liked well of his speeches, yet would she blame him, and take him vp very short sometimes for the same, till in the end, Cutbert shewed himselfe to be desperate, saying hee would drowne himselfe rather than liue in her disdaine. O my sweet heart not so, quoth shee, God forbid I should be the death of any man: Comfort thy selfe, kind Cutbert, and take this kisse in token of further kindnesse, and if thou wilt haue my fauour, thou must be wise 
and circumspect, and in my husbands sight $I$ would alwayes haue thee to find fault with my doings, blame my bad huswifries, dispraise my person, and take exceptions at euery thing, whereby he will be as well pleased, as Simon of South-hampton with a messe of pottage.

Deare Mistresse, quoth he, I will fulfill your charge to the vttermost, so that you will not take my iest in earnest. Shee answered, Thy foulest speeches I will esteeme the fairest, and take euery dispraise to be a praise from thee, turning each word to the contrary: and so for this time adieu, good Cutb. for supper time drawes neere, and it is meet for me to looke for my meat. With that down comes old Bosome, calling his wife, saying, Ho Winifred, is supper ready? they haue done playing aboue: therefore let the Chamberlaine couer the Table. By and by, qd. she, it shall be done straight-way. How now my Masters who wins, qd. Cutbert? Our money walkes to the West, qd. Martin: Cole hath woone 40 pounds of me, and Gray hath gotten well: the best is qd. Hodgekins, they will pay for our supper: then let vs haue good store of Sacke, qd. Sutton. Content said Cole, for I promise you, I striue not to grow rich by Dice-playing, therefore call for what you will, I will pay for all. Yea said Simon! Chamberlaine, I pray thee bring a whole bottle of pottage for me. Now Tom Doue had all the fidlers at a becke of his finger, which follow him vp and down the City, as diligent as little chickens after a hen, and made a vow, that there should want no Musicke. And at that time there liued in London a Musician of great reputation, named Reior, who kept his seruants in such costly garments, that they might seeme to come before any Prince. Their coates were all of one colour; and it is said, that afterward the Nobility of this Land, noting it for a seemely sight, vsed in like manner to keepe their men all in one liuery. This Reior was the most skilfullest Musician that liued at that time, whose wealth was very great, so that all the Instruments whereon his seruants plaid, were richly garnished with studdes of siluer, and some gold: the bowes belonging to their Violines were all likewise of pure siluer. Hee was also for 
his wisedome called to great Office in the City, who also builded (at his owne cost) the Priory and Hospital of S. Bartholomew in Smithfield. His seruants being the best consorts in the City, were by Tom Doue appointed to play before the young Princes. Then supper being brought to the boord, they all sat down, and by and by after comes vp their Oast, who tooke his place among them: and anon after, the good wife in a red peticote and a waistcoate, comes among them as white as a Lilly, saying, $\mathrm{My}$ Masters, you are welcome, I pray you be merry. Thus falling close to their meate, when they had well fed, they found leysure to talke one with another; at what time Cutb. began thus to finde fault, Ywis, my Oast, quoth he, you haue a wise huswife to your wife, heere is meate drest of a new fashion? God sends meate, and the deuil sends cooks. Why what ailes the meate, quoth she, serues it not your turnes? better men then your selfe are content withall, but a paultry companion is euer worst to please. Away, you sluttish thing, qd. Cutbert, your husband hath a sweet Jewell of you : I maruell such a graue ancient man would match himselfe with such a young giglot that hath as much handsomenes in her, as good huswifry, which is iust nothing at all. Well sir, said shee, in regard of my husbands presence, I am loth to aggrauate anger, otherwise I would tell thee thy owne. Goe to, what needs all this, quoth the company? in good faith, Cutbert, you are to blame, you find fault where none is. Tush, I must speake my mind, quoth Cutbert, I cannot dissemble, I trust the good man thinkes neuer the worse of me: so I haue his good will, what the foule euill care I for his wifes. Enough, quoth Tom Doue, let vs with Musicke remoue these brabbles, we meane to be merry, and not melancholy. Then said old Cole, Now trust me, Cutbert, we will have your Oastesse and you friends ere we part: here woman I drinke to you, and regard not his words, for he is babbling wheresoeuer he comes. Quoth the woman, Nothing grieues me so much, as that hee should thus openly checke mee: if he had found any thing amisse, he might haue spied a better time to tell mee of it then nowe, ywis he need not thrust my bad 
huswifrie into my husbands head, I liue not so quietly with him, God wot: and with that she wept. Come Cutbert, quoth they, drinke to her, and shake hands and be friends. Come on, you puling baggage, quoth he, I drinke to you, here will you pledge mee and shake hands? No, (quoth shee) I will see thee choackt first, shake hands with thee? I will shake hands with the deuill as soone. Goe to, said her husband, you shall shake hands with him then: If you will not shake hands, Ile shake you: what, you young huswife? Well, husband, said she, it becomes a woman to obey her husband, in regard whereof, I drink to him. Thats well said, quoth the company: and so she tooke her leave and went downe. And within a while after they paid the shot, and departed thence to Iarrats Hall, where they went to their lodging; and the next day they tooke their way homeward alltogether : and comming to Colebrooke, they tooke vp their lodging: and it was Coles custome to deliuer his money to the good wife of the house to keepe it till morning, which in the end turned to his vtter destruction, as hereafter shall be shewed.

\section{CHAPTER III.}

How Grays wife of Glocester, with one or two more of her neighbours, went to the Faire, where seruants came to be hired, and how she tooke the Earle of Shrewesburies Daughter into her seruice.

Ir was wont to be an old custome in Glocestershire, that at a certaine time in the yeere, all such young men and Maidens as were out of seruice, resorted to a faire that was kept neere Glocester, there to be ready for any that would come to hire them, the young men stood all on a row on the one side, and the maidens on the other. It came to pass, that the Earle of Shrewsburies daughter, whose father was lately banished, being driven into great distresse, and weary with trauell, as one whose delicate life was neuer vsed to such toyle, sate her downe vpon the high-way side, making this lamentation: 
$O$ false and deceitfull world, quoth she! who is in thee that wishes not to be rid of thee, for thy extremities are great? Thou art deceitfull to all, and trusty to none. Fortuner is thy treasurer, who is like thy selfe, wauering and vnconstant, she setteth vp tyrants, beateth downe Kings : giueth shame to some, and renowne to others: Fortune giueth these euils, and we see it not: with her hands she toucheth vs, and we feele it not; she treades vs vnder foot, and we know it not; she speakes in our eares, and we heare her not; she cries aloud, and we vnderstand her not: And why? because we know her not, vntil misery doth make her manifest.

Ah my deare father, well maist thou doe. Of all misfortunes it is most vnhappy to be fortunate: and by this misfortune came my fall. Was euer good Lady brought to this extremity? What is become of my rare Jewels, my rich aray, my sumptuous fare, my waiting seruants, my many friends, and all my vaine pleasures? my pleasure is banisht by displeasure, my friends fled like foes, my seruants gone, my feasting turned to fasting, my rich array consumed to ragges, and my iewels decke out my chiefest enemies : therefore of all things the meanest state is best, pouerty with surety, is better than honour mixed with feare: seeing God hath allotted me to this misery of life, I will frame my heart to embrace humility, and carry a mind answerable to my misfortunes, fie on this vaine title of Ladiship, how little doth it auaile the distressed? No, no, I must therefore forget my birth and parentage, and think no more on my fathers house, where I was wont to bee serued, now will I learne to serue, and plaine Meg shall be my name, good Lord grant I may get a good seruice, nay any seruice shall serue, where I may haue meat, drinke, and apparell. She had no sooner spoken these words, but she spied a couple of maidens more comming towards her ; who were going to the faire : and bidding her good morrow, asked her if she went to the faire. Yea mary qd. she I am a poor mans child that is out of seruice, and I heare that at the Statute, folkes doe come of purpose to hire seruants. True it is, said the Maidens, and thither goe we for the same purpose, and would be glad of 
your company. With a good will, and I am right glad of yours, said she, beseeching you good Maidens, you will doe me the fauour, to tell me what seruice were best for me: for the more too blame my parents, they would neuer put me forth to know any thing. Why what can you doe (quoth the Maidens ?) can you brew and bake, make butter and cheese, and reape corne well : No verily, said Margaret, but I would be right glad to learne to do any thing whatsoeuer it be. If you could spin or card, said another, you might do excellent well with a Clother, for they are the best seruices that I know, there you shall be sure to fare well, and so liue merrily.

'Then Margaret wept, saying, alas, what shall I doe? I was neuer brought vp to these things. What, can you doe nothing, quoth they? No truly (quoth she) that is good for any thing, but I can read and write, and sowe, some skill I have in my needle, and a little on my Lute: but this, I see will profit me nothing. Good Lord, quoth they, are you bookish? wee did neuer heare of a Maide before that could reade and write. And although you can doe no other thing, yet possible you may get a seruice, if you can behaue your selfe manerly. I pray you qd. another, seeing you are bookish, will you doe so much as to reade a loue-letter that is sent me? for I was at a friends of mine with it, and he was not at home, and so I know not what is in it. I pray you let me see it, quoth Margaret, and I will shew you. Whereupon she readeth as followeth.

O Ienny my ioy, I die for thy loue, And now I heare say that thou dost remoue:

And therefore, Ienny, I pray thee recite,

Where shall I meete thee soone at night.

For why, with my Master no more will I stay,

But for thy loue I will runne away:

O Ienny, Ienny, thou puttest me to paine,

That thou no longer wilt here remaine.

I will weare out my shooes of Neats-leather,

But thou and I will meete together,

And in spight of Fortune, Rat, or Mouse,

We will dwell together in one house. 
For who doth not esteeme of thee,

Shall haue no seruice done of me :

Therefore good Ienny haue a care,

To meete poore Fragment at the Faire.

Now alas, good soule (quoth Ienny) I thinke he be the kindest young man in the world. The rest answered, that he seemed no lesse, and surely it appeareth that he is a pretty witty fellow, quoth one of them, how finely hee hath written his letter in rime, trust me, I will giue you a good thing, and let me have a copy of it to send to my sweet-heart : that you shall with all my heart: and so comming to the faire, they tooke vp their standing.

Within a while after, goodwife Gray of Glocester came thither to store her selfe of diuers commodities; and when shee had bought what she would, she told her neighbour she had great need of a maid-seruant or twaine; therefore, qd. she, good neighbour goe with me, and let me haue your opinion. With a good will, said her neighbour, and together they went, and looking and viewing the maidens ouer, she tooke speciall notice of Margaret. Beleeue me, quoth shee, there stands a very proper maiden, and one of a modest and comely countenance. Verily, said her neighbour, so she is, as euer I looked vpon.

The maiden seeing them to view her so well, was so abashed, that a scarlet colour overspred her lilly cheekes, which the woman perceiuing, came vnto her, and asked if she were willing to serue. The maid with a low curtesie, and a most gentle speech, answered, it was the onely cause of her comming. Can you spinne or card, said good-wife Gray? Truly Dame, said she, though my cunning therein be but small, my good will to learne is great, and I trust, my diligence shall content you. What wages will you take, quoth good-wife Gray? I will referre that, said Margaret, to your conscience and courtesie, desiring no more then what I shall deserue. Then asking what Countrywoman she was, the maiden wept, saying: Ah good Dame, I was vntimely borne in Shropshire, of poore parents, and yet not so needy as vnfortunate, but death hauing ended their sorrowes, hath left me to the cruelty of these enuious times, to finish my 
Parents Tragedy with my troubles. What? maiden qd. her dame, haue you a care to doe your busines, and to liue in Gods feare, and you shall haue no care to regard fortunes frownes, and so they went home together.

Now, so soone as the good-man saw her, hee asked his wife where she had that maiden? She said, at the Faire. Why then quoth he, thou hast brought all the faire away, and I doubt it were better for vs, to send the faire to another Towne, then to keepe the faire here. Why man, quoth she, what meane you by that? Woman, I meane this, that she will proue a Loadstone, to draw the hearts of all my men after her, and so we shall have wise service done of all sides. Then said his wife, I hope, husband, Margaret will have a better care both to her owne credit, and our commodity then so, and so let her alone to looke to such matters. Is thy name Margaret, quoth her Master? proper is thy name to thy person, for thou art a pearle indeed, orient, and rich in beauty.

His wife hearing him say so, began to change her opinion: What husband (quoth she) is the wind at that doore? Begin you to like your maid so well? I doubt I had most need to looke to your selfe: before God, I had rather then an angell I had chosen some other: but heare you maid, you shall packe hence, I will not nourish a Snake in my bosome, and therefore get you gone, I will none of you, prouide a seruice where you may.

The maiden hearing her say so, fell downe on her knees, and besought her, saying, $\mathrm{O}$ sweet dame, be not so cruell to me, to turne me out of doores, now : alas, I know not where to goe, or what to doe, if you forsake me. $O$ let not the fading beauty of my face dispoile me of your fauour: for rather then that shall hinder my seruice, this my knife shall soone disfigure my face, and I will banish beauty as my greatest enemy. And with that, her aboundant teares stopped her speech, that shee could not vtter one word more.

The woman seeing this, could not harbour any longer, nor could her Master stay in the roome for weeping. Well, Mar- 
garet, said her dame (little knowing that a Lady kneeled before her) vsing thy selfe well I will keepe thee, and thou shalt haue my good will, if thou gouerne thyselfe with wisedome; and so she sent her about her businesse. Her husband comming to supper, said, How now wife, art thou so doubtfull of me, that thou hast put away thy maiden? I wis (qd. she) you are a wise man, to stand praising of a maidens beauty before her face : and you a wise woman, qd. he, to grow iealous without a cause. So to supper they went, and because Margaret shewed her selfe of finest behauiour aboue the rest, she was appointed to waite on the table. And it is to be vnderstood, that Gray did neuer eate his meat alone, but still had some of his neighbours with him, before whom he called his maid, saying, Margaret, come hither. Now because there was another of the same name in the house, she made answer. I call not you, maiden, quoth he, but Margaret with the lilly-white hand. After which time she was euer called so.

\section{CHAPTER IV.}

How the Kings Maiestie sent for the Clothiers, and of the sundry fauours which he did them.

King HENRY prouiding for his voyage into France, against King Lewis and Robert Duke of Normandie his owne brother, committed the Gouernment of the Realme in his absence, to the Bishop of Salisbury, a man of great wisedome and learning, whom the king esteemed highly, and afterward he thought good to send for the chiefe Clothiers of England, who according to the kings appointment came to the Court, and hauing licence to come before his Maiestie, he spake to this effect.

The strength of a King is the loue and friendship of his people, and he gouernes ouer his Realme most surely, that ruleth iustice with mercy: for he ought to feare many, whom many doe feare: therefore the Gouernors of the Common-wealth ought to obserue two speciall precepts: the one is, that they so maintaine the profit of the Commons, that whatsoeuer in their calling they doe, 
they referre it thereunto: the other, that they be alwayes as well carefull ouer the whole Common-wealth, as ouer any part thereof; lest, while they vphold the one, the other be brought to vtter decay.

And forasmuch as I doe vnderstand, and haue partly seene, that you the Clothiers of England are no small benefit to the wealth publike, I thought it good to know from your owne mouthes, if there be any thing not yet granted that may benefit you, or any other thing to be remoued that doth hurt you.

The great desire I haue to maintaine you in your trades, hath moued me hereunto. Therefore boldly say what you would haue in the one thing or the other, and I will grant it you.

With that, they all fell downe vpon their knees, and desired God to saue his Maiestie, and withall, requested three dayes respit to put in their answere: which was graunted. And thereupon they departed.

When the Clothiers had well considered of these matters, at length they thought meete to request of his Maiestie for their first benefit, that all the Cloth-measures thorow the Land might be of one length, whereas to their great disaduantage before, euery good towne had a seuerall measure, the difficulty thereof was such, that they could not keepe them in memory, nor know how to keepe their reckonings. The second thing whereof they found themselues grieued, was this, that the people would not take crackt money, though $t$ were neuer so good siluer? whereupon it came to passe, that the Clothiers and diuers others, receiuing great summes of money, doe take among it much crackt money, it serued them to no vse, because it would not goe currant, but lay vpon their hands without profit or benefit, whereof they prayed reformation. The third was a griefe, whereof Hodgekins of Halifax complained, and that was, That whereas the Towne of Halifax liued altogether vpon Cloathing, and by the reason of false borderers, and other euill minded persons, they were oft robbed, and had their clothes carried out of their fieldes, where they were drying: That it would please his Maiestie to graunt the Towne this priuilege, That whatsoever he was that was taken stealing their Cloth, might presently without any further tryall be 
hanged up. When the day of their appearance approached, the Clothiers came before the King, and deliuered vp their petition in writing, which his Maiestie most graciously perusing, said, hee was ready to fulfill their request : and therefore for the first point of their Petition, he called for a staffe to be brought him, and measuring thereupon the iust length of his owne arme, deliuered it to the Clothiers, saying, This measure shall be called a yard, and no other measure thorowout all the Realme of England shall be vsed for the same, and by this shall men buy and sell, and we will so prouide, that whosoeuer he be that abuseth our subiects by any false measure, that he shall not onely pay a fine for the same to the King, but also haue his body punished by imprisonment. And as concerning the second point of your Petition, because of my sudden departure out of the Land, I know not better how to ease you of this griefe (of crackt money) this Decree I make, because they account crackt money not currant, I say, none shall be currant but crackt money. And therefore I will giue present charge, that all the money thorow the Land shall be slit, and so you shall suffer no losse.

But now for your last request for the Towne of Halifax; where by theeues your Clothes are so often stolne from you, seeing the Lawes already prouided in that case, are not sufficient to keepe men in awe, it is indeed high time to haue sharper punishment for them.

With that Hodgekins vnmannnerly interrupted the King, saying in broad Northerne speech, Yea gude faith, mai Liedg, the faule eule of mai saule, gift any thing will keepe them whiat, till the karles be hanged by the scragge. What the dule care they for boaring their eyne, sea lang as they mae gae groping vp and downe the Country like fause lizar lownes, begging and craking ?

The King smiling to heare this rough-hewne fellow make this reply: Content thee Hodgekins, for we will have redresse for all: and albeit that hanging of men was never seene' in England, yet seeing the corrupt world is growne more bold in all wickednesse, I thinke it not amisse to ordain this death for such malefactors : and peculiarly to the towne of Halifax I give this 
priuilege, That whosoever they finde stealing their Cloth, being taken with the goods, that without further iudgement, they shall be hanged vp.

Thus (said our King) I haue granted what you request, and if hereafter you find any other thing that may be good for you, it shall be granted; for no longer would I desire to liue among you, then I have care for the good of the Common-wealth: at which words ended, the King rose from his Royall Throne, while the Clothiers on their knees prayed for both his health, and happy successe, and shewed themselves most thankefull for his Highnesses fauour. His Maiestie bending his body towards them, that at his home returne, hee would (by the grace of God) visit them.

\section{CHAPTER V.}

How the Clothiers had prouided a sumptuous feast for the Kings sonnes, Prince William and Prince Robert, at Gerards Hall; shewing also what chance befell Cutbert of Kendall at that same instant.

ThE Clothiers departing from the Court in a merry mind, ioyfull of their good successe, each one to other praised and magnified the Kings great wisedome and vertue, commending also his affability and gentle disposition, so that Hodgekins affirmed on his faith, that hee had rather speake to his Kings Maiestie, then to many Justices of peace. Indeed (said Cole) he is a most mild and mercifull Prince, and I pray God he may long raigne over vs. Amen said the rest.

Then said Cole, My Masters, shall we forget the great courtesie of the Kings sonnes, those sweet and gentle Princes, that still showed us fauour in our suite? in my opinion, it were reason to gratifie them in some sort, that we may not vtterly bee condemned of ingratitude, wherefore (if you thinke good) we will prepare a banquet for them at our Oast Garrats, who as you know, hath a faire house, and goodly roomes: Besides, the man himselfe is a most courageous mind and good behauiour, suffi- 
cient to entertain a Prince : his wife also is a dainty fine Cooke : all which considered, I know not a fitter place in London. Tis true, quoth Sutton, and if the rest be content, I am pleased it shall be so. At this they all answered, Yea, for quoth they, it will not be passing forty shillings a piece, and that we shall recouer in our crackt money.

Being thus agreed, the feast was prepared. Tom Doue, quoth they, we will commit the prouiding of musicke to thee; and I, said Cole, will inuite diuers of our Merchants and their wiues to the same. That is well remembred, said Gray. Upon this they called to the Oast and Oastesse, shewing their determination, who most willingly said, all things should be made ready, but I would haue two dayes liberty, said the goodwife, to prepare my house and other things. Content, said the Clothiers, in the meane space we will bid our guests, and dispatch our other affaires. But Simon of Southampton charged his Oastesse, that in any case she should not forget to make good store of pottage. It shall be done, quoth she.

It is to be remembred, that while this preparation was in hand, that Cutb. of Kendall had not forgot his kindnes to his Oastesse of Bosomes Inne. Therefore finding time conuenient when her husband was ouerseeing his hay-makers, hee greeted her in this sort, Sweet Oastesse, though I were the last time I was in towne, ouer-bold with you, yet I hope it was not so offensiue to you, as you made shew for. Bold, my Cutbert? quoth she, thou hast vowed thy selfe my seruant : and so being, you are not to bee blamed for doing what I wild you. By my honesty, I could not chuse but smile to my selfe, so soone as I was out of their sight, to thinke how prettily you began to brabble. But now, quoth he, we will change our chidings to kissings, and it vexeth me that these cherry lipps should be subiect to such a Lobcocke as thy husband.

Subiect to him, quoth she: In faith sir, no, I will haue my lips at as much liberty as my tongue, the one to say what I list, and the other to touch whom I like: In troth, shall I tell thee, Cutbert, the churles breath smels so strong, that I care as 
much for kissing of him, as for looking on him : it is such a mis-shapen mizer, and such a bundle of beastlinesse, that I can neuer thinke on him without spitting. Fie vpon him, I would my friends had carried me to my graue, when they went with me to the Church, to make him my husband. And so shedding a few dissembling teares, she stopt. What, my sweet Mistresse (quoth he) weepe you? Nay sit downe by my side, and I will sing thee one of my Countrey Iigges to make thee merry. Wilt thou in faith (quoth shee)? Yes verily, said Cutbert: and in troth, quoth she, if you fall a-singing I will sing with you. That is well you can so suddenly change your notes, quoth Cuthbert, then haue at it.

MaN. Long haue I lou'd this bonny Lasse,

Yet durst not shew the same.

Wom. Therein you proue your selfe an Asse,

MAN. I was the more to blame.

Yet still will I remaine to thee,

Trang dilly do, trang dilly :

Thy friend and louer secretly,

WoM. Thou art my owne sweet bully.

MAN. But when shall I enioy thee,

delight of thy faire loue?

WoM. Euen when thou seest that fortune doth

all manner lets remoue.

MAN. O, I will fold thee in my armes,

Trang dilly do, trang dilly.

And keepe thee so from sudden harmes.

WOM. Thou art my owne sweet bully.

WoM. My husband he is gone from home,

you know it very well.

MAN. But when will he returne againe?

WoM. In truth I cannot tell.

If long he keepe him out of sight,

Trang dilly do, trang dilly.

Be sure thou shalt haue thy delight.

MAN. Thou art my bonny lassie.

While they were singing this song, her husband being on a sudden come home, stood secretly in a corner and heard all, 
and blessing himselfe with both his hands, said, $\mathrm{O}$ abominable dissimulation, monstrous hypocrisie, and are you in this humour? can you brawle together and sing together? Well, qd. hee, I will let them alone, to see a little more of their knauery. Neuer did Cat watch Mouse so narrowly, as I will watch them: And so going into the kitchin, he asked his wife if it were not dinner time. Euen by and by, husband (quoth she) the meat will be ready. Presently after comes in Hodgekins and Martin, who straight asked for Cutbert of Kendall. Answer was made, that he was in his chamber. So when they had called him, they went to dinner: then they requested that their Oast and Oastesse would sit with them.

Husband, said she, you may goe if you please: but as for me, I will desire pardon. Nay, good-wife, goe vp, said her husband. What woman, you must beare with your guests. Why husband, qd. she, doe you thinke that any can beare the flirts and fromps, which that Northerne tike gaue me the last time he was in towne; now God forgiue me, I had as liefe see the diuell as to see him: therefore good husband goe vp your selfe, and let me alone, for in faith, I shall neuer abide that Jacke while I liue. Upon these words away went her husband, and though he said little, he thought the more. Now when he came $\mathrm{vp}$, his guests bade him welcome. I pray you sit downe, good mine Oast, quoth they, where is your wife? What will she sit with vs? No, verily, said he, the foolish woman hath taken such a displeasure against Cutbert, that she sweares she will neuer come in his company. . Is it so, said the other? then trust me we are well agreed : and I sweare by my fathers sale, qd. hee, that were it not meete for good will to you, then loue to her, I would neuer come to your house meere. I beleeue it well, said old Bosome. And so with other communication they droue out the time, till dinner was ended.

After they were risen, Martin and Hodgekins got them forth about their affaires, but Cutb. tooke his Oast by the hand, saying, My Oast, Ile goe talke with your wife; for my part I thought we had bin friends: but seeing her stomacke is so big, 
and her heart so great, I will see what she will say to me; and with that he stept into the kitchin, saying, God speed you Oastis. It must be when you are away then, said she. What is your reason, said the other? Because God neuer comes where knaues are present. Gip goodly draggletaile, qd. he, had I such a wife, I would present her tallow-face to the deuil for a candle. With that she bent her browes, and like a Fury of hell began to flie at him, saying, Why you gag-tooth Jacke, you blinking companion, get thee out of my kitchin quickly, or with my powdred beefe-broth, I will make your pate as bald as a Fryers.

Get me gone, quoth he? thou shalt not bid me twice: out you durty heeles, you will make your husbands haire growe thorow his hood I doubt: and with that he got him into the Hall, and sat him downe on the bench by his Oast, to whom he said : 'Tis pittie, my Oast, that your aged yeeres that loues quietnesse, should be troubled with such a scolding queane. I, God helpe me, God helpe me, quoth the old man, and so went towards the stable: which his wife watching, suddenly stept out and gaue Cutbert a kisse.

Within an houre after, the old man craftily called for his Nag to ride to field: but as soone as he was gone, Cutbert and his Oastesse were such good friends, that they got into one of Ware-houses, and lockt the doore to them: but her husband hauing set a spie for the purpose, suddenly turned backe, and called for a capcase which lay in the Warehouse. The seruant could not find the key by any meanes. Whereupon hee called to haue the locke broke open. Which they within hearing, opened the doore of their owne accord. So soone as her husband espied her in that place, with admiration he said: $O$ passion of my heart, what doe you here? what, you two that cannot abide one another? what make you so close together? is your chiding and rayling, brabling, and brauling, come to this? O what dissemblers are these! Why, my Oasst, qd. Cutbert, what need you take the matter so hot? I gaue a Cheese to my Country-man Hodgekins, to lay vp, and deliuered it to your wife to be keept; and then is it not reason, 
that she should come and seeke me my Cheese? O, quoth the old man, belike the dore was lockt, because the Cheese should not run away. The doore said his wife vnknowne to vs clapt to it selfe, and hauing a spring locke, was presently fast. Well, huswife, qd. he, I will give you as much credit as a Crocadile, but as for your companion, I will teach him to come hither to looke Cheeses.

And with that he caused his men to take him presently, and to bind him hand and foot. Which being done, they drew him $\mathrm{vp}$ in a basket into the smoky louer of the hall, and there they did let him hang all that night, euen till the next day dinner time, when he should haue beene at the banquet with the Princes: for neither Hodgekins nor Martin could intreat their inflamed Oast to let him downe.

And in such a heate was hee driuen with drawing him vp, that he was faine to cast off his gownes, his coates, and two paire of his stockings, to coole himselfe, making a vow he should hang there seuen yeeres, except the Kings sons came in person to beg his pardon, which most of all grieued Cutb. When Cole and the rest of the Westerne-Yeomen heard hereof, they could not chuse but laugh, to thinke that he was so taken tardy.

The young Princes hauing given promise to be with the clothiers, kept their houre, but when all the rest went to giue them entertainment, Simon was so busie in supping his pottage, that he could not spare so much time. Which when the Princes saw, with a smiling countenance they said, Sup Simon, theres good broth: or else beshrew our Oastesse, quoth he, neuer looking behind him to see who spake, till the Prince clapt him on the shoulder. But good Lord, how blanke he was when hee spied them, knowing not how to excuse the matter.

Well, the Princes hauing ended their banket, Garrat comes and with one of his hands tooke the table of sixteene foote long quite from the ground ouer their heads, from before the Princes, and set it on the other side of the hall, to the great admiration of ali them that beheld it.

The Princes being then ready to depart, the Clothiers moued them in pleasant maner, to be good to one of their company, 
that did neither sit, lie, nor stand. Then hee must needs hang, qd. the Princes. And so he doth, most excellent Princes, qd. they; and therewithall told them the whole matter. When they heard the storie, downe to Bosomes Inne they goe, where looking vp into the roofe, spied poore Cutbert pinned vp in a basket, and almost smoaked to death, who although hee were greatly ashamed, yet most pitifully desired that they would get him release.

What is his trespasse, said the Prince? Nothing if it shall like your Grace, qd. he, but for looking for a cheese: But hee could not find it without my wife, said the good man: the villaine had lately dined with mutton, and could not digest his meate without cheese, for which cause $I$. haue made him to fast these twenty houres, to the end he may haue a better stomacke to eate his dinner, then to vse dalliance.

Let me intreate you, quoth the Prince, to release him: and if euer hereafter you catch him in the corne, clappe him in the pownd. Your Grace shall request or command any thing at my hand, said the old man: and so Cutbert was let downe vnbound, but when he was loose, he vowed neuer to come within that house more. And it is said, the old man Bosome ordained, that in remembrance of this deed, euery yeere once all such as came thither to aske for cheeses, should be so serued: which thing is to this day kept.

\section{CHAPTER VI.}

How Simons wife of Southampton, being wholly bent to pride and pleasure, requested her husband to see London, which being granted, how she got good-wife Sutton of. Salisbury to goe with her, who tooke Crab to go along with them, and how he prophecied of many things.

ThE Clothiers being all come from London, Suttons ${ }^{1}$ wife of South-hampton, who was with her husband very mery and pleasant, brake her mind vnto him in this sort:' 
Good Lord, husband, will you neuer be so kind as let me goe to London with you ? shall I be pend vp in South-hampton, like a Parrat in a cage, or a Capon in a coope? I would request no more of you in lieu of all my paines, carke and care, but to haue one weeks time to see that faire City: what is this life, if it be not mixt with some delight? and what delight is more pleasing then to see the fashions and maners of vnknowne places? Therefore good husband, if thou louest me deny not this simple request. You know I am no common gadder, nor haue oft troubled you with trauell. God knowes, this may be the last thing that euer I shall request at your hands.

Woman, quoth he, I would willingly satisfie your desire, but you know it is not conuenient for both of vs to be abroad, our charge is so great, and therefore our care ought not no ${ }^{1}$ be small. If you will goe your selfe, one of my men shall goe with you, and money enough you shall have in your purse: but to go with you my selfe, you see my businesse will not permit me.

Husband, said she, I accept your gentle offer, and it may be I shall intreat my gossip Sutton to goe along with me. I shall be glad qd. her husband, prepare your selfe when you will.

When she had obtained this licence, she sent her man Welsell to Salisbury, to know of good-wife Sutton if shee would keepe her company to London. Suttons wife being as willing to goe, as she was to request, neuer rested till she had gotten leaue of her husband; the which when she had obtained, casting in her mind their pleasure would bee small, being but they twaine: thereupon the wily woman sent letters by collericke Crabbe her man, both to Grayes wife, and Fitzallens wife, that they would meet them at Reading, who liking well of the match, consented, and did so prouide, that they met according to promise at Reading, and from thence with Coles wife they went all together, with each of them a man to London, each one taking vp their lodging with a seuerall friend.

When the Merchants of London vnderstood they were in 1 Qu. to. 
towne, they inuited them euery day home to their owne houses, where they had delicate good cheere: and when they went abroad to see the commodities of the City, the Merchants wiues euer bore them company, being attired most dainty and fine: which when the Clothiers wiues did see, it grieued their hearts they had not the like.

Now, when they were brought into Cheap-side, there with great wonder they beheld the shops of the Goldsmiths; ard on the other side, the wealthy Mercers whose shops shined with all sorts of coloured silkes : in Watling-street they viewed the great number of Drapers : in Saint Martins, Shoomakers: at Saint Nicholas Church, the flesh shambles; at the end of the old Change, the Fish-mongers : in Candleweek-street, the Weauers : then came into the Iewes-street, where all the Iewes did inhabite : then came they to Blackwel-hall, where the Country Clothiers did vse to meete.

Afterwards they proceeded, and came to S. Pauls Church, whose steeple was so hie, that it seemed to pierce the clowdes, on the top whereof, was a great and mighty Weather-cocke, of cleane siluer, the which notwithstanding seemed as small as a sparrow to mens eyes, it stood so exceeding high, the which goodly Weather-cocke was afterwards stolne away, by a cunning Cripple, who found meanes one night to clime vp to the top of the steeple, and tooke it downe: with the which, and a great summe of money which he had got together by begging in his life time, he builded a gate on the North side of the City, which to this day is called Cripple-gate.

From thence they went to the Tower of London, which was builded by Iulius Cæsar, who was Emperour of Rome. And there they beheld salt and wine, which had lyen there euer since the Romanes inuaded this Land, which was many yeeres before our Sauiour Christ was borne, the wine was growne so thicke, that it might haue beene cut like a Ielly. And in that place also they saw the money that was made of leather, which in ancient time went currant amongst the people:

When they had to their great contentation beheld all this, 
they repaired to their lodgings, hauing also a sumptuous supper ordained for them, with all delight that might be. And you shall vnderstand, that when the Country Weauers, which came up with their dames, saw the Weauers of Candlewike-street, they had great desire presently to haue some conference with them; and thus one began to challenge the other for workemanship: quoth Weasell, Ile worke with any of you all for a crowne, take if you dare, and he that makes his yard of cloth soonest, shall haue it. You shall be wrought withall, said the other, and if it were for ten crownes: but we will make this bargaine, that each of vs shall winde their owne quilles. Content, quoth Weasell : and so to worke they went, but Weasell lost. .Whereupon another of them tooke the matter in hand, who lost likewise: so that the London Weauers triumphed against the Country, casting forth diuers frumps.

Alas poore fellowes, quoth they, your hearts are good, but your hands are ill. Tush the fault was in their legs, quoth another, pray you friend, were you not borne at home? Why doe you aske, quoth Weasell? Because, said hee, the biggest place of your legge is next to your shooe.

Crab hearing this, being Cholericke of nature, chafed like a man of Law at the Barre, and he wagers with them four crownes to twaine: the others agreed, to worke they go: but Crab conquered them all. Whereupon the London Weauers were nipt in the head like birds, and had not a word to say.

Now, saith Crab, as we haue lost nothing, so you haue wonne nothing, and because I know you cannot be right Weauers, except you be good-fellowes, therefore if you will goe with vs, we will bestow the Ale vpon you. That is spoken like a good-fellow and like a Weauer, quoth the other. So along they went as it were to the signe of the red Crosse.

When they were set downe, and had drunke well, they began merrily to prattle, and to extoll Crab to the skies. Whereupon Crab protested, that hee would come and dwell among them. Nay, that must not be, said a London Weauer: the King hath giuen vs priuiledge, that none should liue among us, but such as 
serue seuen yeeres in London. With that Crab, according to his old maner of prophesying, said thus :

The day is very neere at hand,

When as the King of this faire Land,

Shal priuiledge you more then so:

Then Weauers shall in skarlet goe.

And to one brotherhood be brought,

The first is in London wrought,

When other Trades-men by your fame,

Shall couet all to doe the same.

Then shall you all liue wondrous well,

But this one thing I shall you tell :

The day will come before the doome,

In Candleweek-street shall stand no loome.

Nor any Weauer dwelling there,

But men that shall more credit beare :

For Clothing shall be sore decayde,

And men vndone that vse that trade.

And yet the day some men shall see,

This trade againe shall raised be.

When as Bayliffe of Sarum towne;

Shall buy and purchase Bishops downe.

When there neuer man did sow,

Great store of goodly corne shall grow ;

And Woad, that makes all colours sound,

Shall spring vpon that barren ground.

At that same day I tell you plaine,

Who so aliue doth then remaine,

A proper Maiden they shall see,

Within the towne of Salisburie.

Of fauour sweet, and nature kind,

With goodly eyes, and yet starke blind,

This poore blind Maiden I do say,

In age shall goe in rich aray.

And he that takes her to his wife,

Shall lead a ioyfull happy life,

The wealthiest Clothier shall he be,

That euer was in that Country. 
But clothing kept as it hath beene,

In London neuer shall be seene :

For Weauers then the most shall win,

That worke for clothing next the skin.

Till pride the Common-wealth doth peele,

And causeth huswiues leaue their wheele,

Then pouerty vpon each side,

Vnto those workemen shall betide.

At that time, from Eagles nest,

That proudly builded in the West,

A sorte shall come with cunning hand,

To bring strange weauing in this Land,

And by their gaines that great will fall, They shall maintaine the Weauers Hall :

But long they shall not flourish so,

But folly will them ouerthrow.

And men shall count it mickle shame,

To beare that kind of Weauers name,

And this as sure shall come to passe,

As here is Ale within this glasse.

When the silly soules that sate about him heard him speake in this sort, they admired, and honoured Crabbe for the same. Why my masters, said Weasell, doe you wonder at these words? he will tell you twenty of these tales, for which cause we call him our canuas Prophet: his attire fits his title, said they, and we neuer heard the like in our liues : and if this should be true, it would be strange. Doubt not but it will be true, qd. Weasell; for Ile tell you what, he did but once see our Nicke kisse Nel, and presently he powred out this rime:

That kisse, O Nell, God giue thee ioy,

Will nine months hence breed thee a boy.

And Ile tell you what, you shall heare: we kept reckoning, and it fell out iust as Iones buttockes on a close stoole, for which cause our maids durst neuer kisse a man in his sight; vpon this they broke company, and went euery one about his business, the London Weauers to their frames, and the Country fellowes to 
their Dames, who after their great banqueting and merriment, went euery one home to their owne houses, though with lesse money than they brought out, yet with more pride.

Especially Simons wife of South-hampton, who told the rest of her gossips, that she saw no reason, but that their husbands should maintaine them, as well as the Merchants did their wiues : for I tell you what, quoth she, we are as proper women (in my conceit,) as the proudest of them all, as handsome of body, as faire of face, our legs as well made, and our feet as fine: then what reason is there (seeing our husbands are of as good wealth,) but we should be as well maintained.

You say true gossip, said Suttons wife: trust me, it made me blush, to see them braue it out so gallantly, and wee to goe so homely: but before God said the other, I will haue my husband to buy me a London gowne, or in faith he shall haue little quiet: so shall mine said another: and mine too qd. the third: and all of them sing the same note: so that when they came home, their husbands had little to doe: Especially Simon, whose wife daily lay at him for London apparell, to whome he said, Good woman, be content, let us goe according to our place and ability: what will the Bailiffes thinke, if I should prancke thee up like a peacocke, and thou in thy attire surpasse their wiues? they would either thinke I were mad, or else that I had more money then I could well vse, consider, I pray thee good wife, that such as are in their youth masters, doe proue in their age starke beggars.

Besides that, it is enough to raise me vp in the kings booke, for many times, mens coffers are iudged by their garments : why, we are Country folks, and must keepe our selues in good compasse: gray russet, and good hempe-spun cloth doth best become vs; I tell thee wife, it were as vndecent for vs to goe like Londoners as it is for Londoners to goe like courtiers.

What a coyle keepe you, quoth she? are we not Gods creatures as well as Londoners? and the kings subiects, as well as they? then finding our wealth to be as good as theirs, why should we not goe as gay as Londoners? No, husband, no, 
here is the fault, wee are kept without it, onely because our husband be not so kind as Londoners: why man, a cobler there keepes his wife better then the best Clothier in this Countrey: nay, I will affirme it, that the London Oyster-wiues, and the very kitchin-stuffe cryers, doe exceed vs in their Sundaies attire: nay, more then that, I did see the Water-bearers wife which belongs to one of our Merchants, come in with a Tankerd of Water on her shoulder, and yet halfe a dozen gold rings on her fingers. You may then thinke, wife (quoth he) she got them not with idlenesse.

But wife, you must consider what London is, the chiefe and capitall City of all the Land, a place on the which all strangers cast their eyes, it is (wife) the Kings Chamber and his Maiesties royall seate: to that City repaires all nations vnder heauen. Therefore it is most meete and conuenient, that the Citizens of such a City should not goe in their apparell like peasants, but for the credit of our Country, weare such seemely habits, as doe carry grauity and comelinesse in the eyes of all beholders. But if wee of the Country went so (quoth she) were it not as great credit for the Land as the other? Woman, qd. her husband, it is altogether needlesse, and in diuers respects it may not be. Why then, I pray you, quoth she, let us go dwell at London. A word soone spoken, said her husband, but not so easie to be performed : therefore wife, I pray thee hold thy prating, for thy talk is foolish: yea, yea husband, your old churlish conditions will neuer be left, you keepe me here like a drudge and a droile, and so you may keepe your money in your purse, you care not for your credit, but before I will goe so like a shepheardesse, I will first goe naked: and I tell you plaine, I scorne it greatly, that you should clap a gray gowne on my backe, as if I had not brought you two pence: before I was married, you swore I should haue any thing that $I$ requested, but now all is forgotten. And in saying this, she went in, and soone after she was so sicke, that needes she must goe to bed: and when she was laid, she draue out that night with many grieuous groanes, sighing and sobbing, and no rest she could take God wot. And in the 
morning when shee should rise, the good soule fell downe in a swowne, which put her maidens in a great flight, who running downe to their master, cryed out; Alas, alas, our Dame is dead, our Dame is dead. The good-man hearing this, ran vp in all hast and there fell to rubbing and chafing of her temples, sending for aqua vitæ, and saying, Ah my sweet-heart, speake to me, good-wife, alacke, alacke: call in the neighbours, you queanes, quoth he. With that she left vp her head, fetching a great groane, and presently swouned againe, and much a doe ywis, he had to keepe life in her: but when she was come to her selfe, How dost thou wife, qd. he? What wilt thou haue? for Gods sake tell me if thou hast a mind to any thing, thou shalt haue it. Away dissembler (qd. she) how can I beleeve thee? thou hast said to me as much a hundred times, and deceiued me, it is thy churlishnesse that hath killed my heart, neuer was woman matcht to so vnkind a man.

Nay, good-wife, blame me not without cause; God knoweth how heartily I loue thee. Loue me? no, no, thou didst neuer carry my loue but on the tip of thy tongue, quoth she, I dare sweare thou desirest nothing so much as my death, and for .my part, I would to God thou hadst thy desire; but be content, I shall not trouble thee long; and with that fetching a sigh, shee swouned and gaue a great groane. The man seeing her in this case, was wondrous woe: but so soone as they had recouered her, he said, O my deare wife, if any bad conceit hath ingendered this sicknesse, let me know it; or if thou knowst any thing that may procure thy health, let me vnderstand thereof, and I protest thou shalt have it, if it cost me all that euer I haue.

O husband, quoth she, how may I credit your words, when for a paltry sute of apparell you denyed me? Well, wife, quoth he, thou shalt haue apparell or any thing else thou wilt request, if God send thee once health. O husband, if I may find you so kind, I shall thinke my selfe the happiest woman in the world, thy words haue greatly comforted my heart, mee thinketh if I had it, I could drinke a good draught of Renish wine. Well, wine was sent for: O Lord, said she, that $I$ had a piece of 
chicken, I feele my stomache desirous of some meate: Glad am I of that, said her husband, and so the woman within a few dayes after was very well.

But you shall vnderstand, that her husband was faine to dresse her London-like, ere he could get her quiet, neither would it please her except the stuffe was bought in Cheapside : for out of Cheapside nothing would content her, were it neuer so good: insomuch, that if she thought a Taylor of Cheapside made not her gowne, she would sweare it were quite spoiled.

And hauing thus wonne her husband to her will, when the rest of the Clothiers wiues heard thereof, they would be suted in the like sort too; so that euer since, the wiues of South-hampton, Salisbury, of Glocester, Worcester, and Reading, went all as gallant and as braue as any Londoners wiues.

\section{CHAPTER VII.}

How the Clothiers sent the King aide into France, and how he ouercame his brother Robert, and brought him into England, and how the Clothiers feasted his Maiesty and his sonne at Reading.

The Kings Maiestie being at the warres in France, against Lewis the French King, and Duke Robert of Normandy, sending for diuers supplies of Souldiers out of England, the Clothiers at their owne proper cost set out a great number, and sent them ouer to the King.

Which Roger Bishop of Salisbury, who gouerned the Realme in the Kings absence, did certifie the King thereof, with his letters written in their commendations.

And afterwards it came to passe, that God sent his Highnes victory ouer his enemies, and hauing taken his brother prisoner, brought him most ioyfully with him into England, and appointed him to be kept in Cardife Castle prisoner, yet with this fauour, that he might hunt and hawke where he would, vp and downe 
the Country, and in this sorte hee liued a good while, of whom we will speake more at large hereafter.

The King being thus come home, after his Winters rest, he made his Summers progresse into the West-countrey, to take a view of all the chiefe Townes: whereof the Clothiers being aduertised, they made great preparation against his comming, because he had promised to visit them all.

And when his Grace came to Reading, he was entertained and receiued with great ioy and triumph: Thomas Cole being the chiefe man of regard in all the Towne, the King honored his house with his Princely presence, where during the Kings abode, he, and his sonne, and Nobles were highly feasted.

There the King beheld the great number of people, that was by that one man maintained in worke, whose hearty affection and loue toward his Maiestie did well appeare, as well by their outward countenances, as their gifts presented vnto him. But of Cole himselfe the King was so well perswaded, that he committed such trust in him, and put hinı in great authority in the Towne. Furthermore the King said, That for the loue which those people bore him liuing, that hee would lay his bones among them when he was dead. For I know not, said he, where they may be better bestowed, till the blessed day of resurrection, then among these my friends which are like to be happy partakers of the same.

Whereupon his. Maiestie caused there to be builded a most goodly and famous Abbey: in which he might shew his deuotion to God, by increasing his seruice, and leaue example to other his successors to doe the like. Likewise within the towne he after builded a faire and goodly Castle, in the which he often kept his Court, which was a place of his chiefe residence during his life, saying to the Clothiers, that seeing he found them such faithfull subiects, he would be their neighbour, and dwell among them.

After his Maiesties Royall feasting at Reading, he proceeded in progresse, till he had visited the whole West-countries, being wondrously delighted, to see those people so diligent to apply 
their businesse : and comming to Salisbury, the Bishop receiued his Maiesty with great ioy, and with triumph attended on his Grace to his Palace, where his Highnesse lodged.

There Sutton the Clothier presented his Highnesse with a broad cloth, of so fine a thread, and exceeding good workmanship, and therewithall of so faire a colour, as his Grace gaue commendation thereof, and as it is said, he held it in such high estimation, that thereof he made his Parliament robes, and the first Parliament that was euer in England, was graced with the Kings person in those robes, in requitall whereof his Highness afterward yeelded Sutton many princely fauours.

And it is to be remembred, that Simon of South-hampton (seeing the King had ouerpast the place where he dwelt) came with his wife and seruants to Salisbury, and against the $\mathrm{K}$. going forth of that City, hee caused a most pleasant arbour to be made vpon the toppe of the hill leading to Salisburie, beset all with red and white roses, in such sort, that not any part of the timber could be seen, within the which sat a maiden attired like a Queen, attended on by a faire traine of maidens, who at the Kings approach presented him with a garland of sweet flowres, yeelding him such honour as the Ladies of Rome were wont to doe to their Princes after their victories : which the King tooke in gracious part, and for his farewell from that Country, they bore him company ouer part of the Plaine, with the sound of diuers sweet instruments of musicke. All which when his Grace vnderstood was done at the cost of a Clothier, he said he was the most honoured by those men, aboue all the meane subiects in his Land: and so his Highness past on to Exeter, hauing giuen great rewards to these maidens.

Tomas Doue and the residue of the Clothiers, against his Graces comming thither, had ordained diuers sumptuous shews; first, there was one that presented the person of Augustus Cesar the Emperour, who commanded after the Romane inuasion, that their City should be called Augustus, after his owne name, which before time was called Isca, and of later yeeres, Exeter.

There his Maiesty was royally feasted seuen dayes together, at 
the onely cost of Clothiers, but the diuers delightes and sundry pastimes which they made there before the King, and his Nobles, is too long here to be rehearsed, and therefore I will ouerpasse them to auoid tediousnesse.

His Grace then coasting along the Country, at last came to Glocester, an ancient City, which was builded by Gloue, a Brittish King, who named it after his owne name, Glocester. Here was his Maiesty entertained by Gray the Clothier, who profest himselfe to be of that ancient family of Grayes, whose first originall issued out of that ancient and Honorable Castle and Towne of Rithin.

Here was the King most bountifully feasted, hauing in his company his brother Robert (although his prisoner the same time.) And his Grace being desirous to see the Maidens card and spinne, they were of purpose set to their worke: among whom was faire Margaret with her white hand, whose excellent beauty hauing pierc't the eyes of the amorous Duke, it made such an impression in his heart, that afterward he could neuer forget her: and so vehemently was his affection kindled, that he could take no rest, till by writing he had bewrayed his mind: but of this we will speak more in another place: and the King at his departure said, that to gratifie them, hee would make his sonne Robert their Earle, who was the first Earle that euer was in Glocester.

Now when his Grace was come from thence, he went to Worcester, where William Fitz-allen made preparation in all honourable sort to receiue him, which man being borne of great parentage, was not to learne how to entertaine his Maiestie, being descended of that famous Family, whose patrimony lay about the Towne of Oswestrie, which Towne his predecessors had inclosed with stately walls of stone.

Although aduerse fortune had so grieuously frowned on some of them, that their children were faine to become Tradesmen, whose hands were to them in stead of lands, notwithstanding God raised againe the fame of this man, both by his great wealth, and also in his posterity, whose eldest son Henry, the Kings god-son, became afterward the Maior of London, who was 
the first Maior that euer was in that City, who gouerned the same 23 yeeres: and then his son Roger Fitz-allen was the second Maior.

The princely pleasures that in Worcester were shewn the King, were many and maruelous, and in no place had his Maiesty receiued more delight then here: for the which at his departure he did shew himselfe very thankefull. Now when his Grace had thus taken view of all his good townes Westward, and in that progresse had visited these Clothiers, he returned to London, with great ioy of his Commons.

\section{CHAPTER VIII.}

How Hodgekins of Hallifax came to the Court, and complained to the King, that his priuiledge was nothing worth, because when they found any offender, they could not get a hangman to execute him: and how by a Fryer a gin was deuised to chop off mens heads of it selfe.

AFTER that Hodgkins had got the priuiledge for the towne of Halifax, to hang vp such theeues as stole their cloth in the night, presently without any further iudgement, all the Clothiers of the towne were exceeding glad, and perswaded themselues, that now their goods would be safe all night, without watching them at all, so that whereas before, the town maintained certaine watchmen to keepe their cloth by night, they were hereupon dismissed as a thing needlesse to be done, supposing with themselues, that seeing they should be straight hanged that were found faulty in this point, that no man would be so desperate to enterprise any such act. And indeed the matter being noysed through the whole Country, that they were straight to be hanged that vse such theeuery, it made many lewd liuers to restraine such theeuery.

Neuertheles, there was at that same time liuing, a notable Theefe named Wallis, whom in the north they called Mighty Wallis, in regard of his valour and manhood: This man being 
most subtile in such kind of knauery, hauing heard of this late priuiledge, and therewithall of the Townes security, said that once he would venture his necke for a packe of Northerne cloth : and therefore comming to one or two of his companions, he asked if they would be partners in his adventure, and if (quoth he) you will herein hazard your bodies, you shall be sharers in all our booties.

At length by many perswasions the men consented: whereupon late in the night, they got them all into a Farriours shop, and called vp the folkes of the house. What the foule ill wald you haue (quoth they) at this time of the night? Wallis answered, saying, Good-fellowes, we would haue you to remoue the shooes of our horses feete, and set them on againe, and for your paines you shall be well pleased. The Smith at length was perswaded, and when he had pluckt off all the shooes from their horses feete, they would needes haue them all set on againe, quite contrary with the cakins forward, that should stand backward. How? fay, fay man, qd. the Smith, are ye like fules? what the deele doe you meane to breake your crags? gud faith I tro the men be wood. Not so, Smith, qd they, do thou as we bid thee, and thou shalt haue thy mony: for it is an old prouerbe,

Be it better, or be it worse,

Please you the man that beares the purse.

Gudd faith and see I sall, qd. the Smith, and so did as hee was willed. When Wallis had thus caused their horses to be shod, to Hallifax they went, where they without any let, laded their horses with cloth, and so departed contrary way.

In the morning, so soone as the Clothiers came to the field, they found that they were robd, whereupon one ranne to another to tell these things. Now when Hodgekins heard thereof, rising vp in haste, he wild his neighbors to mark and to see, if they could not descry either the foot-steppes of men or Horses. Which being done, they perceiued that horses had been there, and seeking to pursue them by their foot-steppes, they went a cleane contrary way, by reason that the horses were shodde 
backward: and when in vaine they had long pursued them, they returned, being neuer the neere. Now Wallis vsed his feate so long, that at length he was taken, and two more with him: whereupon according to the priuilege of the Towne, they put Halters about the theeues neckes presently to hang them vp.

When they were come to the place appointed, Wallis and the rest being out of hope to escape death, prepared themselues patiently to suffer the rigor of the Law. And therewith the rest laying open the lewdnesse of his life, grieuously lamenting for his sinnes, at length commending their soules to God, they yeelded their bodies to the graue, with which sight the people were greatly mooued with pity, because they had neuer seene men come to hanging before: but when they should have beene tyed vp, Hodgekins willed one of his neighbours to play the Hang-mans part, who would not by any meanes doe it, although he was a very poore man, who for his paines should haue beene possest of all their apparell. When he would not yeeld to the office, one of those which had his cloth stolen, was commanded to doe the deed; but he in like manner would not, saying: When I haue the skill to make a man, $I$ will hang a man, if it chance my workmanship doe not like me.

And thus from one to another, the office of the Hang-man was posted off. At last a Rogue came by, whom they would hauc compelled to haue done that deed. Nay, my masters, qd. he, not so: but as you haue got a priuiledge for the Towne, so you were best to procure a Commission to make a hang-man, or else you are like to be without one for me. Neighbor Hodgkins quoth one, I pray you doe this office your selfe, you haue had most losse, and therefore you should be the most ready to hang them your selfe. No, not I (quoth Hodgkins,) though my losse were ten times greater then it is, notwithstanding look which of these Theeues will take vpon him to hang the other, shall haue his life saued, otherwise they shall all to prison till I can prouide a hangman.

When Wallis saw the matter brought to this passe, he began stoutly to reply, saying, My masters of the Towne of Halifax, 
though your priuiledge stretch to hang men vp presently that are found stealing of your goods, yet it gives you no warrant to imprison them till you prouide them a hang-man, my selfe, with these my fellowes, haue here yeelded our selues to satisfie the Law, and if it be not performed, the fault is yours, and not ours, and therefore we humbly take our leaue: from the gallowes the xviii of August. And with that he leapt from the ladder, and hurl'd the halter at Hodgkins face.

When the Clothiers saw this, they knew not what to say, but taking them by the sleeues, entreated to haue their owne againe. Not so, qd. Wallis, you get not the value of a packe or a bawby: wee haue stolne your cloth, then why doe you not hang vs? here we haue made our selues ready, and if you will not hang vs, chuse. A plague vpon you, quoth he, you haue hindred me God knowes what, I made account to dine this day in heauen, and you keepe me here on earth where there is not a quarter of that good cheare. The foule euill take you all, I was fully prouided to giue the gallowes a boxe on the eare, and now God knowes when I shall be in so good a minde againe: and so he with the reste of his companions departed.

When Hodgekins saw, that notwithstanding their theeuery, how they flowted at their lenity, he was much mooued in minde; and as he stood in his dumps chewing his cud, making his dinner with a dish of melancholy, a gray Fryar reuerently saluted him in this sort: All haile, good-man Hodgekins, happinesse and health be euer with you, and to all suppressors of lewd liuers, God send euerlasting ioyes.

I am sorry good-man Hodgekins, that the great priuiledge which our King gaue to this towne, comes to no greater purpose; better farre had it beene that it had neuer beene granted, then so lightly regarded; the towne hath suffered through their owne peeuishnesse, an euerlasting reproch this day, onely because foolish pitty hath hindred Justice.

Consider, that compassion is not to be had vpon theeuves and robbers; pity onely appertaineth to the vertuous sort, who are 
ouerwhelmed with the waues of misery and mischance. What great cause of boldnesse haue you giuen to bad liuers, by letting these fellowes thus to escape, and how shall you now keepe your goods in safety, seeing you fulfill not the Law which should be your defence? neuer thinke that theeues will make any conscience to carry away your goods, when they find them selues in no danger of death, who haue more cause to praise your pity, then commend your wisedome: wherefore in time seeke to preuent the ensuing euill.

For my owne part, I haue that care of your good, that I would worke all good meanes for your benefit, and yet not so much in respect of your profit, as for the desire I haue to vphold Justice, and seeing $I$ find you and the rest so womanish, that you could not find in your hearts to hang a Theefe, I haue deuised how to make a gin, that shall cut off their heads without mans helpe, and if the King will allow thereof.

When Hodgekins heard this, he was somewhat comforted in mind, and said to the Fryer, that if by his cunning he would performe it, he would once againe make sute to the King to haue his grant for the same. The Fryer willed him to haue no doubt in him; and so when he had deuised it, he got a Carpenter to frame it out of hand.

Hodgekins in the meane time posted it vp to the Court, and told his Maiesty that the priuiledge of Hallifax was not worth a pudding. Why so, said the King? Because, quoth Hodgekins, we can get neuer a hangman to trusse our theeues : but if it shall like your good Grace, (quoth he) there is a feate Fryar, that will make vs a deuise, which shall without the hand of man cut off the cragges of all such carles, if your Maiesty will please to allow thereof.

The King vnderstanding the full effect of the matter, at length granted his petition: whereupon till this day, it is obserued in Hallifax, that such as are taken stealing of their cloth, haue their heads chopt off with the same gin. 


\section{CHAPTER IX.}

How the Bailiffes of London could get no man to bee a Catchpole, and how certaine Flemings tooke that office vpon them, whereof many of them were fledde into this Realme, by reason of certaine waters that had drowned a great part of their Country.

The City of London being at that time gouerned by Bailiffes, it came to passe, that in a certaine fray two of their Catch-poles were killed, for at that time they had not the name of Sergeants : and you shall vnderstand, that their office was then so much hated and detested of Englishmen, that none of them would take it vpon him: so that the Bailiffes were glad to get any man whatsoeuer, and to giue him certain wages to performe that office.

It came to passe, as I said before, that two of their Officers by arresting of a man, were at one instant slaine, by meanes whereof the Bailiffes were enforced to seeke others to put in their roomes; but by no meanes could they get any, wherefore according to their wonted manner, they made proclamation, that if there were any man that would present himselfe before them, he should not onely be settled in that office during their liues, but also should haue such maintenance and allowance, as for such men was by the City prouided: and notwithstanding that it was an office most necessary in the Commonwealth, yet did the poorest wretch despise it, that liued in any estimation among his neighbours.

At last, a couple of Flemings, which were fled into this Land, by reason that their Country was drowned with the sea, hearing the Proclamation, offered themselues vnto the Bayliffes, to serue in this place, who were presently receiued and accepted and according to order had garments giuen them, which were of 2. colors, blue and red their coates, breeches and stockings, whereby they were knowne and discerned from other men.

Within halfe a yeere after, it came to passe, that Thomas 
Doue of Exeter came vp to London, who hauing by his iollity and goodfellowship, brought himselfe greatly behind hand, was in danger to diuers men of the Cite, among the rest, one of his Creditors feed an Officer to arrest him. The Dutch-man that had not beene long experienced in such matters, and hearing how many of his fellowes had beene killed for attempting to arrest men, stood quiuering and quaking in a corner of the street to watch for Thomas Doue, and hauing long waited, at length he espied him: whereupon he prepared his mace ready, and with a pale countenance proceeded to his Office; at what time comming behind the man, suddenly with his mace he knockt him on the pate, saying, I arrest you, giuing him such a blow, that he fell him to the ground.

The Catchpole thinking he had killed the man, he left his mace behind him and ranne away: the Creditor he ran after him, calling and crying that he should turne againe: But the Fleming would not by any meanes turne backe, but got him quite out of the City, and tooke Sanctuary at Westminster.

Doue being come to himselfe, arose and went to his Inne, no man hindring his passage, being not a little glad he so escaped the danger. Yet neuerthelesse, at his next comming to London, another Catchpole met with him, and arrested him in the Kings name.

Doue being dismayed at this mischieuous mischance, knew not what to doe: at last hee requested the Catchpole that hee would not violently cast him in prison, but stay till such time as he could send for a friend to be his surety; and although kindnesse in a Catchpole be rare, yet was he won with faire words to doe him this fauour: whereupon Doue desired one to goe to his Oast Iarrat, who immediately came with him, and offered himselfe to be Doues surety.

The Officer, who neuer saw this man before, was much amazed at his sight : for Iarrat was a great and mighty man of body, of countenance grim, and exceeding high of stature, so that the Catchpole was wonderfully afraid, asking if he could find neuer a surety but the deuill, most fearfully intreating him to coniure 
him away, and he would doe Doue any favour. What, will you not take my word, qd. Iarrat? sir, qd. the Catchpole, if it were for any matter in hell, I would take your word as soone as any diuels in that place, but seeing it is for a matter on earth, I would gladly haue a surety.

Why, thou whorson cricket, (quoth Iarrat,) thou maggat-apie, thou spinner, thou paultry spider, dost thou take me for a deuill? Sirra, take my word, I charge thee, for this man, or else goodman butter-fly, Ile make thee repent it. The Officer, while he was in the house, said, he was cōtent, but as soon as he came into the street, he cryed, saying: Helpe, helpe, good neighbors, or else the deuill will carry away my prisoner : notwithstanding, there was not one man would stirre to be the Catchpoles aide. Which when he saw, he tooke fast hold on Thomas Doue, and would not by any meanes let him goe.

Iarrat seeing this, made no more adoe, but comming to the Officer, gaue him such a fillop on the forehead with his finger, that he fell the poore Fleming to the ground: and while he lay in the street stretching his heeles, Iarrat tooke Doue vnder his arme and carried him home, where he thought himselfe as safe, as King Charlemaine in Mount-albion.

The next morning Iarrat conueyed Doue out of Towne, who afterward kept him in the Country, and came no more in the Catchpoles clawes.

\section{CHAPTER X}

How Duke Robert came a wooing to Margaret with the white hand, and how he appointed to come and steale her away from her Masters.

ThE beautiful Margaret, who had now dwelt with her Dame the space of foure yeeres, was highly regarded and secretly beloued of many gallant and worthy Gentlemen of the Country, but of two most especially, Duke Robert, and Sir William Ferris. It chanced on a time, that faire Margaret with many others of her Masters folkes, went a hay-making, attired in a red stammell 
peticoate, and a broad strawne hat vpon her head, she had also a hay-forke, and in her lappe shee did carry her breake-fast. As she went along, Duke Robert, with one or two of his keepers, met with her, whose amiable sight did now anew re-inkindle the secret fire of loue, which long lay smothering in his heart. Wherefore meeting her so happily, he saluted her thus friendly.

Faire maid, good morow, are you walking so diligently to your labour? Needes must the weather be faire, when the Sun shines so cleare, and the hay wholesome that is dryed with such splendent rayes. Renowned and most notable Duke (qd. she) poore haruest folkes pray for faire weather, and it is the laborers comfort to see his worke prosper, and the more happy may we count the day, that is blessed with your princely presence: but more happy, said the Duke, are they which are conuersant in thy company. But let me intreat thee to turne backe to thy Masters with me, and commit thy forke to some that are fitter for such toyle: trust me, me thinkes thy dame is too much ill aduised, in setting thee to such homely busines. I muse thou canst indure this vile beseeming seruitude, whose delicate lims were neuer framed to proue such painefull experiments.

Albeit, quoth she, it becommeth not me to controule your iudiciall thoughts, yet were you not the Duke, I would say, your opinion deceiued you : though your faire eyes seeme cleare, yet I deemed them vnperfect, if they cast before your mind any shadow or sparke of beauty in me: But I rather thinke, because it hath beene an old saying, that women are proud to heare themselues praised, that you either speake this, to driue away the time, or to wring me from my too apparent imperfections. But I humbly intreate pardon, too longe haue I fore-slowed my businesse, and shewne myselfe ouer-bold in your presence; and therewith, with a courtly grace, bending her knees to the courteous Duke, shee went forward to the field, and the Duke to the Towne of Glocester.

When he came thither, he made his Keepers great cheare, intreating them they would giue him respit to be awhile with old Gray; for we twaine must haue a game or two, quoth he: and 
for my safe returne, I gage to you my princely word, that as I am a true Knight and a Gentleman, I will returne safe to your charge againe.

The Keepers being content, the Duke departed, and with old Gray goes to the field, to peruse the Workefolkes, where while Gray found himselfe busie in many matters, he tooke opportunity to talke with Margaret ; shee who by his letters before was priuie to his purpose ; guest beforehand the cause of his comming : to whom he spake to this effect:

Faire Maid, I did long since manifest my loue to thee by my letter ; tell me therefore, were it not better to be a Duches then drudge! a Lady of high reputation, then a seruant of simple degree? with me thou mightest liue in pleasure, where here thou drawest thy dayes forth in paine; by my loue thou shouldst be made a Lady of great treasures; where now thou art poore and beggerly : all manner of delights should then attend on thee, and whatsoeuer thy heart desireth, thou shouldst haue: wherefore seeing it lyes in thy owne choice, make thy selfe happy, by consenting to my suite.

Sir, (quoth she) I confesse your loue deserues a Ladies fauour, your affection a faithful friend, such a one as could make but one heart and mind of two hearts and bodyes; but farre vnfit it is that the Turtle should match with the Eagle, though her loue be neuer so pure, her wings are vnfit to mount so high. While Thales gazed on the starres, he stumbled in a pit. And they that clime vnaduisedly, catch a fall suddenly: what auaileth high dignity in time of aduersity? it neither helpeth the sorrow of the heart, nor remoues the bodies misery : as for wealth and treasure, what are they, but fortunes baits to bring men in danger? good for nothing but to make people forget themselues : and whereas you alleadge pouerty to be a hinderer of the hearts comfort, I find it my selfe contrary, knowing more surety to rest vnder a simple habit, then a royall Robe : and verily there is none in the world poore, but they that think themselues poore: for such as are indued with content, are rich, hauing nothing else, but he that is possessed with riches, without content, is most wretched 
and miserable. Wherefore most Noble Duke, albeit I account my life vnworthy of your least fauour, yet I would desire you to match your loue to your like, and let me rest to my rake, and vse my forke for my liuing.

Consider, faire Margaret, (quoth he) that it lyes not in mans power to place his loue where he list, being the worke of an high deity. A bird was neuer seen in Pontus, nor true loue in a fleeting mind: neuer shall remoue the affection of my heart which in nature resembleth the stone Abiston, whose fire can neuer be cooled: wherefore sweet Maiden giue not obstinate deniall, where gentle acceptance ought to be receiued.

Faire sir, (quoth she) consider what high displeasure may rise by a rash match, what danger a Kings frownes may breed, my worthlesse matching with your Royalty, may perhaps regaine your liberty, and hazard my life; then call to mind how little you should enjoy your loue or I my wedded Lord.

The Duke at these words made this reply, that if she consented, she should not dread any danger. The thunder (quoth he) is driuen away by ringing of belles, the Lions wrath qualified by a yeelding body: how much more a Brothers anger with a Brothers intreaty? By me he hath receiued many fauors, and neuer yet did he requite any one of them : and who is ignorant that the Princely Crown which adorneth his head, is my right? all which I am content he shall still enioy, so he requite my kindnesse. But if he should not, then would I be like those men (that eating of the tree Lutes) forget the Country where they were borne, and neuer more should this clime couer my head, but with thee would I liue in a strange Land, being better content with an egge in thy company, then with all the delicates in England.

The Maiden hearing this, who with many other words was long wooed, at last consented; where yeelding to him her heart with her hand, hee departed, appointing to certifie her from Cardiffe Castle, what determination he would follow: so taking his leaue of Gray he went to his brothers, and with them posted to Cardiffe. 


\section{PLEASANT HISTORIE OF THOMAS OF READING.}

Now it is to be remembred, that sir William Ferrers within a day or two after came vnto Grayes house, as it was his ordinary custome, but not so much ywis for Grayes company, as for the minde he had to Margaret his Maide, who although he were a married man, and had a faire Lady to his wife, yet he laid hard siege to the fort of this Maidens chastity, hauing with many faire words sought to allure her, and by the offer of sundry rich gifts to tempt her. But whē she saw, that by a hundred denials she could not be rid of him, she now chanced on a sudden to giue him such an answer, as droue him from a deceit into such a conceit, as neuer after that time he troubled her.

Sir William Ferrers being very importunate to have her grant his desire, and when after sundry assaults she gaue him still the repulse, hee would needes know the reason why shee would not loue him, quoth he, If thou didst but consider who he is that seeketh thy fauour, what pleasure he may doe thee by his purse, and what credit by his countenance, thou wouldst neuer stand on such nice points. If I be thy friend, who dareth be thy foe? and what is he that will once call thy name in question for any thing? therefore sweet girle, be better aduised, and refuse not my offer being so large.

Truly sir William (quoth she) though there be many reasons to make me deny your suite, yet is there one aboue the rest that causes me I cannot loue you. Now, I pray thee, my wench let me know that, quoth he, and I will amend it whatsoeuer it be. Pardon me sir, said Margaret, if I should speake my mind, it would possibly offend you, and doe me no pleasure because it is a defect in nature, which no phisicke can cure. Sir William hearing on her so, being abashed at her speech, said, Faire Margaret, let me (if I may obtaine no more at thy hands) yet intreat thee to know what this defect should be; I am not wry-neckt, crook-legd, stub-footed, lame-handed, nor bleare-eyed : what can make this dislike? I neuer knew any body that tooke exceptions at my person before.

And the more sorry am I, quoth she, that I was so malapert to speake it, but pardon me my presumption, good sir William, 
I would I had beene like the Storke tonguelesse, then should I neuer have caused your disquiet. Nay sweet Margaret, quoth he, tell me deare loue, I commend thy singlenesse of heart, good Margaret speake. Good sir William let it rest, quoth shee, I know you will not beleeue it when I haue reuealed it, neither is it a thing that you can helpe : and yet such is my foolishnesse, had it not beene for that, I thinke verily I had granted your suite ere now. But seeing you vrge me so much to know what it is, I will tell you: it is sir, your ill-fauoured great nose, that hangs sagging so lothsomely to your lips, that I cannot finde in my heart so much as to kisse you.

What, my nose, quoth he?. is my nose so great and I neuer knew it ? certainely I thought my nose to be as comely as any mans : but this it is we are all apt to think well of our selues, and a great deale better then we ought: but let me see? my nose! by the masse tis true, I doe now feele it my selfe: Good Lord, how was I blinded before? Hereupon it is certaine, that the Knight was driuen into such a conceit, as none could perswade him but his nose was so great indeed; his Lady, or any other that spake to the contrarie, he would say they were flatterers, and that they lied, insomuch that he would be ready to strike some of them that commended and spake well of his nose. If they were men of worship, or any other that contraried him in his opinion, he would sweare they flowted him, and be ready to challenge them the field. He became so ashamed of himselfe, that after that day he would neuer goe abroad, whereby Margaret was well rid of his company.

On a time, a wise and graue Gentleman seeing him grounded in his conceit so strongly, gaue his Lady counsell, not to contrary him therein, but rather say that she would seeke out some cunning Physician to cure him : for, said he, as sir William hath taken this conceit of himselfe, so is he like neuer to heare other opinion, till his owne conceit doth remoue it, the which must be wisely wrought to bring it to passe.

Whereupon the Lady hauing conferred with a Physician that beare a great name in the countrey, hee vndertooke to remoue 
this fond conceit by his skill. The day being appointed when the Phisician should come, and the Knight beeing told thereof, for very ioy he would goe forth to meete him, when a woman of the Towne saw the Knight, hauing heard what rumor went because of his nose, shee looked very stedfastly vpon him: the Knight casting his eye vpon her, seeing her to gaze so wistly in his face, with an angry countenance said thus to her, Why, how now good huswife, cannot you get you about your business? The woman being a shrewish queane, answered him cuttedly, No mary can I not, qd. she. No, you drab, What is the cause, said the Knight? Because, quoth she, your nose stands in my way : wherewith the Knight being very angry, and abashed, went backe againe to his house.

The Physician being come, he had filled a certaine bladder with sheepes blood, and conueyed it into his sleeue, where at the issue of the bladder he had put in a piece of a swans quill, through the which the blood should runne out of the bladder so close by his hand, that hee holding the Knight by the nose, it might not be perceiued, but that it issued thence. All things being prepared, he told the Knight, that by a foule corrupt blood wherewith the veines of his nose were ouercharged, his impediment did grow, therefore, quoth he, to haue redresse for this disease, you must haue a veine opened in your nose, whence this foule corruption must be taken: whereupon it will follow, that your nose will fall againe to his naturall proportion, and neuer shall you be troubled with this griefe any more, and thereupon will I gage my life.

I pray you master Doctor, said the Knight, is my nose so big as you make it? With reuerence $I$ may speake it, said the Physician, to tell the truth, and auoid flattery, I neuer saw a more misshapen nose so foule to sight. Lo you now Madam, quoth the Knight, this is you that said my nose was as well, as hansome, and as comely a nose as any mans.

Alas sir, qd. she, I spake it (God wot) because you should not grieue at it, nor take my words in ill part, neither did it indeed become me to mislike of your nose 
All this we will quickly remedy, said the Physician, haue no doubt : and with that, he very orderly prickt him in the nose, but not in a veine whereby he might bleed: and presently hauing a tricke finely to vnstop the quill, the blood ranne into a bason in great abundance: and when the bladder was empty, and the bason almost full, the Physician seemed to close the veine, and asked him how he felt his nose, shewing the great quantite of filthy blood which from thence he had taken.

The Knight beholding it with great wonder, said, he thought that no man in the world had beene troubled with such abundance of corrupt blood in his whole body, as lay in his mis-shapen nose, and therewithall he began to touch and handle his nose, saying that he felt it mightily asswaged. Immediately a glasse was brought wherein he might behold himselfe. Yea mary, qd. he now I praise God, I see my nose is come into some reasonable proportion, and I feele my selfe very well eased of the burthen thereof; but if it continue thus, thats all. I will warrant your worship, said the Physician, for euer being troubled with the like againe. Whereupon the Knight receiued great ioy, and the Doctor a high reward.

\section{CHAPTER XI.}

How Thomas of Reading was murdered at his Oasts house of Colebrooke, who also had murdred many before him, and how their wickednesse was at length reuealed.

THомаs of Reading hauing many occasions to come to London, as well about his own affaires, as also the Kings businesse, being in a great office vnder his Maiestie, it chanced on a time, that his Oast and Oastesse of Colebrooke, who through couetousnesse had murdered many of the guests, and hauing every time he came thither great store of his money to lay vp, appointed him to be the next fat pig that should be killed: For it is to be vnderstood, that when they plotted the murder of any man, this was alwaies their terme, the man to his wife, and the woman 
to her husband: wife, there is now a fat pig to be had if you want one. Whereupon she would answer thus, I pray you put him in the hogstie till to-morrow. This was, when any man came thither alone without others in his company, and they saw he had great store of money.

This man should be then laid in the chamber right ouer the kitchen, which was a faire chamber, and the better set out then any other in the house: the best bedstead therein, though it were little and low, yet was it most cunningly carued, and faire to the eye, the feet whereof were fast naild to the chamber floore, in such sort, that it could not in any wise fall, the bed that lay therein was fast sowed to the sides of the bedstead: Moreouer, that part of the chamber whereupon this bed and bedstead stood, was made in such sort, that by the pulling out of two yron pinnes below in the kitchen, it was to be let downe and taken vp by a draw-bridge, or in manner of a trap-doore: moreouer in the kitchin, directly vnder the place where this should fall, was a mighty great caldron, wherein they vsed to seethe their liquor when they went to brewing. Now, the men appointed for the slaughter, were laid into this bed, and in the dead time of the night, when they were sound asleepe, by plucking out the foresaid yron pinnes, downe will the man fall out of his bed into the boyling caldron, and all the cloaths that were vpon him: where being suddenly scalded and drowned, he was neuer able to cry or speake one word.

Then had they a little ladder euer standing ready in the kitchin, by the which they presently mounted into the said chamber, and there closely take away the mans apparell, as also his money, in his male or cap-case: and then lifting vp the said falling floore which hung by hinges, they made it fast as before.

The dead body would they take presently out of the caldron and throw it downe the riuer, which ran neere vnto their house, whereby they escaped all danger.

Now if in the morning any of the rest of the guests that had talkt with the murdered man ore eue, chanst to aske for him, as hauing occasion to ride the same way that he should haue done, 
the good-man would answere, that he tooke horse a good while before day, and that he himselfe did set him forward: the horse the good-man would also take out of the stable, and conuay him by a hay-barne of his, that stood from his house a mile or two, whereof himselfe did alwaies keepe the keies full charily, and when any hay was to be brought from thence, with his owne hands he would deliuer it; then before the horse should goe from thence, he would dismarke him: as if he ware a long taile, he would make him curtall; or else crop his eares, or cut his mane, or put out one of his eies; and by this meanes hee kept himselfe vnknowne.

Now Thomas of Reading, as I said before, being markt and kept for a fat pig, he was laid in the same chamber of death, but by reason Gray of Glocester chanced also to come that night, he escaped scalding.

The next time he came, he was laid there againe, but before he fell asleepe, or was warme in his bed, one came riding thorow the Towne and cryed piteously, that London was all on a fire, and that it had burned downe Thomas Beckets house in Westcheape, and a great number more in the same street, and yet (quoth he) the fire is not quencht.

Which tidings when Thomas of Reading heard, he was very sorrowfull, for of the same Becket that day he had received a great peece of money, and had left in his house many of his writings, and some that appertained to the King also: therefore there was no nay but he would ride backe againe to London presentiy, to see how the matter stood; thereupon making himselfe ready, departed. This crosse fortune caused his Oast to frowne, neuertheless the next time (qd. he) will pay for all.

Notwithstanding God so wrought, that they were preuented the likewise, by reason of a great fray that hapned in the house betwixt a couple that fell out at dice, insomuch as the murderers themselues were inforced to call him vp being a man in great authority, that he might set the house in quietnesse, out of the which by meanes of this quarrell, they doubted to lose many things. 
Another time when hee should haue beene laid in the same place, he fell so sicke, that he requested to haue some body to watch with him, whereby also they could not bring their vile purpose to passe. But hard it is to escape the ill fortunes whereunto a man is allotted: for albeit that the next time that he came to London, his horse stumbled and broke one of his legs as he should ride homeward, yet hired he another to hasten his owne death; for there is no remedy but he should goe to Colebrooke that night: but by the way he was heauy asleepe, that he could scant keepe himselfe in the saddle; and when he came neere vnto the Towne, his nose burst out suddenly a bleeding.

Well, to his Inne he came, and so heauy was his heart that he could eate no meat: his Oast and Oastesse hearing he was so melancholy, came vp to cheare him, saying, Jesus Master Cole, what ayles you to night? neuer did we see you thus sad before: will it please you to haue a quart of burnt sacke? With a good will (quoth he) and would to God Tom Doue were here, he would surely make me merry, and we should lacke no musicke: but I am sorry for the man with all my heart, that he is come so farre behind hand: but alas, so much can euery man say, but what good doth it him? No, no, it is not words can helpe a man in this case, the man had need of other reliefe then so. Let me see: I haue but one child in the world, and that is my daughter, and halfe that I haue is hers, the other halfe my wifes. What then? shall I be good to no body but them? In conscience, my wealth is too much for a couple to possesse, and what is our Religion without charity? And to whom is charity more to be shewne, then to decaid house-holders?

Good my Oast lend me a pen and inke, and some paper, for I will write a letter vnto the poore man straight; and something I will giue him: That almes which a man bestowes with his owne hands, he shall be sure to haue deliuered, and God knowes how long I shall liue.

With that, his Oastesse dissemblingly answered, saying, Doubt 
not, Master Cole, you are like enough by the course of nature to liue many yeeres. God knowes (quoth he) I neuer found my heart so heauy before. By this time pen, inke, and paper was brought, setting himselfe in writing as followeth.

In the name of God, Amen. I bequeath my soule to God, and my body to the ground, my goods equally betweene my wife Elenor, and Isabel, my daughter. Item I giue to Thomas Doue of Exeter one hundred pounds, nay that is too little, I giue to Thomas Doue two hundred pounds in money, to be paid vnto him presently vpon his demand thereof by my said wife and daughter.

$\mathrm{Ha}$, how say you Oast (qd. he) is not this well? I pray you reade it. His Oast looking thereon, said, why Master Cole, what haue you written here? you said you would write a letter, but me thinks you haue made a Will, what neede haue you to doe thus? thanks be to God, you may liue many faire yeeres. Tis true (quoth Cole) if it please God, and I trust this writing cannot shorten my daies, but let me see, haue I made a Will ? Now, I promise you, I did verily purpose to write a letter: notwithstanding, I have written that that God put into my mind: but looke once againe my Oast, is it not written there, that Doue shall haue two hundred pounds, to be paid when he comes to demand it? yes indeed said his Oaste. Well then, all is well, said Cole, and it shall goe as it is for me. I will not bestow the new writing thereof any more.

Then folding it $\mathbf{v p}$, he sealed it, desiring that his Oast would send it to Exeter : he promised that he would, notwithstanding Cole was not satisfied: but after some pause, he would needs hire one to carry it. And so sitting downe sadly in his chaire againe, vpon a sudden he burst forth a weeping; they demanding the cause thereof, he spake as followeth:

No cause of these feares I know : but it comes now into my minde (said Cole) when I set toward this my last iourney to London, how my daughter tooke on, what a coyle she kept to 
haue me stay, and I could not be rid of the little baggage a long time, she did so hang about me, when her mother by violence tooke her away, she cryed out most mainly, $\mathrm{O}$ my father, my father, I shall neuer see him againe.

Alas, pretty soule, said his Oastesse, this was but meere kind-1 nesse in the girle, and it seemeth she is very fond of you. But alas, why should you grieue at this? you must consider that it was but childishnesse. I, it is indeed, said Cole, and with that he began to nod. Then they asked him if he would goe to bed. No, said he, although I am heauy, I haue no mind to goe to bed at all. With that certaine Musicians of the towne came to the Chamber, and knowing Master Cole was there, drue out their instruments, and very solemnly began to play.

This musicke comes very well (said Cole) and when he had listned a while thereunto, he said, Me thinks these instrumēts sound like the ring of 'St. Mary Oueries bells, but the Base drowns all the rest: and in my eare it goes like a bell that rings a forenoones knell, for Gods sake let them leaue off, and beare them this simple reward. The Musicians being gone, his Oast asked if now it would please him to goe to bed; for (quoth he) it is welneere eleuen of the clocke.

With that Cole beholding his Oast and Oastesse earnestly, began to start backe, saying, what aile you to looke so like pale death? good Lord, what haue you done, that your hands are thus bloody? What my hands, said his Oast? Why, you may see they are neither bloody nor foule;: either your eyes doe greatly dazell, or else fancies of a troubled minde doe delude you.

Alas, my Oast, you may see, said hee, how weake my wits are, I neuer had my head so idle before. Come, let me drinke once more, and then I will to bed, and trouble you no longer. With that hee made himselfe vnready, and his Oastesse was very diligent to warme a kerchiffe, and put it about his head. Good Lord, said he, I am not sicke, I praise God, but such an alteration $I$ finde in my selfe as I neuer did before.

With that the scritch-owle cried pitiously, and anon after. the night-rauen sate croaking hard by his window. Iesu haue 
mercy vpon me, quoth hee, what an ill-fauoured cry doe yonder carrion birds make, and therewithall he laid him downe in his bed, from whence he neuer rose againe.

His Oast and Oastesse, that all this while noted his troubled mind, began to commune betwixt themselues thereof. And the man said, he knew not what were best to be done. By my consent (quoth he) the matter should passe, for $I$ thinke it is not best to meddle on him. What man (quoth she) faint you now? haue you done so many and do you shrinke at this? Then shewing him a great deale of gold which Cole had left with her, she said, Would it not grieue a bodies heart to lose this? hang the old churle, what should he doe liuing any longer? he hath too much, and we have too little: tut husband, let the thing be done, and then this is our owne.

Her wicked counsell was followed, and when they had listned at his chamber doore, they heard the man sound asleepe : All is safe, quoth they, and downe into the kitchin they goe, their seruants being all in bed, and pulling out the yron pins, downe fell the bed, and the man dropt out into the boyling caldron. He being dead, they betwixt them cast his body into the riuer, his clothes they made away, and made all things as it should be : but when hee came to the stable to conuey thence Coles horse, the stable doore being open, the horse had got loose, and with a part of the halter about his necke, and straw trussed vnder his belly, as the Ostlers had dressed him ore eue, he was gone out at the back-side, which led into a great field ioyning to the house, and so leaping diuers hedges, being a lustie stout horse, had got into a ground where a mare was grasing, with whom he kept such a coile, that they got into the high-way, where one of the Towne meeting them, knew the mare, and brought her and the horse to the man that owd her.

In the meane space, the Musicians had beene at the Inne, and in requitall of their euenings gift, they intended to giue Cole some musicke in the morning. The good-man told them he tooke horse before day: likewise there was a guest in the house that would haue bore him company to Reading, vnto whom the 
Oast also answered, that he himselfe set him vpon horsebacke, and that he went long agoe. Anon came the man that owed the mare, inquiring vp and downe, to know and if none of them missed a horse, who said no. At the last hee came to the signe of the Crane where Cole lay: and calling the Oastlers, he demanded of them if they lackt none, they said no: Why then said the man, I perceiue my mare is good for something, for if I send her to field single, she will come home double: thus it passed on all that day and the night following. But the next day after, Coles wife musing that her husband came not home, sent one of her men on horsebacke, to see if he could meete him : and if (quoth she) you meet him not betwixt this and Colebrooke, aske for him at the Crane, but if you find him not there, then ride to London; for I doubt he is either sicke or else some mischance hath fallen vnto him.

The fellow did so, and asking for him at Colebrooke, they answered, hee went homeward from thence such a day. The seruant musing what should be become of his Master, and making much inquiry in the Towne for him: at length one told him of a horse that was found on the high-way, and no man knew whence he came. He going to see the horse, knew him presently, and to the Crane he goes with him. The Oast of the house perceiuing this, was blanke, and that night fled secretly away. The fellow going vnto the Justice desired his helpe: presently after word was brought that Iarman of the Crane was gone, then all the men said, he had sure made Cole away: and the Musicians told what Iarman said to them, when they would haue giuen Cole musicke. Then the woman being apprehended and examined, confessed the truth. Iarman soone after was taken in Windsor Forest, he and his wife were both hangd, after they had laid open al these things before expressed. Also he confessed, that he being a Carpenter made that false falling floore, and how his wife deuised it. And how they had murdered by that means $1 x$. persons. And yet notwithstanding all the money which they had gotten thereby, they prospered not, but at their death were found very farre in debt. 
When the King heard of this murder, he was for the space of vii dayes so sorrowfull and heauie, as he would not heare any suite, giuing also commandement, that the house should quite be consumed with fire, wherein Cole was murdered, and that no man should euer build vpon that cursed ground.

Coles substance at his death was exceeding great, hee had daily in his house an hundred men seruants and xl. maides; hee maintained beside aboue two or three hundred people, spinners and carders, and a great many other house-holders. His wife neuer after married, and at her death shee bestowed a mightie summe of money toward the maintaining of the new builded Monastery. Her daughter was most richly married to a Gentleman of great worship, by whom she had many children. And some say, that the riuer whereinto Cole was cast, did euer since carrie the name of Cole being called The riuer of Cole, and the Towne of Colebrooke.

\section{CHAPTER XII.}

How diuers of the Clothiers wiues went to the Churching of Suttons wife of Salisbury, and of their merriment.

SvTToNs wife of Salisbury which had lately bin deliuered of a sonne, against her going to Church, prepared great cheare : at what time Simons wife of Southampton came thither, and so did diuers others of the Clothiers wiues, onely to make merry at this Churching feast : and whilest these Dames sat at the Table, Crab, Weasell, and Wren, waited on the boord, and as the old Prouerbe speaketh, Many women many words, so fell it out at that time: for there was such prattling that it passed: some talkt of their husbands frowardnes, some shewed their maids sluttishnes, othersome deciphered the costlines of their garments, some told many tales of their neighbours: and to be briefe, there was none of them but would haue talke for a whole day.

But when Crab, Weasell, and Wren saw this, they concluded 
betwixt themselues, that as oft as any of the women had a good bit of meate on their trenchers, they offering a cleane one, should catch that commodity, and so they did: but the women being busie in talke, marked it not, till at the last one found leisure to misse her meat: whereupon she said, that their boldness exceeded their diligence. Not so, forsooth, said Weasell, there is an hundred bolder than we. Name me one, said the woman, if you can. A flea is bolder, quoth Crabbe. How will you proue that, said the woman? Because, quoth he, they will creepe vnder your coates, where we dare not come, and now and then bite you by the buttocks as if they were brawne. But what becomes of them, qd. the woman? their sweet meat hath sowre sauce, and their lustines doth often cost them their liues, therefore take heed. A good warning of a faire woman, said Wren, but $I$ had not thought so fine a wit in a fat belly.

The women seeing their men so merry, said it was a signe there was good ale in the house. Thats as fit for a Churching quoth Weasell, as a cudgell for a curst queane. Thus with pleasant communication and merry quips they droue out the time, till the fruit and spice-cakes were set on the boord: At what time one of them began to aske the other, if they heard not of the cruell murder of Thomas of Reading? What, said the rest, is old Cole murdered? when, I pray you was the deed done? The other answered, on Friday last. $O$ good Lord, said the women, how was it done, can you tell?

As report goes, said the other, he was rosted aliue. $O$ pitifull! was hee roasted? Indeed I heard one say, a man was murdred at London, and that he was sodden at an Inholders house, and serued it to the guests in stead of porke.

No neighbour, it was not at London, said another; I heare say twas coming from London, at a place called Colebrook, and it is reported for truth, that the Inholder made pies of him, and penny pasties, yea, and made his owne seruant eate a piece of him. But I pray you good neighbour, can you tell how it was knowne: some say, that a horse reuealed it.

Now by the masse (quoth Grayes wife) it was told one of 
my neighbours, that a certaine horse did speake, and told great things: That sounds like a lie, said one of them. Why, said another, may not a horse speake, as well as Balaam asse? It may be, but it is vnlikely, said the third. But where was the horse when he spake? As some say, qd. she, he was in the field, and had broke out of the stable, where he stood fast locked in mighty strong yron fetters, which hee burst in peeces as they had beene straws, and broke downe the stable doore, and so got away. The good-man comming in at these speeches, asked what that was they talkt of. Marry, said his wife wee heare that Cole of Reading is murdred: I pray you is it true? I, said Sutton, it is true, that vile villaine his Oast murdered him, in whose house the man had spent many a pound. But did they make pies of him, said his wife; No, no, quoth her husband : he was scalded to death in a boyling caldron, and afterward throwne into a running riuer that is hard by. But good husband, how was it knowne? By his horse, quoth hee. What, did hee tell his master was murdered? could the horse speake English? Jesus what a foolish woman are you, quoth he, to aske such a question? But to end this, you are all heartily welcome, good neighbours, and I am sorry you had no better cheere. So with thanks the women departed. Thus haue yee heard the diuers tales that will be spred abroad of an euil deed.

\section{CHAPTER XIII.}

How Duke Robert deceiued his keepers, and got from them: how he met faire Margaret, and in carrying her away was taken, for the which he had his eyes put out.

DUKE Robert, hauing, as you heard, obtained the loue of faire Margaret, did now cast in his mind, how hee might delude his Keepers, and carry her quite away. In the end he being absolutely resolued what to doe, sent this letter vnto her, wherein he requested, that she would be readie to meet him in the Forrest, betwixt Cardiffe and Glocester. 
The young Lady hauing secretly receiued his message, unknowne to her master or dame, in a morning betime made her ready and got forth, walking to the appointed place, where her Loue should meet her.

During her aboade there, and thinking long ere her Loue came, she entred into diuers passions, which indeed presaged some disaster fortune to follow. O my deare Loue, said shee, how slacke art thou in performing thy promise! why doe not thy deeds agree with thy indicting? see these are thy words, Come, my deare Margaret, and with Cupids swift wings flie to thy friend, be now as nimble in thy footing, as the Camels of Bactria, that runne an hundred miles a day, I will waite and stay for thee, so I stay not too long. There is no Country like Austria for ambling horses, and to carry thee $I$ haue got one.

O my Loue (quoth she) here am I, but where art thou? $\mathrm{O}$ why doest thou play the trewant with time, who like the wind slides away vnseene? An ambling gennet of Spaine is too slow to serue our turnes. A flying horse, for flying Louers were most meete. And thus casting many lookes thorow the Siluane shades, vp and downe to espie him, she thought euery minute an houre, till she might see him, sometimes she would wish her self a bird, that she might flie through the ayre to meet him, or a pretty squirill to clime the highest tree to descry his coming: but finding her wishes vaine, she began thus to excuse him and perswaded her selfe, saying;

How much to blame am I, to finde fault with my friend? Alas, men that lacke their liberty, must come when they can, not when they would, poore prisoners cannot doe what they desire, and then why should I be so hastie? Therefore if safely I may lay me down I will beguile vnquiet thoughts with quiet sleepe: it is said that Galino breeds no Serpents, nor doth Englands forrests nourish Beares or Lyons, therefore without hurt I hope I may rest awile. Thus leauing faire Margaret in a sweet slumber, we will returne to Duke Robert, who had thus plotted his escape from his keepers. 
Hauing liberty of the King to hawke and hunt, hee determined on a day, as he should follow the chase, to leaue the hounds to the Hart, and the hunters to their hornes, and being busie in their sport, himselfe would flie, which hee performed at that time when hee appointed Margaret to meete him, and so comming to the place, his horse all on a water, and himself in a sweat, finding his Loue asleepe, he awaked her with a kisse, saying, Arise faire Margaret, now comes the time wherein thou shalt be made a Queene: and presently setting her on horsebacke, he posted away.

Now, when the Keepers saw they had lost his company, and that at the killing of the game, hee was not present, they were among themselues in such a mutiny, that they were ready one to stabbe another. It was thy fault, said one, that hee thus escapt from vs, that hadst more mind of thy pleasure, then of thy prisoner, and by this meanes we are all vndone. The other said as much to him, that he had thought he had followed him in the chase : but leauing at last this contention, the one posted vp to the King, while the others coasted vp and downe the Country to search for the Duke, who having kild his horse in trauelling, was most vnhappily mette on foot with faire Margaret, ere he could come to any towne, where he might for money haue another. But when he espyed his Keepers come to take him, he desired Margaret to make shift for herselfe, and to seeke to escape them. But she being of a contrary mind, said, she would liue and die with him.

The Duke seeing himselfe ready to be surprized, drew out his sword, and said, he would buy his liberty with his life, before he would yeeld to be any more a prisoner; and thereupon began a great fight betwixt them, insomuch that the Duke had killed two of them : but himselfe being sore wounded, and faint with ouermuch bleeding, at length fell downe, being not able any longer to stand : and by this means the good Duke was taken with his faire loue, and both of them committed to prison.

But in the meane space, when Grayes wife had missed her maide, and saw she was quite gone, she made great lamentation 
for her among her neighbours, for she loued her as dearly as any child that ener she bore of her owne body. O Margaret, (quoth she) what cause hadst thou thus to leaue me? if thou didst mislike of any thing, why didst thou not tell me? If thy wages were too little, I would haue mended it: If thy apparell had been too simple, thou shouldst haue had better: If thy worke had bin too great, I would haue had helpe for thee.

Farewell my sweet Meg, the best seruant that euer came in any mans house, many may I haue of thy name, but neuer any of thy nature, thy diligence is much, in thy hands I laid the whole gouernment of my house, and thereby eased myselfe of that care, which now will cumber me.

Heere shee hath left me my keyes vnto my chests, but my comfort is gone with her presence, euery gentle word that she was wont to speake, comes now into my mind, her courteous behauiour shall I neuer forget: with how sweet and modest a countenance would she qualifie my ouer-hastie nature? It repents my heart that euer I spoke foule word vnto her. O Meg, wert thou here againe, I would neuer chide thee more: but I was an vnworthy Dame for such a seruant: what will become of me now, if I should chance to be sicke, seeing she is gone, that was wont to be both my Apoticary and Physician?

Well, quoth her neighbours, there is no remedy now, but to rest content, you shall one day heare of her, doubt you not, and thinke this, that she was not so good, but you may get another as good, and therefore doe not take it so heauily. $\mathrm{O}$ neighbour, blame me not to grieue, seeing I haue lost so great a iewell, and sure I am perswaded, that scant in a bodies life time, they shall meet with the like.

I protest, I would circuit England round about on my bare feet to meet with her againe. $\mathrm{O}$, my $\mathrm{Meg}$ was surely stole away from me, else would she not haue gone in such sort. Her husband on the other side grieued as much, and rested not night nor day riding $\mathrm{vp}$ and downe to seeke her; but shee poore soule, is fast lockt $\mathrm{vp}$ in prison, and therfore cannot be met withall. 
But when the King vnderstood of his brothers escape, hee was maruelous wroth, giuing great charge and commandement when he was taken, that both his eyes should be put out and be kept in prison till his dying day; appointing also that the Maid should lose her life for presumption of louing him.

This matter being rumoured over all England, it came to the eares of Gray and his wife, who hearing that Margaret also was there in prison appointed to die, the good aged woman neuer rested till she came to the Court, where kneeling before the King with many teares she besought his Maiestie to spare the Maidens life, saying, Most royall King consider, I humbly beseech you, that the Duke your brother was able to entice any woman to his loue: much more a silly Maiden, especially promising her marriage, to make her a Lady, a Dutchesse, or a Queene, who would refuse such an offer, when at the instant they might get both a princely husband and a high dignity: if death be a Louers guerdon, then what is due to hatred? I am in my heart perswaded, that had my poore Margaret thought it would haue bred your Highnes displeasure, she would neuer haue bought his loue so dear. Had your Grace made it known to your Commons, that it was vnlawful for any to marry the Duke your brother, who would haue attempted such an action; if she had wilfully disobeyed your Graces commandement, she might haue been thought worthy of death; but seeing ignorantly she offended, I beseech your Grace to recall the sentence, and let me still enioy my seruant, for neuer will I rise, till your Maiestie haue granted my petition.

His Highnes, who was of nature mercifull, beholding the womans abundant teares, tooke pitie on her, and granted her suite : which being obtained, shee went home in all haste possible. And from thence, shee with her husband taking their iourney to Cardiffe castle, they came at that very instant when the Maiden was led toward her death, who went in most ioyfull sort to the same, saying, that they were not worthy to be accounted true louers, that were not willing to die for loue: and so with a smiling countenance she passed on, as if she had eaten 
Apium Risus, which causeth a man to die laughing: but her Dame Gray seeing her, fell about her necke, and with many kisses imbraced her, saying, Thou shalt not die my wench, but goe home with me; and for thy deliuery, behold here the Kings letters; and with that she deliuered them vp to the governour of the Castle: who reading them found these words written: Wee pardon the maids life, and grant her liberty, but let her not passe, till she see her louers eyes put out, which we will haue you doe in such sort that not onely the sight may perish, but the eye continue faire, for which cause I haue sent downe Doctor Piero, that he may execute the same.

The Gouernour of the Castle hauing read the Kings letter, said thus to the Maiden: The Kings Maiesty hath pardoned thy life, and allowed thy liberty: but you must not passe before you see your Louers eyes put out. O sir, said the Maiden, mistake not your selfe, they are my eyes that must be put out, and not the Dukes: as his offence grew by my meanes, so I being guilty, ought to receiue the punishment.

The Kings commandement must be fulfilled, said the Governour: and therewithall Duke Robert was brought forth, who hearing that he must lose his eyes, said thus: The Noble mind is neuer conquered by griefe, nor ouercome by mischance: but as the Hart reneweth his age by eating the Serpent, so doth a man lengthen his life with deuouring sorrow: my eyes haue offended the King, and they must be punished, my heart is in as great fault, why is not that killed?

The Kings Maiesty, said the Gouernour, spares your life of meere loue, and onely is content to satisfie the Law with the losse of your eyes, wherefore take in good part this punishment, and thinke you haue deserued greater then is granted.

With this Margaret cryed out, saying, O my deare Loue, most gentle Prince, well may you wish that I had neuer bin borne, who by seeing of mee must lose your sight; but happie should I count my selfe, if it so please the King, that I might redeeme thy eyes with my life: or else, that being an equall offender, I might receiue equall punishment: hadst thou sustained this 
smart for some Queene or Princesse of high blood, it might with the more ease be borne, but to indure it for such a one as I, it must needs cause a treble griefe to be increased.

Content thee faire Margaret, said the Duke: for honour ought to be giuen to vertue, and not riches: for Glory, Honor, Nobility, and riches without vertue, are but clokes of maliciousnes. And now let me take my leaue of thy beauty, for neuer must I behold thy face : notwithstanding I account my eyes well lost, in that, I doe forgoe them for so peereles a paragon. Now faire heauens farewell, the Sunne, Moone, and Starres shall I in this world neuer behold againe, and farewell also the fruitfull earth; well may I feele thee, but those poore windowes of my body are now denyed to view thee any more: and though the world hath euer bin my foe, yet will I bid thee farewell too, and farewell all my friends, whiles I live here in this world, I must suppose to sleepe, and wake when I come in heauen, where I hope to see you all againe. Yet had it pleased the King, I had rather haue lost my life then my eyes. Life, why, what is it but a flowre, a bubble in the water, a spanne long, and full of miserie : of such small account is life, that euery Soldier will sell it.for sixpence. And trust me, I doe now detest life, worse then a goat doth hate Basill.

With that the Doctor prepared his instrument, and being ready to set to the Dukes eyes, he said, O stay, Master Doctor, till I haue conueyed my Loues countenance downe into my heart: Come hither my sweet, and let me giue thee my last kisse, while mine eyes may direct me to thy cherry lips. Then imbracing her in his armes, he said, $O$ that $I$ might giue thee a kisse of $\mathrm{xx}$ yeeres long, and to satisfie my greedy eyes with thy sight: yet it doth somewhat content me, because thou art present at my punishment, that I may hold thee by the hand, to comfort my heart, at the sudden pricke of my eye.

This being said, the Doctor performed his duty, and so put out the christall sight: at what time $D$. Robert started vp and with a most manly courage said, I must thanke his Maiestie, that though hee depriueth me of my sight, yet he leaueth.me 
eyes to weepe for my sinnes. But so soon as Margaret beheld the deed, she fell downe in a swoone; and much a doe her dame had to recouer her life : which when the Duke vnderstood, hee was wondrous woe, groaping for her with his bleeding eyes, saying $\mathrm{O}$ where is my Loue? for Gods sake haue regard to her. And I pray you most heartily, good good-wife Gray, let her have this fauour for my sake, that she may be vsed kindly. And with that the Keepers led him into the Castle, and Margaret was carried away wondrous sicke and ill: but her dame was most tender ouer her; and would suffer her to lacke nothing. When she was somewhat well recouered, her Dame Gray set her on horsebacke: and at her comming to Glocester, there was no small ioy.

\section{CHAPTER XIV.}

How Thomas Doue being fallen to decay, was forsaken of his friends, and despised of his seruants: and how in the end he was raised againe through the liberality of the Clothiers.

$\mathrm{SucH}$ as seeke the pleasure of the world, follow a shadow wherein is no substance: and as the adder Aspis tickleth a man to death, so doth vaine pleasure flatter vs, till it makes vs forget God, and consume our substance, as by Tom Doue it is apparent, who had through a free heart, and a liberall minde wasted his wealth; and looke how his goods consumed, so his friends fled from him: And albeit he had beene of great ability, and thereby done good vnto many, yet no man regarded him in his pouerty, but casting a scornefull countenance vpon him, they passed by him with slender salutation: neither would any of his former acquaintance do him good, or pleasure him the value of a farthing; his former friendship done to them was quite forgot, and he made of as much account, as Iob when he sate on the dunghill.

Now, when his wicked seruants saw him in this disgrace with the world, they on the other side began to disdaine him. Notwithstanding that hee (to his great cost) had long time brought 
them vp, yet did they nothing regard it, but behind his backe in most scornefull sort derided him, and both in their words and actions greatly abuse him, reuerence they would doe none vnto him, but when they spake, it was in such malapert sort, as would grieue an honest minde to heare it.

At last it came to passe, that breaking out into meere contempt, they said they would stay no longer with him, and that it was a great discredit for them, to serue a person so beggerly: whereupon they thought it conuenient to seeke for their benefits elsewhere. When the distressed man found the matter so plaine being in great griefe, he spake thus vnto them: Now do I find, to my sorrow, the small trust that is in this false world. Why, my Masters (quoth he) have you so much forgotten my former prosperity, that you nothing regard my present necessity? In your wants I forsooke you not, in your sicknesse I left you not, nor. despised you in your great pouerty: it is not vnknowne, though you doe not consider it, that I tooke some of you vp in the high-way, othersome from your needy parents, and brought the rest from meere beggery to a house of bounty; where from paltrie boyes, I brought you vp to mans state, and haue, to my great cost, taught you a trade, whereby you may liue like men. And in requitall of all my courtesie, cost and good will, will you now on a sudden forsake me? Is this the best recompence that you can find your hearts to yeeld mee?

This is farre from the minds of honest seruants. The fierce Lion is kind to those that doe him good: plucke but one thorne out of his foot, and for the same he will shew manifold fauors. The wilde Bull will not ouerthrow his dam: and the very Dragons are dutifull to their nourishers. Bee better aduised and call to mind, I beseech you, that I have not pluckt a thorne out of your feet, but drawne your whole bodies out of perils, and when you had no meanes to helpe your selues, I onely was your support, and he, that when all other forsooke you, did comfort you in all your extremities.

And what of all this, quoth one of them? because you tooke vs vp poore, doth it therefore follow, that we must be your 
slaues? We are young men, and for our part, we are no further to regard your profit, then it may stand with our preferment: Why should we lose our benefit to pleasure you? if you taught vs our trade, and brought vs vp from boies to men, you had our seruice for it, whereby you made no small benefit, if you had as well vsed it as we got it. But if you be poore, you may thanke your selfe, being a iust scourge for your prodigalitie, and is my opinion plaine, that to stay with you, is the next way to make vs like you, neither able to helpe our selues, nor our friends: therefore in briefe; come pay me my wages, for I will not stay; let the rest doe as they will, for I am resolued.

Well said his Master, if needs thou wilt be gone, here is part of thy wages in hand, and the rest as soone as God sends it, thou shalt haue it: and with that, turning to the rest, he said, Let me yet intreat you to stay, and leaue me not altogether destitute of helpe: by your labours must I liue, and without you I know not what to doe. Consider therefore my need, and regard my great charge. And if for my sake you will doe nothing, take compassion of my poore children; stay my sliding foot, and let me not vtterly fall, through your flying from me.

Tush (quoth they) what do you talke to vs? We can haue better wages, and serue a man of credit, where our fare shall be farre better, and our gaines greater: therefore the world might count vs right coxcomes, if we should forsake our profit, to pleasure you : therefore adieu, God send you more money, for you are like to haue no more men: and thus they departed.

When they were gone, within a while after they met one with another, saying, What cheare? are you all come away: in faith I, what should we doe else, quoth they: but hear'st thou sirra, hast thou got thy wages? Not yet saith the other, but I shall haue it, and that is as good, tis but $x$ shillings. Saist thou so (said he) now I see thou art one of God Almighties idiots: Why so, said the other? Because (quoth he) thou wilt be fed with shales: but Ile tell thee one thing, twere better for thee quickly to arrest him, lest some other doing it before, and there be nothing left to pay thy debt: hold thy peace, faire words 
make fooles faine, and it is an old saying, One bird in hand is worth two in bush : if thou dost not arrest him presently, I will not giue thee two pence for thy $x$. shillings. How shall I come by him, quoth the other? giue me but two pots of ale, and Ile betray him, said he. So they being agreed, this smooth-faced Iudas comes to his late master, and told him that a friend of his at the doore would speake with him. The vnmistrusting man thinking no euill, went to the doore where presently an Officer arrested him at his mans suite.

The poore man seeing this, being strucken into a sudden sorrow, in the griefe of his heart spake to this effect : Ah thou lewd fellow, art thou the first man that seekes to augment my miserie? Haue I thus long giuen thee bread, to breed my ouerthrow? and nourisht thee in thy neede, to worke my destruction? Full little did I thinke, when thou so often diddest dip thy false fingers in my dish, that I gaue food to my chiefest foe : but what boote complaints in these extremes? Goe wife, quoth he, vnto my neighbours, and see if thou canst get any of them to be my baile. But in vaine was her paines spent. Then he sent to his kinsfolkes, and they denied him : to his brother, and he would not come at him, so that there was no shift, but to prison he must: but as he was going, a Messenger met him with a letter from Master Cole, wherein as you heard, hee had promised him two hundred pounds: which when the poore man read, hee greatly reioyced, and shewing the same to the Officer, hee was content to take his owne worde. Whereupon Tom Doue went presently to Reading, where at his comming, he found all the rest of the Clothiers, lamenting Coles vntimely death; where the wofull widdow paid him the money, by which deed all the rest of the Clothiers were induced to doe something for Doue. And thereupon one gaue him ten pounds, another twenty, another thirtie pounds, to begin the world anew: and by this meanes (together with the blessing of God) he grew into greater credit then euer hee was before. And riches being thus come vpon him, his former friends came fawning vnto him and when 
he had no neede of them, then euerie one was readie to proffer him kindnesse. His wicked seruants also that disdained him in his distresse, were after glad to come creeping vnto him, intreating with cap and knee for his fauour and friendship. And albeit hee seemed to forgiue their trespasses done against him, yet hee would often say, he would neuer trust them for a straw. And thus he euer after liued in great wealth and prosperitie, doing much good to the poore, and at his death, left to his children great lands.

\section{CHAPTER XV.}

How faire Margaret made her estate and high birth knowne to hes Master and Dame: and for the intire loue she bore to Duke Robert, made a vow neuer to marry, but became a Nun in the Abbey at Glocester.

AFTER faire Margaret was come againe to Glocester neuer did she behold the cleare day, but with a weeping eye: and so great was the sorrow which she conceiued, for the losse of Duke Robert her faithfull Louer, that she vtterly despised all the pleasures of this life, and at last bewrayed her selfe in this sort vnto her Dame:

O my good Master and Dame, too long haue I dissembled my parentage from you, whom the froward destinies doe pursue to deserued punishment. The wofull daughter am I of the vnhappy Earle of Shrewsburie, who euer since his banishment, haue done nothing but drawne mischance after mee: wherefore let me intreat you (dear Master and Dame) to haue your good wills, to spend the remnant of my life in some blessed Monasterie.

When Gray and his wife heard this, they wondred greatly, as well at her birth, as at her strange demaund. Whereupon her dame knew not how to call her, whether Maiden or Madam, but said, O good Lord, are you a Ladie, and I know it not? I am sorrie that I knew it not before. But when the folkes of the house heard that Margaret was a Lady, there was no small altera- 
tion: and moreouer her Dame said, that she had thought to haue had a match between her and her son: and by many perswasions did seeke to withdraw her from being a Nun, saying in this manner: What Margaret, thou art young and faire, the world (no doubt) hath better fortune for thee whereby thou maist leaue an honourable issue behind thee, in whom thou mayst liue after death.

These and many other reasons did they alledge vnto her, but all in vaine: she making this reply, Who knowes not that this world giueth the pleasure of an houre, but the sorrow of many daies? for it paieth euer that which it promiseth, which is nothing else but continuall trouble and vexation of the minde. Do you think, if I had the offer and choice of the mightiest Princes of Christendom, that I could match my selfe better then to my Lord Jesus? No, no, hee is my husband, to whom I yeeld my selfe both body and soule, giuing to him my heart, my loue and my most firme affections : I have ouerlong loued this vile world: therefore I beseech you farther disswade me not.

When her friends by no meanes could alter her opinion, the matter was made knowne to his Maiestie, who against the time that she should be receiued into the Monasterie, came to Glocester with most part of his Nobilitie, to honour her action with his princely presence.

All things being therefore prepared, the young Lady was in most princely-wise attired in a gowne of pure white sattin, her kirtle of the same, embroidered with gold about the skirts in most curious sort, her head was garnished with gold, pearles, and precious stones, hauing her hair like thrids of burnisht gold, hanging downe behind in manner of a princely bride : about her yuory necke iewels of inestimable price were hung, and her handwrests were compassed about with bracelets of brightshining Diamonds.

The streets thorow the which she should passe, were pleasantly deckt with greene oaken boughs. Then came the young Lady most like an heauenly Angell out of her masters house, at what time all the bells in Glocester were solemnly rung : she being led 
betwixt the Kings Maiestie, hauing on his Royal Robes, and Imperiall Crowne, and the chiefe Bishop wearing his Mitre, in a Cope of cloth of gold, ouer her head a Canopy of white silke, fringed about in princely manner : before her went an hundred Priests singing, and after her all the chiefe Ladies of the Land: then all the wiues and Maidens of Glocester followed, with an innumerable sort of people on euery side standing to behold her. In this sort she passed on to the Cathedrall Church, where she was brought to the Nunry gate.

The Lady Abbesse receiued her: where the beautiful Maiden kneeling downe, made her prayer in sight of all the people : then with her owne hands she vndid her virgins faire gowne, and tooke it off, and gaue it away to the poore: after that, her kirtle, then her iewels, bracelets and rings, saying, Farewell the pride and vanitie of this world. The ornaments of her head were the next shee gaue away: and then was shee led on one side, where she was stripped, and in stead of her smocke of soft silke had a smocke of rough haire put vpon her.

Then came one with a paire of sheares, and cut off her goldencoloured lockes, and with dust and ashes all bestrewed her head and face. Which being done, she was brought againe into the peoples sight bare foot and bare leg'd, to whom she said: Now farewell the world, farewell the pleasures of this life, farewell my Lord the King, and to the Dukes sweet loue farewell, now shall my eyes weepe for my former transgressions, and no more shall my tongue talke of vanity; farewell my good Master and Dame, and farewell all good people.

With which words she was taken away, and neuer after seene abroad. When Duke Robert heard thereof, he desired that at his death, his body might be buried in Glocester : in that Towne, quoth he, where first my cleare eyes beheld the heauenly beauty of my Loue, and where for my sake shee forsooke the world : which was performed accordingly.

The King also at his death requested to be buried at Reading, for the great loue hee bare to that place, among those Clothiers, who liuing were his hearts comfort. Gray dying wondrous 
wealthy, gaue land to the Monasterie whereinto Margaret was taken. William Fitzallen also dyed a most rich man, hauing builded many houses for the poore, whose sonne Henry after was the first Maior that was euer in London.

Sutton of Salisbury did also at his death much good, and gaue an hundred li. to be yeerely lent to poore weauers of the Towne, to the worlds end. Simon of South-hampton gaue a most bounteous gift towards the building of a Monastery at Winchester. Hodgkins of Hallifax did also great good, and so did Cutbert of Kendall, who had married xxiii. couples out of his owne house, giuing each of them $x$. li. to beginne the world withall. Martin Briam of Manchester gaue toward the building of a free-schoole in Manchester, a great masse of money. And thus (gentle reader) haue I finished my storie of these worthy men, desiring thee to take my paines in good part, which will ingage me to greater matters, perceiuing this curteously accepted. 

THE NOBLE PARENTAGE AND THE ATCHIEVEMENTS OF ROBIN HOOD. 



\section{IX.}

\section{THE NOBLE PARENTAGE AND \\ THE ATCHIEVEMENTS OF ROBIN HOOD.}

RoBin Hood was descended of the noble family of the Earl of Huntingdon, and being outlaw'd by Henry the Eight for many extravagances and outrages he had committed, he did draw together a company of such bold and licentious persons as himself, who lived for the most part on robberies committed in or neer unto Sherwood Forest in Nottinghamshire. $\mathrm{He}$ had these always ready at his command, so that if need did require, he at the winding of his horn would have fifty or more of them in a readiness to assist him. He whom he most affected, by reason of his low stature, was called Little. John, but not inferior to any of them in strength of body and stoutness of spirits. He would not entertain any into his service, whom he had not first fought withal himself, and made sufficient tryal of his courage and dexterity how to use his weapons, which was the reason that oftentimes he came home so hurt, and beaten as he was ; which was nevertheless no occasion of the dimanution of his love to the person whom he fought with, for ever afterwards he would be the more familiar with him, and better respect him for it. Many petitions were preferred to the king for a pardon for him, which the king (understanding of the many mad pranks he and his associates played) would give no ear unto; but being attended with a considerable guard, did make a progress himself to find him out, and to bring 
him to condign punishment. At the last, by the means and mediation of Queen Katherine, the king's wrath was qualified, and his pardon sealed, and he spent his old age in peace, at a house of his own, not far from Nottingham, being generally beloved and respected of all. We shall here give you an account of the several combats that he fought and the many odd and merry pranks he played, the one whereof by the strangeness of it, will add more respect unto his story; and the other by their variety, will abundantly serve to give more delight unto the Reader.

\section{ROBIN HOOD'S DELIGHTS}

Or, a gallant combate fought between Robin Hood, Little John, and William Scarlock, and three of the keepers of the King's deer in the forrest of Sherwood in Nottinghamshire.

ON a Midsummers day in the morning, Robin Hood being accompanied with Little John and Will Scarlock, did walk forth betimes, and wished that in the way they might meet with some adventure that might be worthy of their valour: they had not walked long by the forrest side, but behold three of the keepers of the Kings game appeared, with their forrest-bills in their hands, and well appointed with faucheons and bucklers to defend themselves. Loe here (saith Robin Hood) according to our wish, we have met with our mates, and before we part from them we will try what mettle they are made off. What Robin Hood, said one of the Keepers: I the same, reply'd Robin. Then have at you, said the keepers: here are three of us, and three of you, we will single out ourselves one to one; and bold Robin, I for my part, am resolved to have a bout with thee. Content, with all my heart, said Robin Hood, and fortune shall determine who shall have the best, the outlaws or the keepers: with that they did lay down their coats, which were all of Lincoln Green, and fell to it for the space of two hours with their brown bills, in which hot exercise Robin Hood, 
Little John and Scarlock had the better, and giving the rangers leave to breath, demanded of them, how they liked them : why! good stout blades i' faith, saith the keeper that fought with Robin, we commend you, but let us make tryal whether you are as good at your sword and bucklers as you have been at your "quarter-staff. Why, do you doubt of it, said Robin Hood? we shall satisfie you in that immediately. With that having llaid down their staves and thrown off their doublets, they fell to it pell mell : and dealt their blows unmercifully sore, which were carefully always defended with their bucklers. At the last Robin Hood observing Little John and Will Scarlock begin to give ground, which they never did in all their lives before, he dissembled the danger, and calling out for a little respite to breath, he said unto the keepers, Good boys, i' faith, and the best that ever I dealt withal: let me know your names, and for the time to come, I shall give that respect unto you that belongs unto your valour. Tush, said one of the keepers, we lose time in asking after our names, if thou wilt have any more to do with our hands, or with our swords, we are for thee? I see that you are stout men, said Robin Hood, we will fight no more in this place, but come and go with me to Nottingham (I have silver and gold enough about $\mathrm{me}$ ) and there we will fight it out at the King's Head tavern with good sack and claret; and after we are weary, we will lay down our arms, and become sworn brothers to one another, for I love those men that will stand to it, and scorn to turn their backs for the proudest Tarmagant of them all. With all our hearts, jolly Robin, said the keepers to him: So putting up their swords, and on their doublets, they went to Nottingham, where for three days space they followed the pipes of sack, and butts of claret without intermission, and drank themselves good friends. 


\section{ROBIN HOOD'S PROGRESS TO NOTTINGHAM.}

How being affronted with fifteen foresters as he was going to a match at shooting with his long bow before the king, he killed the said fifteen foresters.

The name of Robin Hood did now begin to grow famous up and down the country; those who had occasion to go from one market to another, were either afraid of him, and did forbear to go those ways where his haunts were, or else they were in fee with him, and every quarter did give him money, that with their goods and cattle they might pass by unmolested. This he conceived to be a secure and thriving way to fill his pockets, wherefore he contracted with all the graziers and rich farmers thereabouts, who had rather to give him every quarter a certain sum of money, then to be liable to those thefts and dangers both by day and night, which before did too much afflict them. Robin Hood in the mean time living high, and being out of any fear of hue and crys, or constables warrants, would repair oftentimes to the town of Nottingham, where he would constantly make himself full merry at the Kings Head, and no guest was more respected than himself. It so fell out, that the king lying at that time at a great earls house not far from Nottingham, the townsmen, and some other of the adjacent countrey, did intend to delight his majesty with the honest exercise and recreation of archery. Thither was going many of the rangers of Sherwood Forrest, and thither was going Robin Hood himself, but so disguised, that it was not easie for any one to know him. The forresters meeting of him, demanded of him whether he was going, he told them to the shooting match, to which purpose he had taken his bow of ewe along with him. Thou shoot, said one of the forresters, thou _ _ alas young boy, thou art not able to bend a bow of ewe, much less to draw it being bent, thou shoot before the king. I will hold you twenty mark, said Robin Hood, that I will shoot a good buck one hundred rod off and kill him dead 
in the place. A hundred mark on that (said the forresters.) Down with your dust, said Robin, and having told down the money, with which he did go always provided, he bended his bow, and having drawn a broad arrow up to the head of it, he did let it flye at a fat buck one hundred rod off and more; the arrow entring in between the ribs of the buck, made him give a jump from the ground, and fell down dead on the place, which Robin espying, the wager (said he,) is mine, if it were for a thousand pound. It is none of thine, said the forresters, and began to threaten him with violence, if he did not let the money alone, and get him suddenly gone. Robin Hood smiling with indignation, I will go (saith he,) but you shall stay till you are carried off the place on which you 'stand every mother's son of you. With that he did let flye at one of the forresters, and then at another, and at another, and left not shooting his well-levelled arrows, until that fourteen of the fifteen forresters lay dead on the plain, close unto the buck; the fifteenth was making away with all the speed he could, but Robin sent a forked arrow after him, which entring quite through his back and body, came out of his breast. Now to your costs, said Robin Hood, you have found me to be an archer; and taking up the money with him, he withdrew into the forrest to avoid all farther danger that might ensue and the spilling of more blood. In the mean time the townsmen of Nottingham hearing that Robin Hood was abroad, and that many of the forresters were slain, did go forth in great numbers, hoping that Robin Hood was either slain, or so hurt, that they might now take him, and bring him to the king, but he having sent some of his stinging arrows amongst them, they found to their costs by bleeding experience, that he was safe enough from being hurt or endangered: Wherefore having taken up the fifteen forresters that he had slain, they brought them into Nottingham town, where so many graves being digged in the church-yard, they were all buried by one another, and in death, as well as life, kept company together. 


\section{ROBIN HOOD AND THE TANNER}

\section{OR, ROBIN HOOD MET WITH HIS MATCH.}

Relating the great and fierce combat between Arthur Bland a Tanner of Nottingham, and Robin Hood the great Archer of England.

AFTER this so sad an execution of so many of the forresters, there was not any one so hardy as to question bold Robin concerning any feats of archery, and to speak the truth, he did of himself forbear for the space of many years to come unto the merry town of Nottingham, in regard that his slaughter of so many forresters at once had made him terrible and odious to the inhabitants thereabouts, but especially to the said forresters wives, who did curse him most extreamly. In process of time, as he was walking one summers morning in the forest of Sherwood, he observed a man strong of body and stern of aspect to come up unto him to give him an affront; whereupon he commanded him to stand, and told him he believed he was some bold fellow that came to steal the kings dear, and he being one of the keepers, he must discharge his trust and secure his person. The other, who was a tanner in the town of Nottingham, having. a long staff on his shoulder, and knowing as well how to use it, as any he whatsoever, told him plainly that they must be more than two or three that must make him stand, and that he cared not a straw for his sword, or for his bow, or for his quiver of forked headed arrows, for he believed if he were well put to it, he could as soon - as shoot. Robin Hood being nothing discouraged, desired him to speak cleanly, and give him better terms, or else he would thrash him into better manners. Thrash me (said Bland,) marry gap with a winion! art thou such a goodly man, I care not a fig for thee. Why then thou shalt care for me, said Robin Hood, and unbuckling his belt, and laying down his bow and his arrows, he took up a staff of groundash, and would have Bland to measure the length of his staff 
with his, because he would have no foul play in the tryal of his manhood. But Bland replyed, I pass not for length, my staff is of good oak, and eight foot and a half in length, although shorter than thine, thou shalt find it long enough to reach thy coxcomb. At these words Robin Hood could no longer refrain, but making two or three fine flourishes over his head, he gave him such a remembrance on the top of his crown, that the blood trickled down upon his shoulders. But Arthur Bland did soon recover himself, and bidding Robin Hood look to himself, for he would be even with him, he came up with hand and foot: Robin Hood believing that he would be upon him with the fore-end of his staff, Bland suddenly drew back, and being very nimble at it, he gave Robin Hood so rude a visitation on the right side of his head with the other end of his staffe, that he not only stun'd him, but withal did break his head so pittifully, that the blood ran down amain. Robin Hood being not often used to behold such a sight, did lay at Bland with all the strength and art he had; and Bland was no ways wanting to defend himself, and to return blow for blow. Two hours together they were in this hot exercise, and about, and about they traversed their ground, till the wood and their sides rang with the blows which they did give to one another. At the last Robin Hood desired him to hold his hand, and let the quarrel fall, for he found (he said) nothing was to be gotten on either side but dry blows: he moreover assured him, that for the time to come he should be free of the forrest. God a mercy for nothing, (said Arthur Bland), I have not bought that freedom of thee, I may thank my good staff for it, and the hand that governed it. Hereupon Robin Hood demanded of him, of what trade he was, and where he dwelt? to whom Bland made answer, I am a tanner, and have wrought long in Nottingham, and if thou ever comest thither, I do swear unto thee that I will tan thy hide for nought. Wilt thou so, said Robin, and I will do as much for thee : but if thou wilt forsake the tanners trade, and live here in the forrest with me, I dare assure thee thou shalt have store of gold and silver and want for nothing. Arthur Bland conceiving 
who it was, did say unto him; If thou art Robin Hood, as by thy manhood I believe thou art, here is my hand, that if thou wilt never part with me, I will never part with thee: but where is Little John? I would fain see him, for he is near of kin to me by my mother's side. Robin Hood no sooner heard him say so, but he blew his horn, and presently afterwards they might discover Little John coming down the hill, who observing his master to stand with his staff in his hand, asked him, What the matter was? he told him that he had met with the tanner of Nottingham, who had tanned his hide to some tune: Marry, and that is well done, said Little John, I will see if he can tan my hide also: Friend, look to yourself, have at you. Thereupon Robin Hood cryed out, Hold thy hand, hold thy hand, he is thy friend and kinsman, his name is Arthur a Bland. My cousin Arthur, said Little John, how glad am I to see you, my good cousin, and throwing down his staff, he did run unto him, and did imbrace him in the closest arms of love. After that Robin Hood took them both by the hand, and dancing about an old oak tree, with a song in their mouths, and mirth in their hearts, they expressed all the signs of undissembled affection to one another.

\section{ROBIN HOOD AND THE BUTCHER.}

How Robin Hood bought of the butcher his mare, and the meat with which he was laden, and how he circumvented the sherriff of Nottingham, and deluded him of three hundred pounds.

Nor long afterwards Robin Hood walking in the forrest as it was his daily custome, observed a butcher riding along the way, having good store of meat on his mares back, which he was to sell in the market. Good morrow good fellow, said Robin to the butcher: Good fellow, replied the butcher, heavens keep me from Robin Good fellow, for if I meet with him, I may chance to fall short of my journey, and my meat of the market. I like 
thy company well, what hast thou to sell? said Robin Hood. Flesh, master, said the butcher, with which I am going to Nottingham-market. What is the price of thy flesh, said Robin Hood, and of thy mare that bears it? tell me, for if thou wilt use me well, I will buy both. Four mark, said the butcher, I cannot bate anything of it. Sit down then and tell thy money, said Robin Hood, I will try for once if I can thrive by being a butcher. The money being told, Robin Hood gets up on the mare, and away he rides with the meat to Nottingham market, where he made such good penniworths, that he had sold all his meat by ten of the clock in the morn; He sold more meat for one penny than others could do for five. The butchers in the market, that had their stands by him, said one to another: Certainly this man's meat is nought and putrified, or else he hath stolen it. From whence comes he? saith another, I never did see him before: That will I tell you by and by, said a third butcher, and stepping to Robin Hood, said unto him, brother, thou art the freest butcher that ever came to this market, we be all of one trade, come let us dine together. Accurst be he that will deny a butcher so fair an invitation, said Robin Hood, and going with him to the inn, the table was suddenly covered and furnished, and the best man in the company being to say grace, Robin Hood at the upper end of the table did put off his bonnet: God bless us all (said he) and our meat upon this place, a cup of sack is good to nourish the blood, and so I end my grace. Robin Hood was no sooner sat, but he called for a cup of sack, and drank to them all, desiring them to be merry, for if there were five pounds to pay, he would pay it every farthing. Thou art the bravest blade, said the butchers, that ever came to Nottingham market. Robin Hood still called for more wine, and the cups trouled up and down the table, insomuch that the sheriff, who was newly alighted, and taken his chamber in the inn, understanding of it, said, $\mathrm{He}$ was some prodigal that had sold his land, and would now spend it all at once: which coming to Robin Hood's ear, he after dinner took the opportunity to speak unto him: And what, said the sheriff, Good 
fellow, thou hast made a good market to day, hast thou any more horned beasts to sell? Yes, that I have, said Robin Hood to master sheriff, I have two or three hundred, and a hundred acres of good land to keep them on, as ever the crow flew over, which if you will buy of me, I will make you as good assurance of it, as ever my father made me. The sherriff being a covetous man, and persuading himself that he would make him Robin Hood's penniworths, commanded his horse to be brought forth, and taking some money with him for the purchase, he rode with Robin Hood, who led him into the forrest for a mile or two outright. The sherriff being laden with good store of gold, and surprized with the melancholy of the place, did wish himself at Nottingham again : and why so? said Robin Hood: I tell thee plainly said the sheriff, I do not like thy company. No, said Robin Hood, then I will provide you better. God keep me from Robin Hood, for this is the haunt he useth. Robin Hood smiling observed a herd of three hundred gallant deer, feeding in the forrest close by him, and demanded of the sherriff how he liked those horned beasts, assuring him that they were the best that he could shew him : with that he blew his horn, whereupon Little John with fifty more of his associates came presently in, to whom Robin Hood imparted that he had brought with him the sherriff of Nottingham to dine with him. He is welcome, said Little John, I know he hath store of gold, and will honestly pay for his dinner. I, I, said Robin Hood never doubt it : and taking off the sherriffs portmantle, he took to himself the three hundred pounds that was in it, then leading him back through the forrest, he desired him to remember him kindly to his wife, and so went laughing away. 


\section{ROBIN HOOD AND THE BEGGAR.}

Showing how he fought with the beggar, and changed cloaths with him: and how going afterwards a begging to Nottingham, he saved three brothers who were all condemned for stealing the kings deer.

But Robin Hood took not any long delight in the mare which he bought of the butcher, but having now supplyed himself with good store of money which he had gotten by the sheriff of Nottingham, he bought him a stout gelding, and riding one day on him towards Nottingham, it was his fortune to meet with a poor beggar. Robin Hood was of a frolick spirit, and no accepter of persons, but observing the beggar to have several sorts of bags, which were fastened to his patched coat, he did ride up to him, and giving him the time of the day, he demanded of him what countryman he was? a Yorkshire-man, said the beggar, and I would desire of you to give me something: Give, thee, said Robin Hood: why I have nothing to give thee, I am a poor ranger in the forrest, and thou seemest to be a lusty knave, shall I give thee a good bastinado over the shoulder? Content, content, said the beggar, I durst lay my coat and all my bags to a threaden point thou wilt repent it: with that Robin Hood alighted, and the beggar and he fell to it, he with his sword and buckler, and the beggar with his long quarter-staff, who so well defended himself, that let Robin Hood do what he could, he could not come within the beggar, to flash him to a remembrance of his over-boldness; and nothing vexed him more, then to find that the beggar's staff was as hard and as obdurate as iron it self, but so was not Robin Hood's head, for the beggar with all his force did let his staff descend with such a side blow, that Robin Hood for all his skill could not defend it, but the blood came trickling down his face, which turning Robin Hood's courage into revenge and fury, he let flye at him with his trusty sword, and doubled blow on blow, but perceiving that the beggar did hold him so hard to it, that one of his blows was but the 
fore-runner of another, and every blow to be almost the Postillion of Death, he cryed out to him to hold his hand; That will I not do, said the beggar, unless thou wilt resign unto me thy horse, and thy sword, and thy cloaths, with all the money thou hast in thy pockets : The change is uneven, said Robin Hood, but for once I am content : So putting on the beggars cloaths, the beggar was the gentleman, and Robin Hood the beggar, who entering into Nottingham-town with his patched coat and several wallets, understood that three brethren were that day to suffer at the gallows, being condemned for killing the kings deer, he made no more ado but went directly to the sherriffs house, where a young gentleman seeing him to stand at the door, demanded of him what he would have? Robin Hood returned answer that he came to crave neither meat nor drink, but the lives of those three brothers who were condemned to dye. That cannot be, said the young gentleman, for they are all this day to suffer according to law, for stealing of the kings deer, and they are already conveyed out of town, to the place of execution. I will be there with them presently, said Robin Hood, and coming to the gallows, he found many making great lamentation for them: Robin Hood did comfort them, and assured them they should not dye, and blowing his horn, behold on a sudden a hundred brave archers came unto him, by whose help having released the prisoners, and killed the hangman, and hurt many of the sherriffs officers, they took those who were condemned to dye for killing the king's deer along with them, who being very thankful for the preservation of their lives, became afterwards of the yeomandry of Robin Hood.

\section{ROBIN HOOD REVIVED;}

OR, HIS GALLANT COMBAT WITH A VALIANT YOUNG GENTLEMAN, WHO PROVED AFTERWARDS TO BE HIS KINSMAN.

EvEry day almost did answer the expectation of Robin Hood, for every day did administer him one new adventure or another: 
he now did wish he had continued his butchers trade a little longer, for provisions grew scarce, and he had not therewith to maintain his retinue or himself: riding therefore forth to see what good fortune he could be master of, he met with a young gentleman that had shot a buck; Robin Hood was not far off when it was done, and commended him for his archery, and offered him a place in his service, to be one of his yeomen which the young gentleman disdaining, told him if he would not be gone, he would kick him out of that place : Robin Hood being unused to such affronts, assured him that he had men enough to take his part if he would but blow his horn. Sound it, and thou darest, said the gentleman, I can draw out a good sword that shall cut thy throat and thy horn too: these rough words made Robin Hood so impatient, that he did bend his bow, which the gentleman observing, said unto him, I am as ready for that as you, but then one, if not both of us shall be surely slain, it were far better to try it out with our swords and bucklers : content, said Robin Hood, we can no where find a more fitting place than under the shaddow of this oak. They drew out their swords, and to it they went: Robin Hood gave the young gentleman a cut on the right elbow, and a little prick on his left shoulder, which the gentleman returned with advantage, insomuch that both of them taking respite to breath a little, Robin Hood demanded of him if he had never seen nor heard of him before; I know not who you are said the gentleman, but my name is Gamwel, I was born in Maxfield, and for killing of my fathers steward, I am forced hither to seek out my uncle, known to most men by the name of Robin Hood: why, I am the man, said Robin Hood, and throwing down his sword and buckler he made haste to embrace him whom before he had so rashly wounded. Great was the love and many the reciprocal indearments that were betwixt them, when in the instant there stepped in Little John to whom Robin Hood having communicated what had passed, he gave his kinsman a place next to Little John, Little.John being always next to himself. Not long afterwards he travelled into the north, where a bonny Scot 
offering him his service, he refused to entertain him, alledging that he was never true either to father or kinsman, much less would he prove true to him. At that time the battel grew hot betwixt the Scots and the English, and Robin Hood turning to the English, fight on, said he, my merry men all, our cause is good, we shall not be beaten, and though I am compassed about, with my sword I will cut my way through the midst of my enemies.

\section{ROBIN HOOD AND THE BISHOP.}

Shewing how he changed cloaths with an old woman to escape from the Bishop, and afterwards how he robbed the Bishop of all his gold, and made him sing mass, \&oc.

ROBIN HooD being returned with renown into Nottinghamshire, did walk forth one morning on foot, to see how affairs stood in the world, he had not gone far, but he beheld a bishop riding towards London, and attended with one hundred followers. He perceived that the bishop had notice of him, and being alone, and not knowing how to avoid him, he did steal into an old woman's house, and making his complaint unto her, the old woman asked him who he was, to whom he revealed that he was the famous out-law, commonly called by the name of Robin Hood: if thy name be so, said the old woman I will do the best $I$ can to provide for thee, for $I$ do well remember it is not long since I received some courtesies from thee: the best way that I can advise thee to conceal thyself, is to put on my cloaths, and I will put on thine; with all my heart, said Robin Hood: so putting on her gray coat, he gave her his green one, with his doublet and breeches, and his bow and those few arrows he had. This was no sooner done, but the bishop's men, with their swords drawn entered into the house, did take the old woman, believing she had been Robin Hood, and did set her on a milkwhite steed, and following himself on a dapple gray, being overjoyed at the great purchase he had made. It the mean time Robin Hood being arrayed in the old womans cloaths, with a 
rock and a spindle in his hand, did address himself straight, away unto his company, and Little John beholding him coming over the green, cryed out, $\mathrm{O}$ ! who is she that yonder is coming towards us, and looketh so like a witch, I will shoot her dead, and being dead will nail her to the earth with one of my broad arrows : O hold thy hand, said Robin Hood, I am thy master, and coming nearer he told them what had befallen at the old womans house, and to confirm what he said, they beheld the bishop with a gallant train riding up that way. The bishop espying a hundred brave bowmen standing under a tree, in the way where he was to pass, demanded of his prisoner who they were? Marry, replied the old woman, I think it is Robin Hood with his company: why who art thou then? said the bishop: why I am an old woman, said his prisoner, thou proud blind bishop, and if thou wilt not believe me, lift up my leg and see. Then woe is me said the bishop. He had scarce bemoaned himself, but Robin Hood called to him, and bid him stay, and taking hold of his horse, he tied the bishop fast to the tree, and seizing on his sumpter-horse, he took out of his portmantle five hundred pound: which being done, Robin Hood smiling on Little John, and all his company laughing at one another Robin Hood bid Little John give him his horse and let him go: by no means said the company, for he shall sing us a mass before we let him loose: which being done to the bishops great grief and shame, they set him on his horse again, with his face towards the tail, and bidding him to pray for Robin Hood, they suffered him to go forward on his journey.

\section{RENOWNED ROBIN HOOD;}

OR, HIS FAMOUS ARCHERY BEFORE QUEEN KATHERINE, FOR WHICH AT THAT TIME HIS PARDON, AND HIS FELLOWS, WAS OBTAINED BY THE QUEEN.

ROBIN HOOD having on all hands supplyed himself with good store of gold, he sent thereof a considerable present to Queen 
Katherine, with a petition to mediate to his majesty for a pardon for himself and his associates. The queen accepted of both, and sent one of her pages, Richard Patrington by name, to advise him to come to accomplish his request; great was the hast that Patrington made, being well mounted, he despatched within the compass of two days, and less, so long a journey. Being come to Nottingham he found that friendship, that on the next morning he was brought to Robin Hood's place; where acquainting him with his message from the queen, he assured her by him, that he would not fail to wait upon her majesty, and withal sent a small present of his duty and observance. Immediately he cloathed the chiefest of his men in Lincoln green, with black hats and white feathers, all alike, and himself in scarlet, and thus attended he came to London to the queen, who said unto him, welcome Locksly, the king is now gone into Finsbury Field, to be present at a great game* of shooting with the long-bow, and you come very seasonably unto it, do you go before, I will presently be there myself : when Robin Hood was come into Finsbury-fields, the king spake unto Tephus his bowbearer, and bad him to measure out the line, to know how long the mark should be: and the queen not long afterwards being sat next unto him, the king asked of her, for what wager they should shoot? the queen made answer, the wager is three hundred tun of Rhenish wine, and three hundred tun of beer, and three hundred of the fattest bucks that run on DallumPlains. Beshrew me, said the king, it is a princely wager indeed; well, mark out the ground; this immediately was done, and it was in length full fifteen score; Clifton a famous archer about the town, boasted that he would hit the clout every time. And now the kings archers had shot three goles, and were three for none; but the queen nothing discouraged, desired to know if any would be on her side, and Sir Richard Lee, who was descended of the noble family of the Gowers, standing close unto her, she encouraged him to lay one wager; but he being unwilling to make so desperate adventure, she spake to the Bishop of Hereford, who told her bluntly, that he would not bet one 
penny on her side. For said he, those that shoot on the kings side are excellent and experienced archers, and those that you have made choice of, we know not what they are, nor from whence they come; I durst wager said the bishop, all that I have about me against them. What is that? said Robin Hood. Fifteen score nobles, said the bishop, and that is almost one hundred pounds : 'Tis right, said Robin Hood, I will lay with you, and taking his bag of money from his side, he threw it down upon the green : William Scharlock being present, said, $\mathbf{I}$ will venture my life that $I$ know beforehand who shall win this wager.

Now the archers did begin to shoot again, and now those whom the queen made choice of were equal with those of the kings side, they were both three and three. Whereupon the king spake aloud to the queen and said, the next three must pay for all. Robin Hood in the first place shot, and with such dexterity of art, that his arrow entered into the clout, and almost touched the black: he on the kings side that did second him, did shoot well, and came very near unto the clout: then shot Little John, and hit the black, at which the ladies laught aloud, being now almost sure that the game would go on their side, which Midge the millers son confirmed; for I know not at that time whether I may most commend, his art or his fortune, but so it was that he cleft the very pin in the middle of the black, and that with such a twang of his bow, that it seemed that that did proclaim the victory before the arrow came unto the mark.

The queen having thus wan the wager, she fell down on her knees before the king, and besought his majesty that he would not be angry with any there present who were on her side; this the king (the day being designed to mirth) did condescend unto, although he did not well understand what she did mean by that petition. This being granted, the queen said aloud, then welcome Robin Hood, and welcome Little John, welcome Midge the millers son, and welcome every one of Robin Hood's company that is now in the field. Is this Robin Hood? said the king, I thought he had been slain at the pallace-gate in the North. The Bishop of Hereford turning to the king, said unto him, may it 
pleasure your majesty, this bold outlaw Robin Hood, on Saturday was three weeks, took from me five hundred pound in gold, and bound me fast to a tree, and afterwards made me sing a mass, and to those of his most unruly company that were with him. What if I did, said Robin Hood, I was full glad of it, for I had not heard mass before in many a year ; and for recompense of it, behold sir bishop here is half your gold. No, no, said little John, that must not be, for master before we go, we are to give gifts to the king and queens officers, and the bishops gold will serve for all.

The famous battel betwixt Robin Hood and the Curtal Fryer, and how the Fryer let Robin Hood fall into the water.

RoBin HooD, being now grown most famous for his skill in archery, and being high in the favour of queen Katherine, did return with much honour into Nottinghamshire, whither being come, he instituted a day of mirth for himself and all his companions ; and wagers were laid amongst them, who should exceed at this exercise, and who at that; some did contend who should jump farthest, some who should throw the bar, some who should be swiftest a-foot in a race five miles in length, others there were with which Little John was most delighted, who did strive which of them should draw the strongest bow, and be the best marksman : Let me see, said Little John, which of you can kill a buck, and who can kill a doe, and who is he can kill a hart, being distance from it by the space of five hundred foot. With that Robin Hood going before them, they went directly to the forrest, where they found good store of game feeding before them. William Scarlock that drew the strongest bow of them all, did kill a buck, and Little John made choice of a barren fat doe, and the well directed arrow did enter into the very heart of it : and Midge the millers son did kill a hart above five hundred foot distant from him. The hart falling, Robin Hood stroke him gently on his shoulder, and said unto him, God's blessing on thy heart, I will ride five hundred miles to find a match for thee. William Scarlock hearing him speak those words smiled, and said 
unto him, master, what needs that? here is a Curtal Fryer not far off, that for a hundred pound will shoot at what distance yourself will propound, either with Midge, or with yourself. An experienced man he is, and will draw a bow with great strength, he will shoot with yourself and with all the men you have, one after another. Sayest thou so, Scarlock, replyed Robin Hood, by the grace of God, I will neither eat nor drink till I see this Fryer thou dost speak of. And having prepared himself for his journey, he took Little John and fifty of his best archers with him, whom he bestowed in a convenient place, as he himself thought fitting. This being done, he run down into the dale, where he found the Curtal Fryer walking by the water side. $\mathrm{He}$ no sooner espyed him, but presently he took unto him his broad sword and buckler, and put on his head a steel bonnet. The Fryer not knowing who he was, or for what intent he came, did presently arm himself to encounter with him. Robin Hood, coming neer unto him, alighted from his horse, which he tyed to a thorn that grew hard by, and looking wistly on the Fryer, said unto him, carry me over the water thou Curtal Fryer, or else thy life lyes at the stake. The Frier made no more ado, but took up Robin Hood, and.carried him on his back (the story saith) deep water he did stride, he spake not so much as one word to him, but having carried him over, he gently laid him down on the side of the bank: which being done the Fryer said to. Robin Hood. It is now my turn: therefore carry me over the water thou bold fellow, or be sure I shall make thee to repent. it. Robin Hood to requite the courtesie, took the Fryer on his back, and not speaking the least word to him, carried him over the water and laid him gently down on the side of the bank; and turning to him, he spake thus unto him as at first, and bade him carry him over the water once more, or he should answer it, with the forfeit of his life. The Fryer in a smiling murmur took him up, and spake not a word till he came in the midst of the stream, where being up to the middle and higher, he did shake him from off his shoulders, and said unto him. Now chuse thee, bold fellow, whether thou wilt sink or swim. Robin Hood being 
soundly washed, gat up on his feet, and prostrating himself on the water, did swim to a bush of broom on the other side of the bank; the Fryer swimed to a willow tree, which was not far from it; Robin Hood taking his bow in his hand, and one of his best arrows, did shoot at the Fryer, which the Fryer received in his buckler of steel, and said unto him, shoot on, shoot on thou bould fellow, if thou shootest at me a whole summers day. I will stand thy mark still. That will I try said Robin Hood, and shot arrow after arrow at him, until he had not one arrow left in his quiver. He then laid down his bow, and drew out his sword, which but two days before had been the death of three men. Now hand to hand they meet with sword and buckler; the steel buckler defends whatsoever blow is given : sometimes they make at the head, sometimes at the foot, sometimes at the side, sometimes they strike directly down, sometimes they falsifie their blows, and come in foot and arm with a full thrust at the body; and being ashamed that so long they exercised their unprofitable valour, and cannot hurt one another, they multiply their blows, they hack, they hewe, they slash, they fome. At last Robin Hood desired the Fryer to hold his hand, and to give him leave to blow his horn: Thou wantest breath to sound it, said the Fryer, take thee a little respite, for we have been five hours at it by Fountain Abby clock. Robin Hood took his horn from his side, and having sounded it three times, behold where fifty lusty men, with their bended bows, came to his assistance. The Fryer wondring at it: Whose men, said he, be these? They are mine, said Robin Hood, what is that to thee? False loon, said the Fryer, and making a little pause he desired Robin Hood to return him the same courtesie which he gave him. What is that? said Robin Hood; thou soundest thy horn, said the Fryer, three times, let me now but whistle three times. I with all my heart, said Robin Hood, I were to blame if I should deny thee that courtesie. With that the Fryer set his fist to his mouth, and whistled three times so shrilly, that the place echoed again with it, and behold three and fifty fair ban-dogs (their hairs rising on their back, betokening their rage) were 
almost on the backs of Robin Hood and his companions. Here is for every one of thy men a dog, said the Fryer, and two for thee: That is foul play, said Robin Hood. He had scarce spoken that word, but two dogs came upon him at once, one before, another behind him, who although they could not touch his flesh, (his sword had made so swift a despatch of them) yet they tore his coat in two pieces. By this time his men had so laid about them, that the dogs began to flye back, and their fury to languish into barking. Little John did so bestir himself, that the Curtal Fryer admiring at his courage and his nimbleness, did ask him who he was : He made him answer, I will tell the truth and not lye; I am he who is called Little John, and do belong to Robin Hood, who hath fought with thee this day, five hours together, and if thou wilt not submit unto him this arrow shall make thee. The Fryer perceiving how much he was overpowered, and that it was impossible for him to deal with so many at once, did come to composition with Robin Hood: The articles of agreement were these; That the Fryer should abandon Fountain Dale, and Fountain Abby, and live with Robin Hood at his place not far from Nottingham, where for saying of mass, he should receive a noble for every Sunday throughout the year, and for saying of mass on every Holyday, a new change of garment. The Fryer contented with these conditions, did seal to the agreement. And thus by the courage of Robin Hood and his yeomen he was inforced at the last to submit, having for seven long years kept Fountain Dale, not all the power thereabouts being able to bring him on his knees.

\section{THE NOBLE FISHER-MAN, OR, ROBIN HOOD'S PREFERMENT.}

Shewing how he did win a prize at sea, and how he gave one half of it to his dame, and the other to charitable uses.

THE countreys and the cities being full of the exploits of Robin Hood and his companions, he resolved with himself to make 
some adventure at sea, and to try if he could be as famous at sea, as he was at land. Having therefore called all his yeomen together, he did communicate unto them what was his resolution, but none of them would consent unto it, nor any of them would so much as go along with him in such an expedition. Little John in whom he much trusted, and who was partaker with him in all his counsels, and in all his dangers, was absolutely against it, and told him it was a madness in him to harbour any thought of such an adventure: Wherefore Robin Hood did go alone by himself to Scarborough, where being clad in a seamans habit, he came to a womans house by the waterside, and desired entertainment. The good woman seeing him a tall likely fellow, did ask him what his name was, he made answer, Simon over the Lee. It is a good name, said she, and I hope thou wilt make a good servant. If thou wilt be my man, I will give thee any wages that in reason thou wilt demand. I have a ship of my own, and as good as any that sails upon the sea, neither thou nor it shall want for any accommodation. Robin Hood being content to serve, took covenant-money of her, and on the next morning, the wind serving fair, the ship put forth to sea, where Robin Hood had not been long, but he fell very sick, the sea and he could not agree, which made him in many loud ejaculations to vomit forth the chollar against it. Besides, he was so extreamly unserviceable, that the master of the ship repented a thousand times that he ever took him along with him, and every one would call him the tall unwieldy lubber. When others as they were a fishing would cast into the sea their baited hooks, he would throw in nothing but his bare line, without any hook or bait at all, which amongst other things made him so ridiculous, that a thousand times he wished himself again either in Sherwood forrest or in Plumpton park. At the last the master of the ship espyed a Spanish man of war to make up to him, wherefore he made away from her with all the speed he could, but being impossible to out-sail her, they yielded theniselves lost, and all the goods in the ship. Robin Hood who called himself Simon over the Lee, seeing all men in despair, took courage to himself, and 
bad his master but give him his bow and his arrows, and he would deal well enough with them all. Thou deal with them, said the master, I think we all fare the worse in the ship, for such a lubber as thou art. Robin grew angry at these words, nevertheless taking his bow and arrows in his hand, he went up to the deck, and drawing his arrow up to the very head, killed one Spaniard, and by and by another, and another. The master of the ship seeing the Spaniards to drop so fast, encouraged his men, and boarded the ship, where Robin Hood, alias Simon, behaved himself so manfully, that by his particular valour they possessed themselves of the ship, in which they found twelve thousand pound; half of which money Robin Hood allotted to his dame and her children, and the other half to his companions in the ship. No, said the master, it must not be so, Simon, for you have won it with your own hands, and you shall be master of it; Why then, said Robin Hood, it shall be as I have said. Half of it shall go to my dame and her children, and (since you refuse my bounty) the other half shall be for the building of an alnı-house for the maintenance of the poor.

\section{ROBIN HOOD'S CHASE;}

OR, THE MERRY PROGRESS BETWIXT ROBIN HOOD AND

KING HENRY.

Robin Hood returning to Sherwood forest, did commit in Yorkshire a very strange exploit; I cannot well tell whether he was overseen with wine or rage, but certainly it was one of the worst things that ever he did. It was brought to the kings ear, who protested that such a fact should not escape unpunished: and because the sherriffs had heretofore complained that they could not take him, he was resolved to ride in pursuit of him himself. Being therefore come with a royal retinue unto Nottingham, all the county was laid for him; which Robin Hood understanding, he by the advice of Little John, did privately convey himself from Sherwood forrest into Yorkshire : there were none with him 
but Little John, his cozen Gamwel, William Scarlock, and two or three more. The king being informed that he was escaped into Yorkshire, did follow him with all the speed that could be, and hue and crys were every where issued out to apprehend him. Which Robin Hood knowing, he fled out of Yorkshire to Newcastle; and from thence to Berwick : he had not continued there long, but tydings were brought that the king was gone in the pursuit of him, he was therefore constrained to go to Carlisle, where Little John being known, his stay was very short, and away he posted unto Lancaster, and from thence to Chester, where being in great danger to be betrayed, he conceived with himself that the only way for his safety was to ride to London; where having procured admittance to the queen he told her that he understood that the king was in several places to speak with him, which caused him to come thither, to know what his majesty would have with him. The queen told him, she would do the best she could for him; and that the king going away told her, that he was taking a journey on purpose to seek him out. Having thus dispatched his business at court, the king within few days afterwards came to it, where finding by the queen that Robin Hood understanding his majesty would speak with him, had been there to speak with him. He is a cunning knave, said the king. The queen falling down on her knees, besought him that (for his welcome to court) he would for once give her the life of that poor Outlaw ; which being condescended to, Robin Hood dismissed all his idle companions, and betaking himself to a civil course of life, he did keep a gallant house, and had over all the country, the love of the rich, and the prayers of the poor. 


\section{A P P E N D I X.}

\section{LIFE OF ROBIN HOOD.}

From MS. Sloan. 715. nu. 7. f. 157 .

RoBIN HOOD was borne at Lockesley in yorkeshyre, or after others in Notinghamsh. in $y^{e}$ dayes of Henry $y^{e} 2^{\text {nd }} \cdot$ about $y^{e}$ yeare i 160 , but lyued tyll $y^{e}$ latter end of Richd $y^{e}$ fyrst, he was of wo! 1 parentage, but so ryoto ${ }^{\mathrm{s}} \mathrm{y}^{\mathrm{t}}$ he lost or sould his patrimony $\overline{8}$ for debt became an outlawe, the ioyning to him many stout fellowes of like disposicōn, amongst whome one called little John was principal, or next to him they haūted about Barnsdale forrest, ${ }^{2}$ Clōpton parke, \& such oth ${ }^{\mathrm{r}}$ places, they vsed most of al shooting wherin they excelled all the me of the land, though as occatio required, they had' al so othr weapons. one of his first 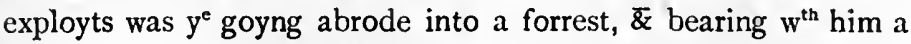 bowe of exceeding great strength, he fell in to cōpayy $w^{\text {th }}$ certayne rangers or woodme, who fell to quarrel $w^{\text {th }}$ him as making showe to vse such a bowe as no ma was able to shoote $\mathbf{w}^{\text {th }}$ all, wherto Robin replyed $\mathrm{y}^{t}$ he had two better the that at Lockesley, only he bare $y^{t} w^{\text {th }}$ him nowe as a byrding bowe, at length the cōtententio ${ }^{3}$ grewe so hote, $y^{t}$ there was a wager layd about the kylling of a deere a great distance of, for pformāce wherof, Robin offred to lay his head to a certayne sōme of money, of $y^{e}$ advantage of $w^{\text {ch }}$ rash speach the oth ${ }^{\text {rs }}$ p'sently tooke, so the marke being found

1 Ritson says " though the material word is illegible, the sense evidently requires noble."

${ }^{2}$ Qy. Plompton Park in Cumberland, formerly very large and set apart for keeping of the king's deer.

"So MS. for "contention." 
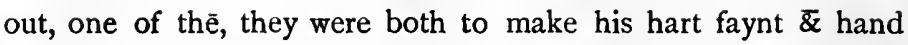 vnsteady as he was about to shoote vrged him $w^{\text {th }} y^{e}$ losse of his head if he myst $y^{e}$ marke, notw ${ }^{\text {th }}$ stāding Robin kyld $y^{e}$ deare, 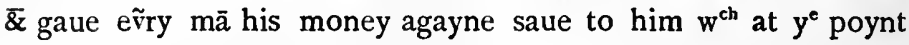 of shooting so vpbrayded him w $^{\text {th }}$ dāgs to loose his hed, for that 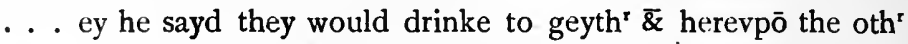 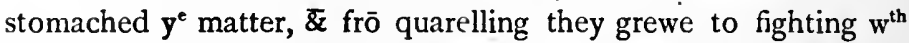 him, but Robin getting him somewhat of $w^{\text {th }}$ shooting dispact 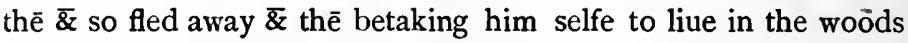 by such booty as he could get his company encreast to an hūdred 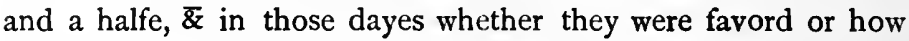 so e $\tilde{v}$ they were coūted invincible, wheresoe $\tilde{v}$ he hard of any $y^{t}$ 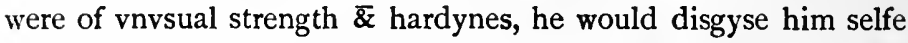 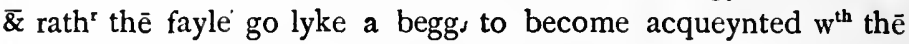 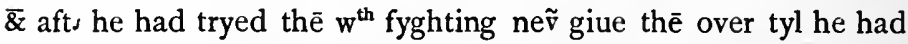 vsed means to drawe thē to lyve aft , his fashiō; aft such mañ he pcurd $y^{e}$ pyner of wakefeyld to become one of his company 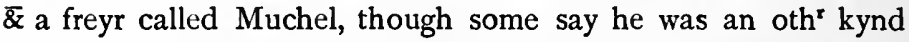 of religio' mā, for $\mathrm{y}^{\mathrm{t}} \mathrm{y}^{\mathrm{e}}$ order of freyrs was not yet sprung vp; Scarlock, he induced vpō this occacōn one day meting him as he 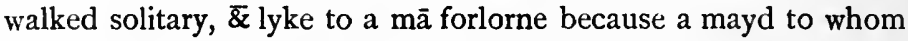 he was affyāced was takē frō by the violence of her frēds \& giuē 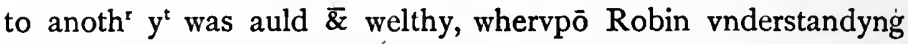 whē $y^{e}$ maryage day should be, came to $y^{e}$ church as a begg ${ }^{\mathbf{r}}, \bar{z}$ having his compāy not far of, $w^{\text {ch }}$ came in so sone as they hard $\mathrm{y}^{\mathrm{e}}$ sound of his horne, he toking $\mathrm{y}^{\mathrm{e}}$ bryde pforce frō him $\mathrm{y}^{\mathrm{t}}$ was 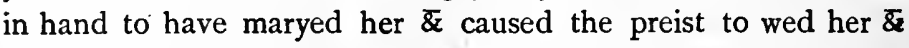 Scarlocke togeyth ${ }^{\mathrm{r}}$. amongst oth ${ }^{\mathrm{r}} \mathrm{y}^{\mathrm{t}}$ greatly frēded him was $\mathrm{S}^{\mathrm{r}}$

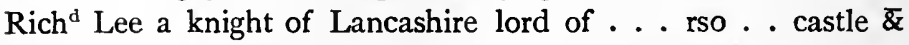
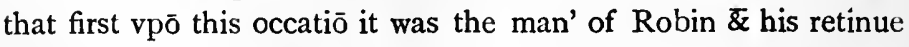 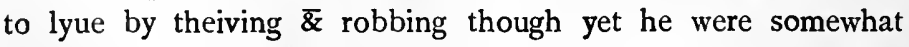 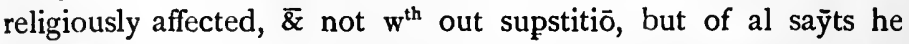 most honored $\mathrm{y}^{\mathrm{e}}$ rgin mary, so $\mathrm{y}^{\mathrm{t}}$ if any for her sake asked ought of him, he wold pforme it if possibly he could, neith ${ }^{r}$ would he suffer any $\mathrm{y}^{\mathrm{t}}$ belonged vnto him to violate womē poremē, or any of the husbādry, al theyr attempts were chiefly against fat p'lats 
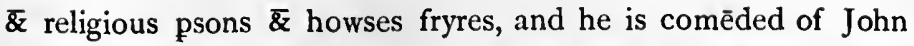 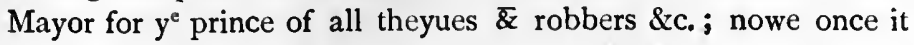 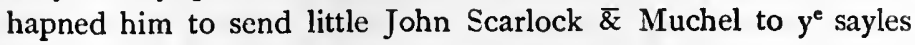 vpō watling streete to meete $\mathrm{w}^{\text {th }}$ some booty they wanted when any prey came to theyr hands to lead them into $y^{e}$ wood to theyr habitacōn, as if they would vse some hospitalitye, but after they had eate, would make the pay deerely for theyr cates, by stripping the of such things as they had, so they dealt $\mathrm{w}^{\text {th }} \mathrm{S}^{\mathrm{r}}$ Richard Lee 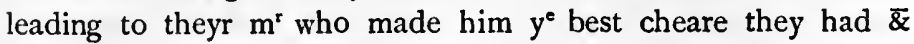 whe $\mathrm{S}^{\mathrm{r}} \mathrm{Rich}^{\mathrm{d}}$. would have depted only $\mathrm{w}^{\text {th }}$ giving the thāks, Robin tould him it was not his man to dyne any where but he payd 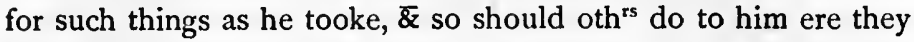 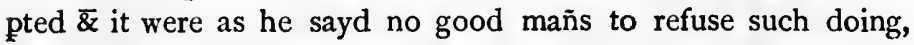 $y^{e}$ knight tould him he had but $x^{\text {sh }}$. $w^{\text {ch }}$ he ment should have 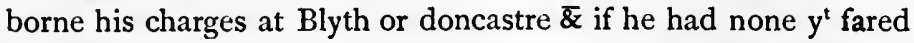 ful $y l w^{\text {th }}$ him at $y^{e}$ tyme to pte frō it onely he promised as he should be able to requite his curtesy $w^{\text {th }} y^{e}$ lyke, but Robin not so cōtented caused him to be searcht $\bar{\varepsilon}$ found no more but what $y^{e}$ knight had told him of, wherevpō he cōmended his true deal 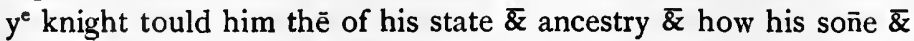 hayre falling at varing $\mathrm{c} \mathrm{w}^{\text {th }}$ a knight in Lācashire, slewe him in $\mathrm{y}^{\mathrm{e}}$ 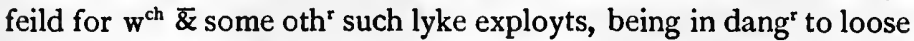 his lyfe, the knight to pcure his deliverance, had been at great 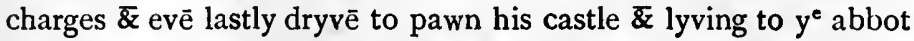 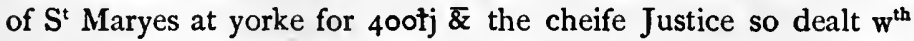 $y^{e}$ abbot for his state or int'est therein, that being lyke to forfeyt his lyving for lacke of money to redeeme it at $\mathbf{y}^{\boldsymbol{c}}$ day appoynted, he despayred now of al recv'y; Robin thē pittying his case gave 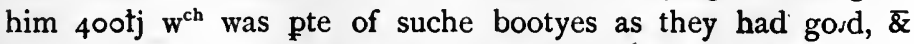 suerty for payment againe $w^{\text {th }}$ in a tweluemonth was os lady, they also furnysht him $\mathrm{w}^{\text {th }}$ apparel out of $\mathrm{w}^{\mathrm{ch}}$ he was worne quyte 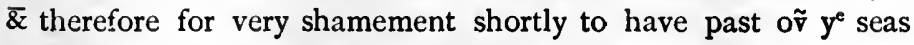 $\bar{Q}$ to spend $y^{e}$ rest of his lyfe as a mournful pylgrime in going to Jerusalē $\bar{\alpha}$ c. but being now enlightned he despayred iust as his day appoynted to $y^{\mathbf{e}}$ abbot $\mathrm{w}^{\mathrm{ch}}$ where the cheife in shire 
 knight to try theyr charity made shewe as if he wanted money to 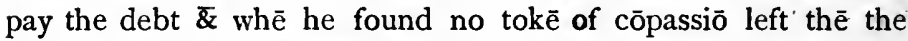 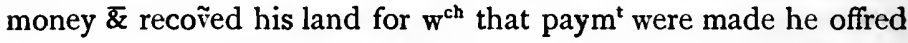 to ferme (farm) $y^{e}$ abbot thereby. nowe ere $y^{e}$ twelvemonth was 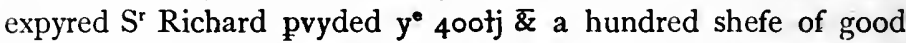 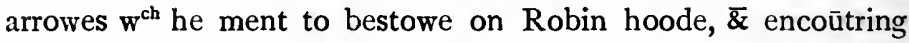 on $y^{e}$ way certayne people $y^{t}$ were wrastling for a great wags, he stood stil to see $y^{e}$ event of $y^{\bullet}$ matt $s$, so there was a yemā $y^{t}$ 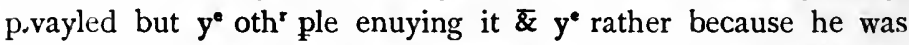 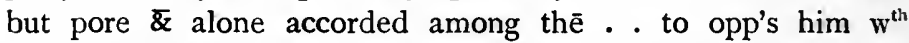 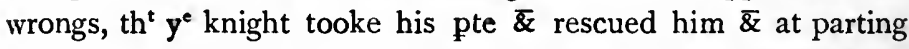 gaue him 5 marks. Nowe it befell, $y^{t}$ neere to Notinghã al the cheifest archers had appoynted a day of shooting for some great wagr $^{r}$, the Sherife him selfe being appoynted to see the game, 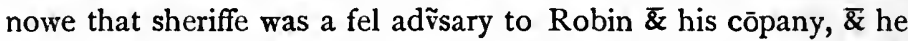 againe of the no lesse maligned, therfore to see into al mattrs little John was sent in disguysed man $/$ to go shoote amongst the , where he sped him so wel, $y^{t} y^{e}$ shyryfe iudged him to be $y^{e}$ best archer, 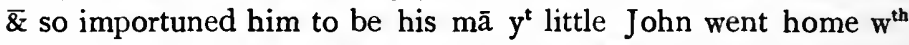 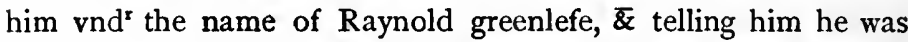 borne in Holdernes, so little John watched al advătages to do his 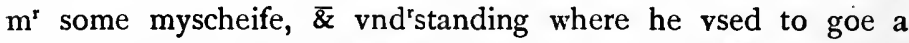 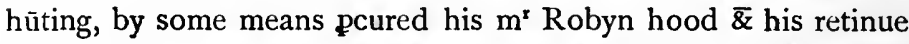 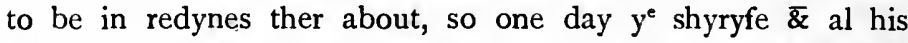  lay a bed as somewhat sicke, but was no son' gat vp enquired for his dyn $\lrcorner$ of $y^{*}$ steward $w^{\text {ch }} w^{\text {h }}$ curse words denyed him victuals tyl his $\mathrm{m}^{\mathrm{r}}$ were come home, whervpō little John beate him downe $\bar{Q}$ entred the buttry $y^{e}$ cooke being a very stout fellowe fought 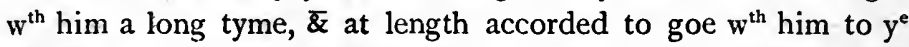 forrest, so they two ryfled the howse, tooke away al the shyryfes 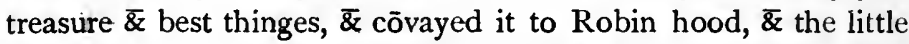 John repayred to $y^{e}$ shyryfe, who in his hūting doubted no such matt ${ }^{r}$, but tooke him for one of his cōpany, whervpō little John tould him he had seene $y^{*}$ goodlyest heard of deere $y^{t}$ was in $y^{e}$ 
forest not far of sevē score in a cōpany $\mathbf{w}^{\text {ch }}$ he could bring him to, $y^{e}$ sheryfe glad to heare of so strange a mattr, went $w^{\text {th }}$ him 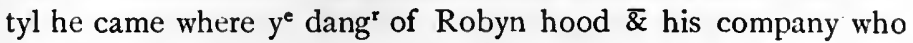 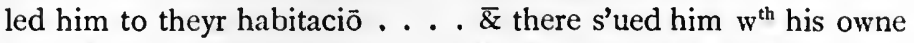 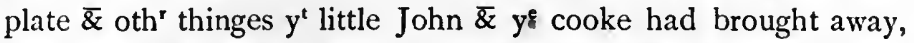 so $\mathrm{y}^{\mathrm{t}}$ night they made him ly on $\mathrm{y}^{\mathrm{e}}$ ground $\mathrm{aft}^{\mathrm{r}}$ theyr owne $\operatorname{man}^{\mathrm{r}}$ 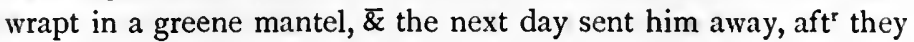 had takē an oth of him nev' to pursve the but $y^{e}$ best he could do to serue thē, but $y^{e}$ shyriffe afterward made no more account of $\mathrm{y}^{\mathrm{e}}$ othe the was meete yt. After this little John, Scarlocke, $\bar{z}$ oth $^{\text {rs }}$ were sent forth to meete $\mathrm{w}^{\text {th }}$ some coppany, if they were pore to helpe the $\mathrm{w}^{\text {th }}$ some such thinges as they had, if rytch to handle thē as they saw occasiō, so vppō the way neare Barensdale, they 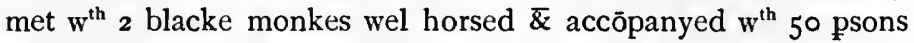 nowe because Robin theyr $\mathrm{m}^{\mathrm{r}}$ had $\mathrm{o}^{\mathrm{r}}$ lady in great reṽence whe any booty came to theyr hand they would say $o^{r}$ lady sent the theyr wherfore whē little John sawe $y^{t}$ company he merily vsed 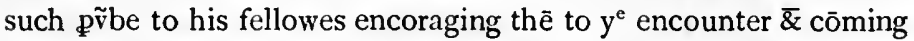 to the monkes he told thē that though they were but 3 , they durst nev see theyr $\mathrm{m}^{\mathrm{r}}$ agayne, but if they brought the to diner to him; $\bar{z}$ whō the monke keapt of, little John beged to speake repchfully for making his $\mathrm{m}^{\mathrm{r}}$ stay din̄er so long, whervpō whō $\mathrm{y}^{\mathrm{e}}$ monkes enquired for his $\mathrm{m}^{\mathrm{rs}}$. name, $\overline{\dot{\alpha}}$ little John tould him it was Robin hood, $y^{\mathbf{e}}$ monk angerly replyde he was an arrant theif, of whom he nev hard good, little John replyed as cōntumeliously, 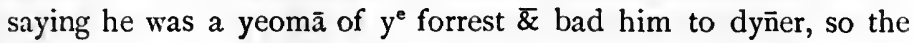 grewe frō wordes to strokes tyl they had kyled al but one or 2, $\mathrm{w}^{\text {ch }}$ they led pforce to theyr $\mathrm{m}^{\mathrm{r}}$, who saluted the lowely, but $\mathrm{y}^{\mathrm{e}}$ monke being stout harted, did not the lyke to his, the Robin 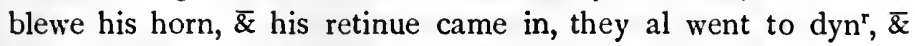 after $y^{t}$ Robin asked him of what abbey he was, who tould he was of $S^{t}$ Mary, now it was to $y^{\mathrm{e}}$ same to whose abbat $y^{\mathrm{e}}$ knight ought $y^{\mathrm{e}} 4$ ootj $\mathrm{w}^{\text {ch }}$ Robin lent him to redeeme his landes $w^{\text {th }}$, al $\mathrm{w}^{\text {ch }}$ Robin pceying, begon to iest $\mathrm{y}^{\mathrm{t}}$ he $\bar{m}$ vayled $\mathrm{o}^{\mathrm{r}}$ lady had not 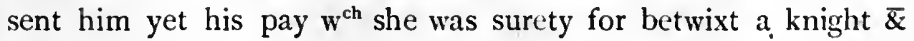 him, have no care $\mathbf{M}^{\mathbf{r}}$ sayd little John, you need not to say this 
monk hath brought it I dare wel swere, for he is of her abbey, so 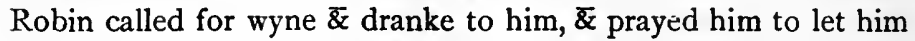 see if he had brought him $\mathrm{y}^{\mathbf{e}}$ money, $\mathrm{y}^{\mathbf{e}}$ monke swore he had nev ${ }^{\mathrm{r}}$ hard speach of such coven ${ }^{t}$ before, but Robyn bare him downe 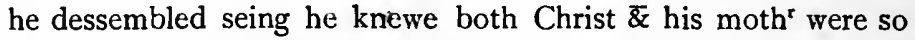 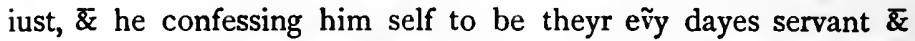 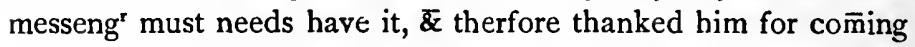 so at his day, $\mathbf{y}^{\mathbf{e}}$ monke stil denying, Robin asked howe much money he had about him, but $x^{\text {ty }} \mathrm{m}^{\mathrm{r}}$ kes sayd $\mathrm{y}^{\mathrm{e}}$ monke, the sayd Robin if we fynd more we will take it as of $o^{r}$ ladyes sending, but wil not of $\mathrm{y}^{\mathrm{t}} \mathrm{w}^{\mathrm{ch}}$, is thy owne spending money, so little John 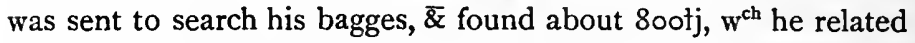 to his $\mathrm{m}^{\mathrm{r}}$, telling him $\mathrm{w}^{\text {th }}$ al $\mathrm{y}^{\mathrm{t}} \mathrm{o}^{\mathrm{r}}$ lady had dobled his paym, yea I tould thee monke, sayd Robyn, what a trusty womā she is, so 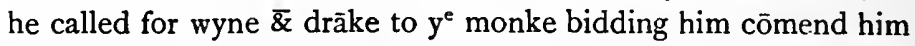 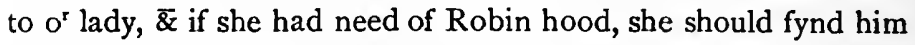 thäkeful for so lib'al dealing, thē they searcht $y^{e}$ lode of another horse, wherefore the monke tould him $y^{t}$ was no curtesy to bid a 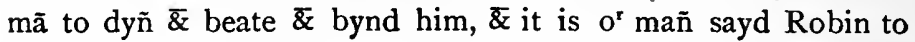 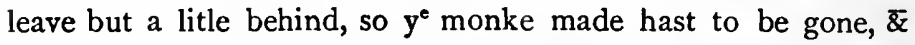 sayd he might have dyned as good cheape at Blyth or Dōcastre, 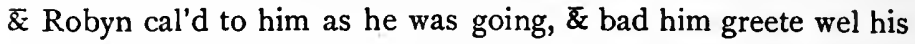 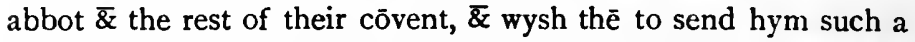 monke ech day to dyn' thē shortly came $y^{e}$ knight to keepe his 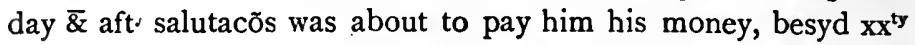 mkes for his curtesy, but Robyn gave it him agayne telling him 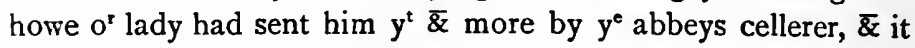 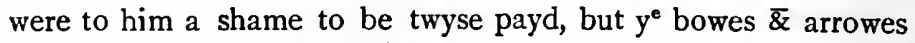 he accepted for $\mathrm{w}^{\mathrm{ch}}$ he gave him at parting oth ${ }^{\mathrm{r}}$ 4ootj. Nowe $\mathrm{y}^{\mathrm{e}}$ shyriffe of Notinghā, to drawe out Robin hood, made to be pclaymed a day of shooting for $y^{e}$ silv arrowe, wherto Robin boldely $\mathrm{w}^{\text {th }}$ al his trayne repayred, apoynting but 6 of his coppany to shooting $\mathrm{w}^{\text {th }}$ him al $\mathrm{y}^{\mathrm{e}}$ rest to stand apoynted to f. f. g. . . d him, ${ }^{1}$ so little John, Robin, mychel, Scarlock, Gylbert, ₹ Reynold 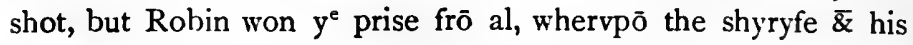

$1 \mathrm{Qy}$ : to safeguard him. 
company begā to quarrel, $\&$ aft' they came to fighting so long 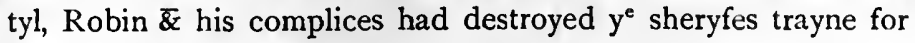 $\mathrm{y}^{\ominus}$ most pte in $\mathrm{y}^{\mathrm{e}}$ cōflyct, little John was sore wounded $\mathrm{w}^{\text {th }}$ an arrow in $\mathrm{y}^{\mathrm{e}} \mathrm{knee}, \overline{\mathrm{z}}$ being not able to goe requested his $\mathrm{m}^{\mathrm{r}}$ to slay him, $\&$ not suffer him to come into $\mathrm{y}^{\mathrm{e}}$ sheryffes handes, avoucht he would not loose him for al England, wherfore mychel was 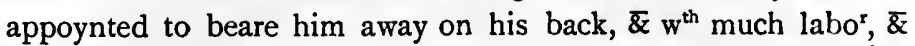 oft resting, he brought him to $S^{r}$ Richard Lees castle, wheth ${ }^{r}$ also 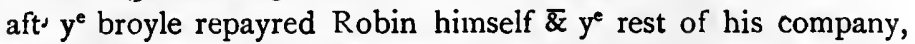 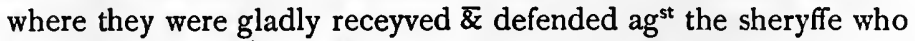 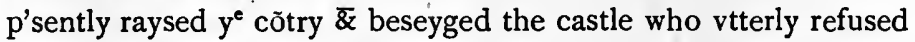 to yield any there tyl he knewe $y^{e}$ kyng mynd. the $y^{e}$ shyriffe went 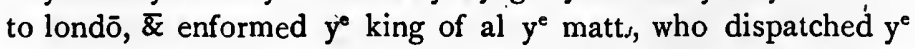 shyryfe backe to levy a power of mē in $y^{t}$ cōtry telling him $y^{t} w^{\text {th }}$ in a fortnight aft', he him selfe would be at Notinghā to $\operatorname{det}^{\prime}$ myne of $y^{t}$ matt $^{r}$, in $y^{\mathbf{e}}$ meane whyle little John being cured of his hurt, they al got thē to $y^{e}$ forest agayne, who the shyriffe hard therof he 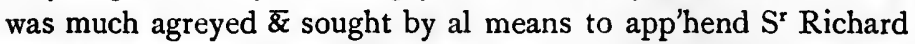 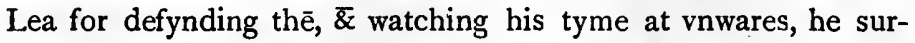 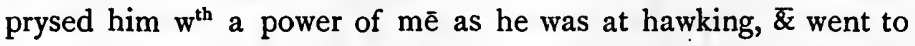 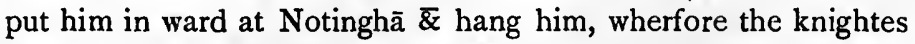 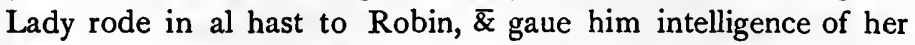 Lordes distres, who in al hast pursued $y^{\mathrm{e}}$ sheryfe $\bar{z}$ oṽtaking him 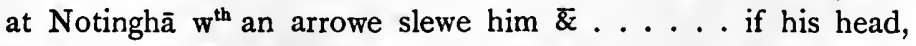 enquyring what message he brought frō $y^{e}$ kyng, obiecting $y^{t}$ breach of pmise he had made to them in $y^{e}$ forest, once after 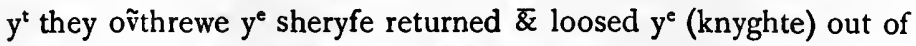 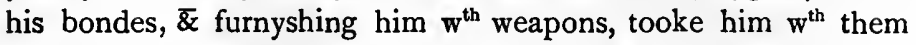 to $\mathrm{y}^{\mathrm{e}}$ forest, entending to vse what means they could to pcure $\mathrm{y}^{\mathrm{e}}$ kyngs pardon, who p'sently herevpō came to Nottinghā $w^{\text {th }}$ a great 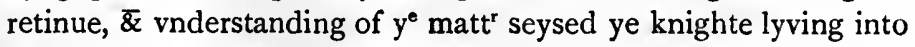 his hande $\&$ surweying al the forrestes in Lancash. he came to 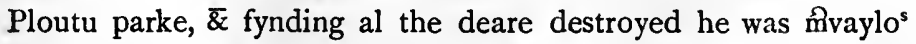 wroth, seeking about for Robin hood \& making pclamatiō, $\mathrm{y}^{\mathrm{t}}$ who so could bring him $\mathrm{S}^{\mathrm{r}}$ Rich ${ }^{d}$ Lees head should have all his land, 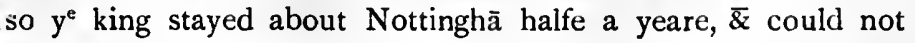 
heare of Robyn tyl being advysed what a hard hãd he bare against 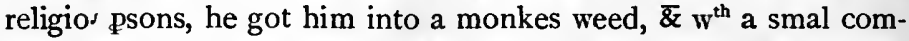 pany went as a traveller on $y^{\mathrm{e}}$ way wher he thought Robyn made abode who espying thē $\mathrm{w}^{\text {th }}$ theyr male horse, toke hold of $\mathrm{y}^{\mathrm{e}}$ 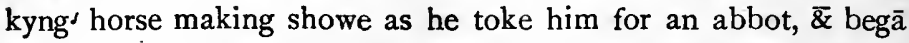 to enquire aft some spending, but the king excused $y^{e}$ matter, telling him howe he had lyen at Notinghā at great charges a fort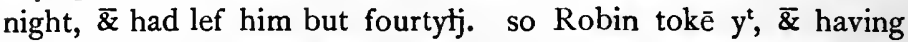 devyded it amongst his mē, gave $\mathrm{y}^{\mathrm{e}}$ kyng pte againe, who semed 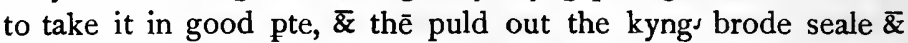 tould him howe the kyng did greet him wel, $\bar{z}$ charged him to 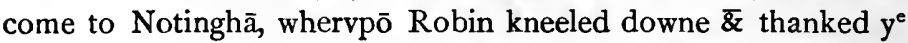 abbot, for he ptended to thinke him none oth ${ }^{r}$ for bringing such 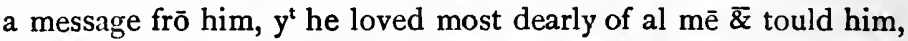 $\mathrm{y}^{\mathrm{t}}$ for his labor he should go dyne $\mathrm{w}^{\text {th }}$ him, so being brought to 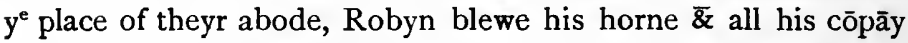 came al a hoste obedyent to theyr $\mathrm{m}^{\mathrm{r}}$, the kyng mvayled, $\mathrm{w}^{\text {ch }}$ Robyn pceyving dyd him selfe $w^{\text {th }}$ his best mẽ s'ue $y^{\text {e }}$ kyng at meete of welcoming him for $y^{e}$ kyngs sake as he sayd, the he 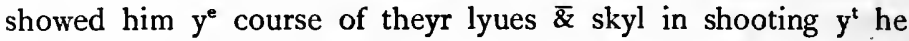 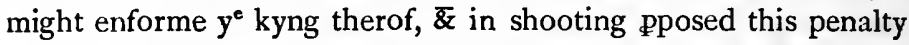 to him $y^{t}$ shot one of $y^{e}$ garland $y^{t} y^{e}$ abbot should giue hym a 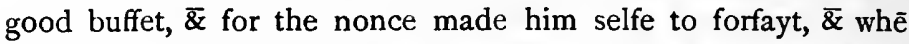 the abbot refused to stryke him, saying it fel not for his order, but Robyn would not cease tyl he make him smyte him soundly $\mathrm{y}^{\mathrm{t}}$ he fel to $\mathrm{y}^{\mathrm{e}}$ ground, for $\mathrm{w}^{\mathrm{ch}}$ Robyn cōmmended him but Robyn him selfe stroke his mē as they fayled afterws. Robyn discoṽed 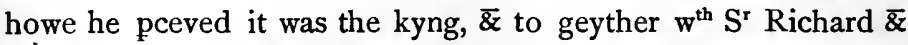 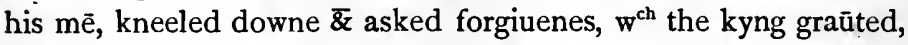 vpō cōdicōn he would be fore him at $y^{\circ}$ court, so Robyn arayed 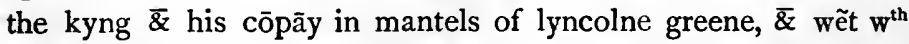 thē to Notinghā, the kyng seeming also to be one of the outlawes $\& y^{e}$ th ... d the kyng for shooting togeyth ${ }^{\mathrm{r}}$ for buffits, 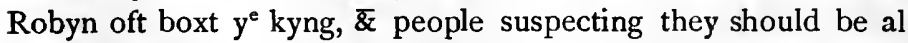 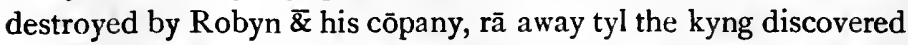 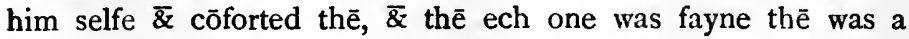 
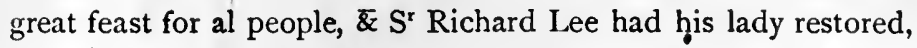 for $\mathbf{w}^{\text {ch }}$ Robin gave the kyng humble thanks, the Robyn dwelt in the court a yeare, tyl $\mathbf{w}^{\text {th }}$ lavysh spending, he had nothing left to 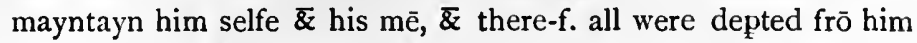  ing, it come to his mynd howe he was alienated frō $\mathrm{y}^{\mathrm{t}}$ exercyse, 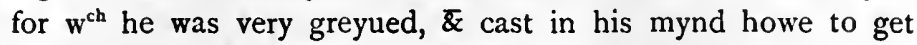 away, wherfore he devysed to tell $y^{e}$ kyng howe he had erected a 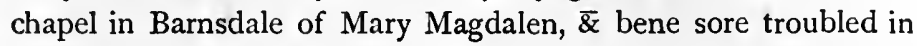 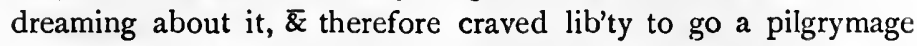 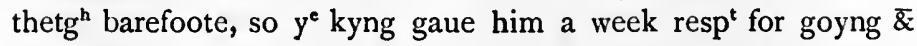 cōming, but Robyn being come thy ${ }^{\text {hr }}$, assembled his awld trayne \& neṽ returned backe to $y^{\mathrm{e}}$ court, after $\mathrm{w}^{\mathrm{ch}}$ tyme he contynued $\mathrm{y}^{\mathrm{t}}$ 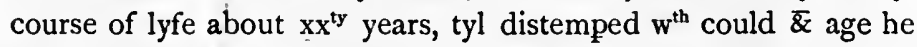 had great payne in his lymes, his bloud being corrupted, therefore to be eased of his payne by letting blud, he repayred to $y^{\mathbf{e}}$ priores of Kyrkesly, $w^{\text {ch }}$ some say was his aunt, a wo $\bar{m}$ very skylful in 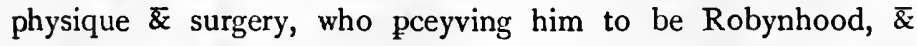 wayin'g howe fel an emy he was to religios psons, toke reveng of 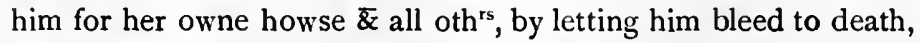 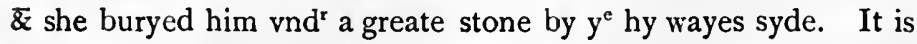 also sayd, $\mathrm{y}^{\mathrm{t}}$ one $\mathrm{S}^{\mathrm{r}}$ Roger of Dancastre, bearing grudge to Robyn for some injury, incyted $y^{e}$ prioress, $w^{\text {th }}$ whom he was very familiar in such mañ to dispatch him, \& the al his company was soone despsed ; the place of little Johns buryal is to this, the celebros for the yeelding of excellent whetstones. 



\section{HISTORY OF GEORGE A GREEN,}

PINDAR OF THE TOWN OF WAKEFIELD. 
. 


\section{$\mathrm{X}$.}

\section{THE HISTORY OF}

\section{GEORGE A GREEN, PINDAR OF THE TOWN OF WAKEFIELD, ÉTC.}

\section{CHAPTER I.}

Of the Parentage and Birth of George A Green; and of some Accidents that happen'd to him in his Childhood, before he could hardly write Man, which gave great hopes of his farther Strength and Valour.

EGat fhis history may gain the greater credit and countenance, and not incur the imputation of a vain and fabulous discourse (of which number this age hath already been abused with too many) I thought it the best course, both for the reputation of the work, and the encouragement of the reader, to follow and observe an exact computation of time; as also, all the series of such circumstances, as are not only known, but very remarkable in our best and most approv'd chronicles.

Thus therefore it followeth:

The reign of Henry the Second of that name, king of England, the son of Geoffrey Plantagenet, earl of Anjou, and Maud the empress, daughter of Henry the First, and younger son to William the Conqueror, began in the month of October, in the year after our blessed Saviour's Incarnation, I1 55, and in the nineteenth year of Lewis the Eighth, king of France. He was a prince of so great valour and courage, that he was often heard to say, That the world was not sufficient to contain or 
limit a valiant and magnanimous spirit. Neither did his words come much short of his heroical attempts, for he subdued Ireland by the sword, and surpriz'd William king of Scots, in battle, joining and annexing the kingdom unto his own. $\mathrm{He}$ comprehended all the land and continent from the south ocean to the north islands of the Orcades, under due principality and government, now spaciously extending his empires more than any of his progenitors : for not any king of England before his time held so many countries and provinces under their dominion and government: for, besides his own kingdom and crown, of which he was immediate and apparent heir, and 'unto which he was lineally descended: he had under his rule and command, the entire dukedoms of Normandy, Gascoigne and Guyenne, Anjou and Chinon: besides, he subjected unto him Auvergne; with divers other lands and territories. Moreover, by his wife Eleanor (who had been before divorced from Lewis the Eighth, king of France) he had in dower the Montes Pyrenæi, the Pyrenean mountains that divide France and Spain. He had by this queen a fair and hopeful issue, namely five sons and three daughters. His sons were William, Henry, Richard, Godfrey, and John, of which two only succeeded him in the kingdom, viz. the third son Richard (after for his invincible courage surnamed Cuer de Lion) and John the younger. The eldest of his daughters was called Maud, who was married unto the duke of Saxony. The second, Eleanor, espoused to the king of Spain. The third, Jane, after wife to William, king of Sicily. This king was very prosperous in the beginning of his reign, but in the latter-end very unfortunate; for, as Gerald the chronicler recordeth of him, he reigned twenty-six years in all worldly prosperity, and to the content of his heart; but the next four years with difficulty and trouble, and the five years after that with infinite vexation and sorrow: but the first combustions that grew in the kingdom, were about the twentieth year of his reign; for his sons being aided by the Scotch king and the two eminent earls of Chester and Lincoln : the cause of taking up arms against their father was, because he had im- 
prison'd his Queen Eleanor, their mother, and kept the fair Rosamond as a Concubine, quite abandoning the bed and company of his lawful wife.

Thus far I have borrow'd of our English annals, the better to illustrate our succeeding history now in hand.

In these civil and domestick tumults, whilst the whole land was in an uproar, the father against the son, and the son oppos'd against the father, the whole land so bewildred in the following and abetting of these two several factions, was disjoin'd: not only peer against peer, and county against county; but, as in all such unnatural and intestine wars it happens, so in this it fell out that the nephews oppos'd the uncles, brother the brother, and the son the father; the one supporting the quarrel of the father, the other animating the faction of the rebellious children, as their fancies and affections diversly led them. Amongst those that abetted the insurrection of the princes was one Geoffrey Green, a rich and wealthy farmer of the town of Wakefield, who both with his purse and person assisted them in all their designs. These wars (as Reinolph witnesseth) lasted for the space of two whole years, to the great disturbance of the realm, at the end of which season the king had the better; for the army of the princes was dispers'd, and the king pursuing his victory, besieged the two earls of Chester and Lincoln, with other great men, in Anwich castle, and in a short space surpriz'd both it and them. These being thus taken, and the princes his sons fled, the king having quieted and pacified all the tumults within the realm, had now leisure to make enquiry after all such of his subjects, as, quite against their oath and allegiance, had taken up rebellious arms against him. In the list of those names was found this Geoffrey Green, whose life being pardon'd by the king's gracious clemency, yet, by a strict command from his highness, directed to the commissioners, all his goods and lands were seiz'd on as forefalt and confiscate to the crown; the grief whereof made such a deep impression on him, that he survived not full two months after, leaving behind him one only son, about the age of nine years, heir only to his father's misfortunes; 
for he had neither house of his own to cover him, nor farm, nor cattle, nor goods by which to subsist.

His name was George, and that very A Green of whom our present discourse is form'd. And here I must give you to understand, that he was not (as some vainly have held) a foundling, that is, a forsaken infant, cast out by his unnatural parents, and taken up in his swaddling-cloaths; and that those charitable people that first lighted on him, very much doubting of his baptism, caused him to be christned, whence the name of George was given him, and surnam'd of Green, of the town which is called Wakefield, on a green, and so brought up and educated by the common charity. Neither was he filius populi, a bastard, as some have ignominiously suggested, designing thereby to sully his worth by the infamy of his birth; but he was the legitimate issue of an honest and substantial farmer of good means and ability, and of an unblemish'd reputation, well thought of by his neighbours, respectfully spoken of by the country, a man free from blemish or unjust taxation, until either over-soon reduced to embrace innovation, or over-much inclining to the immature succession, he fell into the fore-nam'd disaster.

As I have clear'd his birth from bastardy, so my design is to free his bringing-up from calumny; for, according to the ability of his father, he was train'd up in the school of Wakefield to read and to write; for in those days few farmers sons aim'd at any higher learning. Pregnant he was, and of a good capacity, but especially excelling in strength those that exceeded him in years. He in all exercises of the body, especially when any trial was to be made by blows and buffets, had always the mastery, insomuch that his fellow scholars gave him the name of captain of the school. His means now failing, by reason of his father's poverty and untimely decease, his master began to carry a more hard and severe hand over him than before; and because he found him to be as friendless as fatherless, began too much to insult on his poverty, by chastening and beating him on the least, or, perhaps, no occasion ; all which his great spirit (tho' yet a child) being not able to endure he purposed with himself, upon 
the next fit occasion, to put some pretty revenge or other upon his master, and so for ever after to quit the school. Opportunity being after presented to his wishes, it happen'd, that his master for some slight cause was wroth, calling him Cocain, and bid him prepare himself for the lash, for he must be whipp'd without all peradventures: George, at this terrible summons, perceiving his master's threatnings, and the rod menacing, he falls down on his knees with quæso præceptor (for he had so much Latin) in his mouth, to beg pardon, as loth upon so sudden a condemnation, to go to execution; but after many threats on the one side, and many entreaties on the other, and none present that durst interpose themselves to mediate betwixt them, George perceiving his master to be inexorable, and neither to be moved with prayers nor tears, and remembring himself of his former determination, whilst the pedagogue was calling out one to horse him, George suddenly thrust his head betwixt his master's legs, and holding them fast, and heaving with all his strength, he found he could move his heels above his own head; so with a sudden heave he cast him off from his shoulders with such a tumbling quait, as we call a back somerset, and left him (not much considering whether his head or neck came first to the ground) lying flat upon his back, and half-dead, in the midst of the school, which then stood open, and out of which he ran, with an intent and vow to himself never to come within that place after. Thus George in the marring of a scholar had almost spoil'd a schoolmaster; for the poor man, now not so cholerick as before, from threatning, began to entreat his scholars for help to get him upon his legs again, and employ'd others to run home, to get him some aqua vitæ, and others to lead him to his seat, sometimes complaining of a pain in his head, then of a creek in his neck, then of his back, and at other times of his bones; but his scholar George was gone, and having made so bold with his legs, purposed never more to come within his 'fingers. This accident, tho' it distasted some, yet it pleas'd others, especially such as were indulgent over their children, to whom this pedant had been too harsh and tyrannous; but gave 
occasion to all to speak George's strength and boldness, who being so young, durst adventure to cope with this tyrant, whose very looks made all the rest of his schoolfellows quake and tremble. Many other such masteries, he proved with such as equall'd hin in years, and many with those that had out-gone him in time; but in all his exercises he still came off with the best success. He was naturally of so honest a temper, and so gentle a behaviour, that he rather attracted love and amity, than emulation or enemies. But I have hitherto spoken of him as a child; I must now entreat you to imagine so many years past over his head, till he was grown full man, that his understanding was of better capacity, and his body of more able validity, the first to apprehend the other to undertake. These things duly consider'd here, I propose to conclude the first partition of this treatise, and prepare myself to go on with the second.

\section{CHAPTER II.}

How George A Green was perswaded by a friend of his to go to an Astronomer, or Fortune-Teller, to cast his nativity.

GEORGE now growing to twenty years of age, and in regard both of his strength and stature, perswading himself he might write full man, began to consider what course of life he had best to take : and in this meditation meeting with a friend of his, and of his long acquaintance much familiar discourse was interchanged betwixt them: at length they fell upon the former argument. To the profession of a soldier he had a very great inclination, but he was frustrated in that; for there was no employment for such persons, because there was a general peace and a cessation of civil arms throughout the kingdom. A serving man he did not much affect, because he held it too servile a life: and besides, he remembred himself of the two English proverbs, "That service was no herritage;" and again, "That an old serving man made a young beggar." He was in no hopes to prove a scholar, because (as you have heard before) he had formerly too early broke up 
school. A trade he did not affect, because he could not endure to be imprison'd seven years in a shop to cry, What do you lack? Much conference to the former purpose passed betwixt them : at length his friend told him, That some twelve miles distant from thence, at Hallifax, lived a south-sayer, or fortune-teller, one that cast figures, and could predict from mens nativities what should happen to them : and so he wished him to be advised by him, and accordingly as he should calculate of his birth, so to frame the course of his life. His friend so far prevail'd with him, that they purposed to undertake this journey; and the rather George was perswaded to the motion, because he had heard from the mouths of others, that this man was a great artist, and got much money by his practice. The time was appointed, and at that time they went; but coming somewhat late into the town, they thought it not best to trouble the artist that night, but rather to make proof of him early in the morning fresh and fasting. Merrily they supp'd together, with some good fellows of their acquaintance, to whom they conceal'd the principal cause of their coming to the town ; but got up betimes, and understanding then, that ten groats was the ordinary price due to the cunning man, George had the fee in his hand ready for his counsel; and being directed to his house, it fortun'd thus: just at the same time he had almost open'd the door, he found that some slovenly fellow or other had laid a beastly and stinking load upon the threshold; at which sight the cunning man seem'd to be out of patience, and amongst other language, utter'd in his great fury as followeth, and spoke to this effect : Well (quoth he) if I could but imagine, or find out by any enquiry what rascal hath put his nasty breech upon me, I would be so revenged on him to make him an example how to use any neighbour's door in that beastly manner hereafter. This was no sooner spoke, but he clapp'd too the door, and in he went; when, saith his friend, Come, George, let's follow in close, for 'tis ten to one but we shall find hin private. But he having another apprehension newly come into his head, told his friend, he should excuse him, for he was sorry he had taken so much pains to so little purpose; and 
though he had made him such a fool to lose so much labour, yet he had so much wit left him as to keep his money. His friend demanding of him the reason why he utter'd such speech; George reply'd, Because I purpose to be as cunning as the cunning man, so as not to part with my money for nothing; for (saith he) shall I ever believe he can resolve me of things to come, that cannot inform himself of a thing lately past: or that he can satisfie me in the future course of my life and fortune, that cannot give himself satisfaction who hath this morning play'd the sloven upon his threshold? No, saith George, let him keep his art unto his own use, and I will reserve my money for my own spending: and so without any further questions, he alter'd his course back to Wakefield, where he arriv'd something wiser than he went thither; but his friend, as arrant a fool as he was, got first thither.

\section{CHAPTER III.}

How George A Green was chosen Pindar of the Town of Wakefield: how he carried himself in the place; and of some other accidents that happen'd unto him.

IT happen'd, that soon after this his journey to Hallifax, that the Pindar of the Town of Wakefield died, and though the place was of no great reputation or credit, yet it was of some profit ; and therefore divers of the town, and others of the neighbouring villages made suit for it ; but George, being well belov'd, partly for his father's sake, but chiefly for his own temper and genteel carriage, (being a town-born child, and destitute both of means and employment) the most voices went, that though he made no sult for it, either by his own mouth or the mediation of friends, that it should be mention'd unto him, if he would think fit to accept of so poor a favour, which proceeded from their general love, till a better fortune; and so was told, he should be possess'd of it, notwithstanding all competitors. George being much pleased with such voluntary love, and being naturally in himself a hater of all ingratitude, besides that he was without a 
calling, and had no dependance on any man, he revolved within himself, that it was much better, and more commendable, to enter and undertake a mean profession, than none at all, and therefore he return'd the townsmen a thankful answer of acceptance, modestly excusing his own demerit; but with this condition, that in regard he understood there were many suiters for the place that seem'd more able and expert than himself, and withal, that it was an office that requir'd a strong and sufficient man, that must undergo many enterprizes without being overtopt and baffled. $\mathrm{He}$, for his own part, desired rather that merit might carry it than favour; and therefore his request was, that all such as had interested themselves in the suit might appear next holiday, after even-song, upon the green of the town, to have a bout or two at quarter-staff, which was a weapon most in use in those days; and to take off all pretence for his being hated or envied in it. The motion was so necessary and just that it could be denied by none, but accepted of all, and he was much commended for proposing it, and the rather, because thereby the townsmen were acquitted from seeming inclin'd more to one party than another. Upon this the day was appointed, and summons sent speedily, not only to the neighbouring villages, but proclaim'd in all the market towns in the county (without exception) that whosoever would make their personal appearance, as well strangers as others, should not only have fair admittance, but he that could maintain his claim by staff and law, should not only have their general voice, but have the possession of the Pindarship during his life, \&c. When the time came, a great confluence of people appear'd, for the country came in from all parts and corners, and many champions entred within the lists. Many a stout tinker in the country was seen with his long staff upon his neck (for lances belong'd only to horsemen) and not one but would venture his budget in the quarrel. George was their champion and challenger; the rest were defendants. The prize proposed for the conqueror was the Pindarship. Neither bakers nor butchers were exempted: nay ${ }_{2}$ even fencers were not excluded, for the challenge was 
general. Many that made no pretensions to the place, came in for their renown, and to shew their valour. The champion stands forth, a defendant appears, the charge is given, not by trumpets, but bag-pipes, as the seers-men go to war. As one was struck down, another started up in his place. I can compare George in this war most properly to Hercules fighting with Hydra; for as one is vanquished, there appears in his place two or three. Fewer staves have been broken at a tilt on a coronation day, than quarter staves at this trial of strength. Twenty of their heads which stood right upon their shoulders, in less than an hour's space stoop'd lower than their knees: yet in him. there was neither seen weakness nor weariness, but he appear'd as fresh as when he first began the encounter. Others, who came with a resolution to make proof of their valour, learn'd by other mens harms how to beware, and seeing so many able and stout fellows foil'd, forbore to come into the lists : for, seeing crack'd crowns pass so currant, they thought it the safest way to sleep in a whole skin. In short, he staid there so long to oppose, that none appear'd to resist: so that the place (with the common consent of the whole country) was conferr'd on him, which, they all acknowledged, came to him not by favour, but his merit and pure desert; and as he attracted the hearts of all men, so questionless his valour being accompany'd with his fair and genteel carriage, (as before hinted) interested him in the bosoms of many women, especially one fair damosel, whose name was Beatrice, the only daughter and heir of a rich justice of the peace, whose name was Grymes, a man of a fair revenue, and of no mean reputation in the country; who being the prime beauty in all those northern parts, was soon espied by George at such interims of breathing, wherein having foil'd one champion, he cast his eyes about till he perceiv'd another to appear before him. She perceiving him at all opportunities to cast a loving look at her, fail'd not to meet his eyes with the like interview of amorous glances: and according to the proverb, "Who ever lov'd that lov'd not at first sight?" So it may be said of George and Beatrice: for ever after that time there was such an impression 
of cordial and entire love betwixt them, as never could be raiz'd out by any prevention or disaster whatsoever, as shall further appear in the sequel. But here we shall leave our new made Pindar, with a loud applause of all the lusty lads of the town and country, carry'd home to his lodgings; and his sweet-heart attended by the country maidens (according to her degree) unto her father's house, some two miles off, who had rather (would modesty have permitted her) have made a shorter journey of it, and born him company that night in the town, as he would likewise have been willing to have made a longer journey, and have usher'd her home; but neither of these could have their desire with any convenience. Part they must, and part they did, meeting as near in their thoughts, as they were divided far in their bodies, where I must now likewise take leave of them for a little time, to inform you what happen'd in the mean time in the nation.

\section{CHAPTER IV.}

Of a great Insurrection in the Kingdom, made by the Earl of Kendall, and his Accomplices, by Reason of a vain Prophecy: and how George $A$ Green demeaned himself towards the Rebels, Soc.

RICHARD the First, son of Henry the Second, after his father's decease, began his reign in the month of July, in the year of grace, one thousand one hundred four-score and nine, who having established and settled Normandy, and ordered his affairs in England, after he had released his mother Eleanor from prison, whom the king his father had kept long in durance, by reason that she was the death of his best beloved Rosamond; he likewise conferred many honours on his younger brother John, as giving him the provinces of Nottingham, Devonshire and Cornwall, and creating him earl of Lancaster, and moreover had marry'd him to the earl of Gloucester's sole daughter, by which that earldom came shortly into his hands. I say, Richard having settled his affairs, he prepar'd for a voyage to the Holy . Land, in conjunction with Philip the Second, then king of 
France. During his absence he constituted the bishop of Ely, then chancellor of England, vicegerent of the kingdom. This bishop being on the one side covetous, and by many unjust impositions oppressing the nation, and the king's brother ambitious on the other, as presuming much upon his royal birth, and his great possessions, some persons fomented great factions and combinations against the tyranizing prelate; so that all things grew out of frame and order; and great distractions ensued; nay, a third ulcer, worse than the former, broke into open rebellion, namely, an insurrection was raised by the earl of Kendal, with divers of his adherents, as, the Lord Bouteil, Sir Gilbert Armestrong, and others. These having gather'd an army of some twenty thousand malecontents, made publick proclamation, that they came into the field for no other cause, but to purchase their country-mens liberty, and to free then from the great and insufferable oppression which they then liv'd under, by the prince and prelate. This drew to the earl many followers for the present, so that he seem'd to have got together a very potent army. But the main reason of this rebellion was, that when the earl was but a child, a wizard had prophesy'd of him, That Richard and he should meet in London, and the king should there vail his bonnet unto him: and this prediction of the south-sayer prov'd afterwards to be true, but not as he vainly had expounded it. The earl having led his army into the north, struck a great terror into all those honest subjects, that tender'd their allegiance to their absent king and sovereign, and wish'd well to the good of the commonwealth, and the safety of the kingdom; yet many were forced through fear to supply his men with necessary provisions, lest otherwise they should have made spoil and havock of all they had. Now, the earl being for some time destitute of many things that are useful and commodious for an army, and encamping some five miles from the town of Wakefield, the three confederates drew a commission, and having sign'd it with their own seals sent it by one Mannering, a servant of the earl's, to the bailiff and towns-men of Wakefield, requiring seemingly, by way of intreaty, to send unto his host such a 
quantity of provision, of corn and cattle, with other necessaries (of which he was then in great want,) and withal, such a sum of money as he demanded for the payment of so many soldiers, to which this Mannering was to perswade them by all fair means possible : but, if they should deny his request, he was to threaten them with fire and sword, with all the violence that could be suggested to them. The news of this commission coming to their knowledge, the bailiff sent abroad to the neighbouring justices, as, to Mr. Grymes, and others; so that he and his brethren appointed to give them a meeting in the town-house, where many of the Commons were to be present, and, amongst others, George A Green purposed to be there, to hear what would become of the business. The summons being made, the assembly met, and the messenger appear'd, show'd his warrant, and, according to his orders, told them what great conveniences would grow in supplying the army, and withal entreated from the lords their love and favour. The bailiff and the justices were loth, it being contrary to their allegiance, to grant their request: yet they were fearful withal peremptorily to deny it, and stood wavering long and debating amongst themselves what they had best do for their own safeties; which Mannering seeing, without doing any reverence at all unto the bench, he began to alter his phrases, and changed the copy of his countenance, first taunting and deriding their faint-hearted cowardize, and afterward threatning them, that if they gave not present satisfaction to his demand, the army would instantly remove, make havock and spoil of their goods and chattels, ravish their daughters, and deflower their wives before their faces, and make a bonfire of the town, to the terrifying of others, whose insolence durst oppose the earl his master's commission. At this haughty and insufferable menaces, whilst the bench sate quaking, George presseth forward in the face of the court, and desireth, by the favour of the bench, to have the liberty, according to his plain and weak understanding, to give the messenger an answer, which being granted him, he boldly stept up to him, and demanded his name, who made him answer, that his name was Mannering. 
Mannering (saith he;) that name was ill bestow'd on one who can so forget all manners, as to stand cover'd before a bench, upon which the majesty of his sovereign was represented: which manners (saith he) since thou wantest, I will teach thee: and withal, first snatching his bonnet from his head, trod upon it, then spurn'd it before him. At which the other, seing inraged, ask'd him, How he durst to offer that violence to one, who brought so strong a commission? Your commission (saith George) I cry your mercy, sir : and withal, desired the favour of the bench, that he might have the liberty to peruse it, which being granted, I marry (saith he, having read it) I cannot chuse but submit my self to this authority : and making an offer, as if he meant to kiss it, tore it in pieces. Mannering seeing this, began to stamp, stare and swear; but George taking him fast by the collar, so shook him, as if he had purposed to make all his bones loose in his skin, and drawing his dagger, and pointing it to his bosom, told him, He had devised physick to purge his cholerick blood; and gathering up the three seals, told him, It was these three pills which he must instantly take and swallow, and never more expect to return to his master : nor did he leave him, or take the dagger from his breast, till he had seen it down, and afterwards, when he had perceiv'd that they had almost choak'd him, he call'd for a bottle of ale, and said these words : It shall never be said, that a messenger shall be sent by such great persons to the town of Wakefield, and that none would be so kind as to make him drink, therefore here (saith he) Mannering, is a health to the confusion of the traitor thy master, and all his rebellious army, and pledge it me without evasion or delay, or I vow by the allegiance which I owe to my prince and sovereign that thou hast drank thy last already. Mannering, seeing there was no remedy, and feeling the wax still sticking in his throat, drank it off supernaculum; which the other seeing, Now (saith he) commend me to thy master, and the rest, and tell them, one George A Green, no better man than the Pindar of the town of Wakefield, who tho' I have torn their commission, yet I have sent them their seals safe back 
again by their servant. Whatsoever Mannering thought, little was he heard to speak, but went away muttering the devil's Pater Noster, and so left them. Every body commended the resolution of George, and, by his sole encouragement, purposed henceforward to oppose themselves against the insurrection of the rebels.

\section{CHAPTER V.}

How George wrote a letter to fair Beatrice, and of the success thereof: how it was deliverd to her; With other accidents pertinent to the history.

The news of this late exploit done by the Pindar was related at home by Justice Grymes to Beatrice, his fair daughter, which he flourish'd over with such an extraordinary commendation of his spirit and valour, that it added fresh flames to the fire, which was already kindled in her breast ; neither could any thing delight her more, than to hear him commended much, and praised often; and nothing troubled her so much, as that modesty would not suffer her to lay hold of an opportunity to acquaint him with her affection. George, on the contrary was as much perplex'd with the consideration of the difference of their births and estates; she an esquire's daughter, and he but the son of a yeoman : Her father a justice of the peace, his a farmer: she the heir to fair estate, and he born to so mean a fortune: she so rich, and he so poor. These discouragements drove him into so deep a melancholy, that nothing could cheer and comfort him : But then, when he again consider'd with himself, that all vertuous lovers still respected the person more than place, and still preferr'd the man above his means; and moreover, that he that fear'd not the face of a man, should not be daunted at the frowns of a woman; that faint heart never compass'd fair lady; and, that all contracts were first confirm'd in heaven before they could be concluded upon earth. Many of these conceptions, I say, continuing, he begins to devise by what means he might acquaint her with his affection; and knowing it was a commend- 
able ambition, rather to aim high than look low, and to raise his fortune than depress it, he thought to make proof, proposing to himself, that the worst that could befal him could not be death, but the most a denial; and having read, that it is a kind of ingratitude for one to be angry or incensed against any one for loving and honouring them, he therefore took pen in hand (as one loth to offend) and thought cautiously rather to express his own passions, than presumptuously to urge or perswade her affections (especially upon no acquaintance) and being a pretty poet, such as those times afforded, he wrote this fancy.

What art thou, beauty, not commended?

Or what is state, if not attended?

Or gold in ground

If sought not found?

What's favour in a prince offended?

All like smoak and bubbles prove?

And so it happens to my love.

What are pleasures, if untry'd?

Or what great suits, if deny'd?

Or what's to thee,

That cannot see?

Phœbus in his height of pride,

Fair may be, and yet we do annoy

That hope, yet helpless to enjoy.

What wealth, unless we may possess it?

Or vertue, if none dare profess it?

Even so it fares

With these my cares.

Then what my mistress, who can guess it?

Save you that only know it :

I have a heart, but dare not owe it.

In discovering his meaning thus overtly, he was afraid lest it might, perhaps, breed some distaste, yet it could not beget any 
anger; besides, if it came in question, he might thus excuse it : Cats may look upon kings. The air is free for all men to breath in: And, no man is barr'd the privilege to gaze upon the sun, because it shines freely upon all things. This might express he lov'd her, which she could bar no man from doing, and yet never be any injury unto her, and therefore he could incur no just taxation. Being animated with these hopes, he subscrib'd his name, seal'd it, and gave it to his boy, giving him a great charge in the delivery, and to watch some opportunity, when neither suspicious ears or eyes were about her, to shelter it in her private walk, or way, where she might be sure to find it, and take it up. The boy proved an apt scholar, and did as his master had tutor'd him: so good success he had, that the letter came safely to her hands. Upon her perusing it over and over, I may very well say, that never came tidings unto her of more comfort, to her (before) sad and discontented heart. And now all her study and care was how to return him a pleasing and sudden answer; for well she consider'd, that in these affairs there was no benefit in appearing coy, or delaying of time, in regard: she had many suiters propos'd unto her father, of equal means and fortunes, who were daily importunate for answer, and hourly solicited her by letters, and to all which she gave fair answers and seeming entertainment, but with a settled and constant resolution to run her fortune with her best belov'd George, and in this resolution she retired her self into her chamber, and having shut the door, took pen, ink and paper, and writ to him as followeth.

Prove but as constant as th'art bold,

Thy suit shall never be controul'd.

I am not to be bought or sold

For wealth or treasure.

Let suiters fret, and fathers rage,

Then keep me in an iron cage ;

Yet I myself to thee engage;

I'll use my Pleasure. 
Then be no longer discontent :

I write no more than what is meant. With this my hand my heart is sent.

Be't thine endeavour,

To lay some plot how we may meet, And lovingly each other greet

With amorous words and kisses sweet.

Thine for ever.

To this she subscrib'd her name, not standing to examine it, whether any thing had passed her hand rashly or unadvisedly: so great was her love, and so much her fear, either of discovery or prevention. She folded it up, and wore it in her bosom, but destitute of any safe means how it should be privately convey'd without any suspicion into his hands. In this distraction, walking one morning at some distance from her father's house, she espied William, the Pindar's boy, not far from the gate, whom she presently knew to be the same who had dropp'd the first letter, and imagin'd, that his lingering there was to find, if he could learn what success his master's suit had: so that perceiving the coast clear, and that no eyes were fix'd upon her, she let fall her letter in the boy's sight, and, as if she had lost it by chance, retired herself towards the house without any notice thereof, or more speaking; yet warily casting her eye on one side, to see whether he took it up or no. The lad, as crafty as she was cunning, took it up, and finding by the superscription, that it was not his master's hand, was glad within himself, as hoping he should now be the messenger of good news and tidings to his master, he presently runs home with it: but never was man more extacy'd than George, when he had open'd the letter and read it; in which profound contemplation I must leave him to speak of the Rebels, who hearing of the fame of fair Beatrice's beauty, the sole clear and refulgent star of the north, the earl, the Lord Bonvile, and Sir Gilbert, commanding then the country, had left the charge of the army to such as they best trusted, and invited themselves to the House of Justice 
Grymes who, tho' much against his will, was forced to give them a seeming welcome, and liberty to court his daughter: But she being constant in her former resolution, put them off with slight answers, resolving within herself to humour all, but to give satisfaction unto none of them. Whilst they were thus revelling, Mannering, having miss'd them in the army, brought to them that unpleasing answer from the town of Wakefield, relating to them every particular circumstance, and told how, not only he, but even they themselves were baffled by a peasant, one George A Green, who had not only torn their commission, but made him swallow their Seals. 'Tis no wonder they were much incensed at this affront, in regard it proceeded from a man of such low condition, neither wanted they anything in murmuring, by reason of his former disgrace, to incite them to revenge. That night they spent in feasting, and courting fair Beatrice, the earl promising to make her a countess at least: but on the morrow they took their leave of Mr. Grymes and his fair daughter, and coming to the army, they began to lay their heads together to consult how to take the Pindar, in whose only valour (by Mannering's Report) the whole might and strength of the town consisted. Whilst these things were thus debating, Sir William Musgrave, a grave old knight, associated with his son Cuddy Musgrave, a very valiant and successful gentleman, had raised a small power in the absent king's behalf, who, tho' fewer in number, waited an opportunity, upon the least advantage, to fall upon the rebels: but they were so strongly encamp'd, that he could not yet do it without great hazard to his person and people; in which distraction I must leave him for a while, to speak of other adventures pertinent to the story. 


\section{CHAPTER VI.}

How George A Green surpriz'd a spy, who was sent by the rebels to betray Sandon Castle, of which Sir William Musgrave and his son Cuddy had the keeping; and of sundry other passages.

BEFore what happen'd in Wakefield betwixt George and Mannering, the Earl of Kendal had hired a spy, and given him good store of money in his purse, to make tryal if either by favour or reward he could corrupt any man to betray Sandon Castle to him, in which the Musgraves lay with a very small garrison, and had fortified it against any assault which could be made by the rebels. This fellow strolling abroad, chanced to meet with George, whom he knew not, or ever had seen before, and entring into discourse, George perceiving that he was of the Baron's faction, sooth'd him up with smooth language, and began to commend the enterprize, as though it had a pretence of good to the kingdom and liberty of the commonwealth, and screw'd himself first so far into the other's bosom, as that he plainly told him what his purpose was, and withal shew'd him gold very plentiful, which he said, should be his that could devise any plot to bring this stratagem to pass. The Pindar, glad of this occasion, tells him, he would undertake for such a sum to bring him safe into the castle, in the dead of night, that he might at his pleasure set open the gates, and let in as many of his confederates as he pleased. George presently lays the plot, which was agreed to by the other, and thus it was: I am very well known to all that are in the castle, (says he) and am often sent unto them to carry them provisions. Now I would wish you to enter it in the close of the evening. I will take you on my back, (as if you were a burthen of corn, or some other commodity, such as I usually bring thither) and put you with in some corner of the castle that is least suspected: Upon which, in the dead of night, when you think all things very secure, you may get out, and so opening the gates, let all your friends and accom- 
plices in. This was deliver'd with so sober and serious a countenance, that the sack was instantly provided, and he put into it; which was no sooner done, but George lifts it up upon his shoulders, and nimbly carries Sir Troth in ken of the castle, when taking a slering-cord out of his pocket, with which he used to lead strays to the pound, fastned it to the mouth of the sack, and coming to the tree just before the castle-green, and hoisting him more than twice his height from the ground, fasten'd the cord, and leaving him betwixt heaven and earth tottering in the air, bids him farewel, and at his parting left this inscription pinn'd upon his breast.

Whoever next shall pass this way,
A little I entreat to stay ;
And if he'll dain to look so high,
He'll see a most notorious spy.
This sack too I wou'd have you think,
More wholesome is to hang than drink ;
Because in this a plot was laid,
By which you all had been betray'd.
Use him according to your skill,
Who sought this night your blood to spill,
If who did this you shall enquire,
'Twas George A Green did hang him there.

George having done this, trudg'd as fast as he could towards the town, to look to his charge; he was scarce gone out of sight, when Sir William Musgrave and his son Cuddy, walking about to take the evening air, Cuddy by chance casting his eye, espies this strange wonder, and showing it to his father, they drew nearer to be satisfied of the novelty, and having read the bill upon his breast, they might easily perceive, as the proverb has it, What Pig was in the Poke, and what commodity the sack contain'd, when presently cutting him down, with such haste, that he had almost broke his neck with the fall, they open'd the sack, and found the traitor; upon which they sent him to the castle, where they made him confess all the purposes of the rebels, and at the same time much commending. George A Green 
for his witty conceit, as also for his truth and fidelity to his prince and sovereign. But now, for variety's sake, I will break off this discourse, tho' somewhat abruptly, and speak a word or two of Robin Hood, his maid Mariana, and his bold yeoman, who at this time kept revel rout, in the forest of Sheerwood, \&c.

\section{CHAPTER VII.}

Of Robin Hood, Maid Mariana, and the bold Yeoman, and how envying the fame of George A Green, and the rumour of the beauty of fair Beatrice, Mariana could not be in quiet, till it could be tried whether Robin or George were the valientest, or she and Beatrice the fairest.

My purpose is not to trouble the reader with any tedious discourse, by telling of you, how Robin Hood was first earl of Huntington, and for his vertue suppress'd and turn'd out of all his possessions by the covetous bishop before spoken of, and the person whom the king at his departure to prosecute the wars, had made governour of the kingdom; nor how she that stiled herself maid Mariana, was Matilda, daughter to the Lord FitzWalters, and having discovered the royal affections of Prince John, retired herself into the forest of Sherwood, for the true love and affection she bore unto her best beloved Robin; which history would require a small volume of itself, but I only propose to speak so much of them in brief, as is pertinent to the history now in hand. I entreat you to take it into remembrance, that George A Green for his strength and valour, and Beatrice, the daughter of Justice Grymes, for her beauty, were the most famous in all those northern parts : that Robin and his Mariana, before unparallell'd, were now scarce spoken of, insomuch, that an ambitious emulation was the cause that Robin and George, Mariana and Beatrice afterwards grew into great quarrel and zcquaintance, as shall be made more manifest by the sequel. It was their custom still, when he and his yeomen went to the chase, that they all in their green, being arm'd with good yew 
bows, and every one of them a sheaf of arrows hanging at their girdles, came early in the morning to the place where he lay, to call him up, with a song to this purpose :

Now wend we together, my merry men all,

Unto the green wood side-a, And there to kill a buck, or a doe,

Let your cunnings all be try'd-a.

No man may compare with Robin Hood, With Robin Hood's Slathbatch and John-a,

The like was never, nor never shall be,

In case that they were gone-a.

Then let us not linger away the time,

But hie to the merry green wood-a.

And there to strike down a buck or a doe,

For my master Robin Hood-a :

For my master Robin Hood-a.

With this musick of well tun'd voices, it was their custom to salute him, and after attend him to the game. But it happen'd, that having had for the space of four or five days together very rainy and tempestuous weather, Mariana all this time was in a deep and sudden melancholy, the cause whereof he could by no means wrest from her, though he had labour'd it by all fair means and much entreaty; insomuch, that he began to be a little jealous of her love, as falling off from him, and inclining to Prince John, who never left off soliciting her by messengers and letters, with sundry gifts and presents : but having had sufficient proof of her faith and constancy, he then began again to blame and chide his diffidence and mistrust, and attribute her sadness and melancholy to the gloomy, unseasonable and tempestuous weather, which might easily be the cause of that her indisposition. To expel this (for nothing could be more grievous unto him than to behold her sad) he attiring one of his pages in the habit of a wood nymph, and having provided a curious and costly mantle, wrought in divers colours, he by him presented it unto her as she was sitting solitary, with great reverence, with this song, a sweet and delicate consort of musick 
being placed behind her unseen, who with their soft strains thus began :

Beauty's rose and vertue's look, Angel's mind and mortal's book, Both to men and angels dear.

$\mathrm{Oh}$ ! thou fairest on the earth, Heaven did smile in your first birth, And since the days have been most clear.

Only poor St. Swithin now Doth fear you blame his cloudy brow : But that your saint devoutly swears,

It is but a tradition vain,

That his much weeping causeth rain For saints in heaven can shed no tears.

But this he says, that to the feast Comes Iris an unwelcome guest, In her moist robe of colours gay. And when she comes, she ever stays For the full space of forty days, And, more or less, rains every day.

But this good saint, when once he knew This rain was like to fall on you, (If saints cou'd weep) he wept as much,

As when you did the lady lead, That did on burning iron tread;

To virgins his respect is such.

He gently then bid Iris go

Unto th' Antipodes below;

But she for this more sullen grew.

When he saw this with angry look,

From her this rainy robe he took, Which here he doth present to you.

It's fit with you it shou'd abide, As men's great wonder, vertue's pride : Yet if it rains still as before,

St. Swithin prays that you would guess,

That Iris doth more robes possess, And that you wou'd blame him no more. 
The song was no sooner ended, when that Robin appear'd, who in the stead of friendly thanks and courteous salutation, now drew these words from her, "I may wonder, sir, that you can be so stupid and gross to sooth up your self, or to flatter me, to call me the pride of nature and wonder of mankind, when both our lustres are so suddenly eclipsed. Within these few months, who so famous for magnanimity and valour as Robin Hood? And who more renowned for chastity and beauty, than his Mariana? who are now scarce thought on, much less spoken of at all. Are not all the mouths of the multitude only fill'd with the brave deeds, valiant acts and exploits perform'd by George A Green, the famous Pindar of Wakefield; and of the refulgent sun of the north, fair Beatrice, daughter of old Grymes of the north, and both preferr'd before an earl, and I the daughter of an earl; whereas the Pindar is but a Yeoman, and she the child of a mean gentleman; and yet these two very far exceed us in the public voice of the kingdom. Now, can you blame me to be struck into this deep melancholy, hearing of them such loud acclamations abroad, and of ourselves scarce any rumour or report at all?" When she had thus freely utter'd her thoughts, Robin on his part, commended her noble emulation, and demanded of her what in this case was fittest to be done. To whom she reply'd, "That as two suns could not shine in one element, neither could two unparalleled beauties be refulgent in one country, without contending which should have the priority:" then farther councell'd him, that for both their honours, they should travel as far as Wakefield, where he should try masteries with George which was the better man, and she to show herself unto Beatrice, upon which true judgment might pass which was the fairest woman. Robin, than whom a more undaunted and bolder spirit was not known to breath in that age, was not a little pleased to hear, that that was the only cause of her discontent, when taking her by the hand, and raising her from the ground, he bad her be of good chear, for before that month was expired she should be lady of her wishes; and having seal'd this with a sweet kiss, he gave instantly order for his 
journey; but privately, lest being taken from his guard of archers (he being outlaw'd) it might prove some danger to his person. $\mathrm{He}$ therefore selected out of the rest only three of the stoutest amongst his crew, namely, Slathbatch, Little John, and the Fryar, for his attendants, and these were to have the charge of his fair Mariana in the journey, in pursuing which I leave them for the present, the success whereof you shall have more at large hereafter.

\section{CHAPTER VIII.}

How the Earl of Kendal and the Lord Bonvile laid an ambush to betray George $A$ Green, and the success thereof: how he prevented the earl's policy and what happen'd thereupon.

As the name of George grew greater and greater, so the displeasure of the rebels was increased against him more and more, especially for those two merry affronts, the one against Mannering, the other against their spy, of whose surprizal they had lately got intelligence, and therefore thought to defer their revenge no longer : wherefore they having placed a strong ambush, thought they had him fast: for the earl, Bonvile, and Mannering, thinking to lay a bait for him, which he could not chuse but be nibbling at, being well mounted, broke down a strong fence, and put in their horses to feed in the corn. George, whose careful eye was ever watchful over his business, soon espied them, and call'd his boy, commanding him to drive them to the pound. These disguised persons ask'd him what he meant to do with their horses? Whether he would steal them before their faces? and began to offer the lad violence; which George perceiving, and as yet not knowing them, said, "It was base and discourteous in gentlemen, such as they seem'd to be to do an injury in that nature, and then to maintain it by being obstinate in it." To which the earl answer'd, "That these belong'd to him, and were put into the corn to feed in despight of him, or who should say nay." The Pindar seeing no more to appear, thought that their great words should not so carry it away, and told them in plain 
terms what a forfeit they had made, and what amends they should make, or else as they rode on horse-back thither, they should go on foot home; and then he swore (by no be-garrs,) but by the life of good king Richard, he would see it perform'd. The earl hearing him name the king, told him, "That he was but a base groom and peasant, and had affronted one, that ere long would be king Richard's better." The word was no sooner from his lips, but George who could not endure such indignity breath'd against his sovereign, struck him with his staff a sound blow betwixt his neck and shoulders, telling him "that he ly'd like a traitor, and he would make it good upon his carcass." At which Mannering stepping forth told him, "That he was a villain, and had struck an earl ;" who answer'd him with a word and a blow, "That as before he had unseal'd his commission, so now he would sign him a pass-port into another world," and withal laid him at his foot. The Lord Bonvile seeing this, gave the watch-word to the men in ambush, which were about some forty in number, who encompass'd him round: which George seeing, he began to apprehend, that whenever force was near the foil, the surest recourse was to policy, and thereupon craved a parley, which was obtain'd, and George began as followeth: "I wonder, sir, that you, being a nobleman, an earl, and, which is more, the general of so puissant an army, will be so injurious to your power, as to assault and circumvent a poor single man, and of no renown and reputation, with such unequal odds. What have I done more to your person abusing my king, than you would have. expected from your peasant Mannering, if he had heard your honour reviled and abused? If you expect from him the duty of a peasant, will you deny me, or blame me in the same duty to my king? Besides, my lord, if you can make it appear, that your cause is just, and your undertakings for the good and benefit of the commonwealth, I shall be glad to follow you, and to draw my sword in your quarrel." He was about to proceed, when Bonvile taking the earl aside, persuaded him to take his friendly offer, making no question, but if they could insinuate him into their faction, he might persuade others, but 
especially the town of Wakefield to come under their peaceable obedience. This the earl approving, he spoke to him after this manner: "Thy submission and apology, which thou hast so boldly utter'd, hath taken off my spleen, and mediated with me for thy person and pardon:" and thereupon commanding his ambuscade to their camp, he thus proceeded: " My rising in arms is to suppress the insolencies of a proud prince and an insolent prelate, who have much insulted on the privileges and liberties of the commonwealth. For the common good I stand; but the greatest inducement that drew me into this cause was a wizard's infallible prophecy just at my very birth, who thus calculated my nativity, That king Richard and I should meet in London, and he vail his bonnet to me." To whom the Pindar reply'd, "Ay marry, my lord, you speak to the purpose, indeed, and upon this encouragement $I$ am willing to be but your soldier and servant: but, my lord, might I humbly presume to advise you, the better to justifie your proceedings, and for a more compleat notion of your affairs. There is an old reverent man in a cave not far hence, who is a great predicter, and was never known to fail in that speculation. It were not amiss to take his advice and see how nicely his calculation jumps with the former. Please you this night to take some simple provision, such as my poor cottage can afford; my boy shall lead you to his cave, where you may be satisfied of all your doubts and difficulties." The motion was accepted, and concluded on. The morning was much long'd for, and came. The Pindar had provided himself early, and convey'd all things necessary for his purpose into the place last nam'd. The boy conducted them thither, where the Pindar having disguised himself like an old Hermite, such as he had before describ'd, and counterfeiting his voice, told them of all such things as they had before related unto him, at which they wonder'd, calling them particularly by their names, and discover'd unto them the intent of their coming. But suddenly in the midst of their discourse, he throws off his counterfeit habit, and with his good staff, which never fail'd him at his need, he so bestirr'd himself, that, after some small resistance, having no 
hole to creep out at, and being without their ambush, he first disarm'd them, then seiz'd them as his prisoners; and having provided certain officers, with a strong guard, he sent them to the House of Justice Grymes, by him to be safely convey'd to London, to be disposed of by the king, who was now return'd from the holy wars in Palestine.

\section{CHAPTER IX.}

How George A Green, having seiz'd the arch-rebels, plotted a means how to be possess'd of his most beloved Beatrice, and what afterwards became of Armstrong and the army.

As the Pindar was vigilant and careful for the honour of the king, and the welfare of the publick, so he was not altogether forgetful of his own private affairs, especially of that great affection which he bore to fair Beatrice, betwixt whom at all convenient opportunities there had pass'd entertaining letters, she solemnly protesting to him to let slip no occasion of freeing her self from the close confinement of her father's house, and to fly unto him as her only protection and sanctuary. Hereupon he consider'd in some time a devise to accomplish it, viz. That his boy Willy should put himself into the habit of a seamstress's maid, and furnishing him with lace-bands, and other commodities belonging to the trade, he should with least suspicion get admittance to her. Fortune so well favour'd the design, that the boy came to shew his wares, when her father was busied in receiving the Earl of Kendal and his accomplices, which prevented a too curious enquiry about the lad; so that he was freely admitted to shew his wares unto his daughter, who was then in her chamber. He was no sooner entred, but shutting the door, he disclosed himself, with the intent of his coming, namely, that Beatrice should put her self into the habit of a seamstress, and muffling her face, as if she had the tooth ach (for in that posture the boy came in) and taking her box and laces, should pass thro' the gates, leaving the boy in her habit to answer her father, and 
to stand the peril at all adventures. Glad was fair Beatrice of the motion, and with as much speed as willingness put off her own cloaths to put on the other's. Willy was as nimble as she, and was as soon ready to be taken for Mrs. Beatrice, as she for a seamstress's servant ; so that she easily, by holding her handkerchief before her mouth, as troubled with a pain in the teeth, past thro' the people, and got out of the gates unquestion'd, where we leave her on her way towards Wakefield, and Willy in her chamber to answer her escape, and return to Armstrong.

$\mathrm{He}$, in the earl's absence, had the charge of the camp, who thinking himself as secure as the earl had appear'd to be negligent, was set upon in the night by Sir William Musgrave and his son Cuddy, who took him when he was careless and asleep, by which means they quite discomfited the whole army, and young Cuddy fighting with Armstrong, took him prisoner hand to hand. Glad of such a present to welcome the king home from the holy war, and with such progress, he made preparations to hasten with him to London, and to present him as a pattern of his prowess.

In the interim, to return again to Justice Grymes, the greatest part of his business being over, he stole privately to see his daughter, in her chamber; but finding another maid, as he thought, sit sleeping in her habit, he espied a face with which he had not been acquainted; and thereupon he grew first into amazement, and afterwards, fearing what he suspected to be true, he demanded of the boy Willy, first, what she was? Then, how she came thither? Who, with a demure countenance, answer'd, "she was a poor gentlewoman, and came thither upon her legs." Grymes then roughly ask'd him, what was become of his daughter? "Truly, sir, that seamstress's habit which well becomes your daughter hath been the means to convey her abroad; but lest her chamber should be found empty, she left me here as a pawn till her return." The justice was still more and more enraged, threatning with all manner of threats to use all the rigour that the law could possibly afford towards punishing him, without he told him the truth. 
But before this matter could be fully ended betwixt the justice and Willy, he was call'd down again about his commonwealth business, which was instantly to be dispatch'd out of hand ; yet still this young impostor run in Grymes's mind, and had too great an impression upon his affections, therefore he lock'd her in his chamber, and took the key along with him, with this resolution, that if by her means he had lost a daughter, (he being a widower) if she could give a good account of her birth and means, she should make him a wife. These and the like meditations somewhat moderated his choler for the present, therefore he made what expedition he could to dispatch off his prisoners, that he might have a more speedy visit in her quarters. But I nust leave them there, to return to Robin Hood and his fair Mariana, who had now by this time overcome the greatest part of their journey, and shew what happen'd to them at their meeting with the Pindar and his Beatrice.

\section{CHAPTER $\mathrm{X}$.}

Of that which happen'd between Robin Hood and his Mariana, and George $A$ Green and his Beatrice; and how their great animosity was at length reconciled, and of other pertinent accidents.

THE great joy at the meeting of George and his Beatrice was unspeakable, and the rather, because so unexpected. But as there is no day so clear, but there will appear some clouds to eclipse the beauty of the sky, so in. their great alacrity and abundance of present content, there was one thing that appear'd troublesome and grievous unto them, namely, the danger Willy had incurr'd for their sakes. There was no sudden remedy could be used, and so their fears continued, lest the justice, ill inclined and deluded, should use him with the utmost and uncommon rigour and violence. To divert this melancholy, and also to devise the most safe course for his delivery, George one evening took Beatrice by the arm, and willing to show her the pleasant 
and delightful fields full of green corn, and that she might take the benefit of the fresh and wholesome air, when on a sudden they espied a company of rude and irregular fellows, (as they thought) break a wide gap thro' an hedge, pluck up the stakes, and without making choice of any path, tread down the corn and make towards them. This injury George's great spirit being not able to suffer, he made as much haste to meet them as he could, tho' Beatrice by many entreaties would have held him back : but the nature of so wilful a wrong prevailing above her entreaties, or the care of his own safety, he took his staff from his neck and bad them stand, and not only to give him an account, but present satisfaction and recompence for the damage they had done. Robin and his company had put off their forest green, and left their bows and arrows behind, and had only weapon'd themselves with good strong quarter-staves, according to the fashion of the country, who appearing to take the Pindar's affront in great scorn, told him, all ways were alike to them, they being travellers; and when they could make the next way, they saw no reason they had to go about: they had done no damage, or if they had done any, the amends lay in his own hands. "Marry, and so it doth," answer'd the Pindar, "for I have that in my hand, that shall call you to a dear reckoning; but since you seem to be men furnish'd both with limbs and spirit, if you be such, and not base and effœminate cowards, come not all upon me at once, but one by one, and then have at you, if you were twice as many more;" and the motion pleased them. Slathbatch entreated to be the first, and was the first that was laid at his master's feet. Little John would needs revenge his friend and fellow's quarrel, but dipt his finger in the same sauce. At this Beatrice encouraged, began to laugh; but Mariana, who had all this while observ'd her, did nothing but fret and vex. In the mean time, the fryar had buckled himself up for the third encounterer; but George perceiving him to be a churchman by his shaven crown, would have refused him, but the nimble fryar would needs have a bout with George, who answer'd, that since he begg'd a cudgelling at his hands, he was bound in conscience 
to deny the church nothing, and he would give it him surely; for the fryar was laid soon sprawling on God's earth. Still Beatrice smiled, and still Mariana fretted; and whilst Robin and George were preparing for the combat, for Robin was willing to give him liberty to breath, Mariana stept to Beatrice, and call'd her, Proud minx, and bid her now turn her laughter into tears, for she had a companion coming, who would not only revenge his friends, that were disgraced, but beat, baffle, and disarm her lubberly sweet-heart. Beatrice, who was of an high spirit, and the more embolden'd by the present valour of her George, came up close to her, and told her again, "thou shalt find as much difference betwixt my champion and thine in manhood, as betwixt the true and natural colour in my cheeks, and thy painted and plaister'd beauty, dawb'd upon in wearing." These words were enough to begin new wars, and they were going together by the ears at the instant, and much ado had the fryar and the rest (now recovered) to keep them asunder. But the two virgins, who would have been actors themselves, were now forced to be spectators of one of the bravest combates, that (I dare say) was ever fought in Wakefield. Long it lasted, and with great difficulty they contested which should be victor: at length, both being tired and weary, (saith Robin) "Hold thy hand, noble Pindar, for I protest thou art the stoutest man that I ever yet laid my hand on." To whom the Pindar reply'd, "Recal thy words, for thou never yet laid thy hand on me." Robin reply'd, "Nor will I, noble George, but in courtesie. Know then, I am Robin Hood, this is my Mariana, and these my bold yeomen, who are come as far as the forest of Sheerwood only to prove thy valour, and to be spectators of Beatrice's beauty, both which $I$ have found to exceed that liberal report which fame hath given out of them." At which words the Pindar embraced him, and told him, "that, next to King Richard, he was the man he most honour'd, and craved pardon of Matilda, otherwise call'd maid Mariana." He caused Beatrice to submit her self unto her on her knees, to which she willingly assented; but the sweet lady would by no means suffer her, 
but lovingly kiss'd and embraced her, who confess'd, that she could not have thought that the north country could have bred such a beauty. Much joy there was on all sides : so George invited both of them and their friends to an entertainment, wherein he show'd himself to be as bountiful in mind, as he was famous in the strength of his body; for their welcome and chear was nuch above their expectation, as better suiting with a large mannor-house, than a thatch'd cottage. Nor did Robin come altogether unprovided from Sheerwood; for he had both money and divers heiffers laden with provisions of all sorts, which follow'd him on purpose to feast and revel with the Pindar, where I leave them in all the content and felicity that may be, and proceed to King Richard upon his new welcome from his wars in Palestine.

\section{CHAPTER XI.}

How King Richard, after his Return, by reason of many Complaints made unto him, order'd those Abuses, which in his Absence had been committed by the Prince and Bishop, to be redress'd: How the Rebels were presented unto him, and his Disposing of them; and how George $A$ Green was reported of to the King.

RichARD, the first of that name, for his great hardiness and magnanimity surnam'd Cuer de Lion, king of England, after some years spent in the holy wars, was received into the kingdom with much joy and solemnity, which was no sooner past over, but divers complaints petition-wise, were deliver'd unto him concerning sundry oppressions made by the ambitious bishop, and insolencies committed by the prince, which, by the advice of his council, he studied how to reform. Those being brought to some reasonable effect, he then began to consider of fresh forces to be suddenly raised towards the suppression of those rebels in the north. In the middle of these considerations, there arriv'd at London young Cuddy Musgrave, with 
Sir Gilbert Armstrong, and presented him a prisoner to the king, telling the manner of his surprizal, and how the grand army was defeated, which was much further'd by the means of one George A Green, Pindar of the town of Wakefield, who by taking a spy of their's, and hanging him up before the gate of Sandon castle, they thereby discover'd the strength of the rebels, and learn'd how and when to take them careless and unprovided, which was the occasion of so famous and fortunate a victory. The king had scarce leisure to commend their care and diligence, but Justice Grymes likewise, before the king could make suffcient enquiry what became of the others, who were the chief of the rebellion, came and presented, as from George A Green, the Earl of Kendal, the Lord Bonvile, and Mannering; representing it with such an exact testimony of the Pindar's valour (as relating from the beginning all such remarkable things as are spoken of him in this history) that his majesty made open protestations, that he was glad to have so good and valiant a subject, when turning towards the earl of Kendal, the king in meer derision vail'd his bonnet to him, and said withal, "My lord, you are welcome to London. I did not think at my departure you and I should have seen one another here upon these terms." At which salutation the earl, remembring the former prophecy, cursed the wizzard, whose vain and idle prediction had been the occasion of his ruine and downfal. In short, the rebels were all committed to the tower, there to remain till their further trial. This done, the king enquiring further of the Pindar, and finding more and more to be spoken in his commendation, purposed to disguise himself, and, with the earl of Leicester only, who had been a co-partner with him in his wars, and Cuddy Musgrave for their guide and conductor, to travel into the north, to take a view not only of this so famous yeoman, but to listen withal how he was beloved in those parts, and his government beliked of. In this interim of time, whilst the king was preparing himself and the rest for the journey, Justice Grymes being discharged of his prisoners, and having leave to depart into the country, with great thanks from the king for his 
late great care, he long'd to be at home to take a better view of that supposed girl, who was left, as it were, as a pawn. for his daughter. Great charge he had given, that she should be safely kept and well attended, but to trust her no further than her chamber, till he himself came to take her to a further examination, which, by reason of his former pressing business, he had not leisure to do. We may suppose him now on his way towards the country, whither the king himself intended his private progress.

We must now look back again to Robert, earl of Huntington, and Matilda, otherwise call'd Robin Hood and maid Mariana, whom we left feasting with George A Green and his sweet Beatrice, who, besides their courteous entertainment, was willing to shew his guests all the sports and merry passages of the country.

\section{CHAPTER XII.}

Of the Town of Merry Bradstead, and a Custom therein, called Trail-Staff, observed by the Shooe-Makers, otherwise called, The Gentle Craft. How the King, Leicester, and Cuddy past through this Town, and of their meeting with Robin Hood, and George A Green, and what further happen'd.

There is a town not far from Wakefield, which is called Bradstead, where the shooe-makers, by long tradition, have observ'd a custom, that no person shall walk thro' the town with his staff upon his shoulders, unless he will have a bout or two with some one or other of the gentle craft: but if he trail'd it after him, he might pass peaceably without any trouble or molestation; for there was none would say so much as, black was his eye. It so happen'd, that the king's way, with Leicester's and Cuddy's, happen'd to lie thro' this town, who being disguised like country yeomen, and it seems not well acquainted with the custom, like honest plain travellers, (as the use was then) walk'd boldly with their staves upon their necks; which being espied by the trade of shooe-makers, three stout fellows of them, with every one a 
good staff in his hand stepp'd out of their shops, and beat their's from their shoulders. The king having had genteel entertainment in all other places, wonder'd at such rudeness, and gently demanded of them the reason of that violence then offer'd them. They answer'd him again, "that it was a privilege they had, which they had observed time out of mind. Their fathers had kept it, and they would leave it hereditary to their successors." They demanded of them, whether they had any such patent from the king, who answer'd again, " they did not stand upon patents, neither knew they any law for it, saving staff-ends-law; and that all their fraternity were ready to maintain it with downright blows, and therefore bid them peremptorily to handle their staves for there was no other way to save them from a present and sower banging." The king told them, "they were peaceable men, and rather than to break their custom, or to enter into unnecessary "quarrel, they would drag their staves after them," and so did.

Whilst these things were debating, came George A Green disguised, with Robin Hood and his yeomen, with every one a good bat on his neck. George having told Robin what mad merry custom the jolly shoemakers maintain'd, and bringing him that way on purpose only for sport's sake, and to try what mettle they had in them, espies the king, Leicester and Cuddy to trail their staves after them; at which sight being moved, "See, Robin, (saith he) three lusty, able, proper fellows, that dare not advance their staves for fear of the shoemakers." Then asking Robin Hood, what he thought of them? $\mathrm{He}$ answer'd, "That he took them to be base cowardly fellows, and that it was pity such goodly shapes should cover such timorous and degenerate spirits, very cowards." So, saith George, I'll presently correct them, and coming up close to them, he first began to upbraid them with their fear and cowardize, and afterwards concluded, that if they did not presently raise their staves, and bear them up, maugre any that durst to interpose, he himself would cudgel them more soundly, than the townsmen were able to do: Had they ex- 
press'd themselves to be valiant men, they should have been excused. The king answer'd, "I was never put to so hard a choice, as to be beaten, fight or fight not:" and so desired to be excused, since they were travellers, men of peace, and altogether unacquainted with any such hard customs. His words were scarce ended, when out came a crew of shoe-makers, every man well appointed, and told them, that even they should obey their custom, bid them down with their may-poles, and withal began to strike their staves from their necks. That was the watch-word which the Pindar and his comrades look'd for, and now began the greatest combat that was ever seen in the street of Bradstead: for Robin and George began to clear the whole street before them, insomuch that all the town rose, masters, apprentices and journey-men: not a staff to be found, that was not used in defence of their liberty. There was nothing now thought on but havock and pall mall; the Pindar himself seem'd to be pounded in amongst them, and many a shoe-maker was brought to his last, and many a staff was shiver'd, and made skewers : crack'd crowns went current; tho' many were found to take them against their wills: the shooe-makers themselves thought fit to give ground, who had vow'd to lose bodies and souls in the quarrel, and run to shelter themselves most shamefully. This put the king and Leicester in mind of the great conflicts betwixt them and the infidels; for even here no christian could find favour or mercy during this battle, and the victory was still doubtful; for what the gentle craft wanted in strength, they had in number; yet neither party were heard to sound a retreat, till at length the Pindar's disguise falling off in the battle, he was no sooner discover'd and known, but the shoe-makers cry'd, Trail; they flung down their staves, and cast up their caps, and bid them welcome to the merry town of Bradstead with a loud shout. No man thought more of his hurt, for the joy they had to see the Pindar; for as the Trojans thought such more honour'd than harm'd that were hurt by the hand of Achilles, so amongst them it was held rather a dignity than a disparagement to wear 
any honourable scar made by the hand of the Pindar. George having breathed himself a little, thank'd them for their lives, and presently commanded a barrel of the best and strongest ale should be brought and set in the streets, which was instantly done and paid for. Then George entreating them, as they tender'd him, to bid his friends welcome, they then came about him like gnats : but when George had told them who they were, namely, Robin Hood and his bold yeomen, who had travell'd as far as from the forest of Sheerwood to prove what mettle was in their fraternity, this was as good as a plaister to every man's broken head; for, with a joint acclamation, they gave them a loud and hearty welcome. All this the king observing, and perceiving, the two prime men to be there present whom he had such a great desire to see, call'd to Cuddy, and bid him provide him the royal habit, which he had caused to be brought, in case of any needful occasion. In the mean time the champions being all placed in the midst of the street, and beleagured on all sides, the Pindar call'd for a deep wayssel-bowl, and filling it brime full, and falling down upon his knees, all the rest doing the like, he said, "Here, Robin Hood, I drink an health, to good king Richard, and thou being the best man in the company, shalt first pledge it. That done, let it go round amongst the shooe-makers:" but casting his eye aside, continued, "only I except from this health those cowardly travellers, who are unworthy to drink so brave and valiant a prince's health, who for fear durst not carry their staves upon their shoulders." Off went the health with a great shout, and was fill'd for Robin, which he had no sooner drunk, but the king casting a princely mantle about himself, and Leicester and Cuddy plucking off their disguised habits, stept in amongst them, and said, "Nay, Robin Hood, tho' you were of late held to be the best man in the company, yet, by the Pindar's good leave, give king Richard licence to be the third man at least to drink his own health." These words, graced with his majestical habit and countenance, much astonish'd them on a sudden, but especially the shoo-makers. 
who made no question, than that they were all no better than food for the gallows. But at length the Pindar (whom nothing, save so great a majesty, was able to daunt) recollecting himself, most humbly submitted unto the king, desiring his grace and pardon for those vile and rude insolencies committed against his sacred majesty; whom the king as graciously pardon'd, and taking Robin Hood from his knees, saluted him by the name of Robert, Earl of Huntingdon, assuring him, upon his kingly promise, all his lands and revenues, injurious seiz'd and extorted from him by the Bishop of Ely and Prince John, should be restor'd unto him; and that his Matilda, daughter to the Earl of Fitz-Walters, should be conferr'd upon him, maugre those indirect means by which the prince his brother had insidiated her honour. This news of the king was presently spread abroad into the country. Amongst other homages, the king call'd for George A Green, and bid him kneel down, because that, for his great services done to the state, his purpose was to honour him with the style of knighthood; but he humbly besought his majesty, that he might not exceed the title of his father, who liv'd and died only a poor yeoman in the country: that his service, how mean soever, did shew better in that humble and mean state in which he lived, than if he were burthen'd with the greatest titles of honour. In this interim, the shooe-makers had retired themselves to consult how to appease the king's anger, who they made no question was most grievously incensed against them; when Mariana and Beatrice came and submitted themselves upon their knees, the one presenting unto his majesty a rich belt, wrought with her own hands for her Robin; the other a curious scarf, beseeching his majesty to accept of them, not according to their worth, but their tender of good will and loyal meaning towards his sacred person. The king wondering what those choice beauties should be, and being resolved, most graciously accepted of their presents, took them from their knees, and lovingly embraced them, giving them thanks for their fine presents which he promised should be bountifully 
remembred. Now enters Grymes, bringing in Willy, the Pindar's boy, and first desires justice of the king against George for stealing away his daughter; and that if it were so, that the matter was so far past, that he must needs enjoy her, that it would please his majesty that she who was left in her place should be at his free disposal. The king granted both, and first having in his princely goodness reconciled all matters betwixt old Grymes and the Pindar; as that he should firmly enjoy her, with all his estate, after his decease, he next demanded, how he would have the other virgin disposed of? who desired her for his wife: which the king had no sooner granted, but Willy discovering himself, it made a general shout and laughter unto all then present, with all which whilst they were much delighted, the old justice was as much or more displeased. The shooe-makers came, and presented the king with a country morris-dance, in which nothing was omitted that could be prepar'd on a sudden to give content, which was so well order'd, that it much pleas'd him, who bad them ask what in reason they could demand, who only petition'd, that the law of trial-staff, which they had held only by tradition, might still remain; and that it would please his majesty, in regard he had vail'd his staff unto them, it might be sufficient and secured to them for ever; to which his majesty graciously and willingly consented. 



\section{THE PLEASANT HISTORIE OF TOM A LINCOLNE, THE RED ROSE KNIGHT}





\section{XI.}

THE PLEASANT HISTORIE OF TOM A LINCOLNE, THE RED ROSE KNIGHT,

FOR HIS VALOUR AND CHIVALRIE, SURNAMED THE BOAST OF ENGLAND.

\section{CHAPTER I.}

How King Arthur loued faire Angellica, the Earle of Londons Daughter: and likewise of the birth of Tom a Lincolne.

When as King Arthur wore the imperial diadem of England, and by his chivalrie had purchased many famous victories, to the great renowne of this mayden land, hee ordeined the order of the Round Table, and selected many worthy knights to attend his Majestie; of whose glittering renowne many ancient histories doe record; and witnesse to all insuing ages.

This worthy prince, upon a time intending to visit the city of London, with some few number of his knights, came and feasted with Androgius, being at that time Earle of London; whose house (as then) was not onely replenished with most delicate fare, but grac't with a number of beautifull ladyes who gave such a pleasing entertainment to King Arthur and his knights, that they were ravished with pleasure, and quite forgot the sound of martiall drums that had wont to summon them forth to the fields of honour. Amongst these glorious troopes of London ladyes, Angellica the Earles daughter, had the chiefest praise for 
beauty and courtly behaviour; for even as the silver shining moone in a winters frosty night, surpasseth the brightest of the twinckling stars, so faire Angellicas sweet feature exceeded the rest of the ladies; whereby King Arthur was so intangled in the snares of love, that by no means he could withdraw his affections from her divine excellence. $\mathrm{He}$ that before delighted to tread a weary march after Bellonas drums, was now constrained to trace Cupids pleasures in ladies chambers; and could as well straine the strings of a lovers lute as sound a souldiers alarme in the field: her beautie like the adamant drew his steeled heart to lodge in the closure of her brest: and no company delighted so much the love-sicke king as the presence of faire Angellica. So upon a time as he stood looking out of his chamber window, he espied the mistris of his soule sitting in a garden under a bower of vines, prettily picking the ripest grapes with her delicate hands, and tooke such pleasant paines in that mayden-like exercise, that the well coloured blood in her face began to waxe warm, and her cheeks to obtaine such an excellent beauty, that they seemed like two purple roses intermixt with hawthorne-buds : whereby King Arthur grew inamored upon her, and stood for a time senseless through the extreame passion he tooke in beholding her beauty; but at last, recovering his senses, he spake to her in this maner.

Oh most divine Angellica, natures sole wonder, thou excellent ornament of beauty, thy lovely face painted with a crimson dye, thy rosicall cheecks surpassing snow in whitenesse, thy decent necke like purest ivory, hath, like a fowler's net, entangled iny yeelding heart, whereby it is for evermore imprisoned in thy breast. Oh that the golden tresses of thy dainty haire which shine like the rubys glittering in the sun, had never twinckled before my ravisht eyes, then had my heart injoyed his wonted liberty, and my fancie been free from lovers vaine imaginations. Thus, and in like maner complained the king unto himselfe, seeking by all meanes possible to exclude love's fire from his brest. But the more he strove to abandon it the more it increased, and feeling no pollicie might prevaile, but 
that this burning torment must of force bee quenched with her celestial love, hee descended from his chamber, and went bouldly into the garden; where, taking Angellica by the hand as shee sate upon a bed of violets, which, as then, grew under the arbour, in this manner began to court her.

Faire of all faires (sayd the king) divine and beautious paragon, faire flower of London, know that since my aboad in thy father's house, thy beauty hath so conquered my affections, and so bereaved me of my liberty that unless thou vouchsafe to coole my ardent desires with a willing graunt of thy love, I am like to dye a languishing death, and this countrey, England, of force must lose him that hath fill'd her boundes with many triumphant victories: therefore sweete Angellica, if thy hard heart be so obdurate that the teares of my true love may nothing mollifie, yet take pitty on thy countrey, that through thy cruelty she loose not her wanton glory, and be made unhappy by the losse of her soveraigne; thou seest, my divine Angellica, how I, that have made princes stoope, and kings to humble when I have frownde, doe now submissively yeeld my high honour to thy feete, either to be made happy by thy love, or unhappy in thy hate, that in time to come children may either blesse, or curse thee. Of these two consider which thou wilt perform, either with cruelty to kill mee, or with clemencie to preserve mee.

This unexpected request of the king so amazed Angellica that her cheeks were stayned with blushing shame, and like a bashfull maiden (for a time) stood silent, not knowing in what manner to answer him, considering hee was King of England, and shee but daughter to an earle. But at last, when feare and shame had a while strove together in her heart, shee replyed in this sort.

Most mighty king, said she, if your entertainment in my father's house hath been honorable, seek not the foule dishonour of his daughter, nor proffer to blemish the bud of her verginitie with the least thought of your unchast desires, the losse of which sweete jemme, is a torment to my soule more worse than death. Consider with yourselfe (most worthy 
prince) the blacke scandall that it may bring unto your name, and honour, having a queene, a most vertuous and loyall princesse. Thinke upon the staine of your marriage bed, the wrongs of your wedded pheere and lasting infamie of your divine glorie, for this I vow (by Dianaes bright majestie) before I will yield the conquest of my virginitie to the spoyle of such unchast desire, I will suffer more torments then mans heart can imagine: therefore, (most mighty soveraigne) cease your unreverend suite for I will not loose that matchlesse jewell for all the treasure the large ocean containes: And in speaking these words shee departed thence, and left the lovesicke king in the arbour complaining to the emptie ayre, where after hee had numbered many determinations together, this hee purposed; never to cease his suite, till he had gained what his soule so much desired : for continually at the break of day, when Titans beautie began to shine, and Auroraes blush to appeare, would hee always send to her chamber window the sweetest musicke that could be devised; thinking thereby to obtaine her love. Many times would hee solicite her with rich gifts and large promises, befitting rather an empresse than the daughter of an earle, profering such kindnesses, that if she had a heart of iron, yet could she not choose but relent and requite his curtesies, for what is it that time will not accomplish, having the hand of a king set thereunto.

Twelve weary dayes King Arthur spent in wooing of Angellica before he could obtaine his heart's happinesse, and his soul's contente; at the end of which time she was as plyant to his will, as is the tender twig to the hand of the husbandman. But now their secret meaning required a pollicie to keepe their privie loves both from King Arthurs queene, and from old Androgius, Angellica's father : and that their secrete loves might long time continue without mistrust of any partie whatsoever, this device they contrived : that Angellica should desire liberty of her father, to spend the remainder of her life in the service of Diana, like one that abandoned all earthly vanitie, honouring true chastitie and religious life: so with a demure countenance, and a sober 
grace, she went unto her father, and obtained such leave at his hands, that he willingly condiscended that she should live as a professed nunne, in a monasterie that the king before time had builded in the citie of Lincolne; and so furnishing her forthwith such necessaries as her state required, he gave her his blessing, and so committed her to Dianaes service.

But now Angellica being no sooner placed in the monastery and chosen a sister of that fellowship, but King Arthur many times visited her in so secret a manner, and so disguisedly, that no man suspected their pleasant meetings: but so long tasted they the joyes of love, that in the end the nun grew great bellied and bore King Arthurs quittance sealed in her wombe and at the end of forty weeks she was delivered; where in presence of the midwife and one more whom the king largely recompensed for their secresy, shee was made a happy mother of a goodly son, whom King Arthur caused to be wrapped in a mantle of greene silke, tying a purse of gold about his necke, and so causing the midwife to beare it into the field, and to lay it at a shepherds gate neare adjoyning to the citie, in hope the old man should foster it as his own; by which means his Angellica's dishonour might be kept secret from the world, and his own disgrace from the murmuring reports of the vulgar people.

This his commandment was so speedily performed by the midwife, that the very next morning she stole the young infant from his mother's keeping, and bore it secretly to the place appointed, there laying it downe upon a turfe of greene grasse ; it seemed prettily to smile turning its chrystall eyes up towards the elements, as though it foreknew its owne good fortune. This being done, the midwife withdrewe herselfe some little distance from that place, and hid herselfe closely behind a well growne oake, deligently marking what should betide the comfortlesse infant; but long she had not there remained, but there flocked such a number of little birds about the young harmlesse babe, and made such a chirping melody, that it fell into a silent slumber, and slept as sweetly as though it had beene laid in a bed of softest silke. 
By this time, the golden sunne began to glisten on the mountaine top, and his sister Luna to withdraw her waterish countenance: at which time the pleasant shepherds began to tune their morning notes and to rejoyce unto their folded sheepe, according to their wonted manner: Amongst which crew of lusty swaynes, old Antonio approached forth of his gate with a cheerfull countenance, whose beard was as white as polished silver, or like to snowe lying upon the northern mountaines: this bonny shepherd no sooner espyed Angellica's sweete babe lying upon the greene hillocke, but immediately hee tooke it up; and viewing circumspectly every parcell of the rich vestements wherein it was wrapped, at last found out the purse of gold, which the king had tyed unto the child's necke, whereat the shepherd so exceedingly rejoyced, that for the time he stood as a man ravished with pleasure, and was not able to remove from the place where he stood: but yet at last thinking with himselfe that heaven had sent him that good fortune, not onely giving him riches but withall a sonne, to be a comfort to him in his latter yeares; so bearing it in to his old wife, and withall the purse of gold, and the rich mantle, with the other things : who at the sight thereof was as highly pleased as her husband when he found it first: so being both agreed to foster, and bring it up as their own, considering, that nature never gave them in all their life any child, incontinently they caused it to be christned, and called by the name of Tom A Lincolne, (after the towne where it was found) a name most fitting for it, in that they knew not who were his true parents.

But now speake wee againe of the midwife, that after shee had beheld how kindly old Antonio received the young infant, she returned backe unto Angellica's chamber, whom shee found bitterly lamenting the loss of her tender babe, thinking that some fayrie nymph had stolen it away; but such was the kind comfort which the smooth-tonged midwife gave her in that extremity, whereby her sorrow seemed the less, and her mistrustfull feare exchanged into smiling hope: yet neither would the king nor the midwife at any time whatsoever make knowne unto her 
what was become of her little sonne, but driving her off with delayes and fond excuses, lest having intelligence of his abode she should (through kind love and naturall affection) goe visite him, and so discover their loves practices. Thus lived the most faire Angellica many dayes in great griefe wishing his returne, and desiring heaven that the destinies might be so favourable, that once againe before the fatall sisters had finished her life she might behold her infant's face, for whose presence her very soule thirsted. Here will we leave the solitary lady comfortlesse and without company (except it were the king who sometimes visited her by stealth) and report what happened to Tom a Lincolne in the shepherd's house.

\section{CHAPTER II.}

Of the manner of Tom a Lincolne bringing up, and how hee first came to be called the Red Rose Knight, with other things that hapned to him.

GrEat was the wealth that old Antonio gathered together, by means of the treasure he found about the infants attire, whereby hee became the richest in all that country, and purchast such lands and livings, that his supposed sonne (for wealth) was deemed a fit match for a knights daughter : yet for all this his bringing up was but meane, and in a homely sort, for after he had passed ten years of his age he was set to keep Antonio's sheepe, and to follow husbandry, whereby he grew strong and hardy, and continually gave himselfe to painefull endeavours, imagining and devising haughty and great enterprises; yet, notwithstanding, was of honest and virtuous conditions, well featured, valiant, active, quick, and nimble, sharpwitted, and of a ripe judgment: hee was of a valiant and invincible courage, so that from his cradle and infancy, it seemed he was vowed to Mars and martiall exployts. And in his life and manners is deciphered the image of true nobility; for though hee obscurely lived in a countrey cottage, yet had hee a superior mind, ayming 
at state and majesty, bearing in his breast the princely thoughts of his father. For on a time having cattell in the field among other young men of his age and condition, he was chosen (in sport by them) for their lord or knight, and they to attend on him like dutiful servants; and though this their election was but in play, yet hee whose spirits were ravished with great and high matters, first procured them to sweare to him loyalty in all things, and to obey him as a king, where, or when it should please him in any matter to command them, to which they all most willingly condescended. Thus after they had solemnly taken their oathes, he persuaded them to leave that base and servile kind of life, seeking to serve in war, and to follow him, being the generall; the which through perswasion they did, and so leaving their cattell to their fathers and masters, they assembled all together, to the full number of a hundred at least : unto whom he severally gave certain red roses, to be worne for colours in their hats, and commanded them that ever after he should be called the RED Rose KNIGHT.

So in this manner departed he with his followers unto Barnsdale Heath, where they pitched up tents and lived long time upon the robberies and spoyles of passengers, insomuch that the whole country was greatly molested by them.

This disordered life so highly displeased the parents of these unruly outlaws, that many of them dyed with griefe; but especially of all other, old Antonio took it in ill part, considering how dearly hee loved him, and how tenderly he had brought him up from his infancie; therefore he purposed to practice a meane to call him from that uncivill kind of life, if it might possible be brought to passe: so in his old dayes undertaking this taske, hee travelled towards Barnsdale heath, into which being no sooner entered but some of the ruder sorte of these outlawes seized upon the old man, and without any further violence brought him before their lord and captain, who at the first sight knew him to be his father (as he thought) and therefore used him most kindly, giving him the best entertainment that hee could devise: where, after they had some small 
time conferred together, the good old man brake out into these speeches; Oh thou degenerate (quoth he) from natures kind: is this thy duty to thy father's age, thus disobediently to live, wounding thy natural country with unlawfull spoyles? Is this the comfort of mine age, is this thy love unto thy parents, whose tender care hath beene ever to advance thy estate? Canst thou behold these milk white haires of mine all so rent and torne, which I have violently martyred in thy absence? Canst thou. indure to see my dim eyes almost sightlesse through age, to drop down teares at thy disobedient feet? Ah wherefore hast thou infringed the lawes of nature thus cruelly to kill thy father's heart with grief, and to end his dayes by thy vitious life? Returne, returne, deare childe, banish from thy breast these base actions, that I may say I have a virtuous sonne; and be not like the viperous brood that works the untimely death of their parents. And speaking these words, griefe so exceeded the bounds of reason that he stood silent, and beginning againe to speake, teares trickled from his eyes in such abundance, that they stayed the passage of his speech ; the which being perceived by the ' Red Rose Knight,' he humbly fell upon his knees, and in this sort spake unto good Antonio: Most deare and reverend father, if my offence doe seem odious in your eyes that I deserve no forgivenesse, then here behold now your poore inglorious sonne, laying his breast open, ready prepared to receive deaths remorselesse stroke from your aged hands, as a due punishment for this my disobedient crime; but to be reclaimed from this honourable kind of life (I count it honourable, because it tasteth of manhood,) first shall the sun bring day from out the westerne heavens, and the silver moone lodge her brightnesse in the "eastern waves, and all things else against both kind and nature turne their wonted course. Well then (quoth Antonio) if thy resolution be such, that neither my bitter teares, nor my faire intreaties may prevaile to withdraw thy vaine folly, then know (thou most ungratious impe) that thou art no son of mine, but sprung from the bowels ot some untamed tyger, or wild lionesse, else wouldst thou humbly submit thyselfe to my reverent per- 
suasions: from whence thou camest I know not, but sure thy brest harbours the tyranny of some monstrous tyrant, from whose loynes thou art naturally descended. Thou art no fruit of my body, for I found thee (in thy infancie) lying in the fields, cast out as a prey for ravening fowles, ready to be devoured by hunger-starved dogs; but such was my pittie towards thee that I tooke thee up, and ever since have fostered thee as mine owne childe; but now such is thy unbridled folly, that my kind courtesie is requited with extreame ingratitude, which sin above all others the immortall powers of heaven doe condemne, and the very devils themselves doe hate : therefore like a serpent henceforth will I spit at thee, and never cease to make incessant prayers to the justfull heavens, to revenge this thy monstrous disobedience.

These words being ended, he gave such an extreame sigh, that his very heart brake with griefe, and he immediately dyed in the presence of the Red Rose Knight. For whose death hee made more sorrowfull lamentation, then Niobe did for her seven sonnes. But in recompence of old Antonios kind love, that preserved his infancie from the fury of ravenous fowles, he entombed him most stately in the citie of Lincoln, whose body hee sent thither by certaine passengers who hee had taken and withall a thousand pounds in treasures, to be bestowed upon a great bell to be rung at his funerall, which bell he caused to be called Tom a Lincolne, after his own name, where to this day it remaineth in the same citie. These passengers being as then rich merchants of London, having received the dead body of Antonio, and withall the treasure went with all speed into Lincolne and performed every thing as the Red Rose Knight had appointed.

The death of this good old man not only caused a generall sorrow through the whole citie, but strooke such an extreame griefe to old Antonio's wife, that she within few dayes yielded her life to the remorselesse stroke of the frowning destinies, and was buried in the same grave where her husband was intombed: whose death we will now leave to be mourned by their dearest friends, and likewise for brevities sake, passe over many strata- 
gems which were accomplished by the Red Rose Knight and his followers upon Barnsdale Heath, and returne to King Arthur and his knights flourishing in the English Court.

\section{CHAPTER III.}

Of the first Conquest of Portingale by the Red Rose Knight, and how hee was the first that ever triumphed in the Citie of London.

THE report of Tom a Lincolne's practises grew so generall amongst the vulgar sort of people, that at last it came to King Arthur's eares, who imagined in his princely mind, that he was sprung of his blood, and that hee carried lofty thoughts of honour planted in his brest, though shrowded under a countrey life; therefore, through kind nature hee purposed to have him resident in court with him, that he might daily see his lively sparkes of honour shew their resplendent brightnesse, yet in such obscurity, that he should not know the smallest motion of his parentage: therefore he called together three of his approved knights, namely, Lancelot du Lake, Sir Tristram, and Sir Triamore, and gave them in charge, if it were possible to fetch the Red Rose Knight unto his court, whose adventurous exployts hee hath heard so many times reported; and withall hee gave them generall pardon sealed with his privie seale for him and all his lawlesse followers.

This commission being received by the three worthie knights, they with all speed armed themselves in rich corselets, and strong habiliments of war, and so rode towards Barnsdale Heath; where being no sooner come, and delivered their message from the king, but the Red Rose Knight gave them honourable welcome, and for three daies most royally feasted them under large canvasse tents, wherein they slept as securely as they had been in King Arthur's court, or in a strong castle of war. After this Tom a Lincolne selected out a hundred of his resolute followers, such as he best liked of, and came with 
Sir Lancelot and the rest to the English court, where King Arthur not onely gave him a friendly entertainment, but also installed him one of his Knights of the Round Table: and withall proclaimed a solemne turniament that should be holden in the honour of this new made knight, to which turniament assembled from other countries many princes, barons, and knights of high honour, which behaved themselves most nobly, and won great commendations of every beholder; but specially the Red Rose Knight, who for that day stood as chiefe champion against all commers. In that turniament, or first dayes deed of his knighthood, where onely by his valour and prowesse he overthrew three kings and thirty other knights, all famouzed for chivalry; whereby he obtained such grace in the English court, that he had by the king a paire of golden spurres put upon his feet; and generally of the whole assembly he was accounted one of the bravest knights that there lived in the world.

But now marke how frowning fortune ended their triumphes with unlucky newes; for the same day, before the knights had unbuckled their armours, there arrived a messenger, who certified King Arthur how his ambassadors was unjustly done to death in the Portingale Court, (which was an act contrary both to the faith of princes, and the law of armes.) For whose death king Arthur grew so inraged, that he sware by the honour of his bright renowne, and by the golden spur of true knighthood, the Portingales should repent that inhuman violence with the death of many thousand guiltlesse soules: and that babes unborne should have just cause to curse the first contriver of that unjust murther: therefore with all speede hee mustered up a mighty army of souldiers, and (because hee was continually molested with home-bred mutinies and treacherous rebellions, the which himselfe in person of force must pacifie,) appointed the Red Rose Knight as cheife generall over the armie mustered for Portingale. In which service hee accomplished so many famous exployts that hee was for ever after surnamed The Boast of England. For no sooner had hee the whole campe in charge, 
and aboard their ships, but hee proved the perfect patterne of an exquisite souldier; such a one as all martiall captaines may learne to imitate; for hee so circumspectly ordered his captaines, that in his campe was never knowne any brawle or mutinie. Hee was very courteous and liberall, doing honour to all men according to their deserts. Hee so painefully, and with such care instructed his souldiers, that at an instant, allways (if it were needfull) every man by the sound of a drumme or trumpet was found in his charge or quarter. And (to be briefe) his campe resembled one of the greatest cities in the world, for all kind of officers were there found in order; and also a great number of merchants to furnish it with all manner of necessaries. $\mathrm{He}$ in no case permitted any robberies, private fighting, force or violence; but with severity punished those that were therein found guilty. His desire was, that his souldiers should glory in nothing so much as in martiall prowesse, vertue, and wisdome. He evermore gave them their pay without fraud or deceipt. $\mathrm{He}$ honoured, he praised, he imbraced and kissed them, and withall kept them in awe and subjection: by which meanes his fame and honour grew so renowned, that his army dayly increased more and more; for when he first arrived upon the confines of Portingale his campe grew to be as great as ever was Cæsar's, when hee conquered the westerne world, and in matchlesse prowesse nothing inferiour unto his. So fortunate were his proceedings that hee made a great part of the provinces of Portingale desolate, not being intercepted by any, but spoyling every towne and city as hee went, untill such time as the Portingale king had gathered together a marvailous number of souldiers, both olde, and of much experience, by reason of the continuall warres that they had with the Turkish nation adjoyning neere unto them. But when the Portingale king (like an expert souldier) seeing that no way he might resist the English army, nor expell them his country, unlesse hee gave them present battaile, therefore trusting in his approved manhood, and the prowesse of his souldiers, he set his army in a readinesse, and so marched forward to meet the Red Rose Knight, and his warlike followers, 
which at that time had pitched his campe in a large champaine plaine, adjoyning neere unto the city of Lishborne, whereat both these armies met; and setting them in order (as it became good captaines), there they beganne (in the breake of the day) the most cruell and terriblest battle that ever was heard of, or fought in that age, considering the number of both parties, their experience and pollicie, with the valiant courage and prowesse of their captaines.

In great danger continued this fight till the sun beganne to set with marveilous slaughter on both sides; yet remayned the victory doubtfull, declining neither to the Portingales, nor yet to the English; but at last (though long) the Portingales began to faint and flee, more indeed oppressed with the multitude than for any feare they received in the battle; for the most part of them with honour died manfully in the field, some taken prisoners, and the rest fled for their better safety: but now the Portingale king perceiving his souldiers begin to fly, with courage hee sought to withdraw them from flight, resisted in person valiantly the furious rage of the enemy; but in that enterprise he gained such and so many knockes, that at last he was unhorst, and for want of rescue, was forced to yield himselfe as prisoner, whereat the whole armies of the Portingales were discomfeited, and the victory fell to the Englishmen: the which being obtained, the Red Rose Knight with his armie entered into the citie of Lishborne, where the common souldiers were enriched with wealthy spoyles, and the king's palace ransacked by the Red Rose Knight; where he tooke such prisoners as him best liked, and the reste (like an honourable souldier,) hee set at liberty, commanding that no violence should be profered any way.

After this setting his armie in a readinesse, he marched towards England, where after some few dayes travell, hee arrived with all his hoste in the westerne parts of Devonshire, and marching towards London, where against his comming the citizens, with the inhabitants of other villages, neere adjoyning, were that day seen in their most sumptuous and rich attire, 
every one of them endeavouring to place himselfe in some gallery or window, that the better and with more ease they might behold the triumphante returne of the Red Rose Knight. All the churches in London were on every side set open, hanged round about with most costly furniture : the streets were also most gloriously beset with greene boughes, and strowed with perfumes of no small value : and for the infinite multitude of people that were seene in the citie there was appointed a hundred whiflers most richly attired, to keepe the streets plaine and open, whereby the triumphs might have the easier passage, and for that the diversity of the shewes were so many, that they of necessity were constrained to part them into three severall dayes.

The first day hardly suffised in good order to bring in the banners, standards and ensignes of the conquerer, the golden images, and tables of price, which were all brought in on carts, very curiously painted and trimmed.

On the second day came in the armour of the conquered king, as also of all the other Portingale lords; and as they were rich, bright, and glittering, so were they with most cunning ordered and couched in waggons. After these entered three thousand men in order, bearing nothing but money, openly to bee seene, and that in huge platters and vessels of silver, of which were three hundred and fifty in number, and foure of our men allotted to every vessell : the other brought in most artificiall tapestry works, beautifyed with gold and silver. And thus was the second dayes triumphe ended in most pompous solemnity.

Upon the third day even at the rising of the sunne, with the first band entered (as a joyfull sound of conquest) an infinite number of flutes, drummes, and trumpets, with other like martiall and warlike instruments, sounding not after a most pleasant and sweet manner, but in most terrible sort, as it was possible to bee done, even in such order as they doe when they presently joyne battell. And after them came a hundred and twenty kine all white, having their hornes curiously gilded with gold, their bodies covered with vailes (which they accounted 
most sacred and holy) bearing also garlands of flowers upon their heads, driven by certaine young gentlemen, no less well favoured than gorgeously attired. After these followed the coach of the conquered King of Portingale, with his owne armour layed thereon openly to be seene of all men. His crowne and royall scepter was layd in seemely order upon his armour. After this coach came prisoners on foote, with his owne naturall children, being little infants; and after them followed a great troope of his servants and officers, as masters of his household, secretaries, ushers, controllers, chamberlaines, with other gentlemen of his court, all in a most sorrowfull manner, seeing themselves brought into such extremity and servitude, that they moved to compassion all such as beheld them. Of the kings children there were two boyes, and one girle; of age so young and tender, that they had small understanding of their misfortune and misery.

In this triumph followed the father of his owne children (after the usage of his country) clad in black mourning garments, sorrowing likewise for his hard misfortune. Then followed sundry of his approved friends, which, beholding in that plight their unhappy prince brake out into teares and sighs so bitterly that their enemies themselves grieved at their mishaps.

After these followed one which carried certaine precious stones that had beene presented to the Red Rose Knight, from some ancient cities in Portingale who immediately followed in person triumphantly in his ivory charriot, apparelled in vestures of purple tissue, having a lawrell bough in his hand, and a crowne of the same upon his head. After him followed his owne souldiers both foot-men and horsemen all marching in most decent order, armed with rich furniture, holding also each of them a lawrell bough in his hand, their ensignes and banners souldierlike displayed, sounding martiall melody, in honour of their triumphant captaine; with many other like presidents most, royal and magnificent. Thus in this gallant order marched they to the king's chapell, where in the 
presence of the king and his lords, (which came to honour and grace their triumphs) they gave thanks to God for their successfull victory; and after solemn service was ended they departed to king Arthurs court, where every one, as well strangers as others were most royally feasted.

The Portingale king seeing his kind entertainment in the English court, where he was used more like a friend then an enemie, had small care to return home, but frolicked many a day amongst the English lords; whose loves unto strangers be evermore most honourable. But so great were the courtesies that the noble King Arthur bestowed upon the Portingales; who for their proffered disgraces requited them liberally with honour; and not onely sent them home ransomlesse, but promised to lende them ayde and succour from England if occasion required; So bearing them company to the sea shore, hee most friendly committed them to the mercy of the winds and waves which were so favourable, that in short time they arrived safe in their owne country, where many a day after they remembered the honourable kindness of the Englishmen, and caused the chronicles of Portingale to record the renowne of King Arthur and his Knights of the Round Table.

\section{CHAPTER IV.}

How the Red Rose Knight travelled from the King of Englands court, and how he arrived in the Fayerie land, where he was entertained by a Mayden Queene, and what hapned to him in the same country.

Now, after the Portingales were thus conquered, and sent home with great honour, the English king and his lords rested themselves many a day in the bowers of peace, leaving their armour rusting, and their pampered steedes standing in their stables forgetting their usuall manner of wrathfull warre: which idle ease greatly disconcerted the magnanimious Red Rose Knight, who thought it a staine to his passed glory, and a scandal to his 
princely mind to entertaine such base thoughts : and considering with himselfe how ignorant hee was of his true parents, and from whence hee was descended hee could not imagine; therefore hee purposed to begin a new enterprise, and to travell up and down the world till hee had either found his father and mother or else yielded his life to natures course in that pretended journey: so going to the king, (full little thinking that he was sprung from so noble a stocke), craving at his graces hand, to grant him such liberty, for to try his knighthood in forraine countries, whereas yet did never Englishman make his adventure, and to eternize his name to all posterity, rather than to spend his life in such home-bred practises.

To this his honourable request the king, (though loath to foregoe his company yet because it belonged to knightly attempts) hee gave him leave, and withall furnished him a shippe at his owne proper cost and charges, giving free license to all knights whatsoever to beare him company: amongst which number Sir Launcelot du Lake was the chiefest that proffered himselfe to that voyage, who professed such love to the Red Rose Knight, that they plighted their faiths like sworne brothers, and to live and die together in all extremities. So these two English knights, with the number of a hundred more, all resolute gentlemen, tooke leave of the king, and with all speed went a ship board: wherein being no sooner entered, but the pylot hoisted sayle, and dis-anchored, and so committed their lives and fortunes to the pleasure of Neptunes mercie, upon whose watry kingdome they had not many dayes sayled, but Æolus brazen gates burst open, and the windes so violently troubled the swelling waves, that every minute they were in danger to end their lives in the bottome of the seas.

Three moneths the wind and the waters strove together for supremacie, during which time they saw no land, but were driven up and downe to what place the ever changing Destinies listed: so at last they sayled beyond the sunne, diverted onely by the light of the starres, not knowing which way to travell towards land; but in such extremity for want of victuall, that 
they were forced to land at a certaine island in the westerne parts of the world, inhabited onely by women; where being no sooner on land, and giving God thankes for delivering them from that mortall perill, but the Red Rose Knight cast up his eyes towards the higher parts of the country, and espied more than two thousand women coming forth at a citie gate, all most richly armed with brest plates of silver, marching in trim array, like an army of well approved souldiers; the which number coming neare to the sea side they sent two of their damsels as messengers to the English knights, willing them as they loved their lives, presently to retire againe backe to the seas, for that was no countrey for their abode. But when the Red Rose Knight of England had understood the bold message of the two damsels he was sore abashed, (considering the number of armed women he saw before him, and the great dangers they had suffered before on the sea for want of victuall) that hee knew not in what manner hee was best to answer them; but having a good courage, hee at last spake to the two damsels in this sort; Right noble ladies, I have well understood your speeches; therefore, I desire you for to shew such favour unto wandering travellers as to tell us in what countrey fortune hath brought us to, and for what cause we are commanded by you to returne to the sea? Surely Sir Knight (answered one of the damsels) this countrey whereon you are arrived, it is not very bigge, but yet most fertile and commodious; and is called by the name of the Fayerie-Land: And now to shew you the cause why you are commanded to returne, this it is. Not many yeares agoe there raigned in this countrey a king which had to name Larmos, for wisdome and prowesse not his equall was found in any of these parts of the world. This king had such continuall war against the bordering Flanders, that upon a time he was constrained to muster for the same war all the men both young and old which were found in his kingdome, whereby the whole countrey was left destitute of men, to the great discontentment of the ladies and damsels that here inhabited; whereupon they finding 
themselves so highly wronged, living without the company of men, they generally assembled themselves together, with the daughter of King Larmos, which is called Crelia, no lesse in beautie then in virtue and wisedome. These ladies and damsels being gathered together, with a generall consent, dispatched certaine messengers to the king, and to their husbands, willing them to returne unto their countrey, and not to leave their wives and children in such extremity, without the comfort and company of man. Upon which the king answered, that hee had besieged his enemies in their townes of war; and before one man should returne home till he came with conquest, his countrey should be lost and made desolate, and the women given over to the spoyle of his enemies; which answer when the ladies had received, they tooke it in such evill part, that they conspired against their king and husbands, and put to death all the men children that were in the countrey; and after determined, when their husbands, fathers, and friends returned from the war, that they should the first night of their coming be slaine sleeping in their beds, and that never after they should suffer man to enter into their countrey. After this conclusion, they crowned Cælia the king's daughter for their queene : and so afterwards when the king and. his armie returned from the wars, this bloody murder was practised, and not a man left alive, but only the king reserved, whom Cælia would in no wise against nature murther ; but yet notwithstanding she delivered him into the hands of her chiefest ladies, which put him into a boat alone, and so sent him to sea to seeke his fortune. Whereas most noble knight this is the cause why you may not enter into our country, which if you doe, and not presently withdraw yourselves unto the sea, the ladies will suddenly give you a mervaillous battell.

Now by the everliving God which Englishmen adore, (said the noble Red Rose Knight) such extremitie have wee suffered at sea, that we are like to perish and dye with hunger unlesse we find some succour at your hands; and before we will end our lives with famine, we will enter battell with those ladies 
and so dye with honour in the field; yet this kindnesse doe we humbly desire at your hands, to returne unto your Queene, and certifie her of our poor estate and necessity, and that wee altogether instantly desire her, that if there bee any sparke of vertue or nobility harboured in her brest, that shee will have pitie upon us, and suffer us' not to end our lives by such an unhappy kind of death. With this request the two damsels returned to the Queene and recounted from word to word the humble suit of the Red Rose Knight and what extremity they were in: which when the queene understood, and that they were knights of England, the fame of which countrey she had so often heard reported, shee demanded what manner of people they were, and of what condition; suerly madam (answered one of the two damsels) I never in all my life saw more goodly men, nor better spoken: and it is to be supposed they be the choyse of all humane people, and with their courteous demeanors are able to draw the mercilesse and savage nation to affect them.

The queene hearing the damsels so highly to commend the English knights, thinking also upon their request, began (in minde) to have pitie of their misadventures, and so instantly sent for them, and gave them free libertie to make their aboad in her country: which incontinently when the English knights heard, how they should receive a kinde welcome, and a friendly entertainement, grew so exceeding joyfull, as though heaven had sent them present comfort; so comming before the queene and her ladies, they saluted each other most courteously, and with great reverence. But when the vertuous queene beheld this noble company before her, in all humilitie, she delivered to a hundred of her ladies, the hundred English knights, and reserved the princely Red Rose Knight unto herselfe; and so were they brought to the queenes pallace, where every lady feasted her knight in most gallant sorte, and to their hearts contente. But now when the queene had the Red Rose Knight in her chamber, and had beheld the exceeding beautie of the noble prince, shee tooke him by the hand, and led him into one of her chambers, 
where shee shewed him her riches and treasures : and after said unto him in this manner.

Most noble and valiant Englishman, these riches bee all onely at thy commandements, and also my body, which here I offer up as a gift and present to thy divine excellence; and furthermore there is nothing of value which I am mistris of, but shall bee at thy disposing, to the intent that my love may be acceptable to thy gracious eyes. But when the Red Rose Knight perceived to what intent shee spake these gracious words, in this manner answered he her, saying.

Most deare princesse and fair queene of this maiden countrey, I give you right humble thankes for these your courtesies, and by no means possible may I deserve this high honour you have graced me with.

Oh great knight (replyed then the queene) the smallest thought of your honourable mind is sufficient to recompence the uttermost of my deserts; yet let me request this one thing at your noble hands, that never asked the like favour of any one before, for shee that never knew the least motion of love is now pricked with a hundred torments, and unlesse you quench the ardent affection wherewith my heart is fired, with the pleasant hopes of your comfortable smiles, I am like to die desperate, and then the world will accuse you of cruelty, in murdering a constant lady: but if it shall please you to grant mee love, and to espouse mee according to Hymens holy rites; here you shall rule sole king and be the lord of all this countrey.

My right deare lady (answered then the Red Rose Knight), you have done such pleasure to mee, and to my distressed followers in preserving us from famine, as I shall never requite it, though I should spend all the rest of my life in your service:. And know most excellent princesse, that there is no adventure so dangerous, yet at your commandement would I practise to accomplish; yet for to tye myselfe in wedlockes bonds, there is no woman in the world shall procure mee; for untill I have finished an adventure which in my heart I have vowed, I will not linke my affections to any lady in the world. But thinke not (madam) 
that I refuse your love through disdaine; for I sweare by the dignity King Arthur grac'd me with, I should thinke myselfe most fortunate if I had so faire and noble a lady as your divine selfe.

Most worthy knight (then answered the queene) I imagine that the gods have sente you into this countrey for two causes principally: The first is, that you and your followers should be preserved from death by my meanes; the second is, that you should inhabit in this countrey lest it should in short time be left as a desert wildernesse; for it is inhabited onely by women, without a king, and have no other governour but me, which am their chiefe princesse; and for so much as I have succoured you, so succour you this desolate citie, that it may be repeopled with your seed; and in so doing you shall accomplish a vertuous deed, and winne to your names an eternall memorie to all ensuing ages.

I confesse (quoth the Red Rose Knight) that you and your ladies have succoured me and my followers in our great necessitie; and in recompense whereof, wee will employ all our endeavours to the repeopling againe of this countrey; but in regard of the secret vow my heart hath made, I will not yield myselfe to your desires; for if I should infringe my oath mine honour were greatly impaired; and before I would commit that dishonourable fact, I would suffer the greatest torment that mans heart can imagine.

Incontinently when the love sicke queene heard this answer of the English knight, and perceived that he was firme to his purpose, shee took leave of him, and departed for that time: The Red Rose Knight likewise withdrewe himselfe into his chamber, pondring in his mind a thousand imaginations. But shee for her part was so troubled in mind, and so wounded with the darts of blind Cupid, that when the misty darknesse of night had covered the earth, shee laid her downe upon her bed where betwixt shame and her heart beganne a terrible battaille.

Her heart was encouraged, that shee should goe and lie with him ; but shame began to blush and withstood that perswasion; by which meanes the battaile was great and endured a long 
time; but at last the heart was conqueror, and shame vanished and put to flight in such sort that the fairie queene rose from her bed and went and laid downe by her beloved knight, where he slept; and being in the bed shee began fearfully to tremble, for shame still followed her unlawfull practises; where after her quivering heart began a little to be qualified with her trembling hand she awaked him, and after spake in this manner.

My most deare and affectionate friend though like a carelesse wretch I come unto thee apparelled with shame, yet let my true love colour this my infamous presumption, for your princely person and kingly demeanour, like adamants have drawne my steeled heart to commit this shamefull act; yet let not my fervent affection bee requitted with disdaine; and although you will not consente to bee my wedded lord and husband, yet let me bee thy love and secret friend; that a poore distressed queene may thinke herselfe happy in an Englishmans love.

When the noble knight heard the faire Cælia's voyce and felt her by his side, hee was so sore abashed, that hee wist - not what to doe; but yet at last having the nature and courage of a man, hee turned to her, using many amorous speeches, embracing and kissing each other in such manner, that faire Cælia was conceived with child, and waxt great of a right faire sonne; of whom she was in processe of time safely delivered, as you shall heare discoursed of at large in the following historie :

But to be short, during the space of foure monethes, the faiery ladies lay with the English knights, and many of them were conceived with their seede in such sorte, that the countrey was afterwards repeopled with male children, and what happened amongst them in the meane season I will passe over for this time; for the dayes and nights (that hee and the rest) passed on their wonted course, in which time their ship was replenished with all necessaries, and the Red Rose Knight summond together Sir Launcelot and the rest, and being assembled hee said unto them,

My good friends and countrymen, you know, that long time we have sojourned in this countrey spending our dayes in idle 
pastimes, to the reproach of our former glories : now my intent is, within these three dayes to depart this countrey, therefore let every man make himself in readinesse, for there is no greater dishonour to adventurous knights, than to spend their dayes in ladies bosomes.

When Sir Launcelot and the other English gentlemen heard the forward disposition of the Red Rose Knight, they were all exceeding joyfull, and answered him, that with great willingnesse they would all be ready at the time appointed.

But now when the fayerie ladies perceived the preparations that the English knights made for their departure, they grew exceeding sorrowfull, and complained one to another in most greivous manner; and amongst the reste the queene was most displeased, who with a sorrowfull and sad heart, came unto the Red Rose Knight, and in this manner complained to him. Alas, alas, my deare lord, have ye that tyrannous heart to withdraw yourselfe from me, and to forsake me before you see the fruit of your noble person, which is nourished with my bloud. Deare knight behold with pitie my wombe, the chamber and mansion of your bloud; ah let that bee a meanes to stay you, that my child (as yet unborne) be not fatherlesse by your departure. And in speaking these words, shee began to weepe and sigh bitterly, and after to whisper secretly to herselfe in this order,

Oh you immortall heavens, how may mine eyes behold the departure of my joy; for being gone all comfort in the world will forsake me, and all consolation fly from mee; and contrawise all sorrow will pursue me, and all misfortune come against me. Oh what a sorrow will it be to my soule to see thee floating on the dangerous seas, where every minute perils doe arise ready to whelme thee in the bottomlesse ocean, and being once exempted from my sight, my heart for evermore lie in the beds of tribulation, under the coverture of mortale distresse, and betweene the sheets of eternall bewailings. Yet if there be no remedy, but that thou wilt needs depart, sweare unto me, that if ever thou dost accomplish thy pretended voyage (what it is I know not) that thou wilt returne againe to this countrey, to tell 
me of thy happy fortunes, and that mine eyes may once more behold thy lovely countenance, which is as delectable to my soule as the joyes of paradise.

When the noble English knight understood that the queene condescended to his departure, upon condition of his returne, to which he solemnly protested, if the Gods gave him life and good fortune, to performe her request: whereby the fayrie queene was somwhat recomforted: and having great hope in the returne of her deare lorde, shee ceased her lamentation. And now (to abridge the story) the time came that the valiant Englishman should goe a shipboard, upon which day the Red Rose Knight and his followers tooke leave of the noble queene and her ladies, thanking them for their kind entertainments, and so went to the port of the sea, where they entred their ships, and so departed from the fayrie land. After this when Cælia had borne her babe in her wombe full forty weeks she was delivered of a faire sonne, who came afterwards to be called the Fayrie Knight, which for this time we will not touch, but refer it to the second part of this history.

\section{CHAPTER V.}

What hapned to the English Knights, after their departure from the Fayrie Land.

WITH a prosperous wind sayled these English knights, many a league from the Fayrie Land, to their great contente and hearts desire, where every thing seemed to prognosticate their happy adventures; so upon a day when the sun shone cleare, and a gentle calme winde caused the sea to lye as smoothly as chrystall ice, whereby their ship lay floating on the waves, not able to remove; for whilst the dolphins danced upon the silver streames, and the red gild fishes leapt about the ship, the Red Rose Knight requested Sir Launcelot to drive away the time with some courtly discourse, whereby they might not thinke their voyage over long. Unto which the good Sir Launcelot most willingly agreed; and although hee was a martiall knight, delight- 
ing to heare the relentlesse sound of angry drums, which thunders threats from a massaker, yet could hee like an oratour, as well discourse a lovers historie; therefore requesting the Red Rose Knight, and the other English gentlemen to sit downe and listen to the tale that followeth :

\section{The Pleasant History which Sir Launcelot du Lake told to the Red Rose Knight, being a ship-board.}

At that time of the yeare, when the birds had nipt away the tawny leaves, and Flora with her pleasant flowers, had inricht the earth, and incloathed the trees, herbes, and flowers, with natures tapestrie, when the golden sunne, with his glistring beames did glad mens hearts, and every leafe as it were did beare the forme of love, by nature painted upon it : this blessed time did cause the Grecian emperour to proclaime a solemne turniament to be holden in his court, which as then was replenished with many worthy and valiant knights; but his desire chiefly was, to behold his princely sonne, Valentine, to try his valour in the turniament.

Many were the ladies that repayred thither, to behold the worthy triumphs of this young prince; amongst which number came the beautifull Dulcippa, a mayden which as then waited upon the empresse, being daughter to a countrey gentleman.

This Dulcippa; like Apollos flower, being the fayrest virgin in that company, had so firmly settled her love upon the emperours son, that it was impossible to expell it from her heart. Likewise his affection was no lesse in fervencie then hers; so that there was a just equality in their loves and likings, though a difference in their birthes and callings.

This princely Valentine (for so was the emperours sonne called) entred the lists in costly armour most richly wrought with orient pearles, his crest incompassed with saphire stones, and in his hand a sturdie launce. Thus mounted upon a milke white steed, hee vaunted forth himselfe to try his warlike force; and in prauncing up and downe, hee many times 
(thorow his beaver) stole a view of his faire Dulcippas face; at which time there kindled in his breast two sundry lampes; the one was to win the honour of the day; the other, to obtaine the love of his mistresse. On the other side, Dulcippa did nothing but report the valiant acts of his prowesse and chivalrie, in such sort, that there was no other talke amongst the ladies, but of Valentines honourable attempts.

No sooner was the turniaments ended, and this love begun, but Dulcippa departed to her lodging, where sighes did serve as bellowes to kindle loves fire. Valentine in like manner being wounded to death, still roameth up and downe, to find a salve for his stanchlesse thirst; so seeks Dulcippa to restore her former liberty; for shee being both beloved, and in love, knew not the meanes to comforte herself. Sometimes shee did exclaime against her wandering eyes, and wished they had been blind when first they gazed upon the beauty of princely Valentine. Sometimes in visions shee beheld his face cheerfull, smiling upon her countenance, and presently againe shee thought she saw his martiall hands, bathed all in purple blood, scorning her love, and former courtesies. With that shee started from her dreaming passion, wringing her tender hands, till floods of silver dropping teares trinkled down her face; her golden hayre that had wont to be bound up in threds of gold, hung dangling downe about her ivory neck : the which in most outrageous sort shee rent and tore, til! that her hayre which before looked like burnisht gold, were dyed now in purple and vermilion blood. In this strange passion remained this distressed lady, till the golden sunne had three times lodged him in the western seas, and the silver moone her shining face in the pallace of the chrystall clouds. At this time a heavy slumber possessed all her senses; for shee, whose eyes before in three dayes, and as many nights, had not shut up their closets, was now lockt up in silente sleepe, lest her heart overburthened with griefe, by some untimely manner should destroy itselfe.

But now returne we to the worthy Valentine, who sought not to pine in passion, but to court it with the best, considering 
with himselfe that a faint heart never gain'd faire lady; therefore he purposed boldly to discover his love to the fair Dulcippa, building upon a fortunate successe, considering that shee was but daughter to a gentleman, and he a prince borne. So attiring himselfe in costly silkes, wearing in his haire an Indian pearl cut out of ruby red; on eyther side, a golden arrow thrust through a bleeding heart, to declare his earnest affection. In this manner went hee to his beloved lady, whom he found in company with other ladies waiting upon the empresse, who taking her by the hand, he led her aside into a gallery neere adjoyning, where he began in this manner to expresse the passion of his love.

Sacred Dulcippa (quoth hee) in beauty brighter then glistering Cynthia, when with her beames she beautifies the vales of Heaven. Thou art that Cynthia that with thy brightnesse doth light my cloudy thoughts, which have many dayes been overcast with stormy showers of love; shine with thy beames of mercie on my minde, and let thy light conduct mee from the darke and obscure labyrinths of love. If teares could speake, then should my tongue keepe silence, therefore let my sighes bee messengers of true love. And though in words, I am not able to deliver the true meaning of my desires, yet let my cause begg pitie at your hands. Otherwise your deniall drownes my soul in a bottomlesse sea of sorrow: one of these two (most beauteous lady) doe I desire, either to give life with a cheerful smile, or death with a fatall frowne. Valentine having no sooner ended his loves oration, but shee with a scarlet countenance, returned him this joyfull answere.

Most noble prince, thy words within my heart have knit a Gordian knot which no earthly wight may untie; for it is knit with faithfull love, and teares distilling from a constant minde. My heart, which never yet was subject to any one, doe I freely yield up into thy bosom, where it for evermore shall rest, till the fatall sisters cut our lives asunder; and in speaking these words they kissed each other as the first earnest of their loves. With that the empresse came thorow the 
gallerie, who espying their secret conference, presently moved in her secret hate, which shee intended to practise against the guiltlesse lady, thinking it a scandal to her sonnes birthe to match in marriage with one of so base a parentage; therefore purposing to crosse their loves with dismall stratagems, and dreary tragedies, shee departed to her chamber, where shee cloaked her treacheries up in silence, and pondered in her heart how shee might end their loves, and finish Dulcippas life. In this tragical imagination remained shee all that night, hammering in her head a thousand severall practices. But no sooner was the dreary earth comforted with the hot beames of Apollos fire, but this thristing empresse arose from her carefull bed, penning herselfe closely within her chamber, like one that made no conscience for to kill, she in all haste sent for a doctor of physicke, not to give physicke to restore health, but poyson for untimely death; who being no sooner come into her presence, but presently shee lockt her chamber doore, and with an angry countenance, staring him in the face, shee breathed this horrore into his harmlesse eares: Doctor thou knowest how oft in secret matters I have used thy helpe, wherein as yet I never saw thy faith falsifyed; but now amongst the rest I am to require thy ayd in an earnest businesse, so secret, that if thou dost but tell it to the whispering windes, it is sufficient to spread it through the whole world; whereby my practises may be discovered, and I be made a noted reproach to all hearers. Madam, (quoth the doctor, whose heart harboured no thought of bloody deeds) what needs all these circumstances, where duty doth command my true obedience; desist not therefore, gentle empresse to make mee privie to your thoughts; for little did hee thinke her mind could harbour so vile a thought; but having conjured most strongly his service, shee spake to him as followeth: Doctor, the love (nay rather raging lust) which I have spyed of late betwixt my unnaturall sonne and proud Dulcippa may in short time (as thou knowest) bring a suddaine alteration of our state, considering that hee being borne a prince, and descended from a royall race, should 
match in marriage with a base and ignoble mayden, daughter but to a meane gentleman; therefore if I should suffer his secret love to goe forward and seeke not to prevent it, the emperour might condemne mee of falsehood, and judge me an agent in this unlawfull love, which to avoid I have a practice in my head, and in thy hand it lyes to procure thy princes happinesse and countreys good. Dulcippas father (as thou knowest) dwells about three miles from my pallace, unto whose house I will this day send Dulcippa about such businesse as I thinke best, when thou shalt be appointed, and none but thou to conduct her thither; where in a thick and bushy grove, which standeth directly in the midway, thou shalt give her the cup of death, and so rid my heart from suspicious thoughts.

This bloody practice being pronounced by the empresse, caused such a terrour to enter into the doctors minde that hee trembled forth this sorrowfull complaint.

Oh you immortall powers of heaven, you giver of my haplesse fortunes, why have you thus ordayned mee to be the bloody murderer of a chast and vertuous lady, and the true patterne of sobriety; whose untimely overthrow if I should but once conspire, Dianas nymphes would turne their wonted natures and staine their hands with my accursed blood. Therefore most glorious empresse cease your determination for my heart will not suffer my hand to commit so foul a villany.

And wilt thou not doe it then (replied the empresse with a minde fraught with rage and blood): I do protest (quoth shee) by heavens bright majestie, except thou dost consent to accomplish my intent, thy head shall warrant this my secresie.

Stand not on termes, my resolute attempt is cleane impatient of objections.

The doctor hearing her resolution, and that nothing but Dulcippas death might satisfie her wrath, hee consented to her request, (and purposed cunningly to dissemble with the bloody quene) who believed that hee would performe what shee so much desired: so departing out of her chamber, shee 
went to the guiltlesse lady sending her on this fatall message; who like to hapless Bellerophon was ready to carry an embassage of her owne death. But in the meane time the doctor harboured in his brest a world of bitter woes, to thinke how vilely this virtuous lady was betrayed; and considering in his minde how that he was forced by constraint to performe this tragedy; therefore hee purposed not to give her a cup of poyson, but a sleeping drinke, to cast her into a trance, which shee should as a cup of death receive : as well to try her virtuous constancie as to rid himselfe from so hainous a crime.

But now returne wee to Dulcippa, who being sped of her message, went with the doctor walking on the way, where all the talke which they had was of the liberall praise of Prince Valentine, who remained in court, little mistrusting what had happened to his beloved lady, and shee likewise ignorant of the hurt that was pretended against her life; but being both alone together in the wood, where nothing was heard but chirping birds, which with their voices seemed to mourne at the ladies misfortune. But now the doctor breaking off their former talke, took occasion to speake as followeth :

Man of all creatures (most virtuous lady) is most miserable, for nature hath ordained to every bird a pleasant tune, to bemoane their mishaps, the nightingale doth complaine her rape and lost virginity within the desart groves; the swanne doth likewise sing a dolefull heavie tune awhile before shee dies, as though heaven had inspired her with some foreknowledge of things to come. You madam now must sing your swan-like song; for the pretty birds (I see) doe droope their hanging heads, and mourne to thinke that you must die. Marvaile not madame, the angry queene will have it so; accurst am $I$ in being constrayned to bee the bloody instrument of so tyrannous a fact. Accurst am I that have ordained that cup, which must by poyson stanch the thirst of the bloody empresse ; and most accurst am I that cannot withstand the angry fates, which have appointed mee, to offer violence unto virtue. And in speaking these words hee delivered the cup into the ladies 
hands; who like a lambe that was led to the slaughter, used silence for her excuse. Many times lift shee up her eyes towards the sacred throne of heaven, as though the Gods had sent downe vengeance upon her guiltlesse soule, and at last breathed forth these sorrowfull lamentations :

Never (quoth shee) shall vertue stoope to vice. Never shall death affright my soule, nor never poyson quench that lasting love, which my true heart doth beare to princely Valentine; whose spirit (I hope) shall meet mee in the joyfull fields of Elizium, to call those ghosts, that dyed for faithfull love, to beare mee witnesse of my faith and loyalty; and so taking the cup she said; come, come, thou most blessed cup, wherein is contained that happy drinke which gives rest to troubled minds. And thou most blessed wood, beare witnesse that I mixe this banefull drinke with teares distilling from my bleeding heart. These lips of mine that had wont to kisse Prince Valentine shall now most willingly kisse this ground, that must receive my corse. The author of my death Ile blesse; for she honours mee in that I die for my sweet Valentines sake. And now doctor to thee (being the instrument of this my death) I doe bequeath all earthly happinesse: and here withall I drinke to Valentines good fortune: so drinking of the sleeping potion shee was presently cast into a trance, which shee poore lady supposed death. The doctor greatly admiring at her virtuous mind, erected her body against an aged oake, where he left her sleeping, and with all speed returned to the hatefull queene, and told her that he had performed her majesties command; who gave him many thanks, and promised to requite his secresie with a large recompense.

But now speake we againe of Prince Valentine, who had intelligence, how the onely comfort of his heart had ended her dayes by poysons violence, for which cause, he leaves the court, and converted his rich attire to ruthfull roabes; his costly coloured garments, to a homely russet coat; and so travelling to the solitary woods, he vowed to spend the rest of his dayes in a shepherds life; his royall sceptre was turned into a simple 
sheepehooke, and all his pleasure was to keepe his sheepe from the teeth of the ravenous wolves.

Three times had glistering Phœbe renewed her horned wings, and decked the elements with her smiling countenance; three, months were passed, three moones had likewise runne their wonted compasse, before the Grecian emperour mist his princely sonne, whose want was no sooner bruted through the court, but hee ecchoed forth this horrour to himselfe.

What cursed planet thus indirectly rules my haplesse course? or what uncouth dryery fate hath bereaved me of my princely son; Jove send downe thy burning thunder bolts, and strike them dead that be procurers of his want, but if (sweet Venus) hee be dead for love, hover his ghost before mine eyes, that hee may discover the cause of his afflictions ; but contrariwise, if his life be finished by the fury of some murtherous minde, then let my exclamations pierce to the justfull majestie of heaven, that never sun may shine upon his hated head, which is the cause of my Valentines decay; or that the angry furies may lend me their burning whips, incessantly to scourge their purple soules, till my sonnes wrongs be sufficiently revenged. Thus, or in such a like franticke humour ranne he up and downe his pallace, till reason pacified his outrageous thoughts, and by persuasion of his lords, he was brought into his quiet bed. Mean space, Diana (the queen of Chastitie) with a traine of beautiful nymphs, by chance came through the wood where Dulcippa was left in her trance, in which place, rousing the thickets in pursuit of a wild hart, the Queen of Chastity espyed the harmlesse lady, standing against a tree, and beheld her sweet breath to passe through her closed lips, at whose presence the queene awhile stood wondering at; but at last with her sacred hand she awaked her, and withall asked the cause of her trance, and by what meanes shee came thither; which poore awaked lady being amazed both at her sudden majestie, and the strangenesse of her passed fortune and distresse, with farre fetcht sighes shee related what hapned to her in those desart woods. The heavenly goddess being moved with pitie, with a most smiling voyce 
cheered her up, and with a lilly taken from the ground shee wiped the teares from off Dulcippas tender cheeks, which like a river trickled from her chrystall eyes. This being done, Diana with an angels voyce, spake unto her as followeth:

Sweet virgin, (for so it seemeth thou art) farre better would it' befit thy happy estate (happy I terme it) having past so many dangers, to spend the remnant of thy life amongst my traine of nymphs, whereas springeth nothing but chastity and purity of life. Dulcippa, though in her love both firm and constant, yet did she condescend to dwell with Dianas nymphs; where now instead of parley with courtly gallants, shee singeth songs, carols, and roundelayes; instead of pen and ink, wherewith shee was wont to write love letters, shee exerciseth her bow and arrowes to kill the swift fat deare; and her downy beds are pleasant groves where pretty lambs do graze.

But now returne wee againe to the raging emperour, who sifted the matter out in such sorte that hee found the empresse guilty of her sonnes want, and the doctor to be the instrument of Dulcippas death; who being desperat, (like one that utterly detested the cruelty of the empresse) would not allege that hee had but set the lady in a trance, but openly confess'd that he had poyson'd her, and for that fact was willing to offer up his life, to satisfie the law, therefore the angry emperour sweares, that nothing shall satisfy his sonnes revengement but death: and thereupon, straightly commanded the empresse to be put in prison, and the doctor likewise to be lockt in a stronge tower; but yet because shee was his lawfull wife, and a princesse borne, he something sought to mitigate the law, that if any one within a twelvemonth and a day would come and offer himselfe to combat in her cause against himselfe, which would be the appealant champion, she should have life; if not to be burnt to ashes in sacrifice of his sons death; all which was performed as the emperour had commanded.

But now all this while the poor prince lives alone within the woods, making his complaints. to the flocks of sheepe, and washing their wool with his distressed teares; his bed whereon his 
body rested was turned into a sunburnt banke, his chair of state covered with grasse; his musicke the whistling winds; the rethoricke pitifull complaints and moanes, wherewith hee bewailed his passed fortunes, and the bitter crosses of his unhappy love.

The solitarie place wherein this prince remained was not farr distant from the grove, where Dulcippa led her sacred life; who by chance in a morning at the sunnes uprising, attyred in green vestements, bearing in her hand a bow bended, and a quiver of arrowes hanging at her backe, with her hayre tyed up in a willow wreath, lest the bushes should catch her golden tresses to beautifie their branches; in this manner coming to hunt a savage hart, shee was surprised by a bloody satyre bent to rape, who with a bloody mind pursued her; and comming to the same place where Prince Valentine fed his mourning lambes, hee overtooke her, whereat shee gave such a terrible shrieke in the wood, that shee stirred up the shepherds princely mind to rescue her; but now when the bloody satyre beheld a face of majesty shrowded in a shepherds cloathing, immediately he scudded through the woods more swift than ever the fearful deare did run.

But now gentle reader, here stay to reade a while, and thinke upon the happy meeting of these lovers, for surely the imagination thereof will lead a golden wit into the labyrinth of heavenly joyes; but being breathlesse in avoyding passed dangers, they could not speake a word, but with steadfast eyes stood gaping at each other in the face; but comming againe to their former senses, Valentine brake silence with this wavering speech:

What heavenly wight art thou (quoth hee) which with thy beautie hath inspired mee?

I am no goddesse, (replyed shee againe) but a virgin vowed to keepe Diana company, Dulcippa my name : a lady sometime in the Grecian court, whilst happy fortune smiled; but being crossed in love here doe I vow to spend the remnant of my dayes. And with that, hee catching the word out of her mouth said : 
Oh you immortall gods, and is my Dulcippa yet alive; I, I, alive, I see shee is, I see that sweet celestiall beautie in her face, which hath banished deepe sorrow from my heart; and with that kissing her, he said; see see fairest of all faires that nature ever made, I am thy Valentine that unhappy love, the Prince of Greece, the emperoures true sonne, who for thy lovely sake am thus disguised, and for thy love have left the gallant court for this sweet and homely country life. With that shee tooke him about his manly necke and breathed many a bitter sigh into his bosome; and after with weeping teares discoursed all her passed dangers, as well the crueltie of the empresse, as of the vertuous deed of the good doctor. And having both recounted their passed fortunes they consented (disguised as they were) to travell to the Grecian court to see if the destinies had transformed the state of the emperour or his regiment; for now no longer outcries, nor heavy stratagems or sorrowfull thoughts sought to pursue them; but smiling fortune, gracious delights, and happy blessings. Now fortune never meant to turne her wheele againe to crosse them with calamities, but intended with her hand to power into their hearts oyle of lasting peace. Thus * whilst Apolloes beames did parch the tender twigs, these two lovers sate still under the branches of a shadie beech, recounted still their joyes and pleasures; and sitting both thus upon a grassy bancke, there came travelling by them an aged old man, bearing in his withered hand a staffe to stay his benummed body; whose face when Prince Valentine beheld, with a gentle voyce hee spake unto him in this sort:

Father, God save you; how hapneth that you wearied with age, doe travell through the desart groves, befitting such as can withstand the checks of fortunes ficklenesse ; come faire old man, sit down by us, whose minds of late were mangled with griefe, and crost with worldly cares. This good old hermite hearing the courteous request of the prince sate downe by them, and in sitting downe hee trembled forth this speech:

I come (young man) from yonder citie, where as the emperour holds a heavie court, and makes exceeding sorrow for the losse 
of his eldest sonne, and for a lady, which is likewise absent; the empresse being found guilty of their wants is kept close prisoner, and is condemned to be burnt unlesse within a twelve moneth and a day, she can get a champion that will enter battaill in her cause; and with a doctor also is adjudged to suffer death. Great is the sorrow that there is made for this noble prince, and none but commends his virtue : and withall the deserved prayses of the absent lady.

Father (replyed then the prince) thou hast told us tidings full of bitter truth, able to inforce an iron heart to lament; for cruell is the doome, and most unnaturall the emperoure to deale so hardly with his queene.

Nay, (quoth the old man) if shee be guilty, I cannot pitie her, that will cause the ruine of so good a prince; for higher powers must give example unto their subjects.

By lady, father (quoth the princely shepheard) you can well guesse of matters touching kings; and to be a witnesse of this accident, wee will presently goe into the court, and see what shall betide unto this distressed queene. This being said, they left the aged man, and so travailed towards the Grecian court; and by the way, these lovers did consult, that Prince Valentine attired like a shepheard, should offer himselfe to combat in his mothers cause, and so to expresse the kinde love and nature which was lodged in his princely breast. But being no sooner arrived in the court, and seeing his father to take the combat upon himselfe, presently hee kneeled down and like an obedient sonne discovered himselfe, and withall Dulcippas strange fortunes; whereupon the empresse and the doctor were presently delivered, and did both most willingly. consent to joyne these two lovers in the bands of marriage; where after they spent their dayes in peace and happinesse.

This pleasant discourse being ended, which Sir Launcelot had told to the exceeding pleasure of the greatest company, but especially of the Red Rose Knight, who gave many kind thanks. At this time the winds began to rise and blow chearfully, by which they sayled on their journey successfully from 
one coast to another, till at last they arrived upon the coasts of Prester Johns Land, which was in an evening when the day began to lose her chrystall mantle, and to give place to the sable garments of gloomy night, where they cast anchor unseene of any of that countreys inhabitants.

\section{CHAPTER VI.}

What happened to the Red Rose Knight and his company in the court of Prester John, and how the Red Rose Knight slew' a dragon with three tongues that kept a golden tree in the same countrey; with other attempts that happened.

THE next morning by the breake of day the Red Rose Knight arose from his cabbin, and went upon the hatches of the ship, casting his eyes round about to see if he could espy some towne or citie where they might take harbour; and in looking about he espyed a great spacious citie, in the middle whereof stood a most sumptuous pallace, having many high towers standing in the area, like the Grecian pyramides, the which hee supposed to be the pallace of some great potentate; therefore calling Sir Lancelor (with two other knights) unto him, he requested them to goe up into the citie, and to enquire of the countrey, who was the govournour thereof; the which thing they promised to doe, so arming themselves (as it was convenient, being strangers in that countrey) they went up into the citie, where they were presently presented unto Prester John, who, (being alwayes liberall and courteous unto strangers) gave them a royall entertainment, leading them up into his pallace; and having intelligence that they were Englishmen, and adventurous travellers, hee sent foure of his knights for the rest of their company, desiring them in the knights behalfe, to returne to the court, where they should have a friendly welcome, and a knightly entertainment.

Thus when the Red Rose Knight had understood the will of Prester John by his foure knights, the next evening with his 
whole company hee repayred to the citie, which was right noble and faire, and although it was night, yet were the streets as light as though it had beene mid-day, by the cleare resplendent brightnesse of torches, cressetts, and other lights which the citizens ordayned to the entertaining of the English knights.

The streets through which they passed to go to the kings pallace, were filled with people as burgomasters, knights and gentlemen, with ladies and beautifull damsells, which in comely order stood beholding their coming. But when the Red Rose Knight was entred the pallace he found the renowned Prester John, sitting upon his princely throne, under propt with pillars of Jasper stone; who after hee had given them an honourable welcome, hee tooke the Red Rose Knight by the hand and led him up into a large and sumptuous hall, the richest that ever hee had seen in all his life : but in going up certaine stayres hee looked in at a window, and espyed faire Anglitora, the kings daughter sporting amongst other ladies, which was the fayrest mayd that ever mortall eye beheld, and I thinke that nature herselfe could not frame her like; but being entred the hall they found the tables covered with costly fare ready for supper: when as the English knights were set at the kings table in company of Prester John and Anglitora, with other ladies attending (having good stomachs) they fed lustily; but Anglitora, which was placed right over against the Red Rose Knight, fed onely upon his beauty and princely behaviour, not being able to withdraw her eyes from his divine excellencie; but the renowned Prester John for his part spent away the supper time with many pleasant conferences touching the countrey of England and King Arthurs princely court, the report of which, fame had so often sounded in his eares. But amongst all other devices hee told the English knights of a tree of gold, which now grew in his realme, and yearely brought golden fruit, but hee could not enjoy the benefit thereof, by reason of a cruell dragon that continually kept it; for the conquest of which golden tree he had many times solemnly proclaymed through that part of the world, that if any knight durst attempt to conquer it, and by good fortune 
bring the adventure to an end, hee should have in reward thereof, his daughter, the faire Anglitora in marriage; to which many knights resorted, as well of foraigne countreyes as his own nation, but none proved so fortunate to accomplish the wished conquest, but lost their lives in the same adventure; therefore I fully believe, if all the knights in the worid were assembled together, yet were they all unsufficient to overcome that terrible dragon.

With that the Red Rose Knight with a bold courage stood up and protested by the love he bore unto his countreys king he would performe the enterprise or lose his life in the attempt; so in this resolution hee remained all supper time, which being ended the English knights were brought into divers chambers; but amongst the rest the Red Rose Knight and Sir Launcelot were lodged neere to the fayre Anglitora, for there was nothing betwixt their chambers, but a little gallery: into which being come and no sooner laid in their beds, but the Red Rose Knight began to confer with Sir Launcelot in this manner:

What thinke you (quoth hee) of the enterprise I have taken in hand? Is it not a deed of honour and renowne? Surely (replyed Sir Launcelot) in my judgement it is an enterprise of death; for every man in this country adjudgeth you overcome and destroyed, if you but once approach the sight of the dragon; therefore be advised, and goe not to this perilous adventure for you can obtaine nothing thereby but reproach and death; and doubtlesse they are counted wise that can shun the misadventures, and keepe themselves from danger.

But then (quoth the Red Rose Knight) shall I falsifie my promise, and the promise of a noble minde ought still to be kept; therefore ere I will infringe my vow I have made, I will be devoured by the terrible dragon; and in speaking these words they fell asleepe.

During which time of their conference, fayre Anglitora stood . at their chamber doore and heard all that had passed betwixt them, and was so surprised with the love of this gentle knight, that by no meanes shee could restraine her affections; and 
returning to her chamber casting herselfe upon her bed, thinking to have slept, but could not, she begun to say secretly to herselfe, this sorrowfull lamentation :

Alas mine eyes what torment is this you have put my heart unto; for I am not the woman that I was wont to be, for my heart is fired with a flame of amorous desires, and is subject to the love of this gallant English knight, the beautie of the world, and the glory of Christendome. But fond foole that I am, wherefore doe I desire the thing that may not be gotten, for I greatly feare that he is already betrothed to a lady in his owne countrcy. And furthermore his mind is garnished with princely cogitations, that I may not enjoy his love; and hee thinketh no more of me, then on her that he never saw. But grant that hee did set his affection upon me, yet were it to small purpose, for he is resolved to adventure his life, in the conquest of the golden tree, where he will soone be devoured by the terrible dragon. Ah, what a griefe and sorrow will it be to my heart, when I shall heare of his untimely death, for hee is the choice of all nature, the prince of nobilitie, and the flowre of worship: for I have heard him say, that hee had rather die honourably in accomplishing his vow, than to returne with reproach into England. Which happy countrey if these eyes of mine might but once behold, then were my soule possessed with terrestriall joyes.

Anglitora with these words fell asleepe, and so passed the night away till the day came; who no sooner with his bright beames glistered against the pallace walls, but the Red Rose Knight arose from his bed, and armed himselfe in great courage, ready for the adventure; where, after he had taken leave of the king, and all the rest of his English friends, he departed forth of the citie towards the golden tree, which stood in a low valley, some two miles from the kings palace.

This morning was fayre and cleare, and not a cloud was seene, the elements and the sunne cast his resplendent beams upon the earth; at which time the ladies and damsels mounted upon the highest towers in the pallace, and the common people came up 
to the battlements and walls of churches, to behold the adventure of this valiant knight, who as then went most joyfully on his journey, till he came to the vale of the golden tree, wherein being no sooner entred, but he beheld a most terrible and cruell dragon come springing out of his hollow cave. This dragon was farre more bigger than a horse, in length full thirtie foot, the which incontinently as soone as hee was out of his cave, began to raise his necke, set up his eares, and to stretch himselfe, opened his throate, and casting forth thereat most monstrous burning flames of fire: then the Red Rose Knight drew out his good sword, and went towards him, whereat the monster opened his terrible throat, whereout sprang three tongues, casting forth flaming fire in such sort, that it had almost burnt him. The first blow that the knight strucke, hit the dragon betwixt the two eyes so furiously that he staggered; but being recovered, and feeling himselfe most grievously hurt, he discharged from his throat such abundance of thick fuming smoake that it blinded the knight in such sort, that hee saw nothing : but yet, notwithstanding, hee lifted up his sword, and discharged it upon the dragon, where hee imagined his head was, and strucke so furious a blow, that hee cut off his three tongues close by their roots; by which the dragon endured such marveilous paine, that hee turned his body so suddenly round, that his tayle smote the valiant knight a mighty blow upon his backe, whereby he fell downe upon the sands: being thus overthrowne, hee was in minde most marveilously ashamed; but after awhile having recover'd himselfe, hee ran to the dragon againe, and with his good sword smote such a terrible blow upon his tayle, that it cut it off in the middle; the which piece was seven foot in length. The dragon through the great paine that hee felt, came and incountered the knight in such a fashion, that hee beat him downe to the ground, and after stood over him as though hee had beene dead; but the knight tooke his sword, and underneath him thrust it up to the hilt so farre that it pierced his heart; which when the dragon felt, as smitten to death, began to run away with the sword sticking in his belly, thinking to 
have hidden himselfe in his cave, but his life departed before he could get thither. Incontinently when the Red Rose Knight had rested himselfe, and saw that the dragon was dead, he recomforted himselfe, and went and drew out his sword from his belly, which was all to bestained with his blacke blood, and after tooke the dragons three tongues and stucke them upon his sword; and likewise pulled a branche from the golden tree, which he bore in his hand; and so in triumph went towards the citie, and being come within the sight thereof, he lifted up the golden branch into the ayre as high as hee could, that it might glister in the sunne for the people to behold, (which stood upon high turrets, expecting his comming,) who perceiving it with great admiration, began to wonder. Some there were that gathered greene herbes and flowers, and strewed the way, whereas the knight should passe, to goe to the king's pallace, saying, that all honour ought to be given to so noble and glorious a conqueror.

Fayre Anglitora amongst all other, was most joyfull, when she beheld the glistering brightnesse of the golden branch, and commanded her waiting maids to put on their richest attires, to solemnize the honour of that excellent victory.

And to conclude he was met at the citie gate, with the melodie of drums and trumpets, and so conducted to the kings pallace, where he was right honourably entertained of Prester John and his nobles. Surely there is no man so eloquent, that can discourse by writing, the great joy that Anglitora tooke at his returne; and generally the whole inhabitants had thereat exceeding pleasure.

But now when the valiant Red Rose Knight had entred the hall, and had set the golden branch upon an ivory cupboard richly furnished with costly plate, the English knights and many of the ladies began to dance most joyfully, and to spend the time in delicious sports, till supper was ready, and then the king and the Red Rose Knight was set, and with them the noble and faire Anglitora, Launcelot du Lake, and other English knights; where (all supper while) there was no other conference 
holden, but of the valiant encounters of the Red Rose Knight, who for his part did nothing but make secret love signes to faire Anglitora.

What shall I make long circumstances? The supper passed, and the houre came that the generall company withdrew them into their chambers; the Red Rose Knight was conducted to his lodging by many noblemen and others, which brought the golden branch after him, and so bequeathed him for that night, to his silent rest. But presently after the noblemens departure, Anglitora entered into his chamber, bearing in her hand a silver bason full of warme perfumed waters, the which shee had provided to wash the dragons blood from his body; which when the Red Rose Knight perceived, and thinking upon the kind love shee proffered him, put off his clothes, and made himselfe ready to wash. Faire Anglitora being attired in a white frocke without sleeves, turned up her smocke above her elbows, and so with her owne hands washed the body of the Red Rose Knight.

But now when this gentle bachelor beheld her lovely body, her faire and round breasts, the whitenesse of her flesh, and that hee felt her hands marveilous soft, hee was so much inflamed with the ardent desire of love, that in beholding her beauty, he began to embrace her, and kissed her many times most courteously; and so after when hee had beene well washed, Anglitora caused him to lie in his bed, beholding his well formed limbes, of colour faire and quicke, and could not turne her eyes from his sight : thus as they were beholding each other without speaking any word, at last the noble knight spake to her in this manner :

Most deare lady, you know that by this conquest I have deserved to be your husband, and you, through kind love, to be my wife; whereby I may say that you are mine, and I am yours: and of our two bodies there is but one. Therefore $I$ require you to seale up the first quittance of our loves, which is, that wee two for this night might sleepe together; and so accomplish the great pleasure that I have so long wished for.

Ah most noble knight (answered the faire lady) what in nee 
lyeth (that may bring you the least motion of content) shall with all willingnesse be performed; but yet I conjure you by the promise of knighthood, that you will save mine honour, lest I be made a scandall to my fathers glory.

There is no man in the world (quoth he) that shall preserve thine honour more than I. What if you sleepe this night with me in bed, doe you any more than your dutie, in that I am your husband, and best beloved friend.

My deare love (replyed shee againe) there is no pleasure I will deny yee; but for this night you shall have patience; for I will never yield up the pride of my virginity till my father hath given me in marriage; and therefore I desire you, that to-morrow you will request that favour at his hands; which being granted and performed then accomplish your content.

When the Red Rose Knight had understood his ladies mind, hee like an honourable gentleman was content to obey her request. What shall I say more? but that the night drew on to the wonted time of sleepe, which caused these two lovers (for the time) to breake off company. Here slept the Red Rose Knight till the next morning, which at the breake of day was presented with a consort of musicke, which the king himselfe brought into his chamber. Their melody so highly delighted his minde, that hee threw them a gold chaine, which was wrapped about his wrist ; a gift plainly expressing the bounty that beautified his princely breast. The musicians being departed, hee arose from his rich bed, and went unto the king, whom hee found as then walking in a pleasant garden; of whom hee required his daughter in marriage, in recompence of his adventure; the which request so displeased the king, that all his former courtesies was exchanged into sodaine sorrow, and would by no means consent that Anglitora should be his betrothed spouse; and answered, that first hee would lose his kingdome, before shee should be the wife of a wandring knight.

The noble Red Rose Knight when he understood the unkind answer of Prester John, (all abashed) went unto Sir Launcelot and his other friends, and certified them of all things that had 
happened, who counselled him that the next morning they should depart.

After this they went to the king and thanked him for the high honour hee had graced them with; and after that, went and visited their ship, where for that day they passed the time in pleasure; and so when the scouling night approached, the Red Rose Knight went to the faire Anglitora, and certified her of the unkind answere of her cruell father, whereat shee grew sorrowfull, and greived in mind; but at last better considering with herselfe, shee yeilded her fortune fully at his pleasure, promising that for his love shee would forsake both country, parents, and friends, and follow him to what place soever hee pleased to conduct her. And it is to be supposed that this night the faire Anglitora tooke all the richest jewells that shee had, and trussed them in a fardle; and so when it was a little before day, shee came unto the Red Rose Knight and awaked him, who presently made him ready, and so departed secretly from his chamber, till they came to their ships, where they found all the rest of the English knights ready to depart. So when they were all aboord they hoisted sayle, and departed from the port. To whose happy journey wee will now leave them for a time, and speake of the discontents of Prester John, who all that night, was exceeding sorrowfull for the unkind answere which hee had given to the Red Rose Knight, and so melancholy that hee could neither sleepe nor rest; but at the last hee concluded with himselfe, that hee would goe and convey the English knights (at their departing) unto their ships; to the end that being in other countries they might applaud his courtesies used to strangers.

So in the morning hee arose and went to the chamber where the Red Rose Knight was lodged, whom hee found departed contrary to his expectation. After that hee went into his daughters chamber, where he found nothing but relentlesse walls, which in vaine hee might speake unto; whose absence drove him into such a desperate mind, that hee suddenly ran to the sea coasts, where hee found many of his citizens, that shewed him the ships wherein the English knights were, which 
was at that time from the port or haven more then halfe a mile. Then the king (weeping tenderly) demanded of them if they had seene his daughter Anglitora? to whom they answered that they had seene her upon the ship hatches in company of the Red Rose Knight. At which the king bitterly lamented, beating his brest, and tearing his milke white haire from his head, using such violence against himselfe that it greatly greived the beholders.

At that time there was many or his lords present, who by gentle persuasions withdrew him from the sea coasts to his pallace, where he many dayes after lamented the disobedient flight of his daughter.

\section{CHAPTER VII.}

How Coelia the Queene of the Fayrie Land was found dead floting upon the waves of the sea; with other things that happened to the English knights.

MaNy dayes the windes blew cheerfully in such sort that the English ships were within kenning of the Fayrie Land; at which Sir Launcelot took an occasion to speake unto the Red Rose Knight, and put him in remembrance how hee had promised Cælia to returne into her countrey, unto which hee answered and sayd, that hee would keepe promise if the destinies did afford him life. And there upon commanded the master pilot to make thither ward; but the windes not being willing raised such a tempest on the sea that the ship was cast a contrary way, and the mariners by no meanes possible could approach the Fayrie Land. At which time the noble Queene Cælia stood by the sea side, upon a high rocke beholding the English ship as it passed by, as her usuall manner was, every day standing expecting her deare lords returne, many times making this bitter lamentation to hərselfe:

Ah gentle Neptune thou god of seas and windes, where is my desired love? bring him againe unto mee, that day and night 
doe weepe for his company. Thus shee complained at the same instant when her lovers ship sayled by ; for surely shee knew it by the banners and ensignes which were displayed in the winde; but when the poore lady perceived the ship to turne from her, shee was sore abashed and dismayed. Instead of joy shee was forced to weepe teares; and instead of singing was constrayned to make sorrowfull complaints. In this manner shee abode there all that ensuing night, and caused fires and great lights to be made on the shore, thinking thereby to call the Red Rose Knight unto her.

This order kept shee every day and night for the space of six weekes, wayling the want of him, whom shee loved more deare than her own heart; but when the six weekes were past, and that the Fayrie Queene perceived that shee should have no tydings of her love, shee went from the rockes (all in despaire) into her chamber; where being entred shee caused her sonne to be brought unto her, whom shee kissed many times, for the love shee bore unto his father; and after beholding the little infant crossing her armes, with a sigh comming from the bottome of her heart, she sayd; Alas my deare sonne, alasse thou canst not speake to demand tydings of thy father, which is the bravest knight, the most vertuous and the most valiant in armes that God ever formed. Oh where is nature (sweete babe) that should enjoyne thee to weepe, and myselfe more than thee, for the losse of so brave a prince; whose face I never more shall see! Oh cruell and unkind fortune! my heart hath concluded that $I$ goe and cast myselfe headlong into the sea, to the intent that if the noble knight bee there buryed, I may lye in the same sepulcher or tombe with him; where contrariwise if hee bee not dead, that the same sea that brought him hither alive, bring me to him being dead. And to conclude, before I commit this desperate murder upon myselfe, with my blood I will write a letter, which shall be sewed to my vestements or attire, to the intent that if ever my body bee presented to the Red Rose Knight, that then this bloody letter may witnesse the true love that I bore him, to the houre of my death. 
Many ladies and damosells were in her company whilst thus shee lamented her knights absence; who hearing of her desperate intended death, made exceeding sorrow. Some there were that so mightily grieved that they could not speake one word; other some there were that sought to persuade her from that desperate intent; but all in vaine: for shee presently went from them, and with her owne blood writ a letter and wrapped it in a sear-cloth, and then sewed it to the vestures, wherein shee was clothed: then taking her crowne, shee bound it from her head with a golden chaine, which the Red Rose Knight before time had given her. Then when shee had done all this, shee came to her little sonne and many times kissed him, and so delivered him to the ladies and damselles to be nourished: and so after taking leave of them all she departed toward the sea, whither being come, she went to the top of the high rocke, where shee began to looke downe upon the sea, and after casting herselfe upon the earth, looking up towards heaven shee sayd :

Thou God of my fortunes, Lord of the windes and seas, thou that broughtest into this countrey the right perfect knight, in beauty, manhood, and all vertues, grant that when my soule hath made passage out of this world, my body may be intombed in his bosom; which words being sayd, shee turned her eyes towards her pallace, and spake with a high voyce: Adieu my dear babe, adieu you glistning towers, my royall pallace; adieu ladies and damsels, and lastly adieu to all the world. And in saying so, shee cast herselfe into the sea, and there desperately drowned herselfe.

But yet such was her fortune, that the waves of the sea, bore her dead body, the same day to the English knights ship, which as then lay in a road, where they had cast anchor, for to rest that night, and to be short, it so hapned at the same houre when her dead body was cast against the ship, the Red Rose Knight went up the hatches to take the fresh ayre; where looking about he espied the dead lady richly attyred in cloth of gold, that gorgiously shone in the water, the which he presently caused to be taken up and brought into the ship; where looking 
wishly upon her hee knew her perfectly well; and after stooping to kiss her pale lips, hee found a bloody letter, which shee had compiled, wrapt in seare-cloth: so taking it and reading the contents thereof, his blood began to change, and to waxe red like the rose, and presently againe as pale as ashes. Whereat Sir Lancelot and the other knights were greatly abashed; but especially Anglitora, who demanded the cause of his griefe. Whereunto the Red Rose Knight was not able to answer a word, the sorrow of his heart so exceeded; yet notwithstanding he delivered the bloody letter to Anglitora, the contents whereof are these that follow:

\section{The Bloody Letter of Queen Coelia.}

Thou bright star of Europe, thou chosen of England, for prowesse and beauty, when wilt thou returne to fullfill thy promise made unto her, that many a day hath had her eyes planted upon the seas after thee, shedding more teares in thy absence, than the Heavens containe starres? Ah, my deare love, makest thou no reckoning, nor account of thy promise that thou madest to mee at thy departure? Knowest thou not that every noble mind is bound to keepe his word, upon paine of reproach and shame? but thou hast infringed it, and hast broken thy oath of knighthood, which no excuse can recover. For since I last saw thy ship floting on the seas, I never came within my pallace, till the writing hereof, nor never lay me in my bed to take my rest, nor never sate in judgement on my countreys causes; but for the space of forty dayes I stood upon a rocke expecting thy returne, till famine constrained me to depart. There have I stood day and night, in raine and in snow, in the cold of the morning, and in the heat of the sunne; in fasting, in prayers, in desires, in hopes; and finally, languishing in despaire and death: where, when I could heare no newes of thy returne, I desperately cast myselfe into the sea, desiring the gods that they would bring mee either alive or dead to thy presence, to expresse the true affection that I have ever borne thy noble persone: thus 
fare thou well. From her that lived and dyed with an unspotted minde

Thine owne true lover, till we meet in the Elyzian Fields ; thy unhappy Cælia, Queene of the Fayrie Land.

Thus when faire Anglitora had read those bloody lines, she greatly lamented her unhappy death: and withall, requested the Red Rose Knight, in that she dyed for his sake, to beare her body into England, and there most honourably intombe it: to which he most willingly consented. So causing her body to be imbalmed, they hoysted sayle, and departed towards England; unto which country, they within foure months safely arrived. At whose comming the inhabitants and dwellers greatly rejoyced, but chiefly the Red Rose Knight and his company, who at their first arrivall, kneeled downe upon the earth, and gave God thanks for preserving them from so many dangers and perils, to their high renowne; and triumphant victories.

After this, they intombed the body of Cælia most honourably as befitted a princesse of her calling. This being done, they departed toward Pendragon Castle, standing in Wales, where as then King Arthur kept his royall court: where being arived, they found the king, and many other nobles in a readines to give them a princely welcome: amongst whom was fayre Angellica the nun of Lincolne, mother to the Red Rose Knight; yet kept in so secret a manner, that neither he, nor she, had any suspition thereof, but spake one to another as meere strangers: The discovery of whom is discussed at large in the second part of this historie: as likewise the strange fortune of Cælias little sonne, which the ladies in the Fayrie Land called by the name of the Fayrie Knight; and by what meanes he came to be called the Worlds Triumph: with many other strange accidents, \&c. But now (to conclude this first part) the Red Rose Knight and the faire Anglitora were solemnely married together, and lived long time in King Arthurs court, in great joy, tranquilitie, and peace. 


\section{THE SECOND PART OF THE FAMOUS HISTORY OF TOM A LINCOLNE}

\section{CHAPTER I}

How Tom a Lincolne knew not his mother till forty yeares of his age nor whose son he was: Of King Arthur's death, and his dying speeches, and what hapned thereupon.

W.HEN Arthur, that renowned King of England, (being one of the Nine Worthies of the World,) had by twelve severall set battailys, conquered the third part of the earth, and being wearyed with the exploytes of martiall adventures, in his old dayes betooke himselfe to a quiet course of life, turning his warlike habiliaments to divine bookes of celestiall meditations; that as the one had made him famous in this world, so might the other make him blessed in the world to come. Seven yeares continued quiet thoughts in his brest; seven yeares never heard hee the sound of delightfull drummes; nor in seven yeares beheld he his thrice worthy Knights of the Round Table, flourishing in his Court ; by which meanes his pallace grew disfurnished of those martiall troopes that drew commendations from all forraigne kingdomes. In this time most of those renowned champions had yielded their lives to the conquering tyranny of pale Death, and in the bowells of the earth lay sleeping their eternall sleepes; the royall king himselfe laden with the honour of many yeares, and having now (according to nature) the burthen of death lying heavie upon his shoulders, and the stroke lifted up to divide his body from his soule, hee called before him all the chiefest of his Court, but especially his owne Queene, the Red Rose Knight, and his Lady Anglitora, with 
the faire Angelica, the Nunne of Lincolne, whom hee had so many yeares secretly loved; and being at the point to bid a woful farewell to the world, with countenance as majesticall as King Priam of Troy, he spake as followeth :

First, to thee my loved Queene, must I utter the secrets of my very soule, and what wanton escapes I have made from my nuptiall bed, otherwise cannot this my labouring life depart from my fading body in quiet; long have I lived in the delightful sin of adultery, and polluted our marriage bed with that vile pleasure, pardon, I beseech thee, and with that forgivenesse (which I hope will proceed from thy gentle heart,) wash away this long bred evil, the celestiall powers have granted me remission. Then turning to Angelica, the Nunne of Lincolne, he said,

Oh, thou my youth's delight, thou whose love hath bereaved my queene of such marriage pleasure, thou, and but only thou, have I offended withall ; therefore, divine Angelica, forgive me : I, like a ravisher, spotted thy virginity, I cropt thy sweet body of chastity, I with flattery won thy heart, and led thee from thy father's house, (the great Earl of London) to feede my wanton desires; by thee had I a sonne, of whom both thou and I take glory of, for in his worthiness remains the true image of a martialist, and this renowned Knight of the Red Rose is he: hee lives: the fruit of our wanton pleasures born at Lincoln, and there by a shepherd brought up, few knowing (till now) his true parents. Marvaile not, dear sonne, thinke not amisse sweet Queen, nor thou my lovely Angelica: Be not dismayed you honorable states here attending my dying hour, for as I hope presently to enter Elysium Paradise, and weare the crowne of desertful glory, I have revealed the long secrets of my heart, and truely brought to light those things that the darkness of oblivion hath covered. Now the mother knows her son, the son the mother. Now may this valiant knight boast of his pedigree, and a quiet content satisfie all your doubts. Thus have I spoke my mind, and thus quieted, my soul bids the world farewell. Adue, faire queene, adue deare son, farewell lovely Angelica ; Lords and Ladies adue unto you all, you have seene my life, so now behold 
my death; as kings doe live, so kings must die. These were the last of King Arthur's words; and being dead, his death not half so amazed the standers by, as the strange speeches at his life's farewell.

The Queene in a raging jealousie fretted at her marriage wrongs, protested in her heart to be revenged upon the Nun of Lincolne.

The Nun of Lincolne seeing her wantonnesse discovered, tooke more griefe thereat than joy in the finding of her long lost son; supposing now that (the king being gone) she should be made a scandall to the world.

The Red Rose Knight knowing himself to be begot in wantonnesse, and borne a bastard, tooke small joy in the knowledge of his mother.

Anglitora (Tom a Lincoln's wife,) exceeded all the rest in sorrow, bitterly sobbing to her selfe, and in heart making great lamentation, in that she had forsaken father, mother, friends, acquaintance, and country, all for the love of a bastard, bred in the womb of a shamelesse strumpet, therefore she purposed to give him the slip, and with her owne sonne (a young gallant knight, named the Black Knight, in courage like his father,) to travell towards the kingdom of Prester John, where she first breathed life, and her father reigned.

In this melancholy humour spent they many dayes troubling their braines with divers imaginations. The Court which before rung with delights, and flourished in gallant sort, now thundred with complaints; every one disliking his owne estate. Discontent, as a proud commander, governed over them, and their attendants were idle fancies and disquiet thoughts; and to speak truth, such a confused court was seldome seene in the land, for no sooner was King. Arthur's funerall solemnized, but the whole troopes of Lords, Knights, and Gentlemen, Ladies and others, were (like to a splitted ship torne by the tempest of the sea) severed, every one departed whither his fancie best pleased.

The Red Rose Knight conducted his mother Angelica to a cloyster in Lincolne, which place she had so often polluted with 
her shame, there to spend the remnant of her life in repentance and with her true lamentations, to wash away her black spots of sinne that so grievously staineth her soule, who from a pure virgin made herself a desolute strumpet.

Likewise King Arthurs widdowed queene, like to ireful Hecuba or the jealous Juno, kept her chamber for many dayes, pondering in her minde what revenge she might take upon Angelica her husbands late favorite.

On the other side Anglitora, lady and wife to the Red Rose Knight with her son the Black Knight, made provision for their departure towards the land of Prester John, where she was born; so upon a night when neither moone nor starlight appeared they secretly departed the court only attended on by a negar or blackmore : a slave fitting to provide them necessaries and to carry their apparel and jewels after them, whereof they had abundant store. The Blacke Knight her son (so called rather by fierce courage than his blacke complexion) was all fired with the desire that he had to see his grandsire Prester John, therefore without taking leave of his father (being then absent in the company of his lewd grandmother) with noble spirit conducted his mother to the sea side, where a ship was ready then to hoist sayle, where of the pilots they were most willingly received for passengers. And in this manner departed they the land, the Black Knight wore on his helmet for a scutcheon a black raven feeding on dead men's flesh, his caparisons were all of velvet embroidered which most lively figured forth the blacke furie lodged in his princely bosome. Anglitora his mother had the attyre of an amazon, made all of the best Arabian silke, coloured like the changeable hue of the raine-bow : about her neck hung a jewell of a wonderful value, which was a diamond cut in the fashion of a heart split asunder with a Turkish semitar, betokening a doubt that she had of her knights loyalty. The slavish Moore that attended them, went all naked, except a shadow of greene taffeta which covered his privy parts, upon his foot a Morischo shoe, which is nothing but a soale made of an asses hide, buckled with small leathers to his insteps, upon his head he wore a wreath of cypress gilded with pure gold, 
and a plate of brass about his neck close locked, with the word 'Bond-slave' engraven about it. In this manner passed they the seas, and was by these strange habits wondered at in all countries where they came. In which travels we will leave them for a time and speak of other things pertinent to our story.

\section{CHAPTER II.}

Of Tom a Lincolne's strange manner of travelling, his wofull departure from England, and of his sorrozefull lamentations for the unkindnesse of his Lady.

When Tom a Lincolne the Red Rose Knight had spent some two months in the company of his mother at Lincolne, giving her as much comfort as a sonne might, hee left her very penitent for her lives amisse, and returned to the court where he left both his wife and her sonne, the Blacke Knight, thinking at his arrivall to find so joyful a welcome, and so courtious an entertainment, that all the blacke clouds of discontent might be blowne over by their happy meeting : but as ill chance had allotted, all things fell out contrary to all expectation, for hee neither found wife, child, servant, nor any one to make him answer: his plate and treasure was diminished, his household furniture imbesselled and by thieves violently carried away, he had not so much as one steed left in his stable, for them the queene had seazed on for her use : and furthermore (by her commandment) a decree was made that whomsoever in all the land shewed him any or gave him but homely reverence should lose their heads, for shee had entitled him, "The base borne seed of lust, a strumpets brat, and the common shame of the dead king." This was the malice of King Arthurs widow : and surely Queene Juno never thirsted more for the confusion of Hercules, then shee did for Tom a Lincolnes overthrow : but yet this griefe (being cast from a princesse favour to a vulgar disgrace) was but a pleasure to the sorrow hee tooke for the misse of his lady and sonne : no newes could hee heare from them, but that they were fled from the fury of the angry 
queene, which was but a-vaine imagination layd upon the time; but farre otherwise did mischief set in her foot, the doting minde of his lady Anglitora intended to a further reach, which was to abandon his presence for ever, and to thinke him as ominous to her sight as the killing cockatrice.

The effect of this his wifes suddain dislike shee had caused (before her departure) to be carved in stone over the chimney of his lodging, how that shee deserved damnation to leave father, friends, and country, for the disloyall love of a bastard. Of all griefe to him this was the very spring, the roote, the depth, the height; which when hee had read, hee fell into a swound, and had it not been for two pages that accompanied him he had never recovered : in this agony the vaines of his breast sprang out into blood, and all the parts of his body swate with griefe: downe fell he then upon his knees, and immediately pulled the ring from his finger, which shee had given him when they were first betrothed, and wash't it with his tears, kissing it a hundred times; all that ever hee had from her did hee wash with the blood that trickled from his bosome, and after bound them in a cypresse to his left side, directly where his heart lay, protesting by that God that created him, and was the guide of all his past fortunes, never to take them thence till either hee found his lady or ended his life. He likewise made a solemn vow to heaven never to cut his hair, never to come in bed, never to weare sho, never to taste food, but onely bread and water, nor never to take pleasure in humanitie, till hee had eased his griefe in the presence of his dearest Anglitora, and that her love were reconciled to him.

Being thus strangely resolved hee discharged his servants and pages, giving them all the wealth that hee had, and clad himselfe in tann'd sheep skins made close unto his body, whereby he seemed rather a naked wilde man bred in the wildernesse then a sensible creature brought up by civill conversation. Thus bare footed and bare legged with an ivory staff in his hand, he set forward to seeke his unkind wife and unnaturall sonne, giving this wofull farewell to his native country.

Oh you celestial powers (quoth hee) wherefore am I punished 
for my parents offences? Why is their secret sinnes made my public misery? What have I misdone that my wife resisteth me, and like a discourteous lady forsakes me, making her absence my present calamity?

Oh thou gracious Queene of Love, I have beene as loyall a servant in thy pleasures as ever was Hero to his Leander, or Pyramus to his Thisbe : then what madding fury like a cruell commander, hath taken possession of my Anglitora's heart, and placed infernal conditions, whereas the pure virtues of modest behaviour had wont to be harboured: it cannot be otherwise, but the enraged queene, with her unquenchable envie hath driven her hence, and not only of one heart made two, but of two seekes to make none; which is by untimely death, to worke both our confusions; therefore proud queene, farewell : let all the furies haunt thee, and may the court seeme as hatefull to thy sight, as the torments of hell fire to a guilty conscience. Ungratefull England likewise adieu to thee, for all the honours I have brought into thy bounds, and with the spoyles of foraigne countreys made thee the onely prince of kingdomes. Yet thou repaiest me with disgrace; and load'st me with more contempt, then my never conquered heart can endure. So kissing the ground with his warme lips that had so long fostered him, and with many a bitter teare and deepe sob, like a pilgrim (as I sayd before) hee tooke leave of his native countrey, and so went to the sea side: where hee heard of his wife and sonnes departure, after whom (as soone as the wind conveniently served) he tooke shipboard: where wee will now likewise leave him to his fortune upon the sea, and speake of the professed malice the queene prosecuted against Angelica the mother of the Red Rose Knight. 


\section{CHAPTER III.}

Of the Wofull death of Angelica, mother to the Red Rose Knight, and of the death of the jealous Queene and others.

ThE beauttious Angelica being left by her sonne the Red Rose Knight (at his departure) in a monastery at Lincolne, there to bewaile her former offences; and for her youths pleasure in age to taste the bitter food of sorrow: the day time shee spent in grieved passions, the night shee wasted with heart breaking sobs ; she fed on carefull thoughts, her drinke was streames of salt tears; her companions thoughts of her passed wanton pleasures ; her bed no better than the cold earth : her sleeps were few, but her comforts lesse; her continuall exercise was with a needle to worke in silke, upon the hangings of ber chamber, how shee was first wooed then wonne to King Arthurs pleasures, in what manner their meetings were, their wanton dalliances, his embraces, her smiles; his princely gifts, her courteous acceptance; and lastly the birth of her thrice worthy sonne, his bringing up, his honours in the court, and his strange discovery ; all which shee had wrought as an arras worke, with silke of diverse colours, in a piece of the purest Hollande cloth. In doing this twice had the golden sunne runne his circumference round the worlde, twice had the pleasant spring beautified the earth with her changeable mantles, twice had nipping winter made the fields barren, and the woods leaflesse, and twice had the yeare shewn himselfe to all mankinde; in which time of twice twelve months, every day made shee a sorrowfull complaint for the wrack of honour, and her virginities losse which shee so willingly surrendered; and in this so greatly had sorrow and griefe changed her, that her eyes (which had wont like twinckling diamonds to give light to all affections) were now sunke into their cells, and seemed like a hollow sepulchre new opened; her face wherein beautie herselfe dwelt, and her cheeks the true die of the lillie and the rose intermixt, now appeared old and writhen, like to the countenance of Hecuba when her 
husband King Priamus and his princely children were slaine at Troys destruction: and her tresses of gold like hayre, which like to Indian wyers hung over her shoulders, were now growne more white then thistle downe, the isickles of frozen ice, or the white mountains snow ; all these griefes of nature had not age changed, but the inward griefe of her carefull heart.

But now marke the wofull change that hapned, even upon the day, which by computation shee had in former times yielded up her maydens pride, and lost that jewell that kingdomes cannot recover; upon that haplesse day came there a messenger from the queene to bid her make preparation for death, for on that day should be her lives end, and her fortunes period, which shee most willingly accepted of, and tooke more joy thereat than to be invited to a princely banquet.

Be not dismayed (said the messenger) for you shall have as honourable a death as ever had lady: seven severall instruments of death shall be presented to you for a choise, and your owne tongue shall give sentence which of them you will die by ; whereupon this messenger set this sorrowfull lady at a round table, directly in the middle of a very large room whereinto hee had led her, hung all about with blacke; where being placed as to a banquet, or some solemne dinner of state, there entred seven Servitours in disguised shapes like unto murtherers, with seven severall deadly services in dishes of silver plate. The first brought in fire burning in a dish if she would, to consume her body to ashes; the second brought in a dish a twisted coard, to strangle her to death; the third a dish full of deadly poyson, to burst her body withall; the fourth a sharpe edg'd rayzor or knife, to cut her throat; the fifth an iron wracke to teare her body into small pieces; the sixth a dishfull of live snakes to sting her to death: and the seventh an impoysoned garment, being worne, that will consume both flesh and blood. These seven deathfull serviteurs, having set downe their dishes (the least whereof brings present death) shee was commanded by the messenger which of them shee should chose to die withall, and to make speedy choice; for hee was sworne to the queene 
(on whom hee attended) to see it that day accomplished. At these his wordes shee fell presently upon her knees, and with a courage readier to yield to deaths furie then to the mercie of the living queene, sayd as followeth.

Oh thou guider of this earthly globe, thou that gavest my weak nature over unto a wanton life, and from a virgin chaste, hast made me an infamous strumpet, thou that sufficedst onely a king in majestie to prevail against me, and with the power of greatnesse won me to lewdnesse; for which I am now doomed to a present death, and forced by violence to bid this tempted world adieu, inspire me with that happy choice of death, as my soule may have an easy passage from my body. First to die by fire, to an earthly imagination seems terrible, and far different from nature. Secondly, to die with strangling coard, were base, and more fitting for robbers, theeves, and malefactors. Thirdly, to die by deadly poyson were a death for beasts and wormes, that feed upon the bosome of the earth. Fourthly to die by cutting knives and slicing rayzors, were a death for cattle, fowls, and fishes, that die for the use of man. Sixthly, by an iron wracke to end my life, were a barbarous death, and against man's nature, But seventhly, to die a lingring death, which is a life consuming by wearing of impoysoned garments, "where repentance may still be in company) will I chuse; therefore sweet messenger of my death, doe thy office, attyre me in these robes: and the manner of my death $I$ beseech thee make knowne unto the queene : tell ber (I pray thee) I forgive her: and may my death be a quit unto her soule, for my life is to her eares as the fatal sound of night ravens on the mermaid's tunes.

Vaine world now must I leave thy flattering inticements, and instead of thy pomp and glory, must shortly tread the doleful march of pale death; and this body that hath been so pleasing to a prince's eye, must be surrendered up for wormes to feed upon. Many other words would shee have spoken, but that the commanding messenger (being tyed to an houre) caused her to put on the empoysoned robes, which no sooner came to the warmth of her body, but the good lady after a few 
bitter sighes and dreadful gaspes, yielded up the ghost : being (through the extremitie of the infectious garment) made like to an anatomie, which they wrapped in seare cloth, and the next day gave her buriall according to her estate, and so returned to the enraged queene, keeping then her court at Pendragon Castle, in Wales, into whose presence, the messenger was no sooner come, but the angry queene, beyond all measure being desirous to heare of Lady Angelica's death, in a rage ran and clasped him about the middle, saying, Speake Messenger speake, is the vile strumpet dead ? is the shame of womankinde tortured? is my hearts griefe by her death banished my bosome? speake, for I am overmasted with doubts.

Most gracious queen (quoth the Messenger) resolve yourself of her death; for the cold earth hath enclosed up her body; but so patiently took shee her death, that well might it have moved a tiger's heart to remorse, for in truth my heart relented at the manner of her death: never went lambe more gently to the slaughter, nor never turtle dove was more meeke, than this wofull lady at the message of her death; for the elements did seeme to mourne, closing their bright beauties up in black and sable curtaines : and the very flintie walls (as it were) sweate at the agonie of her death, so gentle, meeke, and humble tooke shee her death, commending herselfe unto your majestie, wishing that her death might be your soules contentment. And could she be so patient (quoth the queene) that even in death would wish happinesse to the causers thereof? farewell thou miracle of womankind. I have been to thee a savage lionesse; I was blinded at the report of thy wantonnesse, else hadst thou been now alive : all my cruelties against thee I now deeply repent, and for thy deare hearts blood, by me so rashly spilt, shall bee satisfied with the lives of many soules. Hereupon shee in a furie commanded the messengers head to be stricken off, and the seven servitours to be hanged all at the Court Gate, and afterwards caused their limbs to be set upon high pooles, by the common high wayes side, as an example of her indignation. Never after this houre (such is the remorse of guiltie conscience) 
could shee sleepe in quiet, but strange visions of this lady (as shee thought) seemed to appeare to her : the least noise that shee heard whispering in the silence of the night, did shee imagine to be some furie to dragge her to Hell, for the death of this good lady. The windes (as shee imagined) murmured forth revenge, the running rivers hummed forth revenge, the flying Fowles of the Ayre whistled out Revenge ; yea every thing that made noyse (in her conceit) gave remorse for Revenge : and till that her owne life had given satisfaction by death, for the ruine of so sweet a ladies life, no food could do her good, no sleep quiet her braine, no pleasure content her minde, but despaire with a terrible countenance, did evermore attend her, willing her sometime to throw herselfe headlong from the top of a tower, sometime by poyson to end her dayes, sometime by drowning, sometime by hanging, sometime by one thing, sometime by another: but at last in the middle of the night, having her heart deepely overmastered by despaire, she tooke a girdle of pure Arabian silke, which girdle shee first wore on her princely nuptiall day when King Arthur married her; this fatall girdle shee made a sliding knot of, and therwithall upon her bed post shee hanged herselfe. 'Thus blood (you see) being guiltlesse shed, is quitted againe with blood.

The queene being dead, was not so much pitied of the people, as the good Lady Angellica, little lamentation was made for her death; for every one expected the like untimely ende: but according to the allegiance of subjects, her noblemen gave her a princely funerall, and set over her an Iron Tombe, in signification that she had an iron heart, and flinty conditions.

Here will we leave the dead to their quiet rests, and returne to the Blacke Knight and his Mother Anglitora, with the Indian slave that attends them; for strange bee the accidents that happen to them in forraigne countreyes; and after we will speak what happened to the Red, Rose Knight upon the sea. 


\section{CHAPTER IV.}

By what meanes Anglitora became a Curtizan, and how her Sonne, the Black Knight lost himselfe in a Wildernesse.

THE Black Knight his Mother Anglitora and the Blackamore Slave having happily crossed the seas, and arrived in a countrey very fertill to see to, replenished with all kinds of trees and fruit, yet were there no inhabitants to find, but onely an Old Castle, built of flint stones, the turrets whereof were made like the Grecian Pyramides, square and very high. At this castle gate they knocked so boldly, (each one careless of all accidents that might happen) as it ran into the chamber where the knight of the castle lay; who immediately sent a very low statured dwarfe to see who knocked, and if they were strangers, to direct them up into his chamber, to take such kind curtesies as the castle afforded : for indeed hee was a knight of a bountiful condition, and full of liberality. The Dwarfe no sooner comming to the gate, and espying people in such strange disquieted attires, never having seene the like before, without speaking one word, ranne amazedly up to his master, certifying him that a kinde of people of an unknowne nation was arrived, and that they seemed rather Angells (in shape) then any earthly creatures.

The Knight of the Castle hearing this, came down and met them in a large square court paved with marble stone where hee kindly gave them entertainment, promising them both lodging and other needfull things they were destitute of. The three travellers accepted of his courtesies, and being long before weather-beaten on the seas, thought themselves from a deep dungeon of calamities, lifted to the top of all pleasures and prosperitie; thus from this paved court, the Knight led them up to his owne chamber wherein there was a fire made of Juniper wood and frankincense, which smelled very sweet; the walls were hung about with rich tapestrie, whereon was writ the story of Troys destruction, the Creation of Mankind, and the fearful description of the latter day of Doome; likewise hung 
upon the same walls Instruments of all sorts of musicke, with such varietie of other pleasures, as they had never seene the like.

Now while these weary travellers tooke pleasure in beholding these things, the good knight caused his dwarfe, (which was all the servants that hee kept) to cover the table made of cypress wood, with a fine damaske table cloth, and thereon set such delicates as his castle afforded, which was a piece of a wild boar, rosted the same morning, with divers other services of fowles, whereof the countrie had plentie; their bread was made of the almonds mixed with goats milke, (for no corn grew in that soyle) their drinke of the wild grape likewise mingled with goats milke, which is in my mind accounted restorative : to this banquet were the travellers placed, where having good stomachs, they quickly satisfied hunger, and after began to chat of their adventures, what dangers they endured by sea, and how luckily they arrived in that country, giving the courteous Knight great thanks for his kindnesse.

On the other side, when the banquet was ended, every one rising from the table, he took an Orphirian that hung by, and caused his dwarfe to dance after the sound thereof; the strings whereof he himself strained with such curiositie, that it moved much delight, especially the Lady Anglitora, whose eyes and ears were as attentive to the melodie, as Helens were to the enchanting musicke of the Grecian Paris. In this kind of pleasure consumed they most part of the day, till the bright sun began greatly to decline, then the Black Knight in a courageous spirit, said, Sir Knight (for so you seeme to bee, by your entertainment of strangers) this carpet kind of pleasure I like not, it disagrees with my young desires: the hunting of untamed tygers, the tilts and tournaments of knights, and the battles of renowned warriours, is the glory I delight in; and now, considering no other adventrous exercise may be found in this countrey, but only the hunting of wild beasts, I will into the forests, and by manhood fetch some wild venison for my mother's supper. 
The Knight of the Castle (seeing his resolution) furnished him with a hunting javelin, and so directed him to the forest, where most plentie of such pleasures were: God bee his good speed for we will leave the Blacke Knight in his exercise, and speake of the wanton affections of Anglitora, and the Knight of the Castle, that they cast upon each other: a short tale to make, whereas two hearts make one thought, the bargaine is soone made. The Knight of the Castle having not had the presence nor societie of a woman in seven yeares before, grew as wantonly minded as the Roman Tarquinus, when he ravished the chaste Lady Lucretia. On the other side Anglitora having the renowne of disloyaltie, grew so pliable to his desires, that at his pleasure he obtained that love, which in former times the Red Rose Knight adventured his life for: she that in former times was accounted the worlds admiration for constancie, was now the very wonder of shame, and the byword of modest matrons; this was the first daies entrance into these wanton pleasures, which in all daliance they spent till the sun had lost the sight of the earth : then expecting the return of the Blacke Knight from hunting, they sat as demurely as they had beene the chastest hours in the world; not a glance of wantonnesse passed betwixt them, but all modest and civill behaviours; in this sort stayed they, attending for the return of the Blacke Knight, but all in vaine : for hunting a wild panther in chase, he followed so far in the unknowne forest that he lost himselfe all that night travelling to find the way forth, but could not ; sleepe was to him as meate to a sicke man; his steps were numberlesse, like the starres of heaven, or the sands of the sea; his devises for recoverie little prevailed, the further he went, the further hee was from returning. Thus day and night (for many days and nights) spent hee in these comfortlesse travailes; no hope cheered his. heart, no comfort bore him company, but his patient mind : and now at last, when he saw all meanes frustrate he resolved to live and die in that solitary forrest: his food he made of the fruits of trees, his drinke of the cleare running water; his bed was no better than a heap of sun burnd mosse; his canopies the azure elements full of twinkling lights, his 
curtains a row of thick branched trees; the torches to light him to his bed, the starres of Heaven; the melodie of musicke to bring him asleepe, the croakes of ravens or the fearful cries of night owles; the clocke to tell the houres of the night, were hissing snakes, and toads croaking in foggy grasse: his morning cocke the cheerefull nightingale, or the creeping larke; his companions on the day, were howling wolves, ravening lions, and the wrathfull boars; all (as the fates had decreed) as gentle to him in fellowship, as people of a civill government; for to say truth, time and necessity had converted him, to a man of wild conditions; for his haire was growne long and shaggy, like unto a satyre: his flesh tanned in the sun as an Indian: the nailes of his fingers were as the tallents of eagles, wherwith he could easily climbe the highest trees; garments hee had not any, for they were worne out, and as willingly was he content with nakednesse, as in former times he was with rich habiliments. Thus lived hee for seven long yeares in this desolate forest, by which time he was almost grown out of the favour of a man; where for a short time we will leave him, and proceed to other accidents, also we will overpasse the lewd lives of Anglitora and the Knight of the Castle, nor speak as yet any more of their seven years adultery ; for numberlesse were the sinnes committed by them in those seven yeares, in that accursed castle.

\section{CHAPTER V.}

How the Red Rose Knight found his Lady, and how he was most strangely murthered, and buryed in a dunghill.

THE Blackamore Slave (as you have heard) attended upon them like an obedient servant, and shewed all duty and love, till Anglitora gave her body to the spoile of lust, and from a vertuous lady, converted herself to a hated strumpet; which vile course of life, when the Indian perceived, hee secretly departed the castle, greatly lamenting the wrongs of his master, the Red Rose Knight, whose noble minde deserved better at her hands. Day and night travelled the poor slave towards England, thinking to find his 
master there, and to reveal that which he thought hardly would be believed by him; weary and opprest with hunger, went he this long journey; many provinces he passed thorow, before hee could learne the way towards England; and then was hee so farre from it as at the first, when hee departed from the castle.

The labouring husbandman grieved not more to see his corne and cattell taken by theeves, nor the merchant to heare of his shippes sunke at sea, then did this Indian at his vaine travailes and wearisome journeyes to small purpose, so at last setting forward againe, he came to the sea side, thinking to heare of some ship to give him passage over: but alas one crosse falls after another, one mischiefe comes upon the necke of another: and one mischance seldome happens alone; so as this true-hearted negar stood beholding how the billowes of the sea beat àgainst her bankes, and the whale fishes lay wallowing in the waves, behold such a tempest suddenly arose, that by the force thereof the poore slave was cast into the sea, but by reason of his silken vaile tyed about his middle, and his great skill in swimming (as most negars be perfect therein) kept himself from drowning: and as good fortune would the same tempest drove the weather beaten ship to the same shore, wherein the Red Rose Knight (his master) was, which ship had beene seven yeares upon the sea in great extremitie, and before this tyde could never see land. By that time the tempest ended, the ship floated to land, wherein was left but onely the Red Rose Knight, in his Palmer's weed (for all the rest were starved up for want of food) who being weake and feeble, climbed up to the top of the hatches, where, when he had perceived the negar labouring for life upon the waters, cast out a long coard, and so saved him: whom when the Red Rose Knight saw and perfectly knew, he fell almost into a trance for joy, supposing his lady and sonne not to be far distant; but recovering his former senses he spake as followeth.

Oh blessed Neptune, hast thou vouchsafed to deliver me from the depths of thy bowels and cast me on land, where once againe I may behold my faire Anglitora, and my deare sonne the Black 
Knight. These seven yeares famine endured on the sea, hath beene sweete pleasure to me, in that the end brings me to my desires. Full three score of my miserable companions in this ship, hath death seased upon, and through famine have eaten one another, making their hungry bowels graves for the other carcasses; and though now this belly of mine (like the canibals) have been glutted with humane flesh, and this mouth of mine tasted the blood of man: yet am I as pittifull as the tender hearted mother forgetting her sons offences; and to my Anglitora will be as kind, as if never she had trespassed; nor like the Grecian Helena, left her married lord : so taking the blackamore by the hand, he demanded of her welfare, and in what estate his son remained. The true-hearted negar could hardly speake for griefe, or utter one word for teares: yet at the last with a wofull sigh hee uttered forth these heart killing speeches.

Oh my noble master (quoth he) by you from a Pagan I was made a Christian; by you from a Heathen nation without civilitie, I was brought to a land of princely government, and by you till my departure, was I maintained in good manner; therefore if I should prove a perjured slave, and a false varlet towards you, my body were worthy to bee made foode for hungry fowles of the ayre, and for the ravening beasts of the fields: therefore considering now that dutie binds me to it, I will reveal such wofull chaunces, and such disloyall trickes shewed by your lady, as will make your heart tremble, your sinews shake, and your haire to stand upright. Anglitora your lady and wife, hath dishonoured your bed, and polluted that sacred chamber of secresie, which none ought to know but only you two; that marriage vow she made in God's Holy Temple, hath she infringed, and untyed the knot of nuptiall promise; in a countrey far from hence, hath shee wrought this hated crime, in a country unpeopled lives shee, in a castle which is kept by a knight of a wanton demeanour; thus live they two in adultery, there live they secretly sleeping in wantonnesse, and therefore these seven yeares hath shee made herself the childe of shame; all this with extreme griefe doe I unfold, and with a heart almost kild with sorrow doe 
I breathe out the dutie of a Servant : if I have offended, let my death make amends : for what I speake is truely delivered from a heart unfained.

All this time of this his sorrowfull discourse, stood the Red Rose Knight, in a bitter agonie, like one newly dropt from the cloudes, not knowing how to take these discourtesies; one while purposing to bee revenged, and with his nailes to teare out the strumpets eyes, another whyle bewayling her weake nature, that so easily was woon to lewdnesse; but at last taking to him, (the virtue) patience, he resolved to travell to the castle, and with his meeke perswasions seeke to win her from her wickednesse, and to forget, forgive, and cast out of remembrance all these her unwomanlike demeanours, observing the proverbe, that faire meanes sooner winnes a woman than foule. Thus in company of his true servant the negar, hee tooke his journey toward the castle; where (after foure moneths travell) they arrived; the Red Rose Knight, by the direction of the negar, knocked, and in his pilgrimes habits, desired meate and lodging for himselfe and his guide.

The first that opened the gate, was his owne lady, who immediately, upon the sight of them blushed, as though some sudden feare had affrighted her; yet dissemblingly colouring her knowledge of them, she in a charitable manner gave them entertainment, and conducted them to a by roome, at the back side of the castle, into which place shee sent them (by her dwarfe) victuals from her owne table, with a command, that the next morning, they should avoyed, and never more trouble this place.

This message sent by the dwarfe, much disquieted the Red Rose Knight, and drove such amaze into his mind, that hee grew ignorant what to doe; and seeing his appointed time very short to remaine there, he now thought fit to strike whilst the iron was hot, and to discover what hee was: so taking the scarfe of jewels and rings tyed to his left side against his heart (which she knew perfectly well to be the gifts of her love) and by the dwarfe sent them her. The which no sooner shee beheld, but shee openly said to the Knight of the Castle, that their secret affections were 
discovered, and her husband in the habit of a Palmer made abode in her house, conducted thither by the moore, to bring their shame to light, and to carry her thence to England, there to be punished for her sinnes. Hereupon the knight and shee purposed the same night to rid themselves of that feare, and by some violent death to send the Palmer to his last abiding. Disquietnesse attended on all sides for that day, and every houre seemed ten till night approached, which at last came, though long lookt for. Then Anglitora in company of the knight of the castle, like unto murtherers rose from their beds, even at that houre of night when mischiefes are acted, when no noyse was heard but the barking of wolves, the howling of dogs, and the croaking of night owles, all assistance to blacke actions. In this manner came they into the lodging of the Palmer, who for wearinesse of his journies most soundly slept, little dreaming that such cruelty could be lodged in the bosome of his wedded wife; one whose love he had first gained with great danger, and alwaies esteemed as deare as his owne heart blood. All signes of duty had shee obscured, not any remembrance had shee of womanhood; marriage love was forgotten; their past joyes were as things never beene; not any thought of remorse remained within her, but shee more cruell then the new delivered beare, or the tyger starved for meat, by the helpe of the Knight of the Castle, tooke the scarfe of jewelles, (sent her from him the same evening) and by violence thrust them downe the Palmers throat : by which meanes they bereaved him of life, and without any solemnitie due to so brave a man, they buried him in a dunghill without the gate, not shedding so much as one teare for his death; so great was the envie of this his spitefull lady. The poor negar they set up to the middle in the ground so surely fastned, that by any meanes hee could not stir from thence, where wee will leave him wishing for death. The Red Roșe Knight or rather the unhappy Palmer, in his unchristianlike grave, and the Knight of the Castle with the murtheresse Anglitora, to their surfetting banquets of sinne, and returne to the Black Knight, which had lost himselfe in the woods. 


\section{CHAPTER VI.}

How the Blacke Knight being lost in a Wildernesse became a Wild Man, how his Fathers Ghost appeared unto him, and in what manner he slewe his owne Mother.

By this time the Blacke Knighte grew so naturall a wildman, as though he had beene bred in the wildernesse : for day by day he sported with lions, leopards, tygers, elephants, unicorns, and such like kind of beasts playing as familiarly with them as in King Arthurs court hee had done with gallant gentlemen. But marke how it happened one daye above another; hee chanced to walke downe into a valley where he sate himselfe downe by the rivers side, and in humane complaints bewailed his owne estate, how being borne of a princely race, descended royally, should thus consume his dayes in savage sort, amongst wilde beasts, and by no means could recover his libertie or free himselfe from that solitarie wildernesse. Being in this distress of mind, a suddaine feare assayled him, his heart shriveled, his haire stood upright, the elements seemed to look dimme, a terrible tempest tore up huge trees, the wilde beasts roared and gathered on a heape together. Birdes fell livelesse from the ayre, the ground as it were trembled, and a sodaine alteration troubled each thing about him; in this amaze sate he a good time, marvelling what should ensue; at last there appeared (as he imagined) the ghost of his father newly murthered, with a countenance pale and wan, with hollow eyes (or none at all) gliding up and downe before him, casting such feareful frownes, as might make the stoutest heart in the world to tremble; and at last, setting himselfe before the Blacke Knight, spake as followeth.

Feare not my sonne, I am the ghost of thy murthered father, returned from Pluto's hollow region: I came from that burning kingdome, where continually flames an everlasting furnace: from the fearcfull pitte come I to thee for revenge. Oh thou my sonne, if ever gentle nature were plyant in thy boosome; if ever thou tookest pleasure to hear thy fathers honours spoken of : if ever 


\section{THE PLEASANT HISTORIE OF TOM A LINCOLNE.}

thou desirest to have thy life meritorious in this world, take to thee thy never failing courage, and revenge my death upon thy adulterous mother : thy mother now living in the filthinesse of shame, making the castle where shee now remains in, a lustful stewes; there was I murthered, and there buried in a stinking dunghill; no man gave mee funerall teares, nor any sorrowed for my death; I that have dared death in the face, and purchast honour in many kingdomes, was slaine by my owne wife, by my neerest friend, by my second selfe, by Anglitora, by her whom the whole world admired for virtue. Rise, deare sonne, rise, and hast thee to that castle, polluted with the shame of thy wicked mother : Rise I say, and let the pavements of that castle be sprinkled with their detested blood, the blood of that monster that hath not onely despoyled my marriage bedde of honoured dignities, but like a tyrant to her owne flesh hath murthered mee.

See how the angry heavens (as it were) doe threaten my revenge; hearke how hell-furies doe howle and roare for my revenge; my wifes adulterie at the hand. of heaven deserves revenge! My bleeding soule (Oh my sonne) wandreth in unquiet paths till thou workest revenge: then feare not (sonne) to act it: for duty, love, and nature, bindes thee to it. By heaven and by that great immortall throane of happiness; by that low kingdome of eternall paines; by the huge watery seas I past to follow her; by earth and by the soules of all the mortall men that ever dyed, I command, charge, and constraine thee to persevere in this revenge: hence to that foule defamed castle, defamed by adulterie, defamed by murther; there to my soule doe thy latest duty; there wound thy cursed mothers brest, there sacrifice her lifes blood, there appease thy fathers ghost incenst with furie; so shall my soule in ioy enter the fields of faire Elizium : But if thou provest cowardlike, and through feare deny to execute my glorious revenge, from this day henceforth shall my pale, wan, leane, and withered ghost with ghastly lookes and fearfull steps, pursue and follow thee. These were the words of his fathers ghost: and having spoken these words, with a grievous groane, he vanished. At this his suddaine departure 
the Blacke Knight cryed with a loud and fearfull voyce, saying.

My noble father, stay; oh stay thy hasty steppes : once more let mee heare thee speake. Whither flyest thou. Oh let me heare thy voyce againe: It will not be, he is vanished; and my mother lives as a shame to all our generation. Oh thou staine of womanhood: oh thou bloody lionesse: oh brutish act : oh beastly desires: where shall I now find a place to shed teares in : for my heart is rent in tenne thousand pieces, and the terrour of this deed is too intollerable. Rest thou in peace, sweete father. Thou in thy life wert both wise and valiant: thy vertue, wisedome, and manhood, made the very enemies to love thee: $\mathrm{Oh}$ then, what fortune hadst thou, to die by the friendly trust of thy owne wife, my disloyall mother, thy nearest friend prov'd thy greatest enemie ; and by a woman's malice, that killed, that millions of foes could never daunt. Oh sweete Red Rose Knight; most happy hadst thou beene to have dyed in the fields of bloody warre, and sealed thy lives quittance amongst renowned souldiers; then had thy death beene more honourable, my wicked mother had not murthered thee, nor I been inforst to take such bloody vengeance, as I intend (deare father) for thy sake : for let mee never breathe one day longer, nor view the next mornings rising sunne; let mee ever live imprisoned in this wildernesse, let nothing prosper that ever I take in hand, and here let the worlde end, if I cease to prosecute a mortall revenge, as the soule of my father hath commanded. Hereupon he set forward toward the castle, conducted by what chaunce the heavens had allotted him: not one steppe he knew aright, nor what course to take to finde the direct way: but it happened that an Ignis Fatuus (as hee thought) or a going fire, led him the right way out of the forest directly to the castle where his dishonest mother made her abode. But comming neere unto the gates hee found all close, and neere unto the castle the blackamore set halfe way quicke into the earth, (having for want of food) eaten most part of his flesh from his armes whom the Blacke Knight soon digged up and kept alive, to be a furtherance to his intended revenge. 
The poore Indian, being thus happily preserved from death, revealed all that had hapned in the said castle; how his mother lived in adultery, how his father was murthered, why himselfe was set quicke in the earth; and lastly for the love of his dead master he protested to conduct him through a secret vault into the castle, that in the dead of the night they might the easier accomplish their desired revenge; thus lingring secretly about the castle till the middle of the night : a time (as they imagined) to be the fittest for their tragicall businesse; at last the midnight houre. came, and through a secret cell they entered under the castle into the lodging where his father was murthered. This is the place (quoth the negar) where my sad eyes beheld thy father both alive and dead. So going from thence into the chamber (which by chance and as ill lucke had appointed) was through negligence left open, hee shewed him the bedde where these adulterers lay secretly sleeping in each others arms. Oh dolefull sight, this lust hath made me fatherlesse, and ere long this weapon shall make mee motherlesse: so kneeling down upon his knees, in a whispering manner hee said unto himselfe. You lowring destinies now weave up the webbe of their two lives that have lived too long. You infernall furies draw neare; assist mee thou revengefull God Nemesis, for on this sword sits now such a glorious revenge as being taken the worlde will applaude mee for a loving sonne. Having spoken these wordes, hee sheathed his sword up to the hilts in the boosome of the Knight of the Castle, who lying in the armes of Anglitora gave so deadly a groane that she immediately awaked; first looking to the knight that was slaine in her armes, then perceiving her sonne standing with his weapon drawne; yet wreaking in the blood of the dead knight, menacing likewise her death, with a wofull shrieke she breathed out these words. Oh what hast thou done my cruell sonne; thou hast slaine the miracle of humanitie; and one whom I have chosen to be my hearts paramour, and thy second father.

Oh, Lady, quoth the Blacke Knight, for mother is too proud a title for thee; what furie driveth thee to lament the deserved 
death of that lewde blood shedder, and not rather choose with heart rending sighes, to bewaile the death, of my father, thy renowned husband, whose guiltlesse body, even dead, thou didst despise, by burying him inhumanly upon a dunghill; but heaven hath graunted, and earth hath agreed, detesting both thy misdeedes, and hath sent mee to sacrifice thy blood unto the soule of my murthered father. Whilst hee was speaking these words Anglitora arose from her bed, and in her smock (which was of pure cambrick), shee kneeled to her sonne upon her bare knees, saying,

Oh, thou my deare sonne, whom once I nourisht in my painefull wombe, and fed thee with mine own blood, whom oft I choicely dandled in my arms, when with lullabies and sweet kisses I rocked thee asleep; oh farre bee it from thee (my loving sonne) to harm that breast; from whom thou first receivedst life: of thee (my sonne) thy mother begging life; oh spare the life that once gave thee life, with bleeding teares I doe confesse my wanton offences, I doe confesse through me thy father dyed; then if confession of faults may merit mercie, pardon my life. Obscure not thy renowne with cruelty, making thyselfe unkinde and monstrous in murthering of thy mother. I charge thee by thy dutie that thou owest me; by all the bondes of love betwixt a mother and a sonne; by all the kindnesse shewed to thee in thy infancie, let thy mother live, that begs life upon her bare knees. Do not thou glory in my miseries; let not my teares whet on thy crueltie: let not thy minde bee bent to death and murder; be no savage monster; bee not unnaturall, rude, and brutish; let my intreaties prevaile to save my life; would not the wombe that fostred thee, which now I tearmed wicked by onely fostring thee; what child can glut his eyes with gazing on his parent's wounds, and will not faint in beholding them.

Hereupon the Blacke Knight not able to endure to suffer his mother's further intreaties. lest pitie and remorse might mollifie his heart, and so grant her life (which to heaven to take away hee had deepely sworne), hee cut her off with these deadly words.

Lady, I am not made of flint nor adamant; in kinde regarde 
of calamitie I am almost strucke with remorse; but dutie must quite undoe all dutie; kinde must worke against kinde, all the powers of my body bee at mortall strife, and seeke to confound each other. Love turnes to hatred, nature turnes to wrath, and dutie to revenge, for mee thinkes my father's blood, with a groaning voyce, cryest to heaven for revenge: therefore to appease my father's angry spirit, here shalt thou yeeld up thy dearest blood. Here was hee ready to strike, and with his sword to finish up the tragedie, but that his grieved soule in kinde nature plucked backe his hand; whereupon with a great sigh he said.

Oh heavens, how am I grieved in mind. Father forgive me, I cannot kill my mother. And now againe meethinkes I see the pale shadow of my fathers ghost gliding before mine eyes; methinkes hee shewes me the manner of his murther: mee thinkes his angry lookes threaten mee, and tels how that my heart is possest with cowardise, and childish feare; thou dost prevaile; oh father, even now receive this sacrifice of blood and death; this pleasing sacrifice which to appease thy troubled soule I heare doe offer. And thus in speaking these wordes, with his sword hee split the deare heart of his mother; from whence the blood as from a gushing spring issued. Which when hee beheld, such a sudden conceit of griefe entred his mind, considering that hee had slaine his owne mother, whom in dutie he ought to honour above all living women, that hee rather fell into a frenzie then a melancholly: and so with a pale countenance and gastly lookes, with eyes sparkling like to a burning furnace, began to talke idlely.

What have I done? Whom hath my bloody hand murthered ? Now woe unto my soule, for I am worse then the viperous brood that eats out their dammes wombe to get life unto themselves: they doe but according to nature, I against all nature; for I have digged up the bosome that first gave mee life. Oh wicked wretch, where shall I now hide my head, for I have slaine myselfe in killing her: I have stained this chamber here with humane blood; the heavens abhore mee for this deed: the world con- 
demnes me for this murther, and hell furies will follow me with shame and terror: the Gods are grieved, men (methinks) flie my company; dead ghosts arise in my distresses; I see my mother comes with a brest bleeding, threatning confusion to my fortunes. Oh thou ugly spirit cease to follow mee, torment mee not alive, for the wrath of heaven is fallen upon my head. Dispaire, where art thou? I must find thee out, I will goe seeke thee through the world: and if in the world I find thee not, Ile saddle winged Pegasus, and scale the mantion place of Jove. I will ransake all the corners of the skie, I will throw downe the sunne, the moone, and starres: then leaving heaven I will goe seeke for despaire in the loathsome poole of hell, there in Plutoes court will I binde blacke Cerberus up in chaines, the triple headed hellhound, that porter of hell gates, because he let Despaire passe from thence. In this franticke sort ran he up and downe the chamber, and at last with the nayles of his fingers, hee fell to grave upon the stone walls the picture of his mother, imitating Pigmalion, hoping to have life breathed into the same. Meane while the poore Indian with fleshlesse armes heaved up towards heaven, and on his bare knees, made his supplication to the Gods for the Blacke Knights recovery of his wits.

Oh you angry Heavens (quoth hee) revoke your heavy doomes, forget this crime, forgive this unnaturall murther; pity the state of this distressed Knight, and send some meanes to recover his senses. Thou bright lampe of heaven, thou eternall light, although in justice wee have deserved thy wrath, yet let my prayers, my never ceasing prayers, my hearts renting sighes, my deepe inforced teares, worke some remorse from thy incensed ire, that either this Knight may recover his lost senses, or set him free from death. Thus in a zealous manner prayed the poore negar, desiring God to lay the Knights fault upon his head, and reclaime his unbridled rage; which prayer was soone regarded by heaven, for the Blacke Knight had immediately his madnesse turned into a sad melancholly; and in a more gentle manner made his sad lamentations, as you shall heare in the next chapter. But now the negar, that all the time of Anglitora's murther 
stood in a trance, began now a little (considering the fright hee tooke at the Black Knights madnesse) to summon againe together his naturall senses, and perceiving the unchaste lady dead, cold, pale, wan, lying weltring in her goare and the blood of her false heart (shed by her owne child) all besprinkled about the chambre, sayd as followeth.

Now (quoth the negar betwixt life and death,) have you showne yourselfe a dutifull sonne, and nobly revenged the death of your father. These were the last words of the poor negar Indian, which as then sunke downe, and never after breathed. Thereupon came forth the Dwarfe of the Castle, with great store of treasure, proffering the same to the Blacke Knight; who nothing thirsting after covetousnesse, refused it, and withall took the Dwarfe in satisfaction for the negars death, and crammed the treasure downe his throat; and after buried the two servants together in one grave. This being done he digged up his fathers body from the dunghill, and brought it to the chamber where his mother lay, and after in an abbey yard belonging to the castle, he buried them both likewise in one grave. This being done hee kneeled thereupon and made his complaint in this manner.

\section{CHAPTER VII.}

Of the Blacke Knights melancholly lamentations over the grave of his parents; and of other things that hapned.

$\mathrm{OH}$ thrice happy for evermore bee this ground that containes the bodies of my unfortunate parents; for this earth hath received the sweet darling of nature; and the onely delight of the whole world ; the sunshine of Christendome, and the glory of mankind ; oh thrice happy be the grasse, that from henceforth shall grow upon this grave; let never sithe touch it, nor crafty. lurking serpent with venemous breath, or deadly poyson hurt it. Let no lyons pawes, nor beares foot, tread upon it; let no beasts borne in any manner abuse it, let no birds with pecking, no creeping filthy vermine, no winters nipping frost, no nightly salting dewes, 
no rage of the parching sunnes heat, nor starres have power from heaven, nor fearfull tempest nor horrible lightning in any manner annoy it. Let no ploughman drive hither his weary oxen, nor shepherds bring hither their sheepe, lest by the bulls rage it be harmed, or by the harmlesse sheepe it be eaten : but let it for ever grow, that the displaying thereof may reach to heaven : and may from henceforth this grave be ever accounted sacred; and may the grasse be ever sprinkled with sweet waters. Some good man upon this grave set a burning taper, that then for every anguish of my heart I may beat my brests, till my fistes have strucken the winde from my body; and that my soule may beare them company into Elizium. Come you wanton fleshly satyres; come you friendly fawnes; come you fayries and dryades, and sing sweet epitaphes ; lift up your voyces to heaven, and let your prayses be in the honour of my parents. Myselfe, like a wan, pale, and dead man, will beare you company : I will wearie the world with my complaints; I will make huge streames with my teares; such streames as no banke shall barre; such streames as no drought shall dry. But alas what doe I meane to repeat these severall lamentations; since my deare parents be dead; since from the world they are parted; since they are buried without solemnitie; since my delights are all enclosed in the ground. Yet will I still here make my complaints, though no good ease comes thereby, adding teares to teares, and sorrowes to sorrowes. Oh frowning fortune, oh unlucky starres, oh cursed day that ever I did this deed, for now no sense, nor knowledge, takes their unsensible bodies of my griefes: in this grave there is no feeling; in death there is no pitie taken. Oh thou Silvanus, thou commander of these mountaines, helpe mee poore helplesse soule to shed teares : for my religion, for my devotion, and countries sake helpe mee: either let me have some comfort in my sorrowes, or let mee in death beare my parents company. Thou seest what torments I suffer; how my heart trembles, how my eyes flow with teares, how my head is with teares possest, how my soule is full of horrible anguish : all this thou seest, and yet it little grieves thee to see it. Oh thou churlish ground, from 
henceforth cease any more to beare fruit : cease to be deckt with flowers, cease to be mantled in greene, for the purest flowers are withered; thy garlands are decayed; my deare parents are too untimely bereft of life; their sweet bodies thou harbourest, and in thy wombe deliverest them as food unto wormes. Therefore thou cruell earth howle, and mourne, for thou art unworthy of such blessed bodies. And now, oh you pittifull heavens, heare my complaints, convey them to the soules of my deceased parents; for my lamentations by the gentle windes are blown from the east unto the west; the dry land and the watry seas are witnesses to them; therefore no day shall rise but it shall heare my complaints; no night shall come but it shall give eare unto my moanes; neither day nor night shall be free from my heart-breaking cryes. If that $I$ groane meethinkes the trees are bended, as though they pittied my teares. The very ground (for griefe) I see alters her complexion. All that I heare, all that I see, all that I feele, gives fresh increase to my sorrow. I will never henceforth come in peopled towne, nor inhabited cittie, but wander all alone up and downe by low valleyes and steepy rockes, or I will dwell in darke dennes frequented onely by wilde beastes, where no path of man was ever seene, or to the woods I will goe, so darke, and beset so thicke with shaddow branches, that no sunne may shine there by day, nor no starre by night may be seene, whereas is heard no voyce but the outcryes of horrible goblings, the balefull shrikes of nightowles, the unluckie sounds of ravens and crowes; there shall mine eyes bee made watry fountaines; there will I make such plaints as beastes shall mourne to heare them; such plaintes will I make as shall rend and rive strong trees, make wilde panthers tame, and mollifie hard flinty stones; and if by chance that sleepe oppresse mee, on the bare and cold ground shall these wofull limbes rest, the greene turffe shall serve as a pillow for my head : boughes and branches of trees shall cover mee; and then I hope some venemous serpent will speedily give mee my deaths wound, that this my poore soule may bee released from flesh and blood: by which meanes I may passe to those fields, those faire Elizium 
fields, whereas my murthered parents daily resort. In this manner complained the Blacke Knight upon his parents grave, three dayes and nights together, still kneeling upon the cold ground, and could not by any imagination bee comforted : every thing his eyes beheld renewed fresh sorrow, and drew on new lamentations : but at last the power of heaven intending to graunt him some ease cast his distressed senses into a quiet slumber, where lying upon his fathers grave, we will let him for a time rest.

\section{CHAPTER VIII.}

How the Fayerie Knight came to be called the Worlds Triumph, of his arrivall in England, of the two Knights deaths, and of the Proverbs used of three Cities in England.

You have read in the first part of this Historie how the Fayerie Knight, the sonne of Cælia, begot by the Red Rose Knight, was committed (by his mother, at her death) to the keeping of the Ladies of the Land, for then was there but few men living, being a countrey onely of women : and now being of lusty age, and a knight of renowned valour, he betooke himselfe to travell: the onely cause to finde his father, or some of his kindred, whon he had never seene.

Many were the countries hee passed, but more the dangers hee endured; all which for this time wee omit: onely a little speake of three guifts given him by an hermite, that had three exceeding virtues: for comming to an island to seeke adventures, it was his chance to save a young beautifull mayden from ravishing by a satyricall wildman, for hee having tyed the golden lockes of her hayre to two knotty brambles, and being ready to take his pleasure upon her, the Fayerie Knight comming by, and seeing that dishonour and violence offred to so young a virgin, with his sword at one blow paired away the wildmans head, and so went with the mayden home to her fathers house, which was an hermitage some miles distant off; where being no sooner come, but the good old man, having a head more 
white then silver, but a heart more heavier then lead, by reason of the want of his daughter, so cruelly taken from him, began at her sight to be so cheered, that hee had not the power (for joy) to speake in a good space, but at last, taking the Fayerie Knight by the hand, hee led him to an inward roome, where hee banqueted him with such cheere as his hermitage afforded, and after in lieu of his daughters reschew, hee gave him three such gifts, and of three such virtues, as the like seldome had Knight. The first was a ring, which whosoever did weare should never dye by treason. The second, a sword: that on what gate soever it strucke it would presently fly open. The third and last a viall of such drinke that whosoever tasted thereof should sodainely forget all passed sorrowes.

Having received these three gifts of the good old hermite, he departed and travelled without any adventure till he came and found the Blacke Knight asleepe upon his fathers grave; which when the Fayerie Knight had awaked, in countenance they were so alike as nature had made them both one, (for indeed they were brothers by the fathers side, the one true borne, the other a bastard) yet at the first sight, such a secret affection grew betwixt them, that they plighted their fayths each to each other, vowing never to part friendships. But when the Blacke Knight had revealed his birth and parentage, his fathers name, and place of birth, the Fayerie Knight resolved himselfe that he had found a brother as well in nature as condition; but when hee heard the story of his fathers life, and the manner of his death, with the murther of Anglitora his unchast wife, hee could not choose but shed teares, whereof plenty descended from his faire eyes: whereupon hee tooke occasion to speake as followeth.

Heaven rest thy sweet soule (my unknowne father), and may the fruits of thee prove as famous in the worlct as thou hast been; but more fortunate in their marriage choyse; as for my stepmother, though her unchast life have made her infamous to all womankind, yet this in charitie I desire, that when shee comes to Plutoes realms, that Proserpine may send her to the blessed fields of Elizium; in remembrance of whom, in this 
world, (if ever we arrive in that noble country of England where my Knightly Father was borne) wee will there erect her a stately tombe; yet no epitaph shall shew her disloyall life, nor the cause of her death; onely in letters of beaten gold shall remain engraved upon her tombe the name of Anglitora, daughter to Prester John, and wife to the worthy Red Rose Knight. Hereupon hee gave his new found brother (the Blacke Knight) his viall of drinke which the hermite had given him; who no sooner had tasted, but all former griefes were forgotten; he remembered not the death of his Father, nor the murther of his mother, nor what sorrow he had sustayned in the wildernesse, but like a joconde knight, gyrt his sword round about him, and stood on thornes, till he was set forward to seeke martial adventures. Hereupon these two knights departed towards England, and performed many noble deeds of chivalry by the way: but amongst all others, being in the Turkish court, (this is worthy to be noted) for with one boxe of the eare, the Black Knight killed the Turkes Sonne starke dead: for which cause by treason were their lives conspired, and the following night had their lodging entred by twelve of the Turkes guard, with an intent to murther them; but by reason of the Inchanted Ring in the which they put both their little fingers, the guard of a sodaine fell all fast in a traunce; hereupon the two knights departed the Turkish court. But no sooner were they out of the citie, but a troupe of armed knights pursued them, and followed them so nerely, that they were forced to enter a castle that stood by the sea-side, wherein no creature had abyding: comming to the gate, the Fayerie Knight with his sword strucke thereat, and it presently opened; wherein being no sooner entred, but the armed knights of the Turkish nation closed them fast in, and caused the gates to be walled up with freestone, and so departed. Now were these two knights in more danger of death, than ever they had been in all their lives; and sure they had starved had not good policie preserved their lives; for the castle walles were so high, that none durst venture down without great danger. As in greatest extremity, man's 
wit is the quickest for invention: so the two knights cut off all the haire from their two heads (which were very long) and therwithal made a long twisted line or cord, with the which they steal from the top of the wall to the ground. But this mischance hapned: as the Fayerie Knight glided downe, the coard broke, and his body took such a violent blow against the stonie ground, that it strucke breath quite out of his body, no life by the Black Knight could be perceived, but that his soul was for ever divided. This of all misfortunes was held the extreamest: therefore in great griefe he breathed forth this lamentation.

Oh you partiall fates (quoth hee) oh you unjust destinies; why have you reft two lives by wounding one; now let the sunne forbear his wonted light, let heate and cold, let drought and moysture, let earth and ayre, let fire and water, be all mingled and confounded together; let that old confused Chaos returne againe, and here let the world end. And now you heavens, this is my request, that my soul may presently forsake this flesh; I have no soule of mine owne, for it is the soule of the Fayerie Knight, for but one soule is common to us both; then how can I live having my soule departed, which spightfull death hath now seperated? Oh thou my knightly brother though the fates deny to give thee life, yet in spight of them Ile follow thee. You heavens receive this halfe soule of my true friend and let not life and death part us; with eagles wings will I fly after him and in loves celestiall throne joyne with him in friendship, we two in life were but one, one will, one heart, one minde, one soule made us one; one life kept us both alive, one being dead drawes the other unto death; therefore as wee lived in love, so will we dye in love : and on one grave we may inter both our bodies; how glorious and happy were my death to die with my beloved friend; how doe I loath this life in living alone without my deare brother: whereupon drawing his sword from his side, he sayd,

Oh thou woful weapon, even thou shall be the meane to ridde my soule from this prison of body. Oh faith, unfained, 
oh hand of sacred friendship; I am resolved both with the force of heart, hand, and armes, to give my heart deaths deadly wound: for now my noble Fayerie Knight this blood I offer up unto thy soule. But being ready with his sword to pierce his owne hart, hee saw a lively blood spread in his friends face, and those eyes that were so dolefully closed up, began now to looke abroad; and the countenance that was so pale and wan, recovered a fresh complexion; whereupon the Blacke Knight stayed from his desperate resolution, and from a bloody tragedian became the recoverer of his brothers life: who after a while, began to be perfect sensible: so binding his bruised bones together, they went a shipboard upon a ship that lay at anchor at the next port, making for England, so the next morning (the wind served well) the pilots hoysted sayle, merrily floating on the waters.

Ten weekes had not passed toward the finishing of a yeare before they arrived on the Chaulkie Cliffs of England; upon which they had no sooner sett footing, but with their warme lips they gently kissed the cold earth. This is the land of promised glory (said the Fayrie Knight) to find this land I have indured many miseries: to find this land I have passed many countries, and in this land, must $I$ seale up the last quittance of my life, here shall my bones rest, for I am lawfully descended from the loyns of an English knight: peace be in my end, for all my dayes have been spent in much trouble. In such like discourses left they the shore side, and travailing further into the land, they met with one of King Arthures Knights, named Sir Launcelot Du Lac, so old and lame, that through his bruises in chivalrie, he seemed rather an impotent creature, than a Knight at Armes; yet at the sight of these two adventrous knights, his blood seemed to grow young, and he that before could not march a mile on foot for a kingdome, now went as lively as any of the two other knights did. First came they to London, where for their father's sake they were (by the governours) most gallantly entertained: the streets were hung round with arras hangings and tapestre works; 
pageants were builded up in every street, the conduits ran with wine, and a solemn holy day was then proclaimed to be kept yearely upon that day.

After this the King which then raigned, ordained a solemn justing to be kept in his court, and held in a great honour for forty days; to which knightly sports resorted the chiefest flowers of chivalry from all countries, as Kings, Princes, Dukes, Earls, Lords, and Knights, and for chief challeger and champion for the country, was the Fairy Knight who for his matchless manhood therein shewn, had this title to be given him to be called 'The World's Triumph.'

After this, being desirous to see the city of Lincoln, where the Red Rose Knight was born, he in company of his brother and true friend The Black Knight, and old Sir Lancelot du Lac rode thither: at whose coming into the city, the great bell (called Tom a Lincolne) was rung an hour, which as then was seldom done to any except kings and renowned warriors, returning victoriously from bloody battels.

Here builded they a most sumptuous minster; and likewise a most stately tomb in remembrance of their parents, the like as then no place of England afforded.

Thus having left the noble seats of chivalry, they lived a life zealous and most pleasing to God, erecting many almeshouses for poor people, giving thereto great wealth and treasure, and when nature had ended their days, they were buried in the same minster both in one tomb, with like solemnities: so richly set up with pillars of gold, that above all it grew the most famous : whereupon since that time was the old proverb, of three cities grown common to all, in these words, 'Lincoln is, London was, York shall be.' 
THE KNIGHT OF THE SWANNE 



\section{XII. \\ THE KNIGHT OF THE SWANNE.}

\section{CHAPTER I.}

How the king Pieron of Lilefort hade to wife and spouse Matabrune, for that she was riche, and endowed of great erthly goodes. The which betwene them had a sonne named Oriant.

Zde rede in the auncient and autentike cronicles that sometime ther was a noble king in lilefort, otherwise named the strong yle a muche riche lande, the which kinge had to name Pieron.

And he tooke to wife and spouse Matabrunne the doughter of an other king puissaunt and riche mervailously. Bi the reason of which mariage was made and accorded peace betwene two mightye kinges, the which longe time before had ben adversaries and ennemes one a nother by mortall warre. But as than and by the treatie of mariage was pacified the said discorde. How be it neverthelesse that the said kinge Pieron him accorded to take to wife the said Macabrune for that she had great possession of lands and other infinite richesses wherby as the story saith the mariage was made be coveitise and not by love wherof many harmes grewe, and all bi the said Macabrune that wrongefully sew discorde betwen king Oriant, his wife and his children. The whiche possible came by godes wil for that the said mariage was not cordialli made as is said, or for a more meritorious welth, as sith happened to the high praise of god and his holy faithe, for finably al turned to honour by the grace of the hye god that often approveth them that he loveth sending them some advercites first. For he hath no merite towarde god to have any swetnes if 
first he taste no bitternes of hert, as saint Paule sai th. By many triblations we must entre into the realme of god. But finally our lorde resisteth the pervers, in giving his glory to the meke as in this story appereth. For al the punicion fel on Macabrune finabli that had caused al the yll. And thei that had ben iniustly vilipended were miraculousli exalted, and it is often sene that mariage made by covetise cometh to no perfection of goodnesse. For if the coniuntions be not made bi love as god ordeined often of cometh grevous desolacion as did of her, lyke as thistory sheweth here after.

After the mariage of kinge Pieron and Matabrune as the maner is, they had betwene them a sonne noble and wise named Oriant, the which after the dyscease of his father abode with his mother as heir of the realme, whiche he succeded and governed peasiabli without to be maried.

\section{CHAPTER II.}

How king Oriant chased a hart so swiftely that he lost his folke and came to a fountaine where as he spake with faire Beatrice whome he chose to be his wife.

AFTER that the noble kinge Oriant was growen in age, in force, and prudence, on a day he delibered him for to go to hunt. And whan al thinges were redy and he comen in the Foreste he at the playe and pursuite of his Greyhoundes reised a great harte, whereate he toke so greate pleasure that he chased him so swiftely that his folke might not folowe tyll he turned in plaine feeld where as was hedge ne bushe. And thus he left of his folke he pursued mervailously til he aproched a river wherin the said harte lepte for saufte, and so escaped the kinge and his houndes. Wherfore the king left him and retourned alone till unto a fountaine that he founde, the which was so clere and pleasaunt to his sight that he alight from his horse for to refresshe him a litle the same place. And there he sat downe under a tree, to which he had reined his horse the better to solace and sporte him 
at his owne pleasure. And thus as he was in consolacion there came to him a yonge damoysel moche grevous and of noble maintene named Beatrice accompanied of a noble knight, and two squires, with iiii damoyseles the which she held in her service and famyliarite. And there as she that in title of signorie posseded the saide grounde began to speake to the king Oriant in repreving him for that he was comen to hunte with in the boundes and limites of hir signourye and possession. And as unto him the whiche she knewe not she began to saie prudently. Faire lorde who hath moeved you to come hunte or take ony beastes within the forestes of my region, know ye not that I am lady and possesseresse of this londe, Damoysel said the king nay. And wo hath than said she given you leve or licence so to doo. I have well apperceived the harte that ye have chaced and put to flight, and hath saved him in the river, but howe be it that ye had taken him yet should he not have abiden as yours. And yet is mine intencion if it please god that ye shall recompence me or ye departe. For ye have none accion of right for to chase or to take any beast wilde or tame in mi forestes, nor on $\mathrm{mi}$ ground. And whan king Oriant had hearde the faire Beatrice speake thus bi reason so right notably, he toke her in so great pleasure that he was sodaynly surprysed of her love in suche wise that fro than he purposed in himselfe to take her to wife and spouse. And the better to manyfest and make her have knowledge of him he began to lift up his visage in beholding her with a joifull chere and said, Know ye faire damoysel that I wolde not thinke to do you any displeasure, but me thinke that I maye well come and sporte me stil unto this region and londe as soveraine lorde therof, by reason wherof ye owe me homage. And to thende that ye pretende no cause of ygnoraunce wit ye (without that I wyl hide it) that I am Oriant kyng of Lylefort. Wherby there is neyther lorde ne damoysell in all this countrey but they ben holden to yelde me tribute and homage as my vassayll and feeal subiect. But that not withstandyng if I thought to haue endomaged you of one seile ferdynge I wolde recompence it at your desyre, for that noble prudence, curteysy, and graciosite 
that I perceive beynge in you, by your maintene and moderate speche. How be it that it is well in my power to make your selfe amende and repaire the iniury that ye have doone in reprevinge and chiding me for that which is mine owne. But your noble, faconde, and pleasaunt behavour causeth me somwhat to refraine mi courage, and receive your offence to marci. And whan a noble knight named Savary that long time had served the said damoysel had heard the right mighty king Oriant speake thus benignely he descended incontinent from his horse, and with his knees flexed he prostened him and did him honour and reverence in saluinge him and said. Sir king if it please you ye shall pardon my Ladie if she have ony thing offended you, for sle had no cognycion of your riall mageste whan she reasoned with you. And she knowledgeth also if she hath nothinge but that it is at your pleasure and commaundement, and otherwise wold she not doo, wherfore ye shal pardon her if it please you. For she hath said nothing but bi ignoraunce, and as she that rightwisli and with good courage wil kepe yours and hers. Than answered the kinge to him and said. Know ye noble knight that I accepte ynoughe the excuse that ye have made for your noble lady. - But she shall make me amendes in suche maner as shal be agreeable, for the beaute and formosite of hir noble persone moeveth me to be her husbande, and to take her to wife and spouse, as she the which is my whole desire. Than the king began for to speake in this maner and sayd. Gentill damoysell pleasaunt, vertuous, garnished of al beautie in whome I have totali set the love of my herte, is it not wel your wil that I be your husband. Pleaseth it you not to be my wife and spouse to thende that I make you to be crowned as quene and lady of Lilefort. May ye finde in your hert by suche maner to accomplishe my wil, that you and I might be assembled and conionct by mariage. Answere ye nowe and say your advise. Ha sir saide she right humblye. I am not digne ne suffisaunt that ye do to me suche honour, for the handmaiden or subgecte ought not ne marye nor in any thinge compare to her prence and lorde. But sith that it pleaseth you to commaund me so to doo, in disparsinge to me of your grace I 
wer right simple and evil instruct if I refused your pleasure, and the excellent honour that ye so benignely and of your goodnesse unto me present. For if it shoulde please you to marye me to the least knight of your noble company yet ought I to consent of right. Wherfore to you that is my lorde, and to other incomparable: I am all redy to abey and accept your good and noble wil in the honour wherto ye require me, the which with good hert I ottroye and graunt you. And than king Oriant tooke her by the hand and said Certes lady I promise you on the faith of knighthod that as long as ye be on live never to espouse other woman than you, and I assure you even here that I shal be your husbande. And thus by a comin accorde and by the consentement of them bothe was promised the saide mariage with one cordiall love.

\section{CHAPTER IV.}

Now kinge Orient at his returninge fro the chase brought with him the faire Beatrice for to espouse and tooke her to wife.

WHAN the promesse was thus made the kinge incontinent made her to be led to Lylefort for to marye her. And in May whan the trees spryngeth and bring forthe theyr odiferaunte floures, and that the Birdes bring their armonical tunes on the smal grene twiges was made the entre of the noble quene Beatrice into the realme of Lilefort. At the which entre all the people afflued from all partes leding great joye and mirth everech in his possibilite. That is to wit, some to make fyrs and games of mirthe. Other made divers faire misteries and tourneimentes of feates of armes. And before the same came the olde queene Matrabrune mother of the prue king Oriant. The which whan he sawe her come began for to smile and have great joye of the pleasure that he had to see the noble Beatrice his love, which he loved marveilousli and with al his heart. Wherfore he sayd to his said mother which he perceived murmure a litel. I require you my right dere lady and mother that ye wyl make ioyous chere and beholde here howe I 
have fonde the moost faire ladi of the world, replenisshed of witte and vertues as much as ony woman livinge. And I am advised that never as longe as she liveth to have other wedded wife, for in her is all mi pleasure. Than as hevy and angrie answered his sayd mother by a maner of envye. Ah my sonne litel reioice I for presently I apperceive your ygnouraunce that ye now wil so abate your estate, as to take a simple damoysel and you being a right puissaunt and noble king might demaunde and have to wife the doughter of the moost riche and noble prince that might be found upon the earthe, and finabli you and yours possede his realme by succession. Madame said the kinge, ye, yf it please me soo. Knowe ye that I never founde none that so muche pleased me and that was to me so agreable as she is. And ye knowe that ther is nothinge as to have his pleasure in this worlde. And also mariage ought not to be made but that yf the parties were contente and of good accorde. Wherfore I beseche you to take it in gree as well as I. For to morow in the morning if it please god I wyll that the feast and solempnite of the mariage be celebred as it behoveth. And eke I hope sith it is by the wyll of god, and of good love and assent of us bothe that there may be but al welth come therto. Certainly sonne said she sith that it please the that it be so it cannot displease me in ani maner. But I accorde totallie to thi good wil. All these wordes saide she with mouthe, but not with herte, as many doone that bi faint symulacyon make an other thought and cursed wil at hert. And so had the said Matabrune, for she ceased not to murmure in her selfe against the said mariage, and malignousli thought alwai to put therin som diversite, and seperacion. But not withstanding this the feast was not deferred. For the night before the daye of weddinge for the honour and magnificence of the good king Oriant and of his noble love Beatrice were made moriskes, comedies, daunces, interludes, and al maner of joyous sportes in the kinges palais, where as were many great princes and knightes of renowne. Pipes, taborins, doucimers, fidles, organs, psaltries, clavicordes, and mani other instrumentes there was in great nombre sowning al songes of armony. On the morow the 
King was had to the church accompanied of manie great princes and lordes, in so great triumphe and honour that it may not be recited. And in likewise was apparailed the noble lady Beatrice and conduited of manie noble ladies and damoysels pages with divers liveraies, as well of the kinges as the quenes. In suche wise that at the conioyninge of this noble mariage was made al singuler and inestimable solempnite in the churche. The masse done everi man returned to the palais royal, where they were received in open courte for to take theyr refection. And ther were all the assestentes served of divers delicates and venison, of wines and of al noveltees as plenteously as they could wisshe. And there presentlye for the honour of the noble king Oriant everiche of the Company efforced them to doo honour and service to the noble quene Beatrice, the which was so pleasaunt and acceptable to all the people that echone praised her. And in likewise were made the same daye many other newe games, and service to all honours. Than after with all mirthe and sowne of trumpetes and other armonious instrumentes, the mighti king Oriant and the noble quene Beatrice his wife lay to gether. And on the morrowe was yet made great ioye and exultacion of al other newe pastimes. In this estate lasted the feast and solemnite of the mariage long space in great haboundaunce of giftes, largesse of goodes, and sumptuousnesse of services in suche maner that of long time had not be sene semblable feast, to the pleasure of everi man. But the said Matabrune murmured alway in her selfe by wicked detraccion, which she put sith in effect. And yf she made ani chere at the said feast it was by false semblant and maner of doinge, for uniustly and wrongfully she conspired alway some evill upon the noble quene Beatrice. 


\section{CHAPTER IV.}

How the mighty kinge Oriant espoused the notable Beatrice, the which conccyved of him vi. sonnes and a doughter at one burthen.

Thus as the puissaunte kinge Oriant and his noble spouse Beatrice loved enterly together with as rare and true as was possible and in suche wise that there was never many men that loved their wives as he did his. It happened that right shortely after the solempnite of the marriage she conceived vi. sonnes and a doughter at one burthen. And as the king knewe that she was bigge he loved her better, and all the comins were joyfull of it. And on a daye as she was leninge in a windowe of the chambre roiall she sawe a woman in the strete that bare to christning two children that an other woman had conceived and borne at one time. And than familiarly she called the kinge of whome she was right wel beloved and saide, Sir I greatly mervaile me of a thinge that I see yonder. And wherof swete love saide the kinge. Of .ii. children saide she that a woman hath conceyved at one time, which I see yonder borne to christning, mesemeth that it is difficile for a woman to conceive two children without having the company of two men. Sweet love said the kinge, yes right wel, put away the opinion fro your minde. For by the wil of God and after nature a woman may conceive of one man to the nombre of .xii. children at ones, naturally fourmed, and parfite. The whyche wordes precedentes compared ful derely the forenamed quene, by the false and malignus Matabrune. And it is so often sene fortune, that it is better to be stil than to speake evill, whereof the sage saith. That a great speaking is seldom seen pronounced, without to have any faute, wherby he saith after that he never repented him of to little speche. But al thinges promised that king Orient and quene Beatrice loved well together. Than it happened within a while after that tidinges came unto the king that some of his enemies had destroied and slaine of his folke, and all redi had conquered 
of his londes bi warre. And that soone ynough and easely they had moeved to entre many princes. But what tidinges so ever he had, he made no semblaunt to resist against his contraries. For he was in suche wise enprised and taken in the love of his wife that after the tidinges he was about .vi. moneth that he coulde in no wise leave her, ne purvey anie thinge for the saide affaires, wherbi finabli his enemies came so ferforth in his landes that bi constraint he was driven to prepaire men of warre and to leve his spouse. And consequentely he made to assemble his chivalry to thende that without delaie they might be redy to accompany him in his warres against his enemies the which was doone at his commaundement. Than saw he the time that his wife approched to be delivered, wherfore beningneli he called Matabrun his mother for to be to her as recommaunde and saide, My lady mother, ye see that I am constreyned to depart for to go to war upon mi enemies, Ye know also that in likewise of the grace of god my wife hath conceyved and is greate with child, wherfore I pray you if it please you of your benigne grace to have her for recommaunded in al her singular affaires, prayinge you also that in mine absence ye take and kepe her as your doughter in shewing you to be her mother. And I beleve in the pleasure of God that she wyll have you in honour and reverence as mother and obey you as your doughter. Ye se that she is meek as a dove, softe and amiable as a lambe, prudent and vertuous as is possible, wherefore I recommaunde hereto you as she that knoweth the great love that is conioyned between us two, and as to mi part I wene that never man loved woman more than I love her. Ye know also the daunger that might come to a woman bigge with childe as she is, wherfore if bi your defaut any inconvenient cam to her I should not be glad ne content with you. Ye have folke of all estates at your pleasure for to commaund them to do all the service and helpe that to her shal be requisit. Therfore madame I put and leve her all in your keping and solicitude. Mi faire sonne said Matabrune thou knowest that what pleaseth the, to me is agreable, and all thi wyl is mine wherfore thou maist well knowe that I shall kepe thy wyfe the queene as my singuler 
doughter and better than mi selfe. Thou maist in likewise wit that I am she that wolde be most hevy and soroful if any harme came to her. And therfore doubt not but that I shal diligentli do thi pleasure, for I love her with al mi hert for gracious and noble maintene that $I$ se in her dayli encreace, therfore take no thought. Wel madame said he, I thanke you and totally put her in your grace, wherfore in saying adewe I take my leave humblie at you. Now go said she God be thi guide. And thus the king departed from the said Matabrun his mother, whose wordes were not accordaunt to her dedes, for they were al but abuse and false simulacion, like as untruely she shewed bi her curssednes. Than after the king cam to take leave of his noble spouse and in weeping tenderly spake longe with her, and than took an amerous leave of her, in kissing her beningnely so that she fell downe in a swoune. And he tooke her up amiably making a great lamentacion and sorowe. And at her awaking in weeping bi her were made many complaintes, the which were so prudently ordeined that al the nobles knightes and barons wepte profoundly in beholding her for pitie that they had at herte. And than they kissed eche other right curtesli, taking a cardial leave without power to speake any more for sorow. Than he took leve of her and of the other ladies and damoysells, and without any more tarieng mounted on horse backe for to go to his people against his enemies, where as he did many faire valiantines, and divers great and noble feates of armes.

\section{CHAPTER V.}

How King Oriant toke leave of the noble quene Beatrice his spouse. And how the fals and pervers Matabrune composed and machined with an other matrone to commise crime and treason toward the sayd noble quene Beatrice.

WhaN the noble kinge hade thus taken his leave of his spouse and of many other of his frendes he went to the warre for to be fight his enemies the paynims and to susteine the faythe catholike 
of God, and to defende his lande. But of his noble feates of armes that he with his knightes and many other might doo in the sayd warre as true knightes of all mighty God, and of the victorie that they obtayned as nowe I shall leave to speake any ferther to thende that I may retourne to speake of the effecte of the mater. And also the more sooner to com without prolixite to the true cronicles and miraculous histories, of the which I pretende to make singuler mencion. And consequentli procede unto the deduccion of this present booke conteining divers noble feates and noble vertues worthi of memorie and hie recommendacions as after this declared. So it happened that after the departing of king Oriant and that he was out of the limites of Lilefort with al his army and excercite, the right cursed Matabrune considering the absence of her sonne began to compasse the treason and evil that she had conspired to do unto the noble quene Beatrice. And for to come unto her damnable and cursed wil she sent for the midwife that was chosen and deputed to receive of women the children that ben borne on erthe. The whiche midwife cam incontinent at her sending. To whome Matabrune saied. Mi freende I have sent for you for a certaine secrete that $I$ have to tell you and declare under maner of confession. And therfore ye shal swere and promise to me your faith that never to any creature livinge ye shal discouer mi secrete, and that $I$ intende to tell you. But if you wil consent and do it in keping to me faith and promisse I shall give to you so much golde and silver that you nor none of yours shal never have defaute ne need of goods. And ferthermore I shal helpe you to mary your children and frendes highlie and honorably, whan the old midwife hearde the promesses that Matabrune made to her she consented to her cursed desire saying, Certainlie madame ye may alway saie and commaunde me as to your servaunt, and I promise you mi faith that any thinge what soever it be never to no persone livinge shall it be discovered. Therefore maye that $I$ shall doo as if it were in confession. And verelye said Matabrun yf ye do so $\mathrm{mi}$ desire I shall hold to you that I have promised, wherfore in trusting to your words I shal recite unto mi secret, and that that I 
pretende to do ye know and it is true how my sonne kinge Oriant hath taked the quene Beatrice that present is to his wife, the which was but a simple gentil woman as ye wel know. And ye wote wel that he might have had and may, one richer and more noble of bloude without comparison than she is, seeinge and consideringe the magnifike and excellent lignage wherof he is spronge. But his saide wife hath so enchained and bound him in her lines that he may neither eat, drinke ne rest, but if he be alwaie bi her, and to make short tale, whan his enemies were comen into his londe for to endomage him, for nothinge colde he leave her, in any wise to resist them for his defence, wherfore I wolde that you and I had advised singulerly to turne his hert fro the love of her, and set her in so great indignacion of him that he may aquaint him with some other high and noble lady and mary her. Now ye se that this quene is great with child, wherfore more easely may we cause this diversite and seperacion of his love by some maner. Madame sayde the false olde matrone, even as you please to devise of this mater I accorde me to your wil, and if you seme it good I shal make her to waste and sle the childe within her bodye, and that I shal certifie to the king that she wolde have it slaine. Frende said Matabrune I had thought another meanes more expedient and that should be of right great abominacion and horrour to the kinge as I shall shewe you the maner, ye se that she is mervailousli bigge, wherfore it is to be presupposed that she shal have two or thre children, therfore whan it cometh to the terme of her deliveraunce that shalbe shortely ye shal come to her and by faint semblaunt make maner to presente and offre you al to her service. And whan she shalbe delyvered of her chyldren ye shal give them to me secretely for to transporte them. And I shal ordeine as mani yonge whelpes that I shal make to be taken from under some bitche that hath newli whelped, and by this maner ye shall give her to understande that she hath borne them, and that they ben yssued of her body wherby after we may make her, the king, and all the other barons to beleve that she had the companie of some dogge the which hath engendred the said whelpes, bi the which 
we shall come to our desire without ani contradiccion. For I have my faithfull servaunte that I have nourished of youth to whome I shall secretelye give the children assone as they be borne, and at mine onlye commaundement he shall go and cast them into the river of whome shal never be mencion. And I promise you madame said the false olde matron that I shall doo even as it pleaseth you to adverte and shewe me, by so cautelus and subtill maner that the werke shal seme to be sure and notarious like as bi our entendement ye have devised.

\section{CHAPTER VI.}

How the quene Beatrice childed naturallie .vi. fayre sonnes and a doughter, the whiche in theyr birth brought eche of them a chaine of silver miraculously wrought about theyr neckes.

WHAN the time limited and ordeined of almighti god approched that the noble and goodly quene Beatrice should be delivered after the cours of nature, the false matrone aforsaid went and delibered in her selfe to execute and put in effecte her malignus or moste wicked purpose and the cursed treason the which bi the exhortement and counseile of the pervers and ingrate Matabrune she had consented for to prepare and do against the said noble quene Beatrice and her poore innocent children, the whiche neverthelesse were miraculousli kept and preserved fro death bi the devine grace and proteccion of our saviour Jesu Christe, as it shalbe saide here after. And so than at the houre determined that the noble Beatrice felt her oppression with greefe of childinge incontinent the saide false olde midwife was sent for. The whiche when she was comen by false semblaunt reasoned the noble Quene of her affaires as in suche case is accustomed. And she declared to her all the trouth and how she felt her oppressed sore. Than the said matrone by fained blandisshinges gave her good courage in making semblaunt to expose her al to her service, for that she knew that the hour approched to accomplishe her cursed intente. And forthwith was sent for Matabrune the whiche all redy had 
prepaired the whelpes for to perfourme the treason. But she comen made maners of great welth to the said noble quene Beatrice. And sodainly in great paine and traivable of bodye she childed .vi. sonnes and a faire doughter, at whose birthe eche of them brought a chaine of silver about their neckes issuing out of their mothers wombe. In which was vertuousli demonstred the pure and singuler dignite of the noble mother and her childe, and that God wolde upon them extend his divine grace. But the evil and detestable herts enforce them alway to pervert and totally adnichil al good werkes. And whan Matabrune saw the .vii. litle children borne having echone a chaine of silver at necke, she made them lightli and secretli to be borne a side by her chamberer of her teachinge, and than toke the vii. litle dogges that she had prepared, and all bloudy laide them under the quene in maner as they had issued of her bodye. And anone the matrone or midwife began to escrie with an high voice sayinge. $\mathrm{Ha}$ lady quene here is a great and mervailous mischiefe that to you is presently comen. For I have received vii. stinking dogges the which be issued of your body bi an horroure over detestable. Matabrun in likewise endevored her on the other syde to approve the said iniury (bi her commised and purpensed) saienge, Take away lightly this infamite and make to bere this foulnesse of dogges into the feeldes, and that echone holde secrete this mischiefe and enorme forfaite in suche maner that for the honour and reverence of my sonne it never be knowen ne discovered to any that liveth. Now it is not to be douted that the noble quene Beatrice to whome had be doone this iniurous treasonne was at that houre greatly travailed and vexed of her bodi so to have childed seven children at one burthen, for a woman is often sore pained to bear one all onely. Wherfore she was as dead in her childing and apparceived nothing of the said treason that was to her done. But whan she was comen againe to her selfe having sumwhat more vigoure than she had before, the false Matabrune began to caste an eye on her by a false and cursed regarde more mortal than of a Baselike, and repreved her of the faute that herselfe had made and commised 
arguing her without a cause and saide. O unhappi and miserable woman full of shamful harlotri. Here is the midwife that presently hath received .vii. dogges of your body, the whiche I have made to be borne to the feldes for to hid thorrour and infection of your enorme sinne. And therfore confesse here your dede and declare to us if ye have had compani and habitacion with any dogge wherof this prosedeth and we shall kepe your counsaile. And whan the noble Queene heard these wordes she was so sorowfull that she swouned nere for anguisshe. And after that her courage was a litle renued she prayed Matabrune pitiouslye to shew her that, that she said to be issued of her bodie. And incontinent she made to shewe her the .vii. whelpes that she had ordeined for to doo the treason, whereof the noble quene wepte and sobbed profundly in bearing her culpe beholding them in axing mercy for that she had not done. But that not withstanding the false Matabrune alwai redargued her in approprieng the crime to her sayinge, unhappi woman thou ought to be brente whan thou haste willed to conceive with a dogge. Ha madame said she I thought it never, ne the case never hapened me. And therfore I pray you give me no more great mater of sorowe than I suffre presentli, but thanked be God mi creatour sith that it pleaseth him to be thus. For it is yet in his might to transmut me or anye other that him pleaseth into some dombe beast and that, that pleaseth him ought to please us. Than departed the false Matabrune, and the wicked matron bi faint simulacion made semblatince, to recomfort her saying. Alas madame take not so much sorow that ye be not worse therefore, for if it please God we shall do in such wise that your noble spouse king Oryant in no wise shall have cognicion. And it shalbe kept so secrete that no sclaunder shall come therof. $\mathrm{Ha}$ swete love saide the good quene, never will the king take any consolacion with me, for he wil charge me of this offence without ever to pardon me, and wyll iudge me culpable of death. But if it pleased his grace to assigne mi poore life in sume religion for ever to serve God and do penaunce for my sinnes, alas I wolde take it in pacience and pray for him, and put paine to apease the yre of God which I so 
streatched on me, wherfore I praye you humblie that ye wil require mi lady that she will impetret his grace of the king mi faithful spouse. And thus suffred the good quene anguisshe on all sides. For she was betrayed of them which made maner to be sorowfull and have compassion of her mischiefe, and of thiniuries that them self had made bi their untrue courages.

\section{CHAPTER VII.}

\section{How Markes bare the vii children into a forest and left them on his mantell.}

AND after that the false olde woman had parfet and doone their treason that they had entreprised as said is Matabrune called a squire of hers named Markes and said, Markes my true secretarie it behoveth that presently ye doe me a service the whiche I shall declare to you. Madame said he it is wel reason that I obeye to you, for I have received mi welth and honour of your grace only, wherfore knowe that I shal accomplisshe with right good herte that that ye please to commaunde me. Now Markes said she mi freende it behoveth that to me ye be true and secret in that I have to do with you, for it must not be knowen ne reveled to no persone that liveth upon paine of your life. And also if ye hide and kepe it secrete I shal give you goodes ynough. Lady said Markes comaunde what it pleaseth you, I promise you to be true and loyal. It is of trouth sayd Matabrune that the quene of late hath childed .vi. sonnes and a doughter, the which children hath brought eche of them a chaine of silver about their neckes, which me semeth an evil signe and that in theyr age veril and discret thei mai be murderers or theves, wherfore $I$ have advised that it is better to drowne them or make them to die in their childe hode than to have a greater sclaunder at the last and to eschewe the sorowe that he might have hadde I have given her to understande that .vii. litell dogges ben yssued of her body, that whiche I have made to slee and cast into the feildes. And I prai you on my peril and my wil to take the .vii. children and goo kyll them or 
caste them in some river, in suche wise that never be tidinges of them. Ladie said the Markes it shalbe done wholy as ye have pleased to ordein me, and I promise you that of these .vii. children shal never be any mencion. And than at the commaundement of Matabrune Markes mounted on his horse, and toke the .vii. childred as he was ordeined, the whiche he toke and wrapped in his mantell and in a great haste transported them out of the citie of Lilefort. And whan he was bout .x. mile out of the said citie he entred into a forest he was enspired with the grace of God for to descend of his horse, and to behold how the poore children did. And whan he was descended he laide them in the saide plaine uppon his mantel, and than began for to beholde them, And whan he saw them so faire so pleasaunt, and so wel fourmed he had great pitie at his hert. And considered in himselfe that sith that they had brought those chaines of silver out of their mothers wombe that God hath chosen and ordened them to some perfection of welth and excellent honour. And thus as bi love and benignite he behelde these poore children they begane all to laugh and to beholde him sweetli. And than he was in suche wise moeved with pitie and compassion that he delibered in him selfe to do them no harme but by him selfe commaunded them into the holy garde proteccion and mercy of God in manere of speaking to them sayinge. Nowe I praye to God fayre children that he wil kepe and preserve you from al evil and encombraunce by his holi benigne grace and that shortly be confounded all your enemies, and the false olde witche that hath sent you hither for to purchace your death and distruction. Alas poore chyldren it greueth me sore for to leve you here in this place as desolate, wandred and habandoned of your blode. But I hope that he that hath willed to creat and fourme you to your good mothers body wil not leve you dispurveyed, and fare ye wel to God I commaunde you children, for I shall se you nevermore. And thus amyably took the said Markes leave of the vii. litle children the which at his departing took theym in his armes and pitiousli kissed them in weping tenderly with salt teres. And than he retourned to Lilefort makinge muche sorow inwardly for them. 


\section{CHAPTER VIII.}

How the vii. children wer found in the forest by a devoute hermit named Helyas.

INCONTINENT after that he had thus taken his leave of the children he retourned to Lilefort where as the pervers Matabrune came to fore to meet him for to knowe tidinges of her cursed wyll sayinge. Now my freende Markes have ye done mi commaundement of the .vii. children as I bad you. Madam said he, know you that ye shal never have tidinges of them for I have al to hewed their membres and casted them in the river. And she said mi frende ye have done well and I shall reknoledge the pleasure or.it be longe. For that ye have ben faithfull to me I shall contente you well. And whan my sonne Kinge Oriant shalbe retourned I shal do so muche towarde him that he shall make to die his espouse wherof mi herte shalbe glad, and I shalbe avenged to my gree. And with these wordes departed Matabrune and the fornamed Markes one fro the other.

Thus leave we to speake of them, and returne to speake of the children the whiche were in the forest dolorouslye wayling and as all dead for honger. But by the grace divine of God ther came into that place an holie and devout hermite named Helias, the whiche had his habitacion in the said forest. And whan he apperceived the .vii. poore litle children there abandoned and weping for honger: he had so great sorowe at his hert that he wepte for pitie and compassion to beholde them, wherfore he toke and lapped them tenderly in his mantel and with al their chaines at their neckes he bare them into the litle hous of his hermitage, and there he warmed and sustened them of his poore goodnes as well as he coulde. 


\section{CHAPTER IX.}

How the good and devoute hermit prayed to our Lorde for the ayde and succour of the .vii. poore children, whose praiers were exalted.

AfTer that the good hermit had doone his possibilite to susteine and rechaufe the vii. litle chyldren of the noble Quene Beatrice to him unknowen. He seinge the indigent puerylite of them had great feare that they should die for faute of natural foode and had none hope but only in the marcie of God. And than for them he made his praiers saying humbly Soverayne God allmighty very rectour and gobernatour of all thinges that by thy divine grace wylled to repast the children of Israel in deserte with manna of heven. And that in like wise susteined the good prophet Daniel in the pitte of Lions. And that also sithen in the new testament hast repasted fyve thousand men besyde the women and children with five barley loves and five fisshes. I supplie thee and require humbly that bi thi piti, mercy and swetnes it pleaseth thee to repast and susteine these vii. poore litle children the whiche bi thi grace I have found naked and deinge for hunger in this forest, to thend that whan thou hast nourisshed them thei may devoutlie serve and honour the as thou knowest. And incontinent was exalted to the oraison of the devoute hermit before God, for miraculously there came into his house a faire white goat, the wiche beningnely came nere to the .vii. little children in presenting to them her milke, and ther she gave them sucke naturally as their nource. And than the good hermite knewe clerely that God had vertously sent her for the nourisshing and sustentation of the poore litle children that he had founden, wherof he thanked God greatly of his divine savitude. And thus this white goate gave milke sufficiently to them and than retourned to the wood. And so longe she gave them souke that they began to gro and waxe somwhat stronge and folowed her in the wood and aboute the hermitage. 


\section{CHAPTER X.}

Howe the vii. children were miraculuslie nourisshed of a white goate sent bi Goddes grace. And how Matabrune accused falsly the good quene Beatrice to king Oriant her spouse.

WhaN the forsaid children were come to age of puerilete the devoute hermite. Helyas made and appropryed to eche of them a cote of leaves of the trees or of suche as he coulde get. And so they were playing within the forest where as thei gathered fruite to eate with theyr bread, for in that pointe they were nourisshed under the grace of God, and by the dilygence of the good hermete which with good herte administred the bread of the almesses geven to them. Now it happened by space of time that king Oriant their father retourned victorious out of the warre that he had agaynst his enemies whan he left his good queene bygge with the .vii. children habandoned of their bloud. And when the false olde Matabrune knew that the good kyng Oreant her sonne was comen she went agaynst him makinge the good mother and faynynge as she wolde weepe she began to saye for to accomplishe her fiers courage. A my most deare sonne ye be right hertly welcome. I am all joyful that ye be retourned in joye and health accompanied of your barons. But on the other parte my herte is so heavy and sorye for your wife and for that is to her hapened that lytle lacketh that it ne breaketh. And when the king hearde her speake so he was as abasshed and sayd, why madam is ther any harme come to my wyfe, is she dead or how. $\mathrm{Ha}$ my sonne said she nay: but the case is much more enorme the whiche I maye not ne dare not wel reherce for the horror and abhomynacion of the dead. And also I had lever that an other tel it you than I for it is wel knowen of all your servauntes. Forsothe said the kinge yf ony evyll be happed it is more decent and convenable that ye tel me than an other with whom I should be angry. Ha my chyld syth it pleaseth you so I shal tel you, but it greveth mi hert for the honour of you and yours. Know ye that when ye departed fro this countrey I thought that your 
wife had conceyved a chyld of you, but she had conceyved of a dogge the whiche is a foule sine. For here is the midwyfe that hath received .vii. litle doges of her bodi the which I have made to kyl and be casten in the feldes for to undo the sclaunder, wherfor ye ought to mak her die and cast in a fyre. And the matron was with her for to approve the lye. And whan the king heard these wordes affermed by false tongues he had so great sorow at his hert that none might have more. And bi great dispite he demaunded where that she was. And Matabrune said that she was recluse in her chambre, wherout she durst not come for shame of hir vilanous dead. And than the kinge entred into a chambre with one of his knightes and began inwardly discomforted to say. Alas what is happened to me. Alas what doloure is this, hath mi wife conceived .vii. dogges. Hath she habandoned her to brute beastes she that I thought had be the honour and beaute of al ladies. Hath she betraied me that I loved more than ever man loved woman. Am I bi her dishonoured and brought to confusion in mi realme. Why hath not God avaunced my daies where as I was upon mine enemies. I was wel borne in an unhappie houre for to se nowe this obprobre. Alas who shal counseil me Mi God almighti helpe me, for I require no more to approche her that I have so muche loved. In this sharpe anguishe reconforted him the knight in the beste wise that he might. But he was so inwardli disconforted that he laide him on a bedde where as he fell on slepe for sorow and melancoly. On the other part was the noble quene Beatrice in an other chambre where as she made no lesse sorow than her noble spouse. Than came to her a squier that long time had served her, and declared to her al the maner howe king Oriant was returned fro the warre, wherof she was greatlie abasshed, and axed the squier if in anie wise she had ben spoken of. And he answered yea : and recited to her al how the perverce Matabrune, and the false and disloyal matrone had tolde and affermed to the noble king Oriant of her fait. And than she began for to make her complaint to almighti God and his glorious mother sayinge. Ryght swet lady and sacred mayden mother of 
the savyour and redemptor Jesu Chryst what syne myght I have commysed towarde thy dere sonne Jesu Christ that .vii. dogges ben yssued out of my bodi wherbi I have lost the love of my husband the moste pleasaunt and the best that ever woman might have chosen. Alas soverayn kinge Jesus Chryst that for to washe the crimes and offences of all poore sinners hath shede wather and bloud fro your precious sid wherof your most worthi mother received so great dolour at her hert I besech you that it wil please you to clense, wasshe, and purge me of all my sines and crimes that ever I commised agaynst you. And as trulye as ye comforted your swet mother the day of your holye resurreccion, whan fyrst and before all other ye shewed you to her in body impassible and gloryfied and consequently to the other holy ladyes and to your most happy apostles I besech you humbly that ye will reconfort your servaunte inding to requir you, and to restablisshe her to the good grace and love of her true husband and spouse to whom she never thought to do wrong ne offence in any maner. And thus she abode hevi and sorrowfull in her chambre incessauntly requiringe our swet saviour Jesu Christe and the glorious Virgin Mary his right worthy mother for to impetre and get mercy.

\section{CHAPTER XI.}

How kinge Oriant assembled his counseyle for to know bi what maner he ought to entreate the quene his wife the whiche wrongfully and without cause was iniuried of the parvers Matabrune mother to kynge Oriant.

ThE kinge Oriant beinge reposed in melancoly as it is saide made me incontinent to assemble his counsell, that is to wit Dukes, erles, knightes and other lordes of renowne, with the bisshop and prelate of the church. And whan they were al assembled in the consistory the kinge arose and began to speake in saying. Faire lordes I have made you all to assemble in this place for to discute of a mater, the which to me is hevi and grevous to supporte. It 
is of trouthe notorily that sith my retourning it is shewed to me and affermed that my wife the which ye know duringe my viage hath be delivered of .vii. litle whelpes, which she hath conceyved of a dogge, as it is presupposed, wherfore it were shame to me if ever I retourne to her by copulacion carnall. And I wil that bi your advise this maner be consulted, and howe I may acheve it. And for to answere of this mater was prefered, the bishop that said. Sir king under correccion of you and my lordes here present I shal saie as be semeth of that, that is proposed here of the quene your noble spouse the whiche is saide to have conceived .vii. dogges, me semeth that bi iustice she ought not to receive death. And here is the reason wherfore. It is possible that in her slepe be comen to here som beast that hath done her this outrage without her knowledge and consent, wherefore she is in nothing culpable. And fertermore your noble person hath touched often times to hers after the constitucion of the sacrament of mariage. Wherfore me semeth under reverence that ye ought not consent to her death, but howbeit yè mai make her dyligently to be kept in some honest place bi maner of pryson, and of the surplus let the iudgment to God that is the true iudge and only retribuer of good and evil, and the trouth shall finabli be knowen apartly. Of this counsel the king was somwhat consoled in his herte, for he had alwaye a certaine love to his wife. But after that arose another knight having a fiers Lions courage sayinge there against what sir wolde ye leave this woman thus seing the dishonour and shame that she hath doone to you? yf she be but a loneli put in prison ye mai never mari you to a nother wife and by consequence this pusaunt realme should be left without heire of your body. Bi the which thinge considered if I were beleved she should be brent in a great fire, as it is well knowen that she hath ynough deserved it, and than ye might mari a more noble lady than she is, the which wolde appease the sorow that he have for this. Of this counsel king Oriant was not over glad, but without shewinge great semblaunt as he that desired to save the bodye of the good quene concluded this mater saying. Now lordes I shal tel you in giving you advertence, 
if it so were that she be culpable of death yet have I vowed and againe warde made promesse to God that she being dead or alive never to espouse other wife, for ony treasours or realmes that any man living may give or habandon to me and thus I certifie it you. Than al the nobles and great lords of the asistence concluded with a comune accord that it was convenable bi this maner that she helde aloneli pryson in likewise as the bishop had delibered. And at their advice the kinge ordeined two of his knightes that they shoulde put the quene his wife into some gracious prison and that she shoulde be honestly served and administred of meate and drinke as to her noble estate apperteined and that they should charge her for to praye to God for him, and to advertise her how he had preserved and defended her from death. And whan the cruel Matabrun had knowen the deliberacion of the bisshop she spake to him reverentli, and greatly iniured him for his counseile that he had given to save. the quenes life. After that came the two knightes to the noble quene Beatrice and benignely at the commaundement of the kinge and his counseil put her in a fair chambre bi maner to holde prison and there they reveled to her al that had ben said and ordined by the said counseyl. And how the kinge had defended her from peril, and yet moreover had commaunded to entreat her honistly and that she should praie to God for him, wherof greatly she thanked and praised God which seinge the case wherin she wend to be culpable had saved his life. And thus paciently in wepinges she abode in prison. But she recommaunded her oft to the kinge thanking him of his grace done to her for the offence to her imposed, wherbi she was obliged for ever to pray to God for him. And also she recommended her humbli to God and to the glorious virgin Marie in al her nedes abiding long in that place shitte, tell that one of her sonnes named Helias delivered her out of prison as it shalbe saide here after. 


\section{CHAPTER XII.}

How the devout hermite Helias baptized the vii. litle children in his hermitage.

FOR this time we shal leave to speake of the noble kinge Oriant and of the noble quene Beatrice his true and faithfull spouse for some thing right digne and worthi of memory that I hope to saic of their .vii. litle children esclaves, nourished, and alimented in the poore hous of the good holy and devoute hermite named Helias.

After that the vii. children were nourished and alaced of the saide white goate miraculously sent of God as before is rehersed. The above said devoute hermite to thend that they should be acceptable to God bi the vertue of wasshing in the holi water sacramental made them to be baptized and christened at his good wil and pleasure. And of the said .vii. litle children there was one amonge the other the which to him was right beauteous and agreable and that pleased him muche, the whiche he named and called Helias after his owne name. And whan that they were in the age of theyr pleasaunt and fresshe grene yougth thei reane all about sporting and playinge in the said forest about the trees and floures only cladde and habitued with poore coates made of greene leaves of the trees of the said forest, and were barefeted everichone without ony covering upon their heades in colde and heat, and in this estate wente they alway together the one with the other.

\section{CHAPTER XIII.}

How one of the yomen of the hunte of the pervers Matabrune founde the vii. children in the said forest, the which tolde of them to Matabrune.

UPON a time it fortuned that a yoman of Matabrunes hunte named Savarie went for to chase and hunt in the said forest in the whiche dwelled the devoute hermite Helias. Than almighti God our Lorde willed that the sayd yoman should finde the said 
children of the noble king Oriant and of the good quene Beatrice his wife. The which children satte under a tree echone having a chaine of silver as it is said, under the said tree they gathered wild appelles and eat them with bread. The yoman beheld them gladlie and salued theym beningnely, and they answered nothing but ranne awaie before him. Than he sued and ranne after them unto the hermitage, the better and singulerly to knowe and consider their estate and their maner. And whan the good hermitte sawe the yomen renning after the .vii. children he salued him and said. Good frende I pray you for the love of God that ye doo no harme to these poore children. Nay for God good father said he: But I am greatly admervailed to consider theyr estate, and of the silver chaines that I see aboute their neckes. My frende saide the good hermite know ye for trouthe that even so as ye see $I$ found them as yonge children new borne in this forest. And for to nourisshe theim miraculously came into this pleace a white goate, the which hath well susteyned and given theim her tetes to suke her milke the space of three yeres. And also to my power I have also diligently kept them winter and somer. Faire father said the yoman God yeld you good retribucion, and than he departed fro the holy hermitte, in taking leave benignely of hin and of the .vii. children. And whan the yoman was retourned to Lilefort he went and salued Matabrune and to her he recounted how he had founde .vii. yonge children in the forest havinge chaines of silver about their neckes, the whiche wer sitting under a tre in gathering of wild apples. Of whose words Matabrune was greatly admervailed, wherfore she enquired of him diligently the trouthe. And whan she understode him she wist wel that thei were the .vi. sonnes and the doughter that the noble Quene Beatrice had borne and conceived of king Oriant. The which bi her wickednesse she wende to have made to die, but God our soveraine helper that alwaie saveth them that he hath chose, had kept them from all harmes under his holy proteccion for he is the iust iudge stronge and pacient the which abideth the yre of his vengeaunce unto the houre bi him ordeined. And ye ought to wite that Matabrune 
was ful sorye and pertourbed of these tidinges, wherfore she called secretly the said yoman and saide Come hither my freende I wold not for no treasour but that $I$ had heard these tidinges that thou hast brought. But if thou wilt have my grace and that I gyve the great goodes it behoveth thou take suche felawes with thee as thou wilt, and forthwith go and slea the .vii. children that thou hast founde in the forest. And if thou doo it not at mi pleasure and commaundement I promise thee and be thou sure that I shall make thee dye an evil death. But if thou obey me be thou also sure that I shal rewarde thee and thi felaws in suche wyse that ye shall never have need. Madame said the yoman I shall doo your desyre, and I promyse you to slea them without doubt, so that ye shal know it expressely. Well than said she it suffiseth, go and doo your diligence. And than Matabrune full of woodnesse and furoure came to Markes that she had first ordeyned for to bere the .vii. litel children out of Lilefort and to make them die or to drowne them in a river, the which he had not done for pitie that he had to beholde them when he left them in the forest, and put out his eyen and handled him so that many wende that he had be dead.

\section{CHAPTER XIV.}

How at the commaundement of Matabrune an houndes man named Savary came for to slea the .vii. litle chyldren of king Oriant unknowen in the Forest, where as they were transmued into swannes.

AT the commaundement of the pervers Matabrune her yoman or houndes man named Savary tooke .vii. felowes strong and mighti with him for to put in execucion that, that unto them was commaunded for to slea the .vii. children of the noble King Oriant and his good spouse Beatrice. And so as the sayd yoman and his felawes passed bi a village they sawe muche people assembled, wherfore thei drew nere. And whan they were approched Savarie demaunded wherfore they were so assembled. And they 
answered for to see a woman executed and brent by Justice. And wherfore sayd Savary, what harme hath she doone. And they sayd for that she hath murdred and slaine the childe that she bare in her owne bely. Than Savarie departed thens, and by those wordes remembred the execucion and the murther that he went to doo on the .vii. smal children of the king and of the quene, wherby he was much esmayed and began to refraine his courage and that which he had undertaken to doo in saying to his felowes. My brethren and felawes here is a fayre glasse or spectacle for us. Howe said thei? Have ye not seen said he that these people go for to doo justice and put to death that unhappy woman for that she hath murthred and slaine that childe that she bare in her owne body. And therfore faire frendes ye wot that my lady Matabrune hath sent us hither for to go occise and put to death vii. faire litle children the which the other daye I founde in the middes of the forest, echone of them havinge a faire chayne of sylver at his necke, but cursed be he of God and confounded may he be that any harme shall doo to them. Beholde this woman that they go to brenne and execute for one only childe that she hath murdred and was her owne. Consider we than what punicion might renne to us for to put to death the .vii. chyldren of the whiche I have spoken, the which to us ne to her that commaundeth cannot hinder ne bere any domage. Syr houndes man sayd his felowes ye spake wiseli, and we be al of the same advise. They shall have no harme sayd he: but this wee maye do for to appease and contente the intsaciable iniquite of the perverce Matabrune, we shall go to the .vii. chyldren and take al onely the chaines of silver that ben at theyr neckes, and than bere them to the cursed Matabrune and make her to beleve that we have slaine them and put them to death by the tokens of the sayd chaines. To the which thinge accordid his felawes as good and true counceile. And thus delibered they entred into the forest and came unto the litle hermitage where as were dwelling the said litell chyldren with the devoute hermite Helias. But at that houre they ne founde but .vi. of the said children, for the good hermite was gone to aske meate in 
the villages there aboute and had led with him his godsonne one of the .vii. children for to beare the breade and suche as was given to him in the countrey for fode of him and the .vii. unknowen children. And whan the houndes man Savari and his felowes came nere the .vi. children abiden in the hermytage they set handes on them and toke them for to take away the chaines of sylver that eche of them had at their neckes, but the poore children began to crye piteously for feare that they had. Than sayd Savary. Doubt you of nothinge faire children, for we shall doo you no harme if it please God. And in this saying: thei toke the chaines of their neckes. And as soon as their chaines were of they were al transmued in an instaunt in faire white swannes by the divine grace, and began to flee in the ayre through the forest making a piteous and lamentable crye, wherof Savary and his felowes were so afrayed that they fel to the erthe as in a swonne. And whan they were risen in trimblinge all for feare they sayde one to another alas what have we founde heere? veri God comforte us, what meaneth this that those .vi. children ben transmued into swannes. Ha false, disloyall, and traytresse Matabrune by thee have we over grevously offenced God. And bi thee have we merited right greveous punicion, cursed be thou that ever sent us hither into this forest for to commyt this grevous offence and evill. Departe we hence said Sayarie for all to longe have we ben here, we have founden but .vi. of the children but if the other were here present he should have no harme of us ne displeasure. Returne we lightli with out shewing to ony of this mervaylous adventure. But for to render answere of our commission to that cursed and perverce Matabrune we shal bere to her these .vi. chaines of Silver and shal give her to understande that we have lost one by the way as we retourned. And thus they ben departed out of the forest and ben retourned to Lilefort where as thei have founde Matabrune, to whome thei have certified to have slaine the .vii. children, and for a witnesse they her presented the vi. chaines that they had aboute theyr neckes. And have geven her to understand that they had lost one by the waie, wherof Matabrune nighe enraged and waxed mad for angre 
that they had not brought al seven and in her woodnesse repreved and thretened them sharpli. But for to have peace they promised and offred to her to yelde and restore, the value thereof, wherof she somwhat contented her, and gave them some rewarde for their traveile. And whan Matabrune had the said chaines: she sent to seke for a goldesmith to whome she commaunded to make a cuppe of the chaines. And as the goldesmith had put one in the fyre to approve the silver: it multiplied in suche maner that it alone molten weyed as muche and more than all the vi. together whereof the sayd goldesmyth and all his meyny had great mervayle and were all abasshed, wherfore the sayde goldesmith gave the five other chaynes of silver unto his wife for to kepe and set aparte within her chambre or coffre. For the sayd onlye chayne the whiche he had so molten was suffycyente for to make two such cuppes as that, that Matabrune had ordeined him to make so he forged two cuppes of the which he withheld one for himselfe with the v. other chaines of sylver that he kepte tyl a certayne time ordeyned of God as ye shal heare. And than he brought the other and presented it to Matabrune that was all admervayled how he might have forged a cuppe so great and materyall as it was of so lytle silver as she semed to have gyven, but there as God lyste to worke nothinge abydeth impossyble to his divyne wyll.

\section{CHAPTER XV.}

How the good hermite Helyas retorned to his hermitage with his godsonne one of kynge Oryant sones, and founde not the other chyldren transmued into white swannes.

For to ensue the orygynall of that I have entreprysed to wrytte I shal returne to speake of the devoute Hermite Helyas and of his godsonne one of kyng Oryant sonnes, and of the paciente Quene Beatryce. It is to be knowen that anon after that the vii. children were transmued into white swannes retourned into the hermitage the abovesayde hermite and his godsonne Helias, the which 
founde not the $v$. sonnes and the doughter that they had lefte there whan they departed wherof they were mervaylously displeasaunte. And than they began to cal them with hye voyce within the forest, but none aunswered. The good Hermite sought on the one syde, and his godsonne on the other syde on all partes of the forest as longe as the day lasted, but they founde them not wherfore thei ceassed not to make great dole and sorowe all the nyght longe. And on the morowe yonge Helyas began agayne to seeke his brethern and his sister weeping and wailing dolorouslye as all discomforted through the forest. And so longe he wente hither and thyther that he arived nigh to a stagne or ponde where as he sawe vi. fayre swannes all white swimming on the water, the whiche were his bretheren and syster so transmued by the wyll of God but it was unknowen to him, how wel that naturallie he tooke pleasure to beholde them, wherfore he approched to them and they came and feested him, and he gave them bread that he had and stroked playne theyr fethers with his hande by nature that moeved him therto. And as it is notably recited in the cronycle of this present history the sayde yonge Helyas theyr brother went to visite them every daye, and did bere them to eate of the bread that was given to him for goddes sake. And whan the hermite had apperceived hym divers times so goynge to the sayde stagne he demanded him why he went so diligently theither to sporte him. And he prayed him not to be displeased, for he had founde vi. fayre white swannes the which made the greatest chere that was possible to see. Now was the sayd Helias so faire bigge, and wel fourmed of bodie and membres that his godfather the good Hermite tooke a singuler pleasure for to beholde him, for he was as parfite in his adolence that he semed almost a man viril in his force. He ne knew his pareyl in prudence of understanding. There was not a wilde beast but he tooke lightly bi renning. He was honest and well manered in all his gestes, and well attempred in his force and noble hardinesse, and all bi thinfusion of the divine grace. For he never had conversed ne haunted the worlde. And yet was he sufficientli instructe and right well learned in science and 
good manners in suche wise that his godfather had enterprised and was delibered for to dedie him to the service divine in office of a preste, til that the aungel of heaven came downe and reveled to the said good and devout hermite that God our soverayne Lord almightie had otherwise ordayned for as it shall be expressly reherced here after in this present History.

\section{CHAPTER XVI.}

How the false and parverce Matabrune made malegnelously to afferme by an untrue knight named Makayry that the noble Quene Beatrice had forfayted with a dogge.

DURING this time was the good quene Beatrice incessably deteined of prison, the whiche paciently in her adversite alwaie praised the name of God in praying for her spouse the noble king Oriant, and that it wolde please him to succur her. But the perverce Matabrune sought incessauntly the meanes and occasions that she might for to make her die. So it happed that she had in her courte $\dot{a}$ knight disloial and wicked named Makaire the which she suborned so with money that she made him to tell and afferme to king Oriant that the good quene Beatrice his wife had be knowen and habited of a dogge, whereof she had conceyved vii. litle whelpes, of whom after is made mencion. And that she had moreover delibered to poyson and make the king to die and his mother Matabrun bi venim and other poyson: that he said that the noble quene Beatrice had ordeined to do it with all, wherto the good quene never thought, for she loved as truli her husband as ever woman loved hers, and wolde not have done ony untrouth to his body to have died therfore. But the evyll and wicked folke paine them selfe alway to noye and do accombraunce to them that ben good and loved of God. And whan the noble king Oriant had heard the fals and untrue reporte that bi this cursed knight was affermed he was merveylously sori and angry of the tidinges. Wherfore the more stedfastly to afferme this lie the said fals Makaire presented him to fight against all men that wolde say or defende the contrari of 
that he had reported, wherof the king was more angry than before and totalye dispited against his wife, the which was in nothing culpable of al that she was accused. So he swore God and hys othe that for these tidinges she should die, but if that there were any that wolde defende her therof in champe of bataile. Than went there a noble squire and tolde from ende to ende al these evil tidings to the good quene and how the king had sworne his oth that she shold die grevously therfore, but if there were any that wolde susteine her quarel against the forenamed Makayre, and whan the good quene heard these pitious tidinges litle lacked that she ne died for sorowe, wherfore al lamentably she began to complaine her sayinge. Alas I have anguisshe on all sides. Alas now see I well appertly that I am falsli betrayed, and yet I know no man living that for to susteine and defende mi right wolde in any maner dispose himselfe. But I shall retourne me to my sweete Lord Jesu Christ the whiche is the only piller and foundament of all verite, and I have hope that he wil helpe me. Alas mi God mi creatour that by your divine wil reised the spirite of yonge Daniell for to returne to the judiement and to save ro death the noble ladi Suzanne the which was publikeli led in justice bi to fals iudges, the which with wronge and uniustly had accused her of the vice and sinne of advoutry wherin she never thought, as afterward before al the people was notably knowen and approved the trouth by the good Daniel the which yelded the two judges al confused. Thou knowest my soveraine God in likewise that wrongfulli and without cause I am accused to $\mathrm{mi}$ good and faithful spousy king Oriant, wherfore I beseche and require thee humbli that it wil plaise thee to kepe and preserve me fro shamefull death and confusion of the crime and sinne that I am accused of, wherof thou knowest me innocent and nothing worthy. And than benignely recomforted her the said squire, and after in weeping for pitie he departed humbly from her companie. And the good quene abode alway dolorously reclused and shitte in prison unto the time that God the which in everi place succoureth his servauntes divineli had purveied and ordeined as afterwarde ye shall heare. 


\section{CHAPTER XVII.}

How the aungell of God announced to the devoute hermite Helias that the vi. sonnes and a doughter the whiche he had founde in the forest were king Oriantes children, and that he shoulde sende yonge Helias to prove the trouth.

Now hath God our soveraine lorde hearde and exalted the devout praier of the noble Quene Beatrice, and hath sent his holy aungel fro heaven to tel and declare to the devoute hermite Helias that the six sonnes and a doughter which he had founde in the forest wher the children of king Oriant, and that his good spouse Beatrice had conceived them of him, and had childed them at on only time. But the perverse Matabrune made him to beleve bi the midwife that she had borne and conceived vii. dogges which were issued of her wombe. And also that the swannes that his godsonne Helias hent everi day to feed and susteine with bread in the ponde wher his $\mathbf{v}$. brethern and his sister in such wise transmued whan Savary Matabrunes houndes man and his felowes tooke awaie the chaines the which they had about theyr neckes as he hath. And that he should sende his god sonne for to befight the false Makaire that with wronge and without cause had accused his good mother the saide quene by the enhortement of the perverce Mattabrun that wolde have made hym to dye and the other vi. children, whan she charged a servaunt of hers for to slea or make them perisshe, but for pitie that he had to beholde them he left them in the forest where as the devoute hermite found them. And sith Matabrune made to put their good mother in prison the which al redy hath ben so deceived the space of xvi. yere wherby he would obteine victorie and justice of his enemies, and bi succession of time his brethren and his sister should returne into their owne fourme and nature humaine as they were before And of theim should come a great fruit. For of his lignage should descende Godfrey of Boulion, that for to agment the holy faith of God shal conquere the holy lande of Jherusalem. So descended the hevenly aungel at the holy commaundement of 
our lorde, and came to announce unto the devoute hermit al that to him was ordeined of God as is before said. And whan he had doone his message he returned and the good hermite abode alone all ravisshed in spirit. But after as al reioiced he called beningly his godsonne Helias, the whiche came fro the stagne where as he had given bread to the swannes like as he was accustomed bi natural inclinacion, and recited to him all that the aungel had announced to him, saying: Mi godsonne, mi frende I wish not that ye were of so noble a bloud as ye be, wherof I ought highly to praise and honour you as wel for the honoure that God hath doone to you as for your noble potentes. And how said he godfather, what tidinges have ye heard? wite ye mi lorde and mi frende said the good hermite that an aungell of heaven cam to me that anounced and told to me in goddes name that ye be sonne of the right noble king Oriant and of the good quene Beatrice his faithful spouse and your mother. But it behoveth that bi the divine commaundement of God to you be declared bi me all the tidings as the aungel tolde me. So ye ought to know that your mother conceived you al vii. togither of your noble father, and sith childed of you at one only time. But the perverce Matabrun stepdame of your noble mother bi the consentment of the midwife that you your v. brethren, and your sister reseived of her bodi made her to beleve that vii. whelpes were issued of her wombe the whiche thei had unfaithfulli prepaired, and so wende your said mother. For Matabrune gave you incontinent to one of her servaunts whome she charged to sle or droune you. But the pitie that he had to beholde you moeved him to leve you al naked and nere dead for honger in the same place where as I at first founde you. Than shorte time after the said Matabrun harde some tidinges of you, and sent some folke againe for to destroy you, but thei founde as than but your $\mathbf{v}$. brethern and your sister, from whom thei toke the chaines of silver that echone of them had aboute their necke as ye have, and forthwith bi the divine wil of God thei were transmued into white swannes, and ben they to whome he gave every day bread in the stagne. But in time coming they shal retourne into theyr 
owne nature humaine as they were afore, and shal make great fruite, but for the thinges beforesaid your father commaunded to put and hold your good mother in prison, the which hath be captive the space of xvi. whole yeres. And now againe Matabrune hath so much done bi money that an untrue knight named Makaire of your fathers courte hath affermd that she had conseived and habited with a dogge, and that she had willed to kill and enpoysen him and the said Matabrune wherfore the king hath sworne to make to die your good mother, if none be founde that against the said Makaire'wil susteine her honour and hir quarell in campe of bataile. Wherfore bi me is ordeined of God that I admonest and warne you to go and upholde her good right against the forenamed Makaire and al the other that willinglie hath blamed her. And without doubt ye shal obteine victory and triumph against al her false enemies, where bi she shalbe delivered fro prison and restablisshed unto greater honour than she had before. And also there shall issue of your lignage a valiaunte and chivalrous prince that shal be named Godfrey of Boulion, the whiche in his age virill shall conquere the holy londe of Jherusalem, and other countreis of beyond the sea for ever to augment and encrease the right highe and puissaunt name of Jesus, and the holi faith catholike. And whan yonge Helias (wisely taught and enspired of God) heard his godfather speake in suche maner of that he had commaunded of God, he conformed him al holy to his divine wil and loving he delibered him to go see the father that had engendred him, and the good mother that had childed him, and of whose body he his $\mathbf{v}$. brethern, his sister miraculously issued. And after al these thinges premised to eschue prolixite the hermit and his godsonne disposed them that he should go so clothed in leaves and barfoted as he was with a simple staffe in his hande to succour his said mother, to thend that more apertli the dyvine and vertuous miracle of God should be shewed in him and than in weping thei departed amiably. And at their departing yonge Helias ententively besought his godfather that it wolde please him diligentli to feed with bread the whit swannes his brethren and sister. 
And the good hermite promised him to do his best until it pleased God to dispose for them as he had ordeyned. And then yonge Helias departed and went toward the citie of Lilefort for to accomplisshe the holy commaundement of God.

\section{CHAPTER XVIII.}

How king Oriant sent for the good quene Beatrice his wife for to expose to her that wherof she was accused and to condempne her to death. And how Helias his sonne arived at the palais of his father for to defende and succour his mother fro death.

IN this time came the day that the noble king Oriant had decreed for to condempne and make to die his good spouse Queene Beatrice by the false accusacions that of her uniustli had ben made. So the knight sent for her to the prison for to make to expose in her presence the cryme of the whiche by the sayde Makarie she had be wrongfully accused. And whan she was led thither publykely before many noble knightes and men of councel that there were presente assembled: she began incontinent to salue the king her husbande enclining her knees in requiringe of mercy so pytiouslye that al the noble knightes had pitye to beholde her, and in lyke wise the kinge was so sory of here state that with greate payne myght he speake a worde he had such sorowe at his herte. Than he commaunded the false Makaire to declare in her presence the crime wherof he had accused her to him and forthwith he assured as a false murtherer began to say on high. Syr I have tolde you and yet wyll upholde before all here present, that I have seen her have compani and habitacion with a dogge, wherof she hath conceyved vii. whelpes, the whiche sith ben yssued of her owne bodye. And more over she wolde have gyven venim to me for to have enpoysened and made to dye you and your mother my lady Matabrune the whiche I wolde never do unto you nor to none other person. Now ladye sayde 
the kynge to the good Beatrice his wife, ye heare how ye ben openly accused of shamful, horrible, and vilaineous forfaite before me and my baronny, what defence wyll ye fynde. Your faulte displeaseth me sore. But yf that ye wyll confesse the trouthe ye shall not dye, for I shall assygne your lyfe in some holy monastery of relygyon for to doo there penaunce and satisfaccion for our synne and pray to God for you and me. And yf you confesse not your dede: I promise you that shamefully I shall make you dye, if ye fynde not any that wyl susteine your quarel agaynst him that hath accused you. Alas my lorde sayde the good queene I cannot finde ony knight ne other that for to susteine my good right in ony maner wyll expose hym. But I promise you and swere heretofore all by the faith of gentylnesse that with great wronge and uniustly I am here before you accused. And how be it that it hath pleased the devine grace to so sende me this yet I never commised ne thought for to commit any vilany forfaite agaynst you ne agaynst myne honour. And I complayne me to God Almyghty of this that I am accused in requiring him vengeaunce of all mine enemies.

And thus as this saide assemble was made for to condempne the good queene to death in the kynges palais, thither came the yonge Helyas sonne to kyng Oriant and of the quene Beatryce, the which having a staffe in his hande was delibered in courage in the confydence of God to susteyne his good mother. And whan he was comen to the gate of the palais he mette firste with. a boistous churle that rigorousli axed him what he sought there? I seche (sayd he) a false and traytrous knight named Makayre. And he weeninge to mocke him sayde that it was he. And Helyas than lift up his staffe and with a free wyll hit him on the head that he felled him to the ground. And forthwith came a sergeaunt that tooke him and wenyng that he were a fole for that he was poorely clothed and barefoted and mocked him that had the stroke, saying that he should not play with a foole. Than Helyas drew him vigorously out of the sergeauntes hands and sayde to him. Let me go, for by the faith that I owe to God I shall never cease until I have vengeaunce of the fals Makaire that 
wrongfully hath doone great iniurye unto my mother the good queene. And amonge the other there was one in that place that whan he herde him speake so, tolde him that Makaire was in the consistory in the hall of the palays where as he accused the quene before the kinge of certayne crimes the which him semed to be falsly imposed, and said that the quene was a right notable ladi and ful of vertues, and that with great wronge the same day thei wolde make her dye. And whan Helias heard him saye so he came lightly to him and embrasing him said, Gentil frende I pray thee that it please thee to lede me to the place that thou saiest, and he led him streight. And whan Helias entred into the consistori wher as many folke weare assembled to see the demayne of the noble queene Beatryce, and yet many other that came to see what Helias wolde do that semed to be a wilde man. Than the noyse came to kind Oryant which demaunded what it was. And it was tolde him that it was a yongling as al naked that axed after Makaire, and saith that he will fight against him and put him to death for to susteyne and defende the good quarell of the queene the which he sayth is his mother. Ha said the king it is than a foole, syr sayd a knight $I$ have hearde him speake wisely. And than the king made to question him what he sought there. I seeke said he Makayre. And than one shewed him, and then he approched to him and said. $\mathrm{Ha}$ false traiter and untrue knight I defie thee thou shalt abie. And therwith he gave to Makaire suche a buffet with his fist that he felled him to the grounde incontinent and helde him so that he wolde have cut his throte yf he had any knife for to doo it withall. But he was lyghtly taken from his handes, and then he fled away al be bled with his owne bloud. How well that many noble knightes were right glad of that hie adventure, for thei were sore displeasaunt to see him vilaynously accuse the noble queene so pacient as was possible. And whan the king had seen him give so great a stroke to Makaire with his fist he repreved him and saide. How art thou so hardy to do this outrage in my presence. Ha syr saide he, know ye that I am come hyther at the only commaundement of - God in likewyse as ye see, for to tell you the verite of the 
cause and of al the fait wherfore ye ben here assembled presently in this consistory. And how said the kinge. And Helias answered. Syr I shal shew you, but or I procede any ferther I wil go enbrace and kisse mine owne mother that I see yonder. And incontinent he approched the good queene and in kissinge and a colling her sayd. My right dere and faithful mother be no more sorrowfull at your herte. Cease yoor waylynges for this day I shall yelde to you all joye and consolacion bi the pleasure of God; and shall shew that falsly and with greate wronge ye have be betraied of them that should have kept you. Than of this thinge the kyng was mervaylously abasshed thinking and saying to himselfe. Here is some token of God, and in likewise were admervayled all they that were there present. Than Helyas perfurnisshed his purpose sayinge. My lorde my father I do you to understande for trouthe that whan ye left in the keeping of your mother Matabrune my mother the which was bigge of chylde with me my brethren and my sister and that ye wente to warr and fight against your ennemies, your said mother Matabrune conceyved suche an envy against my mother that she accompanied with the false olde midwife by silver suborned delibered for to do as ye shall heare. And for trouthe at the deliveraunce of her burthen she chylded vi. sonnse wherof I am one and a doughter, and also we brought from her wombe echone a faire chaine of silver at our neckes such as ye se me have one. And whan we were thus borne she made to transport us from this place. Than she tooke the sayd litle dogges and gave my good mother to understande that they were yssued of her bodi, the which she wende to be true for that she perceyved us not for the great anguisshe that she had. Consequentli she had given charge to one of her servauntes for to slea us or to drowne us in some river. But whan he was in a forest he behelde us on a plaine, and of pitie that he had to beholde us he left us there al naked and perisshing for honger without doinge us other harme. Sithen were we founden by a good and devoute hermite named Helias, the which beninegli bare us into his hermitage within the forest wher as he dwelleth yet presently. And there he warmed and 
susteyned us with his smal gooddes as much as to him was possible. Than he made orayson to God that he would purvey us, the which at his devoute prayer sent thither myraculously a faire white gote that susteyned and nourisshed us with milke, and the good hermite fed us with bread that was given him for goddes sake. And one day amonge all other as we were al vii. litle children under 2 tree gathering of wilde apples in the forest the houndes man of Matabrun founde us having eche one a chain of silver at our neckes of whome he made to her reporte. And she sent him agayne for to slea or make us to die. And an other day as the good hermite and I were gone in provision to susteyne our lives the same houndes man came with vii. other felowes the whiche tooke away the chaines fro my v. brethern and my sister, the whiche incontinent by the wyll of God were transmued in faire white swannes, and ben yet presentlie in a fayre stagne or ponde in the sayd forest, where as often times I have fed and given them bread for to eate. Sithen finably is comen the aungel of God that hath recited al to the good and devout hermite my godfather, in making him commaundement by God that this same day he should send me into the place where as I am present for to save mi faithfull mother. And for this intencion I am come hither with courage delibered in the confidence of God for to susteine and defende her from scathe by naturall inclynacion, and to be fight the traitre and untrue Makaire that bi his wickednesse wolde openly blame her. And for to make thys notabli to be verified ye may make the said Makaire and me to be kept in prison til ye please to sende for the good hermit for to witnesse the trouthe. And whan his father king Oryant hearde him speake thus he was yet more admervailed than before. So he began to speake to the noble quene his wife saying. How say ye lady, what semeth you of the words of this yonge man. Certainly my lorde I wot not how it is for I was at the houre of mi childing so sore travailed that I had not on me onie feling. How be it I know wel that mi ladi your mother never loved me, wherfore yf she have doone me yll I beleve that she shal finde it. Thus I report me to God and this yongeling that I see yonder, 
whiche he hath sent me for my champion and I praye you that it please you to make him be entreated as your sonne and graunt him that he requireth, desiringe above all to susteyne your noble honour and myne.

\section{CHAPTER XIX.}

How the kyng Oriant commaunded to make armoures for his sonne Helias to fight agaynst Makayre and than went to the good hermite in the forest.

AFTER these wordes the noble kynge Oryant made to with draw the queene Beatrice honorably into a fayre chambre, in praysynge God his creatour as all recomforted. Than he recited to Matabrune his mother all that yonge Helias had declared wherof she blusshed all red and began to have feare, but not withstandinge she wende well assuredly to have renied al the case. How be it that the kinge made not over great semblaunt for that time: After consequentli he commaunded to enprisone and make sure the untrue knight Makaire the which was doone at his commaundement, for he doubted him of the great treason and malignite commised upon his noble spouse. Than after he gave charge to ii. noble knights to make forge armours propice and meete for yonge Helyas, the whiche by the divine wil was so pleasaunt and hardi of courage that echone loved him with good hert. And whan the king had ordeyned all these things he made maner as he wolde go hount and was mervailousli glad of these tidinges he purposed for to go to the good hermite in the forest, for to be al assured of that that his sonne had said and promised before him and his counsell. And thus is departed the noble king Oriant with divers of his secrete knightes, and is comen in to the sayd forest, and without makinge delay they have so long sought that they have found the hermitage of the hermite Helias. And whan the king sawe him he descended of his horse, and in their saluing reverentli the king demaunded his name. And the good hermite sayd, Syr I am brother Helias, and than. 
knew the king that it was he that he sought wherof he was right joyous, and tooke him a side mekeli to be confessed of him. In the which confession he declared to him all the case as the childe had said. By the whiche the good hermite in likewise declared the houre, the day, and the time that he had founden the vii. children in the foreste and al that was happened by the selfe maner as the yonge Helias had tolde his father. And than king Oriant knew certainlie the malice doone to the good Queene Beatrice. It is not to be doubted of the sorow that he made for the paine and greavous vexacion that so longe time and uniustly he had made his wife to suffre by false and traitrous reportes. $O$ sayde he my right faythfull lady, $\mathrm{O}$ my right deare and noble spouse, how may I make thee amendes how may I satisfie to thee? $O$ false and perverce tongues much worse than deadli venim. Have ye ben so hardy to make strife betwene the husbande and the wyfe. Have ye made to lie in the bead of tribulation betwene the sheetes of wepynges those that were wont to be in all mirth and consolation. O good Lorde God I beseche thee of merci, and pardon me mine ygnourance. Thou knowest how I have done it, for I my selfe have betraied, and malignelousli deceived by fals reporte. In this wise disconforted tooke the kinge leave of the devout hermite. To whome he made for to deliver a great some of golde and silver to the entente that he should founde and edifie a churche of religion for the honour and reverence of the glorious virgin our lady sainct Mary, And for the remuneracion of his vii. children the which in suche wise myraclusly there had be nourisshed and sustented by the divine providence of God. And than he retourned to his citie of Lylefort with his people for to comferme the iourney that he had ordeyned of his sonne yonge Helyas and of the fals knight Makayre, and to dispose all the mater as time semed best. 


\section{CHAPTER XX.}

How the noble king Oriant delivered out of prysone good queene Beatryce his wyfe. And after ordeyned all thinge to his sonne yonge Helyas for to fyght agaynste his enemyes.

Whan the noble kinge Oriant was retourned fro the hermitage, and that he had knowen the veritie of the vii. children he made incontinent to deliver the noble queene Beatrice out of prison, and captivitie, and restored her to al libertie and fraunchyse, the better to love and honoure her without comparison more than ever he did before, so that she might go and come where as her pleased, as innocente and not culpable of that to her was imposed, wherof right humbly she yelded graces and praisynges to God. And also for her deliveraunce made joye in thanking our Lorde. After he made to take Matabrun and put her fast in pryson with iiii. sergeauntes to kepe her that she should not fle thens til her case were determined by justice. Than consequently he sent for the untrue knight Makaire for to be at the journey (ordeyned by the kinge) for to fight against hys sonne yonge Helias, that God hath sent for to susteine the iust quarell of his good mother the queene Beatrice. Helyas than was wel armed by two knightes, that the king had ordeined therto al maner of pieces of harneys right well steled. The helme of the same richeli besene as it apperteined unto a kinges sonne, with precious devises to him condesent. His sheilde on his arme, and his speare in his hande the which he couched in the reest as al enspyred of God. After they gave him a fayre armynge swearde well steeled and cuttinge. And finably they mounted him upon a good and mighty courser well barded and trapped as it belongeth to suche a poynte. And on the other parte was apparelled the false Makayre, the which was not over glad of that, that him behoved to doo. For he consydered well that he had no good cause ne iust quarel of that that he susteined agaynst the faithfull queene Beatrice. And moreover that he sawe her all redy delyvered of pryson at her free liberte, and the false Matabrune straitely holden in prison. 
But al these thinges notwithstandinge yet made he maner to have iuste cause in his fayte, but there is no wisdome agaynst the wyl of God. And whan they were both redy on the one side and other, there assembled anon many knightes the which made theim to sweare that eche of them thought to have good cause in that quarel different that the one against the other wolde susteine. The whiche Makaire like as did Helias, but or he left the feilde him selfe confessed the contrary before the kinge, the quene and many other noble knightes and damoyselles.

\section{CHAPTER XXI.}

How Helyas the noble knight of the swanne vainquisshed and overcame the false Makayre in campe of battayle.

Thus hath Helyas and Makayre sworne before them that were ordeyned for to judge the champ of batayle, and of that, that should be doone. And for to se this noble adventure of armes there came so great multitude of people that they coulde not be numbred.

And also there was present kynge Oriant with his good spouse Beatrice accompanied of great lordes the which desired mervailously that the honour of the good queene might be susteyned in the place. Than entred the ii. champions in to the place, and with yonge Helias that was apoynted as a kinges sonne came many great lordes of the court, and he was al assured as he that had the grace of God with him to whom none may noye. And on the other part was the said Makaire as all hevy and mala. colious of the favour and good grace that every man bare to him. But as al fiers and proude he began to say, Come, come, drawe nere my minion ye shal see this daye if your overwening youth may resist agaynst me. And how be it that he wend to shew himselfe hardy yet he said these words but for great feare that he had. And on the other parte the noble Helias said. A trayter I am nowe right glad to see thee heare in this place, as I have desyred, for I come to thee humbly in the name of our 
lorde and at his commaundement for to susteine veritably the juste quarel of my good mother the which untruely thou hast over muche defamed wherfore in my good confidence I hope this daye to shew agaynst thee, the strength and hie prayse to the right arme of God. Now come, come, sayde Makayre approche. So I wil said Helyas. Than with great cours of hors and the speare couched in the reest they mette with suche raundom that Helias made Makaire and his horse to foundre to the erthe. Of the which thing Makayre was greatly admervayled and sayde. $\mathrm{Ha}$ yonge sonne will ye shewe the might of your pleasaunt youth agaynst me, truly ye shall fele this daye that there is strength in my arme. Wel wel said Helias, come nere, I am all assured of thee. And than with cours of horse Makaire came wening to smite him al unwars, so that by treason he made him a litle wound so that a little bloud yssued. And whan the queene sawe that she was right sori at herte, wherfore she praied mekely unto God and his holy mother that it wolde please them to succour her poore childe, that susteyned verite, and proclamed her voyce sayinge. Soverayne God of Paradise that gave victory unto the children of Isarael against the froward Pharaon that uniustly helde them in captivitie. I praye thee if it please thee to give victory to my sonne, the whych it hath pleased thee to send hither for to deliver me out of prison, and reprove the treason and falsnesse that wickedly and with wrong was propenced against me as thou knowest the trouthe. And also all the assistentes were sory for that stroke, for echone had set theyr love on yonge Helyas but he coulde in no wise perisshe in the kepinge of God. And whan he felt himselfe so traitrously wounded he resembled the knight that taketh courage whan he seeth his bloud shedde. And in escrienge high he sayd to Makayre. A traytre, false, and disloyall haddest thou at this houre thought to betray me. Suffiseth it thee not to have wylled to betrayed mi good mother without wylling to betraye mortally her sonne. Now retourne to me, for I hope in the pleasure of God to mete thee in suche wise that upon thi bodi presently by me shall be executed the insuperable right arme of God wherin 
is all my trust. Well said Makayre come nere I defye thee. So shal I sayde Helyas in suche wise that it shall not nede to returne any more. And in this sayinge Helias broched his horse with his spurres and couched his speare in the reest with suche courage so that he reversed Makaires helme to the erth and uncovered his head. And whan Helias saw that, he alight of his horse and drew his swerd of armes wherwith he gave him suche a stroke that skantly he might remove. And on the other parte came his horse against Makaires horse, the which by might of flynging brake his reines behinde, and sith miraculously made him to fal from his horse, wherby yonge Helyas recovered to smite upon him vertuously smote of his arme with his swerd to the erthe. And whan the false Makaire saw himselfe sodainlye vaynquisshed he began humblye to yelde him to Helias sayinge. Ha yonge sonne, thou hast overcome me, and I yelde me wholy to thee but I adiure thee in the name of God that thou tel me what thou arte. I am said he Helyas sonne of king Oriant and of his good qucene Beatrice that am comen hether at the commaundement of God for to susteine her good and iust quarel against thee and all her enemies. Ha noble kinges sonne said he $I$ require thee take me to mercy and pardon me mine offence. A false recreaunt traytre said Helias thou shalt not escape so. For I will see the consumacion of thi life or I leave this feeld. Yet I pray thee said Makaire that it will please thee to save my life for this houre tyl I have tolde thee, the trouthe of the fals treason that hath be done to thi good mother and to her children without to hide any pointe before the kyng thy noble father, the mother, and the assystentes. And also I shall name and tel where the goldesmith is that hath chaines of silver that thevisshely and by violence were taken fro thi brothren and sister, wherby they were forthwith transmuted into white swannes as thou hast said. And whan Helias heard him speake so he differred to put him streight to death to the ende that by him selfe, should be confessed the treason that to his mother himselfe, with his brethren and sister had be doone. And whan he called them that were ordeined to make reporte of them two doone in the sayd feelde. 


\section{CHAPTER XXII.}

How Makaire confessed openly before the kyng and the queene all the people the treason doone to the sayde queene and his children. And how he was hanged as a fals traytour on the galowes.

ThaN they came reverently as to him that miraculously had abtayned victory and tryumphe over his enemy. And he bad them incontinente that they should make the kynge, the Queene and the knightes to approche thither and tolde them that Makayre had promised to recite the treason that he and Matabrune had doone to his good mother and to her children. The which thinge was incontinent reported to the king, whereof he and his good quene were right joyous, and came nygh to the two champyons with all theyr noble barons and chyvalry. And than the king questioned diligentli with the sayd Makayre saying. Now Makayre be ye confused, demaunde ye mercy of your vainquissher? Alas sir said he, yea. And what sai ye more: Certainly syr I yelde me humbly unto your sonne, and nowe I know well that a good dede is never unrewarded ne an evyll unpunisshed and that none may resist agaynst the will of God. But in demaundinge. you pardon I shall tell you trouthe of all the treason that afore hath Fen done to your noble wife and to your children, and than doo with me what it pleaseth you, for I have well deserved the death. 'That is wel sayd quoth the kinge, now say on. Sir sayd Makaire it is of trouthe that Matabrune your mother counseyled her with me of all that she hath done. And fyrst she gave the good quene your wife to understand that she had conceyved vii. dogges, but know ye that it was a lising, for she childed vii. faire children, that is to wite vi. sonnes and a doughter, the which brought at theyr byrth eche of them a chaine of sylver at theyr neckes. But Matabrune sente them to be loste or slayne by one of her servauntes named Markes, how be it he did not so, but lefte them in a foreste as your sonne hath sayd, wherof whan she was advertysed and that she had tidinges of them : her self 
put out both the eyene of the sayd Markes so that he is yet blind. Than she sent thither other of her servauntes for to put them to death, but they found but vi. children, to whome they did nothing but tooke away theyr chaines that was about their neckes wherby incontinent thei were mued in white swannes. And of the sayd chaines Matabrune made to make a cuppe by her goldsmith, for whom ye may sende and know the trouthe. And of this that I charged culpable the good quene to have poysoned you and your mother, I confesse here presently before you and your baronni that she never propenced it, but my selfe adiusted it to her at thynstygacion of your mother. And here I cry her mercy, and you also of the offence that I have commised. And whan the noble kinge Oriant heard Makayre speake in this wise he began to weepe tenderly and syth benignely he came and embraced his good spouse the noble queene Beatrice in saying. My love I have doone you great wronge, but pardon me if ye please, for I have doone it by ygnoraunce, which displeaseth me greatly. My lord said she I forgive it you with right good herte, for I know well that ye be sorowfull of my grevous mischefe. And therwith the king and the quene went and kyssed theyr sonne Helias in blessing and thankynge him of the victory and tryumphe that he had and yelded graces unto God. And in lykewise all the knightes squires, and ladyes with all the whole comynalty that there were feasted him and made joye and solempnite for so hie and sumptuous a myracle, wherby they saw the king and the quene remised and set in good love and unite of hert togither. Than bi the commaundement of the noble kinge Oriant the sayd fals reproved traytre Makayre was drawen to the galowes and there shamfully hanged and strangled as a recreant knight that he was. 


\section{CHAPTER XXIII.}

How kinge Oryant sent for the goldsmyth the which brought the other v. chaines that he had deteined and recited all the myracle doone with them.

WhaN yonge Helyas sonne of Kynge Oryant and of the good queene Beatryce had myraculously obteyned victory of his enmy Makayre as it is sayde, the kinge and the queene retorned ammerousli together into the hall of the palays with their said sonne. The which by his knightes was incontinent unarmed for to refresshe him. And after with so great joy and honour he was so nobli feasted that non hath possiblite to tell it. Every person reioyced them in theyr degree. Convives, daunces, and sports were incontinent reysed in the palays. Trompets, clerons and mani other instrumentes of musike were assembled there to reioyce his company. The bisshop and the clergy wyth al the habytauntes and burgeyses were honestly receyved. Open courte was holden to all comers, for to collaude in magnificence the sayd noble adventure. That on the morow were made devoute processions whereto all the people came in giving graces and thanks to God of all hys divine benifites, and at the retourninge was songe and celebred a masse solempnely by the sayd bisshop, in the presence of the kinge, the queene, theyr noble sonne Helyas, and al theyr chevalrye, and after masse echone were receyved better than they were before, in suche wise that bi longe space of time was made feest, game, and tourneimentes so that there was never seen such. And during this feest the goldsmith was sent for, to whome Macabrune had gyven the chaynes of silver to make a cuppe, for to know the trouth of him. The which came incontinent and brought $v$. of the sayde chaynes and a cuppe of sylver that he had over whan he made the other, as it pleased God for to recover the vi. children. And so freely he came to the kynge and sayde. Syr here ben vi. chaynes of sylver and a cuppe, the which myraculously I have had of the surplus of the cup that your mother, Matabrune gave me to 
make, and how was this doone sayd the king: wyte ye sir sayd the goldsmyth that your mother brought me vi. chaynes of sylver for to make a cuppe, suche as she devised. But whan I began to melte the first of the sayd chaynes it multiplied so by the grace of God that it weyed twise as muche as all the vi. chaynes together, wherfore I reserved one for payment of the facion. And sith I have kept reverentlye the other $\mathrm{v}$. chaynes in my coffre as precious and ful of vertue, the whych I present you here. And if in this doing $I$ have offended or mysse doone agaynst your riall maiestie: I offre me to make amendes. Certainli sayd the kyng ye speake wisyly and like a good man, and if ye have commised oni wrong in this I forgeve you hertely. Than the king, and the queene tooke those precious chaynes and kissed them reverentlie in weeping and bewayling naturally theyr poore children that by so great treason were mued and converted into swannes. And soone upon that came Markes that was blinde by Matabrune, and by the furour of her rage had both his eyne put out whan the king saw him he demaunded him who hath doone it. Alas syr sayd he, your mother hath done this evill. And wherfore sayde the kinge: Alas syr sayde he, whan your vii. children were borne she gave me them for to drowne or make them die to the ende to make the queene beleve that she had whelped vii. dogges. But whan I was in a forest I layde them all in a playne upon my mantell for to se them. And as I began to behold them they began all to laugh upon me so lovinglye that for to have lost my life I cold not have doone them any harme but yet it greved me sore to be constreyned to leve them in that place all dispourveyed. And whan she wist that they were yet alive, and that $I$ had not fulfilled her wicked wil she herselfe by her madnesse put oute bothe mine eyene. And whan Helyas heard him speke thus he had great pitte on him, wherfore humbly he turned hym to God sayinge. Soverayne God of paradise that by thy divine goodnesse and insaciable mercye enlumined and gave syght to the poore blinde man the whiche satte in the hie way begginge for his life. I thee supplie and requyer humbly by the benignite that it wil please thee to 
enlumyne and geve sight to this poore blinde creature, the which hath ben cause of the salvacion of my life, by the which he hath loste hys eeyen. And whan he had made his prayers he made the signe of the crosse upon the eyen of the sayd Markes, the which incontinent after bi the grace of Almighti God saw as clerely as ever he dyd, wherfore the kinge and the queene with all the whole assistentes were greatli admervayled. And incontinent they gave laudes and thankynges unto our Lord, with him the which was newly enlumined of his sight. In reknowledgyng the graces and vertus of our Saviour, and redemptour Jesu Christ the which he had myraculousli shewed at the praier and supply. cacion of his good knight Helyas.

\section{CHAPTER XXIV.}

How the false Matabrune made the kepers of the prison so dronkin that they slept whiles she fled away. And how the Swannes, retourned to theyr fourme humayne.

Noow ye ought to wit or we procede any ferther that the same day that the justes were made between Helias and Makaire that Matabrune beinge in prison made in suche wyse to drinke them that king Oriant had commysed to keep her that she made them to slepe all dronken. And sith founde maner to escape, and with certayne of her folke she withdrew her in a castel of hers named Maubruiant to thend to kepe and preserve her from harme which she thought should come to her, for the perverce treason and untrouth that she had commised agaynst the kinge and his good spouse the noble queene Beatrice. Wherfore the kyng made grevously to punysshe them that had her in keping.

But for to returne to the subgect of the cronykill of the noble Helias knight of the swanne. It is to be noted that the said Helias knight of the swanne demaunded of kyng Oriant his father that it wolde please him to give him the chaines of silver of his brethern and sister that the goldesmith had brought. The which he delivered him with good herte for to dispose them at his pleasure. Than he made an othe and sware that he wolde 
never rest tyll he had so longe sought by pondes and stagnes that he had founde his v. brethren and his sister, which were transmued in to swannes. But our lorde that consoleth his freendes in exaltinge their good will shewed greatly his vertue. For in the river that ranne about the kinges palays appered visibly the swannes before all the people. And whan Helias had seen them: he called diligentli the king and the queene his father and mother saiing. I pray you my lord and my lady that ye will lightly come and se your other notable children mi v. brethren and my sister. The which ben now presently arived upon the river that is about this palays. And incontinent the kynge and the queene descended wyth many lordes, knightes, and gentilmen, and came with great diligence upon the water syde, for to see the above sayde Swannes. The king and the queene behelde them piteousli in weeping for sorow that they had to se theyr poore children so transmued into swannes. And whan they saw the good Helias come nere them they began to make a mervaylous feast and reioyced them in the water. So he approched upon the brinke, and whan they sawe him nere them : they came lightli fawning and flikering about him making him chere, and he playned lovingli theyr fethers. After he shewed them the chaynes of silver, where by they set them in good ordre before him. And to five of them he remised the chaynes about theyr neckes, and sodeynlye they began to retourne in theyr propre humayne forme as they were before, and before al miraculsly they shewed them iiii. fayr sonnes and a doughter. To whome diligentlie the king and the queene ranne, and naturalli kissed them as their children, wherof everye man had mervaile, and ioyed of the divine miracle of God so notably shewed. And whan the other swanne (whose chaine was molten for to make the cuppes as afore is sayd) saw his brethren and his sister retourned into theyr humaine fourmes he lept agayn all sorowfully into the river, and for dole that he had he plucked almost al his fethers to the bare flesshe. And whan the good Helias saw him so dolorously demeane himselfe; he tooke him to weepe for sorow, and recomforted him sayinge. My dere brother my 
freende, have somwhat pacience, and discomforte you not. For I shall make so meeke and humble praiers unto God almighti for you, that yet I shall se you ones a noble knight. And than the swanne began to enclyne and bowe downe his head as in thanking him and syth plunged hymselfe all togyther in the water. And for him in likewise the kinge and the queene made moche lamentacion. But Helyas conforted them sweetly, and sayde to them that he wolde in suche wyse pray unto our lorde for him that in shorte time he should retourne into his owne naturall fourne. And thus they ceased somwhat of theyr sorowe by the consolacion and goodly wordes of the said Helias for theyr other sonne, wherfore than they toke benignely the other v. children and ledde them to the churche where they made them to be baptised. And the mayden was named Rose, of whome after warde descended a noble lignage and worthy of praising. And the other sonnes were named and called at the fonte after the good discrecion of the kinge and the queene. The whiche sonnes also in lykewise were ryght noble and vertuous knyghtes and beloved of God. Than after their baptising thei were solempnely conduited and ledde into the palays, and there feasted in all joye as it apperteyned well. And thither cam many for to see them in laudinge and magnifienge the name of our almighty saviour, that so miraculously shewed his great vertue.

\section{CHAPTER XXV.}

How kinge Oriant gave his realme to his sonne Helias, whereof he made to crowne him kynge honourably and than gave him leve to go take his mother Matabrun in the castell of Maubruyant, and there he brente her in a great fyre.

AFTER all these thinges afore sayd king Oryant knowledged the grace of God that was sowen in his sonne the noble Helyas: he made to call afore him dyvers great barons and knyghtes with his peers which were alwai with him. And they comen he made to call in present the noble Helias and said to him. 
My right dere and welbeloved sonne. I have knowledged and also my lords here present have sene that ye be fulfilled of Gods grace, as notabli apereth by the miracles and digne faites that by your holi praier have here be shewed, wherfore I depose me presently of al my realme constituing you king and lorde of all my landes and countreys and wil that fro hens forwarde ye be honoured and served and obeyed without any gaynsayinge. And in the witnesse of this thinge, and for to shewe that it so pleaseth me, heare is the crowne of the realme, the which in the presence of the queene your mother and all the noble assistentes I set upon your head and give it to you as king. My lorde sayd Helias I thanke you humbly, how well that I am not worthy ne suffisaunt to rule and governe one so noble and puissaunt realme as yours is. But sith that it pleaseth you so to doo, and that it is the wyll of God, in nothing wyl I gainesay you. For sothe sayd king Oriant I give it you with all my hert. Moreover my sonne noble kinge I doo you to wit that Matabrune my mother the which I had made to enpryson for the treason and iniury that she dyd to your mother and her children wherof ye be one, hath found maner to escape, and is flede for warrandise into a castell of hers called Maubruant. So I tel you that I put her case towarde you for to do right and justice, suche as by you and your counceyll shall be founde and ordeyned, but I wyl not be present, wel my lorde sayd Helyas syth it pleaseth you so, I promise you my faith that I shall never cease tyl I have wonne and taken the sayd castel named Maubruant and done right justice upon her that in suche maner with wronge hath wylled to betray my mother and us her chyldren. And after that the noble Helias was crowned and constituted king and lorde of the realme of Lilefort with all honour and tryumph as afore is saide in the presence of his mother Queene Beatrice and of al the noble prynces and knyghtes of the realme, the whiche were ryght ioyous. He made to prepaire a lytle hoste of men of warre to go with him to Maubrayant, that is to wite aboute foure thousand Crosbowe men, two M. men of armes, al chosen folke beside fotemen 
that were about vi. C. And than accompanyed with an C. noble knightes he departed fro Lylefort, with his people he went and besyeged the castell of Maubruyant, and to make short he gave so stronge and mervaylous assaute to al them that were within that they might nothing resist wherfore he and his men wel armed entred their in valyauntlye without any gaynsaying. And in entringe in to the sayd castell escried kinge Helias with an hie voyce to his people saying. Upon your lives kepe ye that the false Matabrune yssue not out of this place. The which untruelye wolde have betrayed and caused to dye my good mother and all her children. And whan Matabrune had. heard the noyse, and that she sawe the Castel taken, she fortified her within a tour with certayne of her gentylmen and damoyselles wening to holde her there in saufte. But when kynge Helyas knew it he came to the dore of the sayde toure with certayne of his folke and brake it open, and founde her therin. And as soone as the kinge apperceyved her he came to her with great courage and kest her to the earth saying. Ha false olde witche thou hast betrayed my mother and made us to suffre so muche evyll. Yf it were not for the honour of God, and the bloud wherof I am comen my selfe should slea thee. And than she wist not what to saye but that they should lede her to king Oriant her sonne. But Helias told her that she should never se him, and made to lede her downe to the base courte, wher as a great place was made with a stake and wood and coles for to brenne her as she had deserved, wherto echone besied. And whan she was so bounde at the stake, and that ther was no more remedi of her life she was somwhat moved with contricion, and cryed unto kynge Helyas in saying, $\mathrm{Ha}$ my sonne I cry you mercy. I knowledge and it is true that I have wel deserved the deathe for I have falsly betrayed your mother, and made her to understande that of her body were yssued vii. whelpes, and she of trouthe childed vii. fayre children, the which at their birth brought eche of them a chaine of silver at theyr necke but by mine untrouthe I sent them by on of my servauntes for to droune or slea them, but God preserved them from yll, 
and yet by my wickednesse I thought to make to die the good queene Beatryce your mother, in imposynge to her crime that she wold have betraied her spouse king Oriant and me, wherin she never thought, so is it good ryght that I die, for towarde God I have deserved it. To whom I beseche that he pardon me, and that the paine that I shal suffre in dienge may be tourned if it please him to the satisfacion of all my sinnes. And also I require you to pardon me for I die willingly and I forgive you $\mathrm{m}$; death. Truly sayd kinge Helias I pardon you as to my parte, but yet shall ye die by justice, and I pray God forgyve you. Than was wood and dry thornes layde about her and fyre set therin and so she was brent for her demirites before al the people. And whan the exccucion was doone, the kinge with his people retourned diligently to Lilefort wher as he was honourabli received, and than he went and tolde his mother what he had doone sayinge. Mother reioyce you, for ye be revenged now of the perverce Matabrune, for I have made her to be brente for her demerites. And the queene answered, My right dere sonne I thanke you, Jesus forgete her soule. And thus they abole amiable in good peace wherof all the people reioyced.

\section{CHAPTER XXVI.}

How Helyas tooke leave of the kyng his father and of his mother for to folow the adventure of his brother the swanne that appered on the river before a ship.

AfTer certayne tyme that the victoryous kynge Helyas had posseded the Realme of Lyleforte in good peace and tranquilite of justice it happened on a day as he was in his palais loking towarde the river that he apperceived the swanne one of his brethren that was not yet tourned into his fourme humayne, for that his chaine was molten for to make Matabrune a cup as it is sayd. And the sayd swanne was in the water before a ship the which he had led to the wharfe as abiding king Helias. 
And whan Helias saw him: he saide in himselfe. Here is a signification that God sendeth to me for to shew to me that I ought to go by the guyding of this swanne into some countrey for to have honour and consolacion, under the bounte and magneficence of his holy and excellent name. And in this good purpose inspired of the Holi Goste he assembled his brethren and his syster, and came to kynge Oryant his father and queene Beatrice his mother, and in the presence of all his parentes he sayd. My right deare and honoured father, and you also my sweet mother with all my brethren and sister and freendes here present. It is now needful and convenient that I take leve at you. For here bi within the river is $\mathrm{mi}$ brother the swanne that commeth to fetche me in a shippe that he ledeth and gideth to the wharfe in abiding me, wherfore know ye my lorde my father that I render to you the crowne riall the which it pleased you to gyve me. And I remitte whole into your handes the Realme of Lilefort. And thus humbly I take leve of you in leving this noble countrey for to go at the commaundement of our Lord bi the condutinge of my brother. For I have stedfast hope in me that our Lord hath doone all for the best, and that he wyl leve him yet in the fourme of a swanne for to guyde and leade me surely to some good porte where as I maye to his digne wyll doo some vertuous fruyte. And thus wil I go with him, and to Jesu Christ I commaunde you. And in this saying: he went and kissed the kyng and the queene his father and mother, his brethren and his syster. The which wepte so tenderly that it was pitie for to se them.

\section{CHAPTER XXVII.}

How the swanne brother of kyng Helyas conduted the sayd shyppe wherin Helyas was tyll they came to the Citye of Nymaie.

AND whan Helyas had thus mekelye taken his leave of all his parentes and freendes he made to bere his armures and armes of honoure into the shyppe, with hys target and his bright 
sheelde, of whiche as it is writen the felde was of sylver and there on a double crosse of golde. Than after the noble kinge Oriant came and presented to his sonne an horne, and said. My right dere and welbeloved sonne, here is an horne that I gyve you, the which ye shal keep if it please you, for my sake. And be ge sure that it hath suche vertue that what man soever bloweth it loude may not have anoy ne domage at the pleasure of God. And I beseche God humbly that he give you joyful going and honour at your retourning, and saufte in your viage. And thus as Helias was yet in the palays with the kyng the swane kest three or four mervaylous cryes as by maner to call his brother, wherof the king and the queene with all them that were there were greatly abasshed. So descended anon the sayd Helyas with his parentes and frendes, the which came to convey him unto the brinke of the water. And whan the swanne saw hem he flickered and regoysed as in making maner to mete the saide Helyas. And there every man blessed the sayd swanne saying. It is domage of this poore child that hath lost his fourme humain the which God sende him. But yet was not the time comen ordeined of God that he should turne in his humanitie, for a more greater welth that, should ensue after. And there was the kinge and the quene with their children weping profoundeli for pitie that they had to beholde their noble bloude so transfigured into a swane. Than entred Helias into a shyp taking general leave of all his freendes. The which retourned weping and sorowing for the good Helias the noble knight of the swanne, that went at his adventures in strange countries at the good commaundement of God, and the guiding of the swanne. So the swanne put him afore the shippe, the which he made to scoure upon the water in suche wise that they were anon ferre fro Lyleforte. And thus conduited the swanne from ryver to ryver the noble Helyas tyl unto the place ordeyned of God for to gyve him a wyfe, of whome should yssue a fayre doughter that should bere three sonnes, by whome should be gretli exalted the fayth of our lorde Jesu Christ. Of the which the first was Godfrey of Boulyon, the 
which sithen conquered and posseded the realme of the holy lande of Jerusalem. The seconde was his brother Baudwyne the which succeded him in the sayde realme. And the thyrde was theyr brother Eustace the which was a right noble knight. But that not withstanding yet was he not a kinge as the two first were for that he sucked another nourice than his mother bicause the child cried. And the mother was marvalous angry, as hereafter shalbe shewed in folowinge by ordre the true cronycle.

\section{CHAPTER XXVIII.}

How the erle of Frankbourke made to come and appere by justice Clarysse duchesse of Boulyon at Nimaye wyllynge to usurpe her of her duchy, in gyvinge false understandynge to Otton emperour of Almayne, the whiche helde the courte of his parlyament at the sayde cytie of Nymaie.

To come alwaye to the effecte of the noble cronycle the which I have begon to treate to the verite of that which is wryten in many other notable hystoryes. I shall leve a lytle to speake of the noble Helyas knyght of the swanne that is fletinge on the water comynge to the cytye of Nimaye before the emperour and by divine provydence to susteyne the right of the good duchesse of Boulyon, as after it is sayde.

It is so that the ryght noble emperour of almayne named Otton first of that name, that had under him the land of Dardaine, of Lyege, and of Nammur, helde his syege of justice and the court of his parliament in the citie of Nimay. And thither al they that were oppressed, or domaged came to axe right of themperour, that was a verie iust iudge and good justicier. So than the erle of Frankebourke made to apere the duchesse of Boulyon before him, uniustlye to usurpe the duchy bi false giving to understande. And at a day set appered the erle demaundaunt in mater of novelte on the on parte, and the duchesse of Boulyon defendresse on the other parte. The whiche had brought her doughter with her that was a 
faire damoisel. And whan the counsel was comen and assembled afore the emperour, the erle made to plede his cause. In the which plea he made iniuriously to pose and put in faite that the said duchesse had made to enpoysen her husband, the which was his brother. And that her said husband about the space of iii. yeres was in straunge countreys without retourning home. During the whiche time and in his abscence she had conceyved and borne a doughter, the which for the sayde cause he wolde say that she was not of legitime mariage. And moreover that the londe and duchi of Boulias was comen of his father. By the which he wolde say and promise by his pleding that the duchesse might not of right possede ne holde the said duchy as dowayresse of her husbande, ne her doughter in lykewise as heire of the said duke, for she was not legitime as he said before, and that he offred to prove it, tendaunt to the ende to take and holde in his hande the said duchy of Boulion as a successour and seul heritier of his brother (in his life husband to the said duchesse) and duke of Boulion. Than after the pledynge of the said demaundaunt, the duchesse defended her cause to the best she might, denienge al that he had proposed agaynst her and her doughter, whose honour he had hurte in protesting of theniuries. Certes ladi said themperour, here is an iniurious mater and that wil cause your death if ye pourvei not, seing that he offreth him to prove it, if ye be not let by your opposites. Sir sayd the erle to thende that ye seme it not to be true here is my guage for to susteyne it to the utteraunce, and be fight it to the death that it is as I have said. Wherfore she is culpable to die and not to possede the said duchy. Now ladi said themperour ye have heard the offer that he maketh you, which semeth me way of right, wherbi I cannot refuse him his demaund. And therfore máke diligence to seeke a knight for to fighte and susteyne your quarell, by the which ye may denye that which hath be now proposed by your adverse party. And yf ye thinke that ye may finde ony that wyl take thys charge for you: I shall gladly give you space and delaye to pourvey you. Than 
the good lady as al abasshed loked aboute her if there were ony present that in her need wolde helpe her. But none wolde medle seynge the case to her imposed. Wherfore she committed her to God prayinge him humbly to succour her, and reprove thiniury that wickedly to her was imposed by the sayd erle.

\section{CHAPTER XXIX.}

How Helias the noble knight of the swanne aryved at Nymaie for to defende the duchesse of Boulon, who themperour receyved gladly.

FOR to retourne to the myraculous hystory of the ryght noble and valiant Helyas knyght of the swanne, the which hath be somwhat interrupt for to recite this that afore is sayde servinge to the matter followinge. It is to be noted that so as the erle of Franckebourcke and the duchesse of Boulyon were so pledynge before the emperour of Almayne in his parliament at the towne and cytie of Nymaie for the matter aforesayd, approched thyther the good Helyas guided by the swanne the which began to blowe hyghly his horne that his father kyng Oriant had gyven him, in suche maner that they that were in the parlyment with the Emperour were all admervailed to here a sowne so lowde. Than in continent they looked out at the windowes and sawe the swanne come ledinge a shyppe, within the which was the noble Helias knight of the swanne, well garnysshed of spere, swerde and armures as belongeth to a knight. And whan the emperoure sawe him arive he had great mervayle. : For he apperceived the swanne that retourned with the shyp incontinent that the noble Helias was out with his armoures, wherfore he sent for him. And in this wise behelde him the noble Clarysse duchesse of Boulion. The which to this purpose tolde a dreame to her doughter, wherof she hadde visyon the night before saiynge. Truly, doughter I wene that our lorde this daye wyll helpe and succoure me by his divine grace. For this nighte me thought in my dreame that I pleaded agaynste 
the erle of Frankenbourke that by his treason accused me of crime of death wherbi I was condempned to be brente in a fyre. But there came a swanne fleynge that broughte me water that put out the sayde fyre. And of this water yssued a byg fishe the which fructified in suche wyse that echone lyved therwith til into Jerusalem and all the countrey. Wherby I beleve at the pleasure of God that the swanne whiche hath guyded this noble knight hither shalbe cause to delyver me of the crime wherof I am falsely accused. And thus as the duchesse of Boulyon devised with her doughter thyther came the good knight Helias, which at the commaundement of the emperour aryved in the hall where as he helde his parliament. And there reverently he salued the saide emperour. And the emperour againwarde received him muche honestly, in demaunding him of his tidinges and how he was theither comen. Syr said Helias I am a poore knyght adventurous for to serve you trulye whan ye shall have any need of my simple sarvice. Than sayd the emperour. My freend I thanke you, and ye be welcome. And sith you seke adventures in feates of armes and chyvalry ye maye finde them here without goinge ferther. And for to declare you al the case. Here is this noble ladi duchesse of Boulyon with her doughter, the which the erle. of Frankebourke her present hath accused her of a cryme ynough to make her die, and also to disheryte her doughter of the sayde Duchy of Boulion, yf she finde not some champion or noble knight that wolde defende her ryght a gaynst the sayde Erle afore named, the which hath casten his guage for to susteyne publikely against any defendaunte that which he hath proposed. And now ye have hearde the case, the which should be a fayre adventure, yf ye would susteyne it. And I shall save her in restablysshynge unto her her heritage, and also ye shall have her doughter in mariage, which ye se so gracious and a right fayre mayden. And whan the good Helyas had hearde themperour he behelde the duchesse the which semed him moche beninge and of noble mayntene. Also he considered the beaute and gracious countenaunce of her doughter, the which to him was mervaylously 
pleasaunt and agreable to beholde. Than he demaunded of themperour that it wolde please him to give him leave to speake a litle secretly with the duchesse of Boulion, which he graunted gladly, wherfore he thanked him. And than Helias tooke her by the hande and drew her somwhat a parte, and sayd to her. Fayre ladye it behoveth yf it please you that ye tell to me and swere the trouth of this I shal demaunde of you. And this same dai bi the pleasure of God I shall be your faithfull servaunt. Alas noble knyght said she. I promyse you by the livinge God and on the faith of gentilnesse that I shall tel you al the trouthe of that ye shal axe me. Now madame said he by the othe that he have here made, be ye not in any thinge culpable of this cryme whereof ye be presentlye accused? Bi mi trouth my freend said she, naye. And I beseche God that he never doo me anye grace to my body and soule if $I$ ever thought of that wherof I am falsly and without cause accused. And truly madame sayde he than have ye founde a champion of me for to susteyne and defende your ryght in suche wyse that by the pleasure of God that in veray verite this daye your enemy shalbe overcome.

\section{CHAPTER XXX.}

How Helyas the vertuous knight of the swanne dyd fight agaynst the erle of Francbourcke, the which he conquered and slew.

WHAN the noble knight of the swanne had interrougued and questioned the duchesse of Boulyon he came streyght to the emperoure and sayde. Syr make him to come hyther that iniustly accuseth thys noble ladye, for to disherite or make her dye, for I am redye to defende her. And with these wordes yssued the erle saying My freende what demaunde ye? Ye shew you muche over wenynge to medle you of a thinge that toucheth you not. Vassall sayd Helias here is my glove that I deliver you, in suchewise that the honour of God and for this ladyes sake ye shal se what an adventurous knight can do. And the erle receyved his guage. So was the bataile accorded 
incontinent by the emperour, the which receyved theyr othes, demaunded whan they wolde fight. Than Helias required themperour that it wolde please him to ordeyne it presently, the which he graunte. And the erle for shame durst not refuse him. Than forthwith the feeld was prepayred, the listes dressed, and the champions surely armed as behoved in such a case. Incontinent the noble Helias tooke his speare, his swearde, and his sheelde of sylver with a double crosse of golde, the which he set upon his left arme. And on the other parte the erle was mounted on his hors. And syth they came into the feelde arayed for them. And there was present the emperour with his counseyl and the duchesse of Boulion with her doughter, accompayned of many lordes and ladyes. And whan the duchesse and her doughter saw cominge Helias their noble champion, the praied God that he wolde kepe him fro harme, and give him victory over his enemy after the ryght of that he iustly defended. So incontinent was ordeyned the batayle of the two knightes, the which with cours of horse came rinning one agaynst the other the speres in the reste, and encountred so rudely that both theyr speres shivered all in peeces. And than they drewe theyr swerdes wherwith they smote together so longe that the erle might scarce doo any more. But the noble Helias had alwaye good courage as he that had set all his truste in God, and that with iust title susteined charitabli the right of the noble duchesse of Boulion. Than the erle demaunded of the noble Helyas that it wolde please him to gyve him trewes for to speak with him, the which he graunted. Certes free knight sayd the erle yf it wolde please you to apease this batayle and that I may winne that that I demaunde I shall give you my doughter in mariage, and ye shal have my londe of Dardayne that is a noble and fruitfull countrey. And than answered Helias. Traytre wenest thou to make me of thy consorce, wyt thou that I wolde soner let me to be hewen in all my membres than I wolde commit treason as thou hast doone, and therfore speake no more of it. For of me getest thou no merci for this dede. And I promise thee that this dai bi the pleasure of God which hath sent me 
hither I shall deliver the noble duchesse of thy treason, and I shall espouse her doughter maugre thy wicked wyll. Now defende the against me. Than Helias approched the said erle and smote him so courageousli with his swerde that he frushed al his helme wherwith the erle fell backewarde upon his horse. Than the erle thought to revete him selfe and came to Helias, the which he smote so hard upon his right arme that he made the swerde flee out of his hande. And whan Helias sawe that he was dystytute of his swerde, he descended lightli from his horse, and came and seased the erle by the bodye and valiauntly by force kest him to the erthe. And wolde he or not he arached his shield fro his necke. And sith by strength of his handes he deseased him of his swearde maugre his tethe. And whan the erle felte him so dispourveyed he began to yelde him to Helyas saying. A knight save my life and I shal give thee my landes. Ha false traytour sayd Helyas thou shalt not escape so. For I wil have whol victori of the for to venge the noble duchesse and her doughter that thou hast sclaundred. And therwith he lift up the swerde that he had taken fro the erle, and gave him suche a stroke that his helme went of and than he cut of his head and so he dyed mischevousli. And than the duchesse and her doughter gave laudes and graces to God of the victorye of theyr enemy which they saw vainquysshed by the grace of God, which had sent the noble knyght to be their helper.

\section{CHAPTER XXXI.}

How the good Helias wedded the doughter of the Duchesse of Boulyon.

Than after that the noble Helias had victoriouslye conquered the erle of Frankebourke his eneni : he came benigneli and salued the emperour Otton which received him benignely as a prue and noble knight. After he salued Clarysse the noble duchesse of Boulyon, the which thanked hym reverently of that he had doone for her, for he had saved her life, and the heritage 
of her noble douchy. Than Helias tooke the duchesses doughter bi the hand and enbraced and kissed her benignely in saying. Mi love ye ought wel to be my wife, for I have frelie bought you, and saved your honour in champ of batayle. And the mayden answered humbly. Certaynly noble knyght my mother and I ben beholden to God and you of the right happy iurney that this daye we have by you receyved, wherfore at the good pleasure of mi mother I yelde me totalli to you, as it hath ben promised. And forthwith the emperour came to the duchesse saying. Ladi I yelde to you your londe and duchy of Boulyon playnle and peasybly, and restablysshe you in honour without any culpe of cryme as the trouthe is seen. Certes sayde the duchesse I thanke you highly. But as to the regarde of my londe and duchi of Boulion I give it freely to this valiaunt knight that notabli hath conquered it. And also I gyve him my doughter in mariage the which from hensforth with him shalbe sayd and called lady. For I wyll shortly go and yelde me a nune or religiouse in some nonery, as I have avowed to God the which this day hath succoured me by so noble a knight. And whan the Emperour called to him Helias the noble knight of the swane, unto whome he declared publikely and openly before all that he was duke of Boulyon, and that him behoved to wedde the doughter of the noble dame Clarisse lyke as he had promised, wherto benignely consented the said Helias. And thus by consentement of both parties was in continent made apparaile for the morow to make the feast and solempnite of the spousayles.

And al that night til on the morow echone were delibered to sporte and joy. Knights and gentilmen reioyced them of this marvaylous adventure. Ladies and demoyselles daunced with them in al games and merye cheres, and in suche wise that it should be to longe for to tel al the games, daunces, and turneymentes that were doone at the sayd feast. And on the morow was reverently celebred the mariage in the churche where as came many great Lordes, ladies, and other estates. And after was the feaste made in themperours halle, where as every man to his poore reioyced with al his hert. Trumpetes, clerons, 
tabourins and other minstralsi was there in that place assembled to make mirth melodiously. And to make shorte there was the greatest triumphe that ever was seen. Than at nyght the good Helias duke of Boulion lai with his spouse the which night she conceyved of him a daughter that at her baptisme was named Ydian, of whome yssued the prue and worthy prince Godfrey of Boulion, and sith his two brethren Baudwin and Eustace. The which were two noble and valiaunt knightes as theyr dedes shewed afterward. And thus appereth that the noble Helyas knyght of the Swanne conquered and wanne victoriousli the duchi of Boulion with the swearde. And after that the feaste and solempnite of the weddinge had lasted about xv. dayes, the sayd Helias duke of Boulion and his noble wife dysposed them to go into their countrei with their estate. So the said new duke tooke leave of themperour in sweringe and promisinge to him homage of the sayd duchi as it was of right, and in thankinge him honourablye he departed from him and fro al his noble barons and knyghtes for to go to Boulyon. But in goinge he founde many of the parentes and frendes of the foresayd erle of Frankebourke, the which assayled him on the way weening to avenge his death. But he shewed him so valiaunt and knightli that they were not the most strongest, for he and his folke had passage at their owne pleasure whither his enemies wolde or not. And triumphantli he came unto the said place of Boulion wher as he was honourabli received with great ioye and exultation. After he helde on a dai open court to al comers. In which were received honourably al the noble barons and lordes of the countrey, and this time hanging waxed great with childe the noble duchesse his wife in suche maner that at the ende of ix. moneths she childed of a faire doughter. The which was honestlye baptysed in greate company of divers noble lordes and damoyselles. And she was named Ydain at the fonte, the which sithe was mother of the prue and valiaunt prince Godfrey of Boulyon, and of his brethren Baudwin and Eustace. And during the childebed of the noble duchesse were made many notable convives and mery pastimes. Then afterwarde grew and sprainge 
the saide mayden by the wyll of God that she was in pleasaunt age of flouringe youthe. And upon a day as the duchesse wente in sportynge with her husbande the good Helyas, she demanded of him pryvelie of what countrey he was, and what freendes he had. But he sayd nothing, and defended her never to speake therof, or he wolde go his way and never dwel with her any more. So she helde her stil for that time, and they abode the space of vii. yere living in love and cordialite one with the other.

And in this time durynge the auncient duchesse mother of the good Helias wife was yelded in religion, lyke as she had promised and vowed to God.

\section{CHAPTER XXXII.}

How Helias the noble duke of Boulion left his lande for that his wife disobeyed his commaundement, and after the swanne his brother brought him to Nymaye to the emperour Otton.

ON a daye as the Duchesse of Boulion laye in bed with her husband Helyas there toke her a mervaylous wyll to aske agayne of hym of what folke he was comen. The which notably he had defended her, or that he wolde go his way. But as a woman that is lyght herte and wyll sooner doo the contrary to that her husbande commaundeth her than otherwise. It hapened on a night as they were to gether she was not at her ease because she durst not say and fulfil her wil. But at the last she was hardi ynough, so that she sayd. Certainly my lorde I wolde fayne knowe of what place ye be come, and who ben your parentes and freendes, as other whyle I have asked? wherfore I wolde fayne that it wolde please you to tell me. And whan the noble Helias heard her sai so he was greatli angri at his hert. And in anger sayd. Certes ye shall know nothing. And I swere and promise you by my faith that to morow erlye I shall departe fro this countrey. And at Boulion shal ye se me never more. And I shall go streyght to Nimaie and take leave at themperour and of you in the presence of all his barons.

And whan the duchesse understode him: she began to wepe 
tenderli, and sith arose from her bed and came and complained to her folke saying. Alas, alas my lordes and ladies now have I loste the company of my good and faythfull frende, by mine overmuche speaking, and could not hyde my courage. And anon after she came to the bedde of her doughter Ydain that her father loved derely, and tolde her therof. And than she adressed her to her fathers bedd weeping pitiously saying. Alas mi lorde my father have pitie on my good mother and me. Alas wyll ye leve us: Virgin Mary helpe, shall I abide orpheline in mi yonge dais. Alas father leve us not for Gods sake regarde your bloud, and take pitie theron. And than the noble duke that was mervaylously sorye recomforted her sayinge. Fayre doughter make not suche sorow, for I shal wel pourvey your mother and you yf God wyl, or that I departe. Than .n the morning Helias arose and tenderly weping he went and harde masse devoutly as he was accustomed. And after masse he sayd to his knights and familiers. Lords I require and pray you charitably that ye wil guide my wife your lady and my doughter unto the citie of Nimaie wheras themperour is, to the ende that I may take leave of hym honourably as apperteineth, and that I may commaunde also to him mine affaire in these parties, for I shal never retorne. The noble knightes accorded gladly his demaund. And yet he said agayne. My frendes I you recommaunde that ye be alway redy to kepe and defende this noble countrey of Boulyon and the honour of my wife your duchesse and of my doughter. And so they promised him to do at his good wyl. Now my lordes sayd he I thanke you al, prayinge you that ye holde me faith as ye have promised. More over my lordes and frendes the houre is comen that I must departe fro this place, for anon ye shal se come nere the swanne, the which by the wyl of God shal lede his shyppe for to guide me to Nimaie. And as they spake thus together the swanne arived myraculously as he had sayd, and kest a mervaylous crye in callyng his brother Helias. And than he tooke leave mekeli of al his knightes, gentilmen and damoyselles that wept tenderly the departing of their good lord with the noble 
duchesse and her doughter that it was piti to se them. And semblably al the citezins. wept and wailed the abscence and departing of theyr noble duke, that so swetlie had susteined them in good peace and liberte without to vex or trouble them with oni subsides or tailies, but for to take them from grefe had anulled al false usages and set good customes and fredomes wherfore they wende never to recover such a nother. Than entred Helyas into the shippe, where as he and the swanne feasted them ioyusle as brethren, for the houre approched that he should returne to his fourme humayne. And so they left Bulion and drewe toward Nimaie to go to themperour as the noble Helias had proposed to do for to put his wife and his doughter in his saufgarde with theyr noble countree of Boulion.

\section{CHAPTER XXXIII.}

How the duchesse of Boulion complayned to the emperour for the departing of Helyas.

INCONTINENT after that the noble Helyas was departed fro Boulyon, the duchesse his wyfe and her doughter Ydain companyed of many noble knightes and damoyselles prepared them for to go to Nymaie before the emperour. And whan they were comen into his palais she fell downe before him wepynge and complaynynge her of her good husbande that wolde leve her, saying: Alas noble emperour I pray you yf it please you have pitie on me and on my poore doughter, for if it be not by your meane and benignite $I$ shal lese this day the noble knight that here in your presence toke me to wife and spouse. How lady sayd the emperour is your husband dead? Alas syr said she, nay, but he will retourne into the countrey fro thens he came whan he aryved here in this place for to succour me, as echone saw clerely. For the swanne that ye saw is retourned with his shyppe to fetche him, and he is gone with him. It must be than said the emperoure that ye have doone him some offence, wherof he is angre with you. Than the sayd duchesse tolde and recyted to 
hym howe and what maner she had trespassed his commaundement, wherfore he repreved hyr, sayinge that she had not well doone.

And thus as they spake together: came Helias that by the guiding of his brother the swanne arived nigh to the palays of themperour. Wherfore he began to sowne hys vertuous horne, as he had doone whan he arived first. And whan the emperour had heard him he mervailed and sayd to the duchesse that he had heard her husband. Alas said she I know well that he wolde come hither. But it is to take leave at you, without ever to retorne but if ye moeve him by your high sapience.

\section{CHAPTER XXXIV.}

How Helias arived at Nimaie wher as he was goodly receyved of the emperour.

ATr these wordes arived Helias before themperour, the which he salued humbly. And the emperour receyved him benignely in saienge noble duke ye be right welcom. Sir said he pardon me, for I have forsaken my duchi, and never wyll I possede any thinge of it, for it behoveth me singulerly to retourne to the countre fro whens I fyrst departed by the wyll of God. But this not wythstandyng and all stryfe premysed right affectuously I recommaund you my wife. And semblably my noble doughter the which presentli I give you as your doughter. And I pray you that it please you of your benignite to be her good father and frende and to mary her whan time shall come at your good discrecion. $\mathrm{Al}$ redy of your grace and bounte ye have be meane of the cause of our mariage, so againe I require you to kepe theyr honour, and maintene them under your safgarde in the fraunchise of your countrei, and noble duchy of Bolion for I wyl never retourne. A noble duke mi dere freend, yf ye have made any othe therof as ye say, it is not of necessite to holde vowe against charite. For ye shal soner have pardon to breake your othe that is not lawful than to accomplisshe it. If ought be 
misdoone, and so shortly to leave your wife is against God and charite, ye have also your faire doughter Ydain that ye se wepe so piteousli before you of whome ye should have pitie. Certis sir said Helias me behoveth to go lightli into an other region by the commaundement of God that calleth me for an other welth, wherfore I pray you pardon me for I may abide no longer, yonder is the swanne that abideth. My freende said the emperour, sith it is the wyll of God I wyll not gaynsay it. And than he came nere to his wyfe and his daughter the which he kissed tenderly weeping, so that he left them as al in a swoune before themperour, of whome he toke humbli leave in recommaunding them againe to his good grace. And he promised so to do, and to mary his doughter nobly without fayle. And so departed the noble Helias, and went towarde the river where as his brother abode him in likenesse of a swanne. For he kepe the shyppe al way tyl that his brother were returned. And whan he was comen the swanne reioyced for to see him. So she departed with greate dilygence fleting alway fro river to river tyl they came into the countrei of Lilefort that was the londe of theyr nativite.

\section{CHAPTER XXXV.}

How Helias the noble knight of the swanne retourned into the Citie of Lylefort within the shyppe of his brother the swanne. The whiche myraculously and by the will of our lorde retourned before his parentes and freendes in his fyrst fourme humayne.

UPON a day as the noble kynge Oryant sat at the table, and his noble spouse the good quene Beatrice with their iii. sonnes and their doughter, there arived theyr two other noble sonnes Helyas and his brother the swanne that had guided him in his viage as it is said. And whan Helias knewe the place of Lilefort he began ioyously to blow his horne upon the river, in suche maner that the voice therof came to his father. The which incontinent arose fro the table as all reioyced saying. My wife and ye al mi 
children have ye joye and mirthe at harte, for here is mi sone Helias. Than diligently they arose and went to the windowes of the palays. And in beholding to the river they apparceyved the noble Helyas the which al redy yssued out of the shyppe. And anon there ran to mete him his foure brethren with theyr sister for to welcome him. And there they enbraced and kissed him for joy that they had to se him, and after ioyously he went with them into the palais before his father and his mother, wher as was made so goodly meting that it is not possible to tel. For incontinent his father and his mother kissed and enbraced him wepinge for joy that they had to receive him for the noble vertues and miraculous dedes that God had shewed in him. The one feasted him, the other reioyced him. They were all ravisshed to se him and whan thei had wel received him, his mother axed him benignely. Swet sone where have ye be? It is now wel nere viii. yeres that we have not sene you. Mother sayde he ye shal knowe it a nother time if it please God. And wher is sayd she my sonne the swanne that led you in a shyp. Certes madame sayd he, he is retourned into the water. Certaynly said the noble queene, me semed this night in my slepe that the swanne shoulde be turned to his owne fourme humayne, yf that we had the two cuppes that the goldsmith forged of his chaine, and make to be made of them, ii. chalices. And than set the chalyces upon two aulters in the church. And betwene the aulters make a bedde and lay the swanne therin, and after make to say two masses by two good and devoute preestes upon the sayd aulters and consacre in the chalyces. Than that eche of us dispose our conscience wel and devoutly so that we were worthy to pray our Saviour Jesu Christ. And I beleve that he will streche his vertues over him, and he shall retourne to his fourme humayne. Than kyng Oriant and Helias helde her counseyll good. 


\section{CHAPTER XXXVI.}

\section{How queene Beatryce made greate joye of her sonne that was retourned to his right fourme.}

THAN incontinent thei sent for the goldesmith that had forged the two cuppes of the chayne of silver. And he comen to the kinge made to deliver to him the two cuppes for to make two chalices, as it had ben ordeined. And for to make it short were wel and duli ordeined two aulters and a bedde as it was sayd. Than came the noble Helias to the water side where he found his brother the swann and made maner to call him. And famelierly he came to him, and folowed him as his good and faythful brother. And in likewise as afore time he had conduited the sayde Helias, so Helyas conduted him to the churche before the crucifixe. And in the presence of the kynge, the queene, theyr chyldren and other lordes he was layde in the bedde betwene the two aulters, where as were devoutly sayd two masses, which al they above sayd heard wel and devoutly being mekely prosterned on both their knees prayinge Almighty God that by his divine bounte it wolde please him to show his vertue. So it happened that the time ordayned of God was accomplysshed that the swanne should retourne in his fourme humayne. Ryght so as the preestes consacred the body of our Lorde at the masse the swanne retourned into his propre fourme and was a man. And thus transmued he arose fro the bedde joyning his handes, and escried saying, Lordes I thanke you humblye. Jesu by his grace yelde you the devoute prayers that ye have made for me, for bi his mercy I am delivered and put fro great payne. And than wente he and mekely kissed the king his father, his mother, and after al his brethren and his sister. Than after the masse were the belles solempnely rongen and Te Deum songe for joye in thanking God of his devine vertues. After that wer made processyons and praysinges to God. And at the retournynge was baptized the sayd childe, and named Emery. The whiche sith was a noble knight. And at the comyng fro the chyrche the 
tables were arayed in the kings palaice where as echone were honourabli received with greate joye for love of that devine adventure so clerely shewed tofore all. And thus the noble kinge Oriant and the good queene Beatrice finabli recovered all their children bi the grace of God, wherfore fro than forthon they lived holyly and devoutly in our lorde.

\section{CHAPTER XXXVII}

How the noble Helyas tooke leave of his parantes and freendes, and made him selfe religious there as he was nourysshed with the good hermite, where he made to buylde a castell like to that of Boulyon.

WHAN the good and worthy knight of the swanne named Helyas had sith his retourninge abiden a space of tyme in Lylefort with his father and mother in the company of his fyve brethren and his sister the which he loved of a synguler, fylyall, and fraternall love, he disposed him selfe to go into the hermitage where he had be nourisshed with his godfather the good devoute hermit Helyas, the which was disceased in our lorde.

And in that place his father king Oriant had doo make a religion for the honour of God and memorye of his vii. children, as it is sayd before. So the sayd noble knight Helias assembled his parentes and freendes, and to them recounted al the adventures that to him were hapned sith his departinge. And how he had espoused the noble duchesse of Boulyon, the which had conceyved of hym a fayre doughter named Ydain. And whan he had tolde to them as it is sayde, he shewed them his courage and that he had intencion to doo saying. My lorde mi father and you mi lady my mother, my brethren my sister, and al my freendes. I wyll here in generall recommaunde you to God, and say farewell, for to go amende my lyfe and yelde me religyous. For seyinge the graces and devine benefyces that God hath pleased to shew for us, it behoveth to his divine wyll that I take payne to save my soule and pray for al my freendes. Wherfore humbly I recommaund you your subiects that ye treate them 
amyably without to oppresse them with ony grevousnesse. And my brethren and frendes I pray and require you all that knightly ye kepe and defende alway your countrey as good and valiaunt knightes. And in these wordes sayinge there was none that durst gayn say him for the love of God the whiche in all theyr anguysshes had succoured them, but began all to weepe dolorusly for the departing of the good Helias. The which all thinge promised tooke his leave of them benignely, and kyssed them al at his parting lovyngly in weepynge, and thus he departed from them with a simple staffe in his hande. Syth as a good and devoute knight he came to the place of the sayd hermitage that he had chosen for to save his soule. And there he was mekli received of the other religious men that his father the kynge Oriant had there founded. After that he made to edyfye and buylde in that place a castel semblable and like to that of Boulyon. The which whan it was ended he made in lyke wyse to name Boulion, and the forest that was about it Dirdayne. Than in the sayd castell of Boulyon he ordeyned certaine markettes and fayres, the which he made free and quite of all customes and imposicions to all marchauntes goynge, cominge, and soiournyng at the sayd fayres in that place of Boulion, for the augmentacion and profyte of the said relygyon. In suche wise that he ordeyned $x x x$. religious men for to singe and ministre the devine service in the sayd religyon. And there he abode relygyous observinge the rule that there was constituted, and used his dayes in our lorde Jesu Christ.

\section{CHAPTER XXXVIII.}

How the puyssaunt and vertuous emperour Otton espoused the erle of Boulyon to the fayre Ydain doughter of the noble knight of the swanne Helyas. And how after the dreame that she had the aungell of God announced to her that she shoulde conceyve and have thre noble knyghtes.

WhaN fayre Ydain doughter of Helyas the noble knight of the swanne was at the wyll of God comen to the age of xiii. yeres, Otton the puissunte Emperour, of Almayne maryed her to the 
noble Erle of Bouleyn named Eustace. And the feast was made in the emperours palays at Nymaie. And theyther came manye great lordes and noble knightes, gentilmen, and damoiselles, the whiche were well receyved. And amonge the other laydyes was the noble duchesse of Boulion mother of Ydain. The which in weepe piteously bewayled her good spouse the noble Helyas. Than was the feast greate, and the wedding honourably solempnised as themperour wolde for the love of Helyas. And the night comen the sayd erle of Boleyn lay with his spouse fayre Ydaine. The which conceyved of him the prue knight Godfrey of Boulyon. And the same night in her slepe she thought that she found in her bed three fayre children. The which she elacted and gave to souke of her own milke in so great habundaunce that they were well and substauncially nourysshed. And than her semed that the two fyrst had eche of them a crowne of fine golde upon theyr heades, but the crowne of the thyrde was broken by cause another woman than his mother had geven him souke of her milke. And at this point the noble Ydain a waked of her dreame. Than harde she the voyce of an aungell that God had sent her sayinge. Ydayn God sendeth the greeting. Know thou for trouth that thou shalt conceyve of thy husbande three male children which thou shalt nourisshe with thine owne milke. And God shall give them his blessid benediction. For they shall conquere the realme of the holy lande of Jerusalem, and shall delyver the holy sepulcre of our lorde Jesu Christ out of the puissaunce and captivite of the unbelevinge Sarazins. And therfore governe them well. And whan the good Ydaine had hearde these tidinges she thanked and praysed our soverayne lorde God of his good advertisinge, and of the grace that he did to her. And thus by three yeres folowing she conceyved and childed three fayre sonnes. That is to wit the fyrst Godfrey of Boulion, the seconde Baudwin and the thirde Eustace. The whiche she loved and nourisshed diligently. But in a solempnite of penthecost arived at Boulion the bysshop of Liege, the duke of Brabant, the duke of Fryse, the erle of Flaundres, the erle of Nammer and many other great prynces and mighti barons. The 
whiche were there assembled for to make a certayne parlyament touching the provysyon of some affayres that was to do in the countre. So that the countesse was at the -masse that right solempnely was songen before the sayd princes. $\mathrm{Bi}$ the whiche she left yonge Eustace somwhat to longe fro the breste, wherfore he began to weepe so fast that a woman beinge one of the nourices ranne diligently for to apease him, and gave him her pappe for to souke. And whan his mother the countesse retourned to visite him she founde the sayd nourice the whiche gave him to souke of her milke. Wherfore she was so greatly angred and displeased that she sayd. $\mathrm{Ha}$ woman evyll advysed what have ye presently doone. Now shall my sonne Eustace lese his noble dignite for to have taken of your mylke, wherfore I oughte well to hate you. Alas madame sayd the nourice for Goddes love pardon me, for certaynli I wende to have doone well because he wept so fast to thende to have stylled him. : So the sayd countesse abode all the day by her three children without ani meate or drink for the displeasure that she had of that another woman than she had given souke to her chylde. And after dyner the erle of Boulyon led all the princes, lordes, and barons afore named into his secrete chambre for to shewe unto them his three faire sonnes, Godfrey, Baudwin, and Eustace. And whan that they saw the noble countesse besyde her three children they salued her and them right benignely. And in lykewyse on her sede she receyved and fested them with her speche as muche as to her was possible, and to them shewed her iii. chyldren, but for to make them any welcoming she wolde not ons arise. Wherfore her husbande the erle was sor displeased, but he conveyed eche of them to his loging without makyng ony semblaunt therof. Than he returned agayne to her al angry for to blame her therof and sayde. Wyt ye lady that ye have greatly angred me, whan ye dayned not ones to aryse before so high and notable princes, before whome a quene of ony realme should wel have rysen for to salue them. A my lorde sayde she be not discontent with me yf ye please. For by the honour of your thre sonnes I may preaise my selfe as 
muche as any queene how noble that she be. How so said the erle. Certaynlye my lorde sayd she all the worlde ought well to honour and praise me for theyr dignitees. For they shal yet venge ones more the death of our Saviour Jesu Christ. And shall conquere the realme of the holy lande of Jerusalem, wherby they shall delyver the holy sepulcre of our lorde fro the handes of the misbelevinge Sarazyns, the whiche there is no kynge that dare undertake. What sayd the erle I trowe that ye dreme: and of trouthe who that should here you say and preferre suche wordes wold saye that ye had not good mynde. Ha my lorde sayd she, holde not for a vayne thing this that I tell you. For this hathe tolde me and announced the aungell of our Lorde God by holy prophecy.

And at these wordes her husbande the erle of Boulein regarded her no more. But that he sayd, God give that it be so as ye have sayde.

\section{CHAPTER XXXIX.}

How the noble duchesse of Boulion sent many squyers and messengers over all countreys and regyons for to fynde her noble husbande the good Helias knight of the swanne.

$\mathrm{By}$ the holy wyll and commaundement of God the good countesse of Boleyne Ydaine was nourisshing diligently of her three children Godfrei, Baudwyn, and Eustace. And in thys doynge helde her compani her good mother the noble duchesse of Boulyon, the whiche of times devysed with her of her good husbande Helias. For whom she had sent many messagers squyres and other in divers countreys and regyons to the ende that they myght finde him, or in ony maner heare tydinges of him as she right for desired. And amonge the messagers that sought him one her squyre named Ponce arived in Jerusalem, for to knowe and diligently enquyred if the sayd Helias had enterprysed the viage of the holi sepulcre for his remissyon. And in suche wyse that he was the space of xv. dayes within Jerusalem and in the pylgrymages and devoute places cyrcumia- 
centes accustomed to be doone in the said holy vyage. So he came into a church, at the entrynge wherof he founde an abbot of a churche, clothed after the Frenche facion of his religion. Whome he demaunded of whens he was. And he sayd. My frende I am of the countrey of Gaule not ferre fro Boulyon, and am abbot of Saincteron named Girarde. And than in likewise the abbot demaunded of whens he was. My lorde sayde Ponce the noble squire I am of Boulyon proprely. My frende said the abbot, you be right wel founde. Glad am I of your coming, and sith it pleaseth God thus we two together shall retourne into our countrey. Than the good abbot Gyrarde of Saincteron ledde the squyre Ponce to his lodging where as he feasted him greatlie. And there they devised one with another of theyr affaires.

And it is to be noted that at that same time wer assembled in Jerusalem many princes and great lordes, Sarazins and Painims of Turkie. As the sowdan of Perse. The kynge Dorbrye, Abraham of Damas. The king of Dortaine. Dodekin of Thabarie. The king of Anthyoche. Solyment of Nikes. The king Feliston. The kynge of Scabon. Dodequin of Damas. King Mabrun of Oliferne, and Corborant his sonne, the which were comen al thither at the commaundement of king Corbadas, that in theyr presence and during his life wolde give his realme of Jerusalem to Cornumaraunt his sonne and crowne him king therof. The which was xv. yere olde. And the sayd new kynge was crowned by the consentment of the sayd princes resygned fro the father to the sonne in great feast and solempnite within Jerusalem like as thei were accustomed to do after theyr gestes and ceremonies. And it is for to be knowen that the sayd Cornumeraunt the new kyng of Jerusalem founde maner and space for to speake to the abbot of Saincteron the whiche for that time was in the cite of Jerusalem of whome he enquired diligentli of the state of the princes of Gaule and of theyr maner of doing. The which abbot told and cited to him trouthe, wherefore greatlye he praysed and loved him. Than all wisely the sayd abbot of Saincteron demaunded of him familiarly the 
saufconduyt and acquite for the countreys and landes of beyonde the sea for him and the sayd squire Ponce the more sureli to retourne into theyr countries. The which the king Cornumeraunt him graunted benignly, in presentinge to him larglye of his goodes for the wisedome and the honour of spekinge that he had founde in him. And after theyr sauf conduyte made they tooke reverently leave of the king, and on the next day in the morning they departed fro the holy citye of Jerusalem, and sith came unto the port of Jaffe otherwise named Joppen. And fro thens mounted upon the sea and after by valeis and mountaynes they wente tyl thei arived within Rome.

\section{CHAPTER XL.}

How the abbot of Saincteron and the squyre Ponce departed fro Rome at theyr retournyng fro the holye sepulcre. And sith by the wil of God they ariued at the new castell of Boulyon.

After that Gyrarde the abbot of Saincteron, and the squyre Ponce had doone theyr devocions within the cite of Jerusalem they departed diligently for to retourne into theyr countrey. And even as they were in the feeldes Almighti God (that alwai doth for the best) wolde that they should be wandred of theyr way. And in such wise they were fro their way in a place inhabitable that thei wist not what to thinke. So it happened that after mani travailes paines, and labours they arived nigh to the sayd castell of Boulyon that the good Helyas had newly made to edifie after the fourme and construccion of the other Boulion towarde Dardayne. Wherfore Ponce sayd to the abbot, Certes my lorde heare is Boulyon, we ben in our countrey. In our countrey sayd the abbot I trow that it lacketh a great dele. Certainly my lorde sayd Ponce, yet is this castel like and of the same fourme of it named Boulyon, and I beleve that he that made it had intencion so to doo. And after al these wordes bi cause the night came on, they went and lodged them in a vyllage nigh ynough to the said castell. And in theyr lodgis 
they sent for the curat of the vyllage for to wit ot him in what place and in what country they were arived. Truly lordes sayd the curat, you have passed the greatest forest of Dardeyne and ben presently arived nigh to the castell of Boulyon. Now sayd the abbot we ben of the countrey that ye name, and it is well CC. leges fro hens. It is trouth my lorde said the curate, I have be in the countrey that he speake of. But for to declare you the trouth the Castell that ye have seen is called Boulyon le restaure, that is to sai restored, for that a noble and vertuous knight named Helias sonne to the mighty king Oryant and of the quene Beatryce his spouse went in a ship upon the guyding of a swanne, that so led him bi adventure to Nymaie, were as he wanne a champ of batayle agaynste the erle of Frankebourke, wherbi the emperour made to give him in maryage the duchesse of Boulyon wherof ye speake. In suche wyse that he was about viii. yere there and than after he retourned into his realme of Lilefort by the leding of the swanne aforesayd. And at his commyng he did doo make this castel and named it Boulyon as the other and the forest about it Dardayne. And whan Ponce heard him speake so he wist wel that he should have certaine tidings of that he desired, whereot he thanked our lord, and than without making semblaunt he said to the curate, Good syr the king and the queen that ye say to be father and mother of that knyght ben they now abydyng in the castel : Certes syr sayd he ye. For thei loved so muche the said Helyas theyr sonre that they have lefte Lilefort and ben comen to dwell here for the love of him. And the noble knight sayd Ponce that ye speake of is he dead : Nay forsoth sayd thee curate, and it is not vi. dayes sith I saw him. But for to declare you the verite, he hath ben during his youth of so good lyfe that Almyghtye God had doone and shewed mani fayre vertues and divine miracles at his holy prayer and orayson wherby he hath mad him religious. And is now in a devote religion that his father hath edified for the honour of God, and in the commemoracion of him and his brethren, where as he prayeth God and doth penaunce for to save his soule Veryly sayd the squire $I$ am all reioyced in this 
that ye say. Wherfore sayd the curat? For I was sayd he servaunt to the sayd Helias that was duke of Boulion, and am yet servaunt to the duchesse hys wife, the whiche hath sent me into many countries for to seche him and thanked be God I have heard of him. And so Ponce abode mery there al night. And on the morne the abbot and he went to the sayd castell, wherin at comyng fro the masse they met king Oriant, the queene, theyr v. sonnes and theyr doughter. And whan Emeri the last transmued sonne of the king saw them and had knowen theyr habite he came to them and made them chere asking them of whens thei were. And Ponce said, My lord we ben of Boulion in the lond of Dardein. And what do you in these parties said Emery. Syr said Ponce, it is longe syth I cesed not to go in many countreys and regions, as wel on this side as beyonde the se for to finde a noble knight that a swanne guided and ledde out of Boulyon, whan he left his wife the noble duchesse of Boulyon, whose servaunt I am. And whan Emery hearde him he began to laugh, Certes my frende it is my brother Helias. My lorde sayd Ponce, lyveth he yet : Yea truly my frende sayd Emery, and ye shall see him if God wyl or ye passe this country. I pray you thereof sayd Ponce. Than Emery called the king, the quene, his brethren, and his sister and sayd. Certaynly if ye wil heare any tidinges of the duchesse of Boulyon my brothers wife, and of Ydain his noble doughter, here ben to notable lordes, that ben the same countrei. And forthwith thei came to Ponce, the which recyted to them the contency of the noble duchesse of Boulion that was mervailously soroful for that her good husband Helias had left her. And of her noble doughter Ydaine, of whome he tolde them to have receyved certayne tidinges that she was maried to the mighti erle of Boulein. Than sayd the king and the queene, wolde God that they were here. And therwith they enbraced and kissed the abbot and Ponce. And than he led them into the castel, wher they were feasted and served of the kings sonnes and other barons. In the whiche chere they soiourned a whole day in visiting all the places of the castell. And on the morow the noble Emery led the abbot of 
Saincteron and the good squire Ponce to the place where as his brother Helias was relygious. And there his brother Emery founde him kneeling on his knees before the high aulter in the churche. So he salued him humbli. And reverentli he yelded him his salute in saying Fayre brother Emeri, what is ther of new : Brother said Emery, here ben two notable lordes that I bring you. The which wil tel you tidinges of your wife the duchesse of Boulyon and of your doughter Ydain, that is maryed to the erle of Boleyn. Than Helias knew Ponce for he had afore seen him. Wherfore humbly he came and enbraced and kissed him sayinge. My freende ye be welcome, tell me yf it please you some tidinges of my wyfe, and of my doughter Ydain. And than he tolde him how she had sent him into many countrees, and of his adventures syth his departing. And than he asked him if he wold retourne into his countree of Boulion. Certes sayd Helias, nay. For never by the will of God shall I departe fro this regyon where as I pretende to save my soule be his holy and worthy grace. Certes my lorde said he, I am right glade to see you, and also mi ladi shall be greatli reioysed to here of you. My frend sayde Helyas ye shall recommaunde me singulerli to her good grace, and also to my doughter Ydain. Of whom I am right ioyous that she is honourabli maried with the noble erle of Boulion. And than in weeping he tooke the abbot of Sainteron bi the hande and with Ponce ledde him to se all the places of his religion. Than with his brother Emery he made them good chere and fested them greatly and after all these thinges the squire Ponce prayed him humbli of his good plesure to geve him some true token, wherby the duchesse myght notably knowe that he had doone his devoyre to fynde him. And Helias sayd. My frend ye speake wysely. And for a token of me ye shall bere her this rynge. The which or now she gave me ryght amerously. Than after the good Helyas gave greate gyftes to the abbot and to Ponce. And with them he sent to his wife and his doughter Ydain greate treasoures and mani fayre giftes. Than tooke they leve humbly of the sayd Helias and with his brother Emery thei retourned to the castel of Boulion 
restaure, where they were agayne honourably receyved. And than kyng Oryant and the quene his wife prepared riche and sumtuous giftes. The whiche they sent to theyr doughter the noble duchesse of Boulyon, and also to her doughter the noble countesse of Boleon, in recommaunding them singulerly to theyr good grace. Than the abbot of Saincteron and the squyre Ponce tooke reverently theyr leve of the noble king Oriant, and of the queene his wife and of al theyr courte, and departed fro them for to retourn into theyr countrey, in the place of Boulyon in Dardayn.

\section{CHAPTER XLI.}

How the squyre Ponce arived at Boulyon for to bere tydinges to the duchesse of the noble Helias knight of the swanne, the whiche was at that time yolden a religyous.

UPON a daye of the feast of the ascencyon of our lorde Jesu Chryst as the erle of Boulyon, his wife Ydain, and the noble Duchesse her mother with many other lordes and damoyselles were sytting at the table and helde court plenayre by maner of consolacion, arived Ponce the noble squyre at the castell of Boulyon, the whiche led a mule charged with dyvers giftes and riche presentes and came into the halle wher as was the feast aforesayd. And incontinent that the noble duchesse apperceyved him she arose fro the table, and came tenderly enbracing him and sayde. My freende Ponce ye be right welcome. Have ye founde my husbande or can ye ony tidinges of him. Cyrtes madame sayde Ponce. Yea? By the same tooken that here is his rynge that he gave me to beare to you. And whan she saw the rynge she was al reioyced, and kisse it mo than $\mathrm{C}$. times, in weeping and bewayling piteously the abscence of her good and faythfull husbande Helyas, and than sayde. Truley Ponce my freende this is a good tooken that ye have founde him. Madame said he highli I have also brought a mule charged with many 
notable giftes and riche presentes that he and his mighty parentes have sent to you, and to my ladi the countesse $\mathrm{Ydain}$ your noble doughter. For I doo you notabli to wit that he is sonne of the ryght puyssant and redoubted king of Lylefort named Oriant, and of the illustred and noble quene Beatrice his wife. And eke he hath five noble brethren and all valyaunt knightes. And he hath also a fayre sister, and shortly he is of right great kine. Of these wordes was greatly inioyed the duchesse his wife his doughter and the noble erle, in suchwyse that they wept for ioye that they had at theyr hertes to here suche good tidinges. Than the sayd Ponce recited to them that he was religious in a fayre abbai that his father and he had made to constytue and edifie for the honour of God. And how he had seen al with the abbot of Saincteron, in retourning fro the holy cite of Jerusalem, where upon saythe the cronicle and gest of this myraculous history that whan the noble duchesse of Boulyon knew and understoode that her good husbande Helias was yolden religious, she made incontinent to prepare her estate. And with her doughter Ydayn she set her on the way with the sayd Ponce which they tooke for to guyde them to the religion where he had found the good Helias. Than tooke thei leave of the noble erle of Bolyon in recommaunding him his three sonnes Godfrey, Baudwin, and Eustace. The which were all redy in age adolescent. And after they departed fro Boulyon and travayled so longe by mountaynes and valees that they came to the place of religion where as the noble Helias was yolden religious. Than the noble duchesse his wife with her doughter Ydain demaunded so muche after him that they came and found him lieng in a bedde ryght sore sicke. And God knoweth than in what ioye they behelde eche other. The wife be wept her husbande, the doughter bewayled her father. And he on the other side wept tenderly to se there his wife and his doughter, so that all they that behelde them wepte for sorow and pitie. And after that they had ben there a space of time, the good Helias was so sike and weyke of paynes and travayles that he had susteyned in his yough that holili and devoutli he desceased in our lorde Jesu Chryst, the 
which called hym to be with hym for to rewarde him for the paynes and grevous vexaccions, that he had suffred and wyllyngli borne at his holi and dyvine commaundement and to geve him space in the glory pardurable with the happi sainctes of the realme of paradise. And whan the duchesse saw her husbande dead, she was so sorowfull at her herte that she disceased with him in our lorde, wherfore her noble doughter, Ydain and all the lordes and damoyselles that were comen with her made suche sorow that pitie was to see. And after al thinges all the religions of the sayd abbay assembled them and honestly with great reverence they buried the noble Helias and his wife in one tombe before the high aulter of the churche. And theyr service was well and devoutly doone as it apperteined to theyr estate. Than the noble Ydain departed and gave muche of her goodes to the sayd abbay for the honour of God and for the love of her father and mother the which there were engraved. And so departed fro the place with her folke, and retourned into her countrey and duchy of Boulion where as she founde Eustace her noble husbande. To whom she recited in weeping how her good father and mother were discesed in our lorde, and bothe buried togither bi the divine wyll. And whan the sayd Eustace her husband heard these tidinges he was muche sorowfull and dolen at his herte. And he wyth his wyfe and all hys housholde did beare the doole as long as it was expedient for such a noble prince.

\section{CHAPTER XLII.}

How Ydain the noble duchesse of Boulyon endoctryned her three sonnes, Godfrey, Baudwyn, and Eustace in all maner of good operacyons, vertues, and maners.

AfTER that the noble Ydain duchesse of Boulyon was retourned into her countrei she kept syngulerly her three sonnes, Godfrey, Baudwin, and Eustace, whiche she made instructe by a wyse 
master. And she herselfe endoctryned them in all good maners and honeste of life sayinge, Alwai above all thinges give laude and glorye to God in all your workes, and sayd. My children ye ought to knowe that ye be extract and issued of a lignage as noble and vertuous as is possible to be. That is to wete of the noble knight of the swanne sonne of the puyssaunt king Oryant and of the good queene Beatryce his spouse. And ye have v. kinges and a quene of your excellent and illustryous parent. The whyche all myraculously and by the announcement of an aungel have ben producte in valoure and you also in lykewyse. And therefore than my fayre children abide alway in the feare and love of God our soveraigne protectour in giving him laud and honour. Be swet, soft and curteys to your subiectes without oppressyng or domaging them in ani wyse yf ye be able and possible to reedifie the churches of God, and offre willingly your owne bodies in sacrifice in susteyning the holy faythe catholyke. Keepe and defende iustly your countre. Bere and sustayne the right of poore widowes and orphelins. Distribute and deele of your goddes to the nedy, conforte the sorowfull and thinke for to save your soule for to have the grace of God. And I promyse you my chyldren that yf ye governe you that ye shal prospere in this worlde and have heaven at your ende. And in this maner where bi theyr good mother Ydain devoutly introduct and taught these three yong sonnes Godfrey, Baudwyn and Eustace, the whiche were al way together in theyr youthe, often times to remembre the good and helthfull doctrine that she had given them. And semblably also they were bi theyr notable scole maister suffyciently enstructe in scyence and in all good maners. 


\section{CHAPTER XLIII.}

How the three noble brethren Godfrey, Baudwyn, and Eustace appropried and used them in all maner of noble games and assayes of worthinesse.

AND whan in the adolescence they were somwhat comen to the age of strengthe, they began to practyse them in shotinge with theyr bow and arbelstre, to playe with the swerde and buckeler, to runne, to just, to play with a poll axe, and to wrastle. And began to bere harneys, to roune horses and to approve them as desyringe to be good and faythful knightes to susteyne the faith of God. And thus thei grew al three in strength and height mervailously and in suchwyse that of theyr age was none found like to them they were fayre and well fourmed of bodye, wyse, courteys and well taught. They served God gladli, they made them to be beloved of great and small. And echone honoured them echone gave them benediccion, and also they gate grace of great princes and noble lordes. And whan Godfrey the fyrste borne was comen to the age of $\mathrm{xv}$. yeres accomplisshed his good mother Ydain made to dispose and put them in poynt as to him well apperteined for to go to Nimaie to themperour for to receyve the ordre of knighthode, and sayd to him. My fayre sonne Godfrey ye be the eldest of your brethren and are of age competent for to be knight. Wherfore here is a robe of honour the which I have diligently prepaired for you to receyve the noble degree and vertuous title. Your squires and pages ben well appointed of liverayes to you apperteining, and all they of yours also. Wherfore ye shall go into the citie of Nimaie to themperour the which hath good knowledge of you bycause of your grauntfather the noble and vertuous knyght of the swanne, and my good mother his wyfe, whose soules God pardon. And so of him you shalbe made knight in giving you the swearde of honour. And your two brethren shall go with you for to beare you company. And than answered Godfrey My right lady and mother I hertelye thanke you whan you procure me suche honour. And I am al 
redy to departe and go towarde themperour at your good commaundement. Now go than my sonne your case is al redy. And than departed Godfrey of Boulyon mounted upon a horse of price accompanied of his two brethren, and of many noble and gentill knightes, squires, and pages. The which have riden so longe that they came to Nimaye. And incontinent the good Godfrey came and presented hem to fore the emperour, in saluinge him debonayrlye. And he received him gladly and al his company with good hert saying. Right noble chylde and my deare frende, ye be right hertli welcome. I know you to be extract and issued of the moste noble and illustrious Helias Knyght of the Swanne. Therfore for the love of him and of your mother his doughter, the which I have maried and conioyned in my noble palays bi theyr good consentement, wherfore bi the pleasure of God I shal adube you knight or ye departe fro me. Syr sayd Godfrey, I thanke you humbly. And than the noble emperour made to prepare and ordeyne a solempne feast for the love of Godfrey of Boulyon. Than incontinent after the feast were ordeyned justes, tournementes and mani other games and noble feates of armes. In the whiche the noble Godfrei shewed him right prue and valiaunt, in such wise that by the sayde emperour he was made and ordeyned knight with ryght great honour and. joye. And whan the feast was passed Godfrey retourned honourabli to Boulion with his brethren Baudwin and Eustace. The which sith in theyr age were made noble knightes as theyr brother Godfrey. And thus they aryved at Boulyon with theyr company, where they were received with great joye and honour. Than certayne tyme after theyr noble father Eustace duke of Boulion and erle of Boleyn disceased in our Lorde. The whiche by his grace and mercy have him into his infinite glory with the holy saynctes and blessed company of heven. And thus abode the said Godfrey duke of Bulion, as the first borne of his brethern. And he was so good and so prue to right and governe the welth publyke, and so polytike in keping his countrey that he was beloved of every person. Than began soone after to approche the time that our Lorde God had ordeyned for to put and reduce 
the realme of the holy lande of Jerusalem into the handes of prue and noble Godfrey of Boulyon. In the which time chosen of God and by his good enhortement should be unyed and congregeed the princes of Christendom for to passe over the sea and susteyne the fayth of God Jesu Christe agaynst the misbelevinge paynims. As it is writen and recited in the cronicles and faytes of the sayd Godfrey and his brethren. And al by the wil of God the whiche exalteth his freendes in this worlde and after theyr bodely death bringeth them to the life everlastinge of heaven. To the whiche bring us, the Father, the Sonne, and the Holy Gost. Amen.

Thus endeth the life and myraculous hystory of the most noble and illustrious Helyas knight of the swanne with the birth of the excellent knyght

Godfrey of Boulyon, one of the nyne worthiest, and the last of the three chrysten.

Imprinted at London by me-Wyllyam Copland. 
THE HISTORY OF THE DAMNABLE LIFE AND DESERVED DEATH OF
DR. JOHN FAUSTUS. 


\section{-}




\title{
XIII.
}

\section{THE HISTORY OF THE DAMNABLE LIFE AND}

\author{
DESERVED DEATH OF \\ DR. JOH N FAUST US.
}

\section{CHAPTER I. \\ Of his Parentage and Birth.}

gohn gausfus, born in the town of Rhodes, being in the province of Weimer, in Germany, his father a poor husbandman, and not able well to bring him up, yet having an uncle at Wittenburg, a rich man, and without issue, took this Faustus from his father, and made him his heir, insomuch that his father was no more troubled with him, for he remained with his uncle at Wittenburg, where he was kept at the university in the same city, to study Divinity; but Faustus being of a naughty mind, and otherwise addicted, plyed not his studies, but betook him self to other exercises, which his uncle oftentimes hearing, rebuked him for it; as Eli oftentimes rebuked his children for sinning against the Lord, even so, this good old man laboured to have Faustus apply his study to Divinity, that he might come to the knowledge of God and his law. But it is manifest that many vertuous parents have wicked children, as Cain, Reuben, Absolom, and such like, have been to their parents. So Faustus having godly parents, who seeing him to be of a toward wit, were desirous to bring him up in those vertuous studies, namely, of Divinity; but he gave himself secretly to necromancy, and 
conjuration, insomuch that few or none could perceive his profession.

But to the purpose, Faustus continued at study in the university, and was by the rectors, and sixteen masters afterwards, examined how he had profited in his studies, and being found by them, that none of his time were able to argue with him in divinity, or for the excellency of his wisdom to compare with him, with one consent they made him Doctor of Divinity: But Doctor Faustus, within short time after he had obtained his degree, fell into such fantasies, and deep cogitations, that he was mocked of many, and of the most part of the students was called the Speculator, and sometimes he would throw the scriptures from him, as though he had no care of his former profession, so that he began a most ungodly life, as hereafter more at large may appear, for the old proverb saith, Who can hold wha will away? So, who can hold Faustus from the devil, that seeks after him with all his endeavours; for he accompanied himself with divers that were seen in those devilish arts, and that had the Chaldean, Persian, Hebrew, Arabian, and Greek Tongues, using figures, characters, conjurations, incantations, with many other ceremonies belonging to those infernal arts, as necromancy, charms, soothsaying, witchcraft, enchantment, being delighted with their books, words, and names so well, that he studied day and night therein, insomuch that he could not abide to be called Doctor of Divinity, but waxed a worldly man, and named himself an astrologian, and a mathematician, and for a shadow sometimes a physician, and did great cures, namely with herbs, roots, waters, drinks, receits and glysters; and without doubt he was passing wise and excellent perfect in Holy Scriptures: But he that knoweth his master's will, and doth it not, is worthy to be beaten with many stripes. It is written, No man can serve two masters, and thou shalt not tempt the Lord thy God. But Faustus threw all this in the wind, and made his soul of no estimation, regarding more his worldly pleasures than the joys to come; therefore at the day of judgment, there is no hope of his redemption. 


\section{CHAPTER II.}

How Dr. Faustus began to practise his devilish art, and how he conjured the devil, making him to appear, and meet him on the morrow-morning at his own house.

You have heard before that all Faustus's mind was to study the arts of necromancy and conjuration, the which exercise he followed day and night, and taking to him the wings of an eagle thought to fly over the whole world, and to know the secrets of heaven and earth, for his speculation was so wonderful, being expert in using his vocabula, figures, characters, conjuration, and other ceremonial actions, that in all haste he put in practice to bring the devil before him, and taking his way to a thick wood near to Wittenburg, called in the German tongue, Spisser Holt, that is in English, the Spisser's Wood, as Faustus would oftentimes boast of it among the crew, being in jollity, he came into the wood one evening into the cross-way, where he made with a wand a circle in the dust, and within that many more circles and characters; and thus he past away the time until it was nine or ten of the clock in the night, then began Dr. Faustus to call on Mephistophiles the Spirit, and to charge him in the name of Belzebub, to appear there presently, without any long stay; then presently the devil began so great a rumour in the wood, as if heaven and earth would have come together, with wind, and the trees bowed their tops to the ground, then fell the devil to roar, as if the whole wood had been full of lyons, and suddenly about the circle run the devil, as if a thousand waggons had been running together on pavedstones: After this, at the four corners of the wood it thunder'd horribly, with such lightning, as the whole world to his seeming had been on fire. Faustus all this while, half-amazed at the devil's so long tarrying, and doubting whether he were best to abide any more such horrible conjurings, thought to leave his circle, and depart, whereupon the devil made him such musick of all sorts, as if the nymphs themselves had been in place: 
whereat Faustus revived, and stood stoutly in his circle, expecting his purpose, and began again to conjure the spirit Mephistophiles in the name of the Prince of Devils, to appear in his likeness : whereat suddenly, over his head hung hovering in the air a mighty dragon; then calls Faustus again after his devilish manner, at which there was a monstrous cry in the wood, as if hell had been open, and all the tormented souls cursing their condition. Presently, not three fathoms above his head, fell a flame in manner of lightning, and changed itself into a globe; yet Faustus feared it not, but did persuade himself that the devil should give him his request before he would leave. Oftentimes after to his companions he would boast that he had the stoutest head under the cope of heaven at command. Whereat they answered, They knew no stouter than the Pope or Emperor. But Dr. Faustus said, The head that is my servant, is above all upon earth; and repeated certain words out of St. Paul to the Ephesians, to make his argument good, The Prince of the World is upon earth and under heaven. Well, let us come again to his conjuration, where we left him at the fiery globe; Faustus vexed at his spirit's so long tarrying, used his charms, with full purpose not to depart before he had his intent ; and crying on Mephistophiles the spirit, suddenly the globe opened, and sprung up in the height of a man, so burning a time, in the end it converted to the shape of a fiery man. This pleasant beast ran about the circle a great while, and lastly, appeared in the manner of a Gray Fryar, asking Faustus, what was his request? Faustus commanded, that the next morning at twelve of the clock, he should appear to him at his house; but the devil would in no wise grant it. Faustus began to conjure him again, in the name of Belzebub, that he should fulfil his request; whereupon the spirit agreed, and so they departed each on his way. 


\section{CHAPTER III.}

The conference of Dr. Faustus with his spirit Mephistophiles, the morning following at his own house.

DR. FAUSTUS, having commanded the spirit to be with him, at his hour appointed, he came and appeared in his chamber, demanding of Faustus what his desire was: Then began Dr. Faustus anew with hin, to conjure him, That he would be obedient unto him, and to answer him certain articles, to fulfil them in all points :

I. That the spirit would serve him, and be obedient unto him in all things that he asked of him, from that hour until the hour of his death. him.

2. Further, anything that he desired of him, he should bring

3. Also that in all Faustus's demands and interrogations, the spirit should tell him nothing but that which was true.

Hereupon the spirit answered, and laid his case forth, that he had no such power of himself, until he had first given his prince (that was ruler over him) to understand thereof, and to know if he could obtain so much of his lord: Therefore speak farther, that I may do thy whole desire to my prince; for it is not in my power to fulfil without his leave: Shew me the cause why? said Faustus. The spirit answer'd Faustus, Thou shalt understand, that with us it is even as well a kingdom, as with you on earth; yea, we have our rulers and servants, as I myself am one; and we have our whole number the legion, for although that Lucifer is thrust and fallen out of heaven, through his pride and high mind, yet he hath notwithstanding a legion of devils at his command, that we call the Oriental Princes, for his power is infinite, also there is a power in meridie, in septentrio, in occidente, and for that Lucifer hath his kingdom under heaven; we must change and give ourselves to men, to serve them at their pleasure. It is also certain, we have not as yet opened to any man the truth of our dwelling, neither of our 
ruling, neither what our power is, neither have we given any man any gift, or learned him any thing, except he promise to be ours.

Dr. Faustus upon this, arose where he sat, and said, I will have my request, and yet I will not be damned. The spirit answered, Then shalt thou want thy desire, and yet art thou mine notwithstanding, if any man would detain thee, it is but in vain, for thy infidelity hath confounded thee. Hereupon spake Faustus, Get thee hence from me, and take St. Valentine's farewel, and Crisman with thee; yet I conjure thee, that thou be here at evening, and bethink thyself of what I have asked thee, ask thy prince's counsel therein. Mephistophiles, the spirit thus answer'd, vanished away, leaving Faustus in his study, where he sat ponclering with himself how he might obtain his request of the devil, without the loss of his soul, yet he was fully resolved in himself, rather than to want his pleasure, to do what the spirit and his lord should condition upon.

\section{CHAPTER IV.}

The second Time of the Spirit's appearing to Faustus at his House and their Parley.

Faustus continued in his devilish cogitations, never moving out of the place where the spirit left him, such was his fervent love to the devil; the night approaching, this swift-flying spirit appeared to Faustus, offering himself with all submission to his service, with full authority from his prince, to do, whatsoever he would request; if so be Faustus would promise to be his. This answer I bring thee, an answer must thou make by me again : yet I will hear what is thy desire, because thou hast sworn to me to be here at this time. Dr. Faustus gave him this answer, though faintly for his soul's sake, that his request was none other, but to become a devil, or at the least a limb of him, and that the spirit should agree to these articles following :

r. That he might be a spirit in shape and quality.

2. That Mephistophiles should be his servant at his command. 
3. That Mephistophiles should bring him any thing, and do for him whatsoever he desired.

4. That all times he would be in the house invisible to all men, except only to himself, and at his command, to shew himself.

5. That Mephistophiles should at all times appear at his command, in what form or shape soever he would.

Upon these points the spirit answered Dr. Faustus. That all this should be granted him, and fulfilled, and more if he would agree unto him upon certain articles as followeth :

r. That Dr. Faustus should give himself to the lord Lucifer, body and soul.

2. For confirmation of the same, he should make him a writing written in his own blood.

3. That he would be an enemy to all Christian people.

4. That he would deny the Christian belief.

5. That he let not any man change his opinion, if so be, any man should go about to dissuade or withdraw him from it.

Farther the spirit promised Faustus to give him certain years to live in health and pleasure, and when such years were expired, that then Faustus would be fetched away; and if he would hold these articles and conditions, that then he should have whatsoever his heart would wish or desire; and that Faustus should quickly perceive himself to be a spirit in all manner of actions whatsoever. Hereupon Dr. Faustus's mind was inflamed, that he forgot his soul, and promises Mephistophiles to hold all things as he mentioned them: he thought the devil was not so black as they use to paint him, nor hell so hot as the people say.

\section{CHAPTER V.}

The third Parley between Dr. Faustus and Mephistophiles, about a Conclusion.

AfTer Dr. Faustus had made his promise to the devil, in the morning betimes, he called the spirit before him, and com- 
manded him, that he should always come to him like a friar, after the order of St. Francis, with a bell in his hand like St. Anthony, and to ring it once or twice before he appeared, that he might know of his certain coming: then Faustus demanded of his spirit what was his name? The spirit answer'd, my name is as thou sayest, Mephistophiles, and I am a prince, but a servant to Lucifer, and all the circuit from septrenttio to the meridian, I rule under him. Even at these words was this wicked wretch Faustus inflamed, to hear himself to have gotten so great a potentate to serve him, forgetting the Lord his Maker, and Christ his Redeemer, he became an enemy to all mankind; yea, worse than the gyants, whom the poets said to climb the hills to make war with the gods, not unlike the enemy of God and Christ, that for his pride was cast into hell ; so likewise Faustus forgot that high climbers catch the greatest falls, and sweet meats have oft sowrest sauce.

After a while Faustus promised Mephistophiles to write and make his obligation with all assurance of the articles in the chapter before rehearsed: a pitiful case, Christian reader, for certainly this letter or obligation was found in his house, after his most lamentable end, with all the rest of his damnable practices us'd in his whole life.

Wherefore I wish all Christians to take example by this "icked doctor, and to be comforted in Christ, concerning themselves with that vocation, whereunto it hath pleased God to call them, and not so esteem the vain delights of this life as did this unhappy Faustus in giving his soul to the devil : and to confirm it the more assuredly, he took a small penknife, and prickt a vein in his left hand, and for certainty thereupon were seen on his hands these words written, as if they had been written in his own blood, $O$ homo fuge; whereat the spirit vanished, but Faustus continued in his damnable mind. 


\section{CHAP'TER VI.}

How Dr. Faustus set his Blood in a Saucer on warm Ashes, and writ as followeth:

I JoHN FAUSTUS, doctor, do openly acknowledge with mine own hand, to the great force and strengthening of this letter, that since I began to study, and speculate the course and nature of the elements, I have not found, through the gift that is given me from above, any such learning and wisdon that can bring me to my desire, and for that $I$ find that men are unable to instruct me any farther in the matter; now have I Dr. Faustus, to the hellish prince of Orient, and his messenger Mephistophiles, given both body and soul, upon such conditions, that they shall learn $\mathrm{me}$, and fulfill my desires in all things, as they have promised and vowed unto me, with due obedience unto me, according to the articles mentioned between us.

Farther, I do covenant and grant with them by these presents, that at the end of twenty four years next ensuing, the date of this present letter, they being expired, and I in the mean time, during the said years, be served of them at my will, they accomplishing my desires to the full in all points as we are agreed: that then I give to them all power to deal with me at their pleasure, to rule, to send, fetch or carry me or mine, be it either body, soul, flesh, blood, or goods, into their habitation, be it wheresoever : and hereupon I defie God and his Christ, all the Host of Heaven, and all living creatures that bear the shape of God; yea, all that live: And again I say it, and it shall be so, and to the more strengthening of this writing, I have written it with my own hand, and blood, being in perfect memory: and hereupon I subscribe to it with my name and title, calling all the infernal, middle, and supream powers to witness of this my letter and subscription.

John Faustus, approv'd in the elements, and the spiritual doctor. 


\section{CHAPTER VII.}

How Mephistophiles came for his Writing, and in what manner he appeared, and his Sights he shezed him; and how he caused him to keep a Copy of his own Writing.

DR. FAUSTUS sitting pensive, having but one only boy with him, suddenly there appeared his spirit Mephistophiles in likeness of a very man, from whom issued most horrible fiery flames, insomuch that the boy was afraid, but being hardened by his master, he bid him stand still, and he should have no harm : this spirit began to bleat as in a singing manner. This pretty sport pleased Dr. Faustus well; but he would not call his spirit into his counting house until he had seen more: Anon was heard a rushing of armed men, and trampling of horses, this ceasing, came a kennel of hounds, and they chased a great hart in the hall, and there the hart was slain: Faustus took heart, came forth and looked upon the hart, but presently before him there was a lion and a dragon together, fighting so fiercely, that Faustus thought they would have thrown down the house; but the dragon overcame the lion, and so they vanished. After this came in a peacock and a peahen, the cock bruising of his tail, turning to the female, beat her, and so vanished. Afterward followed a furious bull, that with a full fierceness ran upon Faustus, but coming near him vanished away. Afterward followed a great old ape, this ape offered Faustus the hand, but he refused; so the ape ran out of the hall again. Hereupon fell a mist in the hall, that Faustus saw no light, but it lasted not; and so soon as it was gone, there lay before Faustus two great sacks, one full of gold, another of silver.

Lastly, was heard by Faustus all manner of instruments of musick, as organs, clarigolds, lutes, viols, citterns, waits, hornpipes, flutes, anomes, harps, and all manner of other instruments, which so ravished his mind, that he thought he had been in another world, forgot both body and soul, insomuch, that he was minded never to change his opinion concerning that which he 
had done. Hereat came Mephistophiles into the hall to Faustus, in apparel like unto a fryar, to whom Faustus spake, thou hast done me a wonderful pleasure in shewing me this pastime; if thou continue as thou hast begun, thou shalt win my heart and soul, yea, and have it. Mephistophiles answered, This is nothing, I will please thee better; yea, that thou may'st know my power on all, ask what request thou wilt of me, that shalt thou have, conditionally hold thy promise, and give me thy handwriting. At which words the wretch thrust forth his hand, saying, Hold thee, there hast thou my promise. Mephistophiles took the writing and willed. Faustus to take a copy of it; with that the perverse Faustus being resolute in his damnation, wrote a copy thereof, and gave the devil the one, and kept in store the other. Thus the spirit and Faustus were agreed, and dwelt together : no doubt there was a vertuous house keeping.

\section{CHAPTER VIII.}

The manner how Faustus proceeded in this damnable Life and of the deligent Service that Mephistophiles used tow'ards him.

DR. FAUSTUS having given his soul to the devil, renouncing all the powers of heaven, confirming all his lamentable action with his own blood, and having already delivered his writing now into the devil's hand, the which so puffed up his heart, that he forgot the mind of a man, and thought himself to be a spirit. Thus Faustus dwelt at his uncle's house at Whittenburg, who dyed, and bequeathed it in his testament to his cosen Faustus. Faustus kept a boy with him, that was his scholar, an unhappy wag, called Christopher Wagner, to whom this sport and life that he saw his master followed, seemed pleasant. Faustus loved the boy well, hoping to make him as good or better even in his hellish exercises than himself, and he was fellow with Mephistophiles: otherwise Faustus had no company in his house but himself and boy, and spirit that ever. was deligent at Faustus's command, going about the house, cloathed like a fryar, with a little bell in his hand 
seen of none but Faustus. For victuals and other necessaries Mephistophiles brought him at his pleasure, from the Duke of Saxony, the Duke of Bavaria, and the Bishop of Salisburgh : and they had many times their best wine stolen out of their cellars by Mephistophiles, likewise their provisions for their own table: such meat as Faustus wished for, his spirit brought him in. Besides that, Faustus himself was become so cunning, that when he opened his window, what fowl soever he wished for, it came presently flying into the house, were it never so dainty. Moreover, Faustus and his boy went in sumptuous apparel, the which Mephistophiles stole from the mercers at Norenburg, Aspurg, Franckfort and Tipzig; for it was hard for them to find a lock to keep out such a thief; all their maintainance was but stolen and borrowed ware: and thus they lived an odious life in the sight of God, though as yet the World were unacquainted with their wickedness; it must be so, for their fruits be none other, as Christ saith in John, where he calls the devil a thief and murtherer; and that found Faustus, for he stole him away both body and soul.

\section{CHAPTER IX.}

How Dr. Faustus would have married, and how the Devil had almost killed him for it.

Dr. Faustus continued thus in this epicurish life day and night, believed not that there was a God, hell, or devil; he thought that soul and body dy'd together, and had quite forgot divinity, or the immortality of the soul, but stood in that damnable heresie day and night, and bethinking himself of a wife, called Mephistophiles to council : which would in no case agree, demanding of him if he would break the covenant made with him, or if he had forgot it : hast thou (quoth Mephistophiles) sworn thy self an enemy to God and to all creatures? Tis this I answer thee, Thou canst not marry, thou canst not serve two masters, God and my prince : for wedlock is a chief institution ordained of God, and that thou hast promised to defie as we do all, and 
that hast thou not only done : but moreover, thou hast confirmed it with thy blood, persuade thyself that what thou dost in contempt of wedlock, it is all to thy own delight. Therefore Faustus look well about thee, and bethink thyself better, and I wish thee to change thy mind; for if thou keep not what thou hast promised in thy writing, we will tear thee in pieces like the dust under thy feet: Therefore, sweet Faustus, think with what unquiet life, anger, strife, and debate thou shalt live in, when thou takest a wife, therefore change thy mind.

Dr. Faustus was with these speeches in despair : and as all that have forsaken the Lord can build upon no good foundation, so this wretched Doctor having forsook the roc'-, fell into despair with himself; fearing, if he should motion matrimony any more, that the devil should tear him in pieces. For this time (quoth he to Mephistophiles) I am not minded to marry: Then dost thou well, answered his spirit. But within two hours after, Faustus called again to his spirit, who came in his old manner like a fryar. Then Faustus said unto him, I am not able to resist or bridle my fancy, I must and will have a wife, and I pray thee give thy consent to it. Suddenly upon these words came such a whirlwind about the Place, that Faustus thought the whole house would have come down, all the doors of the house flew off the hooks : after all this his house was full of smoak, and the floor covered with ashes; which when Dr. Faustus perceived, he would have gone upstairs, and flying up he was taken and thrown down into the hall, that he was not able to stir hand nor foot, then round about him ran a monstrous circle of fire, never standing still, that Faustus cry'd as he lay, and thought there to have been burned. Then cryed he out to his Spirit Mephistophiles for help, promising him he would live, for all this, as he had vowed by his handwriting. Hereupon appeared unto him an ugly devil, so dreadful and monstrous to behold, that Faustus durst not look on him. The devil said, What wouldst thou have, Faustus? How likest thou thy wedding? What mind art thou in now? Faustus answered, he had forgot his promise, desiring of him pardon, and he would talk no more of such things. Thou art best so to do; and so 
vanished from him. After appeared unto him his friar Mephistophiles, with a bell in his hand, and spake to Faustus, It is no jesting with us, hold thou that which thou hast vowed, and we will perform that which we have promised, and more than that, thou shalt have thy heart's desire of what woman soever thou. wilt, be she alive or dead, and so long as thou wilt thou shalt keep her by thee. These words pleased Faustus wonderful well, and repented himself that he was so foolish to wish himself married, that might have any woman in the whole city brought him at his command, the which he practised and persevered in a long time.

\section{CHAPTER X.}

\section{Questions put forth by Dr. Faustus unto his Spirit Mephistophiles.}

DR. FaUstus living in all manner of pleasure that his heart could desire, continuing of his amorous drifts, his delicate fare, and costly apparel, called on a time his Mephistophiles to him, who being come, brought him a book in his hand of all manner of devilish and enchanting arts, the which he gave Faustus, saying, Hold, my Faustus, work now thy heart's desire : the copy of this enchanting book was afterwards found by his servant Christopher Wagner : Well (quoth Faustus to his spirit) I have called thee to know what thou canst do, if I have need of thy help. Then answered Mephistophiles, and said, My lord Faustus, I am a flying spirit, yea, so swift as thought can think, to do whatsoever. Here Faustus said, But how came lord and master Lucifer to have so great a fall from heaven? Mephistophiles answered, My lord Lucifer was a fair angel, created of God as immortal, and being placed in the Seraphims, which are above the Cherubims, he would have presumed upon the Throne of God, with intent to thrust God out of his seat; upon this presumption the Lord cast him down headlong, and where before he was an angel of light, now dwells in darkness, not able to come near his first place, without God send for him to appear before him; as Raphael, unto the lower degree of angels, that have their conver- 
sation with men, he may come, but not unto the second degree of the heavens, that is kept by the arch-angels, namely Michael and Gabriel, for these are called Angels of God's wonders, these are far inferior places to that from whence my lord and master Lucifer fell : and thus far Faustus, because thou art one of the beloved children of the lord Lucifer, following thy mind in manner as he did his, I have shortly resolved thy request, and more I will do for thee at thy pleasure. I thank thee Mephistophiles (quoth Faustus) come, let us now go to rest, for it is night : upon this they left their communication.

\section{CHAPTER XI.}

How Dr. Faustus dreamed that he had seen Hell in his Sleep, and how he questioned with the Spirit of matters concerning Hell, with the Spirit's answer.

THE night following after Faustus's communication with Mephistophiles, as concerning the fall of Lucifer, Dr. Faustus dreamed that he had seen a part of hell, but in what manner it was, or in what place he knew not, whereby he was much troubled in mind, and called unto him Mephistophiles his spirit, saying unto him, I pray thee resolve me in this doubt: What is hell? What substance is it of? In what place stands it? And when was it made? Mephistophiles answered, Faustus, thou shalt know, that before the fall of my lord Lucifer there was no hell, but even then was hell ordained; it is no substance, but a confused thing; for I tell thee, that before all elements were made, or the earth seen, the spirit of God moved upon the waters, and darkness was over all ; but when God said, Let there be light it was at his word, and the light was on God's right hand, and he praised the light. Judge thou farther, God stood in the middle, the darkness was on his left hand, in the which my lord was bound in chains until the day of Judgment: in this confused hell is nought to find but a sulphurish fire, and stinking mist or fog : farther, we devils know not what substance it is of, but a confused thing; for as the 
bubble of water flyeth before the wind, so doth hell before the breath of God: moreover, the devils know not how God hath laid the foundation of our hell, nor where it is : but to be short, Faustus, we know that hell hath neither bottom nor end.

\section{CHAPTER XII.}

The second question put forth by Dr. Faustus to his spirit, what kingdoms were in hell, how many, and what were the rulers names.

FAustus spake again to his spirit, saying, Thou speakest of wonderful things; I pray thee now tell me what kingdoms are there in your hell? How many are there? What they are called? And who rules them? The spirit answered him, My Faustus, know that hell is, as thou wouldst think with thyself, another world, in the which we have our being under the earth, even to the heavens; within the circumference whereof are contained ten kingdoms, namely, I. Lacus Mortis. 2. Stagnum Ignis. 3. Terra Tenebrosa. 4. Tartarus. 5. Terra Oblivionis. 6. Gehenna. 7. Erebus. 8. Barathrum. 9. Styx. 10. Acheron.

The which kingdoms are governed by five kings; that is, Lucifer in the Orient, Belzebub in Septentrio, Belial in Meredie, Ascheroth in the Occident, and Phlegeton in the midst of them all: whose rules and dominions have no end until the day of doom; and thus far, Faustus, hast thou heard of our rule and kingdom.

\section{CHAPTER XIII.}

Another question put forth by Dr. Faustus to his spirit, concerning his lord Lucifer, with the sorrow that Faustus fell afterwards into.

DR. FAUSTUS began again to reason with Mephistophiles, requiring him to tell in what form and shape, and in what estimation his lord Lucifer was, when he was in favour with God: Whereupon his spirit required of him three days respite, which Faustus 
granted. The three days being expired, Mephistophiles gave him this answer: Faustus, my lord Lucifer, (so called now for that he was banished out of the clear light of heaven) was at the first an angel of God, yea he was so of God ordained for shape, pomp, authority, worthiness, and dwelling, that he far exceeded all the other creatures of God, yea, or gold and precious stones ; and so illuminated that he far surpassed the brightness of the sun, and all other stars where God placed him on the cherubims ; he had a kingly office, and was always before God's seat, to the end he might be the more perfect in all his being; but when he began to be high minded, proud, and so presumptuous, that he would usurp the seat of God's Majesty, then was he banished out from amongst the heavenly powers, separated from their abiding, into the manner of a fiery stone, that no water is able to quench, but continually burneth until the end of the world. Dr. Faustus, when he had heard the words of his spirit, began to ponder with himself having divers and sundry opinions in his head, and very pensively, saying nothing to his spirit, he went into his chamber, and laid him on his bed, recording the words of Mephistophiles, which so pierced his heart that he fell into sighing and great lamentation, crying out, Alas! Ah, woe is me! What have I done? Even so shall it come to pass with me : am I not also a creature of God's making, bearing his own image and similitude, into whom he hath breathed the spirit of life and immortality, unto whom he hath made all things living subject: but woe is me! My haughty mind, proud aspiring stomach, and filthy flesh, hath brought my soul into perpetual damnation, yea, pride hath abused my understanding, insomuch that I have forgot my -Maker, the Spirit of God is departed from me ; I have promised the devil my soul, and therefore it is but a folly for me to hope for grace, but it must be even with me as with Lucifer, thrown into perpetual burning fire, ah! woe is me, that ever I was born. In this perplexity lay this miserable Dr. Faustus, having quite forgot his faith in Christ, never falling to repentance truly, thereby to attain the grace and holy spirit of God again, the which wculd have been able to have resisted the strong assaults of 
Satan; for although he had made him a promise, yet he might have remembred, through true repentance sinners may once come again into the favour of God, which faith the faithful firmly hold, knowing they that kill the body are not able to hurt the soul: but he was in all his opinions doubtful, without faith or hope, and so he continued.

\section{CHAPTER XIV.}

Another disputation betwixt Dr. Faustus and his Spirit, of the Power of the Devil, and his Envy to Mankind.

AfTER Faustus had a while pondered and sorrowed with himself on his wretched estate, he called again Mephistophiles unto him, commanding him to tell him the judgment, rule, power, attempts, tyranny and temptation of the devil; and why he was moved to such kind of living? Whereupon the spirit answered to this question, that thou demandest of me will turn thee to no small discontentment, therefore thou shouldst not have desired of me such matters, for it toucheth the secrets of our kingdom, although I cannot deny to resolve thy request : therefore know Faustus, that so soon as my lord Lucifer fell from Heaven, he became mortal enemy both to God and man, and hath used (as now he doth) all manner of tyranny to the destruction of man, as is manifested by divers examples : one falling suddenly dead, another hangs himself, another drowns himself, others stab themselves, others unlawfully despair, and so come to utter confusion : the first Adam, that was made perfect to the similitude of God, was by my lord's policy, the whole decay of man; yea, Faustus, in him was the beginning and first tyranny of my lord Lucifer to man; the like did he with Cain, the same with the children of Israel when they worshipped strange gods, and fell to whoredom with strange women; the like with Saul, so did he by the seven husbands of her that after was the wife of Tobias ; likewise Dagon our fellow brought to destruction fifty thousand men, whereupon the ark of God was stoln, and Belial made David to number his men, whereupon were slain sixty thousand. Also he deceived King Solomon, that worshipped 
the gods of the heathen : and there are such spirits innumerable, that can come by men, and tempt them, and drive them to sin, and weaken their belief; for we rule the hearts of kings and princes, stirring them up to war and bloodshed, and to this intent do we spread ourselves through all the world, as the utter enemies of God and his son Christ, yea, and all that worship them, and that thou knowest by thyself Faustus. How have we dealt by thee? To this said Faustus, Then thou didst also beguile me? I did what I could to help thee forward, for as soon as I saw how thy heart did despise thy degree taken in divinity, and didst study to search and know the secrets of our kingdom, then did I enter into thee, giving thee divers foul and filthy cogitations, pricking thee forward in thy intent, persuading thee thou couldst never attain to thy desire, till thou hadst the help of some devil; and when thou wast delighted in this, then took I root in thee, and so firmly, that thou gavest thyself to us both body and soul, which thou canst not deny. Hereat answered Faustus, thou sayst true, I cannot deny it. Ah, woe is me, most miserable Faustus! How have I been deceived? Had I not had a desire to know too much, I had not been in this case; for having studied the lives of the holy saints and prophets, and thereby thought to understand sufficient heavenly matters, I thought myself not worthy to be called Dr. Faustus, if I should not also know the secrets of hell, and be associated with the furious fiends thereof; now therefore must I be rewarded accordingly. Which speeches being uttered, Faustus went very sorrowful away from his spirit.

\section{CHAPTER XV.}

How Dr. Faustus desired again of his Spirit, to know the Secrets and Pains of Hell; and whether those damned Devils and their Company, might ever come to the Favour and Love of God again.

Dr. Faustus was pondering with himself how he might get loose from so damnable an end as he had given himself unto, both soul and body : but his repenting was like that of Cain and 
Judas, he thought his sin greater than God could forgive; hereupon resting his mind, he lookt up to heaven, but saw nothing therein, for his heart was so possessed of the devil, that he could think of nought else but of hell, and the pains thereof. Wherefore in all haste he called unto him his spirit Mephistophiles, desiring him to tell him some more of the secrets of hell; what pain the damned are in? And how they were tormented? And whether the damned souls might get again the favour of God, and so be released out of their torments or not. Whereupon the spirit answered, My Faustus, thou may'st well leave to question any more of such matters, for they will but disquiet thy mind; I pray thee, what meanest thou, thinkest thou through these thy fantasies to escape us? No, for if thou shouldest climb up to heaven, there to hide thyself, yet would I thrust thee down again; for thou art mine, and thou belongest to our society: Therefore, sweet Faustus, thou wilt repent this thy foolish demand, except thou be content that I shall tell thee nothing. Quoth Faustus, ragingly, I will know, or I will not live, wherefore despatch and tell me; to whom Mephistophiles answered, Faustus, it is no trouble unto me at all to tell thee; and therefore since thou forcest me thereto, I will tell thee things to the terror of thy soul, if thou wilt abide the hearing: thou wilt have me to tell thee of the secrets of hell, and of the pains thereof : know, Faustus, that hell hath many figures, semblances and names; but it cannot be named or figured in such sort to the living that are damned, as it is to those that are dead, and do both see and feel the torments thereof: for hell is said to be deadly, out of which came never any to life again but one, but he is nothing for thee to reckon upon; hell is blood-thirsty, and is never satisfied; hell is a valley into which the damned souls fall; for so soon as the soul is out of man's body, it would gladly go to the place from whence it came, and climbeth up above the highest hills, even to the heavens, where being by the angels of the first model denied entertainment, (in consideration of their evil life spent on earth) they fall into the deepest pit or valley, that hath no bottom, into a perpetual fire which shall never be 
quenched; for like as the flint thrown in the water loseth not vertue, neither is the fire extinguished; even so the hellish fire is unquenchable: and even as the flint-stone in the fire burns red-hot, and consumeth not, so likewise the damn'd souls in our hellish fire are ever burning, but their pain never diminishing: therefore is hell called the everlasting pain, in which is never hope for mercy: so it is called utter darkness, in which we see neither the light, the sun, moon, nor stars; and were our darkness like the darkness of night, yet were there hope of mercy; but ours is perpetual darkness, clean exempt from the face of God. Hell hath also a place within it, called Chasma, out of which issueth all manner of thunders and lightnings, with such shriekings and wailings, that oftentimes the very devils themselves stand in fear thereof. For one while it sendeth forth wind, with exceeding snow, hail and rain, congealing the water into ice: with the which the damned are frozen, gnash their teeth, howl and cry, yet cannot die.

Other whiles, it sendeth forth most horrible hot mists, or fogs, with flashing of flames of fire and brimstone; wherein the sorrowful souls of the damned lie broiling in their reiterated torments : yea, Faustus, hell is called a prison, wherein the damned lie continually bound ; it is called Pernicies and Exitium, death, destruction, hurtfulness, mischief, a mischance, a pitiful and evil thing, world without end. We have also with us in hell a ladder, reaching of exceeding highth, as though the top of the same would touch the heaven, to which the damned ascend to seek the blessing of God, but through their infidelity, when they are at very highest degree, they fall down again into their former miseries, complaining of the heat of that unquenchable fire: yea, sweet Faustus, so much understand thou of hell, the while thou art desirous to know the secrets of our kingdom. And mark, Faustus, hell is the nurse of death, the heat of fire, the shadow of heaven and earth, the oblivion of all goodness; the pains unspeakable, the griefs unremovable, the dwelling of the devils. Dragons, serpents, adders, toades, crocodiles, and all manner of venemous and noisome creatures; the puddle of sin, the stinking far 
ascending from the Stygian lake, brimstone, pitch, and all manner of unclean metals, the perpetual and unquenchable fire, the end of whose miseries was never purposed by God : yea, yea, Faustus thou sayest I shall, I must, nay, I will tell thee the secrets of our kingdom, for thou buyest it dearly, and thou must and shall be partaker of our torments, that (as the Lord said) shall never cease, for hell, the woman's belly, and the earth, are never satisfied, there shalt thou abide horrible torments, howling, crying, burning, freezing, melting, swimming in a labyrinth of miseries, scolding, smoaking in thine eyes, stinking in thy nose, hoarseness in thy speech, deafness in thy ears, trembling in thy hands, biting thine own tongue with pain, thy heart crushed as with a press, thy bones broken, the devils tossing fire-brands unto thee: yea, thy whole carkase tossed upon muck-forks from one devil to another ; yea, Faustus, then wilt thou wish for death, and he will fly from thee, thine unspeakable torments shall be every day augmented more and more, for the greater the sin the greater is the punishment; how likest thou this, my Faustus? A resolution answerable to thy request.

Lastly, Thou wilt have me tell thee that which only belongeth to God, which is, if it be possible for the damned to come again into the favour of God, or not; why, Faustus, thou knowest that this is against thy promise; for why shouldest thou desire to know that having already given thy soul to the devil, to have the pleasure of the world, and to know the secrets of hell; therefore thou art damned, and how canst thou then come again to the favour of God; wherefore I discreetly answer no ; for whomso ever God hath forsaken and thrown into hell, must there abide his wrath and indignation, in that unquenchable fire, where is no hope of mercy to be looked for, but abiding his perpetual pains, world without end : for even as much it availeth thee, Faustus, to bope for the favour of God again, as Lucifer himself; who indeed, although he and we have a hope, yet it is to small avail, and taketh none effect, for out of that place God will neither hear crying nor singing ; if he do thou shalt have a little remorse, as Dives, Cain, and Judas had. What helpeth the emperor, king, prince, duke, 
sarl, baron, lord, knight, esquire, or gentlemen, to cry for mercy being there? Nothing, for if on earth they would not be tyrants and self-willed, rich with covetousness, proud with pomp, gluttons, drunkards, whoremongers, backbiters, robbers, murtherers, blasphemers, and such like, then were there some hope to be looked for; therefore my Faustus, as thou comest to hell with these qualities, thou mayest say with Cain my sins are greater than can be forgiven, go hang thyself with Judas : and lastly, be contented to suffer torments with Dives. Therefore know Faustus, that the damned have neither end nor time appointed, in the which they may hope to be released; for if there were any such hope that they by throwing one drop of water out of the sea in a day, until it were dry, or there were one heap of sand, as high as from the earth to the heavens, that a bird carrying away but one corn in a day, at the end of this so long labour, that yet they might hope at the last God would have mercy on them, they would be comforted; but now there is no hope, that God once thinks upon them, or that their howling shall ever be heard; yea, so impossible it is for thee to hide thy self from God, as it is impossible for thee to remove the mountains, or to empty the sea, or to tell the drops of rain that have fallen from heaven until this day, or to tell what there is most of in the world: yea, and as for a camel to go through the eye of a needle, even so impossible it is for thee, Faustus, and the rest of the damned, to come again into the favour of God? and thus Faustus hast thou heard my last sentence, and I pray thee, how dost thou like it? but know this, that I counsel thee to let me be unmolested hereafter with such disputations, or else will I vex thee every limb to thy small contentment. Dr. Faustus parted from his spirit very pensive and sorrowful, laying him on his bed, altogether doubtful of the grace and favour of God, wherefore he fell into fantastical cogitations : fain he would have had his soul at liberty again, but the devil had so blinded him, and had taken such deep root in his heart, that he could never think to crave God's mercy; or if by chance he had any good motion, streightways the devil would thrust in a fair lady into his chamber, which fell to kissing and 
dalliance with him; through which means he threw the godly motions in the wind, going forward still in his wicked practice, to the utter ruin both of body and soul.

\section{CHAPTER XVI.}

Another Question put forth by Dr. Faustus to his Spirit Mephistophiles of his own Estate.

DR. FAUSTUS being yet desirous to hear more strange things, called his spirit unto him, saying, my Mephistophiles, I have yet another suit unto thee, which I pray thee deny me not to resolve me of. Faustus (quoth the spirit) I am loath to reason with thee any further, for thou art never satisfied in thy mind, but always bringest me a new : yet I pray thee this once (quoth Faustus) do me so much favour as to tell me the truth in this matter, and hereafter I will be no more so earnest with thee. The spirit was altogether against it: but yet once more he would abide him. Well (said the spirit to Faustus) what demandest thou of me. Faustus said, I would gladly know of thee if thou wert a man in manner and form as I am, what wouldest thou do to please both God and man? Whereat the spirit smiled, saying, my Faustus, if I was a man as thou art, and that God had adorned me with those gifts of nature which thou once hadst, even so long as the breath of God were by and within me, would I humble my self unto his majesty, endeavouring all that I could to keep his commandments, praise him and glorifie him, that I might continue in his favour, so were I sure to enjoy the eternal joy, and felicity of his kingdom. Faustus said, but that I have not done. No, thou sayest truth, quoth Mephistophiles, thou hast not done it; but thou hast denyed the Lord thy Maker, which gave thee the breath of life, speech, hearing, sight, and all other thy reasonable senses, that thou mightest understand his will and pleasure, to live to the glory and honour of his name, and to the advancement of thy body and soul : him, I say, being thy Maker, hast thou 
denyed and defied, yea, wickedly hast thou applied that excellent gift of understanding, and given thy soul to the devil, therefore give none the blame but thine own self-will, thy proud and aspiring mind, which hath brought thee unto the wrath of God and utter damnation. This is most true (quoth Faustus) but tell me Mephistophiles, wouldst thou be in my case as I am now? yea saith the spirit (and with that fetch'd a great sigh) for yet I would so humble my self, that I would win the favour of God. Then, said Dr. Faustus, it were time enough for me, if I amended. True, said Mephistophiles, if it were not for thy great sins, which are so odious and detestable in the sight of God, that it is too late for thee, for the wrath of God resteth upon thee. Leave off (quoth Faustus) and tell me my question to my greater comfort.

\section{CHAPTER XVII.}

Here followeth the Second Part of Dr. Faustus, his Life and Practices, until his End.

DR. FAUSTUS having received denial of his spirit to be resolved any more in such questions propounded, forgot all good works, and fell to be a kalender-maker by the help of his spirit, and also in short time to be a good astronomer or astrologian : he had learned so perfectly of his spirit the course of the sun, moon, and stars, that he had the most famous name of all the mathematicians that lived in his time, as may well appear by his works dedicated unto sundry dukes and lords, for he did nothing without the advice of his spirit, which learned him to presage of matters to come, which have come to pass since his death. The like praise won he with his kalenders and almanacks-making; for when he presaged of any thing, operations, and alterations of the weather or elements, as wind, rain, fogs, snow, hail, moist, dry, warm, cold, thunder, lightning, it fell so duly out, as if an angel of heaven had forewarned it. He did not, like the unskilful astronomers in our time, that set in winter, cold moist air, frosty, and in the dog days, hot, dry, thunder, fire, and such like; but he 
set in all his works, the day and hour, when, where, and how it should happen. If any wonderful thing were at hand, as mortality, famine, plague, wars, he would set the time and place, in true and just order, when it would come to pass.

\section{CHAPTER XVIII.}

\section{$A$ Question put forth by Dr. Faustus to his Spirit, concerning Astronomy.}

Now Faustus falling to practice, and making his prognostications, he was doubtful in many points; wherefore he called unto him Mephistophiles his spirit, saying, I find the ground of the science very difficult to attain unto; for when that I confer Astronomia and Astrologia, as the mathematicians and ancient writers have left in memory, I find them vary, and very much to disagree: wherefore I pray thee to teach me the truth of this matter. To whom his spirit answered, Faustus, thou shalt know, that the practitioners or speculators, or at least the first inventors of these arts, have done nothing of themselves certain, whereupon thou mayest attain to the true prognosticating or presaging of things concerning the heavens, or of the influence of the planets; for if by chance some one mathematician or astronomer have left behind him any thing worthy of memory, they have so blinded it with ænigmatical words, blind characters, and such obscure figures, that it is impossible for any earthly man to attain the knowledge thereof, without the aid of some spirits, or else the special gift of God, for such as are the hidden works of God from men, yet do we spirits, that fly and fleet all elements, know such ; and there is nothing to be done, or by the heavens portended, but we know it, except only the day of doom. Wherefore, Faustus learn of me, I will teach thee the course and re-course of the planets, the cause of winter and summer, the exaltation and declination of the sun, and eclipse of the moon, the distance and highth of the poles and every fixed star, the nature and opposition of the elements, fire, air, water, and earth, and all that is con- 
tained in them, yea, herein there is nothing hidden from me, but only the filthy essence which once thou hadst, Faustus, at liberty, but now thou hast lost it past recovery; therefore leaving that which will not be again had, learn now of me to make thunder, lightning, hail, snow, and rain, the clouds to rend the earth, and craggy rocks to shake and split in sunder, the seas to swell and roar, and over-run their marks ; knowest thou not that the deeper the sun shines, the hotter it pierces; so the more thy art is famous whilst thou art here, the greater shall be thy name when thou art gone. Knowest thou not that the earth is frozen, cold, and dry ; the water rumning, cold and moist, the air flying, hot and moist; the fire consuming hot and dry : yea, Faustus, so must thy heart be inflamed like the fire to mount on high : learn, Faustus, to fly like my self, as swift as thought from one kingdom to another, to sit at princes' tables, to eat their dainty fare, to have thy pleasure of their ladies, wives and concubines; to use all their jewels and costly robes, as things belonging unto thee, and not unto them: learn of me, Faustus, to run through walls, doors, and gates of stone and iron, to creep into the earth like a worm, or swim in the water like a fish; to fly in the air like a bird, and to live and nourish thyself in the fire like a salamander; so shalt thou be famous, renowned, far spoken of, and extolled for thy skill, going on knives not hurting thy feet, carrying fire in thy bosom and not burning thy shirt : seeing through the heavens, as through a crystal, wherein is placed the planets, with all the rest of the presaging comets, the whole circuit of the world from east to west, north and south : there shalt thou know, Faustus, whereof the fiery sphere above, and the signs of the Zodiack doth not burn and consume the whole face of the earth, being hindered by placing the two moist elements between them, the airy clouds and wavering waves of water: yea, Faustus, I will learn thee the secrets of nature, what the cause is, that the sun in summer, being at the highest, giveth all his heat downwards on the earth; and being winter at the lowest, giveth all his heat upwards into the heavens, that the snow should be of so great vertue as the honey, ard the Lady Saturnia in Occulto, more hot than the sun in 


\section{THE FAMOUS HISTORY OF DOCTOR FAUSTUS.}

manifesto. Come on, my Faustus, I will make thee as perfect in these ways as my self, I will learn thee to go invisible, to find out the mines both of gold and silver, the fodines of precious stones, as the carbuncle, the diamond, saphire, emerald, ruby, topas, jacinth, granat, jaspies, amethyst; use all these at thy pleasure, take thy heart's desire : thy time Faustus weareth away, then why wilt thou not take thy pleasure of the world? Come up, we will go unto kings at their own courts, and at their most sumptuous banquets be their guests; if willingly they invite us not, then by force we will serve our own turn with their best meat and daintiest wine. Agreed, quoth Faustus, but let me pause a while upon this thou hast even now declared unto me.

\section{CHAPTER XIX.}

How Dr. Faustus fell into despair with himself, for having put a Question unto his Spirit, they fell at Variance, whereupon the Rout of Devils appeared unto him, threatning him sharply.

DR. FAUSTUS resolved with himself the speeches of his spirit, and became so woful and sorrowful in his cogitations, that he thought himself already frying in the hottest flame of hell ; and lying in this muse, suddenly there appeared unto him his spirit, demanding what thing so grieved and troubled his conscience? Whereat Dr. Faustus gave no answer; yet the spirit lay very earnestly upon him to know the cause, and if it were possible he would find a remedy for his grief, and ease him of his sorrows. To whom Faustus answered, I have taken thee unto me as a servant to do my service and thy service will be very dear unto me; yet I cannot have any diligence of thee farther than thou list thyself, neither dost thou in any thing as it becometh thee. The spirit replyed, My Faustus, thou knowest that I was never against thy commandment as yet, but ready to serve and resolve thy questions, although I am not bound unto thee in such respects as concern the hurt of our kingdom; yet was. I always willing to answer thee, and so am I still: therefore my Faustus, say on boldly, what is 
thy will and pleasure? At which words the spirit stole away the heart of Faustus, who spake in this sort: Mephistophiles, tell me how and after what sort God made the world, and all the creatures in it? And why man was made after the image of God? The spirit hearing this, answered Faustus, Thou knowest that all this is in vain for thee to ask: I know that thou art sorry for what thou hast done, but it availeth thee not; for I will tear thee in a thousand pieces if thou change not thy opinions, and hereat he vanished away. Whereat Faustus, all sorrowful that he had put forth such a question, fell to weeping and to howling bitterly, not for his sins towards God, but that the devil was departed from him so suddenly in such a rage. And being in this perplexity, he was suddenly taken with such extream cold, as if he would have frozen in the place where he sate, in which the greatest devil in hell appeared unto him, with certain of his hideous and infernal company, in most ugly shapes, that it was impossible to think upon; and traversing the chamber round about where Faustus sate, Faustus thought to himself, Now are they come for me, though my time be not come, and that, because I have asked such questions of my servant Mephistophiles: at whose cogitations the chiefest devil, which was the lord unto whom he gave his soul, that was Lucifer, spake in this sort: Faustus, I have seen thy thoughts, which are not as thou hast vowed unto me, by the virtue of this letter; and shewed him the obligation, which he had written with his own blood; wherefore I am come to visit thee, and to shew thee some of our hellish pastimes, in hope that will draw and confirm thy mind a little more stedfast unto us. Content (quoth Faustus) go to, let me see what pastime you can make. At which words the great devil in his likeness, sate him down by Faustus, commanding the rest of his devils to appear in the form as if they were in hell. First entered Belial in form of a bear, with curled black hair to the ground, his ears standing upright; within his ears were as red as blood, out of which issued flames of fire, his teeth were at least a foot long, and as white as snow, with a tail three ells long, at the least, having two wings, one behind each 
arm; and thus one after another they appeared to Faustus in form as they were in hell. Lucifer himself sate in a manner of a man all hairy, but of brown colour like a squirrel, curled, and his tail turning upwards on his back as the squirrels use, I think he could crack nuts too like a squirrel. After him came Belzebub in curled hair of a horse-flesh colour, his head like the head of a bull, with a mighty pair of horns, and two long ears down to the ground, and two wings on his back, with two pricking things like horns; out of his wings issued flames of fire, his tail was like a cow's. Then came Astaroth in the form of a worm, going upright on his tail, and had no feet, but a tail like a glow-worm, under his chops grew two short hands, and his back was coleblack, his belly thick in the middle, yellow, like gold, having many bristles on his back like a hedge-hog. After him came Cannagosta, being white and grey mixed, exceeding curled and hairy, he had a head like the head of an ass, and a tail like a cat, and claws like an ox, lacking nothing of an ell broad. Then came Anobis; this devil had a head like a dog, white and black hair, in shape like a hog, saving that he had but two feet, one under his throat, the other at his tail ; he was four ells long, with hanging ears like a blood-hound. After him came Dithican : he was a short thief, in form of a large bird, with shining feathers, and four feet; his neck was green, and body red, and his feet black. The last was called Brachus, with very short feet, like a hedgehog, yellow and green, the upper side of his body was brown, and the belly like blue flames of fire, the tail red like the tail of a monkey. The rest of the devils were in form of unreasonable beasts, as swine, harts, bears, wolfs, apes, buffes, goats, antelopes, elephants, dragons, horses, asses, lions, cats, snakes, toads, and all manner of ugly odious serpents and worms; yet came in such sort that every one at his entry into the hall, made their reverence unto Lucifer, and so took their places, standing in order as they came until they had fill'd the whole hall, wherewith suddenly fell a most horrible thunder-clap, that the house shook as if it would have fall'n unto the ground; upon which every monster had a muck-fork in his hand, holding them 
towards Faustus, as tho" they would have run a tilt at him: which when Faustus perceived, he thought upon the words of Mephistophiles, when he told him how the souls in hell were tormented, being cast from devil to devil upon muck-forks, he thought verily to have been tormented there by them in like sort : but Lucifer perceiving his thought, spake to him, My Faustus, how likest thou this crew of mine? Quoth Faustus, Why came you not in another manner of shape? Lucifer reply'd, We cannot change our hellish form, we have shewed ourselves here as we are there; yet can we blind men's eyes in such sort, that when we will, we appear unto them as if we were men or angels of light, although our dwelling be in darkness. Then said Faustus, I like not so many of you together. Whereupon Lucifer commanded them to depart, except seven of the principal, forthwith they presently vanished, which Faustus perceiving, he was somewhat better comforted, and spake to Lucifer, where is my servant Mephistophiles, let me see if he can do the like. Whereupon came a fierce dragon flying, and spitting fire round about the house, and coming towards Lucifer, made reverence, and then changed himself to the form of a friar, saying, Faustus, what wilt thou? Faustus said, I will that thou teach me to transform myself in like sort, as thou and the rest have done. Then Lucifer put forth his paw and gave Faustus a book, saying, Hold, do what thou wilt, which he looking upon, straightways changed himself into a hog, then into a worm, then into a dragon, and finding thus for his purpose it liked him well. Quoth he to Lucifer, And how cometh it that so many filthy forms are in the world? Lucifer answered, they are ordained of God, as plagues unto men, and so shait thou be plagued, quoth he; whereupon came scorpions, wasps, emets, bees, and gnats, which fell to stinging and biting him, and all the whole house was filled with a most horrible stinking fogg, insomuch that Faustus saw nothing, but still was tormented; wherefore he cryed for help, saying, Mephistophiles, my faithful servant, where art thou? Help, help, I pray thee. Hereat the spirit answered nothing, but Lucifer himself said, Ho, ho, ho, Faustus, how likest 
thou the creation of the world? And incontinent it was clear again, and the devils and all the filthy cattel were vanished, only Faustus was left alone seeing nothing, but hearing the sweetest musick that ever he heard before, at which he was so ravished with delight, that he forgot his fears he was in before, and it repented him that he had seen no more of their pastime.

\section{CHAPTER XX.}

\section{Hou' Dr. Faustus desired to see Hell, and of the Manner how he was used therein.}

DR. Faustus bethinking how his time went away, and how he had spent eight years thereof, he meant to spend the rest to his better contentment, intending quite to forget any such motions as might offend the devil any more: wherefore on a time he called his spirit Mephistophiles, and said unto him, Bring thou hither unto me thy Lord Lucifer or Belial; he brought him (notwithstanding) one that was called Belzebub, the which asked Faustus his pleasure? Quoth Faustus, I will know of thee if I might see hell, and take a view thereof? That thou shalt said the Devil, and at midnight I will fetch thee. Well, night being come, Dr. Faustus waited very diligently for the coming of the devil to fetch him, and thinking that he tarried too long, he went to the window, where he pulled open a casement, and looking into the element, he saw a cloud in the north more black, and darker, and obscurer than all the rest of the skie, from whence the wind blew most horribly right into Faustus's chamber, and filled the whole house with smoak, that Faustus was almost smothered; hereat fell an exceeding thunder-clap, and withal came a great rugged black Bear all curled, and upon his back a chair of beaten gold, and spake to Faustus, saying, Sir, up and away with me: and Dr. Faustus that had so long abode the smoak, wished rather to be in hell than there, got on the devil, and so they went on together. Mark how the devil blinded him, and made him believe he carried him into hell, for he 
carried him into the lake, where Faustus fell into a sound sleep, as if he had sate into a warm water or bath : at last they came to a place which burneth continually with flashing flames of fire and brimstone, wherout issued an exceeding mighty clap of thunder ; with so horrible a noise that Faustus awaked; but the devil went forth on his way, and carried Faustus therein, yea, notwithstanding however it burnt, Dr. Faustus felt no more heat then as it were the glimps of the sun in May, there heard he all manner of music to overcome him, but saw none playing on them; it pleased him well, but he durst not ask, for he was forbidden it before. To meet the devil and the guest that came with him came three other ugly devils, the which ran back again before the bear, to make the way; against whom there came running an exceeding great hart, which would have thrust Faustus out of the chair; but being defended by the other three devils, the hart was put to the repulse: thence going on the way, Faustus looked, and behold there was nothing but snakes, and all manner of venomous beasts about him, which were exceeding great: unto the which snakes came many storks, and swallowed up the whole multitude of snakes, that they left not one: which when Faustus saw, he marvelled greatly; but proceeding farther on their hellish voyage, there came forth out of an hollow clift an exceeding great flying bull, the which with such a force hit Faustus's chair with his head and horns, that he turned Faustus and his bear over and over, so that the bear vanished away: whereat Faustus began to cry, Oh! woe to me that ever I came here! For he thought there to have been beguiled of the devil; and to make an end before his time appointed or conditioned of the devil: but shortly after came to him a monstrous ape, bidding Faustus to be of good chear, and said, Get upon me. All the fire in hell seemed to Faustus to have been put out, whereupon followed a monstrous thick fog, that he saw nothing, but shortly after it seemed to him to wax clear, where he saw two great dragons fastned unto a waggon, in the which the ape ascended and set Faustus therein; forth flew the dragons into an exceeding dark cloud, where Faustus saw neither dragons nor chariot wherein 
he sate, and such were the cries of tormented souls, with mighty thunder-claps, and flashing lightnings about his ears, that poor Faustus shook for fear; upon this they came to a water, stinking and filthy, thick like mud, into the which ran the dragons, sinking. under with waggon and all, but Faustus felt no water but as it were a small mist, saving that the waves beat so sore upon him, that he saw nothing under or over him but only water, in the which he lost his dragons, ape, and waggon; and sinking yet deeper and deeper, he came at last as it were upon a high rock, where the waters parted and left him thereon: but when the water was gone, it seemed to him he should there have ended his life, for he saw no way but death; the rock was so high from the bottom as heaven is from the earth: there sate he, seeing nor hearing any man, and looked ever upon the rock: at length he saw a little hole out of which issued fire; thought he, how shall I now do? I must either fall to the bottom or burn in the fire; or sit in despair. With that in his madness he gave a skip into the fire hole, saying, Hold, you infernal hags, take here this sacrifice as my last end, that which I have justly deserved. Upon this he was entred, and finding himself as yet unburned or touched of that fire, he was the better appayed. But there was so great a noise that he never heard the like before, it passed all the thunder that ever he had heard. And coming down farther to the bottom of the rock, he saw a fire wherein were many worthy and noble personages, as emperors, kings, dukes, and lords, and many thousand more tormented souls, at the edge of which fire ran a most pleasant, clear, and cold water to behold; into the which many tormented souls sprang out of the fire to cool themselves, but being so freezing cold, they were constrained to return again into the fire, and thus wearied themselves and spent their endless torments out of one labyrinth into another, one while in heat, another while in cold : but Faustus, standing here all this while gazing on them that were thus tormented, he saw one leaping out of the fire, shrieking horribly, whom he thought to have known, wherefore he would fain have spoken unto him, but remembring he was forbidden, he refrained speaking. Then 
this devil that brought him in, came to him again in likeness of a bear, with the chair on his back, and bid him set up, for it was time to depart: so Faustus got up, and the Devil carried him out into the air, where he had so sweet musick, that he fell asleep by the way. His boy Christopher, being all this while at home, and missing his master so long, thought his master would have tarried and dwelt with the devil for ever: but whilst the boy was in these cogitations, his master came home: for the devil brought him home fast asleep as he sate in his chair, and threw him on his bed, where (being thus left of the devil) he lay until day. When he awaked, he was amazed, like a man that bad been in a dark dungeon; musing with himself, if it were true or false that he had seen hell, or whether he was blinded or not; but he rather perswaded himself he had been there than otherwise; because he had seen such wonderful things; wherefore he most carefully took pen and ink, and wrote those things in order as he had seen; which writing was afterwards found by his boy in his study; which afterwards was published to the whole city of Wittenburg in print, for example to all christians.

\section{CHAPTER XXI.}

How Dr. Faustus was carried through the Air, up to the Heavens to see the whole World, and how the Skie and Planets ruled; after the which he wrote a Letter to his Friend of the same to Liptzig, and how he went about the World in eight Days.

THis letter was found by a freeman and citizen of Wittenburg, written with his own hand, and sent to his friend at Liptzig a physician, named Love Victori, the contents of which were as followeth: Amongst other things (my beloved friend and brother) I remember yet the former friendship we had together when we were school-fellows, and students in the university at Wittenburg, whereas you first studied physick, astronomy, astrology, geometry, and cosmography, I to the contrary, you know, studied divinity, notwithstanding now in any of your own studies, I am sure I 
have proceeded farther than your self; for since I began I have never erred, for might I speak it without affecting mine own praise, my kalenders and other practices have not only the commendations of the common sort, but also the chiefest lords and nobles of this our Dutch nation, because (which is chiefly to be noted) I write and presage of matters to come, which all accord and fall out so right, as if they had already been before. And for thee (my beloved Victori) you write to know my voyage which I made unto the heavens, the which (as you certifie me) you have had some suspicion of, although you partly perswade your self that it is a thing impossible; no matter for that, it is as it is, and let it be as it will, once it is done in such a manner as now according unto your request, I will give you here to understand : I being once laid in my bed, and I could not sleep for thinking on my kalender and practice, I marvell'd with myself how it were possible that the firmament should be known, and so largely written of by men, or whether they write true or false, by their own opinions and suppositions, or by due observation and true course of the heavens : behold, I thought my house would have been blown down, so that all my doors and chests flew open, whereat I was not a little astonished, for withal I heard a groaning voice, which said, Get up, the desire of thy heart, mind, and thought thou shalt see. At the which I answered, What my heart desireth that would I fain see, and to make proof if I shall see, I will away with thee. Why then, quoth he, look out the window, there cometh a messenger for thee. That did I, and behold there stood a waggon with two dragons before it to draw the same, and all the waggon was of a light burning fire, and for that the moon shone I was the willinger at that time to depart; but the voice spoke again, sit up, and let us away. I will (said I) go with thee, but upon condition, that I may ask after all things that I see, hear, or think on. The voice answered, I am content for this time. Hereupon I got me into the waggon, so that the dragons carried me up right into the air.

The waggon had four wheels, the which rattled so, and made such a noise, as if it had been all this while running on the stones, 
and round about us flew flames of fire; and the higher that I came, the more the earth seemed to be darken'd, so that methought I came out of a dungeon; and looking down from heaven, behold Mephistophiles my spirit and servant was behind me, and when he perceived that I saw him, he came and sate by me, to whom I said, I pray thee Mephistophiles, whither shall I go now? Let not that trouble thy mind (said he), and yet they carried us higher up. And now I will tell thee (good friend and schoolfellow) what things I have seen and proved; for on the Tuesday I went out, and on Tuesday seven nights following I came home again, that's eight days, in which time I slept not, no not one wink came within my eyes : and we went invisible of any man; and as the day began to appear, after the first night's journey, I said to my spirit Mephistophiles, I pray thee how far have we now ridden? I am sure thou knowest, for methinks we have ridden exceeding far, the world seemeth so little. Mephistophiles answered me, My Faustus believe me, that from the place from whence thou camest unto this place where we now are, is already forty-seven leagues right in heighth. And as the day increased, I looked down into the world, Asia, Europe, and Africa I had a sight of : and being so high, quoth I to my spirit, tell me how those kingdoms lie, and what they are called? The which he denied not, saying, See this on our left hand is Hungaria, this is also Prussia on our left hand, and Poland, Muscovia, Tartary, Silesia, Bohemia, Saxony ; and here on our right hand, Spain, Portugal, France, England, and Scotland; then right on before us lie the kingdoms of Persia, India, Arabia, the king of Althar, and the great Cham: now we are come to Wittenburg, and are right over the town of Weim, in Austria, and ere long we will be at Constantinople, Tripoli, and Jerusalem, and after will we pierce the frozen Zone, and shortly touch the horizon and the zenith of Wittenburg. There looked I on the ocean sea. and beheld a great many ships and galleys ready to battle one against another: and thus I spent my journey, and I cast my eyes here, now there, towards south, north, east, and west : I have been in one place where it rained and hailed, and in another 
where the sun shone excellent fair, and so I think that I saw most things in and about the world, with great admiration, that in one place it rained, and in another hail and snow: on this side the sun shone bright, some hills cover'd with snow never consuming, others. were so hot that grass and trees were burned, and consumed therewith. Then looked I up to the heavens, and behold they went so swift, that I thought they would have sprung into thousands : likewise it was so clear and so hot, that I could nnt gaze upon it, it so dimmed my sight; and had not my spirit Mephistophiles covered me, as it were with a shadowing cloud, I had been burnt with the extream heat hereof: for the skie which we behold here, when we look up from the earth, is so fast and thick as a wall, clear and shining bright as chrystal, in which is placed the sun, which casteth forth his rays and beams over the whole world, to the uttermost confines of the earth. But we think that the sun is very little, no, it is altogether as big as the world: indeed the body substantial is but little in compass, but the rays or streams that it casteth forth by reason of the thing wherein it is placed, maketh him to extend and shew himself all over the whole world, and we think that the sun runneth his course, and that the heavens stand still; no, it is the heavens that moves his course, and the sun abideth perpetually in his place, he is permament and fixed in his place, and although we see him beginning to ascend in the orient or east, at the highest in the meridian or south, setting in occident or west, yet is he in the lowest in septentrio or north, and yet he moveth not, it is the axle of the heavens that moveth, the whole firmament, being a chaos or confused thing, and for that proof I will shew this example: like as thou seest a bubble made of water and soap blown out of a quill, it is in form of a confused mass or chaos, and being in this form is moved at pleasure of the wind which runneth round about that chaos, and moveth him also round, even so the whole firmament or chaos, wherein are placed the sun, and the rest of the planets, is turned and carried at the pleasure of the spirit of God, which is wind: yea, Christian reader, to the glory of God, and to the profit of 
my soul, I will open unto thee a divine opinion touching the rule of this confounded chaos, far more than my rude German author, being possessed with the devil, was able to utter, and prove some of my sentences before to be true, look into Genesis, into the works of God, at the creation of the world, there shalt thou find that the spirit of God moved upon the water, before heaven and earth were made. Mark how he made it, and how by his word every element took his place; these were not his works but his words, for all the words he used before, concluded afterwards in one work, which was in making man : mark reader with patience, for thy soul's health, see into all that was done by the word and work of God; light and darkness was, the firmament stood, and the great and little light in it : the moist waters were in one place, the earth was dry, and every element brought forth according to the word of God. Now follow his works : he made man after his own image. How? Out of the earth. The earth will shape no image without water; there was one of the elements; but all this while there was wind: all elements were at the word of God; man was made, and in a form by the work of God, yet moved not that work before God had breathed the spirit of life into his nostrils, and made him a living soul : here was the first wind and spirit of God, out of his own mouth, which we have likewise from the same seed which was only planted by God in Adam : which wind, breath, or spirit, when he had received, he was living and moved on earth; for it was ordain'd of God for his habitation, but the heavens are the habitation of the Lord: and like as I shewed before of the bubble or confused chaos made of water and soap, thro' the wind and breath of man is turned round, and carried with the wind; even so the firmaments wherein the sun and the rest of planets are fixed, be moved, turned, and carried with the wind, breath, and spirit of God; for the heavens and firmaments are moveable as the chaos, but the sun is fixed in the firmament. And farther (my good schoolfellow), I was thus nigh the heavens, where methought every planet was but as half the earth, and under the firmament ruled the spirits in the air : as I came down, 
I looked upon the world and heavens, and methought that the earth was inclosed (in comparison) within the firmament as the yolk of an egg within the white, methought that the whole length of the earth was not a span long, and the water was as it had been twice as broad and as long as the earth : even thus at eight days end I came home again, and fell asleep, and so I continued sleeping three days and three nights together, and the first hour I waked, fell fresh again to my kalender, and have made them in right ample manner as you know : and to satisfie your request for that you write unto me, I have (in consideration of our old friendship had at the university of Wittenburg) declared unto you my heavenly voyage, wishing no worse unto you than unto myself, that is, that your mind were as mine in all respects : dixi, Dr. Faustus the astrologian.

\section{CHAPTER XXII.}

How Dr. Faustus made his Journey through the principal and most famous Lands in the World.

Dr. Faustus having over run fifteen years of his appointed time, he took upon him a journey, with full intent to see the whole world, and calling his spirit Mephistophiles unto him, he said, Thou knowest that thou art bound unto me upon conditions, to form and fulfil my desire in all things, wherefore my intent is to visit the whole face of the earth visible and invisible, when it pleaseth me; therefore I command and injoyn thee to the same. Whereupon Mephistophiles answered, I am ready, my lord, at thy command: and forthwith the spirit changed himself into the likeness of a flying horse, saying, Faustus, sit up, I am ready. Dr. Faustus softly sate upon him, and forwards they went: Faustus came through many a land and province, as Pannonia, Austria, Germany, Bohemia, Silesia, Saxony, Messene, During, Frankland, Swaalband, Byerland, Sayrir, Corinthia, Poland, Litaw, Lesland, Prussia, Denmark, Muscovia, Tartaria, Turky, Persia, Cathai, Alexandria, Barbaria, Ginny, Porut, the Streights Maghellane, India, all about the frozen zone, and 
Terra-incognita, Nova Hispaniola, the Isles of Tereza, Madera, St. Michaels, the Canaries, and the Trenorirolcio into Spain, and Mainland, Portugal, Italy, Campania, the Kingdom of Naples, the Isles of Sicilia, Malta, Majorca, Minorca, to the Knights of the Rhodes, Candy or Crete, Cypress, Corinth, Switzerland, France, Freezeland, Westphalia, Zeland, Holland, Brabant, and all the seventeen provinces in Netherland, England, Scotland, Ireland, and America, and Island, the Gut-Isles of Scotland, the Orcades, Norway, the Bishoprick of Bream ; and so home again. All these kingdoms, and provinces, and countries he passed in twenty-five days, in which time he saw nothing that delighted his mind, wherefore he took little rest at home, and burning in desire to see more at large, and to behold the secrets of each kingdom, he set forward again, on his journey on his swift horse Mephistophiles, and came to Trent, for that he chiefly desired to see this town, and the monuments thereof, but there he saw not any wonders, except two fair palaces that belonged unto the bishop, and also a mighty large castle that was built with brick, with three walls, and three great trenches, so strong that it was impossible for any prince's power to win it; then he saw a church wherein was buried Simon and the bishop of Popo, their tombs are of most sumptuous stone-marble, closed and joyned together with great bars of iron; from thence he departed to Paris, where he liked well the academy; and what place or kingdom so ever fell in his mind, the same he visited. He came from Paris to Mentz, where the river of Maine falls into the Rhine, notwithstanding he tarried not long there, but went into Campania, in the kingdom of Neapoly, in which he saw an innumerable sort of cloysters, nunneries, and churches, and great houses of stone, the streets fair and large, and streight forth from one end of the town to the other all alike, and all the pavement of the city was of brick, and the more it rained in the town, the fairer the streets were: there saw he the tomb of Virgil, and the highway that he cut through the mighty hill of stone in one night, the whole length of an English mile: where he saw the number of gallies, and argezies that lay there at the city head, 
the wind-mill that stood in the water, the castle in the water, and the houses above the water, where many gallies might ride most safely from rain or wind: then he saw the castle on the hill over the town, and many monuments therein, also the hill called Vesuvius, wheron groweth all the Greekish wine, and most pleasant sweet olives. From thence he came to Venice, whereat he wonder'd not a little, to see a city so famously built, standing in the sea, where through every street the water came in such largeness, that great ships and barks might pass from one street to another, having yet a way on both sides the water whereon men and horses might pass : he marvelled also how it was possible so much victuals to be found in the town, and so good and cheap, considering that for a whole league nothing grew near the same. He wonder'd not a little at the fairness of St. Mark's Place, and the sumptuous church standing thereon, called St. Mark, how all the pavement was set with coloured stones, and all the rood or loft of the church double gilded over. Leaving this, he came to Padua, beholding the manner of their academy, which is called the mother or nurse of christendom, there heard he the doctors, and saw most of the monuments of the town, entred his name in the university of the German nation, and wrote himself Dr. Faustus, the insatiable speculator: Then saw he the worthiest monument in the world for a church, named St. Anthony's cloyster, which for the pinacles thereof, and the contrivement of the church, hath not the like in christendom. The town is fenced about with three mighty walls of stone and earth, betwixt the which runneth goodly ditches of water; betwixt every four and twenty hours passeth boats betwixt Padua and Venice with passengers, as they do here betwixt London and Gravesend, and even so far they differ in distance: Faustus beheld likewise the counsel-house and castle, with no small wonder. Well, forward he went to Rome, which lay, and doth yet lie' on the river Tybris, the which divideth the city into two parts; over the river are four great istone bridges, and upon the one bridge, called Ponte St. Angelo, is the Castle of St. Angelo, wherein are so many great cast pieces as there are days in the year, and such 
pieces as will shoot seven bullets off with one fire: To this castle cometh a privy vault from the church and the Palace of St. Peter, through the which the pope (if any danger be) passeth from his palace to the castle for safeguard. The city hath eleven gates, and a hill called Vaticinium, whereupon St. Peter's church is built: in that church the holy fathers will hear no confessions, without the penitent bring money in his hand. Adjoining to the church is the Campo Santo, the which Carolus Magnus built, where every day thirteen pilgrims, have their dinners served of the best ; that is to say, Christ and his twelve apostles. Hard by this he visited the churchyard of St. Peter, where he saw that pyramid that Julius Cæsar brought forth of Africa; it stood in Faustus's time leaning against the church-wall of St. Peter's; but Pope Sixtus hath erected it in the middle of St. Peter's churchyard ; it is fourteen fathom long, and at the lower end five fathom four square, and so forth smaller upwards; on the top is a crucifix of beaten gold, the stone standing on four lions of brass. Then he visited the seven churches of Rome, that were St. Peter, St. Paul, St. Sebastian, St. John Lateran, St. Laurence, St. Mary Magdalen, and St. Mary Majora. Then went he without the town, where he saw the conduits of waters that run level through hill and dale, bringing water into the town fifteen Italian miles off. Other mountains he saw, too many to recite. But amongst the rest he was desirous to see the pope's court, and his manner of service at his table, wherefore he and his spirit made themselves invisible, and came to the pope's court and privy chamber, where he was; there saw he many servants attending on his holiness, with many a flattering sycophant carrying his meat; and there he marked the pope, and the manner of his service, which he seeing to be so unmeasurable and sumptuous : Fie (quoth Faustus) why had not the devil made a pope of me? Faustus saw there notwithstanding, such as were like to himself, proud, stout, wilful gluttons, drunkards, whoremongers, breakers of wedlock, and followers of all manner of ungodly excess; wherefore he said to his spirit, I thought that I had been alone a hog or pork of the devil's, but he must bear 
with me a little longer ; for these hogs of Rome are ready fatted, and fitted to make him roast meat, the devil might do well to spit them all, and have them to the fire, and let him summon the nuns to turn the spits; for as none must confess the nun but the frier, so none should turn the roasting frier but the nun. Thus continued Faustus three days in the pope's palace, and yet had no lust to his meat, but stood still in the pope's chamber, and saw every thing whatsoever it was. On a time the pope would have a feast prepared for the Cardinal of Pavia, and for his first welcome the cardinal was bidden to dinner, and as he sate at meat the pope would ever be blessing and crossing over his mouth: Faustus would suffer it no longer, but up with his fist and smote the pope on his face, and withal he laughed that the whole house might hear him, yet none of them saw him, or knew where he was. The pope perswaded his company that it was a damned soul, commanding mass presently to be said for his delivery out of purgatory, which was done; the pope sat still at meat, but when the latter mess came to the pope's board, Dr. Faustus laid hands thereon, saying This is mine, and so he took both dish and meat, and flew into the Capitol or Campadolia, calling his spirit unto him, and said, Come let us be merry, for thou must fetch me some wine, and the cup that the pope drinks out of; and hereupon morte caval, we will make good cheer in spight of the pope and all his fat abbey lubbers. His spirit hearing this, departed towards the pope's chamber, where he found them yet sitting, quaking; wherefore he took from before the pope the fairest piece of plate, or drinking goblet, and a flagon of wine, and brought it to Faustus: but when the pope and the rest of his crew perceived they were robbed, and knew not after what sort, they perswaded themselves that it was a damned soul that before had vexed the pope so, and that smote him on the face; wherefore he sent commandment through the whole city of Rome, that they should say a mass in every church, and ring all the bells, for to lay the walking spirit, and to curse him with bell, book, and candle, that so invisibly had misused the pope's holiness, with the Cardinal of Pavia, and the rest of 
their company; but Faustus notwithstanding made good cheer with that which he had beguiled the pope of, and in the midst of the order of St. Bernards, barefooted friars, as they were going on procession through the market place, call'd Campo de fiore, he let fall his plate, dish, and cup, and withal for a farewel, he made such a thunder-clap and storm of rain, as though heaven and earth would have met together, and left Rome, and came to Millain in Italy, near the Alps or borders of Switzerland where he praised much to his spirit the pleasures of the place, the city being founded in so brave a plain, by the which ran most pleasant rivers on every side of the same, having besides within the compass of a circuit of seven miles, seven small seas : he saw also therein many fair places, and goodly buildings, the duke's palace, and the mighty strong castle, which is in a manner half the bigness of the town. Moreover, it liked him well to see the hospital of St. Mary, with divers other things: he did there nothing worthy of memory, but he departed back again towards Bologina, and from thence to Florence, where he was well pleased to see the pleasant walk of merchants, the goodly vaults of the city, for that almost the whole city is vaulted, and the houses themselves are built outwardly in such sort, that the people go under them as under a vault: then he perused the sumptuous church in the duke's castle, called Nostra Dama, our lady's church, in which he saw many monuments, as a marble door most huge to look upon, the gates of the castle are bell-mettal wherein are graven the holy patriarchs, with Christ and his twelve apostles, and divers other histories out of the Old and New Testament: then went he to Senia, where he highly praised the church and hospital of Sancta Maria Formosa, with the goodly buildings, and especially the fairness and greatness of the city, and beautiful women: then came he to Lions in France, where he marked the situation of the city, which lay between two hills, invironed with two waters; one worthy monument pleased him well, that was the great church, with the image therein; he commended the city highly for the great resort that it had unto it of strangers : from thence he went to Cullen, which lyeth 


\section{2}

upon the river of Rhine, wherein he saw one of the antientest monuments in the world, the which was the tomb of the three kings that came by the angel of God, and their knowledge they had in the stars, to worship Christ, which when Faustus saw, he spake in this manner: ah! alas, good men! How have you erred, and lost your way? You should have gone to Palestina, and Bethlehem in Judea; how came you hither? Or belike after your death you were thrown into Mare Mediterraneum, about Tripolis in Syria, and so you steered out of the Straights of Gibralterra, in the ocean seas, and so into the Bay of Portugal. And not finding any rest, you are driven along the coast of Gallicia, Bisky and France, and into the narrow seas : then from thence into Mare Germanicum, and taken up I think about the town of Dort in Holland: you were brought to Cullen to be buried, or else (I think) you came most easily with a whirl-wind over the Alps, and being thrown into the river of Rhine, it conveyed you to this place where you are kept a monument : then saw he the church of St. Ursula, where remains a monument of the thousand virgins ; it pleased him also to see the beauty of the women. Not far from Cullen lieth the town of Ach, where he saw the gorgous temple that the emperour Carolus Quartus built of marblestone for a remembrance of him, to the end that all his successors should there be crowned. From Cullen in Ach, he went to Geneva, a city in Savoy, lying near Switzerland, it it is a town of great traffick, the lord thereof is a bishop, whose wine-seller Faustus and his spirit visited for the love of his good wine: from thence he went to Strasburg, where he beheld the fairest temple that ever he had seen in his life before, for on every side thereof he might see through, even from the covering of the minster, to the top of the pinacle, and it is named one of the wonders of the world; wherefore he demanded why it is call'd Strasburg? His spirit answer'd, because it hath so many highways common to it on every side, for Stros in Dutch is a High-way, and hereof came the name: yea, said Mephistophiles, the church that thou so 
wondrest at, hath more revenues belonging to it, than the twelve dukes of Silesia, are worth, for there pertain unto this church fifty five towns, and four hundred and sixty three villages, besides many houses in the town. From thence went Faustus to Basil, in Switzerland, where the river of Rhine runneth through the town, parting the same as the river of Thames doth London: in the town of Basil he saw many rich rnonuments, the town wall'd with brick round about, without it goeth a great trench : no church pleased him but the jesuits church, which was sumptuously builded, and set full of alabaster pillers, where the spirit told Faustus that before the city was founded, there used a Basiliscus, a kind of serpent ; this serpent killed as many men, women and children, as he took a sight of, but there was a knight that made himself a cover of chrystial, to come over his head, and down to the ground, and being first covered with a black cloth, over that he put the chrystial and so boldly went to see the Basiliscus, and finding the place where she haunted, he expected her coming even before the mouth of the cave, where standing a while, the Basiliscus came forth, where when she saw her own venemous shadow in the chrystial, she split in a thousand pieces, wherefore the knight was richly rewarded of the emperor, after the which the knight founded this town upon the place where he had slain the serpent, and gave it the name Basil, in remembrance of his deed.

From Basil, Faustus went to Costnitz in Sweitz, at the head of the Rhine, where is a most sumptuous bridge that goeth over the Rhine, even from the gates of the town, to the other side of the stream; at the head of the river of Rhine, is a small sea, called of the Switzers, the Black Sea, twenty thousand paces long, and fifty hundred paces broad. The town Costnitz took the name of this; the emperor gave it a clown for expounding of his riddle; wherefore the clown named the town Costnitz, that is in English, Cost me nothing. From Costnitz he came to Ulm, where he saw the sumptuous town-house built by two and fifty of the ancient senators of the city: it took the name Ulm, because the 
whole land thereabouts is full of Elms : but Faustus minding to depart from thence, his spirit said unto him, Faustus, think of the town as you will; it hath three dukedoms belonging to it, the which they have bought with ready money. From Ulm he came unto Watzberg, the chiefest town in Frankland, wherein the bishop altogether keepeth his court, through the which town passeth the river Mayne, that runs into the Rhine: thereabouts groweth strong and pleasant wine, the which Faustus well proved: the castle standeth on a hill on the north-side of the town, at the foot thereof runneth the river ; this town is full of beggarly friers, nuns, priests, and jesuits; for there are five sorts of begging friers, besides three cloysters of nuns; at the foot of the castle stands a church, in the which there is an altar, where are engraven all the four elements, and all the orders and degrees in heaven, that any man of understanding whosoever, that hath a light thereof, may say, that it is the artificialest thing that ever he beheld. From thence he went to Norenberg, whither as he went by the way, his spirit informed him that the town was named of Claudius Tiberius, the son of Nero the Tyrant: in the town are two famous cathedral churches, one called St. Sabelt the other St. Laurence; in which church stands all the relicks of Carolus Magnus, that is to say, his cloak, his hose, his doublet, his sword and crown, the scepter and apple: it hath a very glorious gilded conduit in the market-place of St. Laurence; in which conduit is the spear that thrust our Saviour into the side, and a piece of the holy cross; the wall is called the fair wall of Norenberg, and five hundred and twenty eight streets, a hundred and sixty wells, four great and two small clocks, six great gates, two small doors, eight stone-bridges, twelve small hills, ten fair market-places, thirteen common hot houses, ten churches, within the town are twenty wheels of water-mills, it hath a hundred and thirty eight tall ships, two mighty town-walls of hew'd stone and earth, with very deep trenches: the walls have a hundred and eighty towers about them, and four fair platforms, ten apothecaries, ten doctors of the common-law, fourteen doctors of physic. From Norenberg he went to Auspurg, where at the 
break of the day he demanded of his spirit, whereupon the town took his name: This town (quoth he) hath had many names; when it was first built, it was called Vindelica; secondly, it was called Zizaria, the iron-bridge: lastly, by the Emperour Octavus Augustus, it was called Augusta, and by the corruption of language, the Germans had named it Auspurg. Now for because that Faustus had been there before, he departed (without seeing their monuments) to Ravensberg, where his spirit certified him that the city had seven names: the first Diperia, the second Quadratis, the third Heaspolis, the fourth Reginipolis, the fifth Imbripolis, the sixth Ratisbona, the last is Ravensburg. The situation of this city pleas'd Faustus well, also the strong and sumptuous building; by the walls thereof runneth the river Danubius, in Dutch called Danow, into which not far from the compass of the city falleth near hand threescore other small rivers and fresh waters: Faustus also liked the sumptuous stone-bridge over the same water, with the church standing thereon, the which was founded Anno Iri5, the name whereof is called St. Remedian; in the town Faustus went into the cellar of an inn-holder, and let out all the beer and wine that was in the cellar. After which feat, he returned into Mentz in Bavaria, a right princely town: the town appeared as if it were new, with great streets therein, both of breadth and length from Mentz to Salisburg, where the bishop is always resident : here saw he all the commodities that were possible to be seen, for at the hill he saw the form of a bell made in Chrystial, a huge thing to look upon, that every year groweth bigger and bigger, by reason of the freezing cold. From thence he went to Vienna in Austria, the town is of great antiquity, that it is not possible to find the like; in this town, said the spirit, is more wine than water, for all under the town are wells, which are filled every year with wine, and all the water, that they have, runneth by this town; this is the river Danubius. From thence he went into Prage, the chief city of Bohemia; this is divided into three parts, that is old Prage, little Prage, and new Prage: little Prage is the place where the emperour's court is placed; upon an exceeding high mountain there is a castle, where 


\section{THE FAMOUS HISTORY OF DOCTOR FAUSTUS.}

are two fair churches; in the one he found a monument which might well have been a mirrour for himself, and that was the sepulchre of a notable conjurer, which by his magick had so inchanted his sepulchre, that whosoever set foot thereon, should be sure never to die in their beds. From this castle he came and went down over the bridge; this bridge hath twenty four arches, and in the middle of the bridge stands a very fair monument, being a cross builded of stone, and most artificially carved. From thence he went into the old Prage, the which is separated from the new Prage, with an exceeding deep ditch, and round about inclosed with a wall of brick; unto this is adjoyning the Jews town, wherein are thirteen thousand men, women, and children, all jews; there he viewed the colledge and the gardens, where all manner of savage beasts are kept; and from thence he fetched a compass round about the three towns, whereat he wonder'd greatly to see so mighty a city stand all within the walls. From Prage he flew into the air, and bethought himself what he might do, or which way to take; so looked round about, and behold he espied a passing fair city, which lay not far from Prage, about some four and twenty miles, and that was Bressaw in Silesia, in which when he was entred, it seemed to him that he had been in Paradise so neat and clean were the streets, and so sumptuous were their buildings. In the city he saw not many wonders, except the brazen virgin that standeth on a bridge over the water, and under which standeth a mill like a paper mill, which virgin is made to do execution upon those disobedient town-born children, that be so wild that their parents cannot bridle them; which when any such are found with some hainous offence, turning to the shame of their parents and kindred, they are brought to kiss the virgin, which openeth her arms : the person then to be executed kisseth her, then doth she close her arms together with such violence, that she crusheth out the breath of the party, breaketh his bulk, and so he dieth; but being dead she openeth her arms again, and letteth the party fall into the mill, where he is stamped into small morsels, which the water carrieth away, so that no part is found again. From 
Bressaw he went toward Cracovia in the kingdom of Bolionia, where he beheld the academy, the which pleased him wonderful well : in the city the king most commonly holdeth his court at a castle, in which castle are many famous monuments; there is a most sumptuous church in the same, in which standeth a silver altar guilded, and set with rich stones, and over it is a covenance full of all manner of silver ornaments belonging to mass. In the church hangeth the jaw-bones of a huge dragon, that kept the rock before the castle was edified thereon: it is full of all manner of munition, and hath always victuals for three years to serve three thousand men; through the town runneth a river, called the Vessnal or Wessel, where over is a fair wooden-bridge; this water divideth the town and Gasmere, in this Gasmere dwell the Jews, being a small walled town by themselves, to the number of twenty-five thousand men, women and children; within one mile of the town there is a salt mine where they found stones of pure salt, 'one thousand pound, two thousand pound, or more in weight, and that in great quantity: this salt is as black as the Newcastle coals when it comes out of the mines, but being beaten to powder, it is as white as snow. The like they have four miles from thence at a town called Buckma. From thence, Faustus went to Sandentz, the Captain thereof was called Don Spicket Jordan, in this town are many monuments, as the tomb and sepulchre of Christ, in as ample a manner as that is at Jerusalem, at the proper costs of a gentleman, that went thrice a year to Jerusalem, from that place and returned again; not far from that town is a new town wherein is a nunnery of the order of St. Dioclesian, into which order may none come except they be gentlewomen, and well formed, and fair to look upon, which pleased Faustus well; but having a will to travel farther, and to see more wonders, mounting up towards the east over many lands and provinces, as in Hungaria, Transilvania, Shede, Ingatz, Sardinia, and so into Constantinople, where the Turkish emperor kept his court: this city was surnamed by Constantine the founder thereof, being builded of very fair stone: In the same the Great Turk hath three fair palaces, 
the walls are strong, the pinacles are very huge, and the streets very large: but this liked not Faustus, that one man should have as many wives as he would; the sea runneth hard by the city; the wall hath eleven gates: Faustus abode there a certain time to see the manner of the Turkish emperour's service at his table, where he saw his royal service to be such, that he thought if all the christian princes should banquet together, and every one adorn the feast to the utmost, that they were not able to compare with the Turk and his table, and the rest of his country service. Wherefore it so affrighted Faustus, that he vowed to be revenged on him; for his pomp he thought was more fit for himself; wherefore as the Turks sate at meat, Faustus shewed them a little apish play, for round about the privy chamber he sent forth flashing flames of fire, insomuch that the whole company forsook their meat and fled, except only the Great Turk himself; him Faustus charmed in such sort that he could neither rise nor fall, neither could any man pull him up: With this was the hall so light, as if the sun had shined in the house; then came Faustus in form of a pope to the Great Turk, saying, All hail, emperor, now art thou honoured, that I so worthily appear unto thee, as thy Mahomet was wont to do. Hereupon he vanished, and forthwith it thundred that the whole palace shook: the Turk greatly marvelled what this should be that so vexed him, and was perswaded by the chiefest counsellours, that it was Mahomet his prophet, which had so appeared unto them, whereupon the Turk commanded them to fall down on their knees, and to give him thanks for doing them so great honour, as to shew himself unto them; but the next day Faustus went into the castle where he kept his wives and concubines, in which castle might no man upon the pain of death come, except those that were appointed by the Great Turk to do him service and they were all gelded, which when Faustus perceived, he said to his spirit Mephistophiles, How likest thou this sport? Are not these fair ladies greatly to be pitied, that thus consume their youth at the pleasure of one only 
man? Why, quoth the spirit, mayest not thou instead of the emperour embrace his fair ladies? Do what thy heart desireth herein, and I will aid thee, and what thou wishest thou shalt have it performed. Wherefore Faustus (being before this counsel apt enough to put such matters into practice) caused a great fog to be round about the castle, both within and without, and he himself appeared amongst the ladies in all points as they used to paint Mahomet; at which sight the ladies fell on their knees and worshipped him. Then Faustus took the fairest by the hand, and led her into a chamber, where after this manner he fell to dalliance, and thus he continued a whole day and a night; and when he had delighted himself sufficiently with her, he put her away, and made his spirit bring him another; so likewise he kept with her twenty four hours play, causing his spirit to fetch him most dainty fare, and so he passed away six days, having each day his pleasure of a sundry lady, and that of the fairest; all which time the fog was so thick and so stinking, that they within the house thought that they had been in hell for the time, and they without wondred thereat, in such sort that they went to their prayers, calling on their God Mahomet, and worshipping of the image; where the sixth day Faustus exalted himself into the air like a pope, in the sight of the Great Turk and all his people, and he had no sooner departed the castle, but the fog vanished away: Whence presently the Turk went to his wives and concubines, demanding of them if they knew the cause why the castle was beset with a mist so long: They said it was the God Mahomet himself that had caused it, and how he was in the castle personally six days, and more for certainty he hath lain with six of us six nights one after another. The Turk hearing this fell down upon his knees, and gave Mahomet thanks, desiring him to forgive him for being offended with his visiting his castle and wives these six days; but the Turk commanded that those whom Mahomet had lain by should be most carefully look'd to, perswading himself (and so did all the whole people who 
knew of it) that out of them to Mahomet should be raised a mighty generation: But first he demanded of his ladies, if Mahomet had not actual copulation with them according as earthly men have? Yea my lord (quoth one) as if you had been there yourself, you could not have mended it; for he lay with me stark naked, kissed, and culled me, and so delighted me, that for my part I would he came two or three times a week to serve me in such sort again. From thence Faustus went to Alker, the which before times was called Chairam, or Memphis; in this city the Egyptian Soldian holdeth his court; from thence the river Nilus hath his head and spring, it is the greatest fresh water river that is in the whole world, and always when the sun is in Cancer, it overfloweth the whole land of Egypt. Then he returned again towards the north-east, and to the town of Osen and Sebasa in Hungaria; this Osen is the closest city in Hungaria, and standing in a fertile soil, wherein groweth most excellent wine, and not far from the tower there is a well called Zipzan; the water whereof changeth iron into copper: There are mines of gold and silver, and all manner of metal: we Germans call this town Osen, but in the Hungarian speech it is Start; in the town standeth a very fair castle, and very well fortified. From thence he went to Austria, and so through Silesia into Saxony, unto the towns of Magdeburg, and Lipzig and Lubeck, Magdeburg is a bishoprick: In this city is one of the pitchers wherein Christ changed the water into wine in Cana in Galilee. At Lipzig nothing pleased Faustus so well as the great vessel in the castle made of wood, the which is bound about with twenty-four iron hoops, and every 'hoop weigh'd two hundred pound weight; you must go upon a ladder thirty steps high before you can look into it; he saw also the new churchyard where it was wall'd, and standeth upon a fair plain; the yard is two hundred paces long, and round about the side of the wall are good places, separated one from each ather to see sepulchres in, which in the middle of the yard standeth very sumptuous; therein standeth a pulpit of white work and gold. From thence he went to Lubeck 
and Jamberg, where he made no abode, but away again to Erford in Duriten, where he visited the Frescold; and from Erford he went home to Wittenburg, when he had seen and visited many a strange place. Being from home one year and a half, in which time he wrought more wonders than are here declared.

\section{CHAPTER XXIII.}

\section{How Dr. Faustus had sight of Paradise.}

AfTer this Dr. Faustus set forth again to visit the countries of Spain, Portugal, France, England, Scotland, Denmark, Sweden, Poland, Muscovy, India, Cataia, Africa, Persia, and lastly into Barbaria amongst the Black-Moors; and in all his wandring he was desirous to visit the ancient monuments and mighty hills, amongst the rest, beholding the high hill called Theno Reise, was desirous to rest upon it. From thence he went into the Isle of Britain, wherein he was greatly delighted to see the fair water, and warm baths, the divers sorts of metal, with many precious stones, and divers other commodities, the which Faustus brought thence with him. He was also at the Orcades behind Scotland, where he saw the tree that bringeth forth fruit, that when it is ripe, openeth and falleth in the water, wherein ingendreth a certain kind of fowl and birds; these islands are in number twenty-three, but ten of them are not habitable, the other thirteen were inhabited. From thence he went to the hill Caucasus, which is the highest in all that tropick, it lyeth near the borders of Scythia: hereon Faustus stood and beheld many lands and kingdoms; Faustus being on such an high hill, thought to look over all the world, and beyond; for he went to Paradise, but he durst not commune with his spirit thereof; and being on the hill Caucasus, he saw the whole land of India and Scythia, and as he looked towards the east, he saw a mighty clear streak of fire coming from heaven upon earth, even as if it had been one of the beams of the sun. He saw in the water four mighty waters springing, one had 
his course towards India, the second towards Egypt, the third and fourth towards Armenia; when he saw these he would needs know of his spirit what waters they were, and from whence they came; his spirit gave him gently an answer, saying, it is Paradise that lieth so far in the east, the garden that God himself hath planted with all manner of pleasure : and the fiery streams which thou seest is the wall or fence of the garden : but the clear light which thou seest afar off, that is the angel that hath the custody thereof with a fiery sword : and although thou thinkest thy self to be hard by, thou art yet further thither from hence, than thou hast ever been : the water that thou seest divided in four parts, is the water that issueth out of the well in the middle of Paradise. The first is called Ganges or Pison, the second Gihon, the third Tygris, and the fourth Euphrates, also thou seest that he standeth under Libra and Aries right towards the Zenith; and upon this fiery wall standeth the angel Michael, with his flaming sword, to keep the tree of life, which he hath in charge. But the spirit said to Faustus, neither thou, nor I, nor any after us, yea, all men whatsoever, are denyed to visit, or come any nearer than we be.

\section{CHAPTER XXIV.}

OJ a certain Comet that appeared in Germany, and how Dr. Faustus was desired by certain Friends of his to know the meaning thereof.

In Germany, over the town of St. Elzeben, was seen a mighty great comet, whereat the people wonder'd, but Dr. Faustus being there, was asked of certain of his friends his judgment or opinion in the matter : whereupon he answered, it falleth out often by the course and change of the sun and moon, that the sun is under the earth, and the moon above; but when the moon draweth near the change, then is the sun so strong, that it taketh away the light of the moon, in such sort as she is red as blood, and on the contrary side, after they have been together, she soon taketh her 
light from him, and so increasing in light to the full, she will be as red as the sun was before, and change herself into divers and sundry colours, of which springeth the prodigal monster, or as you call it a comet, which is a figure or token appointed of God as a forewarning of his displeasure: as at one time he sendeth hunger, plague, sword, or such like, being all tokens of his judgements, which comet cometh through the conjunction of the sun and moon, and begetteth a monster, whose father is the sun, and whose mother is the moon: moon and sun.

\section{CHAPTER XXV.}

Another question put forth to Dr. Faustus concerning the Stars.

THERE was a learned man of the town of Halberstat, named N. W. who invited Dr. Faustus to his table, but falling into communication before supper was ready, they looked out of the window, and seeing many stars in the firmament, this man being a Dr. of physick, and a good astrologian, said, Dr. Faustus, I have invited you as my guest, hoping you will take in good part with me, and withal, I request you to impart some of your experience in the stars and planets; and seeing a star fall, he said, I pray you, Faustus, what is the condition, quality or greatness of the stars in the firmament? Faustus answered him, my friend and brother, you see that the stars that fall from heaven, when they come to the earth, they be very small to our thinking as candles, but being fixed in the firmament, they are many as great as a city, some as great as a province or dukedom, others as great as the whole earth, other some far greater than the earth twelve times, and from the height of the heavens there is scarce any earth to be seen, yea, the planets in the heavens are some so great as this land, some so great as the whole empire of Rome, some as Turky, yea, some as great as the whole world. 


\section{CHAPTER XXVI.}

How Faustus was asked a Question concerning the Spirits that vexed Men.

That is most true (said he to Faustus) concerning the stars and planets; but I pray you in what kind or manner do the spirits use to vex men so little by day, and so greatly by night? Dr. Faustus answered, Because the spirits are of God forbidden the light, their dwelling is in darkness, and the clearer the sun shineth, the farther the spirits have their abiding from it, but in the night when it is dark, they have their familiarity and abiding near unto us men. For although in the night we see not the sun yet the brightness thereof so lighted the first moving of the firmament, as it doth here on earth in the day, by which reason we are able to see the stars and planets in the night, even so the rays of the sun piercing upwards into the firmament, the spirits abandon the place, and so come near us on earth, the darkness filling our heads with heavy dreams and fond fancies, with shrieking and crying in many deformed shapes : and sometimes when men go forth without light, there falleth to them a fear, that their hairs standeth up an end, so many start in their sleep, thinking there is a spirit by them, groping or feeling for him, going round about the house in their sleep, and many such like fancies, and all this is, because in the night the spirits are more familiarly by us, than we are desirous of their company, and so they carry us, blinding us, and plaguing us more than we are able to perceive.

\section{CHAPTER XXVII.}

How Dr. Faustus was asked a Question concerning the Stars that fell from Heaven.

DR. Faustus being demanded the cause, why the stars fall from heaven? he answered, That it is but our opinion; for if one star 
fall, it is the great judgment of God upon us, as a forewarning of some great thing to come: for when we think that a star falleth, it is but as a spark that issueth from a candle, or flame of fire; for if it were a substantial thing, we should not so soon lose the sight of them as we do. And likewise if so be that we see as it were a stream of fire fall from the firmament, as it oft happeneth, yet are they not stars, but as it were a flame of fire vanishing, but the stars are substantial ; therefore are they firm and not failing; if there fall any, it is a sign of some great matter to come, as a scourge to a people or country: and then such stars falling, and the gates of heaven are opened, and the clouds send forth floods, and other plagues, to the damage of the whole land and people.

\section{CHAPTER XXVIII.}

How Faustus was asked a Question concerning Thunder.

IN the month of August, there was over Wittenburg a mighty great lightning and thunder; and as Dr. Faustus was jesting merrily in the market-place with certain of his friends and companions, being physicians, they desired him to tell them the cause of that weather: Faustus answered, It hath been commonly seen heretofore, that before a thunder-clap fell a shower of rain, or a gale of wind; for commonly after a wind falleth rain, and after rain a thunder-clap, such thickness come to pass when the four winds meet together in the heavens, the airy clouds are by force beaten against the fixed chrystial firmament, but when the airy clouds meet with the firmament, they are congealed, and so strike, and rush against the firmament, as great pieces of ice when they meet on the water : then each other sounded in our ears, and that we call thunder, which indeed was none other than you have heard. 
The Third and Last of Dr. Faustus his merry Conceits, shewing after what Sort he practised Necromancy in the Courts of great Princes: and lastly of his fearful and pitiful End.

\section{CHAPTER XXIX.}

How the Emperor Carolus Quintus requested of Faustus to see some of his Cunning, whereunto he agreed.

THE Emperor Charles the fifth of that name, was personally with the rest of the nobles and gentlemen, at the town of Intzbrack, where he kept his court, unto the which also Dr. Faustus resorted, and being there well known of divers nobles and gentlemen, he was invited in the court to meat, even in the presence of the emperor, whom when the emperor saw, he looked earnestly upon him, thinking by his looks he was some wonderful fellow : wherefore he asked one of his nobles, whom he should be? $\mathrm{He}$ answered, that he was called Dr. Faustus: whereupon the emperor held his peace until he had taken his repast : after which he called unto him Faustus into his privy-chamber; where being come, he said unto him, Faustus, I have heard much of thee, that thou art excellent in the black art, and none like thee in my empire; for men say that thou hast a familiar spirit with thee, and that thou canst do what thou list : it is therefore (said the emperor) my request of thee, that thou let me see proof of thy experience, and I vow unto thee by the honour of my imperial crown, none evil shall happen unto thee for so doing. Hereupon Dr. Faustus answered his majesty, that upon those conditions he was ready in any thing that he could to do his highness's command in what service he could appoint him. Well, hear then what I say, (quoth the emperor;) being once solitary in my house, I called to mind my elders and ancestors, how it was possible for them to attain to so great a degree and authority, yea, so high, that we, the successors of that line, are not able to come near. As for example: the great and mighty monarch of 
the world, Alexander Magnus, was such a pattern and spectacle to all his successors, as the chronicles make mention of, having so great riches, conquering and subduing so many kingdoms, the which I and those that follow me (I fear) shall never be able to attain unto: wherefore Faustus my hearty desire is, that thou wouldst vouchsafe to let me see that Alexander and his Paramour, the which was praised to be so fair; and I pray thee shew me them in such sort, that I may see their personages, shapes, gesture and apparel, as they used in their lifetime, and that here before my face, to that end that I may say, I have my long desire fulfilled, and to praise thee to be a famous man in thy art and experience. Dr. Faustus answered, my most excellent Lord, I am ready to accomplish your request in all things, so far forth as I and my spirit are able to perform : yet your majesty shall know, that their dead bodies are not able substantially to be brought before you; but such spirits as have seen Alexander and his Paramour alive, shall appear unto you in manner and form as they both lived in their most flourishing time; and herewith I hope to please your Imperial Majesty. Then Faustus went a little aside and spoke to his spirit, but he returned again presently, saying, Now if it please your Majesty you shall see them, yet upon this condition, that you demand no question of them, nor speak unto them; which the emperor agreed unto. Whereupon Dr. Faustus opened the privy-chamber door, where presently entred the great and mighty emperour, Alexander Magnus, in all things to look upon as if he had been alive; in proportion, a strong set thick man, of a middle stature, black hair, and that both thick and curled, head and beard, red cheeks, and a broad face, with eyes like a Basilisk, he had a compleat harness furnished and engraven, exceeding rich to look upon: and so passing towards the Emperor Carolus, he made a low and reverend courtesie: whereat the Emperor Carolus would have stood up to receive and greet him with the like reverence: Faustus took hold on him, and would not permit him to do it. Shortly after Alexander made humble reverence, and went out again; and coming to the door, his paramour met him. She coming in 
made the emperor likewise reverence, she was cloathed in blue velvet, wrought and embroidered with pearls and gold; she was also excellent fair, like blood and milk mixed, tall and slender, with a face as round as an apple, and thus passed they certain times up and down the house, which the emperor marking, said to himself, Now I have seen two persons which my heart hath long wished to behold; and sure it cannot otherwise be (said he to himself) but that the spirits have changed themselves into these forms, and have but deceived me, calling to mind the woman that raised the Prophet Samuel : and for that the emperor should be more satisfied in the matter, he said I have often heard that behind in her neck, she had a great wart or wen; wherefore he took Faustus by the hand without any words and went to see if it were able to be seen on her or not: but she perceiving that he came to her, bowed down her neck, where he saw a great wart, and hereupon she vanished, leaving the emperor and the rest well contented.

\section{CHAPTER XXX.}

How Dr. Faustus, in the sight of the Emperor, conjured a Pair of Harts horns upon a Knight's Head, that slept out at a casement.

When Dr. Faustus had accomplished the emperor's desire in all things, as he was requested, he went forth into the gallery, and leaning over a rail, to look into the privy-garden, he saw many of the emperor's courtiers walking and talking together, and casting his eyes now this way, now that way, he espied a knight leaning out of the window of the great hall, who was fast asleep, (for in those days it was hot) but the person shall be nameless that slept, for that he was a knight, though it was all done to no little disgrace of the gentleman : It pleased Dr. Faustus, through the help of his spirit Mephistophiles, to fix on his head, as he slept, a huge pair of hart's horns: And as the knight awaked, thinking to pull in his head, he hit his horns against the glass, that the panes thereof flew about his ears. Think here how this 
good gentleman was vexed, for he could neither get backward nor forward; which when the emperor heard, all the courtiers laught, and came for to see what had happened: The emperor also, when he beheld the knight with so fair a head, laughed heartily thereat, and was therewith' well pleased. At last Faustus made him quit of his horns again, but the knight perceived not how they came.

\section{CHAPTER XXXI.}

How the above mentioned Knight zent about to be revenged of Dr. Faustus.

Dr. Faustus took his leave of the emperor and the rest of the courtiers, at whose departure they were sorry, giving him many rewards and gifts ; but being a league and a half out of the city, he came into a wood, where he beheld the knight that he had jested with at the court with others in harness, mounted upon fair palfreys, and running with full charge towards Faustus; but he seeing their intent ran towards the bushes, and before he came among the bushes he returned again, running as it were to meet them that chased him: whereupon suddenly all the bushes were turned into horsemen, which also ran to encounter with the knight and his company, and coming to them, they inclosed the knight and the rest, and told them they must pay their ransom before they departed, whereupon the knight seeing himself in such distress, besought Faustus to be good to them, which he denyed not but let them loose; yet he so charmed them, that every one, knight and other, for the space of a whole month, did wear a pair of goat's horns on their brows, and every palfrey a pair of ox' horns on his head; and this was their penance appointed by Faustus. 


\section{CHAPTER XXXII.}

How three young Dukes being together at Wittenburg, to behold the University, requested Faustus to help them at a Wish to the Town of Muncheon in Bavaria, there to see the Duke of Bavaria's Son's Wedding.

THREE worthy young dukes, the which are not here to be named, but being students altogether, at the university of Wittenburg, met on a time altogether, where they fell in reasoning concerning the pomp and bravery that should be in the city of Muncheon in Bavaria, at the wedding of the duke's son, wishing themselves there but one half hour to see the manner of their jollity; to whom one replyed, saying to the two other gentlemen, If it please you to give me the hearing, I will give you good counsel, that you may see the wedding, and be here again to-night, and this is my meaning: Let us send to Dr. Faustus, make him a present of some rare thing, and open our minds unto him, desiring him to assist us in our enterprize, and assure ye he will not deny to fulfil our request: Hereupon they all concluded : sent for Faustus, told, him their minds, and gave him a gift, and invited him to a sumptuous banquet, wherewith Faustus was well contented, and promised to further their journey to the uttermost: And when the time was come that the three young gentlemen came into his house, commanding them that they would put on their best apparel, and adorn themselves as rich as they could : he took off his great large cloak, went into the garden that was adjoyning unto his house, and set the three young dukes upon his cloak, and he himself in the midst : but he gave them in charge, that in any wise they should not at once open their mouths to speak, or make answer to any man so soon as they went out, not so much as if the Duke of Bavaria or his son, should speak to them, or offer them courtesie, they should give no word or answer again; to which they all agreed. These conditions being made, Dr. Faustus began to conjure, and on a sudden arose a mighty wind, heaving up the cloak, and so carried them away in the air, and in 
due time they came unto Muncheon to the duke's court; where being entred into the utmost court, the marshal had espyed them, who presently went to the duke, shewing his grace that all the lords and gentlemen were ready set at the table, notwithstanding there were newly come three goodly gentlemen with one servant, the which stood without in the court, wherefore the good old duke came out unto them, welcoming them, requiring what they were, and 'whence? But they made no answer at all; whereat the duke wonder'd, thinking they had been all dumb : notwithstanding for his honour's sake he took them into the court, and feasted them. Faustus notwithstanding spake to them, if any thing happen otherwise than well, when I say, Sit up, then fall you all on the cloak, and good enough. Well, the water being brought, and that they must wash, one of the three had some manners, as to desire his friend to wash first, which when Faustus heard, he said, Sit up; and all at once they got on the cloak, but he that spoke fell off again, the other two with Dr. Faustus, were again presently at Wittenburg: but he that remained was taken and laid in prison: wherefore the other two gentlemen were very sorrowful for their friend, but Faustus comforted them promising that on the morrow he should also be at Wittenburg. Now all this while was the duke taken in great fear, and strucken into an exceeding dumps, wond'ring with himself that his hap was so hard to be left behind, and not the rest: and now being locked and watched with so many keepers: there was also certain of the guests that fell to reasoning with him to know what he was, and also what the other were that were vanish'd away? but the poor prisoner, thought with himself, if I open what they are, then it will be evil also with me. Wherefore all this while he gave no man any answer, so that he was there a whole day, and gave no man a word: wherefore the old duke gave charge that the next morning they should rack him until he had confessed; which when the young duke heard, he began to sorrow, and to say with himself, It may be, that to morrow (if Dr. Faustus come not to aid me) I shall be racked and grievously tormented, insomuch that I shall be constrained by force to more than willingly $I$ 
would do. But he comforted himself with hope that his friends would entreat Dr. Faustus about his deliverance, as also it came to pass : for that before it was day, Dr. Faustus was by him, and he conjured them that watched him into such a heavy sleep, that he with his charms made open all the locks in the prison, and therewithal brought the young duke again in safety to the rest of his fellows and friends, where they presented Faustus with a sumptuous gift, and so departed one from another.

\section{CHAPTER XXXIII.}

How Dr. Faustus borrowed Money of a Jew, and laid his ozun Leg in Pawn for it.

IT is a common proverb in Germany, that although a conjurer have all things at command, the day will come that he shall not be worth a penny; so it is like to fall out with Dr. Faustus, in promising the devil so largely; but as the devil is the author of all lies, even so he led Faustus his mind in practising things to deceive the people, and blinding them, wherein he took his whole delight, thereby to bring himself to riches; notwithstanding in the end he was never the richer; and although during twenty four years of his time that the devil set him, he wanted nothing; yet was he best pleased when he might deceive any body. For out of the mightiest potentates courts in all these countries, he would send his spirit to fetch away their best cheer. And on a time, being in his merriment, where he was banquetting with other students in an inn, thereunto resorted many Jews: which when Dr. Faustus perceived, he was minded to play a merry jest to deceive a Jew, desiring one of them to lend him some money for a time; the jew was content, and lent Faustus three score dollers for a month, which time being expired, the Jew came for his money and interest: but Dr. Faustus was never minded to pay the Jew again; at length the Jew coming home to his house, and calling importunately for his money, Dr. Faustus made him this answer; Jew, I have no money, nor know I how to pay 
thee; but notwithstanding, to the end thou mayest be contented, I will cut off a limb of my body, be it arm or leg, and the same thou shalt have in pawn for thy money; yet with this condition, that when I shall pay thee thy money again, then thou shalt give me my limb. The Jew that was never a friend to a Christian, thought with himself this fellow is right for my purpose, that will lay his limbs in pawn for money, and was therewith very well content : wherefore Dr. Faustus took a saw, and therewith seemed to cut off his leg, being notwithstanding nothing so. Well, he gave it to the Jew, yet upon this condition, when he got money to pay, the Jew should deliver him his leg, to the end he might set it on again. The Jew was with this matter very well pleased, took his leg, and departed; and having to go far home, he was somewhat weary, and by the way he thus bethought him; what helpeth me a knave's leg? if I should carry it home, it would stink and infect my house; besides, it is too hard a piece of work to set it on again: wherefore what an ass was Faustus, to lay so great a pawn for so small a sum of money? and for my part, quoth the Jew to himself, this will never profit me any thing; and with these words he cast the leg away from him into a ditch. All this Dr. Faustus knew right well, therefore, within three days after sent for the Jew, to make him payment of his sixty dollers: the Jew came, and Dr. Faustus demanded his pawn, there was his money ready for him: the Jew answered, The pawn was not profitable nor necessary for any thing, so I cast it away: But Faustus threatning, replyed, I will have my leg again, or else one of thine for it. The Jew fell to intreat, promising him to give him what money he would ask if he would not deal strictly with him; wherefore the Jew was constrained to give him sixty dollers more to be rid of him, and yet Faustus had his leg on, for he had but blinded the Jew. 


\section{CHAPTER XXXIV.}

\section{How Dr. Faustus deceived the Horse-courser.}

AFTER this manner he deceived a horse-courser, at a fair, called Pheifering : for Faustus, through his conjuring, had gotten an excellent fair horse, whereupon he rid to the fair, where he had many chapmen that offered him money; lastly, he sold him for forty dollers, and willing him that bought him, that in any wise he should not ride him over the water; but the horse-courser marvelled with himself that Faustus bade him ride over no water. But (quoth he) I will prove, and forthwith he rid him into the river, presently the horse vanished from under him, and he was left on a bottle of straw, insomuch that the man was almost drowned; the horse-courser knew well where he lay that had sold him his horse: whereupon he went angerly to his inn, where he found Dr. Faustus fast asleep, and snorting on a bed; but the horse-courser could no longer forbear him, but took him by the leg, and began to pull him off the bed; but he pulled him so that he pulled his leg from his body, insomuch that the horsecourser fell backwards in the place, then began Dr. Faustus to cry with open throat he hath murthered me. Hereat the horsecourser was afraid, and gave the flight, thinking no other with himself, but that he had pulled his leg from his body: by this means Dr. Faustus kept his money.

\section{CHAPTER XXXV.}

\section{How Dr. Faustus eat a Load of Hay.}

DR. FAUSTUS being at a town in Germany called Zwickow, where he was accompanied with many doctors and masters, and going forth to walk after supper, they met with a clown that drew a load of hay. Good even, good fellow, said Faustus to the clown, what shall I give thee, to let me eat my belly-full of hay? The clown thought with himself, what a mad man is this 
to eat hay? Thought he with himself, thou wilt not eat much: they agreed for three farthings he should eat as much as he could; wherefore Dr. Faustus began to eat, and so ravenously, that all the rest of the company fell a laughing; blinding so the poor clown, that he was sorry at his heart, for he seemed to have eaten more than half of the hay; wherefore the clown began to speak him fair, for fear he should have eaten the other half also: Faustus made as though he had pity on the clown, and went away: when the clown came in the place where he would be, he had his hay again, as he had before, a full load.

\section{CHAPTER XXXVI.}

\section{How Dr. Faustus served the twelve Students.}

AT Wittenberg, before Faustus's house, there was a quarrel between seven students, and five that came to part the rest, one part stronger than the other. Wherefore Dr. Faustus seeing them to be over-matcht, conjured them all blind, insomuch that the one could not see the other, and he dealt so with them, that they fought and smote at one another still; whereat all the beholders fell a laughing; and thus they continued blind, beating one another until the people parted them and led each one to his own house, where being enter'd into their houses, they received their sight presently again.

\section{CHAPTER XXXVII.}

\section{How Dr. Faustus served the drunken Clowns.}

DR. FAUSTUS went into an inn wherein was many tables full of clowns, the which was tippling kan after kan of excellent wine; and to be short, they were all drunken; and as they sate, they so sang and hollowed, that one could not hear a man speak for them, this angred Dr. Faustus: wherefore he said to them that called him in, mark, my masters, I will shew a merry jest : the 
clowns continued still hollowing and singing; he conjured them that their mouths stood as wide open as it was possible for them to hold them, and never a one of them was able to close his mouth again; by and by the noise was gone; the clowns notwithstanding looked earnest one upon another, and knew not what was hapned: one by one they went out, and so soon as they came without, they were all as well as ever they were, but none of them desired to go in any more.

\section{CHAPTER XXXVIII.}

How Dr. Faustus sold five Swine for six Dollars apiece.

DR. FAUSTUS began another jest; he made ready five fat swine the which he sold to one for six dollars apiece, upon this condition, that the swine-driver should not drive them into the water. Dr. Faustus went home again, and as the swine had fouled themselves in the mud, the swine-driver drove them into the water, where presently they were changed into so many bundles of straw, swimming upright in the water; the buyer looked wishfully upon them, and was sorry in his heart; but he knew not where to find Faustus; so he was content to let all go, and lose both mony and hogs.

\section{CHAPTER XXXIX.}

How Dr. Faustus played a merry Jest with the Duke of Anhalt in his Court.

Dr. Faustus on a time went to the Duke of Anhalt, who welcomed him very courteously; this was in the month of January; where sitting at table, he perceived the dutchess to be with child; and forbearing himself until the meat was taken from the table, and that they brought in the banqueting dishes, Dr. Faustus said to the dutchess, Gracious Lady, I have always heard that great bellied women do always long for some dainties; I beseech therefore your grace, hide not your mind from me, but tell me 
what you desire to eat: She answered him, Dr. Faustus, now truly I will not hide from you what my heart doth much desire; namely, that if it were now harvest, I would eat my belly full of grapes and other dainty fruit. Dr. Faustus answered hereupon, Gracious lady this is a small thing for me to do, for I can do more than this; wherefore he took a plate and set it upon one of the casements of the window, holding it forth, where incontinent he had his dish full of all manner of fruit, as red and white grapes, pears, and apples, the which came from out of strange countries; all these he presented to the dutchess, saying, Madam, I pray you vouchsafe to taste of this dainty fruit, the which came from a far country, for there the summer is not yet ended. The dutchess thanked Faustus highly, and she fell to her fruit with full appetite. The Duke of Anhalt notwithstanding could not withhold to ask Faustus with what reason there were such young fruits to be had at that time of the year? Dr. Faustus told him, May it please your grace to understand, that the year is divided into two circles of the whole world, that when with us it is winter, in the contrary circle it is notwithstanding summer; for in India and Saba, there falleth or setteth a sun, so that it is so warm, that they have twice a year fruit; and, gracious lord, I have a swift spirit, the which can in the twinkling of an eye fulfil my desire in any thing: wherefore I sent him into those countries, who hath brought this fruit as you see, whereat the duke greatly admired.

\section{CHAPTER XL.}

How Dr. Faustus, through his Charms, made a great Castle in the presence of the Duke of Anhalt.

DR. FAUSTUS desired the Duke of Anhalt to walk a little forth of the court with him; wherefore they went together in the field, where Dr. Faustus (through his skill) had placed a mighty castle, which when the duke saw he wonder'd thereat, so did the dutchess and all the beholders, that on that hill which is called 
Rohumbuel, should on the sudden be so fair a castle. At length Dr. Faustus desired the duke and dutchess to walk with him into the castle, which they denied not: this castle was so wonderful strong, having about it a great deep trench of water, the which was full of fish, and all manner of water-fowl, as swans, ducks, geese, bitterns, and such like: about the wall was five stone doors, and two other doors also; within was a great open court, wherein was inchanted all manner of wild beasts, especially such as was not to be found in Germany, as apes, bears, buffs, antolopes, and many more strange beasts; also there were harts, hinds, roe-bucks, and does, and wild swine : all manner of landfowl that any man could think on, which flew from one tree to another. After all this he set his guests to the table, being the duke and dutchess, with all their train, for he had provided them a most sumptuous feast both of meat, and also of drink; for he set nine messes of meat upon the board at once, and all this must his Wagner do, to place all things on the board, the which was brought unto him by the spirit invisibly, of all things their hearts could desire, as wild-fowl, venison, and all manner of dainty fish that could be thought on; of wine also great plenty, and of divers sorts, French wine, Cullen wine, Crabashir wine, Renish wine, Spanish wine, Hungarian wine, Waszburg wine, Malmsey and Sack; in the whole there was one hundred cans standing round about the house. This sumptuous banquet the duke took thankfully, and afterwards he departed homeward, and but to their thinking, they had neither eat nor drank, so were they blinded while they were in the castle. But as they were in their palace, they looked towards the castle, and beheld it all on a flame of fire, and all those that saw it wonderd to hear so strange a noise, as if a great ordnance had been shot off; and thus the castle burned and consumed clean away, which done, Dr. Faustus return'd to the duke, who gave him great thanks for showing of him so great a courtesie, and gave him a hundred dollars, and liberty to depart, or stay there, at his own discretion. 


\section{CHAPTER XLI.}

\section{How Dr. Faustus, with his Company, visited the Bishop of Salisburg's Wine-cellar.}

DR. FAUSTUS having taken leave of the duke, he went to Wittenburg, near about Shrove-tide, and being in company with certain students, Dr. Faustus was himself the God of Bacchus, who having well feasted the students before with dainty fare, after the manner of Germany, where it is counted no feast, unless all the bidden guests be drunk, which Dr. Faustus intending, said, Gentlemen, and my guests, will it please you take a cup of wine with me in a place or celler whereunto I will bring you? they all said willingly, We will, which, when Dr. Faustus heard, he took them forth, set each of them upon a holly-wand, and so was conjured into the Bishop of Salisburg's Cellar, for thereabouts grew excellent pleasant wine; there fell Faustus and his company a drinking and swilling, not of the worst, but of the best. And as they were merry in the cellar, came to draw drink the bishop's butler; which when he perceived so many persons there, he cry'd with a loud voice, Thieves, thieves. This spighted Dr. Faustus wonderfully, wherefore he made every one of his company to sit on their holly-wand, and so vanished away; and in parting, Dr. Faustus took the butler by the hair of the head, and carried him away with them, until they came to a mighty high lopped tree; and on the top of that huge tree he set the butler, where he remained in a most fearful perplexity. Dr. Faustus departed to his house, where they took their valete one after another, drinking the wine that they had stolen in their bottles out of the bishop's cellar. The butler that had held himself by the hands upon the lopped tree all the night, was almost frozen with the cold, espying the day, and seeing the tree of huge great highness, thought with himself, it is impossible to come off this tree without peril of death; at length, espying certain clowns passing by, he cry'd, For the love of God help me down! The clowns seeing him so high, wonder'd what mad man would climb 
up so huge a tree; wherefore as a thing most miraculous, they carried tydings to the Bishop of Salisburg : then was there great running on every side to see him on the tree, and many devices they practised to get him down with ropes : and being demanded of the bishop how he came there? he said, that he was brought thither by the hair of the head, by certain thieves that were robbing of the wine-cellar, but what they were he knew not, for (said he) they had faces like men, but they wrought like devils.

\section{CHAPTER XLII.}

\section{How Dr. Faustus kept his Shrove-tide.}

THERE were seven students and masters that studied divinity, jurisprudentiæ, and medicinæ; all these having consented, were agreed to visit Dr. Faustus, and to celebrate Shrove-tide with him; who being come to his house, he gave them their welcome, for they were his dear friends, desiring them to sit down, where he served them with a very good supper of hens, fish, and other roast, yet were they but slightly cheared; wherefore Dr. Faustus comforted his guests, excusing himself that they had stolen upon

- him so suddenly, that he had not leisure to provide for them, so well as they were worthy; but my good friends (quoth he) according to the use of our country, we must drink all this night ; and so a draught of the best wine bedwards is commendable. For you know that in great potentates' courts they use at this night great feasting, the like will I do for you ; for I have three great flaggons of wine, the first is full of Hungarian wine, containing eight gallons; the second of Italian wine, containing seven gallons: the third containing six gallons of Spanish wine, all the which we will tipple up before it be day; besides we have fifteen dishes of meat, the which my spirit Mephistophiles hath fetcht so far, that it was cold before he brought it, and they are all full of the daintiest things that one's heart can devise; but saith Faustus, I must make them hot again; and you may believe me, gentlemen, that this is no blinding of you; whereas you 
think that this is no natural food, verily it is as good and as pleasant as ever you eat. And having ended his tale, he commanded his boy to lay his cloth, which done, he served them with fifteen messes of meat, having three dishes in a mess; in the which were all manner of venison, and dainty wild-fowl ; and for wine there was no lack, as Italian wine, Hungarian wine, and Spanish wine; and when they were all made drunk, and that they had eaten their good cheer, they began to sing and dance until it was day, and so they departed every one to his own habitation: at whose departing, Dr. Faustus desired them to be his guests again the next day following.

\section{CHAPTER XLIII.}

How Dr. Faustus feasted his Guests on Ash-wednesday.

UPoN Ash-wednesday came unto Dr. Faustus, his bidden guests, the students, whom he feasted very royally; insomuch that they were all full and lusty, dancing and singing as the night before: and when the high glasses and goblets were caroused one to another, Dr. Faustus began to play them some pretty feats, insomuch that round about the hall was heard most pleasant musick, and that in sundry places; in this corner a lute, in another a cornet, in another a cittern, clarigolds, harp, horn-pipe, in fine, all manner of musick was heard there in that instant, whereat all the glasses and goblets, cups, and pots, dishes, and all that stood upon the board began to dance; then Dr. Faustus took ten stone pots, and set them down on the floor, where presently they began to dance, and to smite one against another, that the shivers flew round about the whole house, whereat the whole company fell a-laughing: then began he another jest, he set an instrument upon the table, and caused a mighty great ape to come among them, which ape began to dance and skip, shewing them merry conceits. In this and such pastime they passed away the whole day; when night being come Dr. Faustus bid them all to supper, which they lightly agreed unto, for students in these cases are 
easily intreated; wherefore he promised to feast them with a banquet of fowl, and afterwards they would go all about with a mask; then Dr. Faustus put forth a long pole out of the window, whereupon presently there came innumerable numbers of birds, and wild fowl, and so many as came had not the power to fly away again, but he took them, and flung them to the students, who lightly pulled off the necks of them, and being roasted, they made their supper; which being ended, they made themselves ready for the mask;.Dr. Faustus commanded every one to put on a clean shirt over the other cloaths : which being done, they looked one upon another; it seemed to each one of them that they had no heads; and so they went forth unto cer tain of their neighbours, at which sight the people were most wonderfully afraid, and as the use of Germany is, that wheresoever a mask entreth, the good man of the house must feast them; so as these maskers were set to their banquet, they seemed again in their former shape with heads, insomuch, that they were all known who they were; and having sat, and well eat and drank, Dr. Faustus made that every one had an ass's head on, with great and long ears, so they fell to dancing and to drive away the time until it was midnight, and then every one departed home, and as soon as they were out of the house, each one was in his natural shape, and so they ended, and went to sleep.

\section{CHAPTER XLIV.}

How Dr. Faustus the Day following was feasted by the Students, and of his merry Jests with them while he was in their Company.

THE last bacchanalia was held on Thursday, where ensued a great snow, and Dr. Faustus was invited unto the students that were with him the day before, where they had prepared an excellent banquet for him, which banquet being ended, Dr. Faustus began to play his old projects. And forthwith was in the place thirteen apes, that took hands, and danced round in a 
ring together, then they fell to tumbling and vaulting one after another, that it was most pleasant to behold; then they leaped out of the window and vanished away: then they set before Dr. Faustus a roasted calve's-head, which one of the students cut a piece off, and laid it on Dr. Faustus his trencher, which piece was no sooner laid down, but the calve's-head began to cry mainly out like a man, murther, murther : but, alas ! what dost thou to me? whereat they were all amazed, but after a while considering of Faustus's jesting tricks, they began to laugh, and they pulled asunder the calve's-head, and eat it up. Whereupon Dr. Faustus asked leave to depart, but they would in no wise agree to let him go, except that he would promise to come again presently. Then Faustus, through his cunning made a sledge, the which was drawn about the house with four fiery dragons, this was fearful for the students to behold, for they saw Faustus ride up and down, as though he would have fired and slain all them that were in the house: this sport continued until midnight, with such a noise that they could not hear one another, the heads of the students were so light, that they thought themselves to be in the air all that time.

\section{CHAPTER XLV.}

\section{How Dr. Faustus shewed the fair Helena unto the Students} upon the Sunday following.

The Sunday following came the students home to Dr. Faustus his own house, and brought their meat and drink with them; those men were right welcome guests unto Faustus, wherefore they all fell to drinking of wine smoothly; and being merry, they began some of them to talk of beauty of women, and every one gave forth his verdict what he had seen, and what he had heard; so one amongst the rest said, I was never so desirous of any thing in this world as to have a sight (if it were possible) of fair Helena of Greece, for whom the worthy town of Troy was destroyed and razed down to the ground; therefore, saith he, that in all men's 
judgements she was more than commonly fair, because that when she was stol'n away from her husband, there was for her recovery. so great blood-shed. Dr. Faustus answered, for that you are all my friends, and are so desirous to see that stately pearl of Greece, fair Helena, the wife to King Menelaus, and daughter of Tyndarus and Leda, sister to Castor and Pollux, who was the fairest lady of all Greece, I will therefore bring her into your presence personally, and in the same form and attire as she used to go when she was in her chiefest flower and choicest prime of youth. The like have I done for the emperor Carolus Magnus; at his desire, I shewed him Alexander the Great, and his paramour; but (said Dr. Faustus) I charge you all that upon your perils you speak not a word, nor rise up from the table so long as she is in your presence; and so he went out of the hall, returning presently again, after whom immediately followed the fair and beautiful Helena, whosè beauty was such, that the students were all amazed to see her, esteeming her rather to be an heavenly than an earthly creature: This lady appeared before them, in a most rich gown of purple velvet, costly imbroidered : her hair hanging down loose, as fair as the beaten gold, and of such length, that it reach'd down to her hams, having most amorous cole-black eyes ; a sweet and pleasant round face, with lips as red as any cherry; her cheeks of a rose colour, her mouth small, her neck white like a swan; tall and slender of personage; in sum, there was no imperfect place in her, she looked round about her with a roling hawk's eye, a smiling and wanton countenance, which near-hand inflamed the hearts of all the students, but that they persuaded themselves she was a spirit, which made them lightly pass away such fancies : and thus fair Helena and Faustus went out again one with another. But the students, at Faustus entring in the hall again, requested him to let them see her again the next day, for that they will bring with them a painter to take a counterfeit, which he denyed, affirming that he could not always raise up his spirit, but only at certain times; yet, said he, I will give unto you her counterfeit, which shall be as good to you, as if yourself should see the drawing thereof; which they received 
according to his promise, but soon after lost it again. The students departed from Faustus to their several lodgings, but none of them could sleep that night for thinking of the beauty of fair Helena; therefore a man may see how the devil blindeth and enflameth the heart oftentimes with lust, that men fall in love with harlots from which their minds can afterwards be hardly removed.

\section{CHAPTER XLVI. \\ How Dr. Faustus conjured the four wheels from the Clown's Waggon.}

Dr. FAustus was sent for to come to the Marshal of Brunswick, who was marvellously troubled with the falling sickness, now Faustus had this quality, he seldom rid, but commonly walkt a-foot, to ease himself when he list, and as he came near unto the town of Brunswick, there overtook him a clown with four horses, and an empty waggon; to whom Dr. Faustus (jestingly to try him) said, I pray thee good fellow, let me ride a little to ease my weary legs; which the buzzardly ass denied, saying, That his horse was weary, and he would not let him get up: Dr. Faustus did this but to prove this clown if there were any courtesie to be found in him, if need were; but such churlishness is usually found among clowns, but he was well requited by Faustus, even with the like payment: for he said to him, Thou dotish clown, void of all humanity, seeing thou art of so churlish a disposition, I will pay thee as thou hast deserved, for the four wheels of thy waggon thou shalt have taken from thee; let me see then how thou canst shift? Whereupon his wheels were gone, his horses fell also down to the ground as though they had been dead: Whereat the clown was sore affrighted, measuring it as a just scourge of God for his sins and churlishness: wherefore with a trembling and wailing, he humbly besought Dr. Faustus to be good unto him, confessing he was worthy of it; notwithstanding if it pleased him to forgive him, he would hereafter do better; which submission made Faustus his heart to 
relent, answering him on this manner : Well, do so no more, but when a poor man desireth thee, see that thou let him ride; but yet thou shalt not go altogether clear, for although thou have again thy four wheels, yet thou shalt fetch them at the four gates of the city, so he threw dust on the horses, and revived them again: and the clown for his churlishness, was fain to fetch his wheels, spending his time with weariness, whereas if before he had shewed a little kindness, he might quietly have gone about his business.

\section{CHAPTER XIVII.}

How four Jugglers cut one anothers Heads off, and set them on again, and Faustus deceived them.

Dr. Faustus came in Lent unto Frankland fair, where his spirit Mephistophiles gave him to understand that in an inn were four jugglers that cut one anothers heads off: and after their cutting off sent them to the barber to be trimmed, which many people saw. This angred Faustus, for he meant to have himself the only cook in the devil's banquet, and went to the place where they were, to beguile them, and as the jugglers were together, ready one to cut off another's head, there stood also the barber ready to trim them, and by them upon the table stood likewise a glass full of stilled waters, and he that was the chiefest among them, stood by it. Thus they began, they smote off the head of the first, and presently there was a lilly in the glass of distilled water, where Faustus perceived this lilly as it was springing, and the chief juggler named it the tree of life: thus dealt he with the first, making the barber wash and comb his head, and then he set it on again, presently the lilly vanished away out of the water, hereat the man had his head whole and sound again: the like did he with the other two: and as the turn and lot came to the chief juggler, that he also should be beheaded, and that this lilly was most pleasant, fair, and flourishing green, they smote his head off, and when it came 
to be barbed, it troubled Faustus his conscience, insomuch that he could not abide to see another do any thing, for he thought himself to be the principal conjurer in the world: wherefore Dr. Faustus went to the table, whereat the other jugglers kept that lilly, and so he took a small knife and cut off the stalk of the lilly, saying, to himself, None of them shall blind Faustus. Yet no man saw Faustus to cut the lilly: but when the rest of the jugglers thought to have set on their master's head, they could not: wherefore they looked on the lilly, and found it bleeding: by this means the juggler was beguiled, and so dyed in his wickedness : yet no one thought that Dr. Faustus had done it.

\section{CHAPTER XLVIII.}

How an old Man, the Neighbour of Faustus, sought to perswade him to mend his Life, and to fall unto Repentance.

A Good Christian, an honest and vertuous old man, a lover of the Holy Scriptures, who was neighbour to Dr. Faustus, when he perceived that many students had their recourse in and out unto Dr. Faustus, he suspected his evil life, wherefore like a friend he invited Dr. Faustus to supper unto his house, to which he agreed, and having entred their banquet, the old man began with these words: My loving friend and neighbour Dr. Faustus, I am to desire of you a friendly and Christian request, beseeching you would vouchsafe not to be angry with me, but friendly resolve me in my doubt, and take my poor inviting in good part. To whom Dr. Faustus answered, My good neighbour, I pray you say your mind. Then began the old patron to say, My good neighbour, you know in the beginning how that you have defied God and all the host of heaven, and given your soul to the devil, wherewith you have incurred God's high displeasure, and are become from a christian far worse than a heathen person; oh! consider what you have done, it is not only the pleasure of the body, but the safety of the soul that you must have respect unto; of which if you be careless, then are you 
cast away, and shall remain in the anger of the Almighty God. But yet it is time enough, $O$ Faustus! If you repent, and call upon the Lord for mercy, as we have example in the acts of the Apostles, the Eighth Chapter, of Simon in Samaria, who was led out of the way, affirming that he was Simon homo sanctus. This man notwithstanding in the end, was converted, after he had heard the Sermon of Philip, for he was baptized, and saw his sin and repented. Likewise I beseech you, good brother Dr. Faustus, let my rude sermon be unto you a conversion, and forget thy filthy life that thou hast led, repent, ask mercy, and live: for Christ saith, come unto me all ye that are weary and heavy laden, and I will refresh you. And in Ezekiel, I desire not the death of a sinner, but rather that he will convert and live. Let my words, good brother Faustus, pierce into your adamant heart, and desire God for his Son Christ his sake to forgive you. Wherefore have you lived so long in your devilish practices, knowing that in the Old and New Testament you are forbidden, and men should not suffer any such to live, neither have any conversation with them, for it is an abomination unto the Lord, and that such persons have no part in the kingdom of God. All this while Dr. Faustus heard him very attentively, and reply'd: Father, your persuasions like me wondrous well, and I thank you with all my heart for your good will and counsel, promising you, as far as I may, to allow your discipline: whereupon he took his leave, and being come home, he laid him very pensive on his bed, bethinking himself of the words of this old man, and in a manner began to repent that he had given his soul to the devil, intending to deny all that he had promised to Lucifer. Continuing in these cogitations, suddenly his spirit appeared unto him, clapping him upon the head, and wrung it as though he would have pulled his head from his shoulders, saying unto him, Thou knowest Faustus, that thou hast given thyself body and soul, to my Lord Lucifer, and thou hast vowed thyself an enemy to God and to all men; and now thou beginnest to hearken to an old doting fool, which perswadeth thee as 
it were to good, when indeed it is too late, for thou art the devil's, and he hath great power presently to fetch thee. Wherefore he hath sent me unto thee to tell thee, That seeing thou bast sorrowed for that which thou hast done; begin again, and write another writing with thine own blood; if not, then will I tear thee in pieces. Hereat Dr. Faustus was sore afraid, and said, My Mephistophiles, I will write again what thou wilt: Then presently he sat him down, and with his own blood wrote as followeth: which writing was afterward sent to a dear friend of Faustus, being his kinsman.

\section{CHAPTER XLIX.}

How Dr. Faustus wrote the second time with his own Blood, and gave it to the Devil.

I DR. JoHn Faustus, do acknowledge by this my deed and hand-writing, that since my first writing, which is seventeen years past, I have right willingly held, and have been an utter enemy to God and all men; the which I once again confirm, and give fully and wholly myself unto the devil, both body and soul, even unto great Lucifer, and that at the end of seven years ensuing after the date hereof, he shall have to do with me according as it pleaseth him, either to lengthen or shorten my life as it pleaseth him; and hereupon I renounce all persuaders, that seek to withdraw me from my purpose by the word of God, either ghostly or bodily; and farther I will never give ear to any man, be he spiritual or temporal, that moveth any matter for the salvation of my soul. Of all this writing, and that therein contained, be witness my blood, which with mine own hands I have begun and ended. Dated at Wittenburg the 25 th of July.

And presently upon the making of this writing, he became so great an enemy to the poor old man, that he sought his life by all means possible; but this good old man was strong in the Holy Ghost, that he could not be vanquished by any 
means ; for about two days after that he had exhorted Faustus, as the poor old man lay in his bed, suddenly there was a mighty rumbling in the chamber, which he was never wont to hear, and he heard as it had been the groaning of a sow, which lasted long: whereupon the good old man began to jest and mock, and said, Oh! what barbarian cry is this? Oh fair bird! what foul musick is this? A fair angel, that could not tarry two days in his place? Beginnest thou now to turn into a poor man's house, where thou hast no power, and wert not able to keep thine own two days? With these and such like words the spirit departed; and when he came home Faustus asked him how he had sped with the old man, to whom the spirit answered: The old man was harnessed so, that he could not once lay hold upon him, but he would not tell how the old man had mocked him, for the devils can never abide to hear of their fall. Thus doth God defend the hearts of all honest Christians that betake themselves to his tuition.

\section{CHAPTER L.}

How Dr. Faustus made a Marriage between two Lovers.

IN the city of Wittenburg was a student, a gallant gentleman, named N. N. This gentleman was far in love with a gentlewoman, fair and proper of personage: this gentlewoman had a knight that was a suiter unto her, and many other gentlemen, which desired her in marriage, but none could obtain her. So it was that in despair with himself, that he pined away to skin and bones. But when he opened the matter to Dr. Faustus, he asked counsel of his spirit Mephistophiles, the which told him what to do. Hereupon Dr. Faustus went home to the gentleman, who bad him be of good cheer, for he should have his desire, for he would help him to that he wished for, and that this gentlewoman should love none other but him only: wherefore Dr. Faustus so changed the mind of the damosel by the practice he wrought, that she could 
do no other thing but think on him whom before she had hated, neither cared she for any man but him alone. The device was thus: Faustus commanded the gentleman that he should cloath himself in all the best apparel that he had, and that he should go unto the gentlewoman and shew himself, giving him a ring, commanding him in any wise that he should dance with her before he departed; who following his counsel, went to her, and when they began to dance, they that were suitors, began to take every one his lady by the hand; this gentleman took her who before had so disdained him, and in the dance he put the ring into her hand that Faustus had given him, which she no sooner toucht, but she fell presently in love with him, smiling at him in the dance, and many times winking at him, rolling her eyes, and in the end she asked him if he could love her, and make her his wife. He gladly answered that he was content; whereupon they concluded, and were married by the means and help of Faustus, for which the gentleman well rewarded him.

\section{CHAPTER LI.}

How Dr. Faustus led his Friends into his Garden at Christmas and shezed them many strange sights, in the nineteenth Year.

IN December, about Christmas, in the city of Wittenburg, were many young gentlemen, which were come out of the country to be merry with their friends, amongst whom there were certain well acquainted with Dr. Faustus, who often invited them home unto his house; they being there on a certain time; after dinner he had them into his garden, where they beheld all manner of flowers and fresh herbs, and trees bearing fruit, and blossoms of all sorts; who wonder'd to see that his garden should so flourish at that time, as in the midst of the summer, when abroad in the streets, and all the country lay full of snow and ice; wherefore this was noted of them as a 
thing miraculous, every one gathering and carrying away all such things as they best liked, and so departed, delighted with their sweet smelling flowers.

\section{CHAPTER LII.}

How Dr. Faustus gathered together a great Army of Men in his extremity, against a Knight that would have Conjured him on his own Journey.

DR. Faustus travelled towards Evzeleben, and when he was nigh half the way, he espied seven horsemen, and the chief of them he knew to be the knight with whom he had jested in the emperor's court, for he had left a great pair of hart's-horns upon his head; and when the knight now saw that he had a fit opportunity to be revenged of Faustus, he ran upon him, and those that were with him, to mischief himself, intending privily to slay him: which when Faustus espied, he vanished away into a wood that was hard by them, but when the knight perceived that he was vanished away, he caused his men to stand still; but where they remained, they heard all manner of warlike instruments of musick, as drums, flutes, trumpets, and such like, and a certain troop of horsemen running towards them; then they turned another way, and were also met on that side; then another way, and yet were freshly assaulted, so that which way soever they turned themselves, they were encountred, insomuch that when the knight perceived that he could escape no way, but that his enemies lay on him which way soever he offered to fly, he took good heart, and ran amongst the thickest, and thought with himself better to dye than to live with so great infamy: therefore being at handy blows with them he demanded the cause, why they should so use them? But none of them would give him answer, until Dr. Faustus shewed himself unto the knight; whereupon they enclosed him round, and. Dr. Faustus said unto him, sir, yield your weapon and your self, otherwise it will go hard with you. The knight 
knew no other, but that he was conjured with an host of men, whereas indeed they were none other but devils, yielded : then Faustus took away his sword, his piece, and horse, with all the rest of his companions. And farther he said unto him, sir, the chiefest general of our army hath commanded me to deal with you, according to the law of arms, you shall depart in peace, whither you please; and then he gave the knight an horse, after the manner, and set him thereon, so he rode, the rest went on foot, until they came to their inn, where he being alighted, his page rode on his horse to the water, and presently the horse vanished away, the page being almost sunk and drowned, but he escaped, and coming home, the knight perceiving the page to be bemired, and on foot, asked where his horse was: who answered, that he was vanished away. Which when the knight heard, he said, of a truth this is Faustus his doing, for he serveth me now, as he did before at the court, only to make me a scorn and laughing stock.

\section{CHAPTER LIII.}

How Dr. Faustus used Mephistophiles, to bring him seven of the fairest Women he could find in all the Countries he had travelled the twenty Years.

WheN Dr. Faustus called to mind that his time from day to day drew nigh, he began to live a swinish and epicurish life : wherefore he commanded his spirit Mephistophiles to bring him seven of the fairest women that he had seen in all the times of his travel : which being brought, first one, then another, he lay with them all, insomuch that he liked them so well, that he continued with them in all manner of love, and made them to travel with him all his journies: these women were two Netherland, one Hungarian, one Scottish, two Walloon, one Franklander. And with these sweet personages he continued long, yea, even to his last end. 


\section{CHAPTER LIV.}

How Dr. Faustus found a Mass of Money, when he had consumed twenty two of his Years.

To the end that the devil would make Faustus his only heir, he shewed unto him where he should go and find a mighty huge mass of money, and that he should find it in an old chapel that was fallen down, half a mile distance from Wittenburg: there he bad him to dig, and he should find it, which he did: and having digged reasonable deep, he saw a mighty huge serpent, which lay on the treasure it self: the treasure it self lay like a huge light burning; but Dr. Faustus charmed the serpent, that he crept into an hole, and when he digged deeper to get up the treasure, he found nothing but coals of fire: there he also saw and heard many that were tormented, yet notwithstanding he brought away the coals, and when he was come home, it was turned into silver and gold, and after his death it was found by his servant which was almost, by estimation, one thousand gilders.

\section{CHAPTER LV.}

How Dr. Faustus made the Spirit of fair Helena of Greece his own Paramour, and Bed-fellow in his twenty-third year.

To the End that this miserable Faustus might fill the lust of his flesh, and live in all manner of voluptuous pleasure it came in his mind, after he had slept his first sleep, and in the twenty third year past of his time, that he had a great desire to lie with fair Helena of Greece, especially her whom he had seen, and shewed unto the students at Wittenburg; wherefore he called his spirit Mephistophiles, commanding him to bring to him the fair Helena, which he also did: Whereupon he fell in love with her, and made her his common concubine and bed-fellow ; for she was so beautiful and delightful a piece, that he could not be an hour from her, if he should therefore have 
suffer'd death, she had stolen away his heart; and to his seeming, in time she was with child, whom Faustus named Justus Faustus. The child told Dr. Faustus many things which were done in foreign countries; but in the end, when Faustus lost his life, the mother and the child vanished away both together.

\section{CHAPTER LVI.}

How Dr. Faustus made his Will, in which he named his Servant Wagner, to be his Heir.

DR. FAustus was now in his twenty-fourth, and last year, and he had a pretty stripling to his servant, which had studied also at the university of Wittenburg: This youth was very well acquainted with his knaveries and sorceries, so that he was hated as well for his own knavery, as also for his master's; for no man would give him entertainment into his service, because of his unhappiness, but Faustus. This Wagner was so well belov'd of Faustus, that he used him as his son, for do what he would, his master was always therewith contented. And then when the time drew nigh, that Faustus should end, he called unto him a notary, and certain masters, the which were his friends, and often conversant with him, in whose pre sence he gave this Wagner his house and garden. Item, He gave him in ready money sixteen thousand gilders. Item, One farm. Item, a gold chain, much plate, and other household stuff, that gave he to his servant, and the rest of his time he meant to spend in inns and students company, drinking and eating, with other jollity: And thus he finished his will at that time.

\section{CHAPTER IVII.}

How Dr. Faustus fell in talk with his Servant touching his Testament and the Covenants thereof.

Now when this will was made, Dr. Faustus called unto his servant saying, I have thought upon thee in my testament, for 
that thou hast been a trusty servant unto me, and faithful, and hast not opened my secrets: And yet farther (said he) ask of me before I dye, what thou wilt, and I will give it unto thee. His servant rashly answered, I pray you let me have your cunning. To which Dr. Faustus answered, I have given thee all my books, upon this condition, that thou wouldest not let them be common, but use them for thy own pleasure, and study carefully in them; and dost thou also desire my cunning? That thou mayest peradventure have, if thou love and peruse my books well. Farther, said Dr. Faustus, seeing that thou desirest of me this request, I will resolve thee: My spirit Mephistophiles his time is out with me, and I have nought to command him, as touching thee: Yet I will help thee to another, if thou like well thereof. And within three days after, he called his servant unto him, saying, Art thou resolved, wouldst thou verily have a spirit? Then tell me in what manner or form thou wouldst have him? To whom his servant answered, That he would have him in the form of an ape: Whereupon appeared presently a spirit unto him in manner and form of an ape, the which leaped about the house. Then, said Faustus, See, there thou hast thy request, but yet he will not obey thee until I be dead; for when my spirit Mephistophiles shall fetch me away, then shall thy spirit be bound unto thee, if thou agree; and thy spirit shalt thou name Aberecock, for so he is called: But all this upon a condition that you publish my cunning; and my merry conceits with all that I have done (when I am dead) in an history, and if thou canst not remember all, the spirit Aberecock will help thee: so shall the acts that I have done be made, manifest unto the world. 


\section{CHAPTER LVIII.}

How Dr. Faustus having but one Month of his appointed Time to come, fell to Mourniug and Sorrowing with himself for his devilish Exercise.

Time ran away with Faustus, as the hour-glass; for he had but one month to come of his twenty-four years, at the end whereof he had given himself to the devil, body and soul, as is before specified. Here was the first token, for he was like a taken murtherer, or a thief, the which finding himself guilty in conscience before the judge had given sentence, fears every hour to die; for he was grieved, and in wailing spent the time, went talking to himself, wringing of his hands, sobbing and sighing; his flesh fell away, and he was very lean, and kept himself close, neither could he abide, see, or hear of his Mephistophiles any more.

\section{CHAPTER LIX.}

How Dr. Faustus complained that he should in his lusty Time, and youthful Years, die so Miserably.

THE sorrowful time drawing near, so troubled Dr. Faustus, that he began to write his mind, to the end he might peruse it often and not forget it, which was in manner as followeth: Ah! Faustus, thou sorrowful and woful man, now must thou go to the damnable company in unquenchable fire, whereas thou mightest have had the joyful immortality of thy soul, the which now thou hast lost! Ah! gross understanding, and wilful will ; What seizeth upon thy limbs; other than robbing of thy life? Bewail with me, my sound and healthful body, will, and soul; bewail with me my senses, for you have had your part and pleasure as well as I. Oh! envy and disdain! How have you crept both at once upon me, and now for your sakes I must suffer all these torments? Ah! whither is pity and mercy fled? Upon what occasion hath heaven repaid me with this reward, by sufferance, to suffer me to perish? Wherefore was I created a man? 
The punishment I see prepared for me of myself, now must I suffer. Ah! miserable wretch! There is nothing in this world to shew me comfort! Then woe is me! What helpeth my wailing?

\section{CHAPTER LX.}

How Dr. Faustus bewailed to think on Hell, and the miserable Pains therein provided for him.

Now thou Faustus, damned wretch! how happy wert thou, if, as an unreasonable beast, thou mightest die with a soul ? so shouldest thou not feel any more doubts; but now the devil will take thee away both body and soul, and set thee in an unspeakable place of darkness ; for although other souls have rest and peace, yet I, poor damned wretch must suffer all manner of filthy stench, pains, cold, hunger, thirst, heat, freezing, burning, hissing, gnashing, and all the wrath and curse of God; yea, all the creatures God hath created are enemies to me. And too late I remember that my spirit Mephistophiles did once tell me, there was great difference amongst the damned, for the greater the sin, the greater the torment; as the twigs of a tree make greater flames than the trunk thereof, and yet the trunk continueth longer in burning, even so the more that a man is rooted in sin, the greater is his punishment. Ah! thou perpetual damned wretch! how art thou thrown into the everlasting fiery lake, that shall never be quenched, there must I dwell in all manner of wailing, sorrow, misery, pain, torment, grief, howling, sighing, sobbing, running at the eyes, stinking at the nose, gnashing of teeth, snare to the ears, horror to the conscience, and shaking both of hand and foot? Ah! that I could carry the heavens upon my shoulders, so that there were time at last to quit me of this everlasting damnation. Oh ! what can deliver me out of the fearful tormenting flame, the which I see prepar'd for me? Oh ! there is no help, nor can any man deliver me; nor my wailing of sins can help me; neither is there rest for me to be found day or night. Ah! woe is me ! for there is no help for me, no shield, no defence, no comfort; where is 
my help? Knowledge dare I not trust ; and for a soul to Godwards, that have I not, for I ashame to speak unto him; if I do, no answer shall be made me; but he will hide his face from me, to the end, that I should not behold the joys of the chosen. What mean I then to complain, where no help is? No, I know no hope resteth in my groanings; I had desired it would be so, and God hath said, Amen, to my misdoings; for now I must have shame to comfort me in my calamities.

\section{CHAPTER LXI.}

Here followeth the Miserable and Lamentable End of Doctor Faustus, by which all Christians may take an Example and Warning.

THE full time of Dr. Faustus, his four and twenty years being come, his spirit appeared unto him, giving him his writing again, and commanding him to make preparation, for that the devil would fetch him against a certain time appointed. Dr. Faustus mourned and sighed wonderfully, and never went to bed, nor slept a wink for sorrow. Wherefore his spirit appeared again, comforting him, and saying, My Faustus, be not thou so cowardly minded; for although thou lovest thy body, it is long unto the day of judgment, and thou must die at the last, although thou live many thousand years: the Turks, the Jews, and many an unchristian emperor are in the same condemnation; therefore, my Faustus, be of good courage, and be not discomforted, for the devil hath promised that thou shalt not be in pains, as the rest of the damned are. This and such like comfort he gave him, for he told him false, and against the saying of the Holy Scriptures : yet Dr. Faustus that had no other expectation but to pay his debt, with his own skin, went (on the same day that his spirit said the devil would fetch him) unto his trusty and dearly beloved brethren and companions, as masters and batchelors of art, and other students more, the which did often visit him at his house in merriment; these he intreated, that they would walk into the 
village called Rimlich, half a mile from Wittenburg, and that they would there take with him for their repast, a small banquet, the which they agreed unto; so they went together, and there held their dinner in a most sumptuous manner. Dr. Faustus with them, dissemblingly was merry, but not from the heart; wherefore he requested them, that they would also take part of his rude supper, the which they agreed unto: for (quoth he) I must tell you what is the victualler's due : and when they slept (for drink was in their heads) then Dr. Faustus paid the shot, and bound the students and masters, to go with him into another room, for he had many wonderful matters to tell them, and when they were entered the room, as he requested, Dr. Faustus said unto them as followeth :

\section{CHAPTER LXII.}

\section{An Oration of Dr. Faustus to the Students.}

My trusty and well-beloved friends, the cause why I have invited you in this place is this: forasmuch as you have known me these many years, what manner of life I have lived; Practising all manner of conjurations, and wicked exercises, the which I obtained through the help of the devil, into whose devilish fellowship they have brought me ; the which use, the art, and practice, urged by the detestable provocation of my flesh, and my stiffnecked and rebellious will, with my filthy infernal thoughts, the which were ever before me, pricking me forward so earnestly that I must perforce have the consent of the devil to aid me in my devices. And to the end I might the better bring my purpose to pass, to have the devil's aid and furtherance, which I never have wanted in my actions, I have promised unto him at the end, and accomplishment of twenty four years, both body and soul, to do therewith at his pleasure; this dismal day, these twenty four years are fully expired; for night beginning, my hour-glass is at an end, the direful finishing whereof I carefully expect; for out of all doubt, this night he will fetch me to whom I have given myself in recompense of his service, body and soul, and twice confirmed 
writings with my proper blood. Now have I called you, my wellveloved lords, friends and brethren, before that fatal hour, to take my friendly farewel, to the end that my departure may not hereafter be hidden from you, beseeching you herewith (courteous loving loris and trethren) not to take in evil part, any thing done by me, but with rriendly commendations to salute all my friends and companions wheresoever, desiring both you and them, if ever I have trespassed against your minds in any thing, that you would heartily forgive me; and as for those lewd practices, the which these full twenty four years I have followed, you shall hereafter find them in writing : and $I$ beseech you let this my lamentable end, to the residue of your lives, be a sufficient warning, that you have God always before your eyes, prayingl unto him, that he will defend you from the temptation of the devil, and all his false deceits, not falling altogether from God, as I wretched and ungodly damned creature have done; having denied and defied baptism, the sacrament of Christ's body, God himself, and heavenly powers, and earthly men : yea, I have denied such a God, that desireth not to have one lost. Neither let the evil fellowship of wicked companions mislead you, as it hath done me : visit earnestly and often the church; war and strive continually against the devil, with a good and steadfast belief in God and Jesus Christ, and use your vocation in holiness. Lastly, to knit my troubled oration, this is my friendly request, That you would go to rest, and let nothing trouble you : also if you chance to hear any noise or rumbling about the house, be not therewith afraid, for there shall no evil happen unto you; also I pray you rise not out of your beds : but above all things, I intreat you, if hereafter you find my dead carcase, convey it unto the earth, for I die both a good and a bad christian, though I know the devil will have my body, and that would I willingly give him, so that he would leave my soul to quiet; wherefore I pray you, that you would depart to bed, and so I wish you a quiet night, which unto me, notwithstanding, shall be horrible and fearful.

This oration was made by Dr. Faustus, and that with a hearty and resolute mind, to the end he might not discomfort them; 
but the students wonder'd greatly thereat, that he was so blinded, for knavery, conjuration, and such foolish things, to give his body and soul unto the devil, for they loved him entirely, and never suspected any such thing, before he had opened his mind unto them; wherefore one of them said unto him, ah! friend Faustus, what have you done to conceal this matter so long from us? We would by the help of good divines, and the grace of God, have brought you out of this net, and have torn you out of the bondage and chains of Satan, whereas we fear now it is too late, to the utter ruin both of body and soul. Dr. Faustus answered, I durst never do it, although often minded to settle myself to godly people, to desire counsel and help; and once my old neighbour counselled me, That I should follow his learning, and leave all my conjurations: yet when I was minded to amend, and to follow that good counsel, then came the Devil, and would have had me away, as this night he is like to do: and said, so soon as I turned again to God, he would dispatch me altogether. Thus, even thus (good gentlemen, and dear friends) was I inthralled in that fanatical bond, all good desires drowned, all piety vanished, all purposes of amendment truly exiled, by the tyrannous oppression of my deadly enemy. But when the students heard his words, they gave him counsel to do nothing else but call upon God, desiring him, for the love of his sweet son Jesus Christ his sake, to have mercy upon him : teaching him this form of prayer : O God! Be merciful unto me, poor and miserable sinner; and enter not into judgment with me, for no flesh is able to stand before thee; although, $O$ Lord! I must leave my sinful body unto the devil, being by hin deluded, yet thou in mercy, may preserve my soul.

This they repeated to him, yet he could take no hold: but even as Cain, he also said, that his sins were greater than God was able to forgive : for all his thought was on the writing, he meant he had made it too filthy in writing with his own blood. The students and the other that were there, when they had prayed for him, they wept, and so went forth ; but Faustus tarried in the hall, and when the gentlemen were laid in bed, none of them 
could sleep, for that they attended to hear if they might be privy of his end. It happened that between twelve and one o'clock at midnight, there blew a mighty storm of wind against the house, as though it would have blown the foundation thereof out of its place. Hereupon the students began to fear, and go out of their beds, but they would not stir out of the chamber, and the host of the house ran out of doors, thinking the house would fall. The students lay near unto the hall, wherein Dr. Faustus lay, and they heard a mighty noise and hissing, as if the hall had been full of snakes and adders, with that the hall-door flew open: wherein Dr. Faustus was, then he began to cry for help, saying, murther, murther; but it was with a half voice, and very hollow; shortly after they heard him no more. But when it was day, the students, that had taken no rest that night, rose and went into the hall, in the which they left Dr. Faustus, where notwithstanding, they found not Faustus, but all the hall sprinkled with blood, the brains cleaving to the wall, for the devil had beaten him from one wall, against an other : in one corner lay his eyes, in another his teeth; a fearful and pitiful sight to behold. Then began the students to weep and wail for him, and sought for his body in many places. Lastly, they came into the yard, where they found his body lying on the horse-dung, most monstrously torn, and fearful to behold, for his head, and all his joints were dashed to pieces: the forenamed students and masters that were at his death, obtained so much, that they buried him in the village, where he was so grievously tormented. After the which they turned to Wittenburg, and coming into the house of Faustus, they found the servant of Faustus very sad, unto whom they opened all the matter, who took it exceedingly heavy. There they found this history of Dr. Faustus noted, and of him written, as is before declared, all save only his end, the which was after, by the students, thereunto annexed: farther, what his servant noted thereof, was made in another book. And you have heard he held by him in his life, the spirit of fair Helena, who had by him one son, the which he named Justus Faustus, even the same day of his death, they vanished away, both mother and son. The housc 
before was so dark, that scarce any body could abide therein : the same night Dr. Faustus appeared unto his servant lively, and shewed unto him many secret things which he had done and hidden in his life-time. Likewise there were certain which saw Dr. Faustus look out of the window by night, as they passed by the house.

And thus ended the whole history of Dr. Faustus his conjuration, and other acts, that he did in his life ; out of which example every Christian may learn, but chiefly the stiff-necked, and highminded, may thereby learn to fear God, and to be careful of their vocation, and to be at defiance with all devilish works, as God hath most precisely forbidden; to the end we should not invite the devil as a guest, nor give him place, as that wicked Faustus hath done: for here we have a wicked example of his writing, promise, and end, that we may remember him, that we go not astray, but take God always before our eyes, to call alone upon him, and to honour him all the days of our life, with heart, and hearty prayer, and with all our strength and soul, to glorifie his holy name, defying the devil and all his works; to the end we may remain with Christ in all endless joy, amen, amen: that wish I to every Christian heart, and God's name be glorified. Amen. 


\section{THE SECOND REPORT OF \\ DR. JOHN FAUSTUS.}

In nomine æternæ \& sempervivæ majestatis. Amen.

Spectatum admissi risum teneatis amici?

\section{CHAPTER I.}

DOCTOR JoHN FAUSTUS whose parentage howsoever hitherto informed, is known to be base, his father when he was at the best, but the son of a poor farmer, his mother the daughter of one of the same condition, born in a small village called Kundling in Silesia, brought up in literature at Gracovia, after at Wittenberg, whose life made him famous, and death notorious: being thus tormented and torn in pieces, at the time appointed betwixt the Divels and him, moved by this example woful and lamentable enough, the hearts of the students and scholars which were witnesses of his distraughture, with an inward terror of conscience vexed and tormented, they departed and declared the whole volumes of his detestable life, which afore his tragedy was thus acted, were not known. Christopher Wagner his familiar servant, unto whom he had committed the secrets of his bosom, and had intimated unto him, what ever his twentyfour years familiarity with the black art, and more black devils had taught him: he after the death of his thus slain master musing at every thing thus done, every thing thus done being wonderful : (as men do whom fear makes passionate, and meditation of former loss, urgeth a latter augment of fresh sorrows:) in a distraughtful fury (the company of students being departed which were eye-witnesses of the Doctors amentable end) con- 
III.

First there is yet remaining the ruins of his house, not farre from Melanchton's house as they call at the townes end of Wittenberg, right opposite to the Schooles.

\section{IV.}

Secondly there is yet to be seene his tree, a greate hollowe trunke, wherein he used to reade Nigromancy to his Scholers, not farre from the towne in a very remote place, which I think is sufficient testimony to any reasonable eare. And enquire of them which have been there, see if they will not affirme it. Notwithstanding I doe not goe by these meanes, I to entreate men to beleeve, for I care not whether they do or no, but onely to certifie you of the trueth as I myselfe would bee.

\section{V.}

Next his tombe is at Mars Temple, a three miles beyond the Citty, uppon which is written on a marble stone by his own hand, this Epitaph, which is somewhat old by reason of his small skill in graving.

" HIC JACEO JOHANNES FAUSTUS, DOCTOR DIVINI JURIS INDIGNISSIMUS, QUI PRO AMORE MAGIAE DIABOLICA SCIENTIAE VANISSIME CECIDI AB AMORE DEI : O LECTOR PRO ME MIERRIMO DAMNATO HOMINE NE PRECERIS, NAM PRECES NON JUVANT QUEM DEUS CONDEMNAVIT : O PIE CHRISTIANE MEMENTO MEI ET SALTEM UNAM PRO INFIDUCIA MEA LACHRYMULAM EXPRIME ET CUI NON POTES MEDERI, EJUS MISERERE ET IPSE CAVE."

The Stone was found in his study, and his wil was fulfilled, and he lieth betwixt a heap of three and thirty fir trees in the fort of the Hill in a great hole where this is erected

\section{VI.}

If these will not serve, then shall you heare the testimonie of a learned man John Wierus, cap. 4 . libro $x$. de magis infamibus. Which I have translated. 
John Faustus borne at Kundling, a little village, learning Magicke at Graconia, where he was openly taught and exercised it.

In sundry places of Germany with the admiration of many and with manifold lies frauds and illusions, with vain vaunting and promises but could doe nothing: one example I will shew to the reader, uppon this condition that he will passe his faith to me that he will not imitate him: Then reherseth he one of his knaveries, how he tooke upon him to make no haire grow upon a man's face, and tooke away with a powder which I will not name, both the beard that he had and all the skinne, causing such inflammations in his face that it burned it all over cruelly. This he committed being taken at Battoburg, uppon the bankes of the river Mosa, hard upon the boundes of Gelderland: Another (saith this learned Physition) not unknowen to me having a blacke bearde, the rest of his face somewhat dark and swarte, witnessing melancholy (for hee was splenaticke) when he came to Faustus who readily saide: Truely I thought you had been my familiar, straightwaie marking your feete, whether long and crooked nailes stood out of them. So likening this man to the divell which he thought had come unto him, which Divell he was wont to call Sorarius.

\section{VII.}

For his death in the same place, thus saith he. At length hee was found in a village of the Dutchy of Wittenberg by his bed side starke dead, and his face turned backwards, and the midnight before, the house was shaken as it is reported. Thus farre he, an authour not to be doubted of and approved through Christendome of singular and exact judgement, as appeareth by his writings of the like argument confutation.

\section{VIII.}

More in the same place he saith: That a schoolmaster amongst the Goslaryens, instructed of Faustus the magician, or rather 
Infaustus his evill doctrine, learned a way how the Divell might be bound by spell on a glasse, who as you may ther reade was so affrighted that lying one whole year speechless at thend he spoke of his feare and divels appearance, and then having received his christian rites died.

As for the Author this Doctor Wier, doubt you not of his credite, for he is alledged of the very singularest schollers as the best that ever wrote in that argument. We have a Gentleman of our owne countrey, Maister Reginold Scot, Esquier, that doth universally quote him as his chiefe and especiall helpe in his discovery of Witchcraft, yea and he testifieth of him not without good desart, saying: I Bode in his lawyerly Phisicke reasoneth contrarily, as though Melancholye were farthest of from these old women whom we call witches. And the most famous and noble physician, John Wier for his opinion in that behalfe: loe where he calleth him the most famous Phisitian as he was then certainly, in Discovery of Witchcraft, lib. 3. cap. 7 .

\section{IX.}

Thus farre I have set downe that you may know and perswade your selves so farre as you see just cause by the reasons. Vale. 


\section{THE SECOND REPORT OF DOCTOR JOHN FAUSTUS,}

CONTAINING HIS APPEARANCES, AND THE DEEDS OF WAGNER.

Written by an English Gentleman, Student in Wittenberg, an University of Germany, in Saxony.

I.

IT is plaine that many thinges in the first book are meere lies, for proofe marke this, it is said that it is translated, so it is, and where it is word for word. But I have talked with the man that first wrote them, having them from Wagner's very friend, wherein he saith many thinges are corrupted, some added de novo, some canceld and taken awaie and many were augmented. As for addition to the Coppy is there were Mephostophiles disputeth of the number of Hels, and some other disputations: And let a man marke them duely, they shall find them I will not say childish, but certainly superficiall, not like the talk of Divels, where with foldings of words, they doe use to dilate at large, and more subtell by farre. But as for his obligation and the most part, it is certain they are most credible and out of all question.

II.

For to take away a doubt, whether there was such a man, which is generally a thing not beleeved, I assure them this, that there was, and it is prooved thus : nor is Germany so unknowen but that the trueth of these thinges following may be founde if any suspect. 
veyed himself unto his master's library, viewing with sorrowful eyes the only monuments of his life, the disputations betwixt him and Mephostophiles, his answers and demands, and else whatsoever questions moved or disputed of betwixt the devils and him; the memorials of his heavens and hells voyages, his conveyance with many the like comical journies. The boy of a sodain fell into a deep considering of his former merriments, sports and delights, in so much that in this conceit he flung out of his study, as if he meant to bury the remembrance of these matters by contempt and negligence : coming into the same hall wherein his masters latest tragedy was perform'd, sighing for his want, he remembered (for as then he lately read it) how that one article to the which his master had bound Mephostophiles was, that after his death he should be a spirit in nature and essences as others were. The wag at this began to smile (oh how such things seeming pleasant make fools hearts merry) conceiving with himself how to make his own master become his man: And to have the number of his spiritual followers doubled, scorning the alonely attendance of one servant. To this therefore he determined a time for the raising of his master's spirit : and therewith he fell to read earnestly of other matters, so long that he began to leave as wearied, and wearied began to muse. Sodainly the air began to receive an alteration and change with a thick foggy mist, as if it would have shut up the desired day from man's view, the winds raged, the thunder lifted up his voyce above the common strain, hail and rain immediately following, and all these but the ordinary presages of an appearing .spirit. At this Kit began to tremble, not as afraid of that which came, but strucken with inward horror of conscience, thinking that no other time had been appointed to be his dooms day. Sodainly (for alwayes such haps are sodain) the doors flew open as if they would have fled from flying, and in all pomp entered as it were the prologue of a comedy, a fellow so short and little, as if he should be of one year, and yet not so briefe as ill favoured, in his hands a club, on his head a crown of laurel, riding upon a low mule, his name was Gomory, a strong and mighty duke, the 
ruler of six and twenty legions, and next in bravery appeared Volac a great governour, in the shape like a boy with wings like an Angel of Hell seeming to be of old rusty iron, riding upon a dragon with four heads, in his hands he held a flaming torch to give light to the after commers and beholders : next after him appeared Asmody a king mighty and puissaunt, ragged and bristled like a bore on foot, bearing a banner or lance. After him issued Lucifer the king of the Orient, with the four monarchs of his dominions, betwixt them were two mighty spaniels which drew in a fiery cart, Doctor John Faustus, whom if reason had not better ruled Wagner would have saluted, for so natural was his semblance, so lively his countenance as if it had either been a new Faustus, or not the old murthered Faustus, but the fear which his masters harm put him in cast him besides the renewing of his old acquaintance, after these came diverse others with trumpets and excellent melody. This right marvelous triumph thus presented each one did his humble obeysance the last beginning (though good there were none) and in the end with huge tumult and echoing of trumpets they crowned him a king, which when they had done, with the like ceremonies they conveyed out again the doctor whom his wretchedness made a king, and his new kingship nothing. Wagner started as if he had now begun to marvail, amazed at this merry interlude; having recovered his memory again, he began softly to speak to himself in such like manner. Is this (quoth he) the honour my master hath in hell? is this the reverence with which the fiends infernal used to entertain such guests? $O$ ye spirits of hell, and ye even now revived emperors of great Limbus, from whence have you drawn this extraordinary humanity, is it to scorn poor Faustus, or to mock Wagner, that you shew such reverence to a vile object, what then would they do to Wagner who is worthy to have a fitter servant than their king? At these words he blusht exceedingly, and began to rage very grievously with his consciences terror, and with some few tears repenting his irreligious conclusion, rose up from the ground, and supposing it to be but an illusion, dream, or 
a temptation, or else some conceit proceeding from his moist and melancholick fantasie overprest with too many vapors, raised up by continual thought into his pores : wherefore he went forthwith into the streets, (so much he distrusted himself) and demanded whether it rain'd, hail'd, or thundred, and it was answered, that it neither rain'd, hail'd, nor thundred. Wagner, albeit he was newly revived from a fear, and scarcely throughly wakened from this his great terror, yet with this comical jest his decayed spirits began to recover their old strength and power, turning these great braveries of devils into a merriment and his conceived fear into a meer fansy. This was the first time that ever Faustus appeared unto his servant Wagner, who recited this unto his companions as a matter of great truth and little moment.

\section{CHAPTER II.}

How certain drunken Dutchmen were abused by their own conceit and self imagination, of seeing the grand Doctor, Doctor Faustus.

IT shall not be impertinent (my very good friends) to declare as I am bound by a Translatours duty, to shew what these my Dutch friends and students have imparted unto me, not for that I will be a king of your hearts to command you to believe, but that you may with the rest of the history conceive the common opinion of him in the vulgars belief here in Germany, as concerning such the like illusions before pretended. About the same time, the next year wherein Faustus was thus handled, betwixt 6. and 7. a clock in the morning, the five and twentieth day of June, 1539, there chanced certain Scholars to the number of nine, and five other Merchants (called of them Copshmen) two being English, to walk abroad to a little village within 4 English mile (which is about one of theirs) of Wittenburg, called Shaftsburg, to the intent to make merry : whither being come they were exceeding pleasant, as Dutchmen are, especially when they be at their good beer, for 
they are men very impatient of thirst wherewith the Italian mocks them saying :

Germani multos possunt tolerare labores,

$O$ utinam possent tam bene ferre sitim.

Unto which they merrily answer,

Ut nos dura sitis, sic vos Venus improba vexat, Lex lata est Veneri Julia, nulla mero.

So long they drunk, that at last they came to be within a little of drunk, fetching over the Green nine Muses so often at sundry draughts till they began to be exceeding merry and pleasant, till it being time to depart, so they set out for Wittenburg, and being within a mile or such a matter of the city, they came to a thick grove called of them the Phogelwald, which is Birdswood in English, a place somewhat delightsome above any thereabouts, situated upon the top of a very high hill, but the armes of it spread themselves somewhat lower into the neighbour vallies and medows, full of very fine crystalline brooks and springs, which running through the large ranks of trees empty themselves into the Elve, a river which keeps his current by Wittenberg; in this place in a fair summer sun shine day, gather together a great number of country maids, servants, and other of the female sex, which they call Phogels (birds) unto them there resort on such like dayes, a great number of scholars to meet with these birds, which exercise venery either for pleasure, but indeed seldome but for gain, with whom when they have danced a great while (after some odd tune as after that which they call Robinsons delight, but more truly a jest, though somewhat tolerable) some 20 . or 30 . or 40 . couple together, then here steps out one couple, and here another, and get them to such odd corners, as their continual practice doth make known: on the same day wherein this merry company were wandering, who if I should not much err, I durst say they were most deeply drunk, being a sun-shining day, having no other way to pass to Wittenberg, but only by this Phogelwald, where they determined to be lusty with some of the Phogels, they came at length to these forenamed places, whereas to them it seemed 
sundry women dancing, and amongst them divers scholars, and verily they deemed Master Doctor Faustus likewise, and seeing divers maids standing idle, so many as would fit their many, they went to take them by the hands, and as their order is saluting them, to hop a bout or two (for all the High Dutchmens dances stand upon hopping, turning, winding, and such odd gestures) and as they seemed, they danced at great leisure till this said Faustus came to them, requesting them not to be amazed, for that it was reported he was dead, assuring them in very deed he was not in this world, but had changed it for a better, which if it did please them he would shew unto them, where betwixt their delights and his were no comparison; at his request they were all contented, and he leading the foremost, brought them down into a fair pleasant green, whereon instead of certain flowers grew pots full of the best beer, which they tasting on found them as good as any that ever they drunk in their whole lives, and farther unto a most rich and sumptuous palace, wherein as they seemed, they dwelt many dayes with great mirth and pleasure, till at length one more full of courtesie than the rest thanked Master Faustus for his good entertainment, at which words sodainly was heard so great a noyse and howling especially of the poor Doctor, who was immediately reared up into the air, accompanyed with such a sort of black clouds and mists, as therewith not only the sky, but also their eyes were mightily darkened, and they brought into a deep cavern, wherein besides most soft beds they had nothing to comfort themselves, in which they wallowed and slept till they snorted, some of the scholars that were present at their departure being in a soberer conceit than the rest, desirous to see whither they would go, followed them fast after, till they espied them in this dirty case, for instead of beds they were all bewrapped, and some more than half sunk in deep and yielding mire by the rivers banks. Whom when they saw in this more than miserable case moved with pity, conveyed them in waggons home : and being demanded in the morning (for then they were a little wiser) the occasion of their so great and seldom seen disorder, they declared it from the beginning to the ending, which 
they were so far from believing that they counted it as canonical which when some students reported unto me, I could not abstain from hearty laughter not only to see how they had abused them selves, but also others by so fond belief. For I said that in drunkenness so thick a vapor as riseth from so thick a matter as their beer, clambering up and spreading it self so universally in the fantasie, maketh it to conceive no other impression, but that which the mind afore it came to be oppressed was conversant about, and it was evident that in all the talk they had, there was nothing mentioned but only Faustus, and Faustus merriments, and where a thing is amongst so many so agreeingly talked of, it is likely it should take effect as well in all as in one. Well I was content to subscribe to their folly rather to satisfie their selfwilled conceits than my own thought. Many odd pranks Faustus is made father of, which are either so frivolous as no body can credit but like frivolous people, are so meerly smelling of the cask, that a man may easily know the child by the father.

\section{CHAPTER III.}

Wagners conference with Doctor Faustus, and how miserably they broke up their disputations.

WAGNER one morning arose betimes and departed to Wittenberg, but a small mile from the house, and having purveyed himself of all necessaries, was admitted for a scholar (immediately after his master was departed out of this world) into the University. Where, for that he was Faustus true and familiar servant, he was both well and manifoldly acquainted, wherein he remained in all solace amongst a great number of his companions, who then rather frequented his company, not only for that he was Faustus his servant whose memory was very freshly continued among them, but that they were verily assured that he had a great part of his masters skill and science, which they honoured with more than lawful reverence. Upon a day Christopher Wagner (as many times he did) separated himself from his other companions and 
friends, to ruminate upon his melancholick conceits, erring far in a place full of trees, and the fulness of trees gave it the name of the Grove, sodainly like as all such chances hap, Faustus or Faustus spirit clapt him up on the shoulder, saying : Wagner good morrow. Wagner vailed his scholers bonnet, thinking verily he was some other student: but beholding his Master Faustus, he was most terribly affrighted, and stepping aside he began to mumble to himself a Benedicite, and crossing himself, rehearsing and saying, Conjuro te in nomine Patris et Filii et Spiritus Sancti, \&c. making a circle, \&c. Faustus rowling his eyes, and for meere fury and anger stamping, bound (for so he seemed) with the vehemency of the exorcism, ran about most terribly the brims thereof, that therewith the neighbour ground did seem to tremble, casting out a blackish slomy sulphury smoak out of his mouth, wherewith the bright air was much darkened : at length appeased, either forced with necessity or knavery, he spake and that very distinctly. Wagner (qd he) art thou afeard of me as of a spirit, or infernal Ghost, am not I (ungrateful rascal) Faustus, am not I thy Master Faustus? Quoth Wagner very confidently, what thou wert I know, what also thou art who knows not? though once my master, now thou shalt be my servant, though once my friend and familiar, now I may justly term thee neither: the laws of Devils hath not made me secure from thy tyranny, and how may thy friendship avail me? For how can that help which is not? affections are not amongst fiends, nor passions amongst spirits. Wherefore Faustus if thou wilt that I be thy master, as whether thou wilt or no, I will conjure thee, \&c. to answer directly and truly to all my questions. Ah Wagner (quoth Faustus) is this the duty of a servant? dost thou mistrust that in me, which neither I mean, nor thou of thy duty oughtest to imagine? And as for affections in Spirits, certainly there is none, but I am none, feel me my good Wagner, behold flesh, blood, and bones; and Spirits have neither flesh, blood nor bones. Believe me I shall teach thee the nature and essence of Devils, I will teach thee that which neither thou canst desire of me or think, Extra captum humanum. Then my good boy 
Wagne... cion: me, and use me not as a spirit, whose body is nothing but psirit, and as logicians say substantia incorporea, and I will open unto thee the secrets of the world, and hell, and else whatsoever in the works of nature. Come my Wagner, my son, my darling, my sweet delight, and rejoicing, the only hope of my labours, boldly, lovingly, courteously, above all, which am the very same matter and substance I once was, and if thou doubtest, as well thou mayest, reach thy hand to me, for I cannot mine to thee, and feel whether I am not as I say I am, flesh, blood, and bones: Wagner half astonished at this his fervent speech, yet rather hearing it than believing it: Why Faustus, let me speak to you somewhat considerately, thou sayst thou art substance, and all substance is heavy, and no heavy thing can ascend upwards, and as thy conference with Mephistophiles doth plainly declare, the place of spirits is in the air, in which nothing that is heavy can remain, and therefore thou art not substance or not Faustus. Quoth Faustus, that no heavy thing is in the air is plainly false, for thou seest that material bodies are in the air, as hail, snow, and other meteors: Whereto Wagner answered, Faustus, they truly are in the air, and not of the air, and you know the causes of them are terrestrial vapors drawn from the earth by the attractive vertue of the sun, and therefore they fall down because they are heavy, for were they of the air as are spirits, then should they still remain in it: but briefly no violent motion may be called natural, as that heavy material dew is carried from the earth by a violent and contrary motion: the sun therefore leaving the Zenith of any horizon and coming to the Nadir oppositely, the material bodies of Dew, (as the causes alwayes fail with the effects) and nextly the concretion of snow and hail, because they are substance, cannot remain in the light and unheavy air: Wherefore I have answered thee that thou art either a spirit or not substance. I wondred when I read this discourse, with what patience the doctor could indure so long an argument, but it proved otherwise, for the Doctor brake forth into these speeches, unable to contain himself any longer.

Wagner, thou seemest to gather natural arguments of meta- 
physical effects, I say unto thee Wagner, sith "thou ${ }^{*}{ }^{*}{ }_{2}$ s far entred into a philosophical discourse, that I hoing as I am Faustus, may be, for so I am, a dweller in the profound Abysse of the Air, whose compass is measurable in this, that it is not measurable: for let us speak according to men naturally, the rather to fit thy capacity, we see that in the regiment of mans body, the man is of quality like to the predominant complexion and element, as if Choler abound, the man is light, nimble, and for a while furious, seldome strong, ready to meddle, and carried away with phanatick illusions : if blood abound, he is ruddy, fair, gentle, \&c. Et sic de reliquis. If therefore the predominant element is able so much to change the nature of men, as to make it above the rest capable or incapable, the same reason maketh that this body of mine which thou seest, being governed and predomineered by that quick and ready spirit and soul which makes a man immortal is no hindrance why this corporal reality of me should accompany my spirit, not as a body, but as a part of the same spirit : and otherwise Wagner, the whole world is in the air, and as it were the centre of the heavens, and what substance soever is made, fishes which dwell in the deep seas except (and yet not always) are moved in the air. Kit believe me, I am as thou seest Faustus and the same very same.

Wagner almost at the last cast, said, we dispute not what you are Faustus, but what by reason you may be. Well, answered Faustus, seeing thou wilt not believe, nor give any credit to my sayings and which I prove by arguments, I hope thou wilt believe thine own eyes, and if thou seest what I say unto thee, thou wilt neither be obstinate nor incredulous, and rather than Wagner (whom I do love as myself) should be carried away with so palpable an heresie, behold Wagner, and believe, and straightways he drew his knife the prologue of his knavery, and looking first upon Wagner, and next on the weapon which he had in his hand, as if with his eyes he would have moved him to some pity, and moved them to be witnesses of the truth, he strook himself into his thigh twice or thrice, and after his stroaks followed blood so hastily, as if it would have overtaken the injurious worker 
of his effusion: which blood Faustus received in a silver boule and stanching his wound, but not until the blood might be seen over the cup-brims, then Faustus lifted the blood on high saying, see here the witness of the truth; Wagner take it, look how fresh it is, it is not that which comes from a spirit, it is blood both in nature and colour, and if this be not enough to make thee believe that which I do tell thee, it boots not, there is not any truth at all.

I thought it enough for an extemporal dis and controversie, I thought the scholar had heard as well and as long as the doctor had taught, but yet he had not ended. Wagner receiving the cup and looking on the blood beheld him without saying any thing, shewing by his silence his meaning. Faustus minding to revenge and recompense Wagner his unbelief, nay further (quoth he) feel my hand, tell me whether it hath not the natural heat and essential solidity, then immediately he stretched forth his arm. Wagner with sodain extasie of joy carried away, ran to embrace his old master as his new friend, whom when Faustus had encircled he fell to beating the poor scholar most miserably that Wagners pitiful roaring seemed to be an eccho to the doctors blows: now (quoth Faustus) hereafter be learned either to be more wary or less mistrustful, and therewith laughing effusedly vanished away, leaving Wagner to be a witness (yet almost half dead with his buffeting) of their conference, and that he was a good substantial burgess of hell : Wagner, poor boy, for the space of seven hours not able scarce of himself to stir or take breath, and without much stirring either of hand or foot, whereby any able life might be conjectured: at length lifting up his head and sighing a little (for a little was as much as he could do at that time) he reared himself up and laying bis head upon his hand, and his hand upon the ground, he after sighs, sent out most sorrowful groans, and after groans some feeble words, as he afterwards reported it to his companıons and familiar acquaintance: to accuse either his masters vigor or his own folly, he thought as meerly vain as little prevailing: wherefore comforting himself with his misery, because he was comfortless, rose up 
and looked for the cup of blood : in place whereof he found his cup full of piss, and all beraied : sore ashamed and sore withal, so well as he might, which was sorely enough, he rose up, and what by creeping and going he got home to his chamber, where he abode till he recovered his health again.

Thus was his philosophical incredulity recompenced with rustical cruelty, such was the good love of the spirit, that for a long space after he was not able to walk out of his chamber. This did he affirm for most certain truth, and to his saying added his beaten skin, as a testimonial and witness to his familiarly beloved acquaintance, one of the which recounted it all summarily in a letter from Wittenberg to me, where I was at Lipzig, knowing that I intended to certifie my friends in England of a matter so notable and strange, and worthy of memory, and augmented by fame more than of very deed, for idle headed fellows having gotten such a notable fellow as Faustus to father their lies upon, ceased not dayly and hourly to beget new children, but they cost very little nursing and bringing up : they had the wide world, a very good grandam, where they might feed their fill : as for the disputations betwixt those two in this place, and those which you shall find in other places likewise abundantly, consider from whose brains they proceed, for you must give the German leave to shew his art; for wit for the most part they have very little, but that which they toil for like cart-horses. But in all their doings you shall easily perceive if any thing be in them excellent, either with how much liking and urging they bring it forth, or how it is wetted over with dropping of the tap exceedingly.

\section{CHAPTER IV.}

Wagners cosenage committed upon the sellers of his masters goods.

According to the law of the country, the goods of Faustus were to be confiscated and applyed to the treasury, by an edict published against conjurers by Sigismond Duke of Saxony. According to the tenor thereof Faustus goods were to be alienated, but 
Wagner so handled the matter that the spear being stuck up, and his goods set to be sold, . Wagner had provided bidders and money of his own, the one were such as were never seen more, and the other but round counters.

The messengers being thus cosened by Wagner, durst not for shame report it, nor he for fear of further punishment vaunt of it : the one content to put up the loss quietly, and the other to enjoy them without further contradiction.

\section{CHAP'TER V. \\ The Description of Vienna.}

FAME had so far carried the report of Faustus death, as it had the memory of his life, and for that by continual motion rumors encrease, as saith the heroical fountain of Latin verse, Virgil,

Mobilitate viget viresque acquirit eundo.

In Austrich these news were very frequent, being a province mightily replenished with people, and marching upon the hems of the Hungarian, is a neer neighbour to the most cruel dog and tyrant, the Turk. In Vienna, a city of the same, by which as the Thames by London, the great and often but never enough praised, river of great Danuby keeps his current (the city itself being every way bigger than the fair city of London) within the walls, the head of the city resteth upon the mountain of Orstkirken, the front displayeth the wild plains upon the descendent of the same hill, but she washes her feet in the river: her body and her brest covering the large valley lying betwixt hill and hill: not far into the city, Danuby is derived in two arms, which by running about a certain hill, of some half a mile and more, meet at length again in the same channel; in this island is the dukes court, out of which are two and thirty marvellous good stone bridges, intending to either side of the city : at the very promontories ends, stand two no less fair than high and strong castles, in this place did the duke keep his court, with very great royalty, unto whom when this was reported, hearing of a certain that 
Wagner had great store of his masters skill, and whatsoever, he caused one that in such matters is commonly commanded, to ride to Wittenberg, to the intent to hear the truth, for many things more than the truth were certified unto him: the messenger without delay (because the journey was long) departed and left the court, and we him a while.

\section{CHAPTER VI.}

A long discourse betwixt the Devil and Wagner, and ended with a good Philosophical repast.

WAGNER solitary musing in his chamber and conversing with many multitudes of thoughts, suddenly appeared Mephistophiles his masters familiar, after him Akercocke, which was Wagners, and after all, Faustus : quoth Mephistophiles, what chear? Sirrah such as you see, we are as we were, and never the better: and welcome Akercocke; but my very good Faustus, that you come at this time I rejoyce. So then they all sat down, and sat right against him. Then entred in divers delicate viands, and there not then to be ended, with unseen symphonies of musick. Then spake Wagner and said, Claud te jam rivos, now we have satisfied our appetite with meat, I pray you hear me with patience, for I have a thing in my mind, of which I would fain be resolved, but because you so foully, and so often foully entreated my master, for demanding some questions, you shall ratifie this article with me again : first, that in my demands you shall answer truely and patiently, for what hurt can redound to you by answering of a question, seeing if you are sure of any thing you may hold fast, a question cannot take it away: without delay these good fellows confirmed the article with a great oath: but he would take their simple word without surety, he knew their honesty so well. Then Wagner pulling down his cap over his eyes, and leaning upon his elbow a while, and throwing up his eyes to heaven, and then sighing, at length folding his arms within themselves, sat still a little time, then spitting a little and fetching a hearty hem with a good courage spake unto them thus: 
Sirs, it is not unknown to you how dear I have always accounted of my Master, whose condition is as far from that it was, as mine from yours, for which I have more often lamented his departure than mine own misery, being once every way a man, so thoroughly instructed with the weapons of all sciences, that in all the world hardly his par could be found, so that your victory over such a man is more to be wailed than over many a thousand such as I am. To be short, that you may understand whither I will go without further oration. Wherefore I desire you, I pray you, nay I by your article command you, that you declare unto me truly without collusion, whether that Faustus here present in that state wherein he now is, may come again to be a living man amongst us, either his old shape renewed, or be in a new : for some philosophers say, and some divines, as Origenes and Tertullian, and whether they say truly or no I know not, that no sooner the soul of man departeth from one, but that it doth enter into another. Wherefore I considering with myself thus much, and often for his cause that he may not onely be Faustus, but also a living man and dweller upon the earth, to enjoy not only those graces which through his great deserts he had lost, but also according to his infinite knowledge, multiply them through God's favors again and again abundantly. And though you shall perhaps deny that the same individual cannot be againe resuscitated, yet that Numero it may in spite of you all, I know it may: for we do not doubt that the same individual may Numero be again regotten, because that after seven and thirty thousand years, the heavenly constellation shall be in every point per totum the same then that now it is, according to Plato and the astronomers. And therefore we shall be the same in Numero, and shall sit in this or that schole or place as now we do, that is in that Magno anno, in that great year: Whereupon Plato said, that after the great year he should return to Athens, and should there read; Because the constellations shall happen so; therefore, that returning, the same effects shall with them likewise return. Now having heard my resolution, answer me to my first proposition in full and amply, as that I may be satisfied. At the conclusion of this 
speech Faustus turned his head aside laying it betwixt his hands hiding it, so sat a great while. Ak. he friskt up and down for he had neither clog nor chain because he was in number of the wild ones, and over the table and back again. Ak. was the familiar which F. gave to IV. who asked him in the fashion of an ape. Such cranks, such lifts, careers, and gambalds, as he plaid there, would have made a horse laugh. Me. who as it seemed was the speaker of the parliament in Hell, rose and walked about very hastily, at length he came to the table and striking his fist on it (the print was seen two years after, and was carried to $\mathrm{S}$. Margaret's Church for a relique, to shew what a fellow the Devil is in his anger) and again beating said, thou, then left them and came and went, and came and went again, here he takes me one book and hurles it against a cupboord; and then he takes the cupboord, and hurles it against the wall, and then he takes the wall and throws it against the house, and the house out at the window. Pacifying his rage at the length, rowling his eyes and seeming to beat his teeth together, he sat down further off, and thus quietly spake with a loud voyce. Were it not Wagner that our solemn vow forbiddeth to disturb or torment thee for any demands, this thy fond pride should be rewarded with most intolerable punishments : as for the question I will answer thee more substantially than such a foolish doltish one doth require. And for that we have day enough before us, I will travel further in it than the gravity of the argument can require, if it be but that thou mayest see how great an ass thou art, which canst imagine so gross a matter in thy more gross head: as for thy great yeer be it as you will, expect in you, in the meantime we will enjoy him and thee at our pleasure in despight of God and heaven, and his imperial armies of saints. Thy question is this : whether the spirit of a damned man can return into the body of another man. To which I answer negatively, it cannot.

I. If this were to them granted, they should observe and keep the embryons in the womb of the mother, that they might constitutively unite themselves to it, to have at least wise, sensuall consolation and delectation. 
2. Then secondly, because it is common to reasonable creatures to fashion and informate the body, and to perfect it with some natural delightment, not to vex it.

3. Then thirdly, because of the law and order of nature, the souls from the places in their departure to them allotted, assigned and deputed of God, neither do nor can depart at any time: for it is written, For the soul is a spirit going and returning. And they which do otherwise hold opinion, are to be accused nay condemned in this with Pythagoras, who did abstain from all living animals and creatures, believing that in some the souls of some men did dwell and abide. Thus far the Arrogonian named Bartholomew Sibylla a Monopolitane, who writ upon this question being at Wittenberg, at the request of him that did set forth the Dutch coppy shews himself to be a good philosopher and no worse divine. But mark what follows: this is written according to men in faith: the Devil was out of the first streete of Coany when he was past this last period. For that Pythagorical opinion; if that were, this absurdity would follow: (I will speak plainly the rather to fit thy capacity) and if the soul should pass out of the dead into the living, then should mortality be the cause of the soul's immortality, (this is prettily spoken) and by that means make it corruptible, which cannot be. And seest thou Wagner? for I will teach thee by demonstrations, and therewith he took a coal of fire and held it to him so long that it came to be but a coal : now thou seest Wagner, that so long as fire was in this subject it had life, but the quality being removed from the quantity, neither is the quality found or seen or known whither it vanisheth, nor can the same fire, though fire, return into another body or subject, albeit the quantity remaineth. Thus may the soul of man be compared to a fire in the soul, as concerning his entrance and departure, but not reentrance, for that coal may take life again, that is fire, but so cannot humane body: because one spirit can be united but to one body, and not two to one, nor one spirit to two bodies: wherefore that spirit being departed it is irrevocable, because 
of the unity, and the impossibility of returning in the one, in the other of receiving any other. As for other reasons directly by circumstance, if the soul goeth either to joy or pain immediately, then I am certain that that hope which thou hast is meeriy vain, as anything which may hap under that title; for proof behold. And so then through the wainscot door of Wagner's study entred in two kings, which drawing their swords did there in presence combate together fiercely and courageously, one of them shortly after fainting under the adversaries strokes fell down, the other victorious, yet wounded, very canonically as a man may say, staggered immediately, as if he would fain have not fallen, yet for all that he fell: then entred two men carrying torches with the snuffs downwards, with great solemnity (more than is here needful to be recapitulated, for I see nothing but that this might have been very well left out for any thing worthy the gravity of the matter) which when they had carried out the first slain combatant, with armed men, and a dying stroke of the drum, clothed all in the colour which best notes by his external hue the internal sorrow. Then next there entred two pages all in silver white crowned with bayes, carrying their torches aloft, declaring the height of their glory by the height of their flames: next to them divers trumpeters and all in white, urging forth into the wast air their victorious flourishes; next a great standard-bearer, and I cannot tell what, but the conclusion was, that the triumph was exceeding great and pompous, adorned with as many ceremonies as such a victory might or could be. The spirit when they were all gone began to speak and said, This was the battle which was fought for the great realm of Asia, by Hercules and Orontides, where Orontides was slain, and Hercules sore wounded, but yet recovered, after which he atchieved his twelve labors, and the thirteenth of which the poet speaketh, the hardest of all.

Tertius hinc decimus labor est durissimus, una

Quinquaginta simul stupravit nocte puellas.

This history is as I do think in the chronicle of hell, for I did never hear of it before, nor any body else, I appeal to all the 
histories. Marry it may be this was when Hercules was a little boy, and then peradventure indeed the records make no mention of it, but yet we have that recorded which he did when he was less than a little boy, as his killing of a serpent in his cradle, and such a history as I do remember is enroll'd in the golden book of the seven wise masters of Rome, an authentical author. But let that pass, and let us draw more near unto the cause; for as the Devil was afore our dayes, so by authority he may alledge experience, and we must of necessity believe that it is either true or a lie. Mephostophiles continued his speech for all this parenthesis, declaring to Wagner his meaning in this point : for (quoth he) as you see these two champions contending for the title of victory, one of them must needs, if they try the extreamest as they did, receive the dishonour, the other the glory, so in the combat wherein the dying body battaileth with the lively soul, the soul if grace hath made it acceptable, shall enjoy those everlasting pleasures of Paradise, and dwell in heaven blessed and glorious amongst the beautiful angels, but if it be counted as reprobate and outcast of God, then according to that punishment which his great sins did deserve, he can have no other place but the continual horror of hell, wherein the miserable dwel, and the ugly company of black devils and frightful angels. There is no other mean but honour and dishonour in this cause, no other mean but joy or pain, no other mean but heaven or hell perpetually : there is no place left for a third. I could more copicusly dispute of this matter, but that I will not be too tedious in so exile a question. For where it is said in an author to which I am witness, for I stood by his elbow when he writ the lines, "Animæ sunt in loco certo et expectant judicium, neq ; se inde possunt commovere." Which place as appeareth in the precedent chapter is heaven or hell : again it is said, "Anima quæ peccaverit ipsa morietur." Of necessity then the soul to whom the Lord imputeth not his sin shall live, for they are immediate oppositions, for the soul that is in joy will not come to these troubles, nor that which is in torment cannot: therefore it is said: "Et revertatur pulvis in terram quem admodum erat, et 
spiritus revertatur ad Dominum, qui dedit illum," so there is no mention in any scripture of the souls returning, but to a certain place deputed of God to him. But before I go any further in the declaring of that which is here to be set down, I know they that have their consciences more of the precise cut, will say, that here was a learned devil : true it is, he is learned, strong, and above all human conceit, subtil and crafty, and if they say it is blasphemously done, to have the word spoken to the world by so vile a mouth, first they know how mightily. the Devil is conversant in holy writ, in anything to overthrow a christian thought, knowing that the word of God is a word of power to attain salvation to whom grace is given and to work eternal damnation where that gift is wanting, knowing it is the only means to debel and conquer the christian thought, for as a man is governed by $a$ law and by it lives, so if any thing be evidently directed against him in it, it stays his heart ${ }_{2}$ it overthrows him, it takes away his power for ever: nor is it more blasphemous to be spoken to us men, than to God himself, as it is in St. Alatherio, where the Devil was not afraid to assail his creator with most terrible arguments of the divine letter. They which have right minds can persuade themselves accordingly: but otherwise they may cavil as long as they will, which they may do to their small profit, assuring them this, that in coveting by fault-finding to seem. learned, they make themselves the notes and reproach, not only of the learned, but even of the absurd and barbarous rude fools, and that they are the only spirits of errour and contention, and the chief causes of unbelief by vain reasonings and questions to the unresolved christian. But as for this speech, which is but humile dicendi genus, in.very truth, let them thus think, that if there were any such controversy betwixt Wagner and his spirit, as is here mentioned, that those are not the words which were spoken, but that they do proceed from a young scholar who gave me this copy, and not of a Devil, of whose familiarity and frequency and of other circumstantive causes, I will God willing in the catastrophe and conclusion of this book deliver unto you my poor opinion. In the mean while I will follow the matter 
into which we are fallen my good friends, and without further ado I pray, without any more excusive phrase, patiently expect the good hour wherein the death of this volum is prepared. Mephostophiles taking breath a little, presented his speech saying : it is said likewise, "Factum est autem ut moreretur mendicus, \&c." And it came to pass that the beggar dyed, and was carried away of Angels into Abrahams bosome, and that rich man died, and was buried, and he being in hell lifted up his eyes, when he was in torments, and saw Abraham afar off, and Lazarus in his bosome. Nor nothing doth that impugn which is said of the Papist that he cannot come into Gods presence, nor be one of the elect, unless he be purified from his sins, for which purification they ordained a place so terribly stuck with pins, needles, daggers, swords, nails, \&c. soultring with hot burning furnaces, and so every way formidable with material sulphury fires, that no tongue can express, nor any heart imagine, wherein the sinful soul must be many times and often cleansed, but I hope if this were true then Lazarus should have been likewise so drest in their terrible imagined terrors, which he was not unless they will be impudent to say that he had no sin. I shall not need to dispute how absurd it is to say, that the sin of the soul in the body committed, must be extirpated and purified by a material substance and rigor, not of the matter of the like argument. And hereupon he seemed to sigh as if some sodain thought had overprest his stomach. I can quoth he largely discourse of all divine and humane propositions, but as the unlearned parat who speaketh oft and much, and understandeth never any thing to profit himself. Ah that unto us spirits no secrets are secret, no doings of man unhid, and yet we Devils cursed of God, are incapable of any of Gods mercies, though through them we were created. We know repentance is the way to attain the celestial favour: we know Gods mercies how great they are, and that we ought to despair of nothing (such is our seeing blindness) so it appertain to God and godliness, of which we do not despair. No Wagner we are so far from living again, as we are from certainty to be saved. But instead of that, we are crossed with all kind of vexations, for 
since the first time that I with my master and fellows fell down from heaven being of the most royal order of angels, potestates, cherubins, and seraphins, riding upon the wings of the wind in all bright shining majesty, and enjoying the most glorious and divine presence of our Creator, till for our hearts swelling pride, and haughty insolency within as little space of time as we were created in, with his dreadful lightning he threw us down headlong into the bottomless abysses of the air, wherein we indure these tortures and alike wicked souls with us, as our manifold deserts have brought upon us: and for that we know that the way to mercy is utterly denied, and that we are as much hated of our selves as of God, we think it the sweetest remedy in these manifold miseries to have partakers of our common wo with us. Wherefore it is most expedient for us to be thus enviously malicious against all mankind, making them as far in Gods dreadful curse as our selves.

Wagner melting at these words, his eyes undid the great burthen of his sorrow, straining himself so long that he wept and yet could say nothing, but only a small volley of sobs hastily following; Mephostophiles seeing how Wagner was drowned in so deep a melancholy, told him pulling him by the sleeve that he would be still demanding of such foolish questions which will profit him so little as mought be. Knowest thou not (quoth he) that all the rhetoricks are the servants of my tongue or that we can move pity or hatred when we please? fool as thou art, forget these vain conferences, perswade thy self that they are but the effect of speech, long canst thou not live, and yet dost thou live as if thou didst not long, youthly should be thy thoughts and fraught with the rank lustiness of conceit and amorous delight, if thou wilt ask questions, let them be such as appertain to love and wealth, to pleasure, to pastime, and to merriment. How sayest thou to such a one, naming a gentlewoman, the most beautiful lady under the cope of heaven? thou shalt enjoy her, nay, any one so she be one whom thou list to call beautiful, whosoever thy eyes shall lay their delight upon. And presently musick was heard so sweet, so plenteous, and so ravishing, as if 
on musick depended all sweet, all plenty, all ravishment. The doors conveying themselves aside, as giving place to so divine a fairness, entring in a blue velvet gown rased, and thickly beset in the gards with most pure oches of gold, not altogether ignorant of precious stones fur'd with royal ermines, loose about her: her heads ornament (though greater ornament to her head than her head there could not be) was a kind of attired caul (such as I have seen none in England according to their description) raised up at corners with stiff square wyres of beaten gold, on that a chaplet or.frontire of roses, on the chaplet a vaile of lawn, which covered all her fair body, denying the sight of such an angel, but only through a shadow. In brief she was such a one as would have roused the basest desire in the whole world, to attempt wonderous enterprises; in her silken soft hand she held a lute, discoursing sweetly upon the solemn strings with her nimble fingers: a maid carrying a blue waxen taper in a silver white candlestick made in the fashion of a censer, but it was derived into two several branches, in whose ends were curiously wrought two most beautiful places to pight tapers on. The maid bi'r lady would have well contented a reasonable proper squire, it was a pretty rank lass, round about as plump as a bladder, which being yet smoking new is blown up with wind; well, I will not trouble you with these rude descriptions any longer, but desire you to conceive the excellency of this fair lady, for it is far more copious in the Dutch copy than is here necessary to be recapitulated. Wagners heart leaping at this sight, looked about him, as if he would have nobody privy to himself but himself, and so it was indeed, for Faustus, Mephostophiles, and Akercock were gone, and thereupon with a boon courage advancing himself upon his toes and weeding himself in the best German fashion, as he could very well, began to travail unto her, but remembring his bad apparel stept back and blusht, and hid his face, but sodainly returning again as if he had known now how rather to become his weeds, began to fewter himself, but $O$ wonder, his habit was changed with his thought, and he was now no more Wagner but Armisuerio the ladies lord. And to 
be short this new Armisuerio and old Wagner, met with the lady, and saluting her in the best kind of Bon noche, used her as he would do his lady and she him as her lord. So passing over their weary night in such pleasure as I could find in my heart to enjoy, or any man, unless an eunuch beside.

\section{CHAPTER VII. \\ The arrival of the Messenger at Wittenberg, and the description of Wagner.}

Ir is time to winde about another furrow with our sweating teem and bring our speech to another matter, entring out of one into another, for change is sweet. Not forgetting by the way the pursevant or as we may better call him, a messenger who lately departed from Vienna in Austria, and I think by that time this disputation was finished, had almost overtaken all the way 'twixt him and home, which was some fifteen dayes travail, after five German miles to the dayes labor, and arrived at Wittenberg, by enquiry came to Wagners chamber, which was in the way as you go to the publick school, as ye go from Melancthons house, a pretty house and of a reasonable large size, built of hewn stone, and environed with a good thick wall, of some three foot and a half thick, and twenty high, at the bottom guarded about with a good broad mount of seven yards over, and round about very large and secret walks, far from all company and resort, and there he might talk without fear with the Devil and his dam too, thither this fellow coming, knocked peremptorily at the door. Wagner was even now gone to his study, and rising up in a pedlers chafe, that he should go to his book, and especially if it were goodness not once in a month, yet then to be troubled, he swore a little thing would make him never study more, it should not, but putting on his cloak and his hat, came down and unbolted the door: unto whom the messenger seeing such a pretty jolly fellow did some little reverence. Wagner as yet scarce having let down his choler, stept back, and perceiving 
him wear such a weed as serjeants there do use to wear, thinking within himself that some had come from the prince for cozening of his servants, shut the door upon him, and went powting and swearing and pittifully chafing, that if the knave offered to sue him he would surely kill him at the least, down he fetcht a good bastinado and set it behind the door and opened it again, and demanded some what mildly what he had to say to him; to whom the messenger said, that he came from the Arch-duke of Austria from Vienna, who willing to hear some certainty of his master, did send for him, assuring himself that not only he could satisfie his desire in that matter, but also shew him as much skill as ever his master had. Wagner hearing the purpose of his message with good effectual words, thankt him again, and rendered most serviceable reverence to his good lord and master for remembring so gently his poor servant, \&c. desiring him to tarry until he might set every thing in due order, and he would not fail to go with him. The messenger did not deny him, and so they went up together into their chamber, whom ever after the messenger loved dearly for his proper behaviour, and personage, for indeed Wagner was a very goodly young man, being about the common stature, straight and reasonable slender, well trust, his hair very yellow, and his face fair, his beard which did but now express the blossoms of his lusty courage, of the like yellow, well mannered, as having been brought up amongst the finest and best sort of Devils : having a pleasant filed tongue, and would make the dainty rhetorick come as smoothly out of his mouth, as an arrow out of a piece of paper, well could he talk of amorous devices, and intreat the bravest ladies with sweet entertainment, in truth by report he was a gentle-like man, and accomplished with as many fine parts as a better man than he might justly vaunt of : he could play upon any fine instrument, and was not ignorant of any laudable exercises, carrying a brave lusty conceit even unto his death: and furnished with many proportions of art, there was nothing wanting in the man but a godly mind. 


\section{CHAPTER VIII.}

The Tragedy of Doctor Faustus seen in the Air, and acted in the presence of a Thousand People of Witten. An. 1540.

IN a brave summer sun-shine day, the whole people of Wittenberg being gathered together, to behold certain matches for the garland, who could drink most, and also to see a match shot at a pair of butts with harquebushiers, as their order is, in a low meadow hard by the Elbe: which now being in his freshest pride, was full of fine and sweet flowers, being the latter end of the month wherein the sun departs from the last embracings of Gemini. On a sodain there was seen a marvellous bright and glorious rainbow, spreading its wide armes over the wide world, and straight was there heard a noise of trumpets, sounding a short flourish, and then another, and by and by another, all alike short, at the which the assembly was wonderful afeard, and listened, desirous to see the effects of this wonder and strange miracle, some of them fell to their Ave Maries lustily, thinking that the universal doom had been at that instant: As thus they beheld with great admiration, they might distinctly perceive a goodly stage to be rear'd (shining to sight like the bright burnisht gold) upon many a fair pillar of clearest crystal, whose feet rested upon the arch of the broad rainbow: therein was the high throne wherein the king should sit, and that proudly placed with two and twenty degrees to the top, and round about curious wrought chairs for divers other potentates, there might you see the groundwork at the one end of the stage, where out the personated devils should enter into their fiery ornaments, made like the broad wide mouth of a huge dragon, which with continual armies of smoak and flame breathed forth his angry stomachs rage, round about the eyes grew hairs, not so horrible as men call bristles, but more horrible, as long as stiff spears: the teeth of this hellsmouth far out stretching, and such as a man might well call 
monstrous and more than a man can by words signifie: to be short, his hew of that colour which to himself means sorrow, and to other ministers like passion, a thick lamp black, blacker than any paint, any hell, blacker than its own self. At the other end in opposition was seen the place wherein the bloodless skirmishes are so often performed on the stage, the walls not (so pleasant as old wives would have their tales adorned with) of pastry-crust, but iron, attempered with the most firm steel, which being brightly filed, shone as beautifully over the whole place as pale shining Cynthia, environed with high and stately turrets of the same metal and beauty, and hereat many in-gates and out-gates : out of each side lay the bended ordnance showing at their wide hollows the cruelty of death : out of sundry loops many large banners and streamers were pendant, briefly nothing was there wanting that might make it a fair castle. There might you see to be short the gibbet, the posts, the ladders, the attiring house, there every thing which in the like houses either use or necessity makes common. Now above all was there the gay clouds Usquequaque, adorned with the heavenly firmament, and often spotted with golden tears which men call stars: There was lively portrayed the whole imperial army of the fair heavenly inhabitants, the bright angels, and such whose names to declare in so vile a matter were too impious and sacreligious. They were so naturally done, that you would have sworn it had been heaven itself or the epitome of it, or some second heaven, and a new heaven it was: from thence like dewie drops wherein the sun layes his golden shine, making them to appear like small golden tears, the sweet odours and comforting liquor stream'd, and seemed always to rain from thence, but they never fell, but kept a beaten path from down on high wherein the descending angel might rejoyce. I should be too long if I should express this rare stage, especially in such sort and such like words as the like occasion in a more worthy subject would require, but of necessity we must barely apply our descriptions to the nature of the whole history. We must not fail in the first principle of art, according to that of Horace ; 
Humano capiti cervicem pictor equinam

Jungere si velit, \& varias inducere plumas

Undique collatis membris, ut turpiter atrum

Desinat in piscem mulier formosa superne :

Spectatum admissi risum teneatis amici?

Credite Pisones isti fabulæ fore librum.

Non ut placidis coeant immitia.

Per similem.

I shall not need to turn back to declare the deep astonishment of the people, who are always in most small matters induced easily to wondering, but now this excellent fair theatre erected, immediately after the third sound of the trumpets, there entered the prologue attyred in a black vesture, and making his three obeysances, began to shew the argument of that scenical tragedy, but because it was so far off they could not understand the words, and having thrice bowed himselfe to the high throne, presently vanished. Then out of this representance of hells mouth, issued out whole armies of fiery flames, and most thick foggy smoaks, after which entred in a great battail of footmen devils, all armed after the best fashion with pike, \&c. marching after the stroak of the couragious drum, who girded about, laid siege to this fair castle, on whose walls after the summons, Faustus presented himself upon the battlements, armed with a great number of crosses, pen and ink-horns, charms, characters, seals, periapts, \&c. who after sharp words defied the whole assembly, seeming to speak earnestly in his own defence, and as they were ready to rear the ladders, and Faustus had begun to prepare for the counterbattery, determining to throw down upon the assemblies heads, so many heavy charms and conjurations that they should fall down half way from the ascendant: whilst these things began to wax hot from the aforesaid heaven there descended a legion of bright angels ri ing upon milk white chariots, drawn with the like white steeds, who with celestial divine melody came into the tower, to the intent to fight for the doctor against his furious enemies, but he wanting pay-money and void indeed of all good thoughts, not able to abide their most blessed presence, sent them away, and they returned from 
whence they came, sorrowfully lamenting his most wilful obstinacy, whilst he had all benointed the walls with holy water, and painted with blood many a crimson cross. At length the alarm was given, and the ladders cleaved to the walls, up the assailants climbed, up they lifted their fearful weapons. Faustus not able (destitute of help) to withstand them was taken prisoner, and his tower down rased to the earth, with whose fall both the large heaven and world shook and quaked mightily, whom when they had fettered they left there, they marching out and the forenamed chairs were presently occupied with all the imperial rulers of hell, who clothed in their holy-day apparel, sate there to give judgment upon this wilfull Faustus, whom two hangmen of hell unloosed, and there in presence of them all, the great devil afore his chief peers, first stamping with his angry foot, and then shaking his great bush of hair, that therewith he made the near places and the most proud devils courage to tremble, and with his fire burnt-scepter, and his like coloured crown all of gold setting one hand by his side, and the other upon the pummel of a chair, shook a pretty space with such angry fury, that the flames which proceeded from his frightful eyes did dim the sight of the Wittenbergers below. There was in this said Wittenberg, a gallant fair lady and a virgin, which now following her mother, accompanied with sundry gallant German gentlemen, had even now entred out of their barge, and seeing the whole world of people as they thought, gazing up into the heaven so very strangely, were partly strucken with wonder, some with fear, and some with sodain merriment, and hasting down the hill more than a round pace, asked some, what was there to do, and they bid them look up (for here is to be noted that they looked up afore but could see nothing but as always they were wont, until they shewed them it) which they did and at the same time wherein the great devil was in his red hot anger, this young gentlewoman looked up, whose most ugly shape so fear'd her, that even then there she fell down in a swon, whom they conveyed away very speedily, yet ere they could come home she was well nigh dead, and so she lay for two years without hope of life, 
or certainty of death: great sorrow to her parents and as cruel pain to her : but she at length recovered her spirit, and if by your patience I may, I will tell you how. There was a most learned and excellent doctor dwelling in the town who had great knowledge in the black-art, who being requested to use some physick to aid her in her great extremity, being promised for reward five thousand dollars; this doctor perceiving the cause of her malady was not caused of any distemperature of her body, but only of the aforesaid fear, knew that physick might well make her body sound, but her mind never. Wherefore not only for the reward but also to become gracious and famous at once, proceeded in his cure on this manner. One night having made his orisons and nine times combed his hair with tears of a pure maid, and nine times gone about a fire made all of pure Heben coal, and thrice nine times called upon the name of the most dreadful Hecate, he laid himself to sleep upon a pure white and clean unspotted maidens smock, and covered himself over with the ashes of a white hind rosted and burned altogether: he slept, and the next morning apparelled in white robes having often and often called, recalled and exorcised the three fairies Millia, Achilya, and Sybilla, at length the ground opened, and with them they brought a milk white steed, and did put upon his finger the ring of invisibility; when they were vanished, he mounted upon his horse, who with more swift flight than the winged Pegasus carried him throughout the wide air so fast and so long, that having passed over Bohem, Hungary, Thracia, all Asia Minor, Mesopotamia, and at length to Arabia Fælix, where he alighted upon a most high mountain, all the way from the top to the bottom of a just breadth and steepness, so that he that were on it, would think himself not in the world, and they beneath would deem him to be in heaven, upon the brims of it round about grew the high pines, and stately cedars, and always so green as the most fresh meadow : the height of this huge rock was two and twenty miles in even altitude, and half a mile of just circuit all the way; there he tyed his horse to a tree, and knocked at the castle gate, where 
afore was never seen any, so that no path could there be seen, so that a man might justly have called it the house of little hospitality; to him there came Neglectment, an old lady, and demanded what he would, who told her his errand, and withal a ring of fine gold from the three fairies, she knew the ring and his errand, and conveyed him into fair rooms wherein she shewed him many a worthy knightes memorials, many an antick monument heaped up; but inner rooms so monstrous dark and nightly, that no humane eye could perceive anything, and forth she brought him unto a garden, out of the midst whereof rose a little hill, from the summity whereof, there was a paved way of pure crystal stone from along whose bosom trilled a small water : this water an old man held, and indeed he had it as a patrimony, for therefore he could shew many an ancient evidence, and worn charter, his hair was all fled to his front, as if some enemy had scared the hinder locks from his scalp, on his back hung a pair of wings which flagged down, as if either they had been broken or he weary, and thus he over-strod a round world, from out of every part whereof gushed out this small river which was conveyed down in this cristal pipe : in one hand he held a long sythe, and in the other an hour-glass: here the Doctor seeing the old ruines of this sumptuous house, and all the fair walls and buildings overgrown with a deadly moss was much amazed, but because he could not tarry, he dipt a small vial in the spring and departed, and for because he was so peremptorily warned not to tarry, he could not behold the most stately galleries, in which he might see the worlds chief pleasures and monuments some wholly worn away, some half and some even now beginning, and some wholly quite overgrown with a thick earthy fur, for as he came by an old wall, he chanc't with his elbow to rub off the thick moss, and then might he see a fair piece of parchment gilded and painted curiously, wherein was truly described the antient tokens of a most brave and worthy gentleman: so having sped of his journey, he came by the same way again as he went. Neglectment shut the doors upon him, whilst he mounted upon his white swift-footed horse, and by the 
like time arrived at his own house, where having with the blood of a new slain heyfer thrice anointed the feet of his Cavallo, and tying at his ear with a string of fine silk, spun by the hands of a pure maid, the received ring of invisibility unto his ear, with many a cross and many an open Ave Maria, dismissed him, who in the same moment returned to the place from whence he came. With this water the doctor came to the maid, and having used a certain incantation, gave her to drink of the water of deep oblivion, which she had no sooner tasted of, but straightways she had forgotten the terrible picture of the devil, and was revived out of all her infernal fears, the doctor called, winning him credit, favour and fame and richly rewarded for his medi. cine, departed, and coming home threw his vial into the deep river burying oblivion with oblivion: the parents of the young lady rejoicing exceedingly at their daughters recovery for ever after caused the place wherein their daughter was thus scared, to be unaccessable for man or beast, compassing it in with a high wall, and overthrowing the banks, so that now there is no mention of the meadow, nor of the wall.

The Devil, the great Devil Lucifer having finished his brief oration descended down out of his judgment seat and pointing unto all his nobles took Faustus by the hand and placed him just before him, taking him by the chin seemed to them to bid him speak freely, he mounted up again unto his high throne, and with a more mild madness expected the speech of the doctor, who having bowed himself submissively unto these damnable company: he began to speak, and yet not long, then he began to walk up and down, and to shew strange gestures, when sodainly for some bug words escaped by Faustus, all the devils there rose up, and with their swords drawn threatened with them the poor Doctor, turning all their bodyes and directing their faces to the king, who with a stern countenance commanded silence. When Faustus having long raged, of a sodain howling loud and tearing his hair, laid both his armes upon his neck and leaped down headlong off the stage, the whole company immediately vanishing, but the stage with a most monstrous thundering crack followed 
Faustus hastily, the people verily thinking that they would have fallen upon them ran all away, and he was happiest that had the swiftest foot, some leapt into the river and swam away; and all of them with great affright ran into the city and clapt the city gates together straight, and to increase this fear, they thought they heard a thing fail into the river, as if a thousand houses had fallen down from the top of heaven into it. But afterwards this was known to be Wagners knavery, who did this to show the pursevant some point of his skill.

\section{CHAPTER IX.}

THE messenger had not tarried above three days, when as Wagner had trust up his baggage, and was now ready to depart, when on the third day at night he caused his boy Arthur Harmarvan, (who was the son of a wealthy boor, witty above many, and praised for his notable waggery: his father dwelt at Malmesburg, a town hard by Wittenberg, in Saxony, in high Dutch-land, with whom Wagner being acquainted had obtained him of his father to serve him, and he to be taught of Wagner) him he caused to go to divers scholars of his acquaintance to sup with him at his departure, who being invited to this hated farewel, came speedily where they had a banquet and other courtesies which in such a time both customes and laws of their fellowship do prescribe : in the suppertime the scholars moved many questions, and amongst the rest one desired the pursevant to describe unto them his lord and master, for they heard say that the Duke Alphonsus was a marvellous qualified gentleman : the pursevant not willing to refuse their request told them that seeing their demands proceeded of a common good zeal, he could not but wrongfully refuse to satisfie: notwithstanding the truth might be better known of another than of him, whom duty bids to be partial, if any defect might breed partiality, but so much as I will tell you, the enemy will not disdain to affirm : and there he 
told them the very stature, proportion, and particular lineaments, concluding that he shewed the uprightness of his mind by the proportion of his body, and keeping in his outward shape the vertue which philosophers would have kept in the mind. There he told them the feature of his countenance, the colour of his hair, eyes, face, cheeks, \&c. He told them his stature, favour and strength, which was such, that with pure cleanness of his force, he hath foiled a gentleman in wrastling, who besides whiteness of body, was very firm without affection, not as some do, which in performing any thing, will with such a ridiculous sowreness act it, as if the force of the body must be personated upon the theater of his face: he declared unto them that the gifts of his mind were such as then he could not for the number reckon up, but even as occasion shall serve might meet with them, being all such as were more ready to be admired than imitated, as if all vertues were gathered in him together, magnanimity, magnificence, affability, modesty, \&c. .Briefly he said, there were in him all those graces which adorn the subject with the title of vertuous. He likewise recounted unto them his studies, unto which he accommodated himself at vacant hours, which were partly poetry. A poem of his he said he had by chance gotten (and by greater chance had it there at that instant) which he had made in the praise of his excellent lady when he was but of young years, his father living, I dare say he would not for ten thousand florens have it seen, being such a one as on a dreaming passion he had let fall from his pen, and of many the most abject, but such as this is deserves commendations, because a prince made it, but if you saw his real devices, you would then say they were prince-like. And then he read it, which I was loth my good friends either to translate, or translated to present it here, for that it was not worthy your censure, considering the nice building of sonnets now a dayes, but according to Ariostos vein you shall find it very conformable, as also for that I knew that if I should have left it out, it would have been more wisht for, then now admired. Yet for that I prefer your well known good wills afore any vain fear, take this 
with the rest, if there be any, with such favour, as if I were by you at the reading

A mio solemente amandona.

Madonna ; Donna non parelia

L'Angelico sembiante e quel bel volte,

Fa l'odio, e l'ira va in oblivione,

Ch' a l', \&c.

Thus have I harshly Englished them verbally.

Angel-like semblance, beauties ornament,

Whose vertue quells all wrath and rancor deep,

Whose life heavens grace and death would monument

Vertue thy life are ....*

How many wounded hearts thou makst to tremble,

And I of many one cannot dissemble,

. How far into in ....* that eye-sore.

So were thy beauty but deserving praise,

So were thy beauty but as feminine,

Then could my quill his strain so high araise,

Then could with it compare the masculine,

Thy beauty praise thy bounty past divine,

No strain, no quill such wonderments assaies.

Then poets pen shall to thy power his power resigne.

What words may well express such excellence,

No humane thought thy beauties may comprise,

And words may tell all humane insolence,

All humane words and wit thy gifts surprize,

To satisfie my self in my pretence,

Our pen unto the heavens must wander hence,

And fill it self with dew of heavenly sapience.

And I my life shall to your hands resigne,

Which live to serve a humane saint so past divine.

Se da colei

Che poco ingegno adhor adhormi lima.

This sonnet was ended with as much praise as it began with desire, and one of them copied it out and so it was made common to the rest, and made a good sort of them poets, rectifying their

- The letters were worn out in these places. 
gross conceits, with so sweet a matter. He told them that this was but a preparative to wondering in respect of his choyce making. Then he shewed them this epigram, which he made when as before the duke his father a brace of fair English grayhounds fell down at the harts heels stark dead (the hart also lying not above six yards off dead too) with chasing, having outstript the rest of the dogs above half a mile.

Then he reckoned unto him the delight he took in limning, and shewed them very many fine devices of his own handiwork. The scholars singularly delighted with the view of the reliques of so great a prince, approved by silence that excellency which by speech they could not. In fine there he reckoned up enough to be praised, and peradventure more than was true, but not more than is desired. There he set forth with great and ardent emphasis other qualities, as his skill and hardy demeanour at the tilt, turney, how he could manage the sturdy steed, leap, run, vault, dance, sing, play on divers instruments, and talk with amiable speech amongst fair ladyes, which we call courting, in all his actions full of gentle familiar affability, still reserving to himself the due honour belonging to his personage. He concluded in fine that he was the most qualified prince, and absolute gentleman that day in all christendom: saying, if they knew his humanity, justice and liberality, you would say in him were all humanity, justice and liberality: and as the greatest thing that the world can shew is beauty, so the least thing that is to be praised in him, is beauty, you would say no less than I have spoken could be in his person if you did but see him. Thus far the digression came in the commendations of this Alphonsus, which truly I was weary of, fearing the great insufficiency of the description, but yet he had not done. I would to God (quoth he) you would come to Vienna, and I promise you such lodging and entertainment, that next to the sight of him should be worthiest of your thanks. Wherefore you shall not sorrow that your friend Wagner departeth, unless you will seem to envy rather his felicity than his departure. I would we were even all of us as we sit at the table in the dukes court, and here again with a wish, and 
here with there knockt one at the door: Wagner craftily feigning that he himself would rise to see him that knockt so desiring them all to sit still in any case, and opening therewith the door there entred two young lords of Tergeste and Moravia bearing torches, and next there came the duke of Austrich as they thought, and Wagner talked with him bare-headed, the pursevant thinking verily it had been his master, would have done his duty unto him, but that the rest hindred him : on his head he wore a little hat of blue velvet, with a rich band of pearle, stone and gold, and a long white feather, his cloak of blue velvet, round garded with gold lace, edged with orient pearle, and betwixt the gards eylet holes, whereout hung by small silk threads long bugles, all the sleeves in the like order : by his side a golden hilted rapier, and on his rapier his hand, his buskins of fine Polonian leather, richly imbroidered on the turnings down with costly goldsmiths work, all his apparel whatsoever most beautiful and princely : he had no sconer passed by (which was not until he was distinctly viewed of them) but that Wagner spake unto them in such manner, saying that that honourable, this mans lord had sent for him, whose commandment I will in no wise repugn. Wherefore I beseech you to take it as you would my greatest advancement. This his description of his feature, judge how rightly he hath said, for my part I confess they are rather less than the truth, than not as he hath reported, and herein to satisfie you the more I have caused my spirit Akercock to take his shape upon him.

Now (quoth he) it is time to depart, but because it shall be the last night of our meeting, none of you shall depart, for I have lodging enough for you all, and because you shall not be forgetful of Wagner when he is gone, let every man wish his woman, and so to bed my masters. They began all to laugh merrily, not as hoping or wishing, but as if they had heard a merry purpose, and therefore they laughed because it was merry, and such mirth they always liked of. Wagner was almost angry, and yet for that he was almost, he was not angry, sending out a great oath as the prologue of his comedy, bidding his boy go prepare their 
beds and chambers, and bid them wish whom they would, he would their wishes should be performed. Then rose up one of the scholars perswading himself of Wagners earnest, and yet doubting, because he feared he was not in earnest. Why (quoth he) if you mean in very deed, my friend Kit, I would I had such a woman, I believe beside herself there is none fairer than the fairest in this town. Why meanest thou I jest, quoth Wagner, go thy wayes, yonder she is upon pain of my head, and so it was indeed : then every one strove who should wish first, and he that wisht last, had his first wish, so every one took his damosel, and for that night departed to their beds, who are witnesses of that nights great pleasures, and in the morning they arose wishing that every morning were the morrow of such a night. Every one gat him a hackney, and brought him on the way a dayes journey, where they with grief left him, who rode till he came to Vienna, and they till they arrived at Wittenberg. Thus still you see these pot-meetings are ended amongst these puft-cheek hannikins with bed dalliances, rightly describing their lives most bestial and epicure-like.

\section{CHAPTER X.}

A lamentable history of the death of sundry Students of Wittenberg. Not long after it was reported and blazed abroad, that Wagner was departed, divers scholars guessing that he had left his books or the most part behind, determined to send for Harmarvan, which they did, who by no perswasions could be won to let them have his masters keyes, so they devised amongst themselves to bind the boy as he should go home to his inn whereas his master had put him to board till his return. And night drawing on Harmarvan went to his lodging, by the way scholars (to the number of seven) met him, and bound him, and beat him sore until he gave them all the keyes, which he carefully' carried about him sowed in a wide German flop, which when they had (they being all mufled and disguised strangely with vizards) they 
loosed, and then they ran hastily to Wagners house, as if they had fled from followers, or else followed some hastily flying: where being come, they opened the gates, and being entred, shut them again, this being about eleven of the clock in the night, and in they went, where they found two barrels of mighty strong March English beer of two years old which they broached, and sat so long drinking till they were all well drunk. And then down they get into a black court, and having lighted tapers, having injuriously framed all the circles, squares, triangles, \&c. and apparelled with all the conjuring robes that the art requireth, there they begin in a most dreadful confusion of hellish sillables to enform the fiend, and after these words followed (as if there needs must such things follow after such words) a terrible roar, and then so bright a smothering thick fiery fume ascended out of the earth as if it would have made an eternal night, then a vehement flame followed, which with continual motion ran about the brims of the circle, until as weary it left moving, (all this while they continued reasonably constant, and continued their invocations without any fear) then from beneath was heard most lamentable outcries, from above huge trembling, thunder, and round about nothing but fear and death in a thousand terrible divers shapes, then they began to quaile a little, but yet by incouragement grew hardy by reason of the number, then round about was sounded alarms with drums, and onset with trumpets, as if there all the world had conflicted, then the flame which all this while ran about the circle became a body, but such a body, as if it had been but a picture would have madded any one. At whose sight they wholly overcome with deadly fear forgat the use of the pantacles or any such gear, but even submitted themselves to the small mercy of the fiend, who with great violence, rent them, and tore them most lamentably. Harmarvan who had raised a great many to the intent to follow them, suspecting that which indeed was, was after long wandring (for they had caused a devil descryer to void all within a certain circuit) with his company brought to the house, where round about they might see in the court wherein these seven were conjuring, huge flames, 
as if some great pile had been made to the burial of a noble heroe, climbing up in huge volumes in the air, or if some great store of stubble had been fired, so vehemently furious was the flame that no man there (and there was above thirty) was able once to draw near to any part of the house, the cry was carried into the city of this fire, whereupon the whole town was assembled with hooks, buckets, ladders, \&c. where in vain they emptied many a large well, till divers learned preachers falling down submissively on their knees, with good faith appeased this seeming fire, which indeed was none, but a mere diabolical illusion, then they entred into the house where they found the barrels brought to bed and delivered, the cups, the whole furniture clean destroyed, broken, and thrown about the house, but drawing near unto the most rueful and lamentable spectacle of all, coming into the yard or grove which was moted about and enclosed with a thick wall of trees very exceeding high, as fir trees are, so very thick that no light was perceivable into it, in the very midst whereof was a round plot of some one hundred feet any way from the centre, there found they the religious circles, there the strange characters, names of angels, a thousand crosses, there found they the five crosshilted daggers for the five kings of hell, there many a strong bulwark builded with rows of crosses, there found they the surplesses, the stoles, pall, mitres, holy water pots broken, their periapts, seats, signs of the angels of the seven dayes, with infinite like trash and damnable roguery the fruits of the Devils rank fansie. But the most lamentable sight of all, the seven scholars utterly torn in pieces, their blood having changed the colour of the ground into a dark crimson, all their bodies as black as any coal, as if they had been scorcht with a material fire, their fiesh violently torn from the bones, and hanging down in morsels like the skirts of a side coat, their bones all broken, their veins cut in sunder, and their bowels broad shed upon the earth, their brains poured out, and covering the red grass all over, their noses stumped, their eyes thrust out, their mouths widened and slit to their ears, their teeth dasht out, and their tongues starting out betwixt their gummes, their hair 
clean singed off, in brief imagine with your selves in your minds, and propound a picture in your thought, the most deformed, torn and ill favoured that you can think on, yet shall it not compare to the most lachrimable sight and shew of them, surpassing as much all credit as my skill duely to describe them, whom when they had buried without tarriance, rased the house to the ground, and filled up the moats with earth, heaping upon the place of this murther the stones of the house defaced, then they returned home discoursing with lamentable judgment upon the high and severe revenge of Gods indignation upon them which durst presume to tempt his glorious majesty. And finally, unless repentance breed a more speedy remorse, such is the fatal end of such proud attempts. And surely this is most true, for I my self have seen the ground where the house stood, and yet the moats damm'd up, and the water breaking through the stones even to this day, there did I see a scull and a shank bone of them not yet rotten: and there did I see the huge heap of stones wherewith they are covered, a fearful example of Gods wrath and justice against such infidel Christians.

\section{CHAPTER XI.}

THE great Turk called Souldan, alias Cham, comprehending as many victories in his sword as some emperors in their thoughts, arrived at length before Vienna, having made his preamble with the destroying and burning of the country before him, thinking upon the ancient politick rule, "Better it is to have a spoyled countrey than a lost," with a brave prepared army of two hundred thousand Saracens, horse and foot, and so many it is certain he had, because they doubted not but there were 300000 . The mighty Cham having erected his royal pavilions, and entrenched himself to besiege the noble Vienna, munified his camp with artillery and deep ditches, and then he sent a letter of defiance unto the honourable Alphonsus, as being principal in his own city, who was invironed within the walls of the city, expecting 
the day of battel, for to this intent the states of Italy and the Emperor of Germany, with the Dukes of Saxony, Bavaria, and the other provinces near, assembled (for now necessity bred unity) with a brave company of souldiers, to exterminate this monster out of their confines: unto the Duke of Austrich only (for he had no intelligence of their assembled forces) he directed his letters with defiance, meaning to conclude his long travails with a certain victory, fearing neither the peril which so many gallant souldiers throughly resolved might bring, nor that ever God or fortune (as they call it) would once shew him any disfavour, whose only favour is only in shew. Nor yet that the heavens great God would not with severe revengement chastize the Leviathans insolency and slaughter of so many martyrs, rather deferring then forgetting so just a punishment.

\section{CHAPTER XII.}

ABout this time the messenger and Wagner arrived at Vienna very late in the night, and passed through the Turkish centinels, and arrived at the city, and for that night they lay at the pursevants house; no sooner had the approaching sun sent afore him the marshals of the morrow light, and a new morning ministred occasion of new matter, but up those two arose, and being ready departed for the court, and now the day was almost in the greatest beauty, when the messenger was admitted into the Dukes presence, unto whom he recited what ever was seen and done in that time of his absence, (only I forgot to tell you how Wagner raged and stormed, and thundred, when Akercock brought him word of the destruction of his house at Wittenberg, as he was in the way to Austria) wherewith the Duke was wonderfully both delighted and astonished. And having welcomed Wagner very graciously and accordingly rewarded, he dismissed them till further leasure, commanding the pursevant to shew him all the pleasure he might. 


\section{CHAPTER XIII.}

After all these most excellent princes were come into the council chamber, the herauld sounded his trumpet after the Turkish summons, then did all the states draw into the great hall, where in a high imperial throne richly ordered with shining cloth of gold, every noble and estate placed correspondently to his degree, where in presence of them all the herauld was admitted, who coming with his coat of armes lying upon the right arm into the bottome of the hall, made three obeysances with the right knee down to the ground, with a loud and distinct voice, spake unto the Duke only, telling him that his soveraign and master Soultan alias Chan, the son of Murad Chan, the son of Rabeck Chan, the son of Mahomet Chan, and so upwards till he came to their great prophet Mahomet, God on earth and emperour of all the east. And then he began to reckon the five hundred titles, with a long \&c. unto thee Alphonsus, Archduke of Austrich, and there he declared the whole effects of his message, and at last with a great bravado ended, and then he did on his gay coat of armes, expecting their answer. When as the Duke craving licence of the Emperour to speak, answered the herauld in most gallant and triumphing terms, commanding him to say unto the proud Turk his master, that ere five days came about he would trample his victorious horns under his feet, and ride in triumph upon his stubborn neck, and that in defence of himself and of brave Christendom he would leese the uttermost drop of his blood, and to make it good he would not be in quiet till he had met his master in the midst of the field, and therewith he drew out his sword, and all they with him, crying God and Saint Michael for the right of Christendom: Then stood up the Emperour and avowed all that they had said afore him, commanding moreover the herauld to say to the proud usurper, that seeing the quarrel would breed great effusion of blood, and yet be never the nearer, that he a man every way equal to hiniself, not only for the speedier advance of his battels, but also to have a certain 
cnd to such an uncertain enterprise, he would fight with him body to body, armed at all points after their own guise, at any time within this fortnight, and herauld bring me word (quoth he) that he will so do, and by my honour I promise to give thee for thy tidings 10000 duckets. Then the herauld being highly rewarded was dismissed, and reported their brave answers unto the Turk, with all the great majesty of the Christian princes, who presently went to counsel together, and so continued till other like necessary business called them away.

\section{CHAPTER XIV.}

In this Chapter (Gentlemen) part of the Dutch copy was wanting, and the other part so rent that it could not be read, yet by some circumstances I conjecture that the Duke of Austrich had divers and dangerous conflicts with the Turk, yet being supported by the English men and other Christians, with the help of Wagner, who standing on a high tower to see the conflicts, caused by his magick such a storm to arise that no man was able to abide, the 'Turk was still discomfited.

\section{CHAPTER XV.}

The gifts of Wagner to the Duke, and three Devils retained for Souldiers to the same Prince.

IN the next morning Wagner presented himself to the Duke in presence of all the whole princes of the Christians, whom very graciously he entertained as he might for his good service, and there in presence of them all he desired the duke to take at his servants hands a small gift, which he condescended unto, and then Wagner caused a chest to be brought in of fine iron, wrought and inamel'd with gold and colour most curiously, then he opened it and took out a whole armour of fine bright steel so 
light as a common doublet, but so sultilly and excellently framed, that it passed all comparison of hardness; there was a musket shot at every piece, whereon remained no great notice of a blow, but as of a little touch, plain, without any broidery work or otherwise carved but so exceedingly bright as would well have dazzled the long beholders eyes, a shield of the same fashion, made like a tortoise shell, a sword of the like fine temper, with all the furniture of a souldier, then took he out a plume, which he had no sooner put into the crest, but he that stood behind could not see any part of his back, nor he that stood before of his brest, so that thus it made him invisible, there he told him it was fetcht. out of the great Turks Armory, which they say was Mahomets, but I say more truly Alias Chams which for himself caused to be made, having called together the most excellent philosophers and workmen that were to be found in all his wide empire. The great rewards the duke would have given him for it he refused, he was only contented with thanks and favor. And then might they see from the door of the chamber 3 most gallant men to enter, which were his three familiars, whom Wagner taking by the hands presented to the whole assembly of princes, but more directly to the duke, assuring them they were the most fortunate, most valiant, strong, hardy, and puissant men that in the world were to be found, and indeed they seemed to be as goodly swart men as any eye beheld, he told their several names, Mephostophiles he termed Mamri, Akercock he termed Simionte, Faustus he called Don Infeligo, shewing that they were born in those fortunate islands, wherein the poets feigned the elysian fields to be, joyned by the west upon the end of Barbary, being from Vienna to those fortunate islands, 35 degrees of longitude and eight minutes, and 48 degrees and 22 minutes from the Equator or Equinoctial, in latitude not then found out. So were they most graciously entertained of all the nobles, and entertained in the dukes most honourable pay. Wagner said that they three left their countrey and sought adventures, and by chance coming this way, I knowing of it by secret intelligence, met them, and certainly assured of their high valours, thought 
good to shew them to you, for he that first had spoke to them had been first served, nor cared they whether to serve us or the infidel.

\section{CHAPTER XVI.}

I SPAKE before of a challenge made by the Emperor unto the Turk, which when the herauld had reported unto the Souldan (who certainly was a very honourable souldier) there he vowed to perform it, and to set the emperors head upon the highest pavilion in view of all the city. And thereupon the next day after this skirmish, he sent the same herauld with purpose and commandment to declare in excellent gallant terms the acceptance of the combate, knowing that it depended upon his honour to shew his small fear in not refusing so equal a foe, whose profer proceeded from a most honourable resolution: when it was reported unto the emperour that the same herauld returned, he caused the hall to be adorned with most brave furniture, his high chair of estate placed, and all about seats for the other princes. The emperor having seated himself full of brave thoughts and gallant hardihood, expecting the answer of the enemy in such sort as it was in very deed. In all brave manner the herauld in proud phrase uttered the purport of his message, requesting that a peace being concluded on both parts for the space of three dayes, and free egress and regress for the nobles on both parties, the one to view the camp, the other the court, and on the third day he would armed in his country manner, meet him in the lists, to shew that he never refused the combate of any christian emperor, albeit he knew his calling far superior to that of his. So then the message was accepted, the herauld had his ten thousand duckets carried to the Turks camp on horse, and they in the city began to keep feasts, and entertained the Turkish nobles in exceeding bravery, and they theirs in the like without damage or thought of treason. 


\section{CHAPTER XVII.}

DURING the time of this truce, these four companions, Infeligo, Wagner, Mamri, Simionte, cast how to abuse the great Turk most notably, and Akercock otherwise called Simionte he would begin first, and lead them the dance. Then he leaves them and gets me up unseen to the Turks camp, and in his camp to his own pavilion, and so into the place where the great infidel himself sate, he being then gone into the lavatory, which is a place wherein he three times a day doth bath himself, which by so doing he doth verily believe that all his sins are remitted and washed away, be they never so horrible, devilish, or wicked: then Akercock or Simionte, which ye will, goes invisible into the lavatory, where the great villain was bathing himself amongst three of his most fair concubines stark naked, swimming as much in their dalliance as in the water, mingling his washing with kisses, and his cleansing with voluptuousness. Akercock in the shape of a bright Angel appears unto him, and with a proud magnifico presented himself unto the slave, who straightwayes very reverently fell down upon his knees, and with his hands high lifted up, worshipped towards him in great humility, whilst Akerc. with good devotion fell aboard the concubines, and there acted them before his face one after another: when he had so done, he takes the great slave by the tip of his pickenovant, and shaking him fiercely (who all this while with great dread and fear lay half astonished and all naked on the ground) told him that he had prepared a more brave place for his so good a servant than so base a bath and no fairer concubines. (Now the Turk had seen how like a lusty rank fellow this Simionte had behaved himself, at which he wondred not greatly, because Faustus whom he thought to have been Mahomet, (as well as he did think Akercock) had also shewed the vertue of so great a (jod as Mahomet, twenty times more beauty than Jupiter.) Then the Turkish Emperor with more than half dying hollow voice, as if his breath had been almost gone, or else but now coming, 
said that he was all at his commandment, and so followed Simionte stark naked as he was born, who led him by the hand round about, and through every lane and place in his camp, to the great wonderment and laughter of his people, who verily thought Mahomet had commanded him to do penance before he fought with the christian emperor. But for all this the people fell into such a laughter that some had well nigh given up the ghost. At the same very instant divers christian nobles saw him all the while who effusedly laughed at so apparent foolery. The Turk for all this not moved, for indeed he heard all and saw nothing, went about wonderful mannerly, like as you shall see a Dutch frow with a handkerchief in her hand, mince it after the hopping German. Could a man devise a more notorious kind of abuse, than to make that man which will not be seen but in great secresy, and abundantly and richly clad, to be not only seen openly, but also stark naked, and become their laughingstock, whose terror he is always? But Akercock had not yet so left him, but down he runs to Danuby (where there was ready Mamri or Mephostophiles to receive him) and there having turned himself and the vilest part of himself unto the Turks mouth, making him kiss and kiss it again, he took him and hurl'd him violently into the water, and then Akercock vanished away.

\section{CHAPTER XVIII.}

\section{The Second Mocking.}

No sooner was he in but he saw then apparently how he had been misled and abused, and there for very shame would have drowned himself in very deed, had not Mamri come swiftly flying over and gave him a terrible blow on the noddle with a good Bastinado, that he almost made his brains fly out, and rapt him up by his long hair out of the water unto the land, where he buffeted him so long till at length he came to himself again, then Mamri fewtred himself to abuse him kindly, and there with sweet and conipassionate speech comforted him, desiring his reverend 
majesty not to take any grief seeing it was done in the sight of all his men, in the knowledge of none. And therwith to shew the more pity of his misery he seemed to shed abundance of tears, desiring him to go with him and he would put upon his soft rayment. The Turk (who then had his crown upon his head or else it had not been half in the right Qu.) seeing one lamenting his case so affectionately, condescended unto him and promised him most large honourable promotion and reward, Mamri set him upon his legs and led him to a little muddy place by the river side, and there varnished the emperor over with most thick terrible excremental mud, not sparing either his face, nose, eyes, mouth, nor any thing, whilst the miserable man thought he had been in most divine contentment. Thus he led him in the view of five thousand people (for here is to be noted that all that ever saw him both knew him to be the great villain Turk, and could not but laugh most entirely at him, nor his own men could do any other nor once think of any rescue or remedy, by the working of infernal instinct) until he came to Vienna, and in Vienna to the most fair gates and where greatest resort of people are always together, there at the city gate he drew out a long taber and a pipe and struck up such a merry note, as the foolish ornament of all London stages never could come near him, no not when he wak'd the writer of the news out of purgatory with a shril noyse. There at the gate stood a carpenter who was then carrying a coffin to a certain house to bury one in, him Mephostophiles beat till he lay on the cold ground, and took the coffin, and caused the Turk to hold it in his hand. Memorandum that none of all these spirits were seen of any one but felt of them which saw them. Then from the gate he began to play, the Turk and the coffin skipt and turned and vaunted and bounded, and leapt, and heaved, and sprung so fast and thick together, that the coffin rapping the miserable man sometime on the shins, breast, thighs, head, face, that the dirty colour was almost wip't away with the streams of blood. At this strange sight and the unheard noyse of that kind of instrument, all the boyes, girls, and rogues in the town were 
gathered with this troop, and this mirth, he conveyed them round about the streets, and all the way as they went, such eggs, such chamber-pots emptying, such excrements, odor, water, \&c. were thrown down upon their heads, that it seemed all those vile matters were reserved for that tempest, until such time (then it being about two of the clock in the afternoon, when every one is busied in some pleasant pastance) as all this fair company came to the court where out at divers windows lay the chiefest of all the nobility, and the most brave gentlewomen, who seeing such a huge crowd of boyes, the great Turk and a coffin dancing, and a taber and pipe plaid upon, they were almost amazed, thus he marched finely round about the whole court, till coming to the court gate he entered in, (but the boyes were excluded,) with this merry morris there in the presence of them all the Turk fell down dead, whom Mamri laid in the coffin and then vanished away.

\section{CHAPTER XIX.}

\section{The Third.}

Then came Infeligo, or Faustus, and touching him revived him to the great wonder of the beholders, and covering him somewhat shamefully, went into his chamber with him, and there benotted him round upon the head and beard, which is the foulest reproach and disgrace that can be offered unto the Turk, which done he conveyed him into the presence of the emperor, where he made them such sport, that unneath they could recover their modesty in three hours space, to see the proud villain plastered over with such muddy morter, all over his head and face, his eyes and his teeth shewing like black Moors, or a pair of eyes looking through a lettice, or as they call it a perriwig, wherein if the eyes had feet they might be set in the stocks: all his lineaments were lineamented with this party, he stood quivering and shaking, either for cold or fear, like an aspine leaf (as they say) whilst every man buffeted him, he standing with a scour-gestick and an old shoe, as they do at blind mans 
buff to see who he could hit. Thus long he made them sport, till one told the emperor that it was the great Turk, at which he was exceeding wroth and sorry.

\section{CHAPTER XX.}

\section{The fourth and last.}

WHEN Wagner seeing him grieved, came and kneeled down before him, declaring that he would undertake to heal all his wounds and other grievances whatsoever, yea and make him utterly forget all that was passed as if it had never been, and promised to carry him home himself safe and sound, which the emperor thanked him highly for, requesting him to perform it presently, for he would not for half his revenues that his foe should have any occasion to alledge against him, for to excuse the combate. Then went Wagner up into his chamber, and apparelled himself in white taffata, made close to his body, and then were they used to wear round hose half a foot deep, stuck with swans feathers, like the skirts of a horsemans coat, his hose, shoos (for all were together) of the same white taffata, and within with white leather, at his heels two fine silver wings, and on his shoulders two marvelous large bright silvery wings, and on his head an upright steel hat (with a white feather of two or three ranges) of white taffata, and in his hand a caduceus or a mercurial rod: in the same white silver colour, he entred into the presence-chamber afore all the assembly, to their singular contentation, for in his personated garments he seemed to be a very angel, for it was in doubt whether Mercury was half so beautiful or no. And there opening a large casement (as there they are very large) with a brave r'ingratio departed from them, taking up his flight in view of them all into the air, as if he should have beat the azure firmament with his vast wings. Thus he carried him lower, and lower till he light upon a great elm, and there he opened his sight to see in what plight he was. The Turk seeing in what a trance he had been, began to swear, 
to ban and curse, and was even then ready to have thrown himself down headlong, but Mercury he stept to him and bade him be of good cheer, for it had pleased the great god Jupiter, whose servant Mahomet was, to shew him those great abuses, to the intent he should be more wary in his actions, and take heed how to tempt the Christians with vain battles and such like speech, but now (quoth he) come and give me thy hand and then will I lead thee to thy pavillion, whereas thou art not missed of the nobles, for in the place where thou were taken away, hath Jove sent one to bear thy shape. Then again he took his flight and all the way as he went he rapt his heels against the tops of high trees, and beat him pitifully upon the shins all the journey, upon the tents tops. Now they arrived at the same place from whence he was tane, and there he laid himself down, who perfectly recovered his former strength in full perfectness, and not only not felt it, but utterly forgot it. Then he continued his wonted solace and prepared himself to the battel, whilst he was made a laughing-stock of the world. Wagner returning through the same path which he had made in the air before, came not yet to the court before they had done laughing, for there the matter from the beginning to the end was rehersed.

\section{CHAPTER XXI. \\ The process of the Combate.}

THE two days of the truce were passed, and the third morning was come, in which time many gallant feats of arms and activity were performed on both parts. Now the time of the combate was come. There was in the river of Danuby a pretty island of a quarter of a mile long or more as even as ground might be all the way, in this place were the lists prepared, and a scaffold richly hanged for the judges to determine in. In the evening about four of the clock (being then reasonable cool) the Christian emperor issued out above a hundred thousand Christians, the rest being above sixty thousand, were left to defend the city (for both the 
Christians and especially the Turks were increased) where he entred into the wide plain, and coming to the banks side he entred into a broad ferry boat, leaving his whole army on the other side of the river whilst he laboured to attain to the island. The duke of Austria with his attendants Mamri, Simionte, Infeligo, and Wagner, the dukes of Cleve, Saxony, Campany, and Brabant, with the like number, all bravely and gloriously mounted : the duke of Austria in his bright armor marshalled the field, and of the Christians sate as judges, the kings of Lussitany and Arragon, with their heraulds. Now the emperor is landed in the island and is mounted into his rich saddle, armed in arn or so costly, strong, curious, and resplendescent, that it seemed all the beauty in the world had been gathered together in it, his courser so firm nimbly joynted, tall and large, such a one might have been the son of Gargantua's, more for the giant-like proportion. Then took he his strong and large ashen launce, bearing in his steel head iron death, at the top whereof hung a fair and rich pennion, the whole shaft of the spear double gilded over and curiously enamel'd, about his neck hung his horn shield, artificially adorned with his own atchievements, the belt whereon his sword hung, of beaten gold, his caparison of pure cloth of gold, whereon the rich stones were so ordinary that they took away the glittering of the mettal, only as it had been the sun-beames, trailed along betwixt precious gutters. On his helmet was fixed a rich crown of the most excellent mettal. In brief, for I would fain have made an end of this idle news, there was all the richness in his empire, in that all the beauty of his richness, in them all the desire of each eye: when he had saluted the judges he trotted twice or thrice about the lists, then lighted at his pavillion which was there erected of cloth of gold, where he sate with convenient company and refreshed himself. Now in the mean the Turk he set forward with an army double the Christian, and 100000 and above still left in the camp. And here I must needs leave to tell you of his exceeding preparation unless I would make a whole volum, for besides the wondrous furniture of his souldiers, the most rare choice of ornaments, 
there was nothing could be devised, nay more than of set purpose could be devised was there : but briefly I will turn to the Turk himself, where if I had art according I should sooner weary you out with delight than words: but rooooo of his men having marched before to the banks, and there embattled themselves by the river all along, with such hideous noise of trumpets, horns, (for so they use) drums of brass, fluits, \&c. that there was more heard than seen by far, then aproached the great Turk himself, before him rode 4000 Janisaries armed in their fashion, with a long gown of scarlet red, laced with gold lace, and long white sleeves, of a very narrow breadth, which was girt close unto them, under that a good armor, with a long high cap like a milk payle for all the world, of white sattin or such like gear, with a long feather enough to come down to a tall mans hams, very thick laced in the brims with gold and pearl, in his hand a short javelin, at his side his cemitar, at his back a great quiver. of broad arrows, and by a string of silk hung his steel bow, over every 100 of these is a Boluch Bassa, a Centurion as we call him, and these be of the Turks guard, and are called Solaquis Archers, and they rode fifty in a rank: then came following them about 200 Peichers or Peiclers, all in one livery of very rich tissue after their fashion, and these are of the Turks laqueis which have a sharp keen hatchet sticking at their girdles, and the haft of Brasil, with this they will stand thirty paces off and cleave a penny loaf, or hit it somewhere, they will commonly stick an inch and a half deep into very tuff ashen wood or Brasil, or such like hard wood: there in great triumph upon an elephant richly trapped, stood a tower of two yards and a half high of pure silver, in the top whereof stood an image of beaten gold representing their Mahomet, round about which upon mules Azamoglands or Iamoglands, who are children of tribute exacted upon the Christian captives, and contributary, fine, sweet, and the most choyce picked gentlemen brought up to sundry dainty qualities, who with heavenly melody followed this elephant, the religious men going round about singing sweetly together: afore all these next to the Janisaries went above 200 
trumpets, and as many followed the great Turk, who then approached, having his chariot of pure silver of above 20,000 pound weight, drawn with eight milk white elephants, round about rode and went bareheaded, Azamoglans Peiclers most gorgeously and resplendescent apparelled, under the Turks feet lay a pillow of clear crystal, embossed at the ends with huge golden knobs, on his head a wreath of purple, with a most rich diadem as it is commonly known the order of it, the stage can shew the making of it, but other things they differ mightily in. Here you must suppose the exceeding glory of his apparell, there he sate upright in the chair with such a majestical, proud, severe, warlike countenance, as justly became so high a throne, before him went Aga, which is the great captain of his Janisaries with the Hali Bassa, the captain of his naval expeditions, Bianco Bassa the captain of his Janisarie harquebushers, the Zanfyretto Bassa captain of his guard, with other of great authority bareheaded. After his chariot came sweet melody, and then five elephants of war (an elephant is well nigh as big as six oxen) gaunt and slender like a horse in the flanks, and of more swift foot than a man would think for, his fashion is like no beast in England, but the ridge of his back is like that of an horse, his feet hath five great horney toes, and a very long snout of above two yards in length, with which he will draw, by only snuffing up, a pretty good big lad, and deliver him to the rider, this long trunk falls down betwixt a large pair of teeth or tushes of above an ell and a half long (as ye may commonly see at the comb-makers in London) bending like a boars, upwards, his ears wel nigh from the top to the neither tip of the hanging down above seven feet long. And after these five elephants, sadled and ordered for a man to ride on, came trumpets and all in the like manner as before, and then marched 500 in a rank, 100,000 footmen, and by their sides for -wings 40000 horsemen, so that he came to the combate with 240000 fighting men, well accomplished in armes: then was the great Turk carried under a goodly canopy upon a black waggon on mens shoulders into the ferry, which was richly prepared, 
where in the view of both camps he landed, whilst the warlike instruments echoed wide in the air. In the island for judyes sat (in armour as did the other) the king of Rhodes, and the king of Pamphylia, now called Alcayer. When the Turk was landed, there was brought to him by the hands of two kings, a great elephant of an ash colour, white embossed very glitteringly, whereon the great Turk mounted by a short ladder of silver, armed very strongly and most beautifully, then took he his javelin in his hand, and vibrated it in great bravery, (as he could handle his weapon well) and hung his quiver of long darts at his back, then his cemiter, \&c. and so having saluted the judges, retired to the utmost part of the field, then mounted up the brave and puissant emperor so lightly in his heavy armor, as if either his gladness had lessened his weight, or the goodness of his cause, to the great rejoycing of the Christians and amazement of the Turks, at whom the Christians yeld so universally and hallowed, and other infinite kinds of gladsome tokens that the Turk astonished stood stone still till the Christians had done, and then as men new risen to life, with such an horrible shout, that their voyce rebounded to the air, at which time the Christians shouted again with them, as if they would have committed a battle with voyces, and surely their voices did fight in the wide coasts and shores of the air. This done, the emperors prepared themselves to the fight.

\section{CHAPTER XXII.}

\section{The Combate.}

AND when they were sworn that neither of them had any magick herb, charm, or incantation, whereby they might prevail in their fight on their adversary, and had solemnized the accustomable ceremonies in like matters of combate. The heraulds gave their words of encounter, then with loud voyce and shril trumpets couragious blast, whilst all the people were in dead night expecting the demeanour of these renowned princes. Now we 
have brought you to behold these two champions, arrived thither with their brave followers, ready to prove their valiance in the face of so great a multitude. Now if you will stand aside lest their ragged spears endammage you, I will give you leave to look through the lattice, where you shall even now see the two emperors with their brave shock press doubt betwixt their cruel encountrings. Now you may see the two combatants, or but as yet champions, coming from the ends of the field, the excellent Christian Emperor with incomparable valour, visiting his horse sides with his spurs, carrying his spear in the rest with an even level, so that the thundring of the brave steed presaged the dint of the greatest thunder-clap. When Ali Chan, gently galloping with his huge beast, came forward with more swift space still as he drew nearer to the emperor. All this while you may behold them hastening in their course, like as you see two great waves galloping from the corners of the sea driven by contrary winds, meeting together by long randome, to make the neighbours shoars to quake and dimb'd with their boystrous carrier. The emperor being now with his greatest fury ready to fasten his launce upon his adversary, and his adversary ready to fasten his javelin on him, when the Turk sudainly stept aside, and the Emperor thrusted his void launce in the air, (for he might easily do it) for though the elephant be but low, yet he was higher than his horse by a yard, and yet his horse was the fairest and tallest to be found in all christendom, so that needs he must lay his spear in an uneven height to break it on him. Sudainly the Turk stopt, and with his nimble beast followed the Emperor as he had fled, whereat the whole army of Turks shouted horribly, clapping their hands, and the Christian stood still in great silence, struck with just wonder of this strange quiddity in combat, and ere the Emperor could make his stop, with a short turn, the Turk had hit him on the shoulder with his javelin, which being denyed entrance, for very anger rent it self in forty pieces, and chid in the air till they broke their necks on the ground, and had not then the horse started, the monstrous 
elephant had overthrown him with his rider to the earth. But then the horse incenst with ire for this injury, and his master more hotly burning with disdain and furious gall leapt, bounded, and sent out at his mouth the foamy arguments of his bitter stomach, but so fast the vile Turk followed that he had spent three long darts upon the barbed flanks of the horse, which all in vain returned to their master. The beholding Turks so eagerly persuing the stroaks with shouting, as if with a hidden sympathie their trayning had augmented the violence of the blows. At length the good emperor sorely ashamed came now to make him amends for his pretty falsery : and with great scope throwing his launce forwards just upon the Turks face, and when he was almost by him, the infidel as if he had but made a sport of the fight, stept aside very deliberately thinking that he should have made him run in the like order as before, but he more cautelous marking of purpose which way he meant to decline, turned with him, and his learned horse could well do it, and indeed desire of revenge had so seated it self in his brave couragious breast, that now he even followed him as if he had been drawn with cart-ropes, the Turk seeing now he was circumvented, fetcht a pretty compass and trod a round, the elephant flying from the horse and the horse following the elephant, as you might see Seignior Prospero lead the way on Mile-end-green, in the ringles, this was a pretty sport to see the matter turn'd to a play.

Now the christians having like occasion to shew their gladness, gave such an applaudite, as never was heard in any theater, laughing so effusedly that they dasht their adversaries clean out of countenance, tickling again with the long loud laughter: when they had run not passing twice about the Turk seeing his time, conveyed himself out of the ring, and then got again on his back spending his cowardly darts upon his strong enemies armor, and so fast he followed and so quickly the good emperor turned back again, that his horses barb of steel out sticking in his front, met just upon the outside of the right eye of the elephant, that it sticking out a foot entred in above 
an inch, which the horse perceiving made the rest follow into his head, (up to the hilts as to say) laying his fore feet out straight, and his hinder legs in like manner, went poaking and crowded himself forward, still gathering upon the elephant, so that not so much with the horses force as the great beasts cruel pain, the elephant swaid back above a hundred foot. Now was the Emperor glad, and with both his hands lifting himself upon his stirrops, took his lance, and strook the Turk with the point full on the vizard so thick and so many times, that some blood followed, with an hue and cry out of the windows of the helmet, to find the worker of his effusion : till the villain slave drawing his fine sword smote the lance very bravely in two, and casting his shield afore him, received the last stroke on the truncheon of it, which the gentle emperor with fell fury threw at him that he made him decline almost to the fall. The Turk sitting on the elephants back, could not with his semiter reach the Christian, nor he the Turk with his curtilar, so that now they sate and lookt one upon the other, and the people at them, and all at this strange coping. The good horse Grauntier by chance being gored a little under the mane betwixt the bendings of barbs with the sharp tusk on the elephant neighed with great stomach, and leasing from the beast which he had welnigh forced to the lists end, being thereto forwarded with the sharp spurs with so exceeding fury, that it was not only a marvail how the good prince could sit him so assuredly and also that he spoil'd not himself, but with more eager fury began to gallop upon the elephant again his mouth wide open, and horrible with the salt foam which in abundance issued from his great heart : for by how much the more a thing is gentle and quiet, by so much the more being moved he is iracund and implacable. But the emperor turning his reins carried him clean contrary to the lists end, where stood launces for the same purpose as the manner is, of which he chose the two stiffest, longest, and rudest of their stature, and came softly pacing to the Turk : who stood even there still where he was, the elephant bleeding in such abundance, that by the loss of 
so much blood his meekness turned into rage, and began to rise and bary, and stamp, and with an uncertain sway to move, so that with much adoe the slave stayed and appeased him, then the brave emperor lifting up his vizor not only to take breath, but the more freely that his speech might have passage, he told the Turk that he had in a base cowardly manner by false fraud and unequal fight dishonoured himself and endangered him, for which he told him Malgrado suo he would be gloriously revenged : and now that they had spent a good time in uncertain fortune, he had brought two lances choose which he would, and either begin the fight anew or make an end of the old; promising upon his honour that if he refused so to do, he would fasten one in his beast, and another in his heart. And if he dared to do that, he bad him come down on foot, and there break a staff with him. The Turk as he was an honourable souldier then presently slipt off his elephant, bravely answering that he came to conquer him in sport, and not meaning to make a purposed battail, but sith he was so presumptuous as to dare him to his face, he should soon perceive how lightly he weighed his proud word, and then skipping to him, reacht a lance out of his hand, and went 100 paces backward, so did the emperor very joyfully, when they are come so far as they thought they might trust to their breath, holding their lances in both their hands, began to run very swiftly, and desire brought them together so fast and courageously, that their launces somewhat too malapart not suffering them to come together, hurld the Turk above seven foot off the launces length, so that not one there but thought that he had been either slain, or his wind dasht out of his belly: the prince reel'd backward above two paces, and yet fell down much astonished. The people on both sides exceedingly amazed and affrighted, especially the Turks who sent out such a doleful Sanutus that it would have moved the stones to ruth, but the dolor of the christians was not so great, for the moving of the emperor revived their spirits much. In a cause on which the beholders safeties do depend the ill success is 
much feared, for it may be seen by this, that they will with a certain alacrity and sympathie seem to help or to pity as the cause requires. On a sodain the emperor lift up his head, at which the christians gave such an universal shoot, as if even now they would have fray'd the mountains adjacent. The two couragious beasts, having lately heaped up red hot rancor in their disdainful stomacks, assaulted the one the other with all the weapons of nature, that it had been enough for to have delighted any one, but the horse had some small advantage by reason the elephants right eye was covered with the trailing down of the blood. By this time the emperor rose again, and the one went to his horse, the other to his elephant, having first splintered their spears, and fenced so long as any vertue remained in their slaughtered launces. When each had gotten to their beasts they began to forward them, who with equal ire moved, needed no incouragement, then did the em. peror coming with full scope upon the Turk, smite the elephant just upon one of the teeth, while with great rage the horse had fastened his pike again in the jaw-bone, so that the elephant still swayed back, but neither of them being able to reach the one the other; the excellent prince casting his golden shield before him, and drawing his glittering curtelar; leapt upon the neck of his horse, and laying one hand upon one tooth of the elephant, with the other hand upon the thonge that went cross his forehead, vaulted up, and settling his feet upon the tusks, on the head of the beast, cast up himself, and laid his sitting place where his hands were, and there he rode by a little and a little, till he might buckle with the insedent. No sooner came he within the reach of the Turk, but he smote the Turk so freely, who was ready prepared for him, that he made him decline a little, there they fought so long that the elephant driven through pain was thrust up to the lists, hereupon all the christian people shouted, in a more free manner than ever at any time before, all the while the hard-mettal'd swords played upon each others shields, so that the glory of their rare fight was so wonderfully pleasing to 
the eye, and so honourable to the combatants, that if they had jested one would well have been contented to view all the long day: but the good prince was too hard for the other, for with his ready blows he urged the great slave out of his cell, and made him sit behind the arson of the saddle, and if this accident had not happen'd he had surely made him sit behind the arson of his elephants tayle. For so soon as the elephant had but touched the lists, the Christian marshals of the field came gallopping and parted the combatants, holding the Turk as vanquished, whilst betwixt the contrary and adverse part there was four negatives, so that well nigh they had fallen to blows, for the case seemed to the Christian plain, to the Turk unjust. That because the beast whereon he rode went to the lists end, therefore the stopper should be blamed. Well, heraulds whose office it is to deal in such royal matters, had the discussing of it, and it was deferred to arbiters, with this condition, that if the Turk was found vanquished, he should be yielded as recreant (and miscreant he was.) So the matter was posted off whilst it never was concluded, and both the parties departed, the one to the camp, the other to the city, in no less solemn pomp than they entred accompanied into the sands, where so rare a chance fortuned betwixt so puissant emperors. And because the matter was as strange as true I have sojourned a little too long in it. But in the next inne you shall have a better refreshment or a newer choice.

\section{CHAPTER XXIII.}

By chance a knight smote Faustus a box on the ear in the presence of a great company of brave ladies, wherefore he swore to be egregiously revenged on him, giving him the field, which the knight refused not, so the weapons, the place, the time, were ordained, and Faustus went out to the field, and no sooner was Faustus gone out of the presence, but Signior di Medesimo who was well known to be a valourous and courageous man in his 
kind as any was about the court, on a sodain fell down on his knees before all the ladies, shaking and quivering with a face as pale as him which was new risen from a months burying, desiring them if ever they tendred any Gentlemans case, to intreat Monsieur Infeligo to forgive him this trespass. At this the whole assembly burst out into a loud laughter, to see the man that was even now in his brave terms and, vaunting words to come in all submissive manner to intreat for a pardon so ridiculously. He yet persisted with many a salt tear and hands lifted up towards the heavens, from whence his pitty came, when Faustus came blowing in like a swash-buckler with his rapier by his side, and his hand on his poynard, swearing all the cross row over. But when he saw the knight in such a pickle, he set himself against a wall and laughed so loud and so heartily, that all the whole rout could not chuse but laugh with him, and there was laughing, and here and there and every where. At length two ladies rose, to whom perhaps this knight owed some particular service, and desiring Don Infeligo with very mild sermon to be friends with Medesimo again, he told them that they could not demand the thing which he could not readily fulfil, marry he requested this, that as the disgrace, which he had received was too great to be forgotten without some such equal revenge that he might use some like injury, whereby he might be satisfied, and he might again come into his grace, which they granted. Faustus came to Medicimo and reared him up upon his feet, and then got upon his back, and so rid twice about the chamber, and when he had done he took him by the chin, who had not yet forgotten how to weep. Shaking worse than any schoolboy when he fears to climb the horse, and gave him a good box on the ear, and went his way. So the knight was utterly disgraced, and for shame durst not be seen all the day after. They which were there had sport abundance, and Faustus was feared for his brave valour, and with his continual delight in knavery got him foes enough too. 


\section{CHAPTER XXIV.}

ANOTHER time he by chance overheard a gentleman which was talking to a lady, and said that whatsoever she commanded him to do he would do it, if she would grant him grace. The gentlewoman belike willing to heare him speak so not to her, required him to build in that place with one word a castle of fine silver, at which the gentleman amazed went away confounded. Faustus followed him fast, and said to him that he had overheard the ladies unjust demand, wherefore go say (quoth he) thou will do it with one word. And so the gentleman did and it was done, whilst he ran laughing in to many nobles and lusty gallants telling them he would shew them the strangest thing that ever they saw, and all they came running into the garden together, where they found the gentleman fast lockt in a pair of stocks, and an ugly foul kitchen wench in his arms. $O$ lord what wondrous sport did he make them there. And when they had laughed their fill, he loosed the gallant, who went and swore all that he could he would be revenged on him. In such monstrous intolerable knaveries, Faustus took especial felicity.

\section{CHAPTER XXV.}

THESE four honest fellowes Faustus, Akercock, Mephostophiles, and Wagner, went out together into the street, and walking there by chance espied four gentlewomen seeming to be sisters, them they cast to abuse, and they were never content to play any merry pranks for honest sport, but they must be so satyrically full of gall, that they commonly proved infamous, spareing neither their good name on whom they committed them, nor any kind of villany, so it might procure mirth : when they had talked sufficiently with them, they did so much that they were contented to ride abroad with them, and so each fetched his horse and came to them masked, and the gentlewomen were wimpled likewise, (for the men as well as women use there to wear 
masks.) Thus they rode to the common furlong where many Italian gentlemen were playing at the Baloun, and there they rode round about, whole armies of shoots accompanying them, they riding still backwards and forward, whilst these men-women had sowed their coats to their doublets, and pin'd upon their backs things of vile reproach amongst them, then rode they to the court not yet satisfied, where they were entertained with more merriment and laughter. And when these men-women saw the greatest multitude that was there likely to be, even upon a piece of ground which was higher than all the rest, they leapt down, and by reason of the friendship betwixt their petticoats and their doublets, they haled them down one after another, the horses ran away, and they lay upon them to their great confusion and reproach, yet they thought all well sith they were personated and masked, but the women stript off their womens garments and their head attires, and there they were well known to be four brave noble young gentlemen brethren, and each of them rent off the masks of Meph. and his mates, and detected them to their great shame, who neither durst revenge themselves for fear of further displeasure, nor of revealing what they were, nor could be moaned of any one for their notable abuses aforehand, so that whereas in others it had been but a common jest, on them it was wonderful strange and ridiculous. So they with shame enough went fretting in vain to their lodging.

\section{CHAPTER XXVI.}

THE emperor being some five or six days in rest within his walls, caused, as sloth cannot dwell in true noble breasts, the whole army to set forward, leaving a convenient garrison within the city of 30000 men, marched into the fields in sundry embattles with above 130000 men. And there in the view of the army Meph. Akerc. Wag. and Faustus prick't up to the Turks camp, armed in compleat harness, and there challenged any four to break a staff with them, then came there forth four Janisaries 


\section{4

horsemen armed at all assaies, and there they ran all together to the singular delight of the beholders, so gallantly they demeaned themselves, but in the cope all the four Janisares were run quite thorow and thorow (as they say) and there lay on the cold earth, then made these four fellows in arms their stop, and expected a fresh revenge, which came immediately thundring out of the entry of the camp, with whom to occur in time they met with the like success as before, to their singular commendations and high praises : then 'gan the Turk to stamp and fret, and commanded four of the best in his whole camp, and four more with them to run at these villains and to captive them, where they should rue the rashness of their presumption with long eternal torment. These eight came with all their power together and broke their launces very hardly upon their faces, and so did they four on theirs, then they drew their swords committing a brave turney, till two of the Turks were slain, and the six fled, which were immediately hanged: at which the Christians laughed heartily, and these four returned thanked highly, and for that the enemy would not advance himself to the general fortune of the fight, they marched in again into the city.

\section{CHAPTER XXVII.}

AвоUт two a clock in the night the Turk approached with all his whole army unto the walls of the city causing particular bands and pyoneers to dig through the countermure, the sentinels which were on the walls, privily espying by reason the moon gave some slender light though she was but three dayes old, gave warning, without any alarm to the chief commanders: so that the whole power of the city almost was gathered into arms, without any stroak of the drum. The place wherein the Turk was entring, was right against a streets end of above two yards over, and not above thirty yards from the breach, they had digged a deep trench, and placed on the scarp nine double cannons throughly round and charged with chain and murthering 
shot, and on each side of the cross street they had erected forts of gravel, \&c. like our barricadoes now, in each of which they placed above fifteen culvering and cannon. Now the breach being sufficient, the Turk having entered above 2000 men, gave the onset, and sounded the bloody alarm, when sodainly the flankers discharged and the bulwarks shot freely together, and utterly cut off all them that entred beyond the ditch, and betwixt those three mentioned forts with their terrible shot, they swept them all out of the place, then began the Turk to thrust his men forward upon the breach (having lost in this assault above 2 I00) and ever as they came up to the breach the cannon heaved them off, and the small shot from the loops so galled them that they durst not approach. But the Turk cared not, for the murdring of his men might weary the cannons insatiate cruelties at length. Then was alarm given through the city, and every one fell to their arms, getting to the walls, and the rest to the assembling places, whilst the Turk freshly filled the breaches with murthered men, he enforcing himself to his power to enter, and they to keep him out. When he saw that how he had stopt the breaches so with ded bodyes which almost. made a new red sea with their blood, in great rage transporting above 30000 men over Danuby, furnished them with scaling ladders, whilst he with great store of cannon beat his own slain men off the forenamed breaches, for he was a merciless tyrant, and caused them to assault the wall it self, which they did. Now began the morning to appear, and the Christians came just upon the backs of the assailants, with the greatest part of. the whole power of the city, and put them all to the sword, save those that escaped from them by water, but killed of their own fellowes. Then the Christians marched upon the Turk, who seeing his power greatly weakened, having lost at this unlucky assault above 23000 men, cursing and banning his disastrous fortune, and his gods the givers of it, retyred in a flying pace to his camp, whilst the plenteous spoils made rich the Christians, for upon the dead carkases were found store of jewels and gold in great plenty. 


\section{CHAPTER XXVIII.}

THIS new victory gladded the Christians exceedingly, as much as it greived the Turks. The breaches were now freshly repaired with all expedition. The Christian princes seeing the inconvenience that followed their keeping within the city, and how great shame it were for them to abstain from the enemy, considering their power to be not much inferior to that of the Turks in number, much more in brave souldiery, wherefore they made a general muster and determined to offer the battel to them in the plain field, which if they refused they would give them in their camps concluding all.under one dayes valiance, then marched forth the English archers, of whom Wagner desired he might be with his fellows, which when they had taken their stand, they brought store of fletchery to them in carts, which were there disburdened, so every archer being five double furnished, the number of them now was 9000 the pike being converted into them, being thereto desirous, and having therefore made great suit, for the emperor was very loth to forgoe their first good service: Fau. counselled the captain to chuse a plot of above one hundred acres square, where it was open to each horseman, which they marvelled at greatly, but yet they easily granted to stand any where: they were so well placed, that they stood as well to defend the friend as to offend the foe. Then in due order marched out the whole army of the Christians, and so settled themselves, whilst the Turk brought forward his thick swarms. Now it had been a brave sight, to see the greatest princes of the whole world east and west, attended on by their whole forces set in aray, their gorgeous and bright armours and weapons casting up long tramels of golden shine to the heavens, the noyse of clarions, trumpets, \&c. incouraging the fainting souldier, and increasing the boldness of the resolute. There was at once in this field all the terror of the world, accompanied with all the beauty. In the city you might have seen the remainders at the churches at prayer, 
solemn procession round about the town with great devotion, \&c. Well, the time was come that the horsemen began to assault the pike, and attempting the ruptures of the aray, and the forlorn hopes fiercely skirmishing whilst with loud outcries the whole use of hearing was taken away: above you nothing but smoak, round about you the thundring cannon, and sharp horrors of sundry weapons, and at your feet death. There might you see the great use of the eughen bow, for the horse no whit fearing the musket, or caliver, as used to it nor yet respects the piercing of a bullet, by the thick tempest of arrows, hiding their eyes and hurting their bodies, overthrew the horsemaster to the ground, on that side could not one horseman appear, but straight they fetcht him down, so that of thirty thousand horsemen of one assault, there was not one that came within five spears length of the battel on foot. The great Turk cursing heaven and earth, and all trees that bore such murthering fruit as bowes and arrows, caused a troup of five hundred barbed horses with twenty thousand more to run upon the archers all together, which they did, but when they came just upon a little ridge, not one horse but sodainly stopt, and the riders which now had rested their staves, lying close upon the saddle pommels, were thrown quite out of the saddle, and either their backs broken, or quite slain. All the whole archerie with the camp wondring hereat, as ignorant of the matter, every one suspending his several judgment, but Faustus laughed heartily, who knew the matter plain, for there had they buried in sand all the way wolves guts, which by natural magick, as authors affirm, suffers not the horse to come over it in any case, nor any force can carry him over with a rider on him. For the archers drew just upon, and so universally shot together, that all the troops were put to flight, and above half spoyled and murthered. To be brief, so much the Christians prevailed upon the Turks in three hours and a half fight, that all them were turned and fled, each one advancing forward in his flight, there were slain in this battel and flight above seven-score thousand Turks, the great Turk himself fighting manfully on 
958 THE SECOND REPORT OF DOCTOR FAUSTUS.

his elephant, was by the emperors own hands slain, all his chief bass is and men of honour to the number of three hundred died manfu'ly about him: now the retreat was sounded, and they marched home in most glorious pomp and rejoicing, where the souldiers made rich with the great spoil of the camp, were dismissed, and the princes returned home, and due order taken for the safety of the city. So the Duke of Austria rid of his enemies, gave himself to his forepassed life, and the other princes with great joy caused general feasts and triumphs to be performed in all their kingdoms, provinces, and territories whatsoever.

FINIS. 



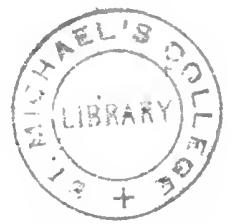


THONS, W.J.

PR

EarlJ English

21. prose romances.

$$
471=5118
$$




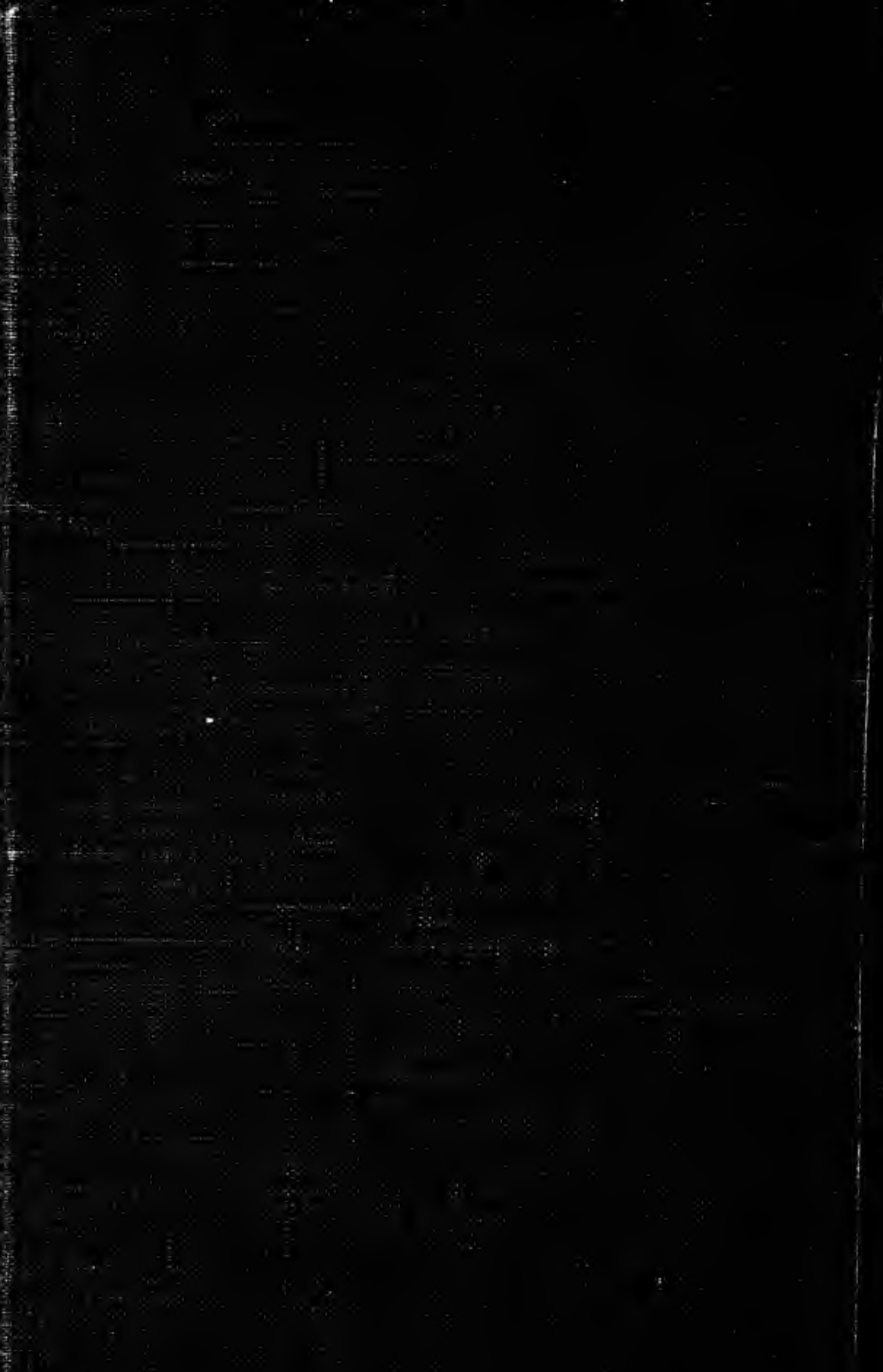

